Historic, Archive Document

Do not assume content reflects current scientific knowledge, policies, or practices. 



$$
925076
$$

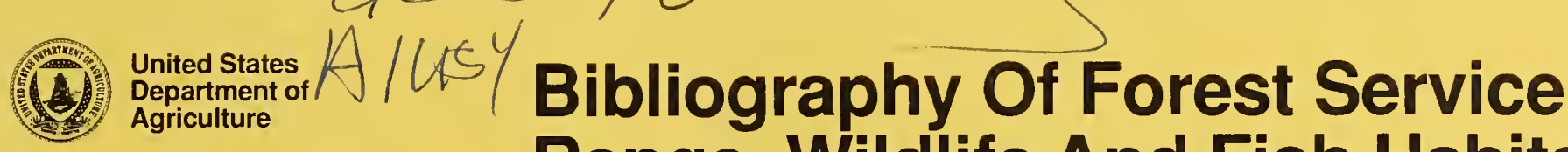

Forest Service

Bibliographies and

Literature of

Agriculture No 95 Range, Wildlife And Fish Habitat, And Related Research Publications: 1977-89

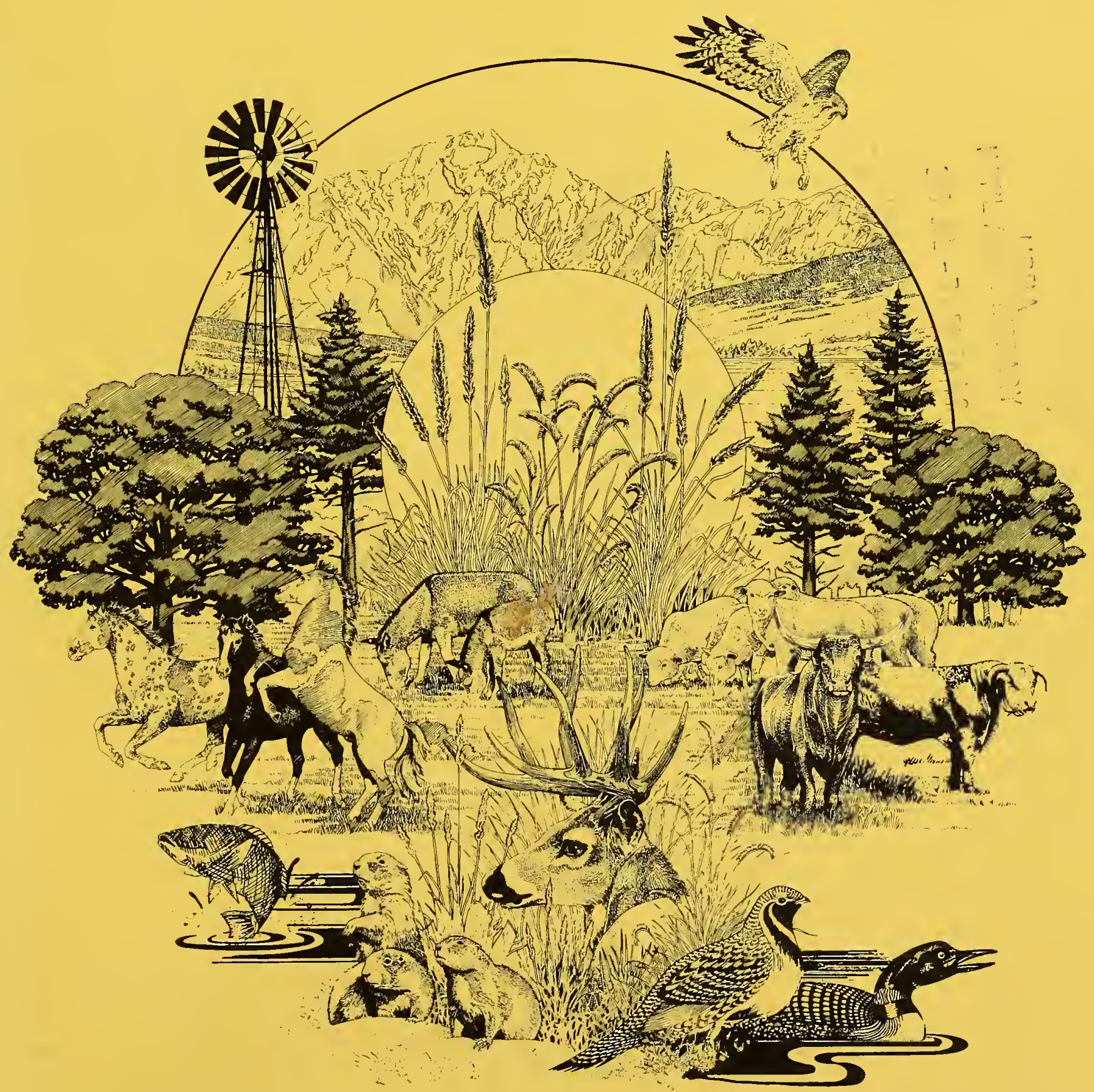





\section{Bibliography Of Forest Service Range, Wildlife And Fish Habitat, And Related Research Publications: 1977-89}

Compiled and edited by

Gale L. Wolters

Range Scientist

Forestry Sciences Laboratory

Rocky Mountain Forest and Range Experiment Station

Albuquerque, New Mexico.

U.S. Department of Agriculture

Forest Service

Bibliographies and Literature of Agriculture No. 95

September 1990 
This bibliography was compiled for those interested in technical literature pertinent to the understanding and management of range, wildlife and fish habitat, and related resources. The first major compilation of rangeland literature was the 1938 publication of A Selected Bibliography of Western Ranges, Livestock, and Wildlife by Renner, Crafts, Hartman, and Ellison. This early bibliography is still requested by rangeland managers, scientists, educators and students more than 50 years after it was published, although the supply has long been exhausted.

This bibliography of technical literature on range, wildlife and fish habitat, and related resources is a listing of literature published by U.S. Department of Agriculture Forest Service scientists, or in cooperation with the Forest Service, and is the continuation of a series. The first 22 bibliographies reported were mimeographed annual listings of published technical literature. From the first report, 1951, through 1957, the literature pertained primarily to management of rangelands.

Since 1958, the scope of the annual reports has evolved to include technical literature on wildlife and fish habitats and related

resources. The 1977 publication, 1973-1976

Range, Wildlife, and Fish Habitat Research

Publications, was an alphabetical listing of

Forest Service publications by author and station.

The current bibliography is a compilation of approximately 3,000 entries arranged alphabetically by author within broad subject matter categories. Some publications relate to more than one subject matter category, and when a clear distinction could not be made as to where an article should most appropriately be listed, it was placed in multiple categories. Cross-references are suggested in the subject matter outline to assist in locating pertinent and related technical literature. 


\section{Acknowledgments}

Many Forest Service employees contributed significantly to the format and content of this publication. The author gratefully acknowledges the important contributions made by each of the following individuals

Malchus B. Baker, Jr., Rocky Mountain Forest and Range Experiment Station, Tempe, $A Z$.

Raymond W. Brown, Intermountain Forest and Range Experiment Station, Logan, UT.

Evelyn L. Bull, Pacific Northwest Forest and Range Experiment Station, LaGrande, OR.

Richard R. Buech, North Central Forest Experiment Station, St. Paul, MN.

Hewlette S. Crawford, Northeastern Forest Experiment Station, Orono, ME.

Richard N. Conner, Southern Forest

Experiment Station, Nacogdoches, TX.
Leonard F. DeBano, Rocky Mountain Forest and Range Experiment Station, Tempe, $A Z$.

Richard M. DeGraaf, Northeastern Forest Experiment Station, Amherst, MA.

Richard E. Francis, Rocky Mountain Forest and Range Experiment Station, Albuquerque, NM.

Philip R. Fresquez, Rocky Mountain Forest and Range Experiment Station, Albuquerque, NM.

Frederick Hall, Pacific Northwest Region, Portland, OR.

Richard F. Harlow, Southeastern Forest Experiment Station, Clemson, SC. (Retired)

William R. Meehan, Pacific Northwest Forest and Range Experiment Station, Juneau, AK. 
E. Durant McArthur, Intermountain Forest and

Range Experiment Station, Provo, UT.

Henry A. Pearson, Southern Forest

Experiment Station, Alexandria, LA.

Raymond D. Ratliff, Pacific Southwest Forest and Range Experiment Station, Fresno, CA.

Mark A. Rumble, Rocky Mountain Forest and Range Experiment Station, Rapid City, SD.

Kieth E. Severson, Rocky Mountain Forest and Range Experiment Station, Tempe, $A Z$.

Roy C. Sidle, Intermountain Forest and Range Experiment Station, Logan, UT.

Carolyn H. Sieg, Rocky Mountain Forest and Range Experiment Station, Rapid City, SD.
Arthur R. Tiedemann, Pacific Northwest Forest and Range Experiment Station, LaGrande, OR.

Daniel W. Uresk, Rocky Mountain Forest and Range Experiment Station, Rapid City, SD.

Jared Verner, Pacific Southwest Forest and Range Experiment Station, Fresno, CA.

Special thanks are given to Diana Carriaga (formerly employed by the Forest Service) and Nora Altamirano for their effort in preparation of the initial draft of this publication and to Susan Gorman (Rocky Mountain Forest and Range Experiment Station, Albuquerque, NM) for her untiring assistance and software-use advisement. 


\section{Contents}

Preface

Acknowledgements

Flora (plants)

Plant Taxonomy (including field guides, species lists, and species ranges)

Plant Genetics (including breeding systems, genetic diversity, population genetics, evolution, and improved plants)

Plant Physiology (including growth processes and rates, phenology, and physiological responses to herbivory)

Water Relations (water use efficiency, etc.)

Germination And Propagation (including seed collection)

Forage Value (including nutritive value, chemical composition, and forage production)

Nutrient And Mineral Responses (nutrient cycling, etc.)

Plant Ecology (including general treatises, population dynamics, and threatened and endangered plant descriptions)

Plant Succession (including stability and diversity)

Plant Communities (habitat types, classifications, and descriptions)

Fire Effects (on flora, fauna, and soil)

Autecology (plants in relation to their environment)

Range Management (including forages and forage management, supplemental pastures, fertilization, prescribed burning, and general management)

Vegetation Management (biological, chemical, and physical plant control including noxious weeds)

Multiple Use (management and resource interrelationships on forest and rangeland ecosystems)

Overstory-Understory Relationships (relationship of forest and shrub density and canopy on forage production and botanical composition)

Grazing Management (systems, stocking rates, livestock management, utilization models, and herbivore mixes)

Reclamation And Restoration (including mined rangelands; for management see Range Management)

Plant Establishment (including seeding and planting techniques, species tolerances, and species selection) 
Rangeland Inventory (including rangeland monitoring, land use inventory, and remote sensing)

Wildlife Habitat Value (assessment and monitoring; including inventory techniques)

Laboratory And Field Techniques (sampling techniques, statistical and laboratory analysis procedures, and plot techniques)

Biomass Estimates (techniques and comparisons of techniques to estimate plant biomass)

Fauna (animals)

Animal Taxonomy (field guides and species lists)

Animal Interactions (influence on ecosystems, fauna and faunal habitats, including animal damage control)

General Wildlife Habitat Requirements (including area and regional habitat assessments, statistics, and management; also see Fish, Birds, and Large and Small Mammal Habitat Requirements)

Fish And Their Habitat (including habitat requirements and management, species growth rates, population dynamics, and threatened and endangered species)

Stream Ecosystems And Aquatic Habitats (descriptions, classifications, and management)

Aquatic Invertebrates And Their Habitat

Management Influences (influences of forest and rangeland management, roads, etc., on fish habitat)

Habitat Restoration And Enhancement

Habitat And Population Inventories

Laboratory And Field Techniques

Cavity And Snag Nesters

Raptors, Including Spotted Owl (species biology, ecology, habitat requirements, and management)

Threatened And Endangered Birds (species biology, ecology, habitat requirements, and management)

Game Birds (species biology, ecology, habitat requirements, and management) 
Songbirds (species biology, ecology, habitat

requirements, and management)

Shorebirds And Waterfowl (species biology, ecology, habitat

requirements, and management)

General Avian Biology And Ecology

Eastern Forests And Urban Habitats (including southeastern and Caribbean forests)

Western Forest And Rangeland Habitats (including Pacific Rim forests)

Large Mammals

Ungulate Food Habits (including food preferences, consumption, and supplemental feeding)

Ungulates And Their Habitats (habitat management, requirements, multispecies management and responses)

Deer And Their Habitat (habitat requirements and management including deer biology and ecology)

Elk And Their Habitat (habitat requirements and management including elk biology and ecology)

Moose, Caribou, And Their Habitat (habitat requirements and management, including species biology and ecology)

Pronghorn Antelope And Their Habitat (habitat requirements and management, including their biology and ecology)

Sheep, Goat, (wild) And Their Habitat (habitat requirements and management, including species biology and ecology)

Livestock Management (including growth rates, husbandry, etc.)

Bear And Their Habitat (habitat requirements and management, including bear biology and ecology)

\section{Small Mammals}

Small Mammal Habitat Management (habitat requirements and species response to habitat change)

Food Habits And Population Dynamics (growth and behavior; see Animal Interactions for related literature)

Canid, Felid, And Their Habitat (habitat requirements and management, including species biology and ecology) 
Amphibian, Reptile, And Their Habitat (habitat requirements and management including species biology and ecology)

Monitoring Terrestrial Wildlife (including species abundance and populations)

Vertebrate Capture Techniques (including marking, tracking, and telemetry techniques)

Special Habitats (including snags, cavities, edges, highwalls, etc.)

Computerized Data Systems And Models

Insects And Diseases Of Animals

Rangeland Soil And Water

Rangeland Soils (chemical and physical factors, soil fertility, and amendments; see Range Management for fertilization)

Soil Biota (species, populations, etc.; for decomposition and nutrient cycling see Nutrient And Mineral Responses)

Rangeland Watersheds (including stability and erosion, soil hydrology, and influences of management and natural events on water quality)

Stream Flow Augmentation (water yield, water harvesting, and irrigation) 
Plant Taxonomy

ANDERSON, LORAN C. 1986. Cytogeography of Chrysothamnus viscidiflorus. In: McArthur, E. Durant; and Bruce L. Welch, comps.

Proceedings--symposium on the biology of Artemisia and Chrysothamnus; 1984 July 9-13; Provo, UT. Gen. Tech. Rep. INT-200. Ogden, UT: U.S. Department of Agriculture, Forest Service, Intermountain Forest and Range Experiment Station: 93-97. (INT)

ANDERSON, LORAN C. 1986. An overview of the genus Chrysothamrius (Asteraceae). In: McArthur, E. Durant; and Bruce L. Welch, comps.

Proceedings--symposium on the biology of Artemisia and Chrysothamnus; 1984 July 9-13; Provo, UT. Gen. Tech. Rep. INT-200. Ogden, UT: U.S. Department of Agriculture, Forest Service, Intermountain Forest and Range Experiment Station: 29-45. (INT)

ANDERSON, LORAN C. 1986. Sympatric subspecies in Chrysothamnus nauseosus. In: McArthur, E. Durant; and Bruce L. Welch, comps. Proceedings-symposium on the biology of Artemisia and Chrysothamnus; 1984 July 9-13; Provo, UT. Gen. Tech. Rep. INT-200. Ogden, UT: U.S. Department of Agriculture, Forest Service, Intermountain Forest and Range Experiment Station: 98-103. (INT)

ATWOOD, N. DUANE; SHEREL GOODRICH; and STANLEY L. WELSH. 1984. New Astragalus (Leguminosae) from the Goose Creek drainage, UtahNevada. Great Basin Naturalist. 44:263264. (INT)

BARKER, P. A. 1977. A colorful mountaineer. Mountainwest. 3(4):22-25. (INT)
BINGHAM, RICHARD T. 1987. Plants of the Seven Devils Mountains of Idaho--an annotated checklist. Gen. Tech. Rep. INT-219. Ogden, UT: U.S. Department of Agriculture, Forest Service, Intermountain Research Station. 146 p. (INT)

BOLSINGER, CHARLES L. 1989. Shrubs of California's chaparral, timberland, and woodland: area, ownership, and stand characteristics. Res. Bull. PNW-160. Portland, OR: U.S. Department of Agriculture, Forest Service, Pacific Northwest Research Station. 50 p. (PNW)

COPPLE, R. F.; and CHARLES P. PASE. 1978. A vegetative key to some common Arizona range grasses. Gen. Tech. Rep. RM-53, Fort Collins, CO: U.S. Department of Agriculture, Forest Service, Rocky Mountain Forest and Range Experiment Station. 106 p. (RM)

DEWEY, D. R.; and A. P. PLUMMER. 1980. New collections of range plants from the Soviet Union. Journal of Range Management. 33:89-94. (INT)

FRANKLIN, JERRY F.; and C. T. DYRNESS. 1988. Natural vegetation of Oregon and Washington. Reprint ed. Corvallis, OR: Oregon State University Press. 452 p. (PNW)

GARRISON, G. A.; J. M. SKOVLIN; C. E. POULTON; and A. H. WINWARD. 1976. Northwest plant names and symbols for ecosystem inventory and analysis. Gen. Tech. Rep. PNW-46. 4th ed. Portland, OR: U.S. Department of Agriculture, Forest Service, Pacific Northwest Forest and Range Experiment Station. 263 p. (PNW)

GIUNTA, B. C.; R. STEVENS; K. R. JORGENSEN; and A. P. PLUMMER. 1978. Antelope bitterbrush--an important wildland shrub. Publication No. 78. Salt Lake City, UT: Utah State Division of Wildlife Resources: 12:48. (INT)

GOODRICH, SHER 
GOODRICH, SHEREL. 1983. Utah flora: Salicaceae. Great Basin Naturalist. 43:531-550. (INT)

GOODRICH, SHEREL. 1984. Checklist of vascular plants of the Canyon and Church Mountains. Great Basin Naturalist. 44:277-295. (INT)

GOODRICH, SHEREL. 1986. Utah flora: Apiaceae (Umbelliferae). Great Basin Naturalist. 46:66-106. (INT)

GOODRICH, SHEREL. 1986. Utah flora: Juncaceae. Great Basin Naturalist. 46:366-377. (INT)

GOODRICH, SHEREL. 1986. Vascular plants of the Desert Experiment Range, Millard County, Utah. Gen. Tech. Rep. INT-209. Ogden, UT: U.S. Department of Agriculture, Forest Service, Intermountain Research Station. 72 p. (INT)

\section{GOODRICH, SHEREL; and ELIZABETH}

NEESE. 1986. Uinta Basin flora. Ogden, UT: U.S. Department of Agriculture, Forest Service, Intermountain Research Station. 319 p. (INT)

GOODRICH, SHEREL; and MONT F. LEWIS. 1982. Noteworthy collections: Carex microglochin, C. parryana, Epilobium nevadense, and Kobresia simpliciuscula. Madrono. 29:57-61. (INT)

GOODRICH, SHEREL; and STANLEY L. WELSH. 1983. New variety of Stephanomeria tenuifolia (Compositae) from Utah. Great Basin Naturalist. 43:375. (INT)

GOODRICH, SHEREL; DOUGLASS HENDERSON; and ANITA CHOKEWA. 1983. Noteworthy collections--Idaho Astragalus gilviflorus and Hackelia davisii. Madrono. 30:63. (INT)
GRELEN, HAROLD E.; and RALPH H. HUGHES. 1984. Common herbaceous plants of southern forest range. Res. Pap. SO-210. New Orleans, LA: U.S. Department of Agriculuture, Forest Service, Southern Forest Experiment Station. 147 p. (SO)

HAINES, ROBERT D.; and CHARLES J. EVANS. 1981. Noteworthy collections: Madia subspicata, Rafinesquia californica, Cryptantha muricata, Carex tumulicola, Epilobium minutum, Argemone munita subsp. rotundata, Apera spicaventi, Rhamnus rubra subsp. yosemitana, and Mimulus gracilipes. Madrono. 28:39-40. (PSW)

HALLS, LOWELL K., ed. 1977. Southern fruit producing woody plants used by wildlife. Gen. Tech. Rep. SO-16. New Orleans, LA: U.S. Department of Agriculture, Forest Service, Southern Forest Experiment Station. 235 p. (SO)

HARNISS, ROY O.; STEPHEN J. HARVEY; and ROBERT B. MURRAY. 1981. A computerized bibliography of selected species (genus Artemisia) in Western North America. Gen. Tech. Rep. INT102. Ogden, UT: U.S. Department of Agriculture, Forest Service, Intermountain Forest and Range Experiment Station. 197 p. (INT)

HEBERT, JEANNE R.; and RONALD W. MEYER. 1984. Lichens of the San Joaquin Experimental Range, California. The Bryologist. 87:251-254. (PSW)

IDAHO NATURAL AREAS COUNCIL, RARE AND ENDANGERED PLANTS TECHNICAL COMMITTEE. 1981. Vascular plants of concern in Idaho. Bull. 34. Moscow, ID: University of Idaho, Forest, Wildlife and Range Experiment Station. 161 p. (INT) 
KNIPE, O. D.; C. P. PASE; and R. S. CARMICHAEL. 1979. Plant species of the Arizona chaparral. Gen. Tech. Rep. RM-64. Fort Collins, CO: U.S. Department of Agriculture, Forest Service, Rocky Mountain Forest and Range Experiment Station. 54 p. (RM)

MCARTHUR, E. D.; and A. P. PLUMMER. 1978. Biogeography and management of native western shrubs: A case study, section Tridentatae of Artemisia. Great Basin Naturalist. 2:229-243. (INT)

MCARTHUR, E. D.; D. L. HANKS; A. P. PLUMMER; and A. C. BLAUER. 1978. Contributions to the taxonomy of Chrysothamnus viscidiflorus (Astereae, Compositae) and other Chrysothamnus species using paper chromatography. Journal of Range Management. 31:216223. (INT)

MCARTHUR, E. D.; W. G. HASSELL; R. STEVENS; J. N. DAVIS; S. E. STRANATHAN; G. L. NOLLER; A. R. TIEDEMANN; and S. K. GOODRICH. 1983. Naming and release of 'Rincon' fourwing saltbush (Atriplex canescens) for wildlife and livestock range and disturbed land reclamation. Plant Release Notice. Salt Lake City, UT: U.S. Department of Agriculture, Soil Conservation Service. 2 p. (INT)

MCARTHUR, E. DURANT. 1979. Sagebrush systematics and evolution. In: The sagebrush ecosystem: a symposium; Logan, UT: Utah State University Press: 14-22. (INT)

MCARTHUR, E. DURANT. 1983. Taxonomy, origin, and distribution of big sagebrush (Artemisia tridentata) and allies (subgenus tridentatae). In: Johnson, $\mathrm{K}$. L., ed. Proceedings, 1st Utah shrub ecology workshop; 1981; Logan, UT: Utah State University: 3-13. (INT)
MCARTHUR, E. DURANT. 1984. Natural diversity of western range shrubs. In: Cooley, James L.; and June H. Cooley, eds. Natural diversity in forest ecosystems: Proceedings of the workshop; 1982 November 29December 1; Athens, GA: Institute of Ecology, University of Georgia: 193-209. (INT)

MCARTHUR, E. DURANT; A. CLYDE BLAUER; A. PERRY PLUMMER; and RICHARD STEVENS. 1979. Characteristics and hybridization of important intermountain shrubs III. Sunflower Family. Res. Pap. INT-220. Ogden, UT: U.S. Department of Agriculture, Forest Service, Intermountain Forest and Range Experiment Station. 82 p. (INT)

MCARTHUR, E. DURANT; and RICHARD STEVENS. 1983. Briefing paper on perennial summer cypress. Tech. Notes, Plant Materials No. 44. Denver, CO: U.S. Department of Agriculture, Soil Conservation Service. 2 p. (INT)

MCARTHUR, E. DURANT; and SHEREL K. GOODRICH. 1986. Artemisia tridentata spp. spiciformis: distribution and taxonomic placement. In: McArthur, E. Durant; and Bruce L. Welch, comps. Proceedings--symposium on the biology of Artemisia and Chrysothamnus; 1984 July 9-13; Provo, UT. Gen. Tech. Rep. INT-200. Ogden, UT: U.S. Department of Agriculture, Forest Service, Intermountain Forest and Range Experiment Station: 55-57. (INT)

MCARTHUR, E. DURANT; and SUSAN E. MEYER. 1987. A review of the taxonomy and distribution of Chrysothamnus. In: Johnson, Kendall L., ed. Proceedings of the 4th shrub ecology workshop: the genus Chrysothamnus; 1986 September 1718; Cedar City, UT, Logan, UT: Utah State University, College of Natural Resources: 9-17. (INT) 
MCARTHUR, E. DURANT; HOWARD C. STUTZ; and STEWART C. SANDERS. 1983. Taxonomy, distribution, and cytogenetics of Purshia, Cowania, and Fallugia (Rosoideae, Rosaceae). In: Tiedemann, Arthur R.; and Kendall L. Johnson, comps. Research and management of bitterbrush and cliffrose in western North America: Proceedings of a symposium; 1982 April 13-15; Salt Lake City, UT. Gen. Tech. Rep. INT152. Ogden, UT: U.S. Department of Agriculture, Forest Service, Intermountain Forest and Range Experiment Station: 4-24. (INT)

MCARTHUR, E. DURANT; SAM E. STRANATHAN; and GRAY L. NOLLER. 1984. 'Rincon' fourwing saltbush-proven for better forage and reclamation. Rangelands. 6:62-64. (INT)

MEDINA, ALVIN LEROY. 1988. An EnglishSpanish glossary of terminology used in forestry, range, wildlife, soils, and botany. Gen. Tech. Rep. RM-152. Fort Collins, CO; U.S. Department of Agriculture, Forest Service, Rocky Mountain Forest and Range Experiment Station. 54 p. (RM)

PLUMMER, A. P.; S. B. MONSEN; and R. STEVENS. 1977. Intermountain range plant names and symbols. Gen. Tech. Rep. INT-38. Ogden, UT: U.S. Department of Agriculture, Forest Service, Intermountain Forest and Range Experiment Station. 82 p. (INT)

POPE, C. L.; and E. D. MCARTHUR. 1977. Chenopodiaceae. In: Love, A. IOPB Chromosome Number Report LV. Taxon. 26:107-109. (INT)

ROBUCK, O. WAYNE. 1989. Common alpine plants of southeast Alaska. Misc. Pub. Portland, OR: U.S. Department of Agriculture, Forest Service, Pacific Northwest Research Station. 207 p. (PNW)
STEVENS, RICHARD. 1988. Field identification characteristics of eight sagebrush taxa and grasses, forbs, and shrubs adapted to areas inhabited by each. In: Roberson, Jay, ed. Fifteenth sage grouse workshop transactions; 1987 July 28-30; Midway, UT. Salt Lake City, UT: Western Association of Fish and Game Agencies, Western States Sage Grouse Committee: 2-8. (INT)

STEVENS, RICHARD; E. DURANT MCARTHUR; and A. H. WINWARD. 1989. Identification characteristics of major sagebrush taxa and species adapted to areas inhabited by each. Habitat Express 89-1. Ogden, UT: U.S. Department of Agriculture, Forest Service, Intermountain Region. 11 p. (INT)

STUTZ, HOWARD C. Broad gene pools required for disturbed lands. In: Aldon, Earl F.; and Wendall R. Oaks, eds. Reclamation of mined lands in the Southwest: Proceedings of the symposium; 1982 October 20-22; Albuquerque, NM: New Mexico Chapter of the Soil Conservation Society of America: 113-118. (RM)

WAGNER, WARREN L.; and EARL F. ALDON. 1978. Manual of the saltbushes (Atriplex spp.) in New Mexico. Gen. Tech. Rep. RM-57. Fort Collins, CO: U.S. Department of Agriculture, Forest Service, Rocky Mountain Forest and Range Experiment Station. 50 p. (RM)

WEBER, D. J.; T. D. DAVIS; E. D. MCARTHUR; and N. SANKHLA. 1985. Chrysothamnus nauseosus (rubber rabbitbrush): multiple-use shrub of the desert. Desert Plants. 7:172-180. (INT)

WELCH, BRUCE L.; and E. DURANT MCARTHUR. 1983. Briefing paper on sagebrush values. Plant Materials Tech. Note No. 45. Washington, DC: U.S. Department of Agriculture, Soil Conservation Service. 2 p. (INT) 
WELCH, S. L.; [and others]. 1981. Preliminary index of Utah vascular plant names. Great Basin Naturalist. 41:1-108. (INT)

WELCH, STANLEY L. 1981. New taxa of western plants--in tribute. Brittonia. 33(3):294-303. (INT)

WELSH, STANLEY L.; DUANE N. ATWOOD; SHEREL GOODRICH; and LARRY C. HIGGINS. eds. 1987. A Utah flora. Provo, UT: Brigham Young University; Great Basin Naturalist Memoir No. 9. 894 p. (INT)

WEST, N. E.; R. J. TAUSCH; K. H. REA; and P. T. TUELLER. 1978. Taxonomic determination, distribution, and ecological indicator values of sagebrush within the pinyon-juniper woodlands of the Great Basin. Journal Range Management. 31:87-92. (INT)

WILLIAMS, TOD B.; and RICHARD E. FRANCIS. 1989. A taxonomic field herbarium. Rangelands. 11:156-157. (RM)

WINWARD, A. H.; E. D. MCARTHUR; D. A. KAFFER; P. A. PLUMMER; and G. K. BRACKLEY. 1986. Another sagebrush in Nevada. Tech. Notes TN-Range NV44. Reno, NV: U.S. Department of Agriculture, Soil Conservation Service. 2 p. (INT)

WINWARD, ALMA H.; and LOREN C. ANDERSON. 1986. Field tour--the biology of Artemisia and

Chrysothamnus. In: McArthur, E.

Durant; and Bruce L. Welch, comps. Proceedings--symposium on the biology of Artemisia and Chrysothamnus; 1984 July 9-13; Provo, UT. Gen. Tech. Rep. INT-200. Ogden, UT: U.S. Department of Agriculture, Forest Service, Intermountain Forest and Range Experiment Station: 6-11. (INT)
WURTELE, EVE SYRKIN. 1989. Responses of callus cultures, microshoot cultures, and whole plants of the halophyte, Atriplex canescens var. gigantea to exogenous $\mathrm{NaCl}$. In: Wallace, Arthur; $\mathrm{E}$. Durant McArthur; and Marshall R. Haferkamp, comps. Proceedings-symposium on shrub ecophysiology and biotechnology; 1987 June 30-July 2; Logan, UT. Gen. Tech. Rep. INT-256. Ogden, UT: U.S. Department of Agriculture, Forest Service, Intermountain Research Station: 40-48. (INT)

\section{Plant Genetics}

ANDERSON, LORAN C. 1986. Sympatric subspecies in Chrysothamnus nauseosus. In: McArthur, E. Durant; and Bruce L. Welch, comps. Proceedings-symposium on the biology of Artemisia and Chrysothamnus; 1984 July 9-13; Provo, UT. Gen. Tech. Rep. INT-200. Ogden, UT: U.S. Department of Agriculture, Forest Service, Intermountain Forest and Range Experiment Station: 98-103. (INT)

BJUGSTAD, ARDELL J. 1987. Hybrid poplar cultivars for maximizing phytomass production on gold mine tailings in the Black Hills. In: National symposium on mining, hydrology, sedimentology, and reclamation; 1986 December 8-11; Lexington, KY: University of Kentucky: 263-266. (RM)

BROWN, R. W.; J. C. CHAMBERS; R. M. WHEELER; E. H. NEELY; and M. I. KELRICK. 1988. Adaptations of Deschampsia cespitosa for revegetation of high elevation disturbances: some selection criteria. In: Keammerer, Warren R.; and Larry F. Brown, eds. Proceedings: high-altitude revegetation workshop no. 8; Information Series No. 59; Fort Collins, CO: Colorado State University, Water Resources Research Institute: 123-126. (INT) 
CLARY, W. P.; and A. R. TIEDEMANN. 1984. Development of 'Rincon' Fourwing saltbush and other shrubs from seed following fire. In: Tiedemann, A. R.; E. D. McArthur; H. C. Stutz; R. Stevens; and K. L. Johnson, comps. Proceedings-symposium on the biology of Atriplex and related chenopods. Gen. Tech. Rep. INT-172. Ogden, UT: U.S. Department of Agriculture, Forest Service, Intermountain Forest and Range Experiment Station: 273-281. (INT)

DAVIS, JAMES N. 1980. Performance comparisons among populations of bitterbrush, cliffrose and bitterbrushcliffrose crosses on study sites throughout Utah. In: Tiedemann, Arthur R.; and Kendall L. Johnson, comps. Research and management of bitterbrush and cliffrose in western North America: Proceedings of a symposium; 1982 April 13-15; Salt Lake City, UT. Gen. Tech. Rep. INT-152. Ogden, UT: U.S. Department of Agriculture, Forest Service, Intermountain Forest and Range Experiment Station: 38-44. (INT)

DAVIS, JAMES N.; and RICHARD STEVENS. 1986. Comparison of production in 27 accessions of 4 sagebrush taxa. In: McArthur, E. Durant; and Bruce L. Welch, comps.

Proceedings--symposium on the biology of Artemisia and Chrysothamnus; 1984 July 9-13; Provo, UT. Gen. Tech. Rep. INT-200. Ogden, UT: U.S. Department of Agriculture, Forest Service, Intermountain Forest and Range Experiment Station: 336-341. (INT)

\section{DUHIGG, PAT; BILL MELTON; and ARDEN} BALTENSPERGER. 1978. Selection for acetylene reduction rates in "Mesilla" alfalfa. Crop Science. 18:813-816.

FREEMAN, D. C.; and E. D. MCARTHUR; 1984. The realtive influences of mortality, nonflowering, and sex change on the sex ratio of six Atriplex species. Botanical Gazette. 145:335-394. (INT)
FREEMAN, D. C.; E. D. MCARTHUR; and K. T. HARPER. 1984. The adaptive significance of sexual lability in plants using Atriplex canescens as a principal example. Ann. Missouri Botanical Garden. 71:265-277. (INT)

FREEMAN, D. C.; E. D. MCARTHUR; K. T. HARPER; and A. C. BLAUER. 1981. Influence of environment on the floral sex ratio of monoecious plants. Evolution. 35:194-197. (INT)

\section{FREEMAN, D. CARL; and E. DURANT} MCARTHUR. 1982. A comparison of twig water stress between males and females of six species of desert shrubs. Forest Science. 28:304-308. (INT)

HARBERD, D. J.; and E. D. MCARTHUR. 1980. Meiotic analysis of some species and genus hybrids in the Brassiceae. In: Tsunoda,S.; K. Hinata, and C. GomezCampo, eds. Brassica crops and wild allies: biology and breeding. Tokyo, Japan. Scientific Societies Press: 65-87. (INT)

HEGERHORST, D. F.; D. J. WEBER; R. B. BHAT; [and others]. 1988. Seasonal changes in rubber and resin contents in Chrysothamnus nauseosus ssp. hololeucus and ssp. turbinatus. Biomass. 15:133-142. (INT)

HEGERHORST, D. F.; DARRELL J. WEBER; E. DURANT MCARTHUR; and A. J. KHAN. 1987. Chemical analysis and comparison of subspecies of Chrysothamnus nauseosus and other related species. Biochemical Systematics and Ecology. 15:201-208. (INT)

LEONARD, D. C.; E. D. MCARTHUR; D. J.; WEBER; and B. W. WOOD. 1981. Electrophoresis of isozymes of 16 western shrubs: technique development. Great Basin Naturalist. 41:377-389. (INT) 
MCARTHUR, E. D. 1977. Environmentally induced changes of sex expression in Atriplex canescens. Heredity. 38:97-103. (INT)

MCARTHUR, E. D.; A. P. PLUMMER; G. A. VAN EPPS; D. C. FREEMAN; and K. R. JORGENSEN. 1978. Producing fourwing saltbush in seed orchards. In: Hyder, Donald N., ed. Proceedings, 1st international rangeland congress; Denver, CO: Society for Range Management: 406-410. (INT)

MCARTHUR, E. D.; and C. L. POPE. 1977. Compositae. In: Love, A. IOPB Chromosome Number Reports. LV. Taxon. 26:107-109. (INT)

MCARTHUR, E. D.; and S. C. SANDERSON. 1985. A crytotanonomic contribution to the western North America rosaceous flora. Madrono. 32:24-28. (INT)

MCARTHUR, E. D.; B. L. WELCH; and S. C. SANDERSON. 1988. Natural and artificial hybridization between big sagebrush (Artemisia tridentate) subspecies. The Joumal of Heredity. 79(4):268-276. (INT)

MCARTHUR, E. D.; D. L. HANKS; A. P. PLUMMER; and A. C. BLAUER. 1978. Contributions to the taxonomy of Chrysothamnus viscidiflorus (Astereae, Compositae) and other Chrysothamnus species using paper chromatography. Journal of Range Management. 31:216223. (INT)

MCARTHUR, E. DURANT. 1979. Sagebrush systematics and evolution. In: The sagebrush ecosystem: a symposium; Logan, UT: Utah State University Press: 14-22. (INT)
MCARTHUR, E. DURANT. 1984. Natural diversity of western range shrubs. In: Cooley, James L.; and June H. Cooley, eds. Natural diversity in forest ecosystems: Proceedings of the workshop; 1982 November 29December 1; Athens, GA. Athens, GA: Institute of Ecology, University of Georgia: 193-209. (INT)

MCARTHUR, E. DURANT. 1988. Breeding systems in shrubs. In: McKell, Cyrus M., ed. The biology and utilization of shrubs. San Diego, CA: Academic Press: 341361. (INT)

MCARTHUR, E. DURANT. 1988. New plant development in range management. In: Tueller, P.T., ed. Vegetation science applications for rangeland analysis and management. Boston, MA: Kluwer Academic Publishers: 81-112. (INT)

MCARTHUR, E. DURANT; A. CLYDE BLAUER; A. PERRY PLUMMER; and RICHARD STEVENS. 1979. Characteristics and hybridization of important intermountain shrubs III. Sunflower Family. Res. Pap. INT-220. Ogden, UT: U.S. Department of Agriculture, Forest Service, Intermontain Forest and Range Experiment Station. 82 p. (INT)

MCARTHUR, E. DURANT; and BRUCE L. WELCH. 1982. Growth rate differences among big sagebrush Artemisia tridentata accessions and subspecies. Journal of Range Management. 35:396401. (INT)

MCARTHUR, E. DURANT; and C. LORENZO POPE. 1979. Karyotypes of four Artemisia species: $A$. carruthii, $A$. filifolia, $A$. frigida, and $A$. spinescens. Great Basin Naturalist. 39:419-426. (INT)

MCARTHUR, E. DURANT; and D. CARL FREEMAN. 1982. Sex expression in Atriplex canescens: Genetics and environment. Botanical Gazette. 143:476-482. (INT) 
MCARTHUR, E. DURANT; C. LORENZO POPE; and D. CARL FREEMAN. 1981. Chromosomal studies of subgenus Tridentatae of Artemisia: Evidence for autopolyploidy. American Journal Botany. 68(6):589-605. (INT)

MCARTHUR, E. DURANT; HOWARD C. STUTZ; and STEWART C. SANDERS. 1983. Taxonomy, distribution, and cytogenetics of Purshia, Cowania, and Fallugia (Rosoideae, Rosaceae). In: Tiedemann, Arthur R.; and Kendall L. Johnson, comps. Research and management of bitterbrush and cliffrose in western North America: Proceedings of a symposium; 1982 April 13-15; Salt Lake City, UT. Gen. Tech. Rep. INT152. Ogden, UT: U.S. Department of Agriculture, Forest Service, Intermountain Forest and Range Experiment Station: 4-24. (INT)

MCARTHUR, E. DURANT; RICHARD STEVENS, and A. CLYDE BLAUER. 1983. Growth performance comparisons among 18 accessions of fourwing saltbush (Atriplex canescens) at two sites in central Utah. Journal of Range Management. 36:78-81. (INT)

MCARTHUR, E. DURANT; STEWART C. SANDERSON; and D. CARL FREEMAN. 1986. Isozymes of an autopolyploid shrub, Atriplex canescens (Chenopodiaceae). Great Basin Naturalist. 46:157-160. (INT)

MCDONOUGH, W. T.; R. O. HARNISS; and R. B. CAMPBELL. 1975. Morphology of ephemeral and persistent leaves of three subspecies of big sagebrush grown in a uniform environment. Great Basin Naturalist. 35:315-326. (INT)
MURPHY, PATRICK M., comp. 1984. The challenge of producing native plants for the Intermountain area. Proceedings, 1983 Intermountain Nurseryman's Association Conference; 1983 August 811; Las Vegas, NV. Gen. Tech. Rep. INT-168. Ogden, UT: U.S. Department of Agriculture, Forest Service, Intermountain Forest and Range Experiment Station. 96 p. (INT)

NOLLER, GARY L.; and E. DURANT MCARTHUR. 1986. Establishment and initial results from a sagebrush (Artemisia tridentata) [Nutt.]) mass selection garden. In: McArthur, E. Durant; and Bruce L. Welch, comps. Proceedings--symposium on the biology of Artemisia and Chrysothamnus; 1984 July 9-13; Provo, UT. Gen. Tech. Rep. INT-200. Ogden, UT: U.S. Department of Agriculture, Forest Service, Intermountain Forest and Range Experiment Station: 104-107. (INT)

PENDLETON, R. L.; S. C. SANDERSON; and E. D. MCARTHUR. 1985. Morphologic and enzymatic variability among Gambel oak clones in north central Utah. In: Johnson, K. L. ed. Proceedings of the third Utah Shrub Ecology Workshop. Logan, UT: Utah State University, College of Natural Resources: 19-28. (INT)

PENDLETON, ROSEMARY L.; BURTON K. PENDLETON; and KIMBALL T. HARPER. 1989. Breeding systems of woody plant species in Utah. In: Wallace, Arthur; E. Durant McArthur; and Marshall R. Haferkamp, comps. Proceedings--symposium on shrub ecophysiology and biotechnology; 1987 June 30-July 2; Logan, UT. Gen. Tech. Rep. INT-256. Ogden, UT: U.S. Department of Agriculture, Forest Service, Intermountain Research Station: 5-22. (INT) 
PENDLETON, ROSEMARY L.; E. DURANT MCARTHUR; D. CARL FREEMAN; and A. CLYDE BLAUER. 1988.

Heterodichogamy in Grayia brandegei (Chenopodiaceae): report from a new family. American Journal of Botany. 75:267-274. (INT)

SANDERSON, STEWART C.; E. DURANT MCARTHUR; and HOWARD C. STUTZ. 1989. A relationship between polyploidy and habitat in western shrub species. In: Wallace, Arthur; E. Durant McArthur; and Marshall R. Haferkamp, comps. Proceedings--symposium on shrub ecophysiology and biotechnology; 1987 June 30-July 2; Logan, UT. Gen. Tech. Rep. INT-256. Ogden, UT: U.S. Department of Agriculture, Forest Service, Intermountain Research Station: 23-30. (INT)

SCHIER, G. A.; and R. B. CAMPBELL. 1976. Differences among populus species in ability to form adventitious shoots and roots. Canadian Journal of Forest Research. 6:253-26I. (INT)

SHAW, NANCY L.; and STEPHEN B. MONSEN. 1983. Phenology and growth habits of nine antelope bitterbrush, desert bitterbrush, Stansbury cliffrose, and apache plume accessions. In: Tiedemann, Arthur R.; and Kendall L. Johnson, comps. Research and management of bitterbrush and cliffrose in western North America: Proceedings of a symposium; 1982 April 13-15; Salt Lake City, UT. Gen. Tech. Rep. INT152. Ogden, UT: U.S. Department of Agriculture, Forest Service, Intermountain Forest and Range Experiment Station: 55-69. (INT)

SHAW, NANCY L.; S. B. MONSEN; and J. R. CARLSON. 1984. Notice of release of "Lassen" antelope bitterbrush. Plant Release Notice. Salt Lake City, UT: U.S. Department of Agriculture, Soil Conservation Service. 4 p. (INT)
SHAW, NANCY; and STEPHEN B. MONSEN. 1986. 'Lassen' antelope bitterbrush: a browse plant for game and livestock ranges. Rangelands. 8:122124. (INT)

STEVENS, R.; K. R. JORGENSON; E. D. McARTHUR; and J. N. DAVIS. 1984. Notice of release of 'Immigrant' forage kochia. Plant Release Notice. Salt Lake City, UT: U.S. Department of Agriculture, Soil Conservation Service. 3 p. (INT)

STEVENS, R.; S. B. MONSEN; N. SHAW; B. WELCH; G. JAMES; K. R. JORGENSEN; and J. N. DAVIS. 1983. Naming and release of 'Paiute' orchardgrass for commercial production and marketing of seeds. Plant Release Notice. Salt Lake City, UT: U.S. Department of Agriculture, Soil Conservation Service. 2 p. (INT)

STEVENS, R.; S. B. MONSEN; N. SHAW; E. D. MCARTHUR; G. JAMES; G. DAVIS; K. R. JORGENSEN; and J. N. DAVIS. 1983. Naming and release of 'Ephraim' crested wheatgrass for commercial production and marketing of seed. Plant Release Notice. Salt Lake City, UT: U.S. Department of Agriculture, Soil Conservation Service. 2 p. (INT)

STEVENS, RICHARD; and STEPHEN B. MONSEN. 1985. Recent plant releases for western wildlands. In: Vegetation rehabilitation and equipment workshop: 39th annual report; 1985 February 1011; Salt Lake City, UT. Missoula, MT: U.S. Department of Agriculture, Forest Service, Equipment Development Center: 34-36. (INT)

STUTZ, HOWARD C.; STEWART C. SANDERSON; and E. DURANT MCARTHUR; CHU GE-LIN. 1987. Chromosome races of Grayia brandegei (Chenopodiaceae). Madrono. 34(2):142149. (INT) 
TIEDEMANN, ARTHUR R.; E. DURANT MCARTHUR; and CARL D. FREEMAN. 1987. Variations in physiological metabolites and chlorophyll in sexual phenotypes of "Rincon" fourwing saltbush. Journal of Range Management. 40:151-155. (INT)

VICKERY, R. K., JR.; E. S. McARTHUR; and S. P. PURCELL. 1978.

Scrophulariaceae. In: A. Love IOPB Chromosome Number Reports LX. Taxon. 27:223-23I. (INT)

WEBER, D. J.; T. D. DAVIS; E. D. MCARTHUR; and N. SANKHLA. 1985. Chrysothamnus nauseosus (rubber rabbitbrush): Multiple-use shrub of the desert. Desert Plants. 7:172-180. (INT)

WEBER, DARRELL J.; DALE F. HEGERHORST; TIM D. DAVIS; and E. DURANT MCARTHUR. 1987. Potential uses of rubber rabbitbrush

(Chrysothamnus nauseosus). In: Johnson, Kendall L., ed. Proceedings of the fourth shrub ecology workshop: the genus Chrysothamnus: 1986 September 17-18; Cedar City, UT. Logan, UT: Utah State University, College of Natural Resources: 27-33. (INT)

WELCH, BRUCE L.; and E. DURANT MCARTHUR. 1979. Feasibility of improving big sagebrush (Artemisia tridentata) for use on mule deer winter ranges. In: Goodin, J.R.; and David K. Northington, eds. Arid land plant resources. Lubbock, TX: Intermountain Center for Arid and Semi-Arid Land Studies, Texas Tech University: 451473. (INT)

WELCH, BRUCE L.; and E. DURANT MCARTHUR. 1979. Variation in winter levels of crude protein among Artemisia tridentata subspecies grown in a uniform garden. Journal Range Management. 32:467-469. (INT)
WELCH, BRUCE L.; and E. DURANT MCARTHUR. 1981. Variation of monoterpenoid content among subspecies and accessions of Artemisia tridentata grown in a uniform garden. Journal of Range Management. 34:380384. (INT)

WELCH, BRUCE L.; and E. DURANT MCARTHUR. 1986. Growth rate of big sagebrush as influenced by accessions, sites, subspecies, and years. In: McArthur, E. Durant; and Bruce L. Welch, comps. Proceedings-symposium on the biology of Artemisia and Chrysothamnus; 1984 July 9-13; Provo, UT. Gen. Tech. Rep. INT-200. Ogden, UT: U.S. Department of Agriculture, Forest Service, Intermountain Forest and Range Experiment Station: 342-346. (INT)

WELCH, BRUCE L.; and STEPHEN B. MONSEN. 1981. Winter crude protein among accessions of fourwing saltbrush grown in a uniform garden. Great Basin Naturalist. 41:343-346. (INT)

WELCH, BRUCE L.; DAVID L. NELSON; and E. DURANT MCARTHUR. 1986. Improvement of wildland shrubs through selection and breeding. In: Joss, P. J.; P. W. Lynch; and O. B. Williams, eds. Rangelands: a resource under siege: Proceedings, 2nd international rangeland congress; 1985 May 13-18; Adelaide, Australia. Canberra, Australia: Australia Academy of Science: 467-468. (INT)

WELCH, BRUCE L.; E. DURANT MCARTHUR; DAVID L. NELSON; JORDAN C. PEDERSON; and JAMES N. DAVIS. 1986. "Hobble Creek"--a superior selection of low-elevation mountain big sagebrush. Res. Pap. INT370. Ogden, UT: U.S. Department of Agriculture, Forest Service, Intermountain Research Station. 10 p. (INT) 
WELCH, BRUCE L.; E. DURANT

MCARTHUR; and RONALD L.

RODRIGUEZ. 1987. Variations in

utilization of big sagebrush accessions

by wintering sheep. Journal of Range

Management. 40:113-115. (INT)

\section{Plant Physiology}

BRIGHT, LARRY. 1978. Weather stress difference between two levels of juniper canopy cover. In: Martin, Robert E.; J. Edward Dealy; and David L. Caraher, eds: Proceedings of the western juniper ecology and management workshop; 1977 January; Bend, OR. Gen. Tech. Rep. PNW-74. Portland, OR: U.S. Department of Agriculture, Forest Service, Pacific Northwest Forest and Range Experiment Station: 91-95. (PNW)

BROWN, R. W. 1987. Ecophysiology and water relations research in the pinyonjuniper vegetation type. In: Everett, Richard L., comp. Proceedings, Pinyonjuniper Conference; 1986 January 1316; Reno, NV. Gen. Tech. Rep. INT215. Ogden, UT: U.S. Department of Agriculture, Forest Service, Intermountain Forest and Range Experiment Station: 398-405 (INT).

CABLE, DWIGHT R. 1977. Seasonal use of soil water by velvet mesquite. Journal of Range Management. 30:4-11. (RM)

CABLE, DWIGHT R. 1982. Partial defoliation stimulates growth of Arizona cottontop. Journal of Range Management. 35:591593. (RM)

CAMPBELL, ALSIE G.; and JERRY F. FRANKLIN. 1979. Riparian vegetation in Oregon's western Cascade Mountains: composition, biomass, and autumn phenology. Coniferous Forest Biome Bulletin 14.90 p. (PNW)

CLARY, WARREN P. 1979. Variation in leaf anatomy and $\mathrm{CO}_{2}$ assimilation in Sitanion hystrix ecotypes. Great Basin Naturalist. 39:427-432. (RM)
CLARY, WARREN P. 1986. Black sagebrush response to grazing in the east-central Great Basin. In: McArthur, E. Durant; and Bruce L. Welch, comps.

Proceedings--symposium on the biology of Artemisia and Chrysothamnus; 1984 July 9-13; Provo, UT. Gen. Tech. Rep. INT-200. Ogden, UT: U.S. Department of Agriculture, Forest Service, Intermountain Forest and Range Experiment Station: 181-185. (INT)

CLARY, WARREN P.; and WILLIAM H. KRUSE. 1979. Phenology and rate of height growth of some forbs in the southwestern ponderosa pine type. Res. Note RM-376. Fort Collins, CO: U.S. Department of Agriculture, Forest Service, Rocky Mountain Forest and Range Experiment Station. 8 p. (RM)

COLEY, PHYLLIS D. 1987. Between-species differences in leaf defenses of tropical trees. In: Provenza, Frederick D.; Jerran T. Flinders; and E. Durant McArthur, comps. Symposium on plant-herbivore interactions; 1985 August 7-9; Snowbird, UT. Gen. Tech. Rep. INT-222. Ogden, UT: U.S. Department of Agriculture, Forest Service, Intermountain Research Station: 30-35. (INT)

CRESS, WILLIAM; and GORDON V. JOHNSON. 1987. The effect of three osmotic agents on free proline and amino acid pools in Atriplex canescens and Hilaria jamessi. Canadian Journal of Botany. 65:799-801. (RM)

EVERETT, R. L.; R. O. MEEUWIG; P. T. TUELLER; and R. A. EVANS. 1977. Water potential in sagebrush and shadscale communities. Northwest Science. 51:271-281. (INT)

EVERETT, RICHARD L. 1987. Allelopathic effects of pinyon and juniper litter on emergence and growth of herbaceous species. In: Proceedings of symposium-seed and seedbed ecology of rangeland plants; 1987 April 21-23; Tucson, AZ: U.S. Department of Agriculture, Agricultural Research: 62-67. (INT) 
EVERETT, RICHARD; PAUL TUELLER; BARRY DAVIS; and ALLEN BRUNNER. 1981. Plant phenology in galletashadscale and galleta-sagebrush associations. Journal of Range Management. 33:446-450. (INT)

FOWLER, W. B.; and A. R. TIEDEMANN. 1980. Phenological relationships of Spiraea betulifolia Pall. and Apocynum androsaemifolium L. Northwest Science. 54:17-25. (INT)

FRANK, CAROLYN T.; BRUCE N. SMITH; and BRUCE L. WELCH. 1986. Photosynthesis, growth, transpiration, and $13 \mathrm{C}$ relationships among three subspecies of big sagebrush (Artemisia tridentata Nutt.). In: McArthur, E. Durant; and Bruce L. Welch, comps.

Proceedings--symposium on the biology of Artemisia and Chrysothamnus; 1984 July 9-13; Provo, UT. Gen. Tech. Rep. INT-200. Ogden, UT: U.S. Department of Agriculture, Forest Service, Intermountain Forest and Range Experiment Station: 332-335. (INT)

HARRINGTON, MICHAEL G. 1989. Gambel oak root carbohydrate response to spring, summer, and fall prescribed burning. Journal of Range Management. 42:504-507. (RM)

HEGERHORST, D. F.; B. B. BHAT; D. J. WEBER; and E. D. MCARTHUR. 1988. Seasonal changes of selected secondary plant products in Chrysothamnus nauseosus_spp. turbinatus. Great Basin Naturalist. 48:17. (INT)

HEGERHORST, D. F.; D. J. WEBER; R. B. BHAT; [and others]. 1988. Seasonal changes in rubber and resin contents in Chrysothamnus nauseosus ssp. hololeucus and ssp. turbinatus. Biomass. 15:133-142. (INT)

HEGERHORST, DALE; DARRELL W. WEBER; and E. DURANT MCARTHUR. 1988. Resin and rubber content in Chrysothamnus. The Southwestern Naturalist. 32:475-482. (INT)
HIELD, HENRY; T. R. PLUMB; and STUART HEMSTREET. 1984. Plant growth regulator influence on chaparral and native grasses. In: Crabtree, Allen F., ed. Proceedings, 3rd international symposium on environmental concerns in rights-of-way management; 1982 February 15-18; San Diego, CA. Mississippi State, MS: Mississippi State University: 389-401. (PSW)

MCARTHUR, E. DURANT; ARTHUR WALLACE; and MARSHALL R. HAFERKAMP. 1989. Introduction: shrub ecophysiology and biotechnology. In: Wallace, Arthur; E. Durant McArthur; and Marshall R. Haferkamp, comps. Proceedings--symposium on shrub ecophysiology and biotechnology; 1987 June 30-July 2; Logan, UT. Gen. Tech. Rep. INT-256. Ogden, UT: U.S. Department of Agriculture, Forest Service, Intermountain Research Station: 1-3. (INT)

MCCONNELL, BURT R.; and JUSTIN G. SMITH. 1977. Influence of grazing on age-yield interactions in bitterbrush. Journal of Range Management. 30:9193. (INT)

MINORE, DON; HOWARD G. WEATHERLY; and JOSEPH E. MEANS. 1988. Growth of whiteleaf manzanita (Arctostaphylos viscida Parry). Forest Science. 34:10941100. (PNW)

MUEGGLER, WALTER F. 1983. Variation in production and seasonal development on mountain grasslands in western Montana. Res. Pap. INT-316. Ogden, UT: U.S. Department of Agriculture, Forest Service, Intermountain Forest and Range Experiment Station. $16 \mathrm{p}$. (INT) 
NOBLE, DANIEL L.; and MARMION HOWE,

SR. 1983. Cyanide in riparian

vegetation. In: Fuerstenau, Maurice C.;

and Bruce R. Palmer, eds. Gold, silver,

uranium, and coal: geology, mining,

extraction and the environment. New

York, NY: The American Institute of

Mining, Metallurgical and Petroleum

Engineers, Inc.: 498-505. (RM)

OHMANN, LEWIS F.; and DAVID F. GRIGAL. 1977. Some individual plant biomass values from northeastern Minnesota.

Res. Note NC-227. St. Paul, MN: U.S.

Department of Agriculture, Forest

Service, North Central Forest

Experiment Station. 2 p. (NC)

OHMANN, LEWIS F.; DAVID F. GRIGAL; and ROBERT B. BRANDER. 1978. Shrub mass: date variability and changes over time. Proceedings of the North American Moose Conference and Workshop. 10:172-214. (NC)

PROVENZA, FREDERICK D.; JERRAN T. FLINDERS; and E. DURANT MCARTHUR. 1987. Introduction: plantherbivore interactions. In: Provenza, Frederick D; Jerran T. Flinders; and E. Durant McArthur, comps. Proceedings-symposium on plant-herbivore interactions; 1985 August 7-9; Snowbird, UT. Gen. Tech. Rep. INT-222. Ogden, UT: U.S. Department of Agriculture, Forest Service, Intermountain Research Station: 1. (INT)

\section{PROVENZA, FREDERICK D.; JERRAN T.}

FLINDERS; and E. DURANT

MCARTHUR, comps. 1987.

Proceedings--Symposium on plantherbivore interactions. 1985 August 7-9; Snowbird UT. Gen. Tech. Rep. INT-222. Ogden, UT: U.S. Department of Agriculture, Forest Service, Intermountain Forest and Range Experiment Station. 179 p. (INT)
QUINN, RONALD D. 1986. Mammalian herbivory and resilency in

Mediterranean-climate ecosystems. In:

Dell, B; A. J. M. Hopkins; and B. B. Lamont, comps., eds. Resilience in Mediterranean-type ecosystems. Dordrecht: Dr. W. Junk Publishers: 113128. (PSW)

ROBBINS, C. T.; T. A. HANLEY; A. E. HAGERMAN; O. HJELJORD; D. L. BAKER; and C. C. SCHWARTZ. 1987. Role of tannins in defending plants against ruminants: reduction in protein availability. Ecology. 68:98-107. (PNW)

ROTHENBERGER, S. J.; G. E. LARSON; W. T. BAKER; and D. S. GALITZ. 1976. Plant community and growth analysis in the vicinity of Stanton, North Dakota. Proceedings, North Dakota Academy Science. 30:39. (RM)

SHAW, NANCY L.; and STEPHEN B. MONSEN. 1983. Phenology and growth habits of nine antelope bitterbrush, desert bitterbrush, Stansbury cliffrose, and apache plume accessions. In: Tiedemann, Arthur R.; and Kendall L. Johnson, comps. Research and management of bitterbrush and cliffrose in western North America: Proceedings of a symposium; 1982 April 13-15; Salt Lake City, UT. Gen. Tech. Rep. INT152. Ogden, UT: U.S. Department of Agriculture, Forest Service, Intermountain Forest and Range Experiment Station: 55-69. (INT)

STEELE, JUDITH M.; RAYMOND D. RATLIFF; GARY L. RITENOUR. 1984. Seasonal variation in total nonstructural carbohydrate levels in Nebraska sedge. Journal of Range Management. 37:465467. (PSW)

STURGES, D. L.; and M. J. TRLICA. 1978. Root weights and carbohydrate reserves of big sagebrush. Ecology. 59:12821285. (RM) 
TIEDEMANN, ARTHUR R.; E. DURANT MCARTHUR; and CARL D. FREEMAN. 1987. Variations in physiological metabolites and chlorophyll in sexual phenotypes of "Rincon" fourwing saltbush. Journal of Range Management. 40:151-155. (INT)

\section{WALLACE, ARTHUR; E. DURANT} MCARTHUR; and MARSHALL R. HAFERKAMP, comps. 1989. Proceedings--symposium on shrub ecophysiology and biotechnology; 1987 June 30-July 2; Logan, UT. Gen. Tech. INT-256. Ogden, UT: U.S. Department of Agriculture, Forest Service, Intermountain Research Station. $183 p$. (INT)

WEBER, D. J.; D. F. HEGERHORST; R. B. BHAT; T. D. DAVIS; and E. D. MCARTHUR. 1989. Phisiological changes in Chrysothamnus nauseosus in relation to rubber and resin production. In: Wallace, Arthur; E. Durant McArthur; and Marshall R. Haferkamp, comps. Proceedings-symposium on shrub ecophysiology and biotechnology; 1987 June 30-July 2; Logan, UT. Gen. Tech. Rep. INT-256. Ogden, UT: U.S. Department of Agriculture, Forest Service, Intermountain Research Station: 173183. (INT)

WELCH, BRUCE L.; and E. DURANT MCARTHUR. 1979. Variation in winter levels of crude protein among Artemisia tridentata subspecies grown in a uniform garden. Journal of Range Management. 32:467-469. (INT)

WELCH, BRUCE L.; and E. DURANT MCARTHUR. 1981. Variation of monoterpenoid content among subspecies and accessions of Artemisia tridentata grown in a uniform garden. Journal of Range Management. 34:380384. (INT)
WELCH, BRUCE L.; and E. DURANT MCARTHUR. 1986. Growth rate of big sagebrush as influenced by accessions, sites, subspecies, and years. In: McArthur, E. Durant; and Bruce L. Welch, comps. Proceedings-symposium on the biology of Artemisia and Chrysothamnus; 1984 July 9-13; Provo, UT. Gen. Tech. Rep. INT-200. Ogden, UT: U.S. Department of Agriculture, Forest Service, Intermountain Forest and Range Experiment Station: 342-346. (INT)

WISDOM, C. S.; C. S. CRAWFORD; and E. F. ALDON. 1989. Influence of insect herbivory on photosynthetic area and reproduction in Gutierrezia species. Journal of Ecology. 77:685-692. (RM)

WOOD, BENJAMIN W.; and JACK D. BROTHERSON. 1986. Ecological adaptation and grazing response of budsage (Artemisia spinescens) in southwestern Utah. In: McArthur, E. Durant; and Bruce L. Welch, comps. Proceedings--symposium on the biology of Artemisia and Chrysothamnus; 1984 July 9-13; Provo, UT. Gen. Tech. Rep. INT-200. Ogden, UT: U.S. Department of Agriculture, Forest Service, Intermountain Forest and Range Experiment Station: 75-92. (INT)

\section{Water Relations}

BROWN, R. W. 1977. Water relations of range plants. In: Rangeland plant physiology. Range Science Series No. 4. Denver, CO: Society for Range Management: 97-140. Chapter IV. (INT)

BROWN, RAY W. 1987. Ecophysiology and water relations research in the pinyonjuniper vegetation type. In: Everett, Richard L., comp. Proceedings--pinyonjuniper conference; 1986 January 13-16; Reno, NV. Gen. Tech. Rep. INT-215. Ogden, UT: U.S. Department of Agriculture, Forest Service, Intermountain Research Station: 398405. (INT) 
CONARD, SUSAN G. 1986. Comparative water relations of three shrub species-preliminary results. Fir Report. 7(4):4-5. (PSW)

DAVIS, E. A.; and C. P. PASE 1977. Root system of shrub live oak: implications for water yield in Arizona chaparral. Journal of Soil and Water Conservation. 32:174180. (RM)

DAVIS, EDWIN A. 1977. Root system of shrub live oak in relation to water yield by chaparral. In: Proceedings, Hydrology and water resources in Arizona; 1977 April; Las Vegas, NV: Arizona Section American Water Resource Association and Hydrology Section, Arizona Academy Science. 7:241-248. (RM)

DRIVAS, EVAN P.; and RICHARD L. EVERETT. 1987. Xylem water potentials of singleleaf pinyon seedlings and sagebrush nurse plants. In: Everett, Richard L., comp. Proceedings--pinyonjuniper conference; 1986 January 13-16; Reno, NV. Gen. Tech. Rep. INT-215. Ogden, UT: U.S. Department of Agriculture, Forest Service, Intermountain Research Station: 423428. (INT)

DRIVAS, EVAN P.; and RICHARD L. EVERETT. 1988. Water relations characteristics of competing singleleaf pinyon seedlings and sagebrush nurse plants. Forest Ecology and Management. 23:27-37. (INT)

FREEMAN, D. CARL; and E. DURANT MCARTHUR. 1982. A comparison of twig water stress between males and females of six species of desert shrubs. Forest Science. 28:304-308. (INT)

GREEN, NORMAN E.; MICHAEL D. SMITH; WILLIAM D. BEAVIS; and EARL F. ALDON. 1983. Influence of vesiculararbuscular mycorrhizal fungi on the modulation and growth of subclover. Journal of Range Management. 36:576578. (RM)
KNIPE, OREN D. 1985. Effects of reducing shrub cover on moisture stress in mountain mahogany. Journal of Soil and Water Conservation. 40:445-447. (RM)

MCDONOUGH, W. T. 1976. Water potentials of seeds of Bromus inermis and Medicago sativa imbibed on media of various osmotic potentials. Candian Journal of Botony. 54:1997-1999. (INT)

MOHLER, ROBERT R.; and RICHARD O. GIFFORD. 1987. A solar-radiationdriven water budget methodology for sloping arid and semiarid lands. Physical Geography. 5:132-141. (INT)

STURGES, DAVID L. 1977. Soil water withdrawal and root characteristics of big sagebrush. American Midland Naturalist. 98:257-274. (RM)

TAUSCH, ROBIN J.; and NEIL E. WEST. 1987. Morphological variation/precipitation relationships of Great Basin single-needled pinyon. In: Everett, Richard L., comp. Proceedings-pinyon-juniper conference; 1986 January 13-16; Reno, NV. Gen. Tech. Rep. INT-215. Ogden, UT: U.S. Department of Agriculture, Forest Service, Intermountain Research Station: 86-91. (INT)

VAN KEKERIX, LORRAINE K.; RAY W. BROWN; and ROBERT S. JOHNSTON. 1979. Seedling water relations of two grass species on high-elevation acid mine spoils. Res. Note INT-262. Ogden, UT: U.S. Department Agriculture, Forest Service, Intermountain Forest and Range Experiment Station: 17 p. (INT) 
WILKINS, SCOTT D.; and JEFFREY M. KLOPATEK. 1984. Moisture stress, Atriplex species, and reclamation at Black Mesa, Arizona. In: Tiedemann, Arthur R.; E. Durant McArthur; Howard C. Stutz; Richard Stevens; and Kendall L. Johnson, eds. Proceedings-symposium on the biology of Atriplex and related chenopods; 1983 May 2-6; Provo, UT. Gen. Tech. Rep. INT-172. Ogden, UT: U.S. Department of Agriculture, Forest Service, Intermountain Forest and Range Experiment Station: 97-107. (INT)

\section{Germination And Propagation}

ALLEN, PHIL S.; SUSAN E. MEYER; and TIM D. DAVIS. 1987. Determining seed quality of winterfat (Ceratoides lanata [Pursh.] J.T. Howell). Journal of Seed Technology. 11(1):7-14. (INT)

APPLEGATE, ROGER D.; LYNN L. ROGERS; DAVID A. CASTEEL; and JAMES M. NOVAK. 1979. Germination of cow parsnip seeds from grizzly bear feces. Journal of Mammalogy. 60:655. (NC)

BJUGSTAD, ARDELL J.; KENDALL E. KISSEL; and WARREN C. WHITMAN. 1984. Germination of shrubs for wildlife habitat restoration in mined lands in the northern Great Plains. In: Issues and technology in the management of impacted western wildlife: proceedings of a national symposium; 1982 November 15-17; Steamboat Springs, CO. Boulder, CO: Thorne Ecological Institute: 238-245. (RM)

CHAMBERS, JEANNE C.; JAMES A. MACMAHON; and RAY W. BROWN. 1987. Germination characteristics of alpine grasses and forbs: a comparison of early and late seral dominants with reclamation potential. Reclamation and Revegetation Research. 6:235-249. (INT)
EDDLEMAN, LEE E. 1979. Germination in black greasewood (Sarcobatus vermiculatus Hook. Ton.). Northwest Science. 53:289-294. (INT)

EVERETT, RICHARD L. 1986. Understory seed rain in harvested pinyon-juniper woodlands. Great Basin Naturalist. 46:706-710. (INT)

EVERETT, RICHARD L.; and CLAYTON R. GAUTIER. 1981. Rooting purple sage stem cuttings. Res. Note INT-316. Ogden, UT: U.S. Department of Agriculture, Forest Service, Intermountain Forest and Range Experiment Station. 4 p. (INT)

EVERETT, RICHARD L.; and STEVEN H. SHARROW. 1983. Understory seed rain on tree-harvested and unharvested pinyon-juniper sites. Journal of Environmental Management. 17:349358. (INT)

EVERETT, RICHARD L.; RICHARD O. MEEUWIG; and JOSEPH H. ROBERTSON. 1978. Propagation of Nevada shrubs by stem cuttings. Journal of Range Management. 31:426429. (INT)

GOTTFRIED, GERALD J. 1987.

Regeneration of pinyon. In: Everett, Richard L., comp. Proceedings--pinyonjuniper conference; 1986 January 13-16; Reno, NV. Gen. Tech. Rep. INT-215. Ogden, UT: U.S. Department of Agriculture, Forest Service, Intermountain Research Station: 249254. (RM)

HAGGAS, LUCINDA; RAY W. BROWN; and ROBERT S. JOHNSTON. 1987. Light requirement for seed germination of Payson sedge. Journal of Range Management. 40:180-184. (INT)

HELMS, JOHN G.; and RAYMOND D. RATLIFF. 1987. Germination and establishment of Pinus contorta var. murrayana (Pinaceae) in mountain meadows of Yosemite National Park, California. Madrono. 34(2):77-90. (PSW) 
KHAN, M. A.; N. SANKHLA; DARRELL J. WEBER; and E. DURANT MCARTHUR. 1987. Seed germination characteristics of Chrysothamnus nauseosus ssp. viridulus (Astereae, Asteraceae). Great Basin Naturalist. 47:220-226. (INT)

KITCHEN, STANLEY; SUSAN E. MEYER; G. RICHARD WILSON; JAMES N. DAVIS; RICHARD STEVENS. 1987. Addition of Hedysarum boreale-northern sweetvetch to the rules. The Newsletter of the Association of Official Seed Analysts. 61(1):65-66. (INT)

MCARTHUR, E. D.; A. P. PLUMMER; G. A. VAN EPPS; D. C. FREEMAN; and K. R. JORGENSEN. 1978. Producing fourwing saltbush in seed orchards. In: Hyder, Donald N., ed. Proceedings, 1st international rangeland congress; Denver, CO: Society for Range Management: 406-410. (INT)

MCARTHUR, E. DURANT; MONSEN, STEPHEN B.; and BRUCE L. WELCH. 1987. Shrubs and forbs for revegetation plantings in the sagebrush ecosystem. In: Onsager, Jerome A., ed. Integrated pest management in rangeland: state of the art in the sagebrush ecosystem: symposium; 1984 March 27-28: [Place unknown]. ARS-50. Washington, DC: U.S. Department of Agriculture, Agricultural Research Service: 28-39. (INT)

MCARTHUR, E. DURANT; SUSAN E. MEYER; and DARREL J. WEBER. 1987. Germination rate at low temperature: rubber rabbitbrush population differences. Journal of Range Management. 40:530-533. (INT)

MCDONOUGH, W. T. 1976. Germination of seeds treated with gibberellic acid and kinetin during stratification. Phyton. 34(1):41-44. (INT)

MCDONOUGH, W. T. 1976. Water potentials of seeds of Bromus inermis and Medicago sativa imbibed on media of various osmotic potentials. Candian Journal of Botany. 54:1997-1999. (INT)
MCDONOUGH, W. T. 1977. Seed physiology. In: Sosebee, R. E., ed. Rangeland plant physiology. Range Science Series No. 4.; Denver, CO: Society for Range Management: 155-184. Chapter 6. (INT)

MEYER, SUSAN E.; and E. DURANT MCARTHUR. 1987. Studies on the seed germination biology of rubber rabbitbrush. In: Johnson, Kendall L., ed. Proceedings of the 4th shrub ecology workshop: the genus Chrysothamnus; 1986 September 17-18; Cedar City, UT. Logan, UT: Utah State University, College of Natural Resources: 19-25. (INT)

MEYER, SUSAN E.; and STEPHEN B. MONSEN. 1989. Seed germination biology of antelope bitterbrush (Purshia tridentata). In: Wallace, Arthur; E. Durant McArthur; and Marshall R. Haferkamp, comps. Proceedings-symposium on shrub ecophysiology and biotechnology; 1987 June 30-July 2; Logan, UT. Gen. Tech. Rep. INT-256. Ogden, UT: U.S. Department of Agriculture, Forest Service, Intermountain Research Station: 147157. (INT)

MEYER, SUSAN E.; E. DURANT MCARTHUR; and STEPHEN B. MONSEN. 1987. Infraspecific variation in germination patterns of rangeland shrubs and its relationship to seeding success. In: Frasier, Gary W.; and Raymond Evans, eds. Seed and seedbed ecology of rangeland plants: Proceedings of symposium; 1987 April 21-23; Tucson, AZ; U.S. Department of Agriculture, Agricultural Research Service: 82-92. (INT)

MEYER, SUSAN E.; PHIL A. ALLEN; RICHARD G. WILSON; JAMES N. DAVIS; and RICHARD STEVENS. 1987. Addition of Penstemon strictus-Rocky Mountain penstemon to the Rules. The Newsletter of the Association of Official Seed Analysts. 61(1):62-63. (INT) 
MEYER, SUSAN E.; PHIL A. ALLEN;

RICHARD G. WILSON; JAMES N.

DAVIS; and RICHARD STEVENS.

1987. Addition of Penstemon palmeri--

Palmer penstemon to the Rules. The

Newsletter of the Association of Official

Seed Analysts. 61(1):62 (INT)

MEYER, SUSAN E.; PHIL A. ALLEN;

RICHARD G. WILSON; JAMES N.

DAVIS; and RICHARD STEVENS.

1987. Addition of Penstemon eatonii--

firecracker penstemon to the Rules. The

Newsletter of the Association of Official

Seed Analysts. 61(1):62. (INT)

MEYER, SUSAN E.; PHIL A. ALLEN;

RICHARD G. WILSON; JAMES N.

DAVIS; and RICHARD STEVENS.

1987. Addition of Elymus elmoides-bottlebrush squirreltail to the Rules. The Newsletter of the Association of Official Seed Analysts. 61(1):59-61. (INT)

MEYER, SUSAN E.; PHIL A. ALLEN;

RICHARD G. WILSON; JAMES N.

DAVIS; and RICHARD STEVENS. 1987. Addition of Secale montanum-mountain rye to the Rules. The Newsletter of the Association of Official Seed Analysts. 61(1):63-65. (INT)

MEYER, SUSAN E.; PHIL A. ALLEN; RICHARD G. WILSON; JAMES N. DAVIS; and RICHARD STEVENS. 1987. Addition of Amelanchier alnifolia-saskatoon serviceberry to the Rules. The Newsletter of the Association of Official Seed Analysts. 61(1):66-68. (INT)

MEYER, SUSAN E.; STANLEY KITCHEN; RICHARD G. WILSON; and RICHARD STEVENS. 1988. Proposal: addition of Artemisia ludoviciana--Louisiana sagewort to the rules. The Newsletter of the Association of Official Seed

Analysts. 62(1):15-16. (INT)
MEYER, SUSAN E.; STANLEY KITCHEN; RICHARD G. WILSON; and RICHARD STEVENS. 1988. Proposal: addition of Ephedra viridis--green Mormon tea to the rules. The Newsletter of the Association of Official Seed Analysts. 62(1):18-19. (INT)

MEYER, SUSAN E.; STANLEY KITCHEN; RICHARD G. WILSON; and RICHARD STEVENS. 1988. Proposal: addition of Artemisia nova--(syn. Artemisia arbuscula subsp. nova) black sagebrush to the rules. The Newsletter of the Association of Official Seed Analysts. 62(1):16-17.(INT)

MIYAMOTO, S.; and J. B. BIRD. 1978. Effects of two wetting agents on germination and shoot growth of some southwestern range plants. Journal of Range Management. 31:74-75. (RM)

MONSEN, STEPHEN B.; and RICHARD STEVENS. 1987. Seed and seedling characteristsics of rabbitbrush. In: Johnson, Kendall L., ed. Proceedings of the 4th shrub ecology workshop: the genus Chrysothamnus; 1986 September 17-18; Cedar City, UT. Logan, UT: Utah State University, College of Natural Resources: 41-49. (INT)

MONSEN, STEPHEN B.; RICHARD STEVENS; and KENT R. JORGENSEN. 1985. Seed harvesters--an evaluation of existing machines and projected needs. In: Vegetative rehabilitation and equipment workshop: 39th annual report; 1985 February 10-11; Salt Lake City, UT. Missoula, MT: U.S.

Department of Agriculture, Forest Service, Equipment Development Center: 37-39. (INT) 
NELSON, DAVID L. 1983. Toward producing disease-free container-grown native wildland plants. In: Murphy, Patrick M., comp. The challenge of producing native plants for the Intermountain area: Proceedings; 1983 intermountain nurseryman's association conference; 1983 August 8-11; Las Vegas, NV. Gen. Tech. Rep. INT-168. Ogden, UT: U.S. Department of Agriculture, Forest Service, Intermountain Forest and Range Experiment Station: 32-38. (INT)

NEVILLE, WALTER M.; and E. DURANT MCARTHUR. 1986. Preliminary report on tissue culture propagation of big sagebrush (Artemisia tridentata). In: McArthur, E. Durant; and Bruce L. Welch, comps. Proceedings-symposium on the biology of Artemisia and Chrysothamnus; 1984 July 9-13; Provo, UT. Gen. Tech. Rep. INT-200. Ogden, UT: U.S. Department of Agriculture, Forest Service, Intermountain Forest and Range Experiment Station: 397-398. (INT)

PAVLICEK, KENNETH A.; GORDON V. JOHNSON; and EARL A. ALDON. 1977. Vegetative propagation of desert saltgrass rhizomes. Journal of Range Management. 30:377-380. (RM)

PLUMMER, A. PERRY; and KENT R. JORGENSEN. 1978. Harvesting, cleaning, and storing seed of western shrubs. Western Forest Nurseryman's Council and Intermountain Nurseryman's Association Conference and Workshop Proceedings: 65-76. (INT)

RADWAN, M. A.; and G. L. CROUCH. 1977. Seed germination and seedling establishment of redstem ceanothus. Journal of Wildlife Management. 11:760766. (RM)
RIETVELD, W. J. 1989. Variable seed dormancy in Rocky Mountain juniper. In: Landis, Thomas D., tech. coord. Proceedings, Intermountain Forest Nursery Association. 1989 August 1418; Bismarck, ND. Gen. Tech. Rep. RM184. Fort Collins, CO: U.S. Department of Agriculture, Forest Service, Rocky Mountain Forest and Range Experiment Station: 60-64. (RM)

ROTHENBERGER, S. J.; AND D. S. GALITZ. 1977. Effects of $\mathrm{Cd}, \mathrm{Zn}, \mathrm{Pb}$, and Mo on germination and growth of selected grasses. Plant Physiology. 59:669. (RM)

SABO, DAVID G.; GORDON JOHNSON; WILLIAM C. MARTIN; and EARL F. ALDON. 1979. Germination requirement of 19 species of arid land plants. Res. Pap. RM-210. Fort Collins, CO: U.S. Department of Agriculture, Forest Service, Rocky Mountain Forest and Range Experiment Station. 26 p. (RM)

SCHIER, G. A. 1976. Physiological and environmental factors controlling vegetative regeneration of aspen. In: Utilization and marketing as tools for aspen management in the Rocky Mountains. Gen. Tech. Rep. RM-29. Fort Collins, CO: U.S. Department Agriculture, Forest Service, Rocky Mountain Forest and Range Experiment Station: 20-23. (INT)

SCHIER, G. A.; and R. B. CAMPBELL. 1976. Differences among populus species in ability to form adventitious shoots and roots. Canadian Journal of Forest Research. 6:253-261. (INT)

SCHIER, GEORGE A. 1978. Root suckering in young aspen, girdled, defoliated, and decapitated at various seasons. In: Proceedings, 5th North American Forestry Biology Workshop, Gainesville, FL: 259-267. (INT) 
SCHIER, GEORGE A. 1978. Variation in suckering capacity among and within lateral roots of an aspen clone. Res. Note INT-24l. Odgen, UT: U.S. Department of Agriculture, Forest Service, Intermountain Forest and Range Experiment Station. 7 p. (INT)

SCHIER, GEORGE A. 1978. Vegetative propagation of Rocky Mt. aspen. Gen. Tech. Rep. INT-44. Odgen, UT: U.S. Department of Agriculture, Forest Service, Intermountain Forest and Range Experiment Station. 13 p. (INT)

SCHIER, GEORGE A.; and ARTHUR D. SMITH. 1979. Sucker regeneration in a Utah aspen clone after clear-cutting, partial cutting, scarification, and girdling. Res. Note INT-253. Ogden, UT: U.S. Department of Agriculture, Forest Service, Intermountain Forest and Range Experiment Station. 6 p. (INT)

SCHIER, GEORGE A.; and ROBERT B. CAMPBELL. 1978. Aspen sucker regeneration following burning and clearcutting on two sites in the Rocky Mountains. Forest Science. 24:303-308. (INT)

SCHIER, GEORGE A.; and ROBERT B. CAMPBELL. 1978. Effect of cold storage on development of suckers on aspen root cuttings. Res. Note INT-248.

Ogden, UT: U.S. Department of Agriculture, Forest Service, Intermountain Forest and Range Experiment Station. 8 p. (INT)

SCHIER, GEORGE A.; and ROBERT B. CAMPBELL. 1978. Effect of ethephon on suckering of excised roots and rooting of cuttings in trembling aspen. Forest Science. 24:66-72. (INT)
SHAW, NANCY. 1981. Propagating and outplanting shrubs on mine sites. In: Stelter, Lavern H.; Edward J. DePuit; and Sharon A. Mikol, tech. coords. Shrub establishment on disturbed arid and semi-arid lands: Proceedings of the symposium; 1980 December 2-3; Laramie, WY. Cheyenne, WY: Wyoming Game and Fish Department: 47-56. (INT)

SHAW, NANCY. 1983. Producing bareroot seedlings of native shrubs. In: Murphy, Patrick M., comp. The challenge of producing native plants for the Intermountain area: Proceedings, 1983 intermountain nurseryman's association conference; 1983 August 8-11; Las Vegas, NV. Gen. Tech. Rep. INT-168. Ogden, UT: U.S. Department of Agriculture, Forest Service, Intermountain Forest and Range Experiment Station: 6-15. (INT)

STEVENS, R.; K. R. JORGENSEN; J. N. DAVIS; and S. B. MONSEN. 1986. Seed pappus and placement influences on white rubber rabbitbrush establishment. In: McArthur, E. Durant; Bruce L. Welch, comps. Proceedings--symposium on the biology of Artemisia and

Chrysothamnus; 1984 July 9-13; Provo, UT. Gen. Tech. Rep. INT-200. Ogden, UT: U.S. Department of Agriculture, Forest Service, Intermountain Forest and Range Experiment Station: 353357. (INT)

STEVENS, RICHARD; KENT R. JORGENSEN; and JAMES N. DAVIS. 1981. Viability of seed from thirty-two shrub and forb species through fifteen years of warehouse storage. Great Basin Naturalist. 41:274-277. (INT)

UPADHYAYA, ABHA; NARENDRA SANKHLA; TIM D. DAVIS; D. J. WEBER; and B. N. SMITH. 1985. In vitro propagation of a rubber-producing desert shrub. HortScience. 20:864-865. (INT) 
VAN EPPS, G. A. 1978. Prototype seed harvester for fourwing saltbush. In: 32nd Annual Report. San Antonio, TX: Vegetative and Rehabilitation Workshop: 13-14. (INT)

VORIES, KIMERY. 1981. Growing Colorado plants from seed: A state of the art. Gen. Tech. Rep. INT-103. Ogden, UT: U.S. Department of Agriculture, Forest Service, Intermountain Forest and Range Experiment Station. 80 p. (INT)

YOUNG, J. A.; R. A. EVANS; C. A. RAGUSE; and J. R. LARSON. 1981. Germinable seeds and periodicity of germination in annual grasslands. Hilgardia. 49(2):137. (PSW)

YOUNG, JAMES A.; RAYMOND A. EVANS; RICHARD STEVENS; and RICHARD L. EVERETT. 1981. Germination of Kochia prostrate seed. Agronomy Journal. 73:957-961. (INT)

YOUNG, JAMES A.; RAYMOND A. EVANS; and DONALD L. NEAL. 1978. Treatment of curlleaf cercocarpus seeds to enhance germination. Journal of Wildlife Management. 42:614-620. (PSW)

\section{Forage Value}

BAKER, R. L.; and J. POWELL. 1979. Western Oklahoma sandhill prairie yield and crude protein response to atrazine, nitrogen, and 2,4-D during drought. In: Goodin, J. R.; and D. K. Northington, eds. Arid land plant resources. Lubbock, TX: Texas Tech University, Intermountain Center for Arid and Semiarid Land Studies: 564-573. (SO)

BAKER, ROGER L.; JEFF POWELL; R. D. MORRISON; and J.F. STRITZKE. 1980. Effects of atrazine, 2, 4-D and fertilizer on crude protein content of Oklahoma tallgrass prairie. Journal of Range Management. 33:404-407. (SO)
BARTOS, DALE L.; and ROBERT S. JOHNSTON. 1978. Biomass and nutrient content of quaking aspen at two sites in the western United States. Forest Science. 24:273-280. (INT)

BEHAN, BARBARA; and BRUCE L. WELCH. 1986. Winter nutritive content of black sagebrush (Artemisia nova) grown in a uniform garden. Great Basin Naturalist. 46:161-165. (INT)

BLAIR, ROBERT M. 1982. Growth and nonstructural carbohydrate content of southern browse species as influenced by light intensity. Journal of Range Management. 35:756-760. (SO)

BLAIR, ROBERT M.; HENRY L. SHORT; and E. A. EPPS, JR. 1977. Seasonal nutrient yield and digestibility of deer forage from a young pine plantation. Journal of Wildlife Management. 41:667-676. (SO)

BLAIR, ROBERT M.; HENRY L. SHORT; LEONARD F. BURKART; [and others]. 1980 . Seasonality of nutrient quality and digestibility of three southern deer browse species. Res. Pap. SO-161. New Orleans, LA: U.S. Department of Agriculture, Forest Service, Southern Forest Experiment Station. 13 p. (SO)

BLAIR, ROBERT M.; RENE ALCANIZ; and AUSTIN HARRELL. 1983. Shade intensity influences the nutrient quality and digestibility of southern deer browse leaves. Journal of Range Management. 36:257-264. (SO)

BUNDERSON, E. D.; BRUCE L. WELCH; and DARRELL J. WEBER. 1986. In vitro digestibility of Juniperus osteosperma (Torr.) Little from 17 Utah sites. Forest Science. 32:834-840. (INT)

CEDARLEAF, JOY D.; BRUCE L. WELCH, and JACK D. BROTHERSON. 1983. Seasonal variation of monoterpenoids in big sagebrush (Artemisia tridentata). Journal of Range Management. 36:492494; (INT) 
CLARY, WARREN P. 1978. Producerconsumer biomass in Arizona ponderosa pine. Gen. Tech. Rep. RM56. Fort Collins, CO: U.S. Department of Agriculture, Forest Service, Rocky Mountain Forest and Range Experiment Station. 4 p. (RM)

CLARY, WARREN P.; BRUCE L. WELCH; and GORDON D. BOOTH. 1988. In vitro digestion experiments: importance of variation between inocula donors. Journal of Wildlife Management. 52:358361. (INT)

CLAWSON, W. J.; and D. A. DUNCAN. 1979. Herbage and chemical composition shifts in annual grasslands. In: Proceedings, Western Section, American Society of Animal Science. 30:190-193. (PSW)

DAVIS, JAMES N.; and BRUCE L. WELCH. 1985. Winter preference, nutritive value, and other range use characteristics of Kochia prostrata (L.) Schrad. Great Basin Naturalist. 45:778-783. (INT)

DAVIS, JAMES N.; and RICHARD STEVENS. 1986. Comparison of production in 27 accessions of 4 sagebrush taxa. In: McArthur, E. Durant; and Bruce L. Welch, comps.

Proceedings--symposium on the biology of Artemisia and Chrysothamnus; 1984 July 9-13; Provo, UT. Gen. Tech. Rep. INT-200. Ogden, UT: U.S. Department of Agriculture, Forest Service, Intermountain Forest and Range Experiment Station: 336-341. (INT)

DEBYLE, NORBERT V.; PHILIP J. URNESS; and DEBORAH L. BLANK. 1989.

Forage quality in burned and unburned aspen communities. Res. Pap. INT-404. Ogden, UT: U.S. Department of Agriculture, Forest Service, Intermountain Research Station. 8 p. (INT)

DRAGT, W. T.; and K. M. HAVSTAD. 1987. Effects of cattle grazing upon chemical constituents within important forages for elk. Northwest Science. 61:70-73. (INT)
GRIGAL, D. F.; and L. F. OHMANN. 1980. Seasonal change in nutrient concentrations in forest herbs. Bulletin of the Torrey Botanical Club. 107:47-50. (NC)

GRIGAL, D. F.; L. F. OHMANN; and R. B. BRANDER. 1976. Seasonal dynamics of tall shrubs in northeastern Minnesota: biomass, and nutrient element changes. Forest Science. 22:195-208. (NC)

GRIGAL, D. F.; L. F. OHMANN; and N. R. MOODY. 1979. Nutrient content of some tall shrubs from northeastern Minnesota. Res. Pap. NC-168. St. Paul, NM: U.S. Department of Agriculture, Forest Service, North Central Forest Experiment Station. 10 p. (NC)

HANLEY, THOMAS A. 1982. The nutritional basis for food selection by ungulates. Journal of Range Management. 35:146151. (INT)

HANLEY, THOMAS A.; and JAMES J. ROGERS. 1989. Estimating carrying capacity with simultaneous nutritional constraints. Res. Note PNW-485. Portland, OR: U.S. Department of Agriculture, Forest Service, Pacific Northwest Research Station. 29 p. (PNW)

HANLEY, THOMAS A.; and JAY D. MCKENDRICK. 1983. Seasonal changes in chemical composition and nutritive value of native forages in a spruce-hemlock forest, southeastern Alaska. Res. Pap. PNW-312. Portland, OR: U.S. Department of Agriculture, Forest Service, Pacific Northwest Forest and Range Experiment Station. $41 \mathrm{p}$. (PNW) 
HANLEY, THOMAS A.; REX G. CATES; BEATRICE VAN HORNE; and JAY D. MCKENDRICK. 1987. Forest stand-agerelated differences in apparent nutritional quality of forage for deer in southeastern Alaska. In: Provenza, Frederick D.; Jerran T. Flinders; and E. Durant McArthur, comps. Proceedings-symposium on plant-herbivore interactions; 1985 August 7-9; Snowbird, UT. Gen. Tech. Rep. INT-222. Ogden, UT: U.S. Department of Agriculture, Forest Service, Intermountain Research Station: 9-17. (PNW)

HARLOW, R. F. 1985. Selected forage values of understory plants in thinned cove hardwoods on three sites. Res. Note SE-328. Asheville, NC: U.S. Department of Agriculture, Forest Service, Southeastern Forest Experiment Station. 5 p. (SE)

HARLOW, RICHARD F. 1983. Food plants of value to wildlife. In: Wenger, Karl F., ed. Forestry handbook. 2nd ed. New York, NY: John Wiley \& Sons: 7|3-726. (SE)

HEGERHORST, D. F.; DARRELL J. WEBER; E. DURANT MCARTHUR; and A. J. KHAN. 1987. Chemical analysis and comparison of subspecies of Chrysothamnus nauseosus and other related species. Biochemical Systematics and Ecology. 15:201-208. (INT)

HEGERHORST, D.; D. J. WEBER; and E. D. MCARTHUR. 1987. Chemical components of Chrysotamnus nauseosus: a preliminary evluation. In: Provenza, Frederick D.; Jerran T. Flinders; and E. Durant McArthur, comps. Proceedings--symposium on plant-herbivore interactions; 1985 August 7-9; Snowbird, UT. Gen. Tech. Rep. INT-222. Ogden, UT: U.S. Department of Agriculture, Forest Service, Intermountain Research Station: 93-98. (INT)
HOBBS, N. THOMPSON; BRUCE L. WELCH; and THOMAS E.

REMINGTON. 1986. Effects of big sagebrush on in vitro digestion of grass cell wall. In: McArthur, E. Durant; and Bruce L. Welch, comps. Proceedings-symposium on the biology of Artemisia and Chrysothamnus; 1984 July 9-13; Provo, UT. Gen. Tech. Rep. INT-200. Ogden, UT: U.S. Department of Agriculture, Forest Service, Intermountain Forest and Range Experiment Station: 186-189. (INT)

JOHNSTON, R. S.; and D. L. BARTOS. 1977. Summary of nutrient and biomass data from two sites in western United States. Res. Note INT-227. Odgen, UT: U.S. Department of Agriculture, Forest Service, Intermountain Forest and Range Experiment Station. 15 p. (INT)

KIE, JOHN G. 1986. Nutritive quality of Ceanothus shrubs in California mixed conifer forest. Journal of Range Management. 39:521-526. (PSW)

MCCONNELL, BURT R.; and JUSTIN G. SMITH. 1977. Influence of grazing on age-yield interactions in bitterbrush. Journal of Range Management. 30:9193. (INT)

MEAD, BERT; JOHN YARIE; and DAVID HERMAN. 1987. Biomass estimates for nontimber vegetation in the Tanana River basin of interior Alaska. In: Estimating biomass regressions and error: Workshop on tree biomass regression functions and contribution to error of inventory estimates; 1986 May 26-30; Syracuse, NY. Gen. Tech. Rep. NE-117. Broomall, PA: U.S. Department of Agriculture, Forest Service, Northeastern Forest Experiment Station: 149-153. (PNW)

MEDIN, DEAN E.; and ROBERT B. FERGUSON. 1980. High browse yield in a planted stand of bitterbrush. Res. Note INT-279. Ogden, UT: U.S. Department of Agriculture, Forest Service, Intermountain Forest and Range Experiment Station. 4 p. (INT) 
MILCHUNAS, DANIEL G.; MELVIN I. DYER; OLOF C. WALLMO; and DONALD E. JOHNSON. 1978. In vivo/in vitro relationships of Colorado mule deer forages. Spec. Rep. 43. Denver, CO: Colorado State Division of Wildlife. 44 p. (RM)

MUEGGLER, W. F.; and W. L. STEWART. 1981. Forage production on important rangeland habitat types in western Montana. Journal of Range Management. 34:347-353. (INT)

MURRAY, R. B.; H. F. MAYLAND; and P. J. VAN SOEST. 1978. Growth and nutritional value to cattle of grasses on cheatgrass range in southern Idaho. Res. Pap. INT-199. Ogden, UT: U.S. Department of Agriculture, Forest Service, Intermountain Forest and Range Experiment Station. 57 p. (INT)

NEEL, J. P.; H. E. KIESLING; G. B. DONART; J. L. HOLECHEK; T. D. GODMANN; and D. MANZANARES. 1986. Nutritive value of forage collected by esophageal fistulated cows in riparian and upland areas on forest land. In: Proceedings, Western Section, American Society of Animal Science; 1985 July 17-19; Moscow, ID: American Society of Animal Science. 36:304-306. (RM)

O'HALLORAN, KATHLEEN A.; ROBERT M. BLAIR; RENE ALCANIZ; and HERSHEL F. MORRIS, JR. 1987. Prescribed burning effects on production and nutrient composition of fleshy fungi. Journal of Wildlife Management. 51:258262. (SO)

PATTON, DAVID R.; and MARY G. ERTL. 1982. Wildlife food plants of the Southwest. RUN WILD wildlife/habitat relationships. Wildlife Unit Tech. Rep. Albuquerque, NM: U.S. Department of Agriculture, Forest Service, Southwestern Region. 49 p. (RM)
PEARSON, H. A.; H. E. GRELEN; E. A. EPPS; M. K. JOHNSON; and B. W. BLAKEWOOD. 1982. Botanical composition and nutritive value of cattle diets on southern pine range. Res. Pap. SO-178. New Orleans, LA: U.S. Department of Agriculture, Forest Service, Southern Forest Experiment Station. 24 p. (SO)

PEDERSON, J. C.; and B. L. WELCH. 1982. Effects of monoterpenoid exposure an ability of rumen inocula to digest a set of forage. Journal of Range Management. 35:500-502. (INT)

PROBASCO, G. E.; and A. J. BJUGSTAD. 1978. Nutrition and in vitro digestibility of tall fescue for white-tailed deer, May through November. Res. Note NC-228. St. Paul, MN: U.S. Department of Agriculture, Forest Service, North Central Forest Experiment Station. 3 p. (NC)

PROBASCO, G. E.; and A. J. BJUGSTAD. 1980. Influence of fertilizer, aspect, and harvest data on chemical constituents and in vitro digestibility of tall fescue. Journal of Range Management. 33:244246. (RM)

SEVERSON, KIETH E. 1982. Production and nutritive value of aspen understory, Black Hills. Journal of Range Management. 35:786-789. (RM)

SHORT, HENRY L.; and E. A. EPPS, JR. 1976. Nutrient quality and digestibility of seeds and fruits from southern forests. Journal of Wildlife Management. 40:283289. (SO)

SHORT, HENRY L.; and E. A. EPPS, JR. 1977. Composition and digestibility of fruits and seeds from southern forests. Special Report. New Orleans, LA: U.S. Department of Agriculture, Forest Service, Southern Forest Experiment Station. 5 p. (SO) 
SHORT, HENRY L.; ROBERT M. BLAIR; and E. A. EPPS, JR. 1975. Composition and digestibility of deer browse plants in southern forests. Res. Pap. SO-111. New Orleans, LA: U.S. Department of Agriculture, Forest Service, Southern Forest Experiment Station. 10 p. (SO)

SMITH, B.; and D. H. HUNTER. 1978. Chemical content and digestibilities of important deer forages on a Florida flatwoods range. IMPAC Reports. 3(8). (SE)

SPALINGER, DONALD E.; CHARLES T. ROBBINS; and THOMAS A. HANLEY. 1986. The assessment of handling time in ruminants: the effect of plant chemical and physical structure o the rate of breakdown of plant particles in the rumen of mule deer and elk. Canadian Journal of Zoology. 64:312-321. (PNW)

STRANSKY, JOHN J; ; and LOWELL K. HALLS. 1977. Browse quality affected by pine site preparation in east Texas. Proceedings of the Annual Conference Southeastern Association Fish and Wildife Agencies. 30:507-512. (SO)

STRANSKY, JOHN J.; JAMES N. HALE; and LOWELL K. HALLS. 1976. Nutrient content and yield of burned or mowed Japanese honeysuckle. Proceedings of the Annual Conference of the Southeastern Association Game and Fish Commissioners. 29:403-406. (SO)

SVEJCAR, TONY; and MARTIN VAVRA. 1985. Seasonal forage production and quality on four native and improved plant communities in eastern Oregon. Tech. Bull. 149. Corvallis, OR: Agricultural Experiment Station, Oregon State University. 24 p. (PNW)

TIEDEMANN, ARTHUR R.; E. D. MCARTHUR; and C. F. LOPEZ. 1984. Carbohydrate and nitrogen concentrations in leaves of three shrub species following microwave, autoclave, and air-drying treatments. Forest Science. 30:113-116. (INT)
URESK, DANIEL W. 1987. Effects of livestock grazing and thinning of overstory trees on understory woody plants. In: Provenza, Frederick D.; Jerran T. Flinders; and E. Durant McArthur, comps. Proceedings-symposium on plant-herbivore interactions; 1985 August 7-9; Snowbird, UT. Gen. Tech. Rep. INT-222. Ogden, UT: U.S. Department of Agriculture, Forest Service, Intermountain Research Station: 168-171. (RM)

URNESS, P. J.; A. D. SMITH; and R. K. WATKINS. 1977. Comparison of in vivo and in vitro dry matter digestibility of mule deer forages. Journal of Range Management. 30:119-12I. (RM)

VAN HORNE, BEATRICE; THOMAS A. HANLEY; REX G. CATES; [and others]. 1988. Influence of seral stage and season on leaf chemistry of southeastern Alaska deer forage. Canadian Journal of Forest Research. 18:90-99. (PNW)

WELCH, B. L. 1978. Relationship of soil salinity, ash, and crude protein in Atriplex canescens. Journal of Range Management. 31:I32-|33. (INT)

WELCH, B. L.; and D. ANDRUS. 1977. Rose hips--A possible high-energy food for wintering mule deer. Res. Note. Int-221. Ogden, UT: U.S. Department of Agriculture, Forest Service, Intermountain Forest and Range Experiment Station. 6 p. (INT)

WELCH, B. L.; H. NARJISSE; and E. D. MCARTHUR. 1982. Artemisia tridentata monoterpenoid effect on ruminant digestion and forage selection. In: Margaris, N.; A. Koedam; and D. Vokou, eds. Aromatic plants: Basic and applied aspects. The Hague Boston/London: Martinus Nijhoff Publishers: 73-86. (INT) 
WELCH, BRUCE L. 1981. Nutritive value of big sagebrush and other shrubs. In: Stelter, Lavern H.; Edward J. DePuit; and Sharon A. Mikol, tech. coords. Shrub establishment on disturbed arid and semi-arid lands: Proceedings of the symposium; 1980 December 2-3;

Laramie, WY. Cheyenne, WY: Wyoming Game and Fish Department: 9-22. (INT)

WELCH, BRUCE L. 1983. Big sagebrush: nutrition, selection, and controversy. In: Johnson, K. L., ed. Proceedings, 1st Utah shrub ecology workshop; 1981; Logan, UT: Utah State University: 21-33. (INT)

WELCH, BRUCE L. 1983. Improving the nutritive value of winter range forage. In: Monsen, Stephen B.; and Nancy Shaw, comps. Managing Intermountain rangelands--Improvement of range and wildlife habitats: Proceedings of symposia; 1981 September 15-17; Twin Falls, ID. 1982 June 22-24. Elko, NV. Gen. Tech. Rep. INT-157. Ogden, UT: U.S. Department of Agriculture, Forest Service, Intermountain Forest and Range Experiment Station: 158-164. (INT)

WELCH, BRUCE L. 1988. Nutritive value of shrubs. In: McKell, Cyrus M., ed. The biology and utilization of shrubs. San Diego, CA: Academic Press: 405-424. (INT)

WELCH, BRUCE L.; and JAMES N. DAVIS. 1984. In vitro digestibility of Kochia prostrata (L.) Schrad. Great Basin Naturalist. 44:296-298. (INT)

WELCH, BRUCE L.; and JORDON C. PEDERSON. 1981. In vitro digestibility among accessions of big sagebrush by wild mule deer and its relationship to monoterpenoid content. Journal of Range Management. 34:497-500. (INT)

WELCH, BRUCE L.; JORDAN C.

PEDERSON; and WARREN P. CLARY. 1983. Ability of different rumen inocula to digest range forages. Journal of Wildlife Management. 47:873-877. (INT)
WHITE, SUSAN M.; and BRUCE L. WELCH. 1981. Paired comparisons: a method for ranking mule deer preference for various browse species. Res. Note. INT-308. Ogden. UT: U.S. Department of Agriculture, Forest Service, Intermountain Forest and Range Experiment Station. 4 p. (INT)

WHITE, SUSAN M.; BRUCE L. WELCH; and JERRAN T. FLINDERS. 1982. Monoterpenoid content of pygmy rabbit stomach ingesta. Journal of Range Management. 35:107-109. (INT)

WOOD, JOHN M.; and GEORGE W. TANNER. 1985. Browse quality response to forest fertilization and soils in Florida. Journal of Range Management. 38:432-435. (SE)

\section{Nutrient And Mineral Responses}

BORMANN, BERNARD T. 1988. A masterful scheme: symbiotic nitrogen-fixing plants of the Pacific Northwest. Seattle, WA: University of Washington, Arboretum Bulletin. 51(2):10-14. (PNW)

CHAMBERS, JEANNE C.; ROY C. SIDLE; and C. VAL GRANT. 1989. Relationships among soil deposition patterns, soil physical and chemical properties, and plant metal uptake on an abandoned zinc-lead tailings pond. In: Walker, D. G.; C. B. Powter; and M. W. Pole, comps. Reclamation, a global perspective: Proceedings of the conference; 1989 August 27-31; Calgary, Alberta, Canada. Alberta Land Conservation and Reclamation Council Report \# RRTAC 89-2:403-414. (INT)

CLARY, W. P.; and A. R. TIEDEMANN. 1985. Biomass distribution in Gambel oak stands in central Utah. In: Johnson, K. L., ed. Proceedings, 3rd Annual Utah Shrub Ecology Workshop. Logan, UT: Utah State University: 9-12. (INT) 
CRESS, W. A.; G. V. JOHNSON; and L. L. BARON. 1986. The role endomycorrhizal fungi in iron uptake by Hilaria jamesii. Journal of Plant Nutrition. 9(3-7):547-556. (RM)

DEBANO, L. F.; and J. M. KLOPATEK, JR. 1987. Effects of management on nutrient dynamics in southwestern pinyon-juniper woodlands. In: Troendle, Charles A.; Merrill R. Kaufmann; R. H. Hamre; and Robert P. Winokur, tech. coords. Management of subalpine forests: building on 50 years of research: Proceedings of a technical conference; 1987 July 6-9; Silver Creek, CO. Gen. Tech. Rep. RM-149. Fort Collins, CO: U.S. Department of Agriculture, Forest Service, Rocky Mountain Forest and Range Experiment Station: 157-160. (RM)

DEBANO, L. F.; and J. M. KLOPATEK. 1988. Phosphorus dynamics of pinyon-juniper soils following simulated burning. Soil Science Society of America Journal. 52:271-277. (RM)

DEBANO, L. F.; H. M. PERRY; and S. T. OVERBY. 1987. Effects of fuelwood harvesting and slash burning on biomass and nutrient relationships in a pinyon-juniper stand. In: Everett, Richard L., comp. Proceedings--pinyonjuniper conference; 1986 January 13-16; Reno, NV. Gen. Tech. Rep. INT-215. Ogden, UT: U.S. Department of Agriculture, Forest Service, Intermountain Research Station: 382386. (RM)

DEBANO, LEONARD F.; and JEFFREY M. KLOPATEK. 1988. Phosphorus dynamics of pinyon-juniper soils following simulated burning. Soil Science Society of America Journal. 52:271-277. (RM)

DENNIS, G. L.; P. R. FRESQUEZ; and G. V. JOHNSON. 1988. Iron uptake by native grasses in a sewage sludge amended semiarid grassland. Journal of Plant Nutrition. 11:1417-1427. (RM)
FINDLAY, STUART; JUDY L. MEYER; and PHILIP J. SMITH. 1986. Incorporation of microbial biomass by Peltoperla sp.

(Plecoptera) and Tipula sp. (Diptera). Journal of the North American Benthological Society. 5:306-310. (SE)

FRESQUEZ, P. R.; and B. R. SABEY. 1989. Microbial community in the rhizosphere of native plant species growing on reclaimed coal mine soils varying in age. Arid Soil Research and Rehabilitation. 3:369-384. (RM)

FRESQUEZ, P. R.; and W. C. LINDEMANN. 1982. Nitrification potential of amended coal mine spoils. New Mexico Journal of Science. 22:36-42. (RM)

FRESQUEZ, P. R.; E. F. ALDON; and W. C. LINDEMANN. 1985. Litter decomposition on reclaimed coal mine spoils and soils in the arid Southwest. In: Graves, Donald, ed. National symposium on surface mining, hydrology, sedimentology, and reclamation; 1985 December 8-13; Lexington, KY: University of Kentucky: 157-161. (RM)

HO, IWAN. 1987. Vesicular-arbuscular mycorrhizae of halophytic grasses in the Alvord desert of Oregon. Northwest Science. 61(3):148-151. (PNW)

KLOPATEK, CAROLE COE; and JEFFREY M. KLOPATEK. 1987. Mycorrhizae, microbes, and nutrient cycling processes in pinyon-juniper systems. In: Everett, Richard L., comp. Proceedings- pinyon-juniper conference; 1986 January 13-16; Reno, NV. Gen. Tech. Rep. INT-215. Ogden, UT: U.S. Department of Agriculture, Forest Service: Intermountain Research Station: 360-364. (RM) 
LI, C. Y. 1987. Association of nitrogen-fixing bacteria with mycorrhizal fungi and feces of forest-dwelling mammals in relation to forest productivity. In: Kiang, Tao; Jeng-Chuan Yany; and Yu-Ping Kao. Proceedings on Forest Productivity and site evaluation; 1987 November 1011; Taipei, Taiwan; Fayetteville, AK; Taipei, Taiwan: Councial [sic] of Agriculture: 125-130. (PNW)

MCNABB, D. H.; J. M. GEIST; and C. T. YOUNGBERG. 1979. Nitrogen fixation by Ceanothus velutinus in Northeastern Oregon. Summary. In: Gordon, J. C.; D. A. Perry; and C. T. Wheeler, eds. Symbiotic nitrogen fixation in the management of temperate forests. Corvallis, OR: Oregon State University Press. 210 p. (PNW)

RATLIFF, RAYMOND D. 1976.

Decomposition of fiber paper and herbage in meadows of the high Sierra Nevada: preliminary results. Res. Note PSW-308. Berkeley, CA: U.S. Department of Agriculture, Forest Service, Pacific Southwestforest and Range Experiment Station. 4 p. (PSW)

RATLIFF, RAYMOND D. 1980.

Decomposition of native herbage and filter paper at five meadow sites in Sequoia National Park, California. Journal of Range Management. 33:262266. (PSW)

ROTHENBERGER, S. J.; and D. S. GALITZ. 1977. Toxic effects of cadmium and zinc on selected grass species. Proceedings, North Dakota Academy Science. 31:26. (RM)

RUMBLE, MARK A. 1986. Radiation dosimetry on revegetated uranium mill tailings in western South Dakota. Northwest Science. 60:145-149. (RM)

RUMBLE, MARK A.; and ARDELL J. BJUGSTAD. 1986. Uranium and radium concentrations in plants growing on uranium mill tailings in South Dakota. Revegetation Research. 4:271-277. (RM)
SCHOLL, D. G.; and S. MIYAMOTO. 1983. Response of alkali sacaton and fourwing saltbush to various amendments on coal-mine spoils from northwestern New Mexico. II. Sodic spoil. Reclamation and Revegetation Research. 2:243-252. (RM)

SCHOLL, D. G.; and S. MIYAMOTO. 1983. Response of alkali sacaton and fourwing saltbush to various amendments on coal-mine spoils from northwestern New Mexico. I. Acid spoil. Reclamation and Revegetation Research. 2:227-236. (RM)

SORENSEN, D. L.; and P. R. FRESQUEZ. 1985. Patterns of denitrification in reclaimed mine spoils in the arid Southwest. In: Williams, Dean; and Scott Fisher, eds. Symposium of the American Society for Surface Mining and Reclamation; 1985 October 8-10; Denver, CO: 327-331. (RM)

THRAN, D. F.; and R. L. EVERETT. 1987. Impact of tree harvest on soil nutrients accumulated under singleleaf pinyon. In: Everett, Richard L., comp. Proceedings-pinyon-juniper conference; 1986 January 13-16; Reno, NV. Gen. Tech. Rep. INT-215. Ogden, UT: U.S. Department of Agriculture, Forest Service, Intermountain Research Station: 387-390. (INT)

THRAN, D. F.; and R. L. EVERETT. 1987. Nutrients in surface soils following tree harvest of singleleaf pinyon. Soil Science Society of America Journal. $51: 462-464$. (INT)

TIEDEMANN, A. R. 1987. Combustion losses of sulfur and forest foliage and litter. Forest Science. 33:216-223. (PNW)

TIEDEMANN, A. R.; and M. M FURNISS. 1985. Soil and litter nutrient responses to looper defoliation of curlleaf mountain mahogany. Forest Science. 31:382-388. (INT) 
TIEDEMANN, A. R.; and W. P. CLARY. 1985. Nitrogen distribution in Gambel oak stands. In: Johnson, K. L., ed.

Proceedings, 3rd Annual Utah Shrub Ecology Workshop. Logan UT: Utah State University: 13-18. (INT)

TIEDEMANN, ARTHUR R.; and C. F. LOPEZ. 1983. Soil nutrient assessment of mine spoils. In: Aldon, Earl F.; and Wendall R. Oaks, eds. Proceedings of symposium, reclamation of mined lands in the southwest. Albuquerque, NM: New Mexico Chapter, Soil Conservation Society of America: 66-79. (INT)

WEBSTER, J. R.; and E. F. BENFIELD. 1986. Vascular plant breakdown in freshwater ecosystems. Annual Review of Ecological Systems. 17:567-594. (SE)

WOOD, JOHN M.; and GEORGE W. TANNER. 1985. Browse quality response to forest fertilization and soils in Florida. Journal of Range Management. 38:432-435. (SE)

WOODMANSEE, R. G.; and D. A. DUNCAN. 1980. Nitrogen and phosphorus dynamics and budgets in annual grassland. Ecology. 61:893-904. (PSW)

WOODWARD, R. A.; K. T. HARPER; and A. R. TIEDEMANN. 1984. An ecological consideration of the significance of cation exchange capacity of roots of some Utah range plants. Plant and Soil. 79:169-180. (INT)

\section{Plant Ecology}

ALLEN, CHARLES L.; and LOWELL K. HALLS. 1978. Feasibility of a green-tree reservoir in eastern Texas. Proceedings of the Annual Conference of the Southeastern Association of Fish and Wildlife Agencies. 30:404-497. (SO)
BARKER, P. A. 1977. Planting strips in street rights-of-way: A key public land resource. In: Andresen, J. W. ed. Trees and forests for human settlements. Toronto, Ontario: University of Toronto Press: 263-274. (INT)

BJUGSTAD, ARDELL J.; MARK A. RUMBLE; RICHARD A. OLSON; and WILLIAM T. BARKER. 1983. Prairie pond morphometry and aquatic plant zonation - northern High Plains. In: Proceedings, 3rd biennial plains aquatic research conference; 1983 August 24-25; Bozeman, MT: Montana State University, Institute of Natural Resources. 1983:101-111. (RM)

BJUGSTAD, ARDELL J. and WILLIAM FORTUNE. 1989. The western prairie fringed orchid (Platanthera praeclara) monitoring and reseach. In: Bragg, Thomas B.; and James Stubbendieck, eds. Prairie pioneers: ecology, history and culture: proceedings of the 11th North American prairie conference; 1989 August 7-11; Lincoln, NE: University of Nebraska Printing: 197-199. (RM)

BJUGSTAD, ROCHELLE; and ARDELL J. BJUGSTAD. 1989. Do you know Planthera praeclara? In: Bragg, Thomas B.; and James Stubbendieck, eds. Prairie pioneers: ecology, history and culture: proceedings of the 11th North American prairie conference; 1989 August 7-11; Lincoln, NE: University of Nebraska Printing: 201-202. (RM)

BRIGHT, LARRY. 1978. Weather stress difference between two levels of juniper canopy cover. In: Martin, Robert E.; J. Edward Dealy; and David L. Caraher, eds: Proceedings of the western juniper ecology and management workshop; 1977 January; Bend, OR. Gen. Tech. Rep. PNW-74. Portland, OR: U.S. Department of Agriculture, Forest Service, Pacific Northwest Forest and Range Experiment Station: 91-95. (PNW) 
CHAMBERS, J. C.; R. W. BROWN; and R. S. JOHNSTON. 1987. A comparison of soil and vegetation properties of seeded and naturally revegetated pyritic alpine mine spoil and reference sites. Landscape and Urban Planning. 14:507-519.

CHRISTENSEN, NORMAN L.; and JERRY F. FRANKLIN. 1987. Small-scale disturbance in forest ecoystems. Bulletin of the Ecological Society of America. 68(1):51-53. (PNW)

CLARY, WARREN P.; and RALPH C. HOLMGREN. 1987. Reversal of desertification on the low-shrub cold desert. In: Aldon, Earl F.; Carlos E. Gonzales Vicente; and William H. Moir, tech. coords. Strategies for classification and management of native vegetation for food production in arid zones: symposium proceedings; 1987 October 12-16; Tucson, AZ. Gen. Tech. Rep. RM-150. Fort Collins, CO: U.S. Department of Agriculture, Forest Service, Rocky Mountain Forest and Range Experiment Station: 138-142. (INT)

CROW, T. R.; and R. R. BUECH. 1977. Temperature and moisture regimes in the Enterprise Forest, 1970-1973. In: Zavitkovski, J. Ed. Enterprise Radiation Forest. TID-26113-P2. USDC, Springfield, VA: National Technical Information Service: 9-18. (NC)

CURTIS, JACK E.; HERSHEL C. REEVES; and LOWELL K. HALLS. 1977. Potential mineral release in loblolly and longleaf pine litter. Southwestern Journal Applied Forestry. 1(2):18-19. (SO)

CUSHING, C. E.; and S. D. SMITH. 1982. Effects of Mount Saint Helens ashfall on lotic algae and caddisflies. Journal of Freshwater Ecology. 1:527-538. (PNW)

DAVIS, B. L.; D. N. BLAIR; L. R. JOHNSON; and S. J. HAGGARD. 1976. A study of the green area effect in the Black Hills of South Dakota. Atomospheric Environment. 10:363-370. (RM)
EBERT, THOMAS A.; and PAUL H. ZEDLER. 1984. Decomposition of ocotillo (Fouquieria splendens) wood in the Colorado desert of California. American Midland Naturalist. 111:143-147. (PSW)

EDDLEMAN, LEE E. 1979. Regeneration strategies of mixed prairie species. In: Goodin, J. R.; and David K. Northington, eds. Arid land plant resources. Lubbock, TX: Texas Tech University: 686-698. (INT)

EDGERTON, PAUL J.; and BURT R. MCCONNELL. 1976. Diurnal temperature regimes of logged and unlogged mixed-conifer stands on elk summer range. Res. Note PNW-277. Portland, OR: U.S. Department of Agriculture, Forest Service, Pacific Northwest Forest and Range Experiment Station. 6 p. (PNW)

EVANS, KEITH E.; CHARLES W. PUTNAM; and SHANNA L. NESBY. 1979. Fire pink and wild pink hybrid. Missouriensis. $1(3): 6$. (NC)

FINLEY, ROBERT W. 1976. Original vegetation cover of Wisconsin compiled from U.S. General Land Office Notes. St. Paul, MN: U.S. Department of Agriculture, Forest Service, North Central Forest Experiment Station. (NC)

FRANKLIN, JERRY F. 1988. Structural and functional diversity in temperate forests. In: Wilson, E. C., ed. Biodiversity. Washington, DC: National Academy Press. 166-175. Chapter 18. (PNW)

FRANKLIN, JERRY F.; H. H. SHUGART; and MARK E. HARMON. 1987. Tree death as an ecological process: the causes, consequences, and variability of tree mortality. Bio Science. 37:550-556. (PNW) 
FRANKLIN, JERRY F.; THOMAS SPIES; DAVID PERRY; MARK HARMON; and ARTHUR MCKEE. 1986. Modifying Douglas-fir management regimes for nontimber objectives. In: Oliver, Chadwick Dearing; Donald P. Hanley; and Jay A. Johnson, comps. eds. Douglas-fir: stand management for the future: Proceedings of symposium; 1985 June 18-20; Seattle, WA: University of Washington, College of Resources: $373-$ 379. (PNW)

GARRISON, GEORGE A.; ARDELL J. BJUGSTAD; DONALD A. DUNCAN; MONT E. LEWIS; and DIXIE R. SMITH. 1977. Vegetation and environmental features of forest and range ecosystems of the United States. Agric. Handb. 475. Washington, DC: U.S. Department of Agriculture, Forest Service. 68 p. (PNW)

GUYETTE, RICHARD; E. A. McGINNES, JR.; G. E. PROBASCO; and K. E. EVANS. 1980. A climate history of Boone County, Missouri, from tree-ring analysis of eastern redcedar. Wood and Fiber. 12(1):17-28. (NC)

HAGGARD, STEVEN, J.; and BRIANT L. DAVIS. 1977. Additional observations of the green area effect in the Black Hills of South Dakota. Atmospheric Environment. Il:549-552. (RM)

HARMON, M. E.; J. F. FRANKLIN; F. J. SWANSON; P. SOLLINS; S. V. GREGORY; J. D. LATTUB; N. H. ANDERSON; S. P. CLINE; N. G. AUMEN; J. R. SEDELL; G. W. LIENKAEMPER; K. CROMACK, JR.; and K. W. CUMMINS. 1986. Ecology of coarse woody debris in temperate ecosystems. Advances in Ecological Research. 15:133-302. (PNW)

HELMS, JOHN A. 1987. Invasion of Pinus contorta var. murrayana (Pinaceae) into mountain meadows at Yosemite National Park, California. Madrono. 34(2):91-97. (PSW)
HORTON, JEROME S. 1977. Development and perpetuation of the permanent tamarisk type in the phreatophyte zone of the Southwest. In: Johnson, R. Roy; and Dale A. Jones, tech. eds. Importance, preservation and management of the riparian habitat; Symposium proceedings; 1977 July 9, Tucson, AZ. Gen. Tech. Rep. RM-43. Fort Collins, CO: U.S. Department of Agriculture, Forest Service, Rocky Mountain Forest and Range Experiment Station: 124-127. (RM)

JOYCE, LINDA A.; and MELVIN D. SKOLD. 1988 Implications of changes in the regional ecology of the Great Plains. In: Mitchell, John E., ed. Impacts of the Conservation Reserve Program in the Great Plains: Symposium proceedings; 1987 September 16-18; Denver, CO.Gen. Tech. Rep. RM-158. Fort Collins, CO: U.S. Department of Agriculture, Forest Service, Rocky Mountain Forest and Range Experiment Station. 115-127. (RM)

KALMBACHER, ROBERT S.; SANDRA S. COLEMAN; CLIFFORD E. LEWIS; and GEORGE W. TANNER, comps. 1986. Tropical American lowland range.

Symposium proceedings; 1986 February 13; Kissimmee, FL. Denver, CO: Society for Range Management. 34 p. (SE)

KIMMELL, VICKI L.; and GEORGE E. PROBASCO. 1980. Change in woody cover on limestone glades between 1938 and 1975. Transactions Missouri Academy Science. 14:69-74. (NC)

KONIAK, SUSAN; and RICHARD L. EVERETT. 1982. Seed reserves in soils of successional stages of pinyon woodlands. American Midland Naturalist. 108:295-303. (INT)

KULHAVY, D. L.; and RICHARD N. CONNER, ed. 1986. Wilderness and natural areas in the eastern United States: a management challenge. Nacogdoches, TX: Stephen F. Austin State University, School of Forestry, Center for Applied Studies. 416 p. (SO) 
KULHAVY, D. L.; RICHARD N. CONNER; F. E. SMEINS; and M. H. LEGG. 1986. An introduction to wilderness and natural area management. In: Kulhavy, D. L.; and Richard N. Conner, eds. Wilderness and natural areas in the eastern United States: a management challenge. Nacogdoches, TX: Stephen F. Austin State University, School of Forestry, Center for Applied Studies: 2-4. (SO)

LABINGER, ZEV; THOMAS E. HOSLER; MARY ANNE FLETT-LAMBERT; and SARAH J. KUPFERBERT. 1986. Oldgrowth mixed-coniferous/red fir forest transition. American Birds. 40:71. (PSW)

LI, HABIN; and JERRY F. FRANKLIN. 1988. Landscape ecology: a new conceptual framework in ecology. Advance in Ecology (China). 5(1):23-33. (PNW)

LYON, L. JACK. 1976. Attrition of lodgepole pine snags on the Sleeping Child burn, Montana. Res. Note INT-219. Ogden, UT: U.S. Department of Agriculture, Forest Service, Intermountain Forest and Range Experiment Station. 4 p. (INT)

LYON, L. JACK. 1976. Vegetal development on the Sleeping Child burn in western Montana, 1961-1973. Res. Pap. INT184. Ogden, UT: U.S. Department of Agriculture, Forest Service, Intermountain Forest and Range Experiment Station. 24 p. (INT)

MACCRACKEN, JAMES G.; LYNNE E. ALEXANDER; and DANIEL W. URESK. 1983. An important lichen of southeastern Montana rangelands. Journal of Range Management. 36:3537. (RM)
MARTIN, ROBERT E.; J. EDWARD DEALY: and DAVID CARAHER, eds. 1978. Proceedings of the western juniper ecology and management workshop; 1977 January; Bend, OR: Gen. Tech. Rep. PNW-74; Portland, OR: U.S. Department of Agriculture, Forest Service, Pacific Northwest Forest and Range Experiment Station. 177 p. (PNW)

MARTIN, S. CLARK; and DAVID R. PATTON. 1981. Characteristics, resources, and uses of the hot deserts of the United States. In: Lund, H. Gyde; Miguel Caballero; R. E. Hamre; [and others], tech. coords. Arid land resource inventories: Developing cost-efficient methods: Proceedings of an international workshop; 1980 November 30-December 6; La Paz, Mexico. Gen. Tech. Rep. WO-28. Washington, DC: U.S. Department of Agriculture, Forest Service: 21-28. (RM)

MARTIN, S. CLARK; and RAY M. TURNER. 1977. Vegetation change in the Sonoran Desert region, Arizona and New Mexico. Journal Arizona Academy Science. 12:59-64. (RM)

MASER, CHRIS; ROBERT F. TARRAMT; JAMES M. TRAPPE; and JERRY $F$. FRANKLIN, tech. eds. 1988. From the forest to the sea: a story of fallen trees. Gen. Tech. Rep. PNW-229. Portland, OR: U.S. Department of Agriculture, Forest Service, Pacific Northwest Research Station. 380 p. (PNW)

MASER, CHRIS; STEVEN P. CLINE; KERMIT CROMACK, JR; [and others]. 1989. What we know about large trees that fall to the forest floor. In: Trappe, James M.; and Jerry F. Franklin, tech. eds. From the forest to the sea: a story of fallen trees. Gen. Tech. Rep. PNW229. Portland, OR: U.S. Department of Agriculture, Forest Service, Pacific Northwest Research Station: 25-45. Chapter 2. (PNW) 
MCARTHUR, E. DURANT; and BRUCE L. WELCH. 1986. Introduction: Artemisia and Chrysothamnus. In: McArthur, E. Durant; and Bruce L. Welch, comps. Proceedings--symposium on the biology of Artemisia and Chrysothamnus; 1984 July 9-13; Provo, UT. Gen. Tech. Rep. INT-200. Ogden, UT: U.S. Department of Agriculture, Forest Service, Intermountain Forest and Range Experiment Station: 2-5. (INT)

MCARTHUR, E. DURANT; and BRUCE L. WELCH, comps. 1986. Proceedings-symposium on the biology of Artemisia and Chrysothamnus; 1984 July 9-13; Provo, UT. Gen. Tech. Rep. INT-200. Ogden, UT: U.S. Department of Agriculture, Forest Service, Intermountain Forest and Range Experiment Station. 398 p. (INT)

MCDONALD, PHILIP M. 1986. Grasses in young conifer plantations-hindrance and help. Northwest Science. 60:271-278. (PSW)

MEEUWIG, RICHARD O. 1983. Stand dynamics and management alternatives for pinyon-juniper woodlands. In: Monsen, Stephen B.; and Nancy Shaw, comps. Managing Intermountain rangelands--Improvement of range and wiidlife habitats: Proceedings of symposia; 1981 September 15-17; Twin Falls, ID. 1982 June 22-24. Elko, NV. Gen. Tech. Rep. INT-157. Ogden, UT: U.S. Department of Agriculture, Forest Service, Intermountain Forest and Range Experiment Station: 172-175. (INT)

MEEUWIG, RICHARD O.; and JERRY D. BUDY. 1979. Pinyon growth characteristics in the Sweetwater Mountains. Res. Pap. INT-227. Ogden, UT: U.S. Department of Agriculture, Forest Service, Intermountain Forest and Range Experiment Station. 26 p. (INT)
MUSSELMAN, LYTTON J.; and HAROLD E. GRELEN. 1979. A population of Aureolaria pedicularia (L.) Raf. (Scrophulariaceae) without oaks. American Midland Naturalist. 102:175177. (SO)

NOBLE, DANIEL L.; and DANIEL C. MACINTYRE. 1979. Management program for leafy spurge. Rangelands. $1: 247$. (NC)

OHMANN, LEWIS F.; and DAVID F. GRIGAL. 1979. Early revegetation and nutrient dynamics following the 1971 Little Sioux forest fire in northeastern Minnesota. Forest Science Monograph 21. 80 p. (NC)

PHILLIPS, L. N.; RICHARD N. CONNER; and D. L. KULHAVY. 1986. An introduction to wilderness management issues. In: Kulhavy, D. L.; and Richard N. Conner, eds. Wilderness and natural areas in the eastern United States: a management challenge. Nacogdoches, TX: Stephen F. Austin State University, School of Forestry, Center for Applied Studies: 146-147. (SO)

PUTNAM, CHARLES W.; and KEITH E. EVANS. 1981. Boreal relics border Ozark glade. Missouriensis. 2(4):6. (NC)

RALPH, C. J. 1978. Hawaiian plant on endangered species list. 'Elepaio. 38:142-143. (PSW)

RALPH, C. JOHN.; ALISON P. PEARSON; and DAVID C. PHILLIPS. 1980. Observations of the life history of the endangered Hawaiian vetch Vicia menziesii Fabaceae and its use by birds. Pacific Science. 34(2):83-92. (PSW)

RAPHAEL, MARTIN G. 1989. There's life in dead trees. Biologue. 39(2):11-12. (RM)

RATLIFF, RAYMOND D. 1982. A correction of Cole's C7 and Hurlbert's C8 coefficients of interspecific association. Ecology. 63:1605-1606. (PSW) 
RATLIFF, RAYMOND D. 1985. Meadows in the Sierra Nevada of California: State of knowledge. Gen. Tech. Rep. PSW-84. Berkeley, CA: U.S. Department of Agriculture, Forest Service, Pacific Southwest Forest and Range Experiment Station. 52 p. (PSW)

RATLIFF, RAYMOND D.; and STANLEY E. WESTFALL. 1976. Disturbance--not protection--may benefit culture of California-poppy (Eschsholzia california var. peninsularis Green). Horticultural Science. 11:210-212. (PSW)

RIEKIRK, H.; J. C. HENDERSON; and W. S. GAIN. 1982. Site and environmental effects of tree biomass silviculture. In: Proceedings, 1981 international gas research conference; September 28October 1; Los Angeles, CA. Rockville, MD: Government Institutes, Inc: 15811591. (SE)

ROEDNER, BEVERLY J.; DAVID A. HAMILTON; and KEITH E. EVANS. 1978. Rare plants of the Ozark Plateau-a field identification guide. St. Paul, MN: U.S. Department of Agriculture, Forest Service, North Central Forest Experiment Station. 238 p. (NC)

ROGERS, LYNN L.; and APPLEGATE, ROGER D. 1983. Dispersal of fruit seeds by black bears. Journal of Mammalogy. 64:310-311. (NC)

RONCO, FRANK, JR. 1987. Stand structure and function of pinyon-juniper woodlands. In: Everett, Richard L., comp. Proceedings--pinyon-juniper conference; 1986 January 13-16; Reno, NV. Gen. Tech. Rep. INT-215. Ogden, UT: U.S. Department of Agriculture, Forest Service, Intermountain Research Station: 14-22. (RM)
SCOWCROFT, PAUL G. 1976. Mamane forest decline on Mauna Kea: A reality or myth. In: Proceedings, 1st conference in natural sciences in Hawaii Volcanoes National Park. Honolulu, HI: University of Hawaii Department of Botany and Cooperative National Park Resources Studies Unit: 187-198. (PSW)

SEDELL, JAMES R.; JERRY F. FRANKLIN; and FREDERICK J. SWANSON. 1980. Out of the ash. American Forestry. 86(10):26-29. (PNW)

SEDELL, JAMES R.; PETER A. BISSON; FREDERICK J. SWANSON; and STANLEY V. GREGORY. 1989. What we know about large trees that fall into streams and rivers. In: Trappe, James M.; and Jerry F. Franklin, tech. eds. From the forest to the sea: a story of fallen trees. Gen. Tech. Rep. PNW-229. Portland, OR: U.S. Department of Agriculture, Forest Service, Pacific Northwest Research Station: 47-81. Chapter 3. (PNW)

SHORT, HENRY L. 1979. Ecology of Arizona cottontop. Res. Pap. RM-201. Fort Collins, CO: U.S. Department of Agriculture, Forest Service, Rocky Mountain Forest and Range Experiment Station. 21 p. (RM)

SIEG, CAROLYN HULL; DANIEL W. URESK; and RICHARD M. HANSEN. 1984. Natural growth of Atriplex suckleyi ((Torrey) Rydb.) on bentonite mine spoils in southeastern Montana. In: Tiedemann, Arthur R.; E. Durant McArthur; Howard C. Stutz; Richard Stevens; and Kendall L. Johnson, comps. Proceedings, symposium on the biology of Atriplex and related chenopods: 1983 May 2-6; Provo, UT. Gen. Tech. Rep. INT-172. Ogden, UT: U.S. Department of Agriculture, Forest Service, Intermountain Forest and Range Experiment Station: 53-58. (RM) 
SKINNER, B. R.; G. E. PROBASCO; and F. B. SAMSON. 1983. Environmental requirements of three threatened plants on limestone glades in southern Missouri. Biology Conservation. 25(1):63-73. (NC)

SMITH, MARK A.; and ARDEN A. BALTENSPERGER. 1983. Agronomic and acetylene reduction evaluation of three annual medics. Journal of Range Management. 36:55-57. (RM)

SMITH, W. H.; and B. F. SWINDEL. 1976. Recent developments in nonpoint source pollution policies, regulations and research: New Research Planned to IMPAC. In: Proceedings, Florida Section, Society of American Foresters Spring Symposium. Resour. Rep. 3. Gainesville, FL: Florida Cooperative Extension Service and the School of Forest Resources and Conservation, University of Florida. (SE)

SPIES, THOMAS A.; and JERRY F. FRANKLIN. 1988. Old growth and forest dynamics in the Douglas-fir region of western Oregon and Washington. Natural Areas Journal. 8:190-201. (PNW)

STEVENS, RICHARD. 1986. Population dynamics of two sagebrush species and rubber rabbitbrush over 22 years of grazing use by three animal classes. In: McArthur, E. Durant; and Bruce L. Welch, comps. Proceedings-symposium on the biology of Artemisia and Chrysothamnus; 1984 July 9-13; Provo, UT. Gen. Tech. Rep. INT-200. Ogden, UT: U.S. Department of Agriculture, Forest Service, Intermountain Forest and Range Experiment Station: 278-285. (INT)

STRICKLER, GERALD S.; and PAUL J. EDGERTON. 1976. Emergent seedlings from coniferous litter and soil in eastern Oregon. Ecology. 57:801-807. (PNW)
SZARO, ROBERT C.; and JOHN N. RINNE. 1988. Ecosystem approach to management of southwestern riparian communities. Transactions of the North American Wildlife and Natural Resources Conference. 53:502-511. (RM)

THILENIUS, JOHN F.; and DIXIE R. SMITH. 1985. Vegetation and soils of an alpine range in the Absaroka Mountains, Wyoming. Gen. Tech. Rep. RM-121. Fort Collins, CO: U.S. Department of Agriculture, Forest Service, Rocky Mountain Forest and Range Experiment Station. 18 p. (RM)

TIEDEMANN, A. R.; E. D. MCARTHUR; H. C. STUTZ; R. STEVENS; and K. L. JOHNSON, comps. 1984. Proceedings of the symposium on the biology of Atriplex and related chenopods. Ogden, UT: U.S. Department of Agriculture, Forest Service, Intermountain Forest and Range Experiment Station. 309 p. (INT)

TOMBACK, DIANA F. 1981. Notes on cones and vertebrate-mediated seed dispersal of Pinus albicaulis (Pinaceae). Madrono. 28:91-94. (PSW)

TUELLER, PAUL T.; C. DWIGHT BEESON; ROBIN J. TAUSCH; NEIL E. WEST; and KENNETH H. REA. 1979. Pinyonjuniper woodlands of the Great Basin: Distribution, flora, vegetal cover. Res. Pap. INT-229. Ogden, UT: U.S. Department of Agriculture, Forest Service, Intermountain Forest and Range Experiment Station. 22 p. (INT)

WEST, N. E.; R. J. TAUSCH; K. H. REA; and P. T. TUELLER. 1978.

Phytogeographical variation within pinyon-juniper woodlands of the Great Basin. In: Intermountain biogeography: a symposium. Provo, UT: Brigham Young University. Great Basin Naturalist Memoirs. 2:119-136. (INT) 
WEST, NEIL E. 1980. Survival patterns of major perennials in salt desert shrub communities of southwestern Utah. Journal of Range Management. 32:442445. (INT)

WEST, NEIL E.; KENNETH H. REA; and ROY A. HARNISS. 1979. Plant demographic studies in sagebrush grass communities of southern Idaho. Ecology. 60:376-388. (INT)

WHISENANT, S. G.; and D. W. URESK. 1989. Burning upland, mixed prairie in Badlands National Park. The Prairie Naturalist. 21:221-228. (RM)

\section{Plant Succession}

ALDON, EARL F. 1981. Long-term plant survival and density data from reclaimed southwestern coal mine spoils. Great Basin Naturalist. 41:271-273. (RM)

ALDON, EARL F. 1983. Vegetation stability on mine spoils in the Southwest. In: Aldon, Earl F.; and Wendall R. Oaks, eds. Reclamation of mined lands in the Southwest: Proceedings of the symposium; 1982 October 20-22; Albuquerque, NM: New Mexico Chapter of the Soil Conservation Society of America: 198-200. (RM)

ARNO, STEPHEN F.; and GEORGE E. GRUELL. 1986. Douglas-fir encroachment into mountain grasslands in southwestern Montana. Journal of Range Management. 39:272-275. (INT)

ARNO, STEPHEN F.; DENNIS G. SIMMERMAN; and ROBER E. KEANE. 1985. Forest succession on four habitat types in western Montana. Gen. Tech. Rep. INT-177. Ogden UT: U.S. Department of Agriculture, Forest Service, Intermountain Forest and Range Experiment Station. 74 p. (INT)
BARTOS, D. L.; and W. F. MUEGGLER. 1981. Early succession in aspen communities following fire in western Wyoming. Journal of Range Management. 34:315-318. (INT)

BENEDICT, NATHAN B. 1982. Mountain meadows: stability and change. Madrono. 29:148-153; (PSW)

BLAIR, ROBERT M.; and LOUIS E. BRUNETT. 1976. Phytosociological changes after timber harvest in a southern pine ecosystem. Ecology. 57:18-32. (SO)

CABLE, DWIGHT, R. 1976. Twenty years of changes in grass production following mesquite control and reseeding. Journal of Range Management. 29:286-289. (RM)

CHAMBERS, J. C.; J. A. MACMAHON; and R. W. BROWN. 1987. Response of an early seral dominant alpine grass and a late seral alpine forb to $\mathrm{N}$ and $\mathrm{P}$ availability. Reclamation and Revegetation Research. 6:219-234. (INT)

CHAMBERS, JEANNE C. 1983. Measuring species diversity on revegetated surface mines: an evaluation of techniques. Res. Pap. INT-322. Ogden, UT: U.S. Department of Agriculture, Forest Service, Intermountain Forest and Range Experiment Station. 15 p. (INT)

CLARY, WARREN P.; and RALPH C. HOLMGREN. 1987. Difficulties in interpretation of long-term vegetation trends in response to livestock grazing. In: Provenza, Frederick D.; Jerran T. Flinders; and E. Durant McArthur, comps. Proceedings--symposium on plant-herbivore interactions; 1985 August 7-9; Snowbird, UT. Gen. Tech. Rep. INT-222. Ogden, UT: U.S. Department of Agriculture, Forest Service, Intermountain Research Station: 154-161. (INT) 
DALE, VIRGINIA H.; MILES HEMSTROM; and JERRY FRANKLIN. 1985. Modeling the long-term effects of disturbance on forest succession, Olympic Peninsula, Washington. Canadian Journal of Forest Research. 16:56-67. (PNW)

EDGERTON, PAUL J. 1983. Response of the bitterbrush understory of a central Oregon lodgepole pine forest to logging disturbance. In: Tiedemann, Arthur R.; and Kendall $L$. Johnson, comps. Research and management of bitterbrush and cliffrose in western North America: Proceedings of a symposium; 1982 April 13-15; Salt Lake City, UT. Gen. Tech. Rep. INT-152. Ogden, UT: U.S. Department of Agriculture, Forest Service, Intermountain Forest and Range Experiment Station: 99-106. (PNW)

EVERETT, RICHARD L.; and KENNETH WARD. 1984. Early plant succession of pinyon-juniper controlled burns. Northwest Science. 58:57-68. (INT)

FERGUSON, ROBERT B.; and DEAN E. MEDIN. 1983. Long-term changes in an ungrazed bitterbrush plant community in southwest Idaho. In: Tiedemann, Arthur R.; and Kendall L. Johnson, comps. Research and management of bitterbrush and cliffrose in western North America: Proceedings of a symposium; 1982 April 13-15; Salt Lake City, UT. Gen. Tech. Rep. INT-152. Ogden, UT: U.S. Department of Agriculture, Forest Service, Intermountain Forest and Range Experiment Station: 107-116. (INT)

\section{GRANILLO, ALFREDO B.; and R. SCOTT} BEASLEY. 1984. Recovery of ground cover after clear-cutting and site preparation. Arkansas Farm Resource. 33(2):12. (SO)
HALL, F. C. 1978. Trends in standing crop and species composition of a rested Kentucky bluegrass meadow over an 11-year period. In: Hyder, D. N., ed. Proceedings, 1 st international rangeland congress; 1978 August 14-18; Denver, $\mathrm{CO}$ : Society for Range Management: 526-529 (PNW)

HARNISS, ROY O. 1981. Ecological succession in aspen and its consequences on multiple use values. In: DeByle, Norbert V., ed. Situation management of two intermountain species: aspen and coyotes. Part I: Aspen: Proceedings of a symposium; 1981 April 23-24; Logan, UT. Logan, UT: Utah State University, College of Natural Resources: 31-39. (INT)

HELMS, JOHN A. 1987. Invasion of Pinus contorta var. murrayana (Pinaceae) into mountain meadows at Yosemite National Park, California. Madrono. 34(2):91-97. (PSW)

KONIAK, SUSAN. 1986. Tree densities on pinyon-juniper woodland sites in Nevada and California. Great Basin Naturalist. 46:179-184. (INT)

KRUSE, WILLIAM H.; RUSSELL P. BALDA; MICHAEL J. SIMONA; A. MICHAEL MACRANDER; and CLARENCE D. JOHNSON. 1979. Community development in two adjacent pinyonjuniper eradication areas twenty-five years after treatment. Journal Environmental Management. 8:237-247. (RM)

LEVENSON, J. B.; and F. W. STEARNS. 1980. Application of diversity to regional ecological assessment: a review with recommendations. Argonne National Laboratory, Energy and Environmental Systems: 21:1-34. 
LI, C. Y.; CHRIS MASER; ZANE MASER; and BRUCE A CALDWELL. 1986. Role of three rodents in forest nitrogen fixation in western Oregon: another aspect of mammal-mycorrhizal fungus-tree mutualism. Great Basin Naturalist. 46:411-414. (PNW)

MARTIN, S. C. 1986. Eighty years of vegetation change on a semi-desert range in southern Arizona, U.S.A. and evaluation of causes. In: Joss, P. J.; P. W. Lynch; and O. B. Williams, eds. Rangelands: a resource under siege: Proceedings, 2nd international rangeland congress; 1985 May 13-18; Adelaide, Australia. Canberra, Australia: Australia Academy of Science: 53. (RM)

MCKEE, ARTHUR; JOSEPH E. MEANS; WILLIAM H. MOIR; and JERRY F. FRANKLIN. 1987. First-year recovery of upland and riparian vegetation in the devastated area around Mount St. Helens. In: Bilderback, David E., comp. ed. Mount St. Helens 1980: botanical consequences of the explosive eruptions. Berkeley, CA: University of California Press: 168-187. (PNW)

MUEGGLER, W. F. 1976. Type variability and succession in Rocky Mountain aspen. In: Utilization and marketing as tools for aspen management in the Rocky Mountains. Gen. Tech. Rep. RM-29. Fort Collins, CO: U.S. Department Agriculture, Forest Service, Rocky Mountain Forest and Range Experiment Station: 16-19. (INT)

MUEGGLER, W. F.; and D. L. BARTOS. 1977. Grindstone Flat and Big Flat exclosures--a 41-year record of changes in clearcut aspen communities. Res. Pap. INT-195. Ogden, UT: U.S. Department of Agriculture, Forest Service, Intermountain Forest and Range Experiment Station. 10 p. (INT)
NORTON, BRIEN E. 1978. The impact of sheep grazing on long-term successional trends in salt desert shrub vegetation of southwestern Utah. In: Hyder, Donald N., ed. Proceedings, 1st international rangeland congress; 1978 August 14-18; Denver, CO: Society for Range Management: 610-613. (INT)

REID, ELBERT H.; GERALD S. STRICKLER; and WADE B. HALL. 1980. Green fescue grassland: 40 years of secondary succession. Res. Pap. PNW-274. Portland, OR: U.S. Department of Agriculture, Forest Service, Pacific Northwest Forest and Range Experiment Station. 63 p. (PNW)

SCHLATTERER, EDWARD F. 1984. Practical strategies for providing for diversity in forest land management planning. In: Cooley, James L.; and June H. Cooley, eds. Natural diversity in forest ecosystems: Proceedings of the workshop; 1982 November 29December 1; Athens, GA: Institute of Ecology, University of Georgia: 231-233. (WO)

SEVERSON, KIETH E. 1986. Woody plant reestablishment in modified pinyonjuniper woodlands, New Mexico. Journal of Range Management. 39:438-442. (RM)

SKOUSEN, J.; JAMES N. DAVIS; and JACK D. BROTHERSON. 1986. Comparison of vegetation patterns resulting from bulldozing and two-way chaining on a Utah pinyon-juniper big game range. Great Basin Naturalist. 46:508-512. (INT)

STEELE, ROBERT; and KATHLEEN GEIERHAYES. 1987. The grand fir/blue huckleberry habitat type in central Idaho: succession and management. Gen. Tech. Rep. INT-228. Ogden, UT: U.S. Department of Agriculture, Forest Service, Intermountain Research Station. 66 p. (INT) 
STICKNEY, PETER F. 1980. Data base for post-fire succession, first 6 to 9 years, in Montana larch-fir forests. Gen. Tech.

Rep. INT-62. Ogden, UT: U.S.

Department of Agriculture, Forest

Service, Intermountain Forest and

Range Experiment Station. 133 p. (INT)

STICKNEY, PETER F. 1985. Data base for early postfire succession on the Sundance burn, northern Idaho. Gen. Tech. Rep. INT-189. Ogden, UT: U.S. Department of Agriculture, Forest Service, Intermountain Forest and Range Experiment Station. 121 p. (INT)

STICKNEY, PETER F. 1986. First decade plant succession following the Sundance forest fire, northern Idaho. Gen. Tech. Rep. INT-197. Ogden, UT: U.S. Department of Agriculture, Forest Service, Intermountain Forest and Range Experiment Station. 26 p. (INT)

WAGNER, WARREN L.; WILLIAM C. MARTIN; and EARL F. ALDON. 1978. Natural succession on strip-mined lands in northwestern New Mexico.

Reclamation Review. 1:67-73. (RM)

WALKER, LAWRENCE R.; JOHN C. ZASADA; and F. STUART CHAPIN, III. 1986. The role of life history processes in primary succession on an Alaskan floodplain. Ecology. 67:1243-1253. (PNW)

WEST, N. E.; R. J. TAUSCH; K. H. REA; and P. T. TUELLER. 1978. Taxonomic determination, distribution, and ecological indicator values of sagebrush within the pinyon-juniper woodlands of the Great Basin. Journal Range Management. 31:87-92. (INT)

\section{Plant Communities}

ALDON, EARL F.; CARLOS E. GONZALES VICENTE; and WILLIAM H. MOIR, tech. coords. 1987. Strategies for classification and management of native vegetation for food production in arid zones: symposium proceedings; 1987 October 12-16; Tucson, AZ. Gen. Tech. Rep. RM-150. Fort Collins, CO: U.S. Department of Agriculture, Forest Service, Rocky Mountain Forest and Range Experiment Station. 257 p. (RM)

ALEXANDER, BILLY G.; LEE E. FITZHUGH; FRANK J. RONCO; [and others]. 1987. A classification of forest habitat types of the northern portion of the Cibola National Forest, New Mexico. Gen. Tech. Rep. RM-143. Fort Collins, CO: U.S. Department of Agriculture, Forest Service, Rocky Mountain Forest and Range Experiment Station. 35 p. (RM)

ALEXANDER, ROBERT R. 1988. Forest vegetation on national forests in the Rocky Mountain and Intermountain regions: habitat types and community types. Gen. Tech. Rep. RM-162. Fort Collins, CO: U.S. Department of Agriculture, Forest Service, Rocky Mountain Forest and Range Experiment Station. 47 p. (RM)

BAILEY, R. G. 1982. Classification systems for habitat and ecosystems. In: Mason, W. T. Jr; and S. Iker, eds. Research on fish and wildlife habitat. EPA-600/8-82022. Washington, DC: U. S.

Environmental Protection Agency, Office of Research and Development: 26-41.

BENEDICT, NATHAN B. 1983. Plant associations of subalpine meadows, Sequoia National Park, California. Arctic and Alpine Research. 15(3):383-396. (PSW)

BENEDICT, NATHAN B.; and JACK A. MAJOR. 1982. Physiographic classification of subalpine meadows of the Sierra Nevada, California. Madrono. 29:1-12. (PSW) 
BROWN, DAVID E.; and CHARLES H. LOWE. 1980. Biotic communities of the Southwest. Gen. Tech. Rep. RM-78. Fort Collins, CO: U.S. Department of Agriculture, Forest Service, Rocky Mountain Forest and Range Experiment Station. Map 1 p. (RM)

BROWN, DAVID E.; CHARLES H. LOWE; and CHARLES P. PASE. 1977. A digitized classification system for the natural vegetation of North America with a hierarchical summary for world ecosystems. In: Classification, inventory and analysis of fish and wildlife habitat symposium; 1977 January 24-27; Phoenix, AZ. USDI, U.S. Fish and Wildlife Service. (RM)

BROWN, DAVID E.; CHARLES H. LOWE; and CHARLES P. PASE. 1978. Biotic communities of the Southwest. Gen. Tech. Rep. RM-41. Fort Collins, CO: U.S. Department of Agriculture, Forest Service, Rocky Mountain Forest and Range Experiment Station. Map $2 \mathrm{p}$. (RM)

BROWN, DAVID E.; CHARLES H. LOWE; and CHARLES P. PASE. 1979. A digitized classification system for the biotic communities of North America, with community (series) and association examples for the Southwest. Journal Arizona-Nevada Academic Science. 14(1):1-16. (RM)

BROWN, DAVID E.; CHARLES H. LOWE; and CHARLES P. PASE. 1980. A digitized systematic classification for ecosystems with an illustrated summary of the natural vegetation of North America. Gen. Tech. Rep. RM-73. Fort Collins, CO: U.S. Department of Agriculture, Forest Service, Rocky Mountain Forest and Range Experiment Station. 93 p. (RM)

CAMPBELL, ALSIE G.; and JERRY F. FRANKLIN. 1979. Riparian vegetation in Oregon's western Cascade Mountains: composition, biomass, and autumn phenology. Coniferous Forest Biome Bulletin 14.90 p. (PNW)
CARAHER, DAVID L. 1978. The spread of western juniper in central Oregon. In: Martin, Robert E.; J. Edward Dealy; and David L. Caraher, eds. Proceedings of the western juniper ecology and management workshop; 1977 January; Bend, OR. Gen. Tech. Rep. PNW-74. Portland, OR: U.S. Department of Agriculture, Forest Service, Pacific Northwest Forest and Range Experiment Station: 3-7. (PNW)

CARMICHAEL, R. S.; O. D. KNIPE; C. P. PASE; and W. W. BRADY. 1978. Arizona chaparral: Plant associations and ecology. Res. Pap. RM-202. Fort Collins, CO: U.S. Department of Agricultural, Forest Service, Rocky Mountain Forest and Range Experiment Station. 16 p. (RM)

COE, PRISCILLA KOLD; and THOMAS QUIGLEY. 1986. Application of a geographic information system for the Oregon range evaluation project. In: Proceedings of a geographic information systems workshop; 1986 April 1-4; Atlanta, GA. Portland, OR: American Society for Photogrammetry and Remote Sensing: 89-98. (PNW)

COOPER, STEVEN V.; [and others]. 1987. Forest habitat types of northern Idaho: a second approximation. Gen. Tech. Rep. INT-236. Ogden, UT: U.S. Department of Agriculture, Forest Service, Intermountain Research Station. $135 \mathrm{p}$. (INT)

DE BYLE, NORBERT V. 1978. Our western aspen ecosystem--quest for management. Western Wildlands. 4(3):18-23. (INT) 
DEALY, J. EDWARD; J. MICHAEL GEIST; and RICHARD S. DRISCOLL. 1978. Communities of western juniper in the Intermountain Northwest. In: Martin, Robert E.; J. Edward Dealy; and David L. Caraher, eds. Proceedings of the western juniper ecology and management workshop; 1977 January; Bend, OR. Gen. Tech. Rep. PNW-74. Portland, OR: U.S. Department of Agriculture, Forest Service, Pacific Northwest Forest and Range Experiment Station: 11-29. (PNW)

DEALY, J. EDWARD; J. MICHAEL GEIST; and RICHARD S. DRISCOLL. 1978. Western juniper communities on rangelands of the Pacific Northwest. In: Hyder, Donald N., ed. Proceedings, 1st international rangeland congress; 1978 August 14-18; Denver, CO: Society for Range Management: 201-204. (PNW)

DRISCOLL, RICHARD S.; [and others]. 1984. An ecological land classification framework for the United States. Misc. Pub. 1439. Washington, DC: U.S. Department of Agriculture, Forest Service. 56 p. (RM)

\section{FERGUSON, DENNIS E.; PENELOPE} MORGAN; and FREDERIC D. JOHNSON, comps. 1989. Proceedings-land classifications based on vegetation: applications for resource management; 1987 November 17-19; Moscow, ID. Gen. Tech. Rep. INT-257. Ogden, UT: U.S. Department of Agriculture, Forest Service, Intermountain Research Station. 315 p. (INT)

\section{FFOLLIOT, PETER F.; and WARREN P.} CLARY. 1986. Pinyon-juniper woodlands in the southwest. In: Ffolliot, Peter F.; and Wayne T. Swank, eds. Potential of noncommercial forest biomass for energy. Tech. Bull. 256. Tucson, AZ: University of Arizona, School of Renewable Resources: 3-10. (INT)
FRANCIS, RICHARD E. 1983. Sagebrushsteppe habitat types in northern Colorado: first approximation. In: Moir, W. H.; and Leonard Hendzel, eds. Proceedings of the workshop on Southwestern habitat types; 1983 April 6-8; Albuquerque, NM. U.S. Department of Agriculture, Forest Service, Southwestern Region: 67-71. (RM)

FRANCIS, RICHARD E. 1986. Phyto-edaphic communities of the upper Rio Puerco watershed. Res. Pap. RM-272. Fort Collins, CO: U.S. Department of Agriculture, Forest Service, Rocky Mountain Forest and Range Experiment Station. 73 p. (RM)

FRANCIS, RICHARD E.; and EARL F. ALDON. 1983. Preliminary habitat types of a semiarid grassland. In: Moir, W. H.; and Leonard Hendzel, eds. Proceedings of the workshop on Southwestern habitat types; 1983 April 6-8, Albuquerque, NM. U.S. Department of Agriculture, Forest Service, Southwestern Region: 62-66. (RM)

FRANCIS, RICHARD E.; and EARL F. ALDON. 1987. An ecological approach to classifying semiarid plant communities. In: Aldon, Earl F.; Carlos E. Gonzales Vicente; and William H. Moir, tech. coords. Strategies for classification and management of native vegetation for food production in arid zones: symposium proceedings; 1987 October 12-16; Tucson, AZ. Gen. Tech. Rep. RM-150. Fort Collins, CO: U.S. Department of Agriculture, Forest Service, Rocky Mountain Forest and Range Experiment Station: 9-14. (RM)

FRESQUEZ, P. R.; G. L. DENNIS; and R. E. FRANCIS. 1989. Soil fungi: an additional parameter for phyto-edaphic community classification. In:

Proceedings--land classifications based on vegetation: applications for resource management. Gen. Tech. Rep. INT-257. Ogden, UT: U.S. Department of Agriculture, Forest Service, Intermountain Research Station: 285287. (RM) 
FRESQUEZ, P. R.; R. E. FRANCIS; and G. L. DENNIS. 1988. Fungal communities associated with phytoedaphic communities in the semiarid Southwest. Arid Soil Research and Rehabilitation. 2:187-202. (RM)

GARRISON, GEORGE A.; ARDELL J. BJUGSTAD; DONALD A. DUNCAN; MONT E. LEWIS; and DIXIE R. SMITH. 1977. Vegetation and environmental features of forest and range ecosystems of the United States. Agric. Handb. 475. Washington, DC: U.S. Department of Agriculture, Forest Service. 68 p. (PNW)

GIRARD, MICHELE M.; HAROLD GOETZ; and ARDELL J. BJUGSTAD. 1984. Native woodlands of southwestern North Dakota. In: Proceedings, 76th Annual Meeting, North Dakota Academy of Science: 38:88. (RM)

GIRARD, MICHELE M.; HAROLD GOETZ; and ARDELL J. BJUGSTAD. 1984. Woody habitats in southwestern North Dakota. In: Proceedings, Forestry Committee, Great Plains Agricultural Council Annual Meeting; 1983 July 1114; Billings, MT: 116-123. (RM)

GIRARD, MICHELE M.; HAROLD GOETZ; and ARDELL J. BJUGSTAD. 1989. Native woodland habitat types of southwestern North Dakota. Res. Pap. RM-281. Fort Collins, CO; U.S. Department of Agriculture, Forest Service, Rocky Mountain Forest and Range Experiment Station. 36 p. (RM)

GUTHERY, FRED S.; FRED A. STORMER, and JEAN M. PATES. 1982. Characterization of playas in central panhandle of Texas. Transactions of the North American Wildlife and Natural Resources Conference. 47:516-527. (RM)
HALL, F. C. 1978. Western juniper in association with other tree species. In: Martin, R. E.; J. E. Dealy; and D. L. Caraher, tech. eds. Proceedings, Western juniper ecology and management workshop. Gen. Tech. Rep. PNW-74. Portland, OR: U.S. Department of Agriculture, Forest Service, Pacific Northwest Forest and Range Experiment Station: 496-499 (PNW)

HALL, F. C. 1980. Application of a classification systems based on plant community types (Associations) with special reference to wildlife, range, and timber management. In: Land-use allocations: Processes, people, professionals; Proceedings, Society of American Foresters Convention; 1980 October 7-9; Spokane, WA.

Washington, DC: Society of American Foresters: 163-169. (PNW)

HANKS, J. P.; E. LEE FITZHUGH; and SHARON R. HANKS. 1983. A habitat type classification system for ponderosa pine forests of northern Arizona. Gen. Tech. Rep. RM-97. Fort Collins, CO: U.S. Department of Agriculture, Forest Service, Rocky Mountain Forest and Range Experiment Station. 22 p. (RM)

HANSEN, PAUL L.; and GEORGE R. HOFFMAN. 1988. The vegetation of the Grand River, Cedar River, Sioux, and Ashland Districts of the Custer National Forest: a habitat type classification. Gen. Tech. Rep. RM-157. Fort Collins, CO: U.S. Department of Agriculture, Forest Service, Rocky Mountain Forest and Range Experiment Station. 68 p. (RM)

HANSEN, PAUL L.; GEORGE R. HOFFMAN; and ARDELL J. BJUGSTAD. 1984. The vegetation of Theodore Roosevelt National Park, North Dakota: a habitat type classification. Gen. Tech. Rep. RM113. Fort Collins, CO: U.S. Department of Agriculture, Forest Service, Rocky Mountain Forest and Range Experiment Station. 35 p. (RM) 
HARPER, KIMBALL T.; STEWART C. SANDERSON; and E. DURANT MCARTHUR. 1987. Vegetation communities of Zion National Park. 11th Annual Report. Laramie, WY: University of Wyoming-National Park Service Research Center. 191-196. (INT)

HARPER, KIMBALL; STEWART C. SANDERSON; E. DURANT MCARTHUR; and JOEL S. TUHY. 1989. Vegetation communities of Zion National Park. 12th Annual Report 1988. Laramie, WY: University of WyomingNational Park Service Research Center: 207-214. (INT)

HOFFMAN, G. R.; and R. R. ALEXANDER. 1976. Forest vegetation of the bighorn Mountains, Wyoming: a habitat type classification. Res. Pap. RM-170. Fort Collins, CO: U.S. Department of Agriculture, Forest Service, Rocky Mountain Forest and Range Experiment Station. $38 \mathrm{p}$.

HOFFMAN, GEORGE R.; and ROBERT R. ALEXANDER. 1980. Forest vegetation of the Routt National Forest in northwestern Colorado: a habitat type classification. Res. Pap. RM-221. Fort Collins, CO: U.S. Department of Agriculture, Forest Service, Rocky Mountain Forest and Range Experiment Station. 41 p. (RM)

HOFFMAN, GEORGE R.; and ROBERT R. ALEXANDER. 1983. Forest vegetation of the White River National Forest in western Colorado, a habitat type classification. Res. Pap. RM-249. Fort Collins, CO: U.S. Department of Agriculture, Forest Service, Rocky Mountain Forest and Range Experiment Station. 36 p. (RM)
JUDAY, GLENN PATRICK; and JOHN C. ZASADA. 1984. Structure and development of an old-growth white spruce forest on an interior Alaska floodplain. In: Meehan, William R.; Theodore, R. Merrel, Jr.; and Thomas A. Hanley, eds. Fish and wildlife relationships in old-growth forests; 1982 April 12-15; Juneau, AK. Morehead City, NC: American Institute of Fishery Research Biologists: 227-234. (PNW)

KEANE, ROBERT E. 1989. Classification and prediction of successional plant communities using a pathway model. In: Ferguson, Dennis E.; Penelope Morgan; and Frederic D. Johnson, comps.

Proceedings--land classifications based on vegetation: applications for resource management; 1987 November 17-19; Moscow, ID. Gen. Tech. Rep. INT-257. Ogden, UT: U.S. Department of Agriculture, Forest Service, Intermountain Research Station: 56-62. (INT)

KOMARKOVA, VERA; ROBERT R. ALEXANDER; and BARRY C. KOHNSON. 1988. Forest vegetation of the Gunnison and parts of the Uncompahgre National Forests: a preliminary habitat type classification. Gen. Tech. Rep. RM-163. Fort Collins, CO: U.S. Department of Agriculture, Forest Service, Rocky Mountain Forest and Range Experiment Station. 65 p. (RM)

MACCRACKEN, JAMES G.; DANIEL W. URESK; and RICHARD M. HANSEN. 1984. Plant community variability on a small area in southwestern Montana. Great Basin Naturalist. 43:660-668. (RM)

MAUK, RONALD L.; and JAN A. HENDERSON. 1984. Coniferous forest habitat types of northern Utah. Gen. Tech. Rep. INT-170. Ogden, UT: U.S. Department of Agriculture, Forest Service, Intermountain Forest and Range Experiment Station. 89 p. (INT) 
MEDINA, ALVIN L. 1986. Riparian plant communities of the Fort Bayard watershed in southwestern New Mexico. The Southwestern Naturalist. 31:345359. (RM)

MUEGGLER, W. F. 1985. Aspen communities in the interior West. In: Proceedings of the 1985 Society of American Foresters national convention; 1985 July 28-31; Fort Collins, CO. Bethesda, MD: Society of American Foresters: 106-111. (INT)

MUEGGLER, W. F.; and W. L. STEWART. 1980. Grassland and shrubland habitat types of western Montana. Gen. Tech. Report INT-66. Ogden, UT: U.S. Department of Agriculture, Forest Service, Intermountain Forest and Range Experiment Station. 154 p. (INT)

MUEGGLER, W. F.; and W. L. STEWART. 1981. Forage production on important rangeland habitat types in western Montana. Journal of Range Management. 34:347-353. (INT)

MUEGGLER, WALTER F. 1984. Diversity of western rangelands. In: Cooley, James L.; and June H. Cooley, eds. Natural diversity in forest ecosystems:

Proceedings of the workshop; 1982 November 29-December 1; Athens, GA: Institute of Ecology, University of Georgia: 211-217. (INT)

MUEGGLER, WALTER F.; and ROBERT B. CAMPBELL, JR. 1982. Aspen community types on the Caribou and Targhee National Forests in southeastern Idaho. Res. Pap. INT-294. Ogden, UT: U.S. Department of Agriculture, Forest Service, Intermountain Forest and Range Experiment Station. 32 p. (INT)

MUEGGLER, WALTER F.; and ROBERT B. CAMPBELL, JR. 1986. Aspen community types of Utah. Res. Pap.

INT-362. Ogden, UT: U.S. Department of Agriculture, Forest Service, Intermountain Forest and Range Experiment Station. 69 p. (INT)
MUNN, L. C.; G. A. NIELSON; and W. F. MUEGGLER. 1978. Relationships of soils to maintain and foothill range habitat types and production in Western Montana. Soil Science Society American Journal. 42:135-139. (INT)

NELSON, DAVID L.; and CHARLES F. TIERNAN. 1983. Winter injury of sagebrush and other wildland shrubs in the western United States. Res. Pap. INT-314. Ogden, UT: U.S. Department of Agriculture, Forest Service, Intermountain Forest and Range Experiment Station. 17 p. (INT)

OHMANN, LEWIS F. 1979. Northeastern and North Central forest types and their management. In: DeGraaf, Richard M., tech. coord. Management of North Central and Northeastern forests for nongame birds: Workshop proceedings; 1979 January 23-25: Minneapolis, MN. Gen. Tech. Rep. NC-51. St. Paul, MN: U.S. Department of Agriculture, Forest Service, North Central Forest Experiment Station: 22-31. (NC)

PASE, CHARLES P. 1982. Alpine tundra. In: Brown, David E., ed. Biotic communities of the American Southwest-United States and Mexico. Desert Plants. 4(14):27-33. (RM)

PASE, CHARLES P. 1982. Californian (coastal) chaparral. In: Brown, David E., ed. Biotic communities of the American Southwest-United States and Mexico. Desert Plants. 4(1-4):91-94. (RM)

PASE, CHARLES P. 1982. Sierran montane conifer forest. In: Brown, David E., ed. Biotic communities of the American Southwest-United States and Mexico. Desert Plants. 4(1-4):49-51. (RM)

PASE, CHARLES P. 1982. Sierran subalpine conifer forest. In: Brown, David E., ed. Biotic communities of the American Southwest-United States and Mexico. Desert Plants. 4(1-4):40-41. (RM) 
PASE, CHARLES P.; and DAVID E. BROWN. 1982. Rocky Mountain (Petran) and Madrean montane conifer forests. In: Brown, David E., ed. Biotic communities of the American Southwest-United States and Mexico. Desert Plants. 4(14):43-47. (RM)

PASE, CHARLES P.; and DAVID E. BROWN. 1982. Rocky Mountain (Petran) subalpine conifer forest. In: Brown, David E., ed. Biotic communities of the American Southwest-United States and Mexico. Desert Plants. 4(1-4):37-39. (RM)

PASE, CHARLES P.; and DAVID E. BROWN. 1982. Californian coastalscrub. In:

Brown, David E., ed. Biotic communities of the American Southwest-United States and Mexico. Desert Plants. 4(14):86-89. (RM)

PASE, CHARLES P.; and DAVID E. BROWN. 1982. Interior chaparral. In: Brown, David E., ed. Biotic communities of the American Southwest-United States and Mexico. Desert Plants. 4(1-4):95-99. (RM)

PASE, CHARLES P.; and EARL F. LAYSER. 1977. Classification of riparian habitats. In: Johnson, R. Roy; and Dale A. Jones, tech. eds. Importance, preservation and management of the riparian habitat: Symposium proceedings; 1977 July 9; Tucson, AZ: Gen. Tech. Rep. RM-43. Fort Collins, CO: U.S. Department of Agriculture, Forest Service, Rocky Mountain Forest and Range Experiment Station: 5-9. (RM)
PEARSON, HENRY A.; HAROLD E. GRELEN; BERNIE R. PARRESOL; [and others]. 1987. Detailed vegetation descriptions of the longleaf-slash pine type, Vernon District, Kisatchie National Forest, Louisana. In: Pearson, Henry A.; Fred Smeins; and Ronald E. Thill, comps. 1987. Ecological, physical, and socioeconomic relationships within southern National Forests: Proceedings of the southern evaluation project workshop; 1987 May 26-27; Long Beach, MS. Gen. Tech. Rep. SO-68. New Orleans, LA: U.S. Department of Agriculture, Forest Service, Southern Forest Experiment Station: 107-115. (SO)

\section{PFISTER, ROBERT D.; and RONALD F.} BATCHELOR. 1984. Montana riparian vegetation types. Western Wildlands. 9(4):19-23. (INT)

PFISTER, ROBERT D.; BERNARD L. KOVALCHIK; STEPHEN F. ARNO; and RICHARD C. PRESBY. 1977. Forest habitat types of Montana. Gen. Tech. Rep. INT-34. Ogden, UT: U.S. Department of Agriculture, Forest Service, Intermountain Forest and Range Experiment Station. 174 p. (INT)

PLATTS, WILLIAM S.; and SHERMAN JENSEN. 1987. Wetland/riparian ecosystems of the Great Basin/desert and montane region: an overview. In: Sather, J. Henry; and Jessop Low, org. Great Basin/desert and montane regional wetland functions: Proceedings of a workshop; 1986 February 27-28; Logan, UT. Washington, DC: U.S. Department of the Interior, Fish and Wildlife Service: 5-10. (INT)

RATLIFF, RAYMOND D. 1982. A meadow site classification for the Sierra Nevada, California. Gen. Tech. Rep. PSW-60. Berkeley, CA: U.S. Department of Agriculture, Forest Service, Pacific Southwest Forest and Range Experiment Station. 16 p. (PSW) 
RATLIFF, RAYMOND D.; and PIEPER, REX D. 1982. Approaches to plant community classification for the range manager. Monograph Series No. 1. Denver, CO: The Society for Range Management. 10 p. (PSW)

ROTHENBERGER, S. J.; G. E. LARSON; W. T. BAKER; and D. S. GALITZ. 1976. Plant community and growth analysis in the vicinity of Stanton, North Dakota. Proceedings, North Dakota Academy Science. 30:39. (RM)

SEVERSON, KIETH E.; and JOHN F. THILENIUS. 1976. Classification of quaking aspen stands in the Black Hills and Bear Lodge Mountains. Res. Pap. RM-166. Fort Collins, CO: U.S. Department of Agriculture, Forest Service, Rocky Mountain Forest and Range Experiment Station. 24 p. (RM)

SMITH, P. W.; E. J. DEPUIT; and B. Z. RICHARDSON. 1988. Plant community development on petroleum drill sites in northwestern Wyoming. Journal of Range Management. 41:372-377. (INT)

STEELE, R. 1983. Forest habitat types of eastern Idaho-western Wyoming. Gen. Tech. Rep. INT-144. Ogden, UT: U.S. Department of Agriculture, Forest Service, Intermountain Forest and Range Experiment Station. 122 p. (INT)

STEELE, ROBERT; ROBERT D. PFISTER; RUSSELL A. RYKER; and JAY A. KITTAMS. 1981. Forest habitat types of central Idaho. Gen. Tech. Rep. INT-114. Ogden, UT: U.S. Department of Agriculture, Forest Service, Intermountain Forest and Range Experiment Station. 138 p. (INT)

SZARO, ROBERT C. 1989. Riparian forest and scrubland community types of Arizona and New Mexico. Desert Plants. $9(3-4): 70-138$. (RM)
SZARO, ROBERT C.; and DAVID R. PATTON. 1986. Riparian habitat classification in the southwestern United States. Transactions of the North American Wildlife and Natural Resources Conference. 51:215-221. (RM)

SZARO, ROBERT C.; and JOHN N. RINNE. 1988. Ecosystem approach to management of southwestern riparian communities. Transactions of the North American Wildlife and Natural Resources Conference. 53:502-511. (RM)

THOMAS, JACK WARD; RODNEY J. MILLER; CHRIS MASER; RALPH ANDERSON; and BERNIE E. CARTER. 1979. Plant communities and successional stages. In: Thomas, Jack Ward, tech. ed. Wildlife habitats in managed forests--the Blue Mountains of Oregon and Washington. Agric. Handb. 553. Washington, DC: U.S. Department of Agriculture, Forest Service: 22-39. Chapter 2. (PNW)

TIEDEMAN, J. A.; R. E. FRANCIS; C. TERWILLIGER, JR.; and LEN H. CARPENTER. 1987. Shrub-steppe habitat types of Middle Park, Colorado. Res. Pap. RM-273. Fort Collins, CO: U.S. Department of Agriculture, Forest Service, Rocky Mountain Forest and Range Experiment Station. 20 p. (RM)

URNESS, PHILIP J. 1981. Desert and chaparral habitats. In: Wallmo, Olof C., ed. Mule and black-tailed deer in North America. A Wildlife Management Institute Book developed in cooperation with U.S. Department of Agriculture, Forest Service. Lincoln, NE: University of Nebraska Press: 347-365. Chapter 9. Part 1. (RM) 
WELLNER, CHARLES A. 1989. Classification of habitat types in the Western United States. In: Ferguson, Dennis E.; Penelope Morgan; and Frederic D. Johnson, comps. Proceedings--land classifications based on vegetation: applications for resource management; 1987 November 17-19; Moscow, ID. Gen. Tech. Rep. INT-257. Ogden, UT: U.S. Department of Agriculture, Forest Service, Intermountain Research Station: 7-21. (INT)

YOUNGBLOOD, ANDREW P.; and RONALD L. MAUK. 1985. Coniferous forest habitat types of central and southern Utah. Gen. Tech. Rep. INT-187. Ogden, UT: U.S. Department of Agriculture, Forest Service, Intermountain Forest and Range Experiment Station. $89 \mathrm{p}$. (INT)

YOUNGBLOOD, ANDREW P.; and WALTER F. MUEGGLER. 1981. Aspen community types on the Bridger-Teton National Forest in western Wyoming. Res. Pap. INT-272. Ogden, UT: U.S. Department of Agriculture, Forest Service, intermountain Forest and Range Experiment Station. 34 p. (INT)

Fire Effects

ANDERSON, LINDA M.; DANIEL J. LEVI; TERRY C. DANIEL; and JOHN H. DIETERICH; 1982. The esthetic effects of prescribed burning: a case study.

Res. Note RM-413. Fort Collins, CO: U.S. Department of Agriculture, Forest Service, Rocky Mountain Forest and Range Experiment Station. 5 p. (RM)

ARNO, STEPHEN F. 1983. Variation in estimates of fire intervals: a closer look at fire history on the Bitterroot National Forest. Res. Pap. INT-301. Ogden, UT: U.S. Department of Agriculture, Forest Service, Intermountain Forest and Range Experiment Station. 8 p. (INT)
ARNO, STEPHEN F.; and GEORGE E. GRUELL. 1983. Fire history at the forest-grassland ecotone in southwestern Montana. Journal of Range Management. 36:332-336. (INT)

BARTOS, D. L.; and W. F. MUEGGLER. 1981. Early succession in aspen communities following fire in western Wyoming. Journal of Range Management. 34:315-318. (INT)

BOCK, CARL E.; and JANE H. BOCK. 1978. Response of birds, small mammals, and vegetation to burning sacaton grasslands in southeastern Arizona. Journal of Range Management. 31:296300. (RM)

BOCK, CARL E.; and JANE H. BOCK. 1983. Responses of birds and deer mice to prescribed burning in ponderosa pine. Journal of Wild life Management. 47:836840. (RM)

BOCK, J. H.; C. E. BOCK; and J. R. MCKNIGHT. 1976. A study of the effects of grassland fires at the research ranch in southeastern Arizona. Journal of the Arizona Academy of Sciences. 11:49-57. (RM)

BOYLE, G. 1982. Erosion from burned watersheds in San Bernardino National Forest. In: Conrad, C. Eugene,; and Walter C. Oechel, tech. coords. Proceedings of the symposium on dynamics and management of Mediterranean-type ecosystems; 1981 June 22-26; Sand Diego, CA. Gen. Tech. Rep. PSW-58. Berkeley CA; U.S. Department of Agriculture, Forest Service, Pacific Southwest Forest and Range Experiment Station: 409-410. (PSW) 
BROCK, J. H.; and L. F. DEBANO. 1982.

Runoff and sedimentation potentials influenced by litter and slope on a chaparral community in central Arizona. In: Conrad, C. Eugene; and Walter C. Oechel, tech. coords. Proceedings of the symposium on dynamics and management of Mediterranean-type ecosystems. Gen. Tech. Rep. PSW-58.

Berkeley, CA: U.S. Department of Agriculture, Forest Service, Pacific Southwest Forest and Range Experiment Station: 372-377. (RM)

BUECH, RICHARD R.; KARL SIDERITS; ROBERT E. RADTKE; [and others]. 1977. Small mammal populations after a wildfire in northeastern Minnesota. Res.

Pap. NC-515. St. Paul, MN: U.S. Department of Agriculture, Forest Service, North Central Forest Experiment Station. 8 p. (NC)

BUNTING, STEPHEN, C.; BRUCE M. KILGORE; and CHARLES L. BUSHEY. 1987. Guidelines for prescribed burning sagebrush-grass rangelands in the Northern Great Basin. Gen. Tech. Rep. INT-231. Ogden, UT: U.S. Department of Agriculture, Forest Service, Intermountain Research Station. 33 p. (INT)

CANON, S. K.; P. J. URNESS; and N. V. DEBYLE. 1987. Habitat selection, foraging behavior, and dietary nutrition of elk in burned aspen forest. Journal of Range Management. 40:433-438. (INT)

CHRISTENSEN, NORMAN L.; JAMES K. AGEE; and PETER F. BRUSSARD. 1989. Ecological consequences of the 1988 fires in the Greater Yellowstone Area. [Yellowstone National Park, WY]: U.S. Department of the Interior, National Park Service. 58 p. (PNW)
CONNER, RICHARD N. 1981. Fire and cavity nesters. In: Wood, Gene W., ed. Prescribed fire and wildlife in southern forests: Proceedings of a symposium; 1981 April 6-8; Myrtle Beach, SC. Georgetown, SC. Belle W. Baruch Forest Science Institute, Clemson University: 61-65. (SO)

CONNER, RICHARD N.; and BRIAN A. LOCKE. 1979. Effects of a prescribed burn on cavity trees of red-cockaded woodpeckers. The Wild life Society Bulletin. 7:291-293. (SO)

DAVIS, E. A. 1989. Prescribed fire in Arizona chaparral: effects on stream water quality. Forest Ecology and Management. 26:189-206. (RM)

DAVIS, EDWIN A. 1984.Conversion of Arizona chaparral to grass increases water yield and nitrate loss. Water Resources Research. 20:1643-1649. (RM)

DAVIS, EDWIN A. 1987.Chaparral conversion and streamflow: Nitrate increase is balanced mainly by a decrease in bicarbonate. Water Resources Research. 23:215-224. (RM)

DAVIS, EDWIN A.; and LEONARD F. DEBANO. 1986. Nitrate increases in soil water following conversion of chaparral to grass. Biogeochemistry 2:53-65. (RM)

DAVIS, KATHLEEN M.; BRUCE D. CLAYTON; and WILLIAM C. FISCHER. 1980. Fire ecology of Lolo National Forest habitat types. Gen. Tech. Rep. INT-79. Ogden, UT: U.S. Deparment of Agriculture, Forest Service, Intermountain Forest and Range Experiment Station. 77 p. (INT)

DEBANO, L. F.; and C. E. CONRAD. 1978. The effect of fire on nutrients in a chaparral ecosystem. Ecology. 59:489497. 
DEBANO, L. F.; and C. E. CONRAD. 1976. Nutrient lost in debris and runoff water from a burned chaparral watershed. In: Proceedings of the Third Federal InterAgency Sedimentation Conference; 1976 March; Denver CO. Washington, DC: Water Resource Council: 3-13 to 327. (RM)

DEBANO, L. F.; and J. M. KLOPATEK. 1987. Effect of management on nutrient dynamics in southwestern pinyon juniper woodlands. In: Troendle, Charles A.; Merrill R. Kaufmann; R. H. Hamre; and Robert P. Winokur, tech. coords. Management of subalpine forests: building on 50 years of research: Proceedings of a technical conference; 1987 July Silver Creek, CO. Gen Tech. Rep. RM-149. Fort Collins, CO: U.S. Department of Agriculture, Forest Service, Rocky Mountain Forest and Range Experiment Station: 157-160. (RM)

DEBANO, L. F.; H. M. PERRY; and S. T. OVERBY. 1987. Effects of fuelwood harvesting and slash burning on biomass and nutrient relationships in a pinyon-juniper stand. In: Everett, Richard L., comp. Proceedings--pinyonjuniper conference; 1986 January 13-16; Reno, NV. Gen. Tech. Rep. INT-215. Ogden, UT: U.S. Department of Agriculture, Forest Service, Intermountain Research Station: 382386. (RM)

DEBANO, LEONARD F. 1981. Water repellent soils: a state-of-the-art. Gen. Tech. Rep. PSW-46. Berkeley, CA: U.S. Department of Agriculture, Forest Service, Pacific Southwest Forest and Range Experiment Station. 21 p. (RM)
DEBANO, LEONARD F. 1989. Effects of fire on chaparral soils in Arizona and California and postfire management implications. In: Berg, Neil H., tech. coord. Symposium on fire and watershed management; 1988 October 26-28; Sacramento, CA. Gen. Tech. Rep. PSW-109. Berkeley, CA: U.S. Department of Agriculture, Forest Service, Pacific Southwest Forest and Range Experiment Station: 55-62. (RM)

DEBANO, LEONARD F.; and JEFFREY $M$. KLOPATEK. 1988. Phosphorus dynamics of pinyon-juniper soils following simulated burning. Soil Science Society of America Journal. 52:271-277. (RM)

\section{DEBANO, LEONARD F.; GARY P.} EBERLEIN; and PAUL H. DUNN. 1979. Effects of burning on chaparral soils: I. Soil nitrogen. Soil Science Society of American Journal. 43:504-509. (PSW)

DEBANO, LEONARD F.; RAYMOND M. RICE; and C. EUGENE CONRAD. 1979. Soil heating in chaparral fires: effects on soil properties, plant nutrients, erosion, and runoff. Res. Pap. PSW145. Berkeley, CA: U.S. Department of Agriculture, Forest Service, Pacific Southwest Forest and Range Experiment Station. 21 p. (RM)

DEBYLE, NORBERT V.; COLLIN D. BEVINS; and WILLIAM C. FISCHER. 1987. Wildfire occurrence in aspen in the interior western United States. Western Journal of Applied Forestry. 2:73-76. (INT)

DESPAIN, DEL W. 1987. History and results of prescribed burning of pinyon-juniper woodlands on the Hualapai Indian Reservation in Arizona. In: Everett, Richard L., comp. Proceedings--pinyonjuniper conference; 1986 January 13-16; Reno, NV. Gen. Tech. Rep. INT-215. Ogden, UT: U.S. Department of Agriculture, Forest Service, Intermountain Research Station: 145151. (RM) 
DICKSON, JAMES G. 1981. Effects of forest burning on songbirds. In: Wood, Gene W., ed. Prescribed fire and wildlife in southern forests: Proceedings of a symposium; 1981 April 6-8; Myrtle Beach, SC: Belle W. Baruch Forest Science Institute, Clemson University: 67-72. (SO)

DIETERICH, J. H. 1980. The composite fire interval--a tool for more accurate interpretation of fire history. In: Proceedings of the Fire History Workshop; 1980 October 20-24; Tucson, AZ. Gen. Tech. Rep. RM-81. Fort Collins, CO: U.S. Department of Agriculture, Forest Service, Rocky Mountain Forest and Range Experiment Station: 8-14. (RM)

DOBROWOLSKI, J. P.; W. H. BLACKBURN; and H. E. GRELEN. 1987. Sediment production from long-term burning of a longleaf pine-bluestem association. In: Pearson, Henry A.; Fred Smeins; and Ronald E. Thill, comps. 1987. Ecological, physical, and socioeconomic relationships within southern National Forests: Proceedings of the southern evaluation project workshop; 1987 May 26-27; Long Beach, MS. Gen. Tech. Rep. SO-68. New Orleans, LA: U.S. Department of Agriculture, Forest Service, Southern Forest Experiment Station: 251-260. (SO)

DUNN, P. H.; and L. F. DEBANO. 1977. Fire's effect on biological properties of chaparral soils. In: Proceedings of the symposium on the environmental consequences of fire and fuel management in mediterranean ecosystems; Palo Alto, CA. Gen. Tech. Rep. WO-3. Washington, DC: U.S. Department of Agriculture, Forest Service: 75-84. (PSW)

DUNN, PAUL H.; LEONARD F. DEBANO; and GARY P. EBERLEIN. 1979. Effects of burning on chaparral soils: II. Soil microbes and nitrogen mineralization. Soil Science Society of American Journal. 43:509-514. (PSW)
DUNN, PAUL H.; SUSAN C. BARRO; and MARK POTH. 1985. Soil moisture affects survival of microorganisms in heated chaparral soil. Soil Biology and Biochemistry. 17:143-148. (PSW)

EVERETT, RICHARD L. 1987. Plant response to fire in the pinyon-juniper zone. In: Everett, Richard L., comp. Proceedings--pinyon-juniper conference; 1986 January 13-16; Reno, NV. Gen. Tech. Rep. INT-215. Ogden, UT: U.S. Department of Agriculture, Forest Service, Intermountain Research Station: 152-157. (INT)

EVERETT, RICHARD L.; and KENNETH WARD. 1984. Early plant succession on pinyon-juniper controlled burns. Northwest Science. 58:57-68. (INT)

EVERETT, RICHARD; and WARREN CLARY. 1985. Fire effects and revegetation on juniper-pinyon woodlands. In: Sanders, Ken; Jack Durham; [and others], eds. Rangeland fire effects: A symposium proceedings; 1984 November 27-29; Boise, ID: U.S. Department of the Interior, Bureau of Land Management, Idaho State Office: 33-37. (INT)

FFOLLIOTT, PETER F.; WARREN P. CLARY; and FREDERIC R. LARSON. 1977. Effects of a prescribed fire in an Arizona ponderosa pine forest. Res. Note RM-336. Fort Collins, CO: U.S. Department of Agriculture, Forest Service, Rocky Mountain Forest and Range Experiment Station. 4 p. (SO)

FFOLLIOTT, PETER F.; WARREN P. CLARY; and FREDERIC R. LARSON. 1977. Fire scene 11 years after. Progressive Agriculture Arizona. 28(1):12-13. (SO) 
FISCHER, WILLIAM C.; and BRUCE D. CLAYTON. 1983. Fire ecology of Montana forest habitat types east of the Continental Divide. Gen. Tech. Rep. INT-141. Ogden, UT: U.S. Department of Agriculture, Forest Service, Intermountain Forest and Range Experiment Station. 83 p. (INT)

GREEN, L. R. 1982. Prescribed burning in the California Mediterranean ecosystem. In: Conrad, C. Eugene,; and Walter C. Oechel, tech. coords. Proceedings of the symposium on dynamics and management of mediterranean-type ecosystems; 1981 June 22-26; Sand Diego, CA. Gen. Tech. Rep. PSW-58. Berkeley CA: U.S. Department of Agriculture, Forest Service, Pacific Southwest Forest and Range Experiment Station: 464-471. (PSW)

GRELEN, H. E. 1976. Responses of herbage, pines, and hardwoods to early and delayed burning in a young slash pine plantation. Journal of Range Management. 29:301-303. (SO)

GRELEN, HAROLD E. 1978. May burns stimulate growth of longleaf pine seedlings. Res. Note SO-234. New Orleans, LA: U.S. Department of Agriculture, Forest Servic, Southern Forest Experiment Station. 5 p. (SO)

GRELEN, HAROLD E. 1978. Winter and spring prescribed fires on Louisiana pine-bluestem range. In: Hyder, Donald N., ed. Proceedings, 1st international rangeland congress; 1978 August 1418; Denver, CO: Society for Range Management: 242-244. (SO)

GRELEN, HAROLD E. 1983. Comparison of seasons and frequencies of burning in a young slash pine plantation. Res. Pap. SO-185. New Orleans, LA: U.S. Department of Agriculture, Forest Service, Southern Forest Experiment Station. 5 p. (SO)
GRELEN, HAROLD E.; and CLIFFORD E. LEWIS. 1981. Value of range data on fire effects to the wildlife manager. In: Wood, Gene W., ed. Prescribed fire and wildlife in southern forests: Proceedings of a symposium; 1981 April 6-8; Myrtle Beach, SC. Georgetown, SC: Belle W. Baruch Forest Science Institute, Clemson University: 155-159. (SO)

HARRINGTON, M. G. 1985. The effects of spring, summer and fall burning on Gambel oak in a southwestern ponderosa pine stand. Forest Science. 3:156-163. (RM)

HARRINGTON, MICHAEL G. 1987.

Predicting reduction of natural fuels by prescribed burning under ponderosa pine in southeastern Arizona. Res. Note. RM-472. Fort Collins, CO: U.S. Department of Agriculture, Forest Service, Rocky Mountain Forest and Range Experiment Station. 4 p. (RM)

HARRINGTON, MICHAEL G. 1989. Gambel oak root carbohydrate response to spring, summer, and fall prescribed burning. Journal of Range Management. 42:504-507. (RM)

HEEDE, B. H.; M. D. HARVEY; and J. R. LAIRD. 1988. Sediment delivery linkages in a chaparral watershed following a wildfire. Environmental Management. 12:349-358. (RM)

HELVEY, J. D.; A. R. TIEDEMANN; and T. D. ANDERSON. 1985. Plant nutrient losses by soil erosion and mass movement after wildfire. Journal of Soil and Water Conservation. 40(1):168-173. (INT)

HIBBERT, A. R.; E. A. DAVIS; and O. D. KNIPE. 1982. Water yield changes resulting from treatment of Arizona chaparral. Gen. Tech. Rep. PSW-58. Berkeley, CA: U.S. Department of Agriculture, Forest Servic, Pacific Southwest Forest and Range Experiment Station: 382-389. (RM) 
HIBBERT, ALDEN R. 1983. Water yield improvement potential by vegetation management on western rangelands. Water Resources Bulletin. 19:375-381. (RM)

HIBBERT, ALDEN R. 1984. Stormflows after fire and conversion in chaparral. In: Proceedings of the 4th international conference on mediterranean ecosystems; 1984 August 13-17; Perth, Australia: 71-72. (RM)

HIBBERT, ALDEN. R. 1985. Storm runoff and sediment production after wildfire in chaparral. In: Hydrology and water resources in Arizona and the Southwest: Proceedings of the Arizona section, American Water Resources Association and the hydrology section of the Arizona-Nevada Academy of Science; 1985 April 27; Las Vegas, NV. Tucson, AZ: Arizona Water Resources Association. 15:31-42. (RM)

HUNTLEY, JIMMY C.; and CHARLES E. MCGEE. 1981. Timber and wildlife implication of fire in young upland hardwoods. In: Proceedings, 1st biennial southern silvicultural research conference; 1980 November 6-7; Atlanta, GA. Gen. Tech. Rep. SO-34. New Orleans, LA: U.S. Department of Agriculture, Forest Service, Southern Forest Experiment Station: 56-66. (SO)

HUNTLEY, JIMMY C.; and CHARLES E. MCGEE. 1983. Impact of fire on regeneration and wildlife habitat in upland hardwoods. In: America's hardwood forests--opportunities unlimited: Proceedings of 1982 Convention of the Society of American Foresters; 1982 September 19-22; Cincinnati, OH. SAF 83-04. Bethesda, $\mathrm{MD}$ : Society of American Foresters: 158-162. (SO)
KILGORE, BRUCE M.; and GEORGE A. CURTIS. 1987. Guide to understory burning in ponderosa pine-larch-fir forests in the Intermountain West. Gen. Tech. Rep. INT-233. Ogden, UT: U.S. Department of Agriculture, Forest Service, Intermountain Research Station. 39 p. (INT)

KLEBENOW, D. 1979. Predicting success of prescribed fires in pinyon-juniper woodland in Nevada. Res. Pap. INT-219. Ogden, UT: U.S. Department of Agriculture, Forest Service, Intermountain Forest and Range Experiment Station. 11 p. (INT)

KLOPATEK, C. COE; L. F. DEBANO; and J. M. KLOPATEK. 1987. Effects of fire on vesicular-arbuscular mycorrhizae in pinyon-juniper woodlands. In: Mycorrhizae in the next decade: practical applications and research priorities: Proceedings of the 7th North American Conference on Mycorrhizae; 1987 May 3-8; Gainesville, FL: Institute of Food and Agricultural Sciences, University of Florida: 155. (RM)

KLOPATEK, CAROLE COE; LEONARD F. DEBANO; and JEFFERY $M$. KLOPATEK. 1988. Effects of simulated fire on vesicular-arbuscular mycorrhizae in pinyon-juniper woodland soil. Plant and Soil. 109:245-249. (RM)

KOMAREK, EDWIN V.; SANDRA S. COLEMAN; CLIFFORD E LEWIS; and GEORGE W. TANNER, comps. 1986. Prescribed fire and smoke management. Symposium proceedings; 1986 February 13; Kissimmee, FL. Denver, CO: Society for Range Management. 21 p. (SE)

KONIAK, SUSAN. 1986. Succession in pinyon-juniper woodlands following wildfire in the Great Basin. Great Basin Naturalist. 45:556-566. (INT) 
KRAMP, BETTY A.; DAVID R. PATTON; and WARD W. BRADY. 1983. The effects of fire on wildlife habitat and species. RUN WILD wildlife/habitat relationships. Wildlife Unit Tech. Rep. Albuquerque, NM: U.S. Department of Agriculture, Forest Service, Southwestern Region. 29 p. (RM)

LAIRD, JEFFREY R.; and MICHAEL D. HARVEY. 1987. Complex-response of a chaparral drainage basin to fire. In: IAHS. International Commission on Continental Erosion; 1986 August 4-8; Albuquerque, NM: University of New Mexico: 165-183. (RM)

LEWIS, CLIFFORD E.; and THOMAS J. HARSHBARGER. 1976. Shrub and herbaceous vegetation after 20 years of prescribed burning in the South Carolina Coastal Plain. Journal of Range Management. 29:13-18. (SE)

LEWIS, CLIFFORD E.; and THOMAS J. HARSHBARGER. 1986. Burning and grazing effects on bobwhite foods in the southeastern coastal plain. The Wildlife Society Bulletin. 14:455-459. (SE)

LEWIS, CLIFFORD E.; HAROLD E. GRELEN; and GEORGE E. PROBASCO. 1982. Prescribed burning in southern forest and rangeland improves forage and its use. Southern Journal Applied Forestry. 6:19-25. (SE)

LOTAN, J. E.; M. E. ALEXANDER; S. F. ARNO; R. F. FRENCH; O. G. LANGDON; R. M. LOOMIS; R. A. NORUM; R. C. ROTHERMEL; W. C. SCHMIDT; and J. V. WAGTENDONK. 1981. Effects of fire on flora: A state-ofknowledge review. National Fire Effects Workshop; 1978 April 10-14; Denver, CO. Gen. Tech. Rep. WO-16. Washington, DC: U.S. Department of Agriculture, Forest Service. 71 p. (INT)
LOWE, PHILIP O.; PETER F. FFOLLIOTT; JOHN H. DIETERICH; and DAVID R. PATTON. 1978. Determining potential wildlife benefits from wildfire in Arizona ponderosa pine forests. Gen. Tech. Rep. RM-52. Fort Collins, CO: U.S. Department of Agriculture, Forest Service, Rocky Mountain Forest and Range Experiment Station. 12 p. (RM)

LYON, L. J.; H. S. CRAWFORD; E. CZUHAI; R. L. FREDRICKSEN; R. F. HARLOW; L. J. METZ; and H. A. PEARSON. 1978. Effects of fire on fauna: A state-ofknowledge review. National Fire Effects Workshop; 1978 April 10-14; Denver, CO. Gen. Tech. Rep. WO-6.

Washington, DC: U.S. Department of Agriculture, Forest Service. 41 p. (SO)

LYON, L. JACK; and PETER F. STICKNEY. 1976. Early vegetal succession following large northern Rocky Mountain wildfires. In: Proceedings, Tall Timbers Fire Ecology Conference and Intermountain Fire Research Council; Missoula, MT: Fire and Land Management Symposium: 355-373. (INT)

MARTIN, ROBERT E.; HAL E. ANDERSON; WILLIAM D. BOYER; JOHN H. DIETERICH; STANLEY N. HIRSCH; VON J. JOHNSON; and W. HENRY. MCNAB. 1979. Effects of fire on fuels: A state-of-knowledge review. National Fire Effects Workshop; 1978 April 10-14; Denver, CO. Gen. Tech. Rep. WO-13. Washington, DC: U.S. Department of Agriculture, Forest Service. 64 p. (RM)

MARTIN, S. CLARK. 1983. Response of semidesert grasses and shrubs to fall burning. Journal of Range Management. 36:604-610. (RM)

MOIR, W. H. 1982. Fire history of the High Chisos, Big Bend National Park, Texas. Southwestern Naturalist. 27:87-98. (RM) 
MOIR, WILLIAM H. 1980. Some questions about fire ecology in southwestern canyon woodlands. In: Stokes, Marvin A.; and John H. Dieterich, tech. coords. Proceedings of the Fire History Workshop; 1980 October 20-24;

Tucson: AZ. Gen. Tech. Rep. RM-81. Fort Collins, CO: U.S. Department of Agriculture, Forest Service, Rocky Mountain Forest and Range Experiment Station: 20. (RM)

MOORE, W. H.; B. F. SWINDEL; and W. S. TERRY. 1982. Vegetative response to prescribed fire in a north Florida flatwoods forest. Journal of Range Management. 35:386-389. (SE)

MUEGGLER, W. F. 1976. Ecological role of fire in western woodland and range ecosystems. In: Use of prescribed burning in western woodland and range ecosystems: A symposium. Logan, UT: Utah State University Agriculture Experiment Station. 1-9. (INT)

NIEMI, GERALD J. 1978. Breeding birds of burned and unburned areas in northern Minnesota. Loon. 50:73-84. (NC)

NORDIN, J. O.; and D. F. GRIGAL. 1976. Vegetation, site, and fire relationships within the area of the Little Sioux Fire, northeastern Minnesota. Canadian Journal Forestry Resource. 6(1):78-85. (NC)

NOSTE, NONAN V.; and CHARLES L. BUSHEY. 1987. Fire response of shrubs of dry forest habitat types in Montana and Idaho. Gen. Tech. Rep. INT-239. Ogden, UT: U.S. Department of Agriculture, Forest Service, Intermountain Research Station. 22 p. (INT)
NOSTE, NONAN V.; ELIZABETH D.

REINHARDT; and RALPH A. WILSON, JR. 1989. Fire effects on Amelanchier alnifolia shrubs during phenological development stages. In: Wallace, Arthur; E. Durant McArthur; and Marshall R. Haferkamp, comps. Proceedings-symposium on shrub ecophysiology and biotechnology; 1987 June 30-July 2; Logan, UT. Gen. Tech. Rep. INT-256. Ogden, UT: U.S. Department of Agriculture, Forest Service, Intermountain Research Station: 158163. (INT)

O'HALLORAN, KATHLEEN A.; ROBERT M. BLAIR; RENE ALCANIZ; and HERSHEL F. MORRIS, JR. 1987. Prescribed burning effects on production and nutrient composition of fleshy fungi. Journal of Wildlife Management. 51:258262. (SO)

PASE, CHARLES P.; and CARL ERIC GRANFELT, tech coords. 1977. The use of fire on Arizona rangelands. Pub. No. 4. Arizona Interagency Range Committee. 15 p. (RM)

PASE, CHARLES P.; and OREN D. KNIPE. 977. Effect of winter burning on herbaceous cover on a converted chaparral watershed. Journal of Range Management. 30:346-348. (RM)

PATTON, DAVID R.; and HERMAN D. AVANT. 1970. Fire stimulated aspen sprouting in a spruce-fir forest in New Mexico. Res. Note. RM-159. Fort Collins, CO: U.S. Department of Agriculture, Forest Service, Rocky Mountain Forest and Range Experiment Station. 3 p. (RM)

PROBASCO, GEORGE E.; and ARDELL J. BJUGSTAD. 1977. Tall fescue response to fire. Res. Note NC-218. St. Paul, MN: U.S. Department of Agriculture, Forest Service, North Central Forest Experiment Station. 3 p. (NC) 
RAPHAEL, MARTIN G.; MICHAEL L. MORRISON; and MICHAEL P. YODERWILLIAMS. 1987. Breeding bird populations during twenty-five years of postfire succession in the Sierra Nevada. The Condor. 89:614-626. (RM)

REAM, CATHERINE. 1981. The effects of fire and other disturbances on small mammals and their predators: an annotated bibliography. Gen. Tech. Rep. INT-106. Ogden, UT: U.S. Department of Agriculture, Forest Service, Intermountain Forest and Range Experiment Station. 55 p. (INT)

RENWALD, J. DAVID; HENRY A. WRIGHT; and JERRAN T. FLINDERS. 1978. Effect of prescribed fire on bobwhite quail habitat in the rolling plains of Texas. Journal Range Management. 31:65-69. (RM)

RIGGAN, PHILIP J.; SUZANNE GOODE; PAÚL M. JACKS; and ROBERT N. LOCKWOOD. 1988. Interaction of fire and community development in chaparral of southern California. Ecological Monographs. 58:155-176. (PSW)

ROPPE, J. A.; and D. HEIN. 1978. Effects on wildlife of a fire in a lodgepole pine forest. Southwestern Naturalist. 23:279288. (RM)

ROTHERMEL, RICHARD C. 1983. How to predict the spread and intensity of forest and range fires. Gen. Tech. Rep. INT143. Ogden, UT: U.S. Department of Agriculture, Forest Service, Intermountain Forest and Range Experiment Station. 161 p. (INT)

ROTHERMEL, RICHARD C.; and JOHN E. DEEMING. 1980. Measuring and interpreting fire behavior for correlation with fire effects. Gen. Tech. Rep. INT93. Ogden, UT: U.S. Department of Agriculture, Forest Service, Intermountain Forest and Range Experiment Station. 4 p. (INT)
SANDBERG, D. V.; J. M. PIEROVICH; D. B. FOX; and E. W. ROSS. 1978. Effects of fire on air: A state-of-knowledge review. National Fire Effects Workshop; 1978 April 10-14; Denver, CO. Gen. Tech. Rep. WO-9. Washington, DC: U.S. Department of Agriculture, Forest Service. 40 p. (RM)

SANDO, RODNEY W. 1978. Natural fire regimes and fire management-foundations for direction. Western Wildlands. 4(4):34-44. (NC)

STARK, N.; and R. STEELE. 1977. Nutrient content of forest shrubs following burning. American Journal of Botany. 64:1218-1224. (INT)

STEUTER, ALLEN E. 1980. Wildlife response to prescribed burning in the Rio Grande Plains. In: Proceedings, prescribed range burning in the Rio Grande plains of Texas; 1979 November 7; Carrinzo Springs, TX. College Station, TX: Texas Agricultural Extension Service: 34-43. (RM)

STOKES, MARVIN A.; and J. H. DIETERICH, eds. 1980. Proceedings of the fire history workshop. 1980 October 20-24; Tucson, Arizona. Gen. Tech. Rep. RM81. Fort Collins, CO: U.S. Department of Agriculture, Forest Service, Rocky Mountain Forest and Range Experiment Station. 142 p. (RM)

STRANSKY, JOHN J.; and LOWELL K. HALLS. 1979. Effect of a winter fire on fruit yield of woody plants. Journal of Wildlife Management. 43:1007-1010. (SO)

STRANSKY, JOHN J.; and RICHARD F. HARLOW. 1981. Effects of fire on deer habitat in the southeast. In: Wood, Gene W., ed. Prescribed fire and wildlife in southern forests: Proceedings of a symposium; 1981 April 6-8; Myrtle Beach, SC. Georgetown, SC: Belle W. Baruch Forest Science Institute, Clemson University: 135-142. (SO) 
THILL, RONALD E.; ALTON MARTIN, JR.; HERSHEL F. MORRIS, JR.; and DIBUCE E. MCCUNE. 1987. Grazing and burning impacts on deer diets on Louisiana pine-bluestem range. Journal of Wildlife Management. 51:873-880. (SO)

TIEDEMANN, A. R. 1981. Regional impacts of fire. In: Mooney, H.; J. M.

Bonnicksen; N. L. Christensen; J. E. Lotan; and W. E. Reiners, eds. Fire regimes and ecosystem properties. Gen. Tech. Rep. WO-26. Washington, D.C.: U.S. Department of Agriculture, Forest Service: 532-556. (INT)

TIEDEMANN, A. R. 1987. Combustion losses of sulfur and forest foliage and litter. Forest Science. 33:216-223. (PNW)

TIEDEMANN, A. R.; C. E. CONRAD; J. H. DEITERICH; J. W. HORNBECK; W. F. MEGAHAN; L. A. VIERECK; and D. D. WADE. 1979. Effects of fire on water resources: A state-of-knowledge review. National Fire Effects Workshop; 1979 April 10-14; Denver, CO. Gen. Tech. Rep. WO-10. Washington, DC: U.S. Department of Agriculture, Forest Service. 29 p. (INT)

TIEDEMANN, A. R.; J. D. HELVEY; and T. D. ANDERSON. 1978. Stream chemistry and watershed nutrient economy following wildfire and fertilization in eastern Washington. Journal of Environmental Quality. 7:580-588.

URESK, D. W.; W. H. RICHARD; and J. F. CLINE. 1980. Perennial grasses and their response to a wildfire in southcentral Washington. Journal of Range Management. 33:111-114. (RM)

WADE, DALE D.; and CLIFFORD E. LEWIS. 1987. Managing southern grazing ecosystems with fire. Rangelands. 9:115-119. (SE)

WAGSTAFF, FRED J. 1980. Impact of the 1975 Wallsburg fire on antelope bitterbrush (Purshia tridentata). Great Basin Naturalist. 40:299-302. (INT)
WELLS, CAROL G.; RALPH E. CAMPBELL; LEONARD F. DEBANO; CLIFFORD E. LEWIS; [and others]. 1979. Effects of fire on soil: A state-of-knowledge review. National Fire Effects Workshop; 1979 April 10-14; Denver, CO. Gen. Tech. Rep. WO-7. Washington, DC: U.S. Department of Agriculture, Forest Service. 34 p. (RM)

WELLS, WADE G. II. 1981. Some effects of brushfires on erosion processes in coastal southern California. In: Erosion and sediment transport in Pacific Rim steeplands; 1981 January; Christ Church, New Zealand. Sponsored jointly by the Royal Society of New Zealand, New Zeland Hydrological Society, IAHS, and the National Water and Soil Conservation Authority of New Zealand. International Association of Hydrologic Publication Sciences. 132:305-342. (PSW)

WELLS, WADE G., II. 1986. The influence of fire or erosion rates in California chaparral. In: Proceedings of the chaparral ecosystems research conference; 1985 May 16-17; Santa Barbara, CA. Rep. 62. Davis, CA: California Water Resources Center, University of California: 57-62. (PSW)

WHISENANT, S. G.; and D. W. URESK. 1989. Burning upland, mixed prairie in Badlands National Park. The Prairie Naturalist. 21:221-228. (RM)

WILSON, CARL C.; and JAMES B. DAVIS. 1988. Forest Fire Laboratory at Riverside and fire research in California: past, present, and future. Gen. Tech. Rep. PSW-105. Berkeley, CA: U.S. Department of Agriculture, Forest Service, Pacific Southwest Forest and Range Experiment Station. 22 p. (PSW) 
WIRTZ, W. O. 1982. Postfire community structure of birds and rodents in southern California chaparral. In: Conrad, C. Eugene; and Walter C. Oechel, tech. coords. Proceedings of the symposium on dynamics and management of Mediterranean-type ecosystems; 1981 June 22-26; San Diego, CA. Gen. Tech. Rep. PSW-58. Berkeley, CA: U.S. Department of Agriculture, Forest Service, Pacific Southwest Forest and Range Experiment Station: 241-246. (PSW)

WIRTZ, WILLIAM O., II. 1984. Postfire rodent and bird communities in the chaparral of southern California. In: Medecos IV, Proceedings of the 4th international conference on Mediterranean ecosystems; 1984 August 13-17; Perth, Western Australia. Nedlands, Western Australia: University of Western Australia: 165-168. (PSW)

WOLFF, JERRY O. 1978. Burning and browsing effects on willow growth in interior Alaska. Journal of Wildlife Management. 42:135-140. (PNW)

ZINKE, PAUL J. 1977. Mineral cycling in firetype ecosystems. In: Proceedings of the Symposium on the Environmental Consequences of Fire and Fuel Management in Mediterranean Ecosysterns; Palo Alto, CA. Gen. Tech. Rep. WO-3. Washington, DC: U.S. Department Agriculture, Forest Service: 85-94. (PSW)

\section{Autecology}

ALABACK, PAUL B.; and F. R. HERMAN. 1988. Long-term response of understory vegetation to stand density in PiceaTsuga forests. Canadian Journal of Forest Research. 18:1522-1530. (PNW)
ALDON, EARL F. 1977. Survival of three grass species after inundation. Res. Note. RM-344. Fort Collins, CO: U.S. Department of Agriculture, Forest Service, Rocky Mountain Forest and Range Experiment Station. 2 p. (RM)

BUDY, JERRY D.; and RICHARD O. MEEUWIG. 1987. Pinyon-juniper silvics and silviculture. In: Everett, Richard L., comp. Proceedings--pinyon-juniper conference; 1986 January 13-16; Reno, NV. Gen. Tech. Rep. INT-215. Ogden, UT: U.S. Department of Agriculture, Forest Service, Intermountain Research Station: 244-248. (INT)

CABLE, DWIGHT R. 1979. Ecology of Arizona cottontop. Res. Pap. RM-209. Fort Collins, CO: U.S. Department of Agriculture, Forest Service, Rocky Mountain Forest and Range Experiment Station. 21 p. (RM)

CLARY, WARREN P.; and ARTHUR R. TIEDEMANN. 1986. Distribution of biomass within small tree and shrub from Quercus gambelii stands. Forest Science. 32:234-242. (INT)

CROUCH, GLENN L. 1980. Regeneration on aspen clearcuts in northern Colorado. Res. Note. RM-407. Fort Collins, CO: U.S. Department of Agriculture, Forest Service, Rocky Mountain and Range Experiment Station. 5 p. (RM)

DEALY, J. EDWARD. 1978. Autecology of curlleaf mountain-mahogany (Cercocarpus ledifolius). In: Hyder, Donald N., ed. Proceedings, 1 st international rangeland congress; 1978 August 14-18; Denver, CO: Society for Range Management: 398-400. (PNW)

EVERETT, RICHARD L., comp. 1987. Proceedings, Pinyon-juniper Conference. 1986 January 13-16; Reno, NV. Gen. Tech. Rep. INT-215. Ogden, UT: U.S. Department of Agriculture, Forest Service, Intermountain Research Station. 582 p. (INT). 
HARRINGTON, M. G. 1985. The effects of spring, summer and fall burning on Gambel oak in a southwestern ponderosa pine stand. Forest Science. 3:156-163. (RM)

HAWS, B. AUSTIN; ALAN H. ROE; and DAVID L. NELSON. 1988. Index to information on insects associated with western wildland shrubs. Gen. Tech. Rep. INT-248. Ogden, UT: U.S. Department of Agriculture, Forest Service, Intermountain Research Station. 296 p. (INT)

HESS, WILFORD M.; DAVID L. NELSON; and DAVID L. STURGES. 1985. Morphology and ultrastructure of a snowmold fungus on sagebrush (Artemisia tridentata). Mycologia. 77:637-645. (RM)

HUANG, J.; W. M. HESS; D. J. WEBER; E. D. MCARTHUR; S. E. MYER; and R. SEEGMILLER. 1988. Computer analysis of cross sections of leaves of

Chrysothamnus taxa and their relation to environmental conditions. Great Basin

Naturalist. 48:334-347. (INT)

JONES, JOHN R.; and NORBERT V.

DEBYLE. 1985. Climates. In: DeByle, Norbert V.; and Robert P. Winokur, eds. Aspen: ecology and management in the Western United States. Gen. Tech. Rep. RM-119. Fort Collins, CO: U.S. Department of Agriculture, Forest Service, Rocky Mountain Forest and Range Experiment Station: 57-64. (INT)

JONES, JOHN R.; and NORBERT V. DEBYLE. 1985. Other physical factors. In: DeByle, Norbert V.; and Robert P. Winokur, eds. Aspen: Ecology and management in the Western United States. Gen. Tech. Rep. RM-119. Fort Collins, CO: U.S. Department of Agriculture, Forest Service, Rocky Mountain Forest and Range Experiment Station: 83-106. (INT)
MCARTHUR, E. DURANT. 1986. Specificity of galls on Chrysothamnus nauseosus subspecies. In: McArthur, E. Durant; and Bruce L. Welch, comps. Proceedings-symposium on the biology of Artemisia and Chrysothamnus; 1984 July 9-13; Provo, UT. Gen. Tech. Rep. INT-200. Ogden, UT: U.S. Department of Agriculture, Forest Service, Intermountain Forest and Range Experiment Station: 205-210. (INT)

MCARTHUR, E. DURANT; CHARLES F. TIERNAN; and BRUICE L. WELCH. 1979. Subspecies specificity of gall forms on Chrysothamnus nauseosus. Great Basin Naturalist. 39:81-87. (INT)

MOORE, T. BLAINE; RICHARD STEVENS; AND E. DURANT MCARTHUR. 1982. Preliminary study of some insects associated with rangeland shrubs with emphasis on Kochia prostrata. Journal of Range Management. 35:128-130. (INT)

NELSON, D. L.; and D. L. STURGES. 1986. A snowmold disease of mountain big sagebrush. Phytopathology. 76:946-951. (RM)

NELSON, DAVID L. 1987. Susceptibility of antelope bitterbrush to seedbed damping-off disease. In: Frasier, Gary W.; and Raymond L. Evan, eds. Seed and seedbed ecology of rangeland plants: Proceedings of symposium; 1987 April 21-23; Tucson, AZ: U.S. Department of Agriculture, Agricultural Research Service: 117-121. (INT) 
NELSON, DAVID L.; KIMBALL T. HARPER;

KENTH C. BOYER; DARRELL J.

WEBER; B. AUSTIN HAWS; and

JAMES R. MARBLE. 1989. Wildland

shrub dieoffs in Utah: an approach to

understanding the cause. In: Wallace,

Arthur; E. Durant McArthur; and

Marshall R. Haferkamp, comps.

Proceedings--symposium on shrub

ecophysiology and biotechnology; 1987

June 30-July 2; Logan, UT. Gen. Tech.

Rep. INT-256. Ogden, UT: U.S.

Department of Agriculture, Forest

Service, Intermountain Research

Station: 119-135. (INT)

RAPHAEL, MARTIN G.; and MICHAEL L MORRISON. 1987. Decay and

dynamics of snags in the Sierra Nevada, California. Forest Science. 33:774-783.

(RM)

REGELIN, WAYNE L.; JULIUS G. NAGY; and O. C. WALLMO. 1978. Effects of snowdrifts on mountain shrub communities. In: Proceedings, 13th International Congress of Game Biologists; Atlanta, GA: 1977 March 1115; Washington, DC: Wildlife Society, Wildlife Management Institute: 414-419. (RM)

SCHIER, GEORGE A. 1976. Physiological and environmental factors controlling vegetative regeneration of aspen. In: Utilization and marketing as tools for aspen management in the Rocky Mountains. Gen. Tech. Rep. RM-29. Fort Collins, CO: U.S. Department Agriculture, Forest Service, Rocky Mountain Forest and Range Experiment Station: 20-23. (INT)

SCHIER, GEORGE A. 1978. Root suckering in young aspen, girdled, defoliated, and decapitated at various seasons. In: Proceedings, 5th North American Forestry Biology Workshop, Gainesville, FL: 259-267. (INT)
SCHIER, GEORGE A. 1978. Variation in suckering capacity among and within lateral roots of an aspen clone. Res. Note INT-241. Odgen, UT: U.S. Department of Agriculture, Forest Service, Intermountain Forest and Range Experiment Station. 7 p. (INT)

SCHIER, GEORGE A. 1978. Vegetative propagation of Rocky Mt. aspen. Gen. Tech. Rep. INT-44. Odgen, UT: U.S. Department of Agriculture, Forest Service, Intermountain Forest and Range Experiment Station. 13 p. (INT)

SCHIER, GEORGE A.; and ARTHUR D. SMITH. 1979. Sucker regeneration in a Utah aspen clone after clear-cutting, partial cutting, scarification, and girdling. Res. Note INT-253. Ogden, UT: U.S. Department of Agriculture, Forest Service, Intermountain Forest and Range Experiment Station. 6 p. (INT)

SCHIER, GEORGE A.; and ROBERT B. CAMPBELL. 1978. Aspen sucker regeneration following burning and clearcutting on two sites in the Rocky Mountains. Forest Science. 24:303-308. (INT)

SCHIER, GEORGE A.; and ROBERT B. CAMPBELL. 1978. Effect of cold storage on development of suckers on aspen root cuttings. Res. Note INT-248. Ogden, UT: U.S. Department of Agriculture, Forest Service, Intermountain Forest and Range Experiment Station. 8 p. (INT)

SCHOLL, DAVID G.; and CHARLES P. PASE. 1984. Wheatgrass response to organic amendments and contour furrowing on coal mine spoils. Journal of Environmental Quality. 13:479-482. (RM)

SCHOLL, DAVID G.; and S. MIYAMOTO. 1983. Response of alkali sacaton and fourwing saltbush to various amendments on coal-mine spoils from northwestern New Mexico. II. Sodic spoil. Reclamation and Revegetation Research. 2:243-252. (RM) 
SCHOLL, DAVID G.; and S. MIYAMOTO. 1983. Response of alkali sacaton and fourwing saltbush to various

amendments on coal-mine spoils from northwestern New Mexico. I. Acid spoil.

Reclamation and Revegetation

Research. 2:227-236. (RM)

SIEG, CAROLYN HULL; DANIEL W. URESK; and FICHARD M. HANSEN. 1983.

Plant-soil relationships in bentonite mine spoils and sagebrush-grassland in the northern High Plains. Journal of Range Management. 36:289-294. (RM)

STARK, NELLIE M. 1989. The ecology of Vaccinium globulare: seedling establishment and nutrition. In: Wallace, Arthur; E. Durant McArthur; and Marshall R. Haferkamp, comps. Proceedings--symposium on shrub ecophysiology and biotechnology; 1987 June 30-July 2; Logan, UT. Gen. Tech. Rep. INT-256. Ogden, UT: U.S. Department of Agriculture, Forest Service, intermountain Research Station: 164-168. (INT)

STEVENS, R.; B. C. GIUNTA; K. R. JORGENSEN; and A.P. PLUMMER. 1977. Winterfat (Ceratoides lanata). Pub. 77-2. Salt Lake City, UT: Utah State Division of Wildlife Resources. 41 p. (INT)

STRANSKY, J. J.; J. C. HUNTLEY; and W. RISNER. 1986. Net community production dynamics in the herb-shrub stratum of a loblolly pine-hardwood forest: Effects of clearcutting and site preparation. Gen. Tech. Rep. SO-61. New Orleans, LA: U.S. Department of Agriculture, Forest Service, Southern Forest Experiment Staion. 11 p. (SO)

STURGES, D. L. 1989. Responses of mountain big sagebrush to induced snow accumulation. The Journal of Applied Ecology. 26:1035-1042. (RM)

STURGES, D. L.; and M. J. TRLICA. 1978. Root weights and carbohydrate reserves of big sagebrush. Ecology. 59:12821285.
STURGES, DAVID L. 1977. Soil water withdrawal and root characteristics of big sagebrush. American Midland Naturalist. 98:257-274. (RM)

STURGES, DAVID L. 1986. Benefits of snow management and $\mathrm{N}$ fertilizer on sagebrush range. In: Steppuhnm H.; and W. Nicholaichuk, eds. Snow management for agriculture:

Proceedings of a symposium; 1985 July 29; Swift Current, Saskatchewan. Lincoln, NE; Great Plains Agricultural Council, University of Nebraska: 403430. (RM)

SUMMERFIELD, HARRY B.; RAY L. MILES; STEPHEN G. LEONARD; and RICHARD L. EVERETT. 1986. Edaphic relationships in climax in singleleaf pinyon stands of western Nevada. Res. Note INT-364. Ogden, UT: U.S. Department of Agriculture, Forest Service, Intermountain Research Station. 3 p. (INT)

TIEDEMANN, A. R.; E. D. MCARTHUR; H. C. STUTZ; R. STEVENS; and K. L. JOHNSON, comps. 1984. Proceedings-symposium on the biology of Atriplex and related chenopods. Gen. Tech. Rep. INT-172. Ogden, UT: U.S. Department of Agriculture, Forest Service, Intermountain Forest and Range Experiment Station. 309 p. (INT)

TIEDEMANN, A. R.; W. P. CLARY; and R. J.BARBOUR. 1987. Underground systems of Gambel oak (Quercus gambelii) in central Utah. American Journal of Botany. 74:1065-1071. (INT)

TIEDEMANN, ARTHUR R.; and CHARLES H. DRIVER. 1983. Snow eriogonum; a native halfshrub to revegetate winter game ranges. Reclamation and Revegetation Resource. 2:31-39. (PNW)

URESK, DANIEL W.; and CHARLES E. BOLDT. 1986. Effect of cultural treatments on regeneration of native woodlands on the Northern Great Plains. Prairie Naturalist. 18:193-202. (RM) 
URESK, DANIEL W.; and TERUO

YAMAMOTO. 1986. Growth of forbs, shrubs, and trees on bentonite mine spoil under greenhouse conditions. Journal of Range Management. 39:113116. (RM)

URESK, DANIEL W.; J. F. CLINE; and W. H. RICHARD. 1979. Growth rates of a cheatgrass community and some associated factors. Journal of Range Management. 32:168-170. (RM)

WELCH, BRUCE L.; and E. DURANT MCARTHUR. 1983. Briefing paper on sagebrush values. Plant Materials Tech. Note No. 45. Washington, DC: U.S. Department of Agriculture, Soil Conservation Service. 2 p. (INT)

WOOD, BENJAMIN W.; and JACK D. BROTHERSON. 1986. Ecological adaptation and grazing response of budsage (Artemisia spinescens) in southwestern Utah. In: McArthur, E. Durant; and Bruce L. Welch, comps. Proceedings--symposium on the biology of Artemisia and Chrysothamnus; 1984 July 9-13; Provo, UT. Gen. Tech. Rep. INT-200. Ogden, UT: U.S. Department of Agriculture, Forest Service, Intermountain Forest and Range Experiment Station: 75-92. (INT)

WOODWARD, R. A.; K. T. HARPER; and A. R. TIEDEMANN. 1984. An ecological consideration of the significance of cation exchange capacity of roots of some Utah range plants. Plant and Soil. 79:169-180. (INT)

\section{Range Management}

ALDON, EARL F. 1976. Management of reclaimed areas in the Southwest. In: Vories, Kimery C., ed. Reclamation of western surface mined lands: Workshop proceedings; 1976 March 1-3; Fort Collins, CO: Ecology Consultants, Inc.: 126-127. (RM)
BEDELL, THOMAS E.; and TAMZEN

STRINGHAN. 1984. Forage sources for eastern Oregon cattle ranches with Federal grazing permits. In: 1984 progress report--research in rangeland management. Special Report 715. Corvallis, OR: Agriculture Experiment Station, Oregon State University; In cooperation with: U.S. Department of Agriculture, Agricultural Research Service. 7-17. (PNW)

BERG, HEIL H., tech. coord. 1989. Proceedings of the symposium on fire and watershed management. 1988 October 26-28; Sacramento, CA. Gen. Tech. Rep. PSW-109. Berkeley, CA: U.S. Department of Agriculture, Forest Service, Pacific Southwest Forest and Range Experiment Station. 164p. (PSW)

BLACK, HUGH, JR.; and JACK WARD THOMAS. 1978. Forest and range wildlife habitat management: ecological principles and management systems. Gen. Tech. Rep. PNW-64. Portland, OR: U.S. Department of Agriculture, Forest Service, Pacific Northwest Forest and Range Experiment Station: 47-56. (PNW)

BLAISDELL, JAMES P.; and LEE A. SHARP. 1979. History of rangeland use and administration. In: Rangeland ecosystem evaluation and management: Proceedings, 4th Workshop of the United States/Australia Rangeland Panel; 1974. Alice Springs, Australia. Perth, Western Australia: Australian Rangeland Society: 1-24. (INT)

\section{BLAISDELL, JAMES P.; and RALPH C.}

HOLMGREN. 1984. Managing Intermountain rangelands-salt-desert shrub ranges. Gen. Tech. Rep. INT-163. Ogden, UT: U.S. Department of Agriculture, Forest Service, Intermountain Forest and Range Experiment Station. 52 p. (INT) 
BLAISDELL, JAMES P.; ROBERT B. MURRAY; and E. DURANT MCARTHUR. 1983. Managing of Intermountain rangelands--sagebrushgrass ranges. Gen. Tech. Rep. INT-134. Ogden, UT: U.S. Department of Agriculture, Forest Service, Intermountain Forest and Range Experiment Station. 41 p. (INT)

BOLDT, CHARLES E.; DANIEL W. URESK; and KIETH E. SEVERSON. 1979.

Riparian woodlands in jeopardy on northern High Plains. In: Johnson, R. Roy; and J. Frank McCormick, tech. coords. Strategies for protection and management of floodplain wetlands and other riparian ecosystems: Proceeding of a symposium; 1978 December 11-13; Callaway Gardens, GA. Gen. Tech. Rep. WO-12. Washington, DC: U.S. Department Agriculture, Forest Service: 184-189. (RM)

BROWN, R. W.; R. S. JOHNSTON; and J. C. CHAMBERS. 1984. Responses of native grasses to repeated fertilizer applications on acidic alpine mine spoils. In: Colbert, T. A.; and R. L. Cuany, eds. Proceedings: high-altitude revegetation workshop no. 6. Information Series No. 53. 1984 March 5-6; Fort Collins, CO: Colorado State University, Water Resources Research Institure: 200-214. (INT)

BUNTING, STEPHEN, C.; BRUCE M. KILGORE; and CHARLES L. BUSHEY. 1987. Guidelines for prescribed burning sagebrush-grass rangelands in the Northern Great Basin. Gen. Tech. Rep. INT-231. Ogden, UT: U.S. Department of Agriculture, Forest Service, Intermountain Research Station. 33 p. (INT)

BYINGTON, E. K. 1980. How is it being utilized? In: Proceedings, Southern forest range and pasture resources symposium. Morrilton, AR: Winrock International: 29-57 (SO)
BYRD, NATHAN A.; CLIFFORD E. LEWIS; and HENRY A. PEARSON. 1985. Tips outlined on managing native forage. Stockman Magazine. 42(1):13-15. (SE)

CABLE, DWIGHT, R. 1976. Twenty years of changes in grass production following mesquite control and reseeding. Journal of Range Management. 29:286-289. (RM)

CLARY, W. P. 1986. Fifty-year response to grazing in the low-shrub cold desert of the Great Basin, U.S.A. In: Joss, P. J.; P. W. Lynch; and O. B. Williams, eds. Rangelands: a resource under siege: Proceedings, 2nd international rangeland congress; 1985 May 13-18; Adelaide, Australia. Canberra, Australia: Australia Academy of Science: 37-38. (INT)

CLARY, WARREN P. 1981. Grazing, natural resource policy, and the biosphere reserves. In: Ffolliott, Peter F.; and Gonzalo Halffter, tech. coords. Social and environmetal consequences of natural resources policies--with special emphasis on biosphere reserves: Proceedings, international seminar; 1980 April 8-13; Durango, Mexico. Gen. Tech. Rep. RM-88. Fort Collins, CO: U.S. Department of Agriculture, Forest Service, Rocky Mountain Forest and Range Experiment Station: 21-23. (INT)

CLARY, WARREN P. 1987. Herbage production and livestock grazing on pinyon-juniper woodlands. In: Everett, Richard L., comp. Proceedings--pinyonjuniper conference; 1986 January 13-16; Reno, NV. Gen. Tech. Rep. INT-215. Ogden, UT: U.S. Department of Agriculture, Forest Service, Intermountain Research Station: 440447. (INT) 
CLARY, WARREN P.; and BERT F. WEBSTER. 1989. Managing grazing of riparian areas in the Intermountain Region. Gen. Tech. Rep. INT-263. Ogden, UT: U.S. Department of Agriculture, Forest Service, Intermountain Research Station. 11 p. (INT)

CLARY, WARREN P.; and RALPH C. HOLMGREN. 1987. Reversal of desertification on the low-shrub cold desert. In: Aldon, Earl F.; Carlos E. Gonzales Vicente; and William H. Moir, tech. coords. Strategies for classification and management of native vegetation for food production in arid zones: symposium proceedings; 1987 October 12-16; Tucson, AZ. Gen. Tech. Rep. RM-150. Fort Collins, CO: U.S. Department of Agriculture, Forest Service, Rocky Mountain Forest and Range Experiment Station: 138-142. (INT)

CLAWSON, W. JAMES; and NEIL K. MCDONALD. 1982. Residual dry matter as utilization standards for California annual range. In: Proceedings, Western Section American Society of Animal Science. 32:289-290. (PSW)

CLAWSON, W. JAMES; NEIL K. MCDONALD; and DON A. DUNCAN. 1982. Guidelines for residue management on annual range. Leaflet 21327. Berkeley, CA: Cooperative Extension, Division of Agricultural Sciences, University of California. 3 p. (PSW)

COLE, DAVID N. 1988. Disturbance and recovery of trampled montane grassland and forests in Montana. Res. Pap. INT389. Ogden, UT: U.S. Department of Agriculture, Forest Service, Intermountain Research Station. 37 p. (INT)
CROUCH, GLENN L. 1979. Long-term changes in cottonwoods on a grazed and ungrazed plains bottomland in northeastern Colorado. Res. Note RM370. Fort Collins, CO: U.S. Department of Agriculture, Forest Service, Forest Service, Rocky Mountain Forest and Range Experiment Station. 4 p. (RM)

DAVIS, LEE G.; MARK K. JOHNSON; and HENRY A. PEARSON. 1983. Sub clover for cattle on winter forests. Louisiana Agriculture. 26(2): 18-19. (SO)

DAVIS, LEE G.; MARK K. JOHNSON; and HENRY A. PEARSON. 1983. Sub-clover on winter forest. Stockman. $40(3): 8,19$, 27. (SO)

DEALY, J. EDWARD; and J. MICHAEL GEIST. 1978. Conflicting vegetational indicators on some central Oregon scablands. Journal of Range Management. 31:56-69, illus. (PNW)

ELDERKIN, R. L., JR.; D. R. DIETZ; B. L. WELCH; P. M. RALPHS; and J. K. CZARNECKI. 1986. Irrigation by mine discharge water and fertilization of big sagebrush: effects on nutritional composition, production, and mule deer use. In: McArthur, E. Durant; and Bruce L. Welch, comps. Proceedings-symposium on the biology of Artemisia and Chrysothamnus; 1984 July 9-13; Provo, UT. Gen. Tech. Rep. INT-200. Ogden, UT: U.S. Department of Agriculture, Forest Service, Intermountain Forest and Range Experiment Station: 140-145. (INT)

EVANS, RAYMOND A. 1988. Management of pinyon-juniper woodlands. Gen. Tech. Rep. INT-249. Ogden, UT: U.S. Department of Agriculture, Forest Service, Intermountain Research Station. 34 p. (INT) 
EVERETT, RICHARD L., comp. 1987. Proceedings--Pinyon-Juniper

Conference; 1986 January 13-16; Reno,

NV. Gen. Tech. Rep. INT-215. Ogden,

UT: U.S. Department of Agriculture,

Forest Service, Intermountain Research Station. 581 p. (INT)

FRISCHKNECHT, NEIL C. 1978. Effects of grazing, climate, fire, and other disturbances on long-term productivity of sagebrush-grass ranges. In: Hyder, Donald N., ed. Proceedings, 1st international rangeland congress; 1978 August 14-18; Denver, CO: Society for Range Management: 633-635. (INT)

GARRISON, GEORGE A.; ARDELL J. BJUGSTAD; DONALD A. DUNCAN; MONT E. LEWIS; and DIXIE R. SMITH. 1977. Vegetation and environmental features of forest and range ecosystems of the United States. Agric. Handb. 475. Washington, DC: U.S. Department of Agriculture, Forest Service. 68 p. (PNW)

GAUTIER, CLAY; and RICHARD EVERETT. 1979. Fertilizing and clipping on seed capsule and forage production of orange globemallow. Res. Note INT-251. Ogden, UT: U.S. Department of Agriculture, Forest Service, Intermountain Forest and Range Experiment Station. 6 p. (INT)

GEIST, J. MICHAEL. 1976. Forested range fertilization in eastern Oregon and Washington. Rangeman's Journal. 3:116-118. (PNW)

GEIST, J. MICHAEL. 1976. Orchard grass growth on nitrogen and sulfur fertilized volcanic ash soil. Journal of Range Management. 29:415-418. (PNW)

GRABER, R.; and G. CROW. 1982. Hiker traffic on and near the habitat of Robbins cinquefoil, an endangered plant species. Station Bulletin. 522. Durham, $\mathrm{NH}$ : University of New Hampshire, New Hampshire Agricultural Experiment Station. 10 p. (NE)
GRELEN, HAROLD E.; and HENRY A. PEARSON. 1977. Liquid supplements for cattle on southern forest range. Journal of Range Management. 30:9496. (SO)

HAGEDORN, C.; V. H. WATSON; and W. E. KNIGHT. 1980. Forage legumes in a forested environment. In: Proceedings southern forest range and pasture resources symposium; Morrilton, AR: Winrock International 143-145. (SO)

HALL, FREDERICK C. 1978. Applicability of rangeland management concepts to forest-range in the Pacific Northwest. In: Hyder, D. N., ed. Proceedings, 1 st international rangeland congress; 1978 August 14-18; Denver, CO: Society for Range Management: 496-499. (PNW)

HALL, FREDERICK C. 1985. Wildlife habitats in managed rangelands--the Great Basin of southeastern Oregon: management practices and options. Gen. Tech. Rep. PNW-189. Portland, OR: U.S. Department of Agriculture, Forest Service, Pacific Northwest Forest and Range Experiment Staiton. $17 \mathrm{p}$. (PNW)

HANLEY, THOMAS A. 1987. Physical and chemical response of understory vegetation to deer use in southeastern Alaska. Canadian Journal of Forestry Research. 17:195-199. (PNW)

HARRIS, G. A.; G. R. ADAMS; R. F. BUTTERY; J. DRAKE; R. W. HAMNER; H. A. PEARSON; J. L.

SCHWENDIMAN; and L. SMITH. 1984. Range management and ecology. In: Wenger, Karl F., ed. Forestry Handbook. 2nd ed. New York, NY: John Wiley \& Sons: $739-800$. (SO)

JOHNSON, M. K.; H. A. PEARSON; K. F. RIBBECK; and L. G. DAVIS. 1985. Management of subclover in pine forests. Louisiana Agriculture. 29(1):3-4, 24. (SO) 
JOHNSON, MARK K.; LEE G. DAVIS;

KENNETH F. RIBBECK; JEFFREY $H$.

RENDER; and HENRY A. PEARSON.

1986. Management of subterranean clover in pine forested range. Journal of

Range Management. 39:454-457. (SO)

JOYCE, LINDA A. 1989. An analysis of the range forage situation in the United States: 1989-2040: a technical document supporting the 1989 USDA Forest Service RPA assessment. Gen. Tech. Rep. RM-180. Fort Collins, CO: U.S. Department of Agriculture, Forest Service, Rocky Mountain Forest and Range Experiment Station. 136 p. (RM)

KILGORE, BRUCE M.; and GEORGE A. CURTIS. 1987. Guide to understory burning in ponderosa pine-larch-fir forests in the Intermountain West. Gen. Tech. Rep. INT-233. Ogden, UT: U.S. Department of Agriculture, Forest Service, Intermountain Research Station. 39 p. (INT)

KINGERY, JAMES L.; and RUSSELL T. GRAHAM. 1987. How animal use affects transitory range management: focus on renewable natural resources. Moscow, ID: University of Idaho, College of Forestry, Wildlife and Range Sciences. 12:26-27. (INT)

KLOCK, G. O. 1976. Response of Penstemon fruticosus to ferilization. Res. Note. PNW-271. Portland, OR: U.S. Department of Agriculture, Forest Service, Pacific Northwest Forest and Range Experiment Station. 4 p. (PNW)

KRUSE, WILLIAM H.; RUSSELL P. BALDA; MICHAEL J. SIMONA; A. MICHAEL MACRANDER; and CLARENCE D. JOHNSON. 1979. Community development in two adjacent pinyonjuniper eradication areas twenty-five years after treatment. Journal Environmental Management. 8:237-247. (RM)
LAYCOCK, WILLIAM A. 1982. Seeding and fertilizing to improve high-elevation rangelands. Gen. Tech. Rep. INT-120. Ogden, UT: U.S. Department of Agriculture, Forest Service, Intermountain Forest and Range Experiment Station. 19 p. (INT)

LEWIS, CLIFFORD E. 1977. Longleaf pine responds through age 15 to early fertilization. Res. Note. SE-239. Asheville, NC: U.S. Department of Agriculture, Forest Service, Southeastern Forest Experiment Station 7 p. (SE)

LEWIS, CLIFFORD E. 1983. Forage resources and integrated management in the slash pine ecosystem. In: Stone, E. L., ed. The managed slash pine ecosystem: Proceedings of a symposium; 1981 June 9-11; Gainesville, FL: University of Florida; School of Forest Resources and Conservation: 360-368. (SE)

LEWIS, CLIFFORD E.; HAROLD E. GRELEN; and GEORGE E. PROBASCO. 1982. Prescribed burning in southern forest and rangeland improves forage and its use. Southern Journal Applied Forestry. 6:19-25. (SE)

LEWIS, CLIFFORD E.; WARREN G. MONSON; and RICHARD J. BONYATA. 1985. Pensacola bahiagrass can be used to improve the forage resource when regenerating southern pines. Southern Journal of Applied Forestry. 9:254-259. (SE)

MARTIN, ROBERT E.; J. EDWARD DEALY; and DAVID CARAHER, eds. 1978. Proceedings of the western juniper ecology and management workshop. 1977 January; Bend, OR: Gen. Tech. Rep. PNW-74; Portland, OR: U.S. Department of Agriculture, Forest Service, Pacific Northwest Forest and Range Experiment Station. 177 p. (PNW) 
MARTIN, S. CLARK. 1987. Converting forage to food with cattle on the Santa Rita Experimental Range. In: Aldon, Earl F.; Carlos E. Gonzales Vicente; and William $H$. Moir, tech. coords. Strategies for classification and management of native vegetation for food production in arid zones: symposium proceedings; 1987 October 12-16; Tucson, AZ. Gen. Tech. Rep. RM-150. Fort Collins, CO: U.S. Department of Agriculture, Forest Service, Rocky Mountain Forest and Range Experiment Station: 179-181. (RM)

MEDINA, ALVIN L. 1983. Range research and resource management in southern Arizona. In: Patton, David R. [and others], tech. coords. Wildlife and range research needs in northern Mexico and southwestern United States: Workshop proceedings; 1981 April 20-24; Rio Rico, AZ: Gen. Tech. Rep. WO-36.

Washington, DC: U.S. Department of Agriculture, Forest Service: 104-108. (RM)

MEDINA, ALVIN L.; and JORGE

SEPULVEDA BETANCOURT. 1987. Strategies for enhanced production of beef and jojoba on Northern Baja California rangelands. In: Aldon, Earl F.; Carlos E. Gonzales Vicente; and William $\mathrm{H}$. Moir, tech. coords. Strategies for classification and management of native vegetation for food production in arid zones: symposium proceedings; 1987 October 12-16; Tucson, AZ. Gen. Tech. Rep. RM-150. Fort Collins, CO: U.S. Department of Agriculture, Forest Service, Rocky Mountain Forest and Range Experiment Station: 190-195. (RM)

MITCHELL, JOHN E. 1983. Analysis of forage production for assessments and appraisals. Gen. Tech. Rep. RM-98. Fort Collins, CO: U.S. Department of Agriculture, Forest Service, Rocky Mountain Forest and Range Experiment Station. 26 p. (RM)
MITCHELL, JOHN E., ed. 1988. Impacts of the Conservation Reserve Program in the Great Plains. Symposium proceedings; 1987 September 16-18; Denver, CO. Gen. Tech. Rep. RM-158. Fort Collins, CO: U.S. Department of Agriculture, Forest Service, Rocky Mountain Forest and Range Experiment Station. 134 p. (RM)

MITCHELL, JOHN E.; and RICHARD H. HART. 1987. Winter of 1886-87: the death knell of open range. Rangelands. 9:3-8. (RM)

MITCHELL, JOHN E.; DAVID M. EISSENSTAT; and ALEX J. IRBY. 1982. Forest grazing--an opportunity for diplomacy. Rangelands. 4:172-175.

\section{MONSEN, STEPHEN B.; and NANCY} SHAW. comps. 1983. Managing Intermountain rangelands--Improvement of range and wildlife habitats.

Proceedings of symposia; 1981 September 15-17; Twin Falls, ID. 1982 June 22-24. Elko, NV. Gen. Tech. Rep. INT-157. Ogden, UT: U.S. Department of Agriculture, Forest Service, Intermountain Forest and Range Experiment Station. 194 p. (INT)

PATRIC, JAMES H.; and J. D. HELVEY. 1986. Some effects of grazing on soil and water in the Eastern forest. Gen. Tech. Rep. NE-115. Broomall, PA: U.S. Department of Agriculture, Forest Service, Northeastern Forest Experiment Station. 25 p. (NE)

\section{PATTON, DAVID R.; CARLOS E.} GONZALES V.; ALVIN L. MEDINA; A. LUIS; T. SEGURA; and R. H. HAMRE, eds. 1986. Management and utilization of arid land plants. Symposium proceedings; 1985 February 18-22; Saltillo, Mexico. Gen. Tech. Rep. Rm135. Fort Collins, CO: U.S. Department of Agriculture, Forest Service, Rocky Mountain Forest and Range Experiment Station. 113 p. (RM) 
PEARSON, HENRY A. 1977. Grazing cattle on forest range; nutrition and returns. In: White, L. D., ed. Beef crisis emphasizes value of range. Res. Rep. No. 4. Gainesville, FL: Institute, Food and Agriculture Science, University of Florida: 18-22. (SO)

PEARSON, HENRY A.; and DOUGLAS A. ROLLINS. 1986. Supplemental winter pasture for southern pine native range. In: Forages: The grassroots of agriculture; 1986 April 15-17; Athens, GA. Lexington, KY: American Forage and Grassland Council: 258-263. (SO)

PEARSON, HENRY A.; and DOUGLAS A. ROLLINS. 1987. Ryegrass pasture for supplementing southern pine native range. Rangelands. 9:19-20. (SO)

PEARSON, HENRY A.; C. H. HERBEL; and D. T. PENDELTON. 1979. A tour of East German agriculture. Rangelands. 1:911. (SO).

PEARSON, HENRY A.; FRED SMEINS; and RONALD E. THILL. 1987. The southern evaluation project--An executive summary. In: Pearson, Henry A.; Fred Smeins; and Ronald E. Thill, comps. 1987. Ecological, physical, and socioeconomic relationships within southern National Forests: Proceedings of the southern evaluation project workshop; 1987 May 26-27; Long Beach, MS. Gen. Tech. Rep. SO-68. New Orleans, LA: U.S. Department of Agriculture, Forest Service, Southern Forest Experiment Station: 1-5. (SO)

PEARSON, HENRY A.; FRED SMEINS; and RONALD E. THILL, comps. 1987. Ecological, physical, and socioeconomic relationships within southern National Forests. Proceedings of the southern evaluation project workshop; 1987 May 26-27; Long Beach, MS. Gen. Tech. Rep. SO-68. New Orleans, LA: U.S. Department of Agriculture, Forest Service, Southern Forest Experiment Station. 293 p. (SO)
PEARSON, HENRY A.; R. DENNIS CHILD; E. K. BYINGTON; HAROLD E. GRELEN; and CLIFFORD E. LEWIS. 1980. Selected bibliography on southern range management, 1973-1979. Gen. Tech. Rep. SO-31. New Orleans, LA: U.S. Department of Agriculture, Forest Service, Southern Forest Experiment Station. 72 p. (SO)

PLATTS, WILLIAM S. 1986. Managing riparian stream habitats. In: Proceedings Wyoming Water and Streamside Zone Conference; 1986 April 28-30; Casper, WY. Laramie, WY: University of Wyoming: 59-62. (INT)

PLATTS, WILLIAM S. 1986. Public and private rangeland management: an overview. In: Transactions of the North American Wildlife and Natural Resources Conference. 51:261-264. (INT)

PLATTS, WILLIAM S. 1987. Riparian stream management. Transactions Western Section, The Wildlife Society. 22:90-93. (INT)

PLATTS, WILLIAM S.; CARL ARMOUR; GORDON D. BOOTH; [and others]. 1987. Methods for evaluating riparian habitats with applications to management. Gen. Tech. Rep. INT-221. Ogden, UT: U.S. Department of Agriculture, Forest Service, Intermountain Research Station. 177 p. (INT)

QUIGLEY, THOMAS M.; and JACK WARD THOMAS. 1989. Range management and grazing fees on the National Forests: a time of transition. Rangelands. 11:28-32. (PNW)

QUIGLEY, THOMAS M.; REED H. SANDERSON; and ARTHUR R. TIEDEMANN. 1989. Managing interior Northwest rangelands: Oregon range evaluation project. Gen. Tech. Rep. PNW-238. Portland, OR: U.S. Department of Agriculture, Forest Service, Pacific Northwest Research Station. 207 p. (PNW) 
QUINN, RONALD D. 1982. Research and management of animals in Mediterranean-type ecosystems: a summary and synthesis. In: Conrad, C. Eugene; and Walter C. Oechel, tech. coords. Proceedings of the symposium on dynamics and management of Mediterranean-type ecosystems; 1981 June 22-26; San Diego, CA. Gen. Tech. Rep. PSW-58. Berkeley, CA: U.S. Department of Agriculture, Forest Service, Pacific Southwest Forest and Range Experiment Station: 276-278. (PSW)

\section{RATLIFF, RAYMOND D. 1983. Nebraska} sedge (Carex nebraskensis Dewey): observations on shoot life history and management. Journal of Range Management. 36:429-430. (PSW)

RATLIFF, RAYMOND D.; MELVIN R. GEORGE; and NEIL K. MCDOUGALD. 1987. Managing livestock grazing on meadows of California's Sierra Nevada: a managers-users guide. Leaf. 21421. Berkeley, CA: University of California Cooperative Extension, University of California. 9 p. (PSW)

RIVERS, JAMES W.; and S. CLARK MARTIN. 1980. Perennial grass improves with moderate stocking. Rangelands. 2:105-106. (RM)

SANDERSON, H. REED; RICHARD A. MEGANCK; and KENNETH C. GIBBS. 1986. Range management and scenic beauty as perceived by dispersed recreationists. Journal of Range Management. 39:464-469. (PNW)

SEGELQUIST, CHARLES A.; MITCHELL J. ROGERS; and FRED D. WARD. 1976. Response of Japanese honeysuckle to management in the Arkansas ozarks. Proceedings of the Annual Conference of the Southeastern Association Game and Fish Commissioners. 29:370-373. (SO)
SEVERSON, KIETH E.; and CHARLES E. BOLDT. 1978. Problems associated with management of native woody plants in the Western Dakotas. In: Proceedings, 6th Wyoming Shrub Ecology Workshop; Laramie, WY: University Station: 51-57. (RM)

SMITH, E. LAMAR; SANDRA S. COLEMAN; CLIFFORD E. LEWIS; and GEORGE W. TANNER, comps. 1986. Use of cover, soils and weather data in rangeland monitoring. Symposium proceedings; 1986 February 12; Kissimmee, FL. Denver, CO: Society for Range Management. 46 p. (SE)

STRICKLER, GERALD S.; and WADE B. HALL. 1980. The Standley allotment: A history of range recovery. Res. Pap. PNW-278. Portland, OR: U.S. Department of Agriculture, Forest Service, Pacific Northwest Forest and Range Experiment Station. 35 p. (PNW)

STURGES, DAVID L. 1983. Long-term effects of big sagebrush control on vegetation and soil water. Journal of Range Management. 36:760-765. (RM)

STURGES, DAVID L. 1986. Benefits of snow management and $\mathrm{N}$ fertilizer on sagebrush range. In: Steppuhnm H.; and W. Nicholaichuk, eds. Snow management for agriculture:

Proceedings of a symposium; 1985 July 29; Swift Current, Saskatchewan. Lincoln, NE; Great Plains Agricultural Council, University of Nebraska: 403430. (RM)

SZARO, ROBERT C.; and CHARLES P. PASE. 1983. Short-term changes in a cottonwood-ash-willow association on a grazed and an ungrazed portion of Little Ash Creek in central Arizona. Journal of Range Management. 36:382-384. (RM) 
TEER, JAMES G.; ERNEST D. ABLES; F. E. BUSBY; DONALD L. HEDRICK; FRED A. STORMER; and JACK W. THOMAS. 1982. Impacts of agricultural trends on western rangeland habitats. In: Impacts of emerging agricultural trends on fish and wildlife habitat. Washington, DC: National Research Council: 122-158. (PNW)

THILL, RONALD E.; and JOHN C. BELLMORE. 1986. Understory responses to fertilization of eroded Kisatchie soil in Louisiana. Res. Note. SO-330. New Orleans, LA: U.S. Department of Agriculture, Forest Service, Southern Forest Experiment Station. 6 p. (SO)

TIEDEMANN, ARTHUR R. 1983. Response of bitterbrush and associated plant species to broadcast nitrogen, phosphorus, and sulfur fertilization. In: Tiedemann, Arthur R.; and Kendall L. Johnson, comps. Research and management of bitterbrush and cliffrose in western North America: Proceedings of a symposium; 1982 April 13-15; Salt Lake City, UT. Gen. Tech. Rep. INT152. Ogden, UT: U.S. Department of Agriculture, Forest Service, Intermountain Forest and Range Experiment Station: 240-253. (INT)

TIEDEMANN, ARTHUR R. 1987. Nutrient accumulations in pinyon-juniper ecosystems--managing for future site productivity. In: Everett, Richard L., comp. Proceedings--pinyon-juniper conference; 1986 January 13-16; Reno, NV. Gen. Tech. Rep. INT-215. Ogden, UT: U.S. Department of Agriculture, Forest Service, Intermountain Research Station: 352-359. (PNW)
TIEDEMANN, ARTHUR R ; and KENDALL L. JOHNSON, comps. 1983. Research and management of bitterbrush and cliffrose in western North America: Proceedings of a symposium; 1982 April 13-15; Salt Lake City, UT. Gen. Tech. Rep. INT152. Ogden, UT: U.S. Department of Agriculture, Forest Service, Intermountain Forest and Range Experiment Station. 279 p. (INT)

TIERNAN, C. F. 1978. The role of entomology in range management. In: Hyder, Donald N., ed. Proceedings, 1 st international rangeland congress; 1978 August 14-18; Denver, CO: Society for Range Management: 477-478. (INT)

URESK, DANIEL W.; JAMES G. MACCRACKEN; and ARDELL J. BJUGSTAD. 1982. Prairie dog density and cattle grazing relationships. In: Proceedings, 5th Great Plains wildlife damage control workshop; 1981 October 13-15; Lincoln, NE: Institute of Agriculture and Natural Resources, University of Nebraska: 199-201. (RM)

WADE, DALE D.; and CLIFFORD E. LEWIS. 1987. Managing southern grazing ecosystems with fire. Rangelands. 9:115-119. (SE)

WESTFALL, STANLEY E.; and RAYMOND D. RATLIFF. 1979. Tilling may improve annual plant rangelands. Rangelands. 1:246-247. (PSW)

WOLTERS, G. L. 1984. Sulfur or sulfur plus nitrogen increases carrying capacity and beef production on annual range. In: Proceedings, 2nd international rangeland congress: working papers; 1984 May; Adelaide, Australia. Deniliquin, NSW: Reliance Printing: $6 c$. (WO) 
WOLTERS, G. L. 1986. Fertilization increases carrying capacity on green and dry season annual range. In: Joss, P. J.; P. W. Lynch; and O. B. Williams, eds.

Rangelands: a resource under siege: Proceedings, 2nd international rangeland congress; 1985 May 13-18; Adelaide, Australia. Canberra, Australia: Australia Academy of Science: 312-313. (WO)

WOLTERS, GALE L.; and GARY P. EBERLEIN. 1986. Sulfur or sulfur plus nitrogen increases beef production on California annual range. Journal of Range Management. 39:125-129. (WO)

WOLTERS, GALE L.; EARL F. ALDON; and GARY B. DONART. 1989. Response of reseeded coal mine spoils to season and intensity of defoliation: Preliminary findings. In: Walker, D. G.; C. B. Powter; and M. W. Pole, comps. Reclamation, a global perspective: Proceedings of the conference; 1989 August 27-31; Calgary, Alberta, Canada. Alberta Land Conservation and Reclamation Council Report \# RRTAC 89-2:289-298. (RM)

YOAKUM, JIM; [and others]. 1980. Habitat improvement techniques. In: Schemnitz Sanford D., ed. Wildlife Management Techniques Manual. 4th ed., rev. Washington, DC: The Wildlife Society: 329-403. (INT)

\section{Vegetation Management}

BAKER, R. L.; and J. POWELL. 1978. Oklahoma tallgrass prairie responses to atrazine with 2,4-D and fertilizer. In: Hyder, Donald N., ed. Proceedings, 1st international rangeland congress; 1978 August 14-18; Denver, CO: Society for Range Management: 681-683. (SO)
BARRO, SUSAN C.; and SUSAN C.

CONRAD. 1987. Use of ryegrass seeding as an emergency revegetation measure in chaparral ecosystems. Gen. Tech. Rep. PSW-102. Berkeley, CA: U.S. Department of Agriculture, Forest Service, Pacific Southwest Forest and Range Experiment Station. 12 p. (PSW)

BARTOS, DALE L. 1981. Changes in aspen and associated species resulting from manipulation by burning and cutting. In: DeByle, Norbert V., ed. Situation management of two intermountain species: aspen and coyotes. Part I: Aspen: Proceedings of a symposium; 1981 April 23-24; Logan, UT: Utah State University, College of Natural Resources: 77-87. (INT)

BJUGSTAD, ARDELL J.; RICHARD E. FRANCIS; and PAUL W. SKINNER. 1984. Leafy spurge--a potential conflict with woody plants on the northern High Plains. In: Proceedings, Forestry Committee, Great Plains Agricultural Council Annual Meeting; 1983 July 11 14; Billings, MT: 124-132. (RM)

BUCHANAN, BRUCE B.; K. T. HARBER; and NEIL C. FRISCHKNECHT. 1978. Allelopathic effects of bur buttercup tissue on germination and growth of various grasses and forbs in vitro and in soil. Great Basin Naturalist. 38:90-96. (INT)

FRANCIS, RICHARD E.; M. J. MORRIS; R. J. MYHRE; and D. L. NOBLE. 1980. Inventory and analysis of leafy spurge (Euphorbia esula) sites--a feasibility study. In: Proceedings, Northern regional leafy spurge conference Billings, MT. 1979 December 17-18; Helena, MT: Montana Department of Agriculture and Bozeman, MT: Montana State University. 3 p. (RM)

FRISCHKNECHT, NEIL C. 1979. Biological methods: A tool for sagebrush management. In: The sagebrush ecosystem: A Symposium, 1978 April. Logan, UT: Utah State University Press: 121-128. (INT) 
GREEN, L. R.; CATHERINE L. HUGHES; and WALTER L. GRAVES. 1978. Goat control of brush regrowth on southern California fuelbreaks. In: Hyder, Donald N., ed. Proceedings, 1 st international rangeland congress; 1978 August 1418; Denver, CO: Society for Range Management: 451-455. (PSW)

KNIPE, O. D. 1982. Angora goats for conversion of Arizona chaparral: Early results. In: Conrad, C. Eugene; and Walter C. Oechel, tech. coords. Proceedings of the symposium on dynamics and management of Mediterranean-type ecosystems; 1981 June 22-26; San Diego, CA. Gen. Tech. Rep. PSW-58, Berkeley, CA: U.S. Department of Agriculture, Forest Service, Pacific Southwest Forest and Range Experiment Station: 264-269. (RM)

KNIPE, O. D. 1982. The use of angora goats in converting Arizona chaparral to grassland. In: Proceedings, 3rd international conference on goat production and disease; 1982 January 10-15; Tucson, AZ. Dairy Goat Journal Publishing Co: 411-416. (RM)

MARTIN, S. CLARK; and HOWARD L. MORTON. 1980. Responses of false mesquite, native grasses and forbs, and Lehmann lovegrass after spraying with picloram. Journal of Range Management. 33:104-106. (RM)

MILLER, JAMES H. 1988. Kudzu eradication trials with new herbicides. In: Proceedings, environmental legislation and its effect on weed science; Southern Weed Science Society, 41st annual meeting; 1988 January 18-20; Tulsa, OK. Champaign, IL: Southern Weed Science Society. 41:220-225. (SO)
NOBLE, DANIEL L. 1980. Leafy spruge-evaluational and educational needs. In: Proceedings, Northern regional leafy spurge conference; 1979 December 1718; Billings, MT. Helena, MT: Montana Department of Agriculture and Bozeman, MT: Montana State University: 15-17. (RM)

NOBLE, DANIEL L.; PAUL H. DUNN; and LLOYD A. ANDRES. 1979. The leafy spurge problem. In: Proceedings, Leafy spurge symposium; 1979 June 26-27; Bismarck, ND. Fargo, ND: North Dakota State University Cooperative Extension Service: 8-15. (RM)

NORRIS, L. A.; H. W. LORZ; and S. V. GREGORY. 1983. Forest chemicals. In: Meehan, William R.; tech. ed. Influence of forest and rangeland management on anadromous fish habitat in western North America. Gen. Tech. Rep. PNW149. Portland, OR: U.S. Department of Agriculture, Forest Service, Pacific Northwest Forest and Range Experiment Station. 95 p. (PNW)

NORRIS, L. A.; M. L. MONTGOMERY; L. E. WARREN; and W. D. MOSHER. 1982. Brush control with herbicides on hill pasture sites in southern Oregon. Journal of Range Management. 35:7580. (PNW)

STURGES, DAVID L. 1986. Responses of vegetation and ground cover to spraying a high elevation, big sagebrush watershed with 2,4-D. Journal of Range Management. 39:141-146. (RM)

WINEGAR, HAROLD; and WAYNE ELMORE. 1978. Mechanical manipulation of western juniper--some methods and results. In: Martin, Robert E.; J. Edward Dealy; and David L. Caraher, eds. Proceedings of the western juniper ecology and management workshop; 1977 January; Bend, OR. Gen. Tech. Rep. PNW-74; Portland, OR: U.S. Department of Agriculture, Forest Service, Pacific Northwest Forest and Range Experiment Station: 107-119. (PNW) 
Multiple Use

ARNO, STEPHEN F.; GEORGE E. GRUELL; JOHN G. MUNDINGER; and WYMAN C. SCHMIDT. 1987. Developing silvicutural prescriptions to provide both deer winter habitat and timber. Western Wildlands. 12(4):19-24. (INT)

BUCKMAN, ROBERT E.; and GALE L. WOLTERS. 1987. Multi-resource management of pinyon-juniper woodlands. In: Everett, Richard L., comp. Proceedings--pinyon-juniper conference; 1986 January 13-16; Reno, NV. Gen. Tech. Rep. INT-215. Ogden, UT: U.S. Department of Agriculture, Forest Service, Intermountain Research Station: 2-4. (WO)

BYINGTON, EVERT; DENNIS CHILD; NATHAN BYRD; HARLAND DIETZ; SAM HALVERSON; HENRY

PEARSON; and FLOYD HORN. 1983. Management of southern U.S. farms for livestock grazing and timber production on forested farmlands and associated pasture and range lands. Morrilton, AR: Winrock International. 60 p. (SO)

BYINGTON, EVERT N.; NATHAN A. BYRD; SAM D. HALVERSON; CLIFFORD E. LEWIS; HENRY A. PEARSON; W. PINT; and MARK K. JOHNSON. 1984. You can integrate grazing with timber management. Forest Farmer. 43(3):202l. (SE)

CHILD, R. DENNIS. 1980. Evaluating interactions. In: Proceedings, Southern forest range and pasture resources symposium. Morrilton, AR: Winrock International: 147-163. (SO)

CLARY, WARREN P. 1989. Test of RPA production coefficients and local assumptions for the pinyon-juniper ecosystem in central Utah. Res. Pap. INT-403. Ogden, UT: U.S. Department of Agriculture, Forest Service, Intermountain Research Station. $11 \mathrm{p}$. (INT)
DEALY, J. EDWARD. 1977. Curleaf mountain-mahogany makes music. American Forests. 83(6):24-27. (PNW)

DEBYLE, NORBERT V. 1985. Management for esthetics and recreation, forage, water, and wildlife. In: DeByle, Norbert V.; and Robert P. Winokur, eds. Aspen: Ecology and management in the Western United States. Gen. Tech. Rep. RM-119. Fort Collins, CO: U.S. Department of Agriculture, Forest Service, Rocky Mountain Forest and Range Experiment Station: 223-232. (INT)

DOWNING, R. L. 1980. Resource allocation for wildlife, forestry, and range. In: Proceedings, Southern Forest Range and Pasture Symposium; 1980 March; New Orleans, La: 89-98. (SO)

EDGERTON, PAUL J.; and JACK WARD THOMAS. 1978. Silvicultural options and habitat values. Tech. Rep. PNW-64. Portland, OR: U.S. Department of Agriculture, Forest Service, Pacific Northwest Forest and Range Experiment Station. (PNW)

EISSENSTAT, D. M.; and J. E. MITCHELL. 1983. Effects of seeding grass and clover on growth and water potential of Douglas-fir seedlings. Forest Science. 29:166-179. (RM)

EVANS, KEITH E.; and ROGER R. KERBS. 1977. Avian use of livestock watering ponds in western South Dakota. Gen. Tech. Rep. RM-35. Fort Collins, CO: U.S. Department of Agriculture, Forest Service, Rocky Mountain Forest and Range Experiment Station. 11 p. (RM)

EVEREST, FRED H. 1984. Coordinating fish and wildlife habitat with other forest management activities. In: Wenger, Karl F., ed. Forestry handbook. 2nd ed. New York, NY: John Wiley \& Sons: 731-736. (PNW) 
FFOLLIOTT, PETER F. 1983. Implications of snag policies on management of southwestern ponderosa pine forests. In: Davis, Jerry W.; Gregory A. Goodwin; and Richard A. Ockenfels, tech. coords. Snag habitat management: Proceedings of the symposium; 1983 June 7-9; Flagstaff, AZ. Gen. Tech. Rep. RM-99. Fort Collins, CO: U.S. Department of Agriculture, Forest Service, Rocky Mountain Forest and Range Experiment Station: 28-32. (RM)

FRANKLIN, JERRY F.; THOMAS SPIES; DAVID PERRY; MARK HARMON; and ARTHUR MCKEE. 1986. Modifying Douglas-fir management regimes for nontimber objectives. In: Oliver, Chadwick Dearing; Donald P. Hanley; and Jay A. Johnson, comps. eds. Douglas-fir: stand management for the future: Proceedings of symposium; 1985 June 18-20; Seattle, WA: University of Washington, College of Resources: 373379. (PNW)

FREAR, SAMUEL T. 1983. High country streams, cattle are compatible. Beef. 19(9):68-69. (PNW)

GRELEN, HAROLD E. 1978. Forest grazing in the south. Journal of Range Management. 31:244-250. (SO)

GRELEN, HAROLD E.; and CLIFFORD E. LEWIS. 1981. Value of range data on fire effects to the wildlife manager. In: Wood, Gene W., ed. Prescribed fire and wildlife in southern forests: Proceedings of a symposium; 1981 April 6-8; Myrtle Beach, SC. Georgetown, SC: Belle W. Baruch Forest Science Institute, Clemson University: 155-159. (SO)

HALL, FREDERICK C. 1984. Vegetation diversity in managed and unmanaged ecosystems and effects on various resources. In: Cooley, J. L.; and J. H. Cooley, tech. eds. Proceedings, Workshop on Natural Diversity in Forest Ecosystems; 1982 November 29 . December 1; Athens, GA: University of Georgia Center for Continuing Education: 251-262. (PNW)
HALLS, LOWELL K. 1978. Effect of timber harvesting on wildlife, wildlife habitat and recreation values. In: Proceedings symposium: complete tree utilization of southern pine: 108-114. (SO)

HARNISS, ROY O. 1981. Ecological succession in aspen and its consequences on multiple use values. In: DeByle, Norbert V., ed. Situation management of two intermountain species: aspen and coyotes. Part I: Aspen: Proceedings of a symposium; 1981 April 23-24; Logan, UT. Logan, UT: Utah State University, College of Natural Resources: 31-39. (INT)

HARRIS, L. D.; and W. H. SMITH. 1978. Relations of forest practices on timber resources and adjacent ecosystems. In: Tippen, T., ed. Proceedings, Symposium on principles of maintaining productivity on prepared sites; New Orleans, LA: U.S. Department of Agriculture, Forest Service, Southern Forest Experiment Station: 28-53. (SE)

HARRIS, LARRY D.; and WAYNE R. MARION. 1982. Forest stand scheduling for wildlife in the multiple use forest. In: Increasing forest productivity:

Proceedings, 1981 convention of the Society of American Foresters; 1981 September 27-30; Orlando, FL. SAF 8201. Bethesda, MD: Society of American Foresters: 209-214. (SE)

HARRIS, LARRY D.; CHRIS MASER; and ARTHUR MCKEE. 1983. Patterns of old growth harvest and implications for Cascades wildlife. Transactions of the North American Wildlife and Natural Resources Conference. 47:374-392. (PNW)

HOEKSTRA, THOMAS W.; and CURTIS H. FLATHER. 1986. Theroetical basis for integrating wildlife in renewable resource inventories. Journal of Environmental Management. 24:95-110. (RM) 
HOEKSTRA, THOMAS W.; CURTIS $H$. FLATHER; and PATRICIA A. FLEBBE. 1987. Regional fish and wildlife habitat models: application for national multiple resource planning. In: Land and resource evaluation for national planning in the tropics: International conference and Workshop; 1987 January 25-31; Chetumal, Mexico. Gen. Tech. Rep. WO-39. Washington, DC: U.S. Department of Agriculture, Forest Service: 404-409. (RM)

HOF, JOHN G.; and TONY J. BALTIC. 1988. Forest and rangeland resource interactions: a supporting technical document for the 1989 RPA Assessment. Gen. Tech. Rep. RM-156. Fort Collins, CO: U.S. Department of Agriculture, Forest Service, Rocky Mountain Forest and Range Experiment Staion. 134 p. (RM)

JOHNSON, MARK K.; HENRY A. PEARSON; and CLIFFORD E. LEWIS. 1983. Agroforestry in the South. Louisiana Cattleman. 16(8):7, 9. (SO)

JOYCE, LINDA A.; THOMAS W. HOEKSTRA; and RALPH J. ALIG. 1986. Regional multiresource models in a national framework. Environmental Management. 10:761-771. (RM)

LENNARTZ, MICHAEL R. 1979. Multiple-use management: for some, a promise unfulfilled. In: Hook, Donald D; and B. Allen Dunn, eds. Multiple-use management of forest resources, Proceedings Symposium, 1979 September. Clemson, SC: Clemson University: 97-106. (SE)

LEWIS, C. E.; G. W. BURTON; W. G. MONSON; and W. C. MCCORMICK. 1983. Integration of pines, pastures, and cattle in south Georgia, USA.

Agroforestry Systems. (Netherlands) I:277-297. (SE)
LEWIS, C. E.; G. W. BURTON; W. G. MONSON; and W. C. MCCORMICK. 1984. Integration of pines and pastures for hay and grazing. Agroforestry Systems. (Netherlands) 2:31-41. (SE)

LEWIS, CLIFFORD E. 1978. Principles and status of integrated management from the range viewpoint. In: Mutual opportunities for forest, range and wildlife management; A symposium; Gainesville, FL: School Forest Resource and Conservation, Florida University Resource Report. 4(1977):26-34. (SE)

LEWIS, CLIFFORD E.; and HENRY A PEARSON. 1987. Agroforestry using tame pastures under planted pines in the southeastern United States. In: Gholz, Henry L., comp. ed. Agroforestry: Realities, possiblities, and potentials. Dordrecht, The Netherlands: Martinus Nijhoff Publishers. 195-212. (SE)

LEWIS, CLIFFORD E.; GEORGE W. TANNER; and J. JEFF LEWIS. 1983. Agroforestry in Florida. Florida Cattleman. 47(12):82-83, 91. (SE)

LEWIS, CLIFFORD E.; GEORGE W. TANNER; and W. STEPHEN TERRY. 1982. Multiple-use management practices for the flatwoods. In: Coleman, Sandra L.; Arnett C. Mace, Jr.; and Benee F. Swindel, eds. Impacts of intensive forest management practices: Proceedings of a symposium; 1982 March 9-10; Gainesville, FL: University of Florida, School of Forest Resources and Conservation: 71-84. (SE)

LYON, L. JACK. 1981. Coordinating forestry and elk management. Transactions of the North American wildlife and Natural Resources Conference. 45:278-287. (INT) 
MARION, WAYNE R.; and LARRY D. HARRIS. 1982. Relationships between increasing forest productivity and fauna in the flatwoods of the Southeastern Coastal Plain. In: Increasing forest productivity: Proceedings, 1981 convention of the Society of American Foresters; 1981 September 27-30; Orlando, FL. SAF 82-01. Bethesda, MD: Society of American Foresters: 215-222.

MARQUIS, DAVID A. 1986. Integration of timber and wildlife in silvicultural prescription writing. In: 18th IUFRO World Congress; 1986 September 2-21; Ljubjana, Yugoslavia. Division 1, Volume II. International Union of Forestry Research Organizations: 565573. (NE)

MCDONALD, PHILIP M. 1986. Grasses in young conifer plantations-hindrance and help. Northwest Science. 60:271-278. (PSW)

MEEUWIG, RICHARD O. 1983. Stand dynamics and management alternatives for pinyon-juniper woodlands. In: Monsen, Stephen B.; and Nancy Shaw, comps. Managing Intermountain rangelands--Improvement of range and wildlife habitats: Proceedings of symposia; 1981 September 15-17; Twin Falls, ID. 1982 June 22-24. Elko, NV. Gen. Tech. Rep. INT-157. Ogden, UT: U.S. Department of Agriculture, Forest Service, Intermountain Forest and Range Experiment Station: 172-175. (INT)

NEAL, DONALD L. 1986. Obstacles to cooperation between range and wildlife managers. In: Transactions of the Western Section of the Wildlife Society. 22:15-17. (PSW)

PATTON, DAVID R. 1982. Management applications of biotic community data. In: Brown, David E., ed. Biotic communities of the American Southwest-United States and Mexico. Desert Plants. 4(14):7. (RM)
PEARSON, HENRY A. 1977.

Interrelationships--range, timber, and wildlife. In: Forests for people: A challenge in world affairs. Proceedings, Society of American Foresters; 1977 National Convention: 137-138. (SO)

PEARSON, HENRY A. 1979. Range opportunities in the south. Rangelands. $1: 179-181$. (SO)

PEARSON, HENRY A. 1980. Livestock in multiple-use management of southern forest range. In: Proceedings, Southern forest range and pasture resources symposium. Morrilton, AK: Winrock International: 75-88. (SO)

PEARSON, HENRY A. 1981. Forest and range interactions. In: Proceedings of the first biennial southern silvicultural research conference; 1980 November 67; Atlanta, GA. Gen. Tech. Rep. SO-34. New Orleans, LA: U.S. Department of Agriculture, Forest Service, Southern Forest Experiment Station: 339-342. (SO)

PEARSON, HENRY A. 1984. Agroforestry. In: Merkle, Dan; Roy Carter; and John L. Artz, eds. Southeastern regional conference: Grazing lands and people; 1984 December 10-12; Atlanta, GA. Athens, GA: University of Georgia: 7279. (SO)

PEARSON, HENRY A. 1987. Southern pine plantations and cattle grazing. Journal of Forestry. 85(10):36-37. (SO)

PEARSON, HENRY A. 1987. The southern evaluation project: Development and results. In: Pearson, Henry A.; Fred Smeins; and Ronald E. Thill, comps. 1987. Ecological, physical, and socioeconomic relationships within southern National Forests: Proceedings of the southern evaluation project workshop; 1987 May 26-27; Long Beach, MS. Gen. Tech. Rep. SO-68. New Orleans, LA: U.S. Department of Agriculture, Forest Service, Southern Forest Experiment Station: 17-19. (SO) 
PEARSON, HENRY A.; FRED SMEINS; and RONALD E. THILL. 1987. The southern evaluation project--An executive summary. In: Pearson, Henry A.; Fred Smeins; and Ronald E. Thill, comps. 1987. Ecological, physical, and socioeconomic relationships within southern National Forests: Proceedings of the southern evaluation project workshop; 1987 May 26-27; Long Beach, MS. Gen. Tech. Rep. SO-68. New Orleans, LA: U.S. Department of Agriculture, Forest Service, Southern Forest Experiment Station: 1-5. (SO)

PEARSON, HENRY A.; FRED SMEINS; and RONALD E. THILL, comps. 1987.

Ecological, physical, and socioeconomic relationships within southern National Forests. Proceedings of the southern evaluation project workshop; 1987 May 26-27; Long Beach, MS. Gen. Tech. Rep. SO-68. New Orleans, LA: U.S. Department of Agriculture, Forest Service, Southern Forest Experiment Station. 293 p. (SO)

PLATTS, WILLIAM S. 1979. Including the fishery system in land planning. Gen. Tech. Rep. INT-60. Ogden, UT: U.S. Department of Agriculture, Forest Service, Intermountain Forest and Range Experiment Station. 37 p. (INT)

PLATTS, WILLIAM S. 1987. Managing riparian stream habitats. In: Proceedings of the 21st annual meeting, American Fisheries Society, Colorado-Wyoming Chapter: 81-86. (INT)

SANDERSON, H. REED; RICHARD A. MEGANCK; and KENNETH C. GIBBS. 1986. Range management and scenic beauty as perceived by dispersed recreationists. Journal of Range Management. 39:464-469. (PNW)
SEVERSON, KIETH E.; and CHARLES E. BOLDT. 1978. Cattle, wildlife, and riparian habitats in the Western Dakotas. In: Proceedings, Management and use of Northern Plains rangeland: Regional rangeland symposium; 1978 February 27-28; Fargo, ND: North Dakota State University, Cooperative Extension Service: 90-103. (RM)

SWEENEY, JAMES M.; and GALE L. WOLTERS. 1986. Techniques for future decisionmaking in range, wildlife and fisheries management. In: Crowley, John, ed. Research for tomorrow: 1986 yearbook of agriculture. Washington, DC: U.S. Department of Agriculture: 209-212. (WO)

TANNER, GEORGE W. ; and CLIFFORD E. LEWIS. 1986. Alternative tree spacings for wood and forage production in Florida. Fact Sheet FRC-36. Gainesville, FL: Florida Cooperative Extension Service, University of Florida. 2 p. (SE)

THILL, RONALD E. 1985. Cattle and deer compatibility on southern forest range. In: Baker, Frank H.; and R. Katherine Jones, eds. Proceedings of a conference on multi-species grazing; 1985 June 25-28; Morrilton, AR: Winrock Institute for Agricultural Development: 159-177. (SO)

THOMAS, JACK WARD. 1983. Forestland grazing--one part of a bigger picture. In: Roche, Ben F., Jr.; and David M. Baumgartner, comps., eds. Forestland grazing: Proceedings of a symposium; 1983 February 23-25; Spokane, WA. Pullman, WA: Washington State University: 23-26. (PNW)

THOMAS, JACK WARD. 1987. Multiple-use forestry: moving from platitudes to reality. In: Northwest forestry in transition: the 1987 Starker Lecture Series. Corvallis, OR: College of Forestry, Oregon State University: 4352. (PNW) 
THOMAS, JACK WARD; DONAVIN A. LECKENBY; L. JACK LYON; [and others]. 1988. Integrated management of timber-elk-cattle: interior forest of Western North America. Gen. Tech. Rep. PNW-225. Portland, OR: U.S. Department of Agriculture, Forest Service, Pacific Northwest Research Station. 12 p. (PNW)

WILLIAMSON, ROBERT M. 1987. National outlook for National Forest System lands and resource management in the Southeast. In: Pearson, Henry A.; Fred Smeins; and Ronald E. Thill, comps. 1987. Ecological, physical, and socioeconomic relationships within southern National Forests: Proceedings of the southern evaluation project workshop; 1987 May 26-27; Long Beach, MS. Gen. Tech. Rep. SO-68. New Orleans, LA: U.S. Department of Agriculture, Forest Service, Southern Forest Experiment Station: 9-10. (WO)

WOLTERS, GALE L.; and RONALD D. LINDMARK. 1987. A basis for the southern evaluation program. In: Pearson, Henry A.; Fred Smeins; and Ronald E. Thill, comps. 1987. Ecological, physical, and socioeconomic relationships within southern National Forests: Proceedings of the southern evaluation project workshop; 1987 May 26-27; Long Beach, MS. Gen. Tech. Rep. SO-68. New Orleans, LA: U.S. Department of Agriculture, Forest Service, Southern Forest Experiment Station: 15-16. (WO)

\section{Overstory-Understory Relationships}

BALOGH, JAMES C.; and DAVID F. GRIGAL. 1988. Tall shrub dynamics in northern Minnesota aspen and conifer forests. Res. Pap. NC-283. St. Paul, MN: U.S. Department of Agriculture, Forest Service, North Central Forest Experiment Station. 15 p. (NC)
BEDELL, THOMAS E.; and THOMAS R. BUNCH. 1978. Effects of western juniper on forage production and livestock grazing management. In: Martin, Robert E.; J. Edward Dealy; and David L. Caraher, eds. Proceedings of the western juniper ecology and management workshop; 1977 January; Bend, OR. Gen. Tech. Rep. PNW-74. Portland, OR: U.S. Department of Agriculture, Forest Service, Pacific Northwest Forest and Range Experiment Station: 1963-1967. (PNW)

BERK, DONALD E.; and RICHARD F. HARLOW. 1984. Understory forage production following thinning in Southern Appalachian cove hardwoods. In: Sweeney, John R., ed. Proceedings, 35th annual conference Southeastern Association Fish and Wildlife Agencies; 1981 October 18-21; Tulsa, OK. Nashville, TN: Southeastern Association Fish and Wildlife Agencies. 35:185-196. (SE)

BLAIR, ROBERT M.; and DONALD P. FEDUCCIA. 1977. Midstory hardwoods inhibit deer forage in loblolly pine plantations. Journal of Wildlife Management. 41:677-684. (SO)

BOLDT, CHARLES E.; and KIETH E. SEVERSON. 1976. Productivity of pure and mixed stands of trees and low vegetation in the Black Hills. Proceedings South Dakota Academy Science. 55:181. (RM)

CLARY, WARREN P. 1979. Grazing and overstory effects of rotationally burned slash pine plantation ranges. Journal of Range Management. 32:264-266. (SO)

CLARY, WARREN P. 1983. Overstoryunderstory relationships: spruce-fir forests. In: Overstory-understory relationships in western forest. West. Reg. Res. Pub. I. Fort Collins, CO: Colorado Agriculture Experiment Station, Colorado State University: 9-12. (INT) 
CLARY, WARREN P. 1988. Silvicultural systems for forage production in ponderosa pine forests. In: Baumgartner, David M.; and James E. Lotan, comps. Ponderosa pine: the species and its management: symposium proceedings; 1987 September 29-October 1; Spokane, WA. Pullman, WA: Washington State University, Office of Conferences and Institutes: 185-191. (INT)

CLARY, WARREN P.; and CHESTER E. JENSEN. 1981. Mathematical hypothesis for herbage production potential on pinyon-juniper areas. Res. Pap. INT-279. Ogden, UT: U.S. Department of Agriculture, Forest Service, Intermountain Forest and Range Experiment Station: 8 p. (INT)

CLARY, WARREN P.; and DONALD A. JAMESON. 1981. Herbage production following tree and shrub removal in the pinyon-juniper type of Arizona. Journal of Range Management. 34:109-113. (INT)

CRAWFORD, HEWLETTE S. 1976.

Relationships between forest cutting and understory vegetation: an overview of eastern hardwood stands. Res. Pap. NE-349. Broomall, PA: U.S. Department of Agriculture, Forest Service, Northeastern Forest Experiment Station. 9 p. (NE)

CROUCH, GLENN L. 1983. Effects of commercial clearcutting of aspen on understory vegetation and wildlife habitat values in Southwestern Colorado. Res. Pap. RM-246. Fort Collins, CO: U.S. Department of Agriculture, Forest Service, Rocky Mountain Forest and Range Experiment Station. 8 p. (RM)
CROUCH, GLENN L. 1986. Effects of thinning pole-sized lodgepole pine on understory vegetation and large herbivore activity in central Colorado.

Res. Pap. RM-268. Fort Collins, CO: U.S. Department of Agriculture, Forest Service, Rocky Mountain Forest and Range Experiment Station. 10 p. (RM)

DEALY, J. EDWARD; and PAUL J. EDGERTON. 1977. Effects of thinninglogging on production of forage and cover for big game and livestock. In: Range management short course; Corvallis, OR: Oregon State University. 4 p. (PNW)

EDGERTON, PAUL J. 1987. Influence of ungulates on the development of the shrub understory of an upper slope mixed conifer forest. In: Provenza, Frederick D.; Jerran T. Flinders; and E. Durant McArthur, comps. Proceedings-symposium on plant-herbivore interactions; 1985 August 7-9; Snowbird, UT. Gen. Tech. Rep. INT-222. Ogden, UT: U.S. Department of Agriculture, Forest Service, Intermountain Research Station: 162-167. (PNW)

\section{EVERETT, RICHARD L.; and STEVEN H.} SHARROW. 1983. Response of understory species to tree harvesting and fire in pinyon-juniper woodlands. In: Monsen, Stephen B.; and Nancy Shaw, comps. Managing Intermountain rangelands--Improvement of range and wildlife habitats: Proceedings of a symposium; 1981 September 15-17; Twin Falls, ID; 1982 June 22-24; Elko, NV. Gen. Tech. Rep. INT-157. Ogden, UT: U.S. Department of Agriculture, Forest Service, Intermountain Forest and Range Experiment Station: 62-66. (INT)

EVERETT, RICHARD L.; and SUSAN KONIAK. 1982. Understory vegetation in fully stocked pinyon-juniper stands. Great Basin Naturalist. 41:467-475. (INT) 
EVERETT, RICHARD L.; STEVEN H. SHARROW; and RICHARD $O$. MEEUWIG. 1983. Pinyon-juniper woodland understory distribution patterns and species associations. Bulletin of the Torrey Botanical Club. 110:454-463. (INT)

FFOLLIOTT, PETER F.; and GERALD J. GOTTFRIED. 1989. Production and utilization of herbaceous plants in small clearcuts in an Arizona mixed conifer forest. Res. Note. RM-494. Fort Collins, CO: U.S. Department of Agriculture, Forest Service, Rocky Mountain Forest and Range Experiment Station. $5 \mathrm{p}$. (RM)

\section{FFOLLIOTT, PETER F.; and WARREN P.} CLARY. 1983. Understory-overstory vegetation relationships: An annotated bibliography. Gen. Tech. Rep. INT-136. Ogden, UT: U.S. Department of Agriculture, Forest Service, Intermountain Forest and Range Experiment Station. 39 p. (INT)

GRELEN, HAROLD E.; and CLIFFORD E. LEWIS. 1978. Herbage yield related to basal area and rainfall in a thinned longleaf plantation. Res. Note SO-232, New Orleans, LA: U.S. Department Agriculture Forest Service, Southern Forest Experiment Station. 4 p. (SO)

HALL, FREDERICK C. 1978. Applicability of rangeland management concepts to forset-range in the Pacific Northwest. In: Hyder, Donald N., ed. Proceedings, 1st international rangeland congress; 1978 August 14-18; Denver, CO: Society for Range Management: 496-499. (PNW)
HANLEY, THOMAS A.; REX G. CATES; BEATRICE VAN HORNE; and JAY D. MCKENDRICK. 1987. Forest stand-agerelated differences in apparent nutritional quality of forage for deer in southeastern Alaska. In: Provenza, Frederick D.; Jerran T. Flinders; and E. Durant McArthur, comps. Proceedings-symposium on plant-herbivore interactions; 1985 August 7-9; Snowbird, UT. Gen. Tech. Rep. INT-222. Ogden, UT: U.S. Department of Agriculture, Forest Service, Intermountain Research Station: 9-17. (PNW)

HOLLAND, V. L. 1980. Effect of blue oak on rangeland forage production in Central California. In: Plumb, T. R., tech. coord. Proceedings of the symposium on the ecology, management and utilization of California oaks; 1979 June 22-26; Claremont, CA. Gen. Tech. Rep. PSW44. Berkeley, CA: U.S. Department of Agriculture, Forest Service, Pacific Southwest Forest and Range Experiment Station: 314-318. (PSW)

JOHNSON, M. K.; and L. G. DAVIS. 1983. Potentials for forest grazing in the southeastern United States. International Tree Crops Journal. 2:121131. (SO)

JOYCE, L. A.; and R. L. BAKER. 1987. Forest overstory-understory relationships in Alabama forests. Forest Ecology and Management. 18:49-59. (RM)

JOYCE, LINDA A.; and JOHN E. MITCHELL. 1989. Understory cover/biomass relationships in Alabama forest types. Agroforestry Systems. 9:205-210. (RM)

KELTY, MATTHEW J.; RALPH D. NYLAND. 1983. Hardwood browse production following shelterwood cutting. Journal of Wildlife Management. 47:1216-1220. (NE) 
LARSEN, FREDRICK R.; and GALE L.

WOLTERS. 1983. Overstory

relationships: mixed conifer forests. In:

Overstory-understory relationships in

western forests. Western Regional

Research Publication 1. Fort Collins,

CO. Colorado State University

Experiment Station: 21-25. (PNW)

MCCAMBRIDGE, W. F.; M. J. MORRIS; and

C. B. EDMINSTER. 1982. Herbage production under ponderosa pine killed

by the mountain pine beetle in Colorado.

Res. Note RM-416. Fort Collins, CO:

U.S. Department of Agriculture, Forest

Service, Rocky Mountain Forest and

Range Experiment Station. 3 p. (RM)

MITCHELL, J. E.; P. N. S. BARTLING; and R.

O'BRIEN. 1987. Understory cover-

biomass relationships in the Front

Range ponderosa pine zone. Res. Note

RM-471. Fort Collins, Co; U.S.

Department of Agriculture, Forest

Service, Rocky Mountain Forest and

Range Experiment Station. 5 p. (RM)

MOORE, WILLIAM H.; BENEE F. SWINDEL; and W. STEPHEN TERRY. 1982.

Vegetative response to clearcutting and chopping in a north Florida flatwoods forest. Journal of Range Management. 35:214-218. (SE)

MUEGGLER, W. F. 1985. Forage. In: DeByle, Norbert V.; and Robert P. Winokur, eds.

Aspen: Ecology and management in the Western United States. Gen. Tech. Rep. RM-119. Fort Collins, CO: U.S.

Department of Agriculture, Forest

Service, Rocky Mountain Forest and

Range Experiment Station: 129-134. (INT)

MYERS, CLIFFORD A. 1977. Simulating timber and deer food potential in loblolly pine plantations. Gen. Tech. Rep. SO12. New Orleans, LA: U.S. Department of Agriculture, Forest Service, Southern Forest Experiment Station. 29 p. (SO)
NIXON, CHARLES M.; MILFORD, W. MCCLAIN; ROBERT K. LANDES; LONNIE P. HANSEN; and H. REED SANDERSON. 1983. Response of suppressed hickories to release cutting. The Wildlife Society Bulletin. 11(1):4246. (PNW)

REGELIN, WAYNE L.; and OLOF C. WALLMO. 1978. Duration of deer forage benefits after clearcut logging of subalpine forest in Colorado. Res. Note. RM-356. Fort Collins, CO: U.S. Department of Agriculture, Forest Service, Rocky Mountain Forest and Range Experiment Station. 4 p. (RM)

SEVERSON, KIETH E.; and CHARLES E. BOLDT. 1977. Options for Black Hills forest owners; timber, forage, or both. Rangeman's Journal. 4:13-15. (RM)

SEVERSON, KIETH E.; and DANIEL W. URESK. 1988. Influence of ponderosa pine overstory on forage quality in the Black Hills, South Dakota. Great Basin Naturalist. 48:78-82. (RM)

STEWART, G. H. 1988. The influence of canopy cover on understory (understory) development in forests of the western Cascade Range, Oregon, USA. Vegetation. 76:79-88. (PNW)

STRANSKY, JOHN J.; and DOUGLAS C. RICHARDSON. 1979. Fruiting of browse plants affected by pine site preparation in east Texas. Proceedingsof the Annual Conference Southeastern Association Fish and Wildlife Agencies. 31:5-7. (SO)

STRANSKY, JOHN J.; and LOWELL K. HALLS. 1979. Forage yield increased by clearcutting and site preparation. Proceedings of the Annual Conference Southeastern Association Fish and Wildlife Agencies. 32:38-41. (SO)

STRANSKY, JOHN J.; and LOWELL K. HALLS. 1980. Fruiting of woody plants affected by site preparation and prior land use. Journal of Wildlife Management. 44:258-263. (SO) 
STURGES, D. L. 1983. Establishment and growth of shelterbelt species and grass barriers on windswept Wyoming rangeland. Transportation Research Rec. 913:4-11. (RM)

THILL, RONALD E.; and JOHN C. BELLMORE. 1986. Understory responses to fertilization of eroded Kisatchie soil in Louisiana. Res. Note. SO-330. New Orleans, LA: U.S. Department of Agriculture, Forest Service, Southern Forest Experiment Station. 6 p. (SO)

THILL, RONALD E.; PETER F. FFOLLIOTT; and DAVID R. PATTON. 1983. Deer and elk forage production in Arizona mixed conifer forests. Res. Pap. RM248. Fort Collins, CO: U.S. Department of Agriculture, Forest Service, Rocky Mountain Forest and Range Experiment Station. 13 p. (SO)

TIEDEMANN, ARTHUR R.; and JAMES O. KLEMMEDSON. 1977. Effect of mesquite trees on vegetation and soils in the desert grassland. Journal of Range Management. 30:361-367. (PNW)

URESK, DANIEL W. 1987. Effects of livestock grazing and thinning of overstory trees on understory woody plants. In: Provenza, Frederick D.; Jerran T. Flinders; and E. Durant McArthur, comps. Proceedings-symposium on plant-herbivore interactions; 1985 August 7-9; Snowbird, UT. Gen. Tech. Rep. INT-222. Ogden, UT: U.S. Department of Agriculture, Forest Service, Intermountain Research Station: 168-171. (RM)

URESK, DANIEL W.; and KIETH E. SEVERSON. 1989. Understoryoverstory relationships in ponderosa pine forests, Black Hills, South Dakota. Journal of Range Management. 42:203208. (RM)
WATSON, VANCE H.; CHARLES

HAGEDORN; WILLIAM E. KNIGHT; and HENRY A. PEARSON. 1984. Shade tolerance of grass and legume germplasm for use in the southern forest range. Journal of Range Management. 37:229-232. (SO)

WIGGERS, ERNIE P.; D. LAMAR

ROBINETTE; JOHN R. SWEENEY; [and others]. 1978. Predictability of deer forages using overstory measurements. Proceedings of the Annual Conference of the Southeastern Association of Fish and Wildlife Agencies. 32:187-194.

WOLTERS, GALE L. 1977. Timber, browse, and herbage on selected loblollyshortleaf pine-hardwood forest stands. Res. Note. SO-223. New Orleans, LA: U.S. Department Agriculture, Forest Service, Southern Forest Experiment Station. 9 p. (SO)

WOLTERS, GALE L. 1981. Timber thinning and prescribed burning as methods to increase herbage on grazed and protected longleaf pine ranges. Journal of Range Management. 34:494-497. (SO)

WOLTERS, GALE L. 1982. Longleaf and slash pine decreases herbage production and alters herbage composition. Journal of Range Management. 35:761-763 (SO)

WOLTERS, GALE L.; ALTON MARTIN, JR.; and WARREN P. CLARY. 1977. Timber, browse, and herbage on selected loblolly-shortleaf pine hardwood forest stands. Res. Note. SO-223. New Orleans, LA: U.S. Department of Agriculture, Forest Service, Southern Forest Experiment Station. 9 p. (SO)

WOLTERS, GALE L.; ALTON MARTIN; and HENRY A. PEARSON. 1982. Forage response to overstory reduction on loblolly-shortleaf pine-hardwood forest range. Journal of Range Management. 35:443-446. (SO) 
Grazing Management

BONHAM, CHARLES D.; SANDRA S. COLEMAN; CLIFFORD E. LEWIS; and GEORGE W. TANNER, comps. 1986. Statistical analyses and modeling of grazing systems: Symposium proceedings; 1986 February 13; Kissimmee, FL. Denver, CO: Society for Range Management. 73 p. (SE)

BRYANT, LARRY D. 1985. Livestock management in the riparian ecosystem. In: Johnson, R. Roy; Charles D. Ziebell; David R. Patton; Peter F. Ffolliott; and R. H. Hamre, tech. eds. Riparian ecosystems and their management: Reconciling conflicting uses: Proceedings, First North American riparian conference; 1985 April 16-18; Tucson, AZ. Gen. Tech. Rep. RM-120. Fort Collins, CO: U.S. Department of Agriculture, Forest Service, Rocky Mountain Forest and Range Experiment Station: 285-289. (PNW)

FORERO, L.; L. R. RITTENHOUSE; and J. E. MITCHELL. 1989. A cow-calf vs. yearling substitution ratio for shortgrass steppe. Journal of Range Management. 42:343-345. (RM)

KINGERY, JAMES L.; and CAROL BOYD. 1987. Photo guide used to evaluate grazing on transitory rangelands: Focus on Renewable Natural Resources.

Moscow, ID: University of Idaho, College of Foresty, Wildlife and Range Sciences. 12:28. (INT)

LAYCOCK, W. A.; and P. W. CONRAD. 1981. Responses of vegetation and cattle to various systems of grazing on seeded and native mountain rangelands in eastern Utah. Journal of Range Management. 34:52-58. (INT)
LUNDGREN, G. K. j. R. CONNER; and H. A. PEARSON. 1984. Five forest-grazing management systems in the southeastern United States. MP-1551. College Station, TX: Texas Agriculture Experiment Station; Texas A \& M University Agricultural Experiment Station. 8 p. (SO)

MARTIN, S. CLARK. 1978. Grazing systems, what can they accomplish? Rangeman's Journal. 5:14-16. (RM)

MARTIN, S. CLARK. 1978. The Santa Rita grazing system. In: Hyder, Donald N., ed. Proceedings, 1st international rangeland congress; 1978 August 1418; Denver, CO: Society for Range Management: 573-575. (RM)

MARTIN, S. CLARK; and DONALD E. WARD. 1976. Perennial grasses respond inconsistently to alternate year seasonal rest. Journal of Range Management. 29:346. (RM).

MARTIN, S. CLARK; and KIETH E. SEVERSON. 1988. Vegetation response to the Santa Rita grazing system. Journal of Range Management. 41:291-295. (RM)

MCINNIS, MICHAEL L.; THOMAS M. QUIGLEY; and MARTIN VAVRA. 1986. Using computer simulation to estimate grazing capacity and beef production. Spec. Rep. 773. Corvallis, OR: Oregon State University, Agricultural Experiment Station: 25-31. (PNW)

MITCHELL, JOHN E.; and LINDA A. JOYCE. 1986. Use of a generalized linear model to evaluate range forage production estimates. Environmental Management. 10:403-411. (RM)

MITCHELL, JOHN E.; and RICHARD H. HART. 1987. Winter of 1886-87: the death knell of open range. Rangelands. 9:3-8. (RM) 
NEAL, DONALD L. 1981. Improvement of Great Basin deer winter range with livestock grazing. In: Peek, James A.; and P. D. Dalke, eds. Proceedings, wildlife-livestock relationships symposium; 1981 April 20-22; Coeur d'Alene, ID. Moscow, ID: University of Idaho; Forest, Wildlife and Range Experiment Station: 61-73. (PSW)

PLATTS, WILLIAM S. 1981. Sheep and cattle grazing strategies on riparian-stream environments. In: Peek, James A.; and P. D. Dalke, eds. Proceedings, Wildlifelivestock relationships symposium; 1981 April 20-22; Coeur d'Alene, ID. Moscow, ID: University of Idaho; Forest, Wildlife and Range Experiment Station: 251270. (INT)

QUIGLEY, THOMAS M. 1987. Short-duration grazing: an economic Perspective. Rangelands. 9:173-175. (PNW)

QUIGLEY, THOMAS M.; and JOHN A TANAKA. 1988. The Federal grazing fee: a viewpoint. Rangelands. 10:130131. (PNW)

QUIGLEY, THOMAS M.; KENNETH GIBBS; and $H$. REED SANDERSON. 1986. Rancher response to changes in federally permitted livestock numbers in eastern Oregon. Rangelands. 8:276278. (PNW)

RATLIFF, RAYMOND D.; MELVIN R. GEORGE; and NEIL K. MCDOUGALD. 1987. Managing livestock grazing on meadows of California's Sierra Nevada: A managers-users guide. University of California Cooperative Extension Leaflet 21421. Berkeley, CA: University of California. 9 p. (PSW)

RISSER, PAUL G.; and J. B. MANKIN. 1986. Simplified simulation model of the plant producer function in shortgrass steppe. American Midland Naturalist. 115:348360.
SANDERSON, $H$. REED; THOMAS M. QUIGLEY; and LOU R. SPINK. 1988. Defining, implementing, and evaluating grazing management strategies. Journal of Soil and Water Conservation. 43:345348. (PNW)

SKOVLIN, JON M.; PAUL J. EDGERTON; and BURT R. MCCONNELL. 1983. Elk use of winter range as affected by cattle grazing, fertilizing, and burning in southeastern Washington. Journal of Range Management. 36:184-189. (PNW)

SVEJCAR, TONY; and MARTIN VAVRA. 1985. The influence of several range improvements on estimated carrying capacity and potential beef production. Journal of Range Management. 38:395399. (PNW)

SWEENEY, JAMES M.; and GALE L. WOLTERS. 1986. Techniques for future decisionmaking in range, wildlife and fisheries management. In: Crowley, John, ed. Research for tomorrow: 1986 yearbook of agriculture. Washington, DC: U.S. Department of Agriculture: 209-212. (NC)

TIEDEMANN, A. R.; H. R. SANDERSON; and N. J. CIMON. 1986. Site productivity considerations of short-duration, highintensity grazing. In: Tiedemann, J. A., ed. Proceedings, short-duration grazing and current issues in grazing management short course; 1986 January 21-23; Kennewick, WA. Pullman, WA: Washington State Universisty: 137-144. (PNW)

WIGLEY, THOMAS B.; DAVID E. WESLEY; CARROLL J. PERKINS; and ALFRED D. SULLIVAN. 1980. Use of a cottonwood monoculture by white-tailed deer. Journal of Wildlife Management. 44:264-265. 
Reclamation And Restoration

ALDON, EARL F. 1978. Reclamation of coalmined land in the Southwest. Journal of Soil and Water Conservation. 33:75-79. (RM)

ALDON, EARL F. 1981. Long-term plant survival and density data from reclaimed southwestern coal mine spoils. Great Basin Naturalist. 41:271-273. (RM)

ALDON, EARL F. 1983. Vegetation stability on mine spoils in the Southwest. In: Aldon, Earl F.; and Wendall R. Oaks, eds. Reclamation of mined lands in the Southwest: Proceedings of the symposium; 1982 October 20-22; Albuquerque, NM: New Mexico Chapter of the Soil Conservation Society of America: 198-200. (RM)

ALDON, EARL F. 1984. Mine reclamation in arid lands. In: Vegetation rehabilitation and equipment workshop; 38th annual report; 1984 February 14-15; Rapid City, SD. San Dimas, CA: U.S. Department of Agriculture, Forest Service, Equipment Development Center: 18-19. (RM)

ALDON, EARL F.; and H. W. SPRINGFIELD. 1977. Reclaiming coal mine spoils in the four corners. In: Thames, John L., ed. Reclamation and use of disturbed land in the Southwest. Tucson, AZ: The University of Arizona Press: 229-237. (RM)

ALDON, EARL F.; and WENDALL R. OAKS, eds. 1983. Reclamation of mined lands in the Southwest. Proceedings of the symposium; 1982 October 20-22; Albuquerque, NM: New Mexico Chapter of the Soil Conservation Society of America. 200 p. (RM)

BJUGSTAD, ARDELL J. 1979. Bentonite mine spoil and pit reclamation: A major research problem. In: Proceedings, Mineral Waste Stabilization Liaison Committee; 1979 June 21; Eveleth, MN: 1-18. (RM)
BJUGSTAD, ARDELL J. 1987. Hybrid poplar cultivars for maximizing phytomass production on gold mine tailings in the Black Hills. In: National symposium on mining, hydrology, sedimentology, and reclamation; 1986 December 8-11; Lexington, KY: University of Kentucky: 263-266. (RM)

BJUGSTAD, ARDELL J.; and WARREN C. WHITMAM. 1989. Promising native forbs for seeding on mine spoils. In: Walker, D. G.; C. B. Powter; and M. W. Pole, comps. Reclamation, a global perspective: Proceedings of the conference; 1989 August 27-31; Calgary, Alberta, Canada. Alberta Land Conservation and Reclamation Council Report \# RRTAC 89-2:255-262. (RM)

BROWN, R. W.; and R. S. JOHNSTON. 1976. Revegetation of an alpine mine disturbance: Beartooth Plateau, Montana. Res. Note INT-206. Ogden, UT: U.S. Department of Agriculture, Forest Service, Intermountain Forest and Range Experiment Station. $8 \mathrm{p}$. (INT)

BROWN, R. W.; and R. S. JOHNSTON. 1976. Revegetation of alpine disturbances. Logan, UT: Utah State University, Range Guide. 2:2-3. (INT)

BROWN, R. W.; and R. S. JOHNSTON. 1978. Rehabilitation of high elevation mine disturbance. In: Kenny, S. T., ed. Proceedings: high-altitude revegetation workshop no. 3; Information Series No. 28; 1978 March 13-14; Fort Collins, CO: Colorado State University, Water Resources Research Institute: 116-130. (INT)

BROWN, R. W.; and R. S. JOHNSTON. 1979. Revegetation of disturbed alpine rangelands. In: Johnson, D. A., ed. Special management needs of alpine ecosystems. Range Sci. Series No. 5. Denver, CO: Society for Range Management: 76-94. (INT) 
BROWN, R. W.; and R. S. JOHNSTON. 1980. An assessment of revegetation techniques for alpine disturbances. In: Jackson, Charles L.; and Mark A Schuster, eds. Proceedings: highaltitude revegetation workshop no. 4; Information Series No. 42; 1980 February 26-27; Fort Collins, CO: Colorado State University, Water Resources Research Institute: 126-146. (INT)

BROWN, R. W.; and R. S. JOHNSTON. 1981. Reclaiming disturbed alpine lands. Western Wildlands. 7(3):38-42. (INT)

BROWN, R. W.; R. S. JOHNSTON; and J. C. CHAMBERS. 1984. Revegetation of alpine ecosystems disturbed by mining. Restoration and Management Notes. 2(3):83. (INT)

BROWN, R. W.; R. S. JOHNSTON; and D. A. JOHNSON. 1978. Rehabilitation of alpine tundra disturbances. Journal of Soil and Water Conservation. 33:154160. (INT)

BROWN, R. W.; R. S. JOHNSTON; B. Z. RICHARDSON; and E. E. FARMER 1976. Rehabilitation of alpine disturbances: Beartooth Plateau, Montana. In: Zuck, R. H. and L. F. Brown, eds. Proceedings: high-altitude revegetation workshop no. 2; Infomation Series No. 21; 1976 April 5-6; Fort Collins, CO: Colorado State University, Water Resources Research Institute: 58-73. (INT)

BROWN, RAY W.; and JEANNE C. CHAMBERS. 1989. Reclamation of severly disturbed alpine ecosystems: New perspectives. In: Walker, D. G.; C. B. Powter; and M. W. Pole, comps. Reclamation, a global perspective: Proceedings of the conference; 1989 August 27-31; Calgary, Alberta, Canada. Alberta Land Conservation and Reclamation Council Report \# RRTAC 89-2:59-68. (INT)
BROWN, RAY W.; and ROBERT S. JOHNSTON. 1979. Rehabilitation of disturbed alpine rangelands. In: Hyder, Donald N., ed. Proceedings, 1st international rangeland congress; 1978 August 14-18; Denver, CO: Society for Range Management: 704-706. (INT)

BROWN, RAY W.; and ROBERT S. JOHNSTON. 1979. Revegetation of disturbed alpine rangelands. In: Special Management Needs of Alpine Ecosystems: 76-94. (INT)

BROWN, RAY W.; and ROBERT S. JOHNSTON. 1981. Reclaiming disturbed alpine lands. Western Wildlands. 7(3):38-42. (INT)

BURTON, TIMOTHY A.; GERALD F. GIFFORD; and GEORGE E. HART. 1979. An approach to the classification of Utah mine spoils and tailings based on surface hydrology and erosion. Environmental Geology. 2(5):269-278.

BUTTERFIELD, RICHARD; TUELLER, PAUL. 1980. Revegetation potential of acid mine wastes in northeastern California. Reclamation Review. 3:2131. (INT)

CHAMBERS, JEANNE C.; RAY W. BROWN; and R. S. JOHNSTON. 1987. A comparison of soil properties and vegetation properties of seeded and naturally revegetated pyritic alpine mine spoil and reference sites. Landscape and Urban Planning. 14: 507-519. (INT)

CLARK, WILLIAM R.; and RICHARD J. MEDCRAFT. 1986. Wildlife use of shrubs on reclaimed surface-mined land in northeastern Wyoming. Journal of Wildlife Management. 5O:714-718. (RM)

COLLING, GENE, comp. 1980. Bibliography of SEAM publications. Gen. Tech. Rep. INT-88. Ogden, UT: U.S. Department of Agriculture, Forest Service, Intermountain Forest and Range Experiment Station. 20 p. (INT) 
COX, JERRY R.; HOWARD L. MORTON; THOMAS N. JOHNSON; GILBERT L. JORDAN; S. CLARK MARTIN; and LOUIS C. FIERRO. 1984. Vegetation restoration in the Chihuahuan and Sonoran deserts of North America. Rangelands. 6:112-115. (RM).

CZAPOWSKYJ, M. M. 1976. Annotated bibliography on the ecology and reclamation of drastically disturbed areas. Tech. Rep. NE-21. Broomall, PA: U.S. Department of Agriculture, Forest

Service, Northeastern Forest

Experiment Station. 98 p. (NE)

EVERETT, RICHARD L.; RICHARD O. MEEUWIG; and RICHARD I. BUTTERFIELD. 1980. Revegetation of untreated acid spoils, Leviathan Mine, Alpine County, California. California Geology. 32(1):8-10.

FARMER, E. E.; B. Z. RICHARDSON; and R. W. BROWN. 1986. Revegatation of acid mining wastes in central ldaho. Res. Pap. INT-178. Ogden, UT: U.S. Department of Agriculture, Forest Service, Intermountain Forest and Range Experiment Station. 18 p. (INT)

FARMER, E. E.; and W. G. BLUE. 1978. Reclamation of lands mined for

disturbed lands; American Society Agronomy: 585-608. (INT).

FARMER, EUGENE E. 1979. Mining waste dump construction, stability, and reclamation in the western phosphate field. In: Proceedings Mineral Waste Stabilization Liaison Committee; 1979 June 21; Eveleth, MN. 23 p. (INT)

FARMER, EUGENE E.; and BLAND Z. RICHARDSON. 1980. Phosphate mine dump stability and revegetation. In: Symposium on watershed management; New York, NY: American Society of Civil Engineers: 888-897. Volume II. (INT)
FARMER, EUGENE E.; and GERALD E. SCHUMAN. 1987. Reclamation of uranium mining and milling disturbances. In: Majumdar, Shyamal K.; Fred J. Brenner; and E. Willard Miller, eds. Environmental consequences of energy production: problems and prospects. Eaton, PA: The Pennsylvania Academy of Science: 182-197. (INT)

FERGUSON, ROBERT B. 1983. Use of rosaceous shrubs for wildland plantings in the Intermountain West. In: Monsen, Stephen B.; and Nancy Shaw, comps. Managing Intermountain rangelands-Improvement of range and wildlife habitats: Proceedings of a symposium; 1981 September 15-17; Twin Falls, ID; 1982 June 22-24; Elko, NV. Gen. Tech. Rep. INT-157. Ogden, UT: U.S. Department of Agriculture, Forest Service, Intermountain Forest and Range Experiment Station: 136-149. (INT)

FERGUSON, ROBERT B.; and NEIL C. FRISCHKNECHT. 1983. Revegetating processed oil shale in the upper mountainbrush zone of Colorado. Res. Pap. INT-321. Ogden, UT: U.S. Department of Agriculture, Forest Service, Intermountain Forest and Range Experiment Station. 9 p. (INT)

FERGUSON, ROBERT B.; and NEIL C. FRISCHKNECHT. 1985. Reclamation on Utah's Emery and Alton coal fields: Techniques and plant materials. Res.

Pap. INT-335. Ogden, UT: U.S.

Department of Agriculture, Forest

Service, Intermountain Forest and Range Experiment Station. 78 p. (INT)

FERRANTE, LYNN M.; and EDWARD C. THOR. 1980. Predicting events in the development of a coal surface mine in the west. Gen. Tech. Rep. PSW-41. Berkeley, CA: U.S. Department of Agriculture, Forest Service, Pacific Southwest Forest and Range Experiment Station. 11 p. (PSW) 
FRESQUEZ, P. R.; B. R. SABEY; and D. A. KLEIN. 1988. Soil fungal communityplant rhizosphere interactions during the early stages of ecosystem development on reclaimed coal mine soils. In:

Proceedings, 1988 Mine drainage and surface mine reclamation conference; 1988 April 19-22; Pittsburgh, PA. IC 9184 , Vol. 2. Washington, DC: U.S. Department of the Interior, Bureau of Mines: 9-14. (RM)

FRESQUEZ, P. R.; EARL F. ALDON; and W. C. LINDEMANN. 1986. Changes in microbial populations and enzyme activities resulting from coal mine spoil reclamation. In: Symposium on mining, hydrology, sedimentology, and reclamation; 1986 December 8-11; Lexington, $\mathrm{KY}$ : University of Kentucky: 63-70. (RM).

FRESQUEZ, P. R.; EARL F. ALDON; and W. C. LINDEMANN. 1987. Enzyme activities in reclaimed coal mine spoils and soils. Landscape and Urban Planning. 14:359-367. (RM)

FRISCHKNECHT, NEIL C. 1978. Use of shrubs for mined land reclamation and wildlife habitat. In: Reclamation for wildlife habitat: workshop proceedings; Fort Collins, CO: Ecology Consultants, Inc.: 113-127. (INT)

FULTON, GARY W.; WILLIAM T. BARKER; and ARDELL J. BJUGSTAD. 1983. Rooted aquatic plant revegetation of strip mine impoundments in the northern Great Plains. In: Proceedings, 3rd Biennial Plains Aquatic Research Conference; 1983 August 24-25; Bozeman, MT. Bozeman, MT: Montana State University, Institute of Natural Resources: 113-117. (RM)

GEIST, J. MICHAEL. 1989. A new breed of Johnny Appleseed. Rangelands 11:3334. (PNW)
GIBSON, D. F.; and T. E. LEHMAN. 1977. Productivity improvement of surface coal mining operations. In: Proceedings, Institute of Industrial Engineering conference; 1977 May; Dallas, TX: Institure of Industrial Engineering. 8 p. (INT)

HEADY, HAROLD F., ed. 1988. The Vale rangeland rehabilitation program: an evaluation. Res. Bull. PNW-RB-157. Portland, OR: U.S. Department of Agriculture, Forest Service, Pacific Northwest Research Station, U.S. Department of the Interior, Bureau of Land Management. 151 p. (PNW)

HINGTEN, TERRENCE M.; and WILLIAM R. CLARK. 1986. Impact of small mammals on the vegetation of reclaimed land in the Northern Great Plains. Journal of Range Management. 37:438-441. (RM)

JASMER, GERALD E.; GARY B. DONART; and EARL F. ALDON. 1983. Responses of reestablished vegetation to simulated grazing. In: Aldon, Earl F.; and Wendall R. Oaks, eds. Reclamation of mined lands in the Southwest: Proceedings of the symposium; 1982 October 20-22; Albuquerque, NM: New Mexico Chapter of the Soil Conservation Society of America: 188-191. (RM)

MCARTHUR, E. DURANT. 1983. Important shrubs for wildland plantings, Compositae (Asteraceae). In: Monsen, Stephen B.; and Nancy Shaw, comps. Managing Intermountain rangelands-Improvement of range and wildlife habitats: Proceedings of symposia; 1981 September 15-17; Twin Falls, ID. 1982 June 22-24. Elko, NV. Gen. Tech. Rep. INT-157. Ogden, UT: U.S. Department of Agriculture, Forest Service, Intermountain Forest and Range Experiment Station: 150-157. (INT) 
MCARTHUR, E. DURANT; A. PERRY

PUMMER; and JAMES N. DAVIS. 1978.

Rehabilitation of game range in the Salt

Desert. In: Wyoming Shrublands:

Proceedings, Seventh Wyoming shrub ecology workshop; 1978 May 31-June 1; Laramie, WY: Range Management Division, University of Wyoming: 23-50. (INT)

MCARTHUR, E. DURANT; STEPHEN B. MONSEN; and A. CLYDE BLAUER. 1986. Inventory of and rehabilitation recommendations for sites disturbed by modern man's activities in Grand Teton National Park. In: University of Wyoming-National Park Service Research Center ninth annual report. Laramie, WY: University of Wyoming: 75-82. (INT)

MONSEN, S. B.; and D. R. CHRISTENSEN. 1976. Woody plants for rehabilitating rangelands in the intermountain region. In: Stutz, H. C., ed. Proceedings, symposium and workshop: Wildland Shrubs; Provo, UT: Brigham Young University Press: 72-119. (INT).

MONSEN, S. B.; and A. P. PLUMMER. 1978. Plants and treatment for revegetation of disturbed sites in the Intermountain area. In: Wright, Robert A., ed. The reclamation of disturbed arid lands; Albuquerque, NM: University New Mexico Press: 155-173. (INT)

MONSEN, STEPHEN B. 1983. Plants for revegetation of riparian sites within the Intermountain Region. In: Monsen, Stephen B.; and Nancy Shaw, comps. Managing Intermountain rangelands-Improvement of range and wildlife habitats: Proceedings of symposia; 1981 September 15-17; Twin Falls, ID. 1982 June 22-24. Elko, NV. Gen. Tech. Rep. INT-157. Ogden, UT: U.S. Department of Agriculture, Forest Service, Intermountain Forest and Range Experiment Station: 83-89. (INT)
MONSEN, STEPHEN B. 1984. Use of shrubs on mine spoils. In: Murphy, Patrick M., comp. The challenge of producing native plants for the Intermountain area: Proceedings, Intermountain Nurseryman's Association; 1983 conference; 1983 August 8-11; Las Vegas, NV. Gen. Tech. Rep. INT-168. Ogden, UT: U.S. Department of Agriculture, Forest Service, Intermountain Forest and Range Experiment Station: 26-31. (INT)

MONSEN, STEPHEN B.; and NANCY SHAW. 1983. Benefits of seeding legumes with grasses on western phosphate mine disturbances. In: Robertson, David J., ed. Reclamation and the phosphate industry:

Proceedings of the symposium; 1983 January 26-28; Clearwater Beach, FL. Publ. 03-036-010. Bartow, FL: Florida Institute of Phosphate Research: 464478. (INT)

MONSEN, STEPHEN B.; and NANCY SHAW. 1986. Response of an alkali sagebrush/fescue site to restoration treatments. In: McArthur, E. Durant; and Bruce L. Welch, comps. Proceedings-symposium on the biology of Artemisia and Chrysothamnus; 1984 July 9-13; Provo, UT. Gen. Tech. Rep. INT-200. Ogden, UT: U.S. Department of Agriculture, Forest Service, Intermountain Forest and Range Experiment Station: 126-133. (INT)

ORR, HOWARD K. 1977. Reestablishment of wooded waterways and associated upland shrub communities in surface coal mine areas of the Northwestern Great Plains. In: Proceedings, 5th symposium on surface mining and reclamation. NCA/BCR Coal Conference and Exposition. IV:235-243. (RM)

PACKER, PAUL E.; and EARL F. ALDON. 1978. Revegetation techniques for dry regions. In: Reclamation of drastically disturbed lands. American Society Agronomy: 425-450. (INT) 
PACKER, PAUL E.; CHESTER E. JENSEN; EDWARD L. NOBLE; and JOHN A. MARSHALL. 1979. A prediction model to estimate revegetation potentials of land surface mined for coal in the West. Proceedings, International Congress on Energy and the Ecosystem. Vol. 1. Grand Forks, ND: University North Dakota, Pergamon Press: 396-411. (INT)

PACKER, PAUL E.; CHESTER E. JENSEN; EDWARD L. NOBLE; and JOHN A. MARSHALL. 1982. Models to estimate revegetation potentials of land surface mined for coal in the West. Gen. Tech. Rep. INT-123. Ogden, UT: U.S. Department of Agriculture, Forest Service, Intermountain Forest and Range Experiment Station. 25 p. (INT)

PARKER, L. W.; N. Z. ELKINS,; E. F. ALDON; [and others]. 1987.

Decomposition and soil biota after reclamation of coal mine spoils in an arid region. Biology and Fertility of Soils. 4(12):129-135. (RM)

PLUMMER, A. P. 1976. Shrubs for the subalpine of the Wasatch Plateau. In: Zuck, R. H. and Brown, R. F., eds.. Proceedings: high-altitude revegetation workshop no. 2. Information Series No. 21; 1976 April 5-6; Fort Collins, CO: Colorado Sate University, Water Resources Research Institute: 33-40. (INT)

PLUMMER, A. P. 1977. Revegetation of disturbed intermountain area sites. In: Thames, J. L., ed. Reclamation and use of disturbed land in the Southwest. Tucson, AZ: University of Arizona Press: 302-339. (INT)

POWER, J. F.; F. M. SANDOVAL; and R. E. RIES. 1979. Topsoil-subsoil requirement to restore North Dakota mined land to original productivity. Mining Engineering. December: 1708-1712. (RM)
RICHARDSON, BLAND Z. 1980. Reclamation of acid-producing spoils on a western surface mine. In: Jackson, Charles L.; and Mark A. Schuster, eds.

Proceedings: high-altitude revegetation workshop no. 4; Information Series No. 42; 1980 February 26-27; Golden, CO. Fort Collins, CO: Colorado State University, Water Resources Research Institute: 101-112. (INT)

RICHARDSON, BLAND Z.; and EUGENE E. FARMER. 1983. Revegetation of phosphate mined lands in the Intermountain West. In: Robertson, David J., ed. Reclamation and the phosphate industry: Proceedings of the symposium; 1983 Jariuary 26-28; Clearwater Beach, FL. Publ. 03-036010. Bartow, FL: Florida Institute of Phosphate Research: 373-389. (INT)

RICHARDSON, BLAND Z.; and MARILYN M. PRATT. 1981. Environmental effects of surface mining of minerals other than coal: Annotated bibliography and summary report. Gen. Tech. Rep. INT95. Ogden, UT: U.S. Department of Agriculture, Forest Service, Intermountain Forest and Range Experiment Station. 145 p. (INT)

RICHARDSON, BLAND Z; ; and TAMARA P. TRUSSELL. 1981. Species diversity for wildlife as a consideration in revegetating mined areas. In: Stelter, Lavern H.; Edward J. DePuit; and Sharon A. Mikol, tech. coords. Shrub establishment on disturbed arid and semi-arid lands: Proceedings of the symposium; 1980 December 2-3; Laramie, WY. Cheyenne, WY: Wyoming Game and Fish Department: 70-80. (INT) 
RICHARDSON, BLAND Z.; STEPHEN B. MONSEN; and DIANE M. BOWERS. 1986. Interseeding selected shrubs and herbs on mine disturbances in southeastern Idaho. In: McArthur, E. Durant; and Bruce L. Welch, comps. Proceedings--symposium on the biology of Artemisia and Chrysothamnus; 1984 July 9-13; Provo, UT. Gen. Tech. Rep. INT-200. Ogden, UT: U.S. Department of Agriculture, Forest Service, Intermountain Forest and Range Experiment Station: 134-139. (INT)

RIKER, R. E.; L. R. ANDERSON; and R. W. JEPPSON. 1978. Engineering properties and slope stability settlement analysis related to phosphate mine spoil dumps in southeastern Idaho. Serv. Rep. H-78-001. Logan, UT: Utah State University. 107 p. (INT)

SCHOLL, DAVID G. 1987. Soil salinity and water movement during irrigation of a topsoil-coal spoil profile. In: 4th Annual Meeting, American Society for Surface Mining and Reclamation; 1987 March 17-19; Billings, MT. Princeton, WV: American Society for Surface Mining: D3-1 to D-3-7. (RM)

SHAW, NANCY. 1980. Propagating and outplanting shrubs on mine sites. In: Stelter, Lavern H.; Edward J. DePuit; and Sharon A. Mikol, tech. coords. Shrub establishment on disturbed arid and semi-arid lands: Proceedings of the symposium; 1980 December 2-3; Laramie, WY. Cheyenne, WY: Wyoming Game and Fish Department: 47-56. (INT)
SHAW, NANCY; and STEPHEN B. MONSEN. 1983. Nonleguminous forbs for rangeland sites. In: Monsen, Stephen B.; and Nancy Shaw, comps. Managing Intermountain rangelands--Improvement of range and wildlife habitats:

Proceedings of symposia; 1981

September 15-17; Twin Falls, ID. 1982 June 22-24. Elko, NV. Gen. Tech. Rep. INT-157. Ogden, UT: U.S. Department of Agriculture, Forest Service, Intermountain Forest and Range Experiment Station: 123-131. (INT)

SIEG, CAROLYN HULL; DANIEL W. URESK; and RICHARD M. HANSEN. 1984. The biological costs of not reclaiming bentonite mine spoils. In: Proceedings of the Annual Conference of the Western Association of Fish and Wildlife Agencies; 1982 July 18-22; Las Vegas, NV: 272-277. (RM)

STEVENS, R.; K. R. JORGENSEN; J. N. DAVIS; and S. B. MONSEN. 1986. Seed pappus and placement influences on white rubber rabbitbrush establishment. In: McArthur, E. Durant; and Bruce L. Welch, comps. Proceedings-symposium on the biology of Artemisia and Chrysothamnus; 1984 July 9-13; Provo, UT. Gen. Tech. Rep. INT-200. Ogden, UT: U.S. Department of Agriculture, Forest Service, Intermountain Forest and Range Experiment Station: 353-357. (INT)

STEVENS, RICHARD. 1983. Selecting species mixtures for optimum wildlife habitat development on disturbed lands. In: Proceedings, 3rd annual reclamation symposium; 1983 January 10-11; Salt Lake City, UT: Soil Conservation Service, Native Plants, Inc.: 41-55. (INT) 
STEVENS, RICHARD. 1983. Species adapted for seeding mountain brush, big, black, and low sagebrush and pinyon-juniper communities. In: Monsen, Stephen B.; and Nancy Shaw, comps. Managing Intermountain rangelands-Improvement of range and wildlife habitats: Proceedings of symposia; 1981 September 15-17; Twin Falls, ID. 1982 June 22-24. Elko, NV. Gen. Tech. Rep. INT-157. Ogden, UT: U.S. Department of Agriculture, Forest Service, Intermountain Forest and Range Experiment Station: 78-82. (INT)

STEVENS, RICHARD. 1985. Depth of interseeding scalps can affect growth of seeded mountain big sagebrush. In: Vegetative rehabilitation and equipment workshop: 39th annual report; 1985 February 10-11; Salt Lake City, UT. Missoula, MT: U.S. Department of Agriculture, Forest Service, Equipment Development Center: 25-27.

U.S. DEPARTMENT OF AGRICULTURE, FOREST SERVICE. 1979. User guide to engineering, mining and reclamation in the West. Gen. Tech. Rep. INT-70. Odgen, UT: U.S. Department Agriculture, Forest Service, Intermountain forest and Range Experiment Station. 58 p. (INT)

U.S. DEPARTMENT OF AGRICULTURE, FOREST SERVICE. 1979. User guide to soils, mining and reclamation in the West. Gen. Tech. Rep. INT-68. Ogden, UT: U.S. Department Agriculture, Forest Service, Intermountain Forest and Range Experiment Station. 80 p. (INT)

U.S. DEPARTMENT OF AGRICULTURE, FOREST SERVICE. 1979. User guide to vegetation, mining and reclamation in the West. Gen. Tech. Rep. INT-64. Odgen, UT: U.S. Department Agriculture, Forest Service, Intermountain Forest and Range Experiment Station. 85 p. (INT)
U.S. DEPARTMENT OF AGRICULTURE, FOREST SERVICE. 1980. User guide to hydrology, mining and reclamation in the West. Gen. Tech. Rep. INT-74. Odgen, UT: U.S. Department Agriculture, Forest Service, Rocky Mountain Forest and Range Experiment Station. 64 p. (INT)

U.S. DEPARTMENT OF AGRICULTURE, FOREST SERVICE. 1980. User guide to sociology and economics, mining and reclamation in the West. Gen. Tech. Rep. INT-73. Odgen, UT: U.S. Department Agriculture, Forest Service, Rocky Mountain Forest and Range Experiment Station. 53 p. (INT)

U.S. DEPARTMENT OF AGRICULTURE, FOREST SERVICE. 1982. Wildlife user guide for mining and reclamation. Gen. Tech. Rep. INT-126. Ogden, UT: U.S. Department of Agriculture, Forest Service, Intermountain Forest and Range Experiment Station. 77 p. (INT)

VOGEL, WILLIS G. 1987. A manual for training reclamation inspectors in the fundamentals of soils and revegetation. Ankeny, IA: Soil and Water Conservation Society. 178 p. (NE)

VOORHEES, M. E.; M. J. TRLICA; and D. W. URESK. 1987. Growth of rillscale on bentonite mine spoil as influenced by amendments. Journal of Environmental Quality. 16:411-416. (RM)

WOLTERS, GALE L.; EARL F. ALDON; AND GARY B. DONART. 1989. Response of reseeded coal mine spoils to season and intensity of defoliation: preliminary findings. In: Walker, D. G.; C. B. Powter; and M. W. Pole, comps. Reclamation, a global perspective: Proceedings of the conference; 1989 August 27-31;

Calgary, Alberta, Canada. Alberta Land Conservation and Reclamation Council Report \# RRTAC 89-2:289-298. (RM) 
YAMAMOTO, TERUO. 1979. Mixing overburden to simulate soil conditions: AR Company Black Thunder Mine. In: Mohan K. Wali, ed. Ecology and coal resource development; New York, NY: Pergamon Press: 791-797. Volume II. (RM)

YAMAMOTO, TERUO. 1982. A review of uranium spoil and mill tailings revegetation in the western United States. Gen. Tech. Rep. RM-92. Fort Collins, CO: U.S. Department of Agriculture, Forest Service, Rocky Mountain Forest and Range Experiment Station. 20 p. (RM)

\section{Plant Establishment}

ALDON, EARL F. 1976. Seed sources, species selection, and current research on species adaptation for mine spoil reclamation. In: Vories, Kimery C., ed. Reclamation of Western Surface Mined Lands: Workshop proceedings; 1976 March 1-3; Fort Collins, CO: Ecology Consultants, Inc.: 99-101. (RM)

ALDON, EARL F. 1984. Broadcast seeded western wheatgrass successfully spreads on mine spoil. Reclamation and Revegetation Research. 3:167-170. (RM)

ALDON, EARL F. 1984. Methods for establishing fourwing saltbush (Atriplex canescens Pursh Nutt.) on disturbed sites in the Southwest. In: Tiedemann, Arthur R.; E. Durant McArthur; Howard C. Stutz; Richard Stevens; and Kendall L. Johnson, eds. Proceedings-symposiun on the biology of Atriplex and related chenopods; 1983 May 2-6;

Provo, UT. Gen. Tech. Rep. INT-172. Ogden, UT: U.S. Department of Agriculture, Forest Service, Intermountain Forest and Range Experiment Station: 265-268. (RM)
ALDON, EARL F. 1984. Vegetation parameters for judging the quality of reclamation on coal mine spoils in the Southwest. Great Basin Naturalist. 44:441-446. (RM)

ALDON, EARL F.; and CHARLES P. PASE, 1981. Plant species adaptability on mine spoils in the Southwest: A case study. Res. Note RM-398. Fort Collins, CO: U.S. Department of Agriculture, Forest Service, Rocky Mountain Forest and Range Experiment Station. 3 p. (RM)

ALDON, EARL F.; DAVID G. SCHOLL; and CHARLES P. PASE. 1980. Establishing cool-season grasses on mine spoil. In: Proceedings, 1980 watershed management symposium; 1980 July 2123; Boise, ID; New York, NY: Irrigation and Drainage Division, American Society of Civil Engineers. Vol. 1: 91-97. (RM)

ALLEN, EDITH B.; JEANNE C. CHAMBERS; KRISTINA F. CONNOR; MICHAEL F. ALLEN; and RAY W. BROWN. 1987. Natural reestablishment of mycorrhizae in disturbed alpine ecosystems. Arctic and Alpine Research. 19:11-20. (INT)

BJUGSTAD, ARDELL J. 1984. Establishment of trees and shrubs on lands disturbed by mining in the West. In: New forests for a changing world: Proceedings, 1983 SAF national convention; 1983 October 16-20; Portland, OR. Bethesda, MD: Society of American Foresters: 434-438. (RM)

BJUGSTAD, ARDELL J. 1984. Shrub and tree establishment on coal spoils in the northern High Plains, USA. Minerals and the Environment. 6(3):127-130. (RM)

BJUGSTAD, ARDELL J. 1984. Shrub and tree establishment on coal spoils in northern High Plains. In: Symposium on surface coal mining and reclamation in the Great Plains; 1984 March; Billings, MT: Montana State University, Reclamation Research Unit: 223-236. 
BJUGSTAD, ARDELL J.; and WARREN C. WHITMAN. 1984. Perennial forbs for wildlife habitat restoration on mined lands in the northern Great Plains. In: Proceedings, Annual Conference of the Western Association of Fish and Wildlife Agencies; 1982 July 18-22; Las Vegas, NV; 257-271. (RM)

BJUGSTAD, ARDELL J.; TERUO YAMAMOTO; and DANIEL W. URESK. 1981. Shrub establishment on coal and bentonite clay mine spoils. In: Proceedings, 1980 Symposium on Shrub Establishment on Disturbed Arid and Semi-Arid Lands; 1980 December 2-3; Laramie, WY: Wyoming Agricultural Experiment Station: 104-122.

BROCK, JOHN G. 1983. Interseeding and interplanting techniques for Southwest reclamation. In: Aldon, Earl F.; and Wendall R. Oaks, eds. Reclamation of mined lands in the Southwest:

Proceedings of the symposium; 1982 October 20-22; Albuquerque, NM: New Mexico Chapter of the Soil Conservation Society of America: 192-195. (RM)

BROWN, RAY W. 1980. Revegetation with native and introduced plant species. In: Proceedings, 26th Grass Breeders Conference; 1980 June 18-20; Logan, UT: Utah State University:-9-16. (INT)

BROWN, RAY W.; JEANNE C. CHAMBERS; RAY M. WHEELER; ELIZABETH E. NEELY; and MICHAEL I. KELRICK. 1988. Adaptions of Deschampsia sespitosa (tufted hairgrass) for revegetation of high elevation disturbances: some selection criteria. In: Keammerer, Warren R.; and Larry F. Brown, eds. Proceedings: High-altitude revegetation workshop no. 8; Information Series No. 59; 1988 March 3-4; Fort Collins, CO: Colorado State University, Water Resources Research Institute: 147-172. (INT)
BROWN, RAY W.; R. S. JOHNSTON; and K. VAN CLEVE. 1978. Rehabilitation problems in alpine and arctic regions. In: Reclamation of drastically disturbed lands; Americn Society Agronomy: 2344. (INT)

BUMAN, ROBERT A.; STEPHEN B. MONSEN; and ROLLIN H. ABERNETHY. 1988. Seedling competition between mountain rye, 'Hycrest' crested wheatgrass, and downy brome. Journal of Range Management. 41:30-34. (INT)

CABLE, DWIGHT R. 1977. Western wheatgrass transplants grow well on raw mine spoil. Res. Note RM-345. Fort Collins, Co: U.S. Department of Agriculture, Forest Service, Rocky Mountain Forest and Range Experiment Station. 2 p. (RM)

CHAMBERS, JEANNE C. 1989. Native species establishment on an oil drill pad site in the Uintah Mountains, Utah: effects of introduced grass density and fertilizer. Res. Pap. INT-402. Ogden, UT: U.S. Department of Agriculture, Forest Service, Intermountain Research Station. 9 p. (INT)

CHAMBERS, JEANNE C.; J. A. MACMAHON and RAY W. BROWN. 1988. Seedling establishment in disturbed alpine ecosystems: implications for revegetation. In: Keammerer, Warren R.; and Larry F. Brown, eds. Proceedings: high-altitude revegetation workshop no. 8; Information Series No. 59; 1988 March 3-4; Fort Collins, CO: Colorado State University, Water Resources Research Institute: 123-126. (INT)

CHAMBERS, JEANNE C.; JAMES A. MACMAHON; and RAY W. BROWN. 1987. Response of an early seral dominant alpine grass and a late seral dominant alpine forb to $N$ and $P$ availability. Reclamation and Revegetation Research. 6:219:234. (INT) 
CHAMBERS, JEANNE C.; JAMES A MACMAHON; and RAY W. BROWN. 1988. Seedling establishment in disturbed alpine ecosystems: implications for revegetation. In; Keanmerer, Warren R.; and Larry F. Brown, eds. Proceedings: high-altitude revegeation workshop no. 8; Information Series No. 59. 1988 March 3-4; Fort Collins, CO: Colorado State University, Water Resources Research Institute: 173-191. (INT)

CHAMBERS, JEANNE C.; RAY W. BROWN; and R. S. JOHNSTON. 1984.

Examination of plant successional stages in disturbed alpine ecosystems: a method of selecting revegetation species. In: Colbert, T. A.; and R. L. Cuany, eds. Proceedings: high-altitude revegetation workshop no. 6 ; Information Series No. 53; 1984 March 5-6; Fort Collins, CO: Colorado State University, Water Resources Research Institute: 215-224. (INT)

CHAMBERS, JEANNE C.; RAY W. BROWN; and R. S. JOHNSTON. 1984. Identification of alpine revegetation species: use of natural succession. Restoration and Management Notes. 2(3):82. (INT)

CLARY, WARREN P. 1988. Plant density and cover response to several seeding techniques following wildfire. Res. Note INT-384. Ogden, UT: U.S. Department of Agriculture, Forest Service, Intermountain Research Station. 6 p. (INT)

CLARY, WARREN P. 1989. Revegetation by land imprinter and rangeland drill. Res. Pap. INT-397. Ogden, UT: U.S. Department of Agriculture, Forest Service, Intermountain Research Station. 6 p. (INT)
CLARY, WARREN P.; and FRED J. WAGSTAFF. 1987. Biological and economic effectiveness of several revegetation techniques in the pinyonjuniper-sagebrush zone. In: Everett, Richard L., comp. Proceedings--pinyonjuniper conference; 1986 January 13-16; Reno, NV. Gen. Tech. Rep. INT-215. Ogden, UT: U.S. Department of Agriculture, Forest Service, Intermountain Research Station: 305315. (INT)

CLARY, WARREN P.; and THANE J. JOHNSON. 1983. Land imprinter results in Utah. In: Vegetation Rehabilitation and Equipment Workshop; 37th annual report; 1983 February 13-14;

Albuquerque, NM. Missoula, MT; San Dimas, CA: U.S. Department of Agriculture, Forest Service, Equipment Development Center: 23-24. (INT)

DICKSON, JAMES G.; CHARLES A. SEGELQUIST; and MITCHELL J. ROGERS. 1979. Establishment of Japanese honeysuckle in the Ozark Mountain. In: Proceedings, 32nd annual conference Southeastern Association Fish and Wildlife Agencies. 32:242-245. (SO)

DIETZ, DONALD R.; DANIEL W. URESK; HAROLD E. MESSNER; and LOWELL C. McEWEN. 1980. Establishment, survival, and growth of selected browse species in a ponderosa pine forest. Res. Pap. RM-219. Fort Collins, CO: U.S. Department of Agriculture, Forest Service, Rocky Mountain Forest and Range Experiment Station. 11 p. (RM) 
EDGERTON, PAUL J.; J. MICHAEL GEIST; and WAYNE G. WILLIAMS. 1983.

Survival and growth of apache-plume, stansbury cliffrose and selected sources of antelope bitterbrush in northeast Oregon. In: Tiedemann, Arthur R.; and Kendall L. Johnson, comps. Research and management of bitterbrush and cliffrose in western North America: Proceedings of a symposium; 1982 April 13-15; Salt Lake City, UT. Gen. Tech. Rep. INT-152. Ogden, UT: U.S. Department of Agriculture, Forest Service, Intermountain Forest and Range Experiment Station: 45-54. (PNW)

EVERETT, RICHARD L. 1980. Use of containerized shrubs for revegetating arid roadcuts. Reclamation Review. 3:33-40. (INT)

FERGUSON, ROBERT B.; NEIL C. FRISCHKNECHT. 1981. Shrub establishment on reconstructed soils in semiarid areas. In: Stelter, Lavern H.; Edward J. DePuit; and Sharon A. Mikol, tech. coords. Shrub establishment on disturbed arid and semi-arid lands: proceedings of the symposium; 1980 December 2-3; Laramie, WY. Cheyenne, WY: Wyoming Game and Fish Department: 57-63. (INT)

FISHER, JAMES T.; JOHN B. MCCRAE; and EARL F. ALDON. 1983. Methods for establishing containerized native juniper on surface disturbed sites in the Southwest. In: Pope, P. E., ed. Proceedings, 3rd Annual Better Reclamation with Trees Conference; 1983 June 2-3; Terre Haute, IN. West Lafayette, IN: Purdue University, Department of Forestry and Natural Resources: 76-88. (RM)
FRISCHKNECHT, NEIL C. 1983. Plants adapted to summer rangelands. In: Monsen, Stephen B.; and Nancy Shaw, comps. Managing Intermountain rangelands--Improvement of range and wildlife habitats: Proceedings of a symposium; 1981 September 15-17; Twin Falls, ID; 1982 June 22-24; Elko, NV. Gen. Tech. Rep. INT-157. Ogden, UT: U.S. Department of Agriculture, Forest Service, Intermountain Forest and Range Experiment Station: 102107. (INT)

HOPKINS, CURTIS R.; and JIM C.

HUNTLEY. 1979. Establishment of sawtooth oak as a mast source for wildlife. The Wildlife Society Bulletin. 7:253-258. (SE)

JACOBSON, TRACY L. C.; and BRUCE L. WELCH. 1987. Planting depth of 'Hobble Creek' mountain big sagebrush seed. Great Basin Naturalist. 47:497499. (INT)

LASHER, DOUGLAS N.; and EDWARD P. HILL. 1979. An evaluation of polypropylene mesh tubing as a deer browse deterrent for southern hardwood seedlings. In: Proceedings, 31st annual conference Southeastern Association Fish and Wildlife Agencies. 31:329-245.

MARTIN, ROBERT E. 1983. Antelope bitterbrush seedling establishment following prescribed burning in the pumice zone of the southern Cascade mountains. In: Proceedings--research and management of bitterbrush and cliffrose in western North America; 1982 April 13-15; Salt Lake City, UT. Gen. Tech. Rep. INT-152. Ogden, UT: U.S. Department of Agriculture, Forest Service, Intermountain Forest and Range Experiment Station: 82-90. (PNW) 
MCARTHUR, E. DURANT. 1981. Shrub selection and adaptation to rehabilitation plantings, In: Stelter, Lavern H.; Edward J. DePuit; and Sharon A. Mikol, tech. coords. Shrub establishment on disturbed arid and semi-arid lands: Proceedings, symposium; 1980 December 2-3; Laramie, WY. Cheyenne, WY: Wyoming Game and Fish Department: 1-8. (INT)

MEDIN, DEAN E.; and ROBERT B. FERGUSON. 1980. A pilot planting trial on a southwestern Idaho deer winter range. Res. Pap. INT-261. Ogden, UT: U.S. Department of Agriculture, Forest Service, Intermountain Forest and Range Experiment Station. 13 p. (INT)

MIYAMOTO, S. 1978. Tolerance of some southwestern range plants to sodium chloride and sulfate. PR-3480. College Station, TX: Texas Agriculture Experiment Station, Texas A\&M University. 8 p. (RM)

MODEN, W. L., JR.; D. W. McKENZIE; and R. STEVENS. 1978. Interseeder for rocky and brushy terrain. Progress Report. San Dimas, CA: U.S. Department of Agriculture, Forest Service, Equipment Development Center. 8 p. (PSW)

MONSEN, STEPHEN B. 1987. Shrub selections for pinyon-juniper plantings. In: Everett, Richard L., comp. Proceedings--pinyon-juniper conference; 1986 January 13-16; Reno, NV. Gen. Tech. Rep. INT-215. Ogden, UT: U.S. Department of Agriculture, Forest Service, Intermountain Research Station: 316-329. (INT)

MONSEN, STEPHEN B.; and NANCY SHAW. 1983. Reynolds Creek species adaptability plantings. In: Comprehensive report: ARS/BLM cooperative studies: Reynolds Creek watershed. Boise, ID: U.S. Department of Agriculture, Agricultural Research Service, Northwest Watershed Research Center. 5-16--5-26. Volume 2. (INT)
MONSEN, STEPHEN B.; and NANCY L. SHAW. 1983. Seeding antelope bitterbrush with grasses on south-central Idaho rangelands--a 39-year response. In: Tiedemann, Arthur R.; and Kendall L. Johnson, comps. Research and management of bitterbrush and cliffrose in western North America: Proceedings of a symposium; 1982 April 13-15; Salt Lake City, UT. Gen. Tech. Rep. INT152. Ogden, UT: U.S. Department of Agriculture, Forest Service, Intermountain Forest and Range Experiment Station: 126-136. (INT)

MONSEN, STEPHEN B.; and RICHARD STEVENS. 1987. Seed and seedling characteristsics of rabbitbrush. In: Johnson, Kendall L., ed. Proceedings of the Fourth Shrub Ecology Workshop: the genus Chrysothamnus; 1986 September 17-18; Cedar City, UT. Logan, UT: Utah State University, College of Natural Resources: 41-49. (INT)

MOORE, WILLIAM H. 1980. Survival and growth of oaks planted for wildlife in the flatwoods. Res. Note SE-286. Asheville, NC: U.S. Department of Agriculture, Forest Service, Southeastern Forest Experiment Station. 4 p. (SE)

NOLLER, GARY L.; and E. DURANT MCARTHUR. 1986. Establishment and initial results from a sagebrush (Artemisia tridentata) [Nutt.]) mass selection garden. In: McArthur, E. Durant; and Bruce L. Welch, comps. Proceedings--symposium on the biology of Artemisia and Chrysothamnus; 1984 July 9-13; Provo, UT. Gen. Tech. Rep. INT-200. Ogden, UT: U.S. Department of Agriculture, Forest Service, Intermountain Forest and Range Experiment Station: 104-107. (INT) 
PLATTS, WILLIAM S.; CARL ARMOUR; GORDON D. BOOTH; MASON

BRYANT; JUDITH L. BUFFORD; PAUL CUPLIN; [and others]. 1987. Methods of evaluating riparian habitats with applications to management. Gen. Tech. Rep. INT-222. Ogden, UT: U.S. Department of Agriculture, Forest Service, Intermountain Research Station. p. (INT)

RICHARDSON, BLAND Z.; and EUGENE E. FARMER. 1981. Test of methods for amending and seeding spoils at the Blackbird Mine. Res. Pap. INT-265. Ogden, UT: U.S. Department of Agriculture, Forest Service, Intermountain Forest and Range Experiment Station. 6 p. (INT)

SCHOLL, DAVID G.; and CHARLES P. PASE. 1984. Wheatgrass response to organic amendments and contour furrowing on coal mine spoils. Journal of Environmental Quality. 13:479-482. (RM)

SCHOLL, DAVID G; and EARL F. ALDON. 1979. Water harvesting to establish perennial plants on semi-arid coal mine spoil. In: Mohan, K. Wali, ed. Ecology and coal resource development: New York, NY: Pergamon Press: 735-739. Volume II. (RM)

SKOUSEN, J. G.; J. N. DAVIS; and J. D. BROTHERSON. 1989. Pinyon-juniper chaining and seeding for big game in central Utah. Journal of Range Management. 42:98-104. (INT)

STARK, NELLIE M. 1989. The ecology of Vaccinium globulare: seedling establishment and nutrition. In: Wallace, Arthur; E. Durant McArthur; and Marshall R. Haferkamp, comps. Proceedings--Symposium on Shrub Ecophysiology and Biotechnology; 1987 June 30-July 2; Logan, UT. Gen. Tech. Rep. INT-256. Ogden, UT: U.S. Department of Agriculture, Forest Service, Intermountain Research Station: 164-168. (INT)
STEIN, WILLIAM I.; RODGER DANIELSON; NANCY SHAW; SCOTT WOLFF; and DAVID GERDES. 1986. Users guide for seeds of western trees and shrubs. Gen. Tech. Rep. PNW-193. Portland, OR: U.S. Department of Agriculture, Forest Service, Pacific Northwest Research Station. 45 p. (INT)

STEVENS, R. 1978. Interseeder for rocky and brushy areas. In: 32nd Annual Report. San Antonio, TX: Vegetative and Rehabilitation Workshop: 6-10. (INT)

STEVENS, R.; K. R. JORGENSEN; J. N. DAVIS; and S. B. MONSEN. 1986. Seed pappus and placement influences on white rubber rabbitbrush establishment. In: McArthur, E. Durant; and Bruce L. Welch, comps. Proceedings-symposium on the biology of Artemisia and Chrysothamnus; 1984 July 9-13; Provo, UT. Gen. Tech. Rep. INT-200. Ogden, UT: U.S. Department of Agriculture, Forest Service, Intermountain Forest and Range Experiment Station: 353-357. (INT)

STEVENS, RICHARD. 1981. Techniques for planting shrubs on wildland disturbances. In: Stelter, Lavern H.; Edward J. DePuit; and Sharon A. Mikol, tech. coords. Shrub establishment on disturbed arid and semi-arid lands: Proceedings of the symposium. 1980 December 2-3; Laramie, WY. Cheyenne, WY: Wyoming Game and Fish Department: 29-36. (INT)

STEVENS, RICHARD. 1985. Interseeding with a modified Sieco fireplow can result in increased seedling numbers. In: Vegetative Rehabilitation and Equipment Workshop: 39th annual report; 1985 February 10-11; Salt Lake City, UT. Missoula, MT: U.S. Department of Agriculture, Forest Service, Equipment Development Center: 22-24. 
STEVENS, RICHARD; and STEPHEN B. MONSEN. 1988. Cedar Palmer penstemon: a selected penstemon for semiarid ranges. Rangelands. 10:163164. (INT)

STEVENS, RICHARD; and STEPHEN B. MONSEN. 1988. "Hatch" winterfat: a quality shrub for ranges and wildlands. Rangelands. 10:104-105. (INT)

STEVENS, RICHARD; WALTER L. MODEN, JR.; and DAN W. McKENZIE. 1981. Interseeding and transplanting shrubs and forbs into grass communities. Rangelands. 3:55-58. (INT)

STUTZ, HOWARD C. Broad gene pools required for disturbed lands. In: Aldon, Earl F.; and Wendall R. Oaks, eds. Reclamation of mined lands in the Southwest: Proceedings of the symposium; 1982 October 20-22; Albuquerque, NM: New Mexico Chapter of the Soil Conservation Society of America: 113-118. (RM)

URESK, DANIEL W.; and CHARLES E. BOLDT. 1986. Effect of cultural treatments on regeneration of native woodlands on the Northern Great Plains. Prairie Naturalist. 18:193-202. (RM)

VAN EPPS, G. A.; and C. M. McKELL. 1978. Major procedures for selecting and establishing range shrubs as rehabilitators of disturbed lands. In: Hyder, Donald N., ed. Proceedings, 1 st international rangeland congress; 1978 August 14-18; Denver, CO: Society for Range Management: 352-354. (INT)

VOGEL, WILLIS G.; and FREDERICK M. ROTHWELL. 1986. Bark mulch aids establishment of black walnut planted on western Kentucky mine spoils. In: Kolar, Clay A., ed. Proceedings of the 5th Annual Better reclamation with tree conference; 1985 June 5-7; Carbondale, IL: Amax Coal Company: 104-110. (NE)
VOORHEES, MARGUERITE E.; DANIEL W. URESK; and RICHARD M. HANSEN. 1984. Atriplex suckleyi (Torrey) Rydb.: A native plant for revegetating bentonite mine spoils. In: Tiedemann, Arthur R.; E. Durant McArthur; Howard C. Stutz; Richard Stevens; and Kendall L. Johnson, comps. Proceedings-symposium on the biology of Atriplex and related chenopods: 1983 May 2-6; Provo, UT. Gen. Tech. Rep. INT-172. Ogden, UT: U.S. Department of Agriculture, Forest Service, Intermountain Forest and Range Experiment Station: 306-309. (RM)

\section{Rangeland Inventory}

ALDRICH, R. C., tech. coord. 1976. Evaluation of skylab (EREP) data for forest and rangeland surveys. Res. Pap. PSW-113. Berkeley, CA: U.S. Department of Agriculture, Forest Service, Pacific Southwest Forest and Range Experiment Station. 74 p. (RM)

BROOKS, ROBERT T.; and CHARLES T. SCOTT. 1983. Quantifying land-use edge from aerial photographs. The Wildlife Society Bulletin. 4:389-39l. (NE)

BROOKS, ROBERT T.; and KAREN J. SYKES. 1984. Sampling land use edge from aerial photographs--line transect vs. circular pattern. Research Note NE321. Broomall, PA: U.S. Department of Agriculture, Forest Service, Northeastern Forest Experiment Station. 6 p. (NE)

CHAMBERS, JEANNE C.; and RAY W. BROWN. 1983. Methods for vegetation sampling and analysis on revegetated mined land. Gen. Tech. Rep. INT-151. Ogden, UT: U.S. Department of Agriculture, Forest Service, Intermountain Forest and Range Experiment Station. 57 p. (INT) 
CHAN, S. S.; R. W. MCCREIGHT; and T. A. SPIES. 1986. Evaluating forest vegetation cover with computerized analysis of fisheye photographs. Forest Science. 32:1085-1091. (PNW)

CIMON, NORMAN; and THOMAS QUIGLEY. 1986. Evolution of a geographic information system: integration into the Oregon range evaluation computing facility. In: Proceedings of geographic information systems workshop; 1986 April 1-4; Atlanta, GA. Portland, OR: American Society for Photogrammetry and Remote Sensing: 99-109. (PNW)

CLARY, WARREN P. 1989. Test of RPA production coefficients and local assumptions for the pinyon-juniper ecosystem in central Utah. Res. Pap. INT-403. Ogden, UT: U.S. Department of Agriculture, Forest Service, Intermountain Research Station. 11 p. (INT)

CUPLIN, PAUL; WILLIAM S. PLATTS; OSBORNE CASEY; and ROY MASINTON. 1985. A comparison of riparian area ground data with large scale airphoto interpretation. In: Johnson, R. Roy; Charles D. Ziebell; David R. Patton; Peter F. Ffolliott; and R. H. Hamre, tech. eds. Riparian ecosystems and their management: Reconciling conflicting uses: Proceedings, First North American riparian conference; 1985 April 16-18; Tucson, AZ. Gen. Tech. Rep. RM-120. Fort Collins, CO: U.S. Department of Agriculture, Forest Service, Rocky Mountain Forrest and Range Experiment Station: 67-68. (INT)

DAMS, R. V.; and RICHARD E. FRANCIS. 1985. Aerial photography for post-mine vegetation inventory. In: Ciesla, W. M.; and R. S. Driscoll, co-chair. Proceedings: PECORA 10-remote sensing in forest and range resource management. 1985 August 20-22; Fort Collins, CO. Falls Church, VA: American Society of Photogrammetry and Remote Sensing: 419-420. (RM)
FERGUSON, DENNIS E.; PENELOPE MORGAN; and FREDERIC D. JOHNSON, comps. 1989. Proceedings-land classifications based on vegetation: applications for resource management; 1987 November 17-19; Moscow, ID. Gen. Tech. Rep. INT-257. Ogden, UT: U.S. Department of Agriculture, Forest Service, Intermountain Research Station. 315 p. (INT)

FRANCIS, RICHARD E. 1978. Current rangeland inventory methods-compatability towards an ecological base? In: Lund, H. Gyde; Vernon J. LaBau; Peter F. Ffolliott; and David W. Robinson, tech. coords. Integrated inventories of renewable natural resources: Proceedings of the workshop; 1978 January 8-12; Tucson, AZ. Gen. Tech. Rep. RM-55. Fort Collins, CO: U.S. Department of Agriculture, Forest Service, Rocky Mountain Forest and Range Experiment Station: 91-103.

FRANCIS, RICHARD E. 1982. Vegetation measurements for multiresource inventories: An ecological concept. In:Brann, Thomas B.; Louis O. House; and $\mathrm{H}$. Gyde Lund, tech. coords. Inplace resource inventories: principles and practices: Proceedings of a national workshop; 1981 August 9-14; Orono ME. SAF 82-02. Bethesda, MD: Society of American Foresters: 339-344. (RM)

FRANCIS, RICHARD E.; and R. S. DRISCOLL. 1976. Range inventory-classification and plant community mapping. In: Aldrich, Robert C., tech. coord. Res. Pap. PSW-113. Berkeley, CA: U.S. Department of Agriculture, Forest Service, Pacific Southwest Forest and Range Experiment Station: 35-54. (RM) 
FRANCIS, RICHARD E.; and R. S. DRISCOLL. 1979. Integrated resource inventory for the Resources Planning Act. In: Proceedings PECORA 4 remote sensing symposium: application of remote sensing data to wildlife management; 1978 October 10-12; Sioux Falls, SD. National Wildlife Federation, Scientific and Technical Series. 3:269-273. (RM)

GILL, JOHN; and DAVE WORLEY. 1980. Forest land and objectives inventory. In: Proceedings, Ohio private woodlands workshop 1979; Ohio Department Natural Resource, Division of Wildlife: 10-19. (NE)

GREENTREE, W. J.; and R. C. ALDRICH. 1976. Evaluating stream trout habitat on large-scale aerial color aerial photographs. Res. Pap. PSW-123. Berkely, CA: U.S. Department of Agriculture, Forest Service, Pacific Southwest Forest and Range Experiment Station. 21 p. (RM)

GRELEN, HAROLD E.; and RICHARD E. LOHREY. 1978. Multi-resourse inventories: A potential of the forest survey. In: Lund, H. Gyde; Vervon J. LaBau; Peter F. Ffolliott; and David W. Robinson, tech coords. Integrated inventories of renewable natural resources: Proceedings of the workshop; 1978 January 8-12, Tucson, AZ. Gen. Tech. Rep. RM-55. Fort Collins, CO. U.S. Department of Agriculture, Forest Service, Rocky Mountain Forest and Range Experiment Station: 425-429.(SO).

HAGEN, R.; and M. MEYER. 1977. Remote sensing of vegetation as related to black bear habitat, spruce budworm damage and plantation release appraisals on the Superior National Forest. IAFHE-RSL Res. Rep. 77-4. St. Paul, MN. College of Forestry and Agricultural Experiment Station, University of Minnesota. 23 p. (NC)
ISAACSON, D. L.; and D. A. LECKENBY. 1981. Remote sensing inventory of Rocky Mountain elk habitat in the Blue Mountains. In: Technical papers of the American Society of Photogrammetry: ASP-ACSM fall meeting; 1981 September 9-11; San Francisco, CA.: 282-291. (RM)

ISAACSON, D. L.; D. A. LECKENBY; and C. J. ALEXANDER. 1982. The use of largescale aerial photography for interpreting landsat digital data in an elk habitatanalysis project. Journal Applied Photography Engineering. 8(1):51-57. (RM)

LECKENBY, D. A.; and D. L. ISAACSON. 1980. Remote sensing inventory of elk habitat in the Blue Mountains. In: Research in rangeland management. Spec. Rep. 586. Corvallis, OR: Oregon State University, Agricultural Experiment Station: 19-21. (PNW)

LECKENBY, DONAVIN A. 1980. Elk cover and forage inventory via satellite and computer. Oregon Lands. 3(1):2-3. (PNW)

LECKENBY, DONAVIN A.; and DENNIS L. ISAACSON. 1982. Identification and description of northeast Oregon elk habitat through radio telemetry and mapping by earth resources satellite. In: Britt, T. L.; and D. P. Theobald, eds. Proceedings of the Western States Elk Workshop; 1982 February 22-24; Flagstaff, AZ. Phoenix, AZ: Western Association of Fish and Wildlife Agencies; Arizona Game and Fish Department: 151-156. (PNW)

LEWIS, CLIFFORD E. 1978. Inventory and forage capability determination. Proceedings, Cooperative Forestry Management, Technical Training; Florida Division Forestry: 9-19. (SE) 
MITCHELL, JOHN E.; DALE SNYDER; LYNN D. DRAWE; NORMAN R. FRENCH; and JOHN L. CAPINERA. 1986. Assessment of habitat factors. In: Cook, C. Wayne: and James Stubbendieck, eds. Range research: basic problems and techniques. Denver, CO: Society for Range Management: 19-50. Chapter 2. (RM)

PASE, CHARLES P. 1980. Community structural analysis-a rapid, effective range condition estimator for semi-arid ranges. In: Lund, H. Gyde; Miguel Caballero; R.E. Hamre; [and others], tech. coords. Arid land resource inventories: Developing cost-efficient methods: Proceedings of an international workshop; 1980 November 30-December 6; La Paz, Mexico. Gen. Tech. Rep. WO-28. Washington, DC: U.S. Department of Agriculture, Forest Service: 425-430. (RM)

PEARSON, HENRY A.; and HERBERT S. STERNITZKE. 1976. Deer browse inventories in the Louisiana coastal plain. Journal of Wildlife Management. 40:325-329. (SO)

PEARSON, HENRY A.; and HERBERT S. STERNITZKE. 1978. Short communications: Response to comments on browse inventories in Louisiana. Journal of Wildlife Management. 42:171-172. (SO)

QUIGLEY, THOMAS M.; DAVID S. DILLARD; and JERRY B. REESE. 1989. New criteria for measuring range management activities. Gen. Tech. Rep. PNW-248. Portland, OR: U.S. Department of Agriculture, Forest Service, Pacific Northwest Research Station. 27 p. (PNW)

ROBINOVE, CHARLES J.; PAR S. CHAVEZ; DALE GEHRING; and RALPH HOLMGREN. 1981. Arid land monitoring using landsat albedo difference images. Remote Sensing of Environment. 11:133-156. (INT)
URESK, DANIEL W.; and DEBORAH D. PAULSON. 1988. Estimated carrying capacity for cattle competing with prairie dogs and forage utilization in western South Dkota. In: Szaro, Robert C.; Kieth E. Severson; and David R. Patton, tech. coords. Management of amphibians, reptiles, and small mammals in North America: Proceedings of the symposium; 1988 July 19-21; Flagstaff, AZ. Gen. Tech. Rep. RM-166. Fort Collins, CO: U.S. Department of Agriculture, Forest Service, Rocky Mountain Forest and Range Experiment Station: 387-390. (RM)

YAMAMOTO, TERUO. 1976. Geophysical measurements of a mountain watershed. Journal Soil Water Conservation. 31:105-109. (RM)

\section{Wildlife Habitat Value}

BROOKS, R. T.; and W. F. PORTER. 1983. Development of a procedure to establish conditions and monitor changes in regional wildlife habitat quality. In: Proceedings, renewable resource inventories for monitoring changes and trends; 1983 August 15-19; Corvallis, OR. Corvallis, OR: Oregon State University, College of Forestry: 223-226. (NE)

CRAWFORD, H. S.; and W. L. STUTZMAN. 1977. Measuring deer habitat attributes with microwave signal attenuation. In: Transactions, 11th Meeting North Deer Study Group; 1975 September; Quebec, City, PQ: 123-132. (NE)

EVEREST, F. H.; F. B. LOTSPEICH; and W. R. MEEHAN. 1982. New perspectives on sampling, analysis, and interpretation of spawning gravel quality. In: Armantrout, Neil B., ed. Acquisition and utilization of aquatic habitat inventory information: Proceedings of a symposium; 1981 October 28-30; Portland, OR. Bethesda, MD: Western Division, American Fisheries Society: 325-333. (PNW) 
FENWOOD, J. D.; D. F. URBSTON; and R. F. HARLOW. 1984. Determining deer habitat capability in Ouachita National Forest pine stands. Proceedings of the Annual Conference of the Southeastern Association of Fish and Wildlife Agencies. 38:13-22. (SE)

GREENTREE, WALLACE J.; and ROBERT C. ALDRICH. 1978. Measuring trout habitat as an indication of population on large-scale aerial color photographs. In: PECORA IV, Proceedings of the Symposium; Application of Remote Sensing Data to Wildlife Management; 1978 October 10-12; Sioux Falls, SD: National Wildlife Federation, Science and Technical Series. 3:65-71. (RM)

GRUBB, TERYL G. 1988. Pattern recognition--a simple model for evaluating wildlife habitat. Res. Note RM-487. Fort Collins, CO; U.S. Department of Agriculture, Forest Service, Rocky Mountain Forest and Range Experiment Station. 5 p. (RM)

HARLOW, R. F. 1979. In defense of inkberry-dangers of ranking deer forage. The Wildlife Society Bulletin. 7:21-24. (SE)

HARLOW, R. F. 1984. Habitat evaluation. In: Halls, L. K., ed. White-tailed deer: ecology and management. Washington, DC: Wildlife Management Institute, and Harrisburg, PA: Stackpole Books: 601628. (SE)

HOEKSTRA, THOMAS W.; and CURTIS H. FLATHER. 1986. Theroetical basis for integrating wildlife in renewable resource inventories. Journal of Environmental Management. 24:95-110. (RM)
LECKENBY, DONAVIN A.; JACK WARD THOMAS; MARK G. HENJUM; and LEONARD J. ERICKSON. 1987. An index to evaluate forage quantity and quality interactions: one of four variables proposed for modeling elk habitat effectiveness on winter ranges in the Blue Mountains of Oregon and Washington. In: Proceedings of the 1986 Western States and Provinces Elk Workshop; 1986 March 17-19; Coos Bay, OR. Portland, OR: Oregon Department of Fish and Wildlife: 195212. (PNW)

LYON, L. JACK. 1987. HIDE2: evaluation of elk hiding cover using a personal computer. Res. Note INT-365. Ogden, UT: U.S. Department of Agriculture, Forest Service, Intermountain Research Station. 2 p. (INT)

LYON, L. JACK; and C. LES MARCUM. 1987. A report on a field test of a PC program designed to evaluate hiding cover for elk. In: Proceedings of the 1986 Western States and Provinces Elk Workshop; 1986 March 17-19; Coos Bay, OR. Portland, OR: Oregon Department of Fish and Wildlife: 271274. (INT)

MAURER, BRIAN A. 1986. Predicting habitat quality for grassland birds using densityhabitat correlations. Journal of Wildlife Management. 50:556-566. (RM)

MCINTIRE, PATRICK W.; and ANDREW B. CAREY. 1989. A microhistological technique for analysis of food habitats of mycophagous rodents. Res. Pap. PNW404. Portland, OR: U.S. Department of Agriculture, Forest Service, Pacific Northwest Research Station. 16 p. (PNW) 
O'NEIL, L. JEAN; and ANDREW B. CAREY. 1986. Introduction: When habitats fail as predictors. In: Verner, Jared; Michael L. Morrison; and C. John Ralph, eds. Wildlife 2000: modeling habitat relationships of terrestrial vertebrates; 1984 October 7-11; Fallen Leaf Lake, CA. Madison, WI: The University of Wisconsin Press: 207-208. (PNW)

PLATTS, WILLIAM S. 1981. Stream inventory garbage in--reliable analysis out: only in fairy tales. In: Armantrout, Neil B., ed. Acquisition and utilization of aquatic habitat inventory information:

Proceedings of a symposium; 1981 October 28-30; Portland, OR: Western Division, American Fisheries Society: 75-84. (INT)

PLATTS, WILLIAM S.; and RODGER LOREN NELSON. 1983. The electronic capacitance meter: a tool for evaluating riparian-fishery habitat. North American Journal of Fishery Management. 3:219227. (INT)

QUIGLEY, THOMAS M. 1981. Estimating contribution of overstory vegetation to stream surface shade. The Wildlife Society Bulletin. 9(1):22-27. (PNW)

RALPH, C. JOHN. 1981. An investigation of the effect of seasonal activity levels on avian censusing. In: Ralph, C. John; and J. Michael Scott, eds. Estimating numbers of terrestrial birds: Proceedings of an international symposium; 1980 October 26-31; Asilomar, CA. Studies Avian Biology No. 6. Cooper Ornithological Society: 265-270. (PSW)

RINNE, JOHN N. 1978. Development and application of methods of population estimation and habitat evaluation for management of the Arizona and Gila trouts. In: Moring, John R., ed. Proceedings, wild trout-catchable trout symposium; 1978 February 15-17; Eugene, OR. Oregon Department Fish and Wildlife, Resource and Development Section: 113-125. (RM)
RUMBLE, MARK A. 1983. Classifying aquatic resources: A quantitative approach. In: Proceedings, third plains aquatic research conference; 1983 August 2425; Bozeman, MT: Montana State University, Institute of Natural Resources: 89-99. (RM)

SPOWART, RICHARD A.; and FRED B. SAMSON. 1986. Carnivores. In: Cooperrider, Allen Y.; Raymond J. Boyd; and Stuart R. Hanson, comps. eds. Inventory and monitoring of wildlife habitat. Denver, CO: U.S. Department of the Interior, Bureau of Land Management, Service Center: 475-476. (PNW)

SWANSTON, DOUGLAS N.; WILLIAM R. MEEHAN; and JAMES A. MCNUTT. 1977. A quantitative geomorphic approach to predicting productivity of pink and chum salmon streams in southeast Alaska. Res. Pap. PNW-227. Portland, OR: U.S. Department of Agriculture, Forest Service, Pacific Northwest Forest and Range Experiment Station. 26 p. (PNW)

THOMAS, JACK WARD; and JARED VERNER. 1986. Forests. In: Cooperrider, Allen Y.; Raymond J. Boyd; and Stuart R. Hanson, comps. eds. Inventory and monitoring of wildlife habitat. Denver, CO: U.S. Department of the Interior, Bureau of Land Management, Service Center: 73-91. (PNW)

THOMAS, JACK WARD; DONAVIN A. LECKENBY; MARK HENJUM; RICHARD J. PEDERSEN; and LARRY D. BRYANT. 1988. Habitat-effectiveness index for elk on Blue Mountain winter ranges. Gen. Tech. Rep. PNW-218. Portland, OR: U.S. Department of Agriculture, Forest Service, Pacific Northwest Research Station. 28 p. (PNW) 
TOTH, EDWARD F.; and JOHN W.

BAGLIEN. 1986. Summary: When

habitats fail as predictors--the managers

viewpoint. In: Verner, Jared; Michael L.

Morrison; and C. John Ralph, eds.

Wildlife 2000: modeling habitat

relationships of terrestrial vertebrates;

1984 October 7-11; Fallen Leaf Lake,

CA. Madison, WI: The University of

Wisconsin Press: 255-256. (PSW)

VERNER, JARED. 1986. Summary:

Predicting effects of habitat patchiness

and fragmentation. In: Verner, Jared;

Michael L. Morrison; and C. John Ralph, eds. Wildlife 2000: modeling habitat relationships of terrestrial vertebrates; 1984 October 7-11; Fallen Leaf Lake, CA. Madison, WI: The University of Wisconsin Press: 327-329. (PSW)

WALKOTTEN, WILLIAM J.; and MASON D. BRYANT. 1980. An instrument to measure stream channel gradient and profiles. Res. Note PNW-345. Portland, OR: U.S. Department of Agriculture, Forest Service, Pacific Northwest Forest and Range Experiment Station. $5 \mathrm{p}$. (PNW)

\section{Laboratory And Field Techniques}

ALDON, EARL F.; and RICHARD E.

FRANCIS. 1984. A modified utilization gauge for western range grasses. Res. Note RM-432. Fort Collins, CO: U.S. Department of Agriculture, Forest Service, Rocky Mountain Forest and Range Experiment Station. 2 p. (RM).

ARMOUR, CARL L.; KENNETH P.

BURNHAM; and WILLIAM S. PLATTS.

1983. Field methods and statistical analyses for monitoring small salmonid streams. FWS/OBS-83-33. Washington,

DC: U.S. Department of the Interior,

Fish and Wildlife Service, Research and Development, Division of Biological Services, Western Energy and Land Use Team. 200 p. (INT)
AULT, STACEY C.; and FRED A STORMER. 1983. A suction device for sampling seed availability. The Wildlife Society Bulletin 11:63-65. (RM)

BAKER, ROGER L.; and HENRY A. PEARSON. 1981. Plot delineation with a pin-and-chain. Journal of Range Management. 34:336-337. (SO)

BROWN, R. W. 1976. New techniques for measuring the water potential of detached leaf samples. Argonomy Journal. 68:432-434. (INT)

BROWN, R. W.; and R. S. JOHNSTON. 1976. Extended field use of screencovered thermocouple psychrometers. Argonomy Journal. 68:995-996. (INT)

BROWN, R. W.; and R. S. JOHNSTON. 1979. Bioassay of alpine mine spoils for plant growth and development. Res. Note INT-285. Ogden, UT: U.S. Department of Agriculture, Forest Service, Intermountain Forest and Range Experiment Station. 11 p. (INT)

BROWN, RAY W.; and JAMES M. COLLINS. 1979. Protection of instrument wires in the field. Journal of Range Management. 32:476-479. (INT)

BROWN, RAY W.; and JEANNE C. CHAMBERS. 1987. Measure of in situ water potential with thermocouple psychrometers: A critical evaluation. In: Proceedings, intenational conference on measurement of soil and plant water status; 1987 July; Ogden; UT: Utah State University: 125-136. (INT);

BROWN, RAY W.; and WALTER T. McDONOUGH. 1977. Thermocouple psychrometer for in situ leaf water potential determinations. Plant and Soil. 48:5-10. (INT) 
CHAMBERS, JEANNE C.; and RAY W. BROWN. 1983. Methods for vegetation sampling and analysis on revegetated mine lands. Gen. Tech. Rep. INT-151. Ogden, UT: U.S. Department of Agriculture, Forest Service, Intermountain Forest and Range Experiment Station. 57 p. (INT)

CHAMBERS, JEANNE C.; and RAY W. BROWN. 1988. A mapping table for obtaining plant population data. Journal of Range Management. 41: 267-

268. (INT)

COX, L. M.; L. D. BARTEE; A. G. CROOK; P. E. FARNES; and J. L. SMITH. 1979. The care and feeding of snow pillows. In: 46th Annual Meeting, Western Snow Conference; 1978 April 18-20; Otter Crest, OR: 40-47. (PSW)

CRAIG, A. MORRIE; and MICHAIL J. SAVAGE. 1980. Automated analysis of indoles in bovine serum and rumen fluid. Altex Chromatogram. 3(4):1,4.

CRAWFORD, H. S.; and D. H. HANKINSON. 1984. White-tailed deer vs. bovine inocula for in vitro digestibilities. Journal of Wildlife Management. 48:649-652. (NE)

CURRIE, PAT O.; and FREDERICK L. HAMMER. 1979. Detecting depth and lateral spread of roots of native range plants using radioactive phosphorous. Journal of Range Management. 32:101103. (RM)

CUSHING, C. E.; [and others]. (n.d.) Comparative of physical-chemical variables of streams using multivariate analyses. Archive for Hydrobiologia. 89(3):343-352. (PNW)
EVEREST, FRED. 1983. Subsurface analysis. In: Platts, William S.; Walter F. Megahan; and G. Wayne Minshall, eds. Methods for evaluating stream riparian, and biotic conditions. Gen. Tech. Rep. INT-138. Ogden, UT: U.S. Department of Agriculture, Forest Service, Intermountain Forest and Range Experiment Station: 17-21. (PNW)

EVEREST, FRED H.; and JEFFREY RODGERS. 1982. Two economical photoperiod controls for laboratory studies. Progressive Fish-Culturist. 44:113-114. (PNW)

EVEREST, FRED H.; CARL E. MCLEMORE; and JOHN F. WARD. 1980. An improved tri-tube cryogenic gravel sampler. Res. Note PNW-350. Portland, OR: U.S. Department of Agriculture, Forest Service, Pacific Northwest Forest and Range Experiment Station. 8 p. (PNW)

HANLEY, THOMAS A.; and JAMES J. ROGERS. 1989. Estimating carrying capacity with simultaneous nutritional constraints. Res. Note PNW-485. Portland, OR: U.S. Department of Agriculture, Forest Service, Pacific Northwest Research Station. 29 p. (PNW)

HARLOW, R. F. 1977. A technique for surveying deer forage in the Southeast. The Wildlife Society Bulletin. 5:185-191. (SE)

HOLECHEK, JERRY L.; and MARTIN VAVRA. 1981. The effect of slide and frequency observation numbers on the precision of microhistological analysis. Journal of Range Management. 34: 337338. (PNW)

JOHNSON, MARK K.; HELEN WOFFORD; and HENRY A. PEARSON. 1983. Microhistological techniques for food habits analyses. Res. Pap. SO-199. New Orleans, LA: U.S. Department of Agriculture, Forest Service, Southern Forest Experiment Station. 40 p. (SO) 
LEONARD, R. L.; E. D. MCARTHUR; D. J. WEBER; and B. W. WOOD. 1982.

Electrophoresis of isoenzymes of 16 western shrubs: technique development. Great Basin Naturalist. 41:377-388. (INT)

LII, C. Y.; and CHRIS MASER. 1986. New and modified techniques for studying nitrogen-fixing bacteria in small mammal droppings. Res. Note PNW-441. Portland, OR: U.S. Department of Agriculture, Forest Service, Pacific Northwest Forest and Range Experiment Station. 4 p. (PNW)

LOTSPEICH, FREDERICK B.; and FRED H. EVEREST. 1981. A new method for reporting and interpreting textural composition spawning gravel. Res. Note PNW-369. Portland, OR: U.S.

Department of Agriculture, Forest Service, Pacific Northwest Forest and Range Experiment Station. 11 p. (PNW)

MAWSON, JOSEPH C.; JACK WARD

THOMAS; and RICHARD M.

DEGRAAF. 1976. Program HTVOL. The determination of tree crown volume by layers. Res. Pap. NE-354; Upper Darby, PA: U.S. Department of Agriculture, Forest Service, Northeastern Forest Experiment Station. 9 p. (NE)

MCINTIRE, PATRICK W.; and ANDREW B. CAREY. 1989. A microhistological technique for analysis of food habitats of mycophagous rodents. Res. Pap. PNW404. Portland, OR: U.S. Department of Agriculture, Forest Service, Pacific Northwest Research Station. 16 p. (PNW)

MCNABB, D. H.; and J. M. GEIST. 1979. Acetylene reduction assay of symbiotic N2 fixation under field conditions. Ecology. 60:1070-1072. (PNW)

MEEUWIG, R. O. 1977. Slope-compensating stick-type angle gage. Southern Journal of Applied Forestry. 1:25-26. (INT)
MITCHELL, JOHN E.; DALE SNYDER; LYNN D. DRAWE; NORMAN R. FRENCH; and JOHN L. CAPINERA. 1986. Assessment of habitat factors. In: Cook, C. Wayne: and James Stubbendieck, eds. Range research: basic problems and techniques. Denver, CO: Society for Range Management: 19-50. Chapter 2. (RM)

MITCHELL, JOHN E.; PATRICIA N. S. BARTLING; and RENEE O'BRIEN. 1988. Comparing cover-class macroplot data with direct estimates from small plots. American Midland Naturalist. 120:70-78. (RM)

MUEGGLER, W. F. 1976. Number of plots required for measuring productivity on mountain grasslands in Montana. Res. Note INT-207. Ogden, UT: U.S. Department of Agriculture, Forest Service, Intermountain Forest and Range Experiment Station. 6 p. (INT)

NEAL, DONALD L.; RAYMOND D. RATLIFF; and STANLEY E. WESTFALL. 1988. A quadrat frame for backcountry vegetation sampling. Journal of Range Management. 451:353-355. (PSW)

PEDERSON, JORDAN C.; and BRUCE L. WELCH. 1982. Effects of monoterpenoid exposure on ability of rumen inocula to digest a set of forages. Journal of Range Management. 35:500502. (INT)

POPHAM, THOMAS W.; and ROGER L. BAKER. 1987. Ocular and densimeter estimates of understory foliar cover in forests of Alabama. Res. Note SO-334. New Orleans, LA: U.S. Department of Agriculture, Forest Service, Southern Forest Experiment Station. 4 p. (SO)

PROBASCO, GEORGE E.; ARDELL J. BJUGSTAD; and R. W. PIERCE. 1976. A supporting device for use with stepwise thermal sensors. Journal of Range Management. 29:348. (NC) 
PUGLISI, MICHAEL J.; STEPHEN A.

LISCINSKY; and RICHARD F.

HARLOW. 1978. An improved

methodology of rumen content analysis

for white-tailed deer. Journal of Wildlife

Management. 42:398-403. (SE)

RATLIFF, RAYMOND D.; and R. D. PIEPER. 1981. Deciding final clusters: an approach using intra-and intercluster distances. Vegetatio. 48:83-86. (PSW)

RUMBLE, MARK A. 1987. Using twig diameters to estsimate browse utilization on three shrub species in southeastern Montana. In: Provenza, Frederick D.; Jerran T. Flinders; and E. Durant McArthur, comps. Proceedings-symposium on plant-herbivore interactions; 1985 August 7-9; Snowbird, UT. Gen. Tech. Rep. INT-222. Ogden, UT: U.S. Department of Agriculture, Forest Service, Intermountain Research Station: 172-175. (RM)

STEELE, JACQUELINE G.; [and others]. 1983. Core versus nuclear guage methods of determining soil bulk density and moisture content. Res. Note. SO295. New Orleans, LA: U.S. Department of Agriculture, Forest Service, Southern Forest Experiment Station. 6 p. (SO)

STEELE, ROBERT. 1984. An approach to classifying seral vegetation within habitat types. Northwest Science. 58:2939. (INT)

STURGES, DAVID L. 1986. Precipitation measured by dual gages, Wyomingshielded gages, and in a forest opening. In: Kane, Douglas L., ed. Proceedings: cold regions hydrology symposium; 1986 July 22-25; Fairbanks, AK. TPS86-1. Bethesda, MD: American Water Resources Association: 387-396. (RM)

WARD, JOHN F.; and WILLIAM R. MEEHAN. 1984, Inexpensive digital daylight integrator. Progressive Fish-Culturist. 46(1):62-66. (PNW)
WESCHE, T. A.; and P. A. RECHARD. 1980. A summary of instream flow methods for fisheries and related research. In:

Determining instream flows for management of aquatic and riparian ecosystems; Eisenhower Consortium Bull. 9. Laramie, WY: University of Wyoming, Water Resource Research Institute. 128 p. (RM)

WHITE, SUSAN M.; and BRUCE L. WELCH. 1981. Paired comparisons: a method for ranking mule deer preference for various browse species. Res. Note INT-308.

Ogden, UT: U.S. Department of Agriculture, Forest Service, Intermountain Forest and Range Experiment Station. 4 p. (INT)

WHITE, W. ELTON; and CLIFFORD E. LEWIS. 1982. Establishing circulat plot boundaries with a wedge prism and an adjustable target pole. Journal of Range Management. 35:677-678. (SE)

WIEBE, HERMAN H.; and RAY W. BROWN. 1979. Temperature gradient effects on in situ hygrometer measurements of soil water potential. II. Water movement. Agronomy Journal. 71:397-401. (INT)

WIGGERS, E. P.; D. L. ROBINETTE; J. R. SWEENEY; R. F. HARLOW; and H. S. HILL, JR. 1980. Predictability of deer forages using overstory measurements. In: Proceedings, Annual Conference Southeastern Association Fish and Wildlife Agencies. 32:187-194. (SE)

\section{Biomass Estimates}

BUECH, RICHARD R.; and DAVID J. RUGG. 1989. Biomass relations of shrub components and their generality. Forest Ecology and Management. 26:257-264. (NC) 
CONNER, RICHARD N.; and KATHLEEN A. O'HALLORAN. 1986. A comparison of the MacArthur foliage density estimate with actual leaf surface area and biomass. Southwestern Naturalist. $31: 270-273$. (SO)

CRAWFORD, HEWLETTE S.; and WARREN L. STUTZMAN. 1983. Microwave attenuation as an indicator of sampling weight of herbaceous and wood plants in the field. Forest Science. 29:726-734. (NE)

DEAN, SHEILA; J. WAYNE BURKHARDT; and RICHARD O. MEEUWIG. 1981. Estimating twig and foliage biomass of sagebrush, bitterbrush, and rabbitbrush in the Great Basin. Journal of Range Management. 34:224-227. (INT)

DEBANO, LEONARD F.; H. M. PERRY; and S. T. OVERBY. 1987. Effects of fuelwood harvesting and slash burning on biomass and nutrient relationships in a pinyon-juniper stand. In: Everett, Richard L., comp. Proceedings--pinyonjuniper conference; 1986 January 13-16; Reno, NV. Gen. Tech. Rep. INT-215. Ogden, UT: U.S. Department of Agriculture, Forest Service, Intermountain Research Station: 382386. (RM)

\section{EBERLEIN, GARY P. 1982. Estimating} growth of young mountain whitethorn shrubs. Res. Note. PSW-357. Berkeley, CA: U.S. Department of Agriculture, Forest Service, Pacific Southwest Forest and Range Experiment Station. $3 \mathrm{p}$. (PSW)
FRISCHKNECHT, NEIL C. 1981. Doublefrequency sampling for inventorying vegetation on salt desert shrub ranges. In: Lund, H. Gyde; Miguel Caballero; R. $H$. Hamre; [and others], tech. coords. Arid land resource inventories: Developing cost-efficient methods: Proceedings of an international workshop; 1980 November 30December 6; La Paz, Mexico. Gen. Tech. Rep. WO-28. Washington, DC: U.S. Department of Agriculture, Forest Service: 435-440. (INT)

GRIGAL, DAVID F.; and LEWIS F. OHMANN. 1977. Biomass estimation for some shrubs from northeastern Minnesota. Res. Note. NC-226. St. Paul, MN: U.S. Department of Agriculture, Forest Service, North Central Forest Experiment Station. 3 p. (NC)

GRIGAL, DAVID F.; and N. R. MOODY. 1980. Estimation of browse by size classes for snowshoe hare. Journal of Wildlife Management. 44:34-40. (NC)

HARNISS, R. O.; and R. B. MURRAY. 1976. Reducing bias in dry leaf weight estimates of big sagebrush. Journal Range of Management. 29:43-432. (INT)

JOHNSON, MARK K. 1986. Estimating ratios of live and dead plant material in clipped plots. Journal of Range Management. 39:90. (SO)

KIE, JOHN G. 1985. Production of deerbrush and mountain whitethorn related to shrub volume and overstory crown closure. Res. Note. PSW-377. Berkeley, CA: U.S. Department of Agriculture, Forest Service, Pacific Southwest Forest and Range Experiment Station. $4 \mathrm{p}$. (PSW) 
MEEUWIG, RICHARD O. 1981. Point sampling for shrub biomass. In: Lund, $\mathrm{H}$. Gyde; Miguel Caballero; R.E. Hamre; [and others], tech. coords. Arid land resource inventories: developing costefficient methods: Proceedings of an international workshop; 1980 November 30-December 6; La Paz, Mexico. Gen. Tech. Rep. WO-28. Washington, DC: U.S. Department of Agriculture, Forest Service: 323-326. (INT)

MITCHELL, JOHN E.; DALE SNYDER; LYNN D. DRAWE; NORMAN R. FRENCH; and JOHN L. CAPINERA. 1986. Assesment of habitat factors. In: Cook, C. Wayne; and James Stubbendieck, eds. Range research: basic problems and techniques. Denver, CO: Society for Range Management: 19-50. Chapter 2. (RM)

O'HALLORAN, KATHLEEN A.; and RICHARD N. CONNER. 1986. A comparison of the MacArthur foliage density estimate with actual leaf surface area and biomass. The Southwestern Naturalist. 31:270-273. (SO)

OHMANN, LEWIS F.; D. F. GRIGAL; and R. B. BRANDER. 1976. Biomass estimation for five shrubs from northeastern Minnesota. Res. Pap. NC133. St. Paul, MN: U.S. Department of Agriculture, Forest Service, North Central Forest Experiment Station. $11 \mathrm{p}$. (NC)

OHMANN, LEWIS F.; DAVID F. GRIGAL; and LYNN L. ROGERS. 1981. Estimating plant biomass for undergrowth species of northeastern Minnesota. Gen. Tech. Rep. NC-61. St. Paul, MN: U.S. Department of Agriculture, Forest Service, North Central Forest Experiment Station. 10 p. (NC)
PLATTS, WILLIAM S.; WALTER F. MEGAHAN; and WAYNE G. MINSHALL. 1983. Methods for evaluating stream, riparian, and biotic conditions. Gen. Tech. Rep. INT-138. Ogden, UT: U.S. Department of Agriculture, Forest Service, Intermountain Forest and Range Experiment Station. 70 p. (INT)

STONE, T. L.; and H. S. CRAWFORD, JR. 1981. Estimating foliage and twig weight of spruce and fir. Journal of Wildlife Management. 45:280-281. (NE)

STUTZMAN, W. L.; F. W. COLLIVER; and H. S. CRAWFORD. 1977. Electromagnetic propagation measurenents for estimating the weight of standing forest vegetation. In: Proceedings, International Institute of Electrical and Electronics Engineers Society, Antennas and Propagation; AP-102. Stanford, CA: Stanford University. (NE)

STUTZMAN, W. L.; F. W. COLLIVER; and H. S. CRAWFORD. 1979. Microwave transmission measurements for estimation of the weight of standing pine trees. In: Proceedings, International Institute of Electrical and Electronics Engineers Society, Antennas and Propagation; Stanford, CA: Stanford University. 1:22-26. (NE)

STUTZMAN, WARREN L.; and HEWLETTE S. CRAWFORD. 1985. Estimation of the weight of vegetation using microwave transmission measurements. In: Carver, K. R., ed. Digest, Remote sensing instrumentation: Technology for science and application; International Geoscience and Remote Sensing Symposium; 1985 October 7-9; Amherst, MA: The Institute of Electrical and Electronics Engineers, Inc.: 164167. Volume 1. (NE) 
STUTZMAN, WARREN L.; and HEWLETTE

S. CRAWFORD. 1986. Estimation of the weight of vegetation using microwave transmission measurements. In: Institute of Electrical and Electronics Engineers transactions on Geoscience and Remote Sensing., Inc.: GE-24(6):10171020. (NE)

TERRY, W. STEVEN; DENNIS H. HUNTER; and BENEE F. SWINDEL. 1981. Herbage capacitance meter: An evaluation of its accuracy in Florida rangelands. Journal of Range Management. 34:240-241. (SE) 


\section{Animal Taxonomy}

BAQAI, I. U.; and M. WARIAUZZAMAN. 1977. Taxonomy and relative abundance of some wild animals in southwest of Insus-delta. Journal of Science. 3:23-29. (RM)

JENKINS, J. MARK. 1983. The native forest birds of Guam. Ornithology Monog. No. 31. Washington, DC: American Ornithologists' Union. 61 p. (PSW)

JOHNSON, MURRAY L.; and CHRIS MASER. 1982. Generic relationships of Phenacomys albipes. Northwest Science. 56:17-19. (PNW)

LEHMKUHL, JOHN F.; DAVID R. PATTON; and RICHARD P. MARTIN. 1983. Revised vertebrate checklist for Arizona and New Mexico. RUN WILD wildlife/habitat relationships. Wildlife Unit Tech. Rep. Albuquerque, NM: U.S. Department of Agriculture, Forest Service, Southwestern Region. 83 p. (RM)

MASER, CHRIS; BRUCE R. MATE; JERRY F. FRANKLIN; and C. T. DYRNESS. 1981. Natural history of Oregon coast mammals. Gen. Tech. Rep. PNW-133. Portland, OR: U.S. Department of Agriculture, Forest Service, Pacific Northwest Forest and Range Experiment Station. 496 p. (PNW)

MEDINA, ALVIN LEROY. 1988. An EnglishSpanish glossary of terminology used in forestry, range, wildlife, soils, and botany. Gen. Tech. Rep. RM-152. Fort Collins, CO; U.S. Department of Agriculture, Forest Service, Rocky Mountain Forest and Range Experiment Station. 54 p. (RM)

MORRIS, M. J.; V. H. REID; R. E. PILLMORE; and M. C. HAMMER. 1977. Birds and mammals of Manitou Experimental Forest, Colorado. Gen. Tech. Rep. RM-38. Fort Collins, CO: U.S. Department of Agriculture, Forest Service, Rocky Mountain Forest and Range Experiment Station. 17 p. (RM)
PATTON, DAVID R. 1978. Vertebrate checklist for Arizona and New Mexico. Wildlife Habitat Tech. Bull. No. 5. Albuquerque, NM: U.S. Department of Agriculture, Forest Service, Southwest Region. 25 p. (RM)

RAISANEN, R. A.; and J. K. WERNER. 1977. A survey of fishes of the McCormick Forest. Res. Pap. NC-147. Fort Collins, CO: U.S. Department of Agriculture, Forest Service, Rocky Mountain Forest and Range Experiment Station. $10 \mathrm{p}$. (NC)

TAYLOR, CATHY A.; and MARTIN G. RAPHAEL. 1988. Identification of mammal tracks from sooted track stations in the Pacific Northwest. California Fish and Game. 74(1):4-15. (RM)

\section{Animal Interactions}

ARENDT, WAYNE J. 1986. An observation of iguana feeding on eggs of the cattle egret (Bubulcus ibis) at Fox's Bay, Montserrat, West Indies: a case of predation or scavenging? Caribbean Journal of Science. 22:221-222. (SO)

ARENDT, WAYNE J. 1986. Bat predation by the St. Lucia boa (Boa constrictor orophias). Caribbean Journal of Science. 22:219-220. (SO)

BJUGSTAD, ARDELL J.; DANIEL W. URESK; and R. H. HAMRE, tech. coords. 1989. Ninth Great Plains wildlife damage control workshop proceedings; 1989 April 17-20; Fort Collins, CO: Gen. Tech. Rep. RM-171. Fort Collins, CO: U.S. Department of Agriculture, Forest Service, Rocky Mountain Forest and Range Experiment Station. 181 p. (RM)

BLUM, BARTON M. 1976. Animal damage to young spruce and fir in Maine. Res. Note NE-231. Broomall, PA: U.S. Department of Agriculture, Forest Service, Northeastern Forest Experiment Station. (NE) 
BRYANT, FRED S.; FRED S. GUTHERY; and WILLIAM M. WEBB. 1981. Grazing management in Texas and its impact on selected wildlife. In: Peek, James A.; and P. D. Dalke, eds. Proceedings, Wildlife-livestock relationships symposium; 1981 April 20-22; Coeur d'Alene, ID. Moscow, ID: University of Idaho; Forest, Wildlife and Range Experiment Station: 94-112. (RM)

BRYANT, LARRY D.; and JON M. SKOVLIN. 1982. Effect of grazing strategies and rehabilitation on an eastern Oregon stream. In: Habitat disturbance and recovery: Proceedings of a symposium; 1981 January 29; San Luis Obispo, CA. San Francisco, CA: California Trout, Inc. 1982:27-30. (PNW)

BUCKHOUSE, J. C.; and C. C. BOHN. 1983. Response of coliform bacteria concentration to grazing management. In: 1983 progress report--research in rangeland management. Special Report 682. Corvallis, OR: Agricultural Experiment Station, Oregon State University: 1983:1-7. In cooperation with: U.S. Department of Agriculture, Agricultural Research Service. (PNW)

CINCOTTA, RICHARD P.; DANIEL W. URESK; and RICHARD M. HANSEN. 1989. Plant compositional change in a colony of black-tailed prairie dogs in South Dakota. In: Bjugstad, Ardell J.; Daniel W. Uresk; and R. H. Hamre, tech. coords. 9th Great Plains wildlife damage control workshop proceedings; 1989 April 17-20; Gen. Tech. Rep. RM-171. Fort Collins, CO: U.S. Department of Agriculture, Forest Service, Rocky Mountain Forest and Range Experiment Station: 171-177. (RM)

\section{CLARY, WARREN P.; and DONALD M.}

BEALE. 1983. Pronghorn reactions to winter sheep grazing, plant communities, and topography in the Great Basin. Journal of Range Management. 36:749-752. (INT)
CLARY, WARREN P.; and RALPH C. HOLMGREN. 1981. Observations of pronghorn distribution in relation to sheep grazing on the Desert Experimental Range. In: Peek, James A.; and P. D. Dalke, eds. Proceedings, wildlife-livestock relationships symposium; 1981 April 20-22; Coeur d'Alene, ID. Moscow, ID: University of Idaho; Forest, Wildlife and Range Experiment Station: 581-592. (INT)

CLARY, WARREN P.; and RALPH C. HOLMGREN. 1987. Difficulties in interpretation of long-term vegetation trends in response to livestock grazing. In: Provenza, Frederick D.; Jerran T. Flinders; and E. Durant McArthur, comps. Proceedings--symposium on plant-herbivore interactions; 1985 August 7-9; Snowbird, UT. Gen. Tech. Rep. INT-222. Ogden, UT: U.S. Department of Agriculture, Forest Service, Intermountain Research Station: 154-161. (INT)

COLE, DAVID N. 1987. Effects of three seasons of experimental trampling on five montana forest communities and a grassland in western Montana, USA. Biological Conservation. 40:219-244. (INT)

COLE, DAVID N. 1988. Disturbance and recovery of trampled montane grassland and forests in Montana. Res. Pap. INT389. Ogden, UT: U.S. Department of Agriculture, Forest Service, Intermountain Research Station. 37 p. (INT)

CRAWFORD, HEWLETTE S. 1984. Silvicultural practices and bird predation on spruce budworm. Forest Techniques. 84(9):12. (NE)

CRAWFORD, HEWLETTE S.; and D. T. JENNINGS. 1982. Relationships of birds and spruce budworm--literature review and annotated bibliography. BLA No. 24. Washington, DC: U.S. Department of Agriculture. 38 p. (NE) 
CRAWFORD, HEWLETTE S.; R. W.

TITTERINGTON; and D. T. JENNINGS. 1983. Bird predation and spruce budworm populations. Journal of Forestry. 81:433-435, 478. (NE)

CROUCH, GLENN L. 1978. Effects of protection from livestock grazing on a bottomland wildlife habitat in northeastern Colorado. In: Proceedings, lowland river and stream habitat in Colorado. 1978 October 4-5, Greeley, CO: 118-125. (RM)

CROUCH, GLENN L. 1982. Pocket gophers and reforestation on western forests. Journal Forestry. 80:662-664. (RM)

CROUCH, GLENN L. 1986. Pocket gopher damage to conifers in western forests: A historical and current perspective of the problem. In: Salman, T. P., ed. 12th vertebrate pest conference; 1986 March 4-6; San Diego, CA. Davis, CA: University of California: 196-198. (RM)

DEBYLE, NORBERT V. 1985. Animal impacts. In: DeByle, Norbert V.; and Robert P. Winokur, eds. Aspen: Ecology and management in the Western United States. Gen. Tech. Rep. RM-119. Fort Collins, CO: U.S. Department of Agriculture, Forest Service, Rocky Mountain Forest and Range Experiment Station: 115-123. (INT)

DEISCH, MICHELE S.; DANIEL W. URESK; and RAYMOND L. LINDER. 1989. Effects of two prairie dog rodenticides on ground-dwelling invertebrates in western South Dakota. In: Bjugstad, Ardell J.; Daniel W. Uresk; and R. H. Hamre, tech. coords. 9th Great Plains wildlife damage control workshop proceedings; 1989 April 17-20; Fort Collins, CO. Gen. Tech. Rep. RM-171. Fort Collins, CO: U.S. Department of Agriculture, Forest Service, Rocky Mountain Forest and Range Experiment Station: 166-170. (RM)
DRAGT, W. T.; and K. M. HAVSTAD. 1987. Effects of cattle grazing upon chemical constituents within important forages for elk. Northwest Science. 61:70-73. (INT)

EDGERTON, PAUL J. 1987. Influence of ungulates on the development of the shrub understory of an upper slope mixed conifer forest. In: Provenza, Frederick D.; Jerran T. Flinders; and E. Durant McArthur, comps. Proceedings-symposium on plant-herbivore interactions; 1985 August 7-9; Snowbird, UT. Gen. Tech. Rep. INT-222. Ogden, UT: U.S. Department of Agriculture, Forest Service, Intermountain Research Station: 162-167. (PNW)

EISSENSTAT, D. M.; J. E. MITCHELL; and W. W. POPE. 1982. Trampling damage by cattle on northern Idaho forest plantations. Journal of Range Management. 35:715-716. (RM)

EVANS, JAMES. 1982. General biology of ten mammals that affect reforestation in southwestern Oregon. In: Hobbs, S. D.; and $\mathrm{O}$. T. Helgerson eds. Reforestation of skeletal soils: Proceedings of a workshop; 1981 November 17-19; Medford, OR. Corvallis, OR: Oregon State University, Forest Research Laboratory: 30-36. (PNW)

EVANS, JAMES; DAN L. CAMPBELL; GERALD D. LINDSEY; VICTOR G. BARNES, JR.; and ANTHONY R. MICHAEL. 1981. Distribution of animal damage in southwestern Oregon forests. Wildlife Leaf. 514. Washington, DC: U.S. Department of the Interior, Fish and Wildlife Service. 12 p. (PNW)

GRIFFEL, DAVID E.; and JOSEPH V. BASILE. 1981. Identifying sheep killed by bears. Res. Note INT-313. Ogden, UT: U.S. Department of Agriculture, Forest Service, Intermountain Forest and Range Experiment Station. 3 p. (INT) 
HANLEY, THOMAS A. 1987. Physical and chemical response of understory vegetation to deer use in southeastern Alaska. Canadian Journal of Forestry Research. 17:195-199. (PNW)

HANLEY, THOMAS A.; and JERRY L. PAGE. 1982. Differential effects of livestock use on habitat structure and rodent populations in Great Basin communities. California Fish and Game. 68:160-173. (INT)

HILL, EDWARD P.; DOUGLAS N. LASHER; and R. BLAKE ROPER. 1978. A review of techniques for minimizing beaver and white-tailed deer damage in southern hardwoods. In: Proceedings, 2nd symposium southeast hardwoods: 7993. (SO)

HINGTEN, TERRENCE M.; and WILLIAM R. CLARK. 1986. Impact of small mammals on the vegetation of reclaimed land in the Northern Great Plains. Journal of Range Management. 37:438-441. (RM)

HOLT, COLEMAN. 1980. Impacts of high deer population on forest regeneration and herd condition in the Allegheny hardwood region of Pennsylvania. The Allegheny News, Allegheny Section, Society of American Foresters. Winter. 2 p. (SE)

JENNINGS, DANIEL T.; and HEWLETTE S. CRAWFORD. 1985. Predators of the spruce budworm. Agric. Handb. 644. Washington, DC: U.S. Department of Agriculture. 77 p. (NE)

JOHNSON, STEVEN R.; HOWARD L. GARY; and STANLEY L. PONCE. 1978. Range cattle impacts on stream water quality in the Colorado Front Range. Res. Note RM-359. Fort Collins, CO: U.S. Department of Agriculture, Forest Service, Rocky Mountain Forest and Range Experiment Station. 8 p. (RM)
KINGERY, JAMES L.; and RUSSELL T. GRAHAM. 1987. Cattle grazing and forest animal damage interaction. In: Animal damage management in Pacific Northwest forests: Proceedings of symposium; 1987 March 25-27; Spokane, WA. Pullman, WA: Washington State University, Cooperative Extension. 119-132. (INT)

KINGERY, JAMES L.; RUSSELL T. GRAHAM; and JEFFREY S. WHITE. 1987. Damage to first-year conifers under three livestock grazing intensities in Idaho. Res. Pap. INT-376. Ogden, UT: U.S. Department of Agriculture, Forest Service, Intermountain Research Station. 8 p. (INT)

KULHAVY, D. L.; J. H. MITCHELL; and RICHARD N. CONNER. 1988. The southern pine beetle and red-cockaded woodpecker: Potential for interaction. In: Payne, T. L.; and H. Saarenmaa, eds. Integrated control of scolytid bark beetles: Proceedings symposium; XVII International Congress of Entomology; Vancouver, British Columbia: 337-343. (SO)

LEFTWICH, TIMOTHY J.; and C. DAVID SIMPSON. 1978. The impact of domestic livestock and farming on Texas pronghorn. In: Proceedings, 8th biennial pronghorn antelope workshop; 1978 May 2-4; Jasper, Alberta: Alberta Recreation, Parks and Wildlife, Fish and Wildlife Division: 307-320. (RM)

LEWIS, CLIFFORD E. 1980. Simulated cattle injury to planted slash pine: combinations of defoliation, browsing, and trampling. Journal of Range Management. 33:340-345. (SE)

LEWIS, CLIFFORD E. 1980. Simulated cattle injury to planted slash pine: effects of defoliation. Journal of Range Management. 33:345-348. (SE)

LEWIS, CLIFFORD E. 1980. Simulated cattle injury to planted slash pine: effects of girdling. Journal of Range Management. 33:337-340. (SE) 
LOFT, ERIC R.; JOHN W. MENKE; and JOHN G. KIE. 1986. Interaction of cattle and deer on mountain rangeland. California Agriculture. 40:6-9. (PSW)

LOFT, ERIC R.; JOHN W. MENKE; JOHN G. KIE; and RON C. BERTRAM. 1987. Influence of cattle stocking rate on the structural profile of deer hiding cover. Journal of Wildlife Management. 51:655664. (PSW)

LONGHURST, WILLIAM M.; ANTHONY L. LESPERANCE; MORSE MARK; RICHARD J. MACKIE; DONALD L. NEAL; HAL SALWASSER; DEANE SWICKARD; PAUL T. TUELLER; PHILLIP J. URNESS; and JAMES D. YOAKUM. 1983. Livestock and wild ungulates. In: Menke, John W., ed. Proceedings, workshop on livestock and wildlife-fisheries relationships in the Great Basin; 1977 May 3-5; Sparks, NV. Spec. Publ. 3301. Berkeley, CA: Division of Agricultural Sciences, University of California: 42-64. (PSW)

MALAJCZUK, N.; J. M. TRAPPE; and R. MOLINA. 1987. Interrelationships among some ectomycorrhizal trees, hypogeous fungi and small mammals: Western Australian and northwestern American parallels. Australian Journal of Ecology. 12:53-55. (PNW)

MARBLE, JAMES R.; and KIMBALL T. HARPER. 1989. Effect of timing of grazing on soil-surface cryptogamic communities in a Great Basin low-shrub desert: a preliminary report. Great Basin Naturalist. 49:104-107. (INT)

MARQUIS, DAVID A. 1981. Effect of deer browsing on timber production in Allegheny hardwood forests of Northwestern Pennsylvania. Res. Pap. NE-475. Broomall, PA: U.S. Department of Agriculture, Forest Service, Northeastern Forest Experiment Station. 10 p. (NE)
MARQUIS, DAVID A. 1987. Silvicultural techniques for circumventing deer browsing. In: Deer, forestry, and agriculture: interactions and strategies for management; 1987 June 15-17; Warren, PA. Erie, PA: Plateau and Northern Hardwood Chapters, Allegheny Society of American Foresters: 125-136. (NE)

MARQUIS, DAVID A.; and RONNIE BRENNEMAN. 1981. The impact of deer on forest vegetation in Pennsylvania. Gen. Tech. Rep. NE-65. Broomall, PA: U.S. Department of Agriculture, Forest Service, Northeastern Forest Experiment Station. 7 p. (NE)

MARTIN, S. CLARK. 1979. Evaluating the impacts of cattle grazing on riparian habitats in the national forests of Arizona and New Mexico. In: Cope, Oliver B., ed. Proceedings of the forum-grazing and riparian/stream ecosystems. 1978 November 3-4; Denver, CO: Trout Unlimited: 35-38. (RM)

MASER, CHRIS; and ZANE MASER. 1988. Interactions among squirrels, mycorrhizal fungi, and coniferous forests in Oregon. Great Basin Naturalist. 48:358-369. (PNW)

MASER, CHRIS; JAMES M. TRAPPE; and DOUGLAS C. URE. 1978. Implications of small mammal mycophagy to the management of western coniferous forests. Transactions of the North American Wildlife and Natural Resources Conference. 43:78-88. (PNW)

MASER, CHRIS; JAMES M. TRAPPE; and RONALD A. NUSSBAUM. 1978.

Fungal-small mammal interrelationships with emphasis on Oregon coniferous forests. Ecology. 59:799-809. (PNW) 
MCARTHUR, E. DURANT; A. CLYDE BLAUER; and STEWART C.

SANDERSON. 1988. Mule deer-induced mortality of mountain big sagebrush.

Journal of Range Management. 41:114117. (INT)

MCARTHUR, E. DURANT; STEPHEN B. MONSEN; and DEAN E. MEDIN. 1986. Grazing and passerine breeding birds in a Great Basin low-shrub desert. Great Basin Naturalist. 46:567-572. (INT)

MECH, L. DAVID; and PATRICK D. KARNS. 1977. Role of the wolf in a deer decline in the Superior National Forest. Res. Pap. NC-148. St. Paul, MN: U.S. Department of Agriculture, Forest Service, North Central Forest Experiment Station. 23 p. (NC)

MECH, L. DAVID; STEVEN H. FRITTS; and WILLIAM J. PAUL. 1988. Relationship between winter severity and wolf depredations on domestic animals in Minnesota. The Wildlife Society Bulletin. 16:269-272. (NC)

MEDIN, DAVID E. 1986. Grazing and passerine breeding birds in a Great Basin low-shrub desert. Great Basin Naturalist. 46:557-572. (INT)

MEEHAN, WILLIAM R.; and WILLIAM S. PLATTS. 1978. Livestock grazing and the aquatic environment. Journal of Soil and Water Conservation. 33:274-278. (PNW)

NELSON, MICHAEL E.; and L. DAVID MECH. 1981. Deer social organization and wolf predation in Northeastern Minnesota. Wildlife Monographs No. 77. Washington, DC: The Wildlife Society. 53 p. (NC)

NELSON, MICHAEL E.; and L. DAVID MECH. 1984. Observation of a swimming wolf killing a swimming deer. Journal of Mammalogy. 65:143-144. (NC)
NORTON, BRIEN E. 1978. The impact of sheep grazing on long-term successional trends in salt desert shrub vegetation of southwestern Utah. In: Hyder, Donald N., ed. Proceedings, 1st international rangeland congress; 1978 August 14-18; Denver, CO: Society for Range Management: 610-613. (INT)

NOWAKOWSKI, NANCY A.; PETER F. FFOLLIOTT; and DAVID R. PATTON. 1982. Livestock-wildlife interactions in the Southwest. RUN WILD wildlife/habitat relationships. Wildlife Unit Tech. Rep. Albuquerque, NM: U.S. Department of Agriculture, Forest Service, Southwestern Region. $10 \mathrm{p}$. (RM)

PATRIC, JAMES H.; and J. D. HELVEY. 1986. Some effects of grazing on soil and water in the Eastern forest. Gen. Tech. Rep. NE-115. Broomall, PA: U.S. Department of Agriculture, Forest Service, Northeastern Forest Experiment Station. 25 p. (NE)

PLATTS, WILLIAM S. 1978. Livestock interactions with fish and aquatic environments: problems in evaluation. Transactions of the North American Wildlife and Natural Resources Conference. 43:498-504.(INT)

PLATTS, WILLIAM S. 1979. Livestock interactions with fish and their environments: a symposium summary. Cal-Neva Wildlife Transactions. 1978:92-96. (INT)

PLATTS, WILLIAM S. 1979. Livestock grazing and riparian/stream ecosystems--An overview. In: Cope, Oliver B., ed. Proceedings, Forum-grazing and riparian/stream ecosystems. Trout Unlimited, Inc: 39-45. (INT) 
PLATTS, WILLIAM S. 1981. Effects of livestock grazing. In: Meehan, William R.; tech. ed. Influence of forest and rangeland management on anadromous fish habitat in western North America. Gen. Tech. Rep. PNW-124. Portland, OR: U.S. Department of Agriculture, Forest Service, Pacific Northwest Forest and Range Experiment Station. 25 p. Chapter 7. (INT)

PLATTS, WILLIAM S. 1981. Effects of sheep grazing on a riparian-stream environment. Res. Note. INT-307. Ogden, UT: U.S. Department of Agriculture, Forest Service, Intermountain Forest and Range Experiment Station. 6 p. (INT)

PLATTS, WILLIAM S. 1981. Sheep and streams. Rangelands. 3:158-160. (INT)

PLATTS, WILLIAM S. 1981. Sheep and cattle grazing strategies on riparian-stream environments. In: Peek, James A.; and P. D. Dalke, eds. Proceedings, wildlifelivestock relationships symposium; 1981 April 20-22; Coeur d'Alene, ID. Moscow, ID: University of Idaho; Forest, Wildlife and Range Experiment Station: 251270. (INT)

PLATTS, WILLIAM S. 1982. Livestock and riparian-fishery interactions: what are the facts. Transactions of the North American Wildlife and Natural Resources Conference. 47:507-515. (INT)

PLATTS, WILLIAM S.; and RODGER LOREN NELSON. 1985. Impacts of rest-rotation grazing on stream banks in forested watersheds in Idaho. North American Journal of Fisheries Management. 5:547-556. (INT)

PLATTS, WILLIAM S.; and SUSAN B. MARTIN. 1980. Livestock grazing and logging effects on trout. In: Proceedings of wild trout II; 1979 September 24-25; Yellowstone National Park, WY. Trout Unlimited and Federation of Fly

Fishermen: 34-46. (INT)
PLATTS, WILLIAM S.; ROBERT J. BEHNKE; JOHN C. BUCKHOUSE; OSBORNE E. CASEY; ERROL W. CLAIRE; JAMES COPPER; DONALD A. DUFF; WILLIS A. EVANS; GORDON HAUGEN; PATE. MARCUSON; WILLIAM R. MEEHAN; ROBERT W. PHILLIPS; ROBERT F. RALEIGH; and JON M. SKOVLIN. 1977. Livestock interactions with fish and their environments. In: Menke, John W., ed. Livestock and wildlife-fisheries relationships in the Great Basin: Proceedings of a workshop; 1977 May 3-5; Sparks, NV. Special Publication. 3301. Berkeley, CA: University of California: 36-41. (INT)

PROVENZA, FREDERICK D.; JERRAN T. FLINDERS; and E. DURANT MCARTHUR, comps. 1987. Proceedings--Symposium on plantherbivore interactions. 1985 August 7-9; Snowbird UT. Gen. Tech. Rep. INT-222. Ogden, UT: U.S. Department of Agriculture, Forest Service, Intermountain Forest and Range Experiment Station. 179 p. (INT)

REDDING, JIM. 1987. Impact of deer on forest vegetation and timber production in northern Pennsylvania. In: Deer, forestry, and agriculture: interactions and strategies for management; 1987 June 15-17; Warren, PA. Erie, PA: Plateau and Northern Hardwood Chapters, Allegheny Society of American Foresters: 23-32. (NE)

RINNE, JOHN N. 1988. Effects of livestock grazing exclosure on aquatic macroinvertebrates in a montane stream, New Mexico. Great Basin Naturalist. 48:146-153. (RM)

RINNE, JOHN N. 1988. Grazing effects on stream habitat and fishes: research design consideration. North American Journal of Fisheries Management. 8:240-247. (RM) 
RINNE, JOHN N.; and T. THARLSON. 1987. Effects of domestic livestock grazing on montane streams: Aquatic

macroinvertebrates. In: Proceedings of the Annual Conference of the Western Association of Fish and Wildlife Agencies; 1986 July 20-23; Portland, OR. Sacramento, CA: Western Association of Fish and Wildlife Agencies. 66:91-98. (RM)

ROATH, LEONARD ROY; and WILLIAM C. KRUEGER, 1982. Cattle grazing influence on a mountain riparian zone. Journal of Range Management. 35:100103. (RM)

RODRIQUEZ, RONALD L.; and BRUCE L. WELCH. 1989. Effects of heavy grazing by mule deer on Hobble Creek mountain big sagebrush seed stalk production. In: Wallace, Arthur; E. Durant McArthur; and Marshall R. Haferkamp, comps. Proceedings--symposium on shrub ecophysiology and biotechnology; 1987 June 30-July 2; Logan, UT. Gen. Tech. Rep. INT-256. Ogden, UT: U.S. Department of Agriculture, Forest Service, Intermountain Research Station: 141-143. (INT)

ROGERS, LYNN L.; and L. DAVID MECH. 1981. Interactions of wolves and black bears in northeastern Minnesota. Journal of Mammalogy. 62:434-436. (NC)

SAMSON, FRED B.; FRITZ L. KNOPF; and LISA B. HASS. 1988. Small mammal response to the introduction of cattle into a cottonwood floodplain. In: Szaro, Robert C.; Kieth E. Severson; and David R. Patton, tech. coords. Management of amphibians, reptiles, and small mammals in North America: Proceedings of the symposium; 1988 July 19-21; Flagstaff, AZ. Gen. Tech. Rep. RM-166. Fort Collins, CO: U.S. Department of Agriculture, Forest Service, Rocky Mountain Forest and Range Experiment Station: 432-438. (PNW)
SCHOLL, DAVID G. 1989. Soil compaction from cattle trampling on a semiarid watershed in northwest New Mexico. New Mexico Journal of Science. 29(2):105-112. (RM)

SCOWCROFT, PAUL G. 1983. Tree cover changes in mamane Sophora chrysophylla forests grazed by sheep and cattle. Pacific Science. 37(2):109119. (PSW)

SCOWCROFT, PAUL G.; and HOWARD F. SAKAI. 1983. Impact of feral herbivores on mamane forests of Mauna Kea, Hawaii: bark stripping and diameter class structure. Journal of Range Management. 36:495-498. (PSW)

SCOWCROFT, PAUL G.; and JON G. GIFFIN. 1983. Feral herbivores suppress mamane and other browse species on Mauna Kea, Hawaii. Journal of Range Management. 36:638-645. (PSW)

SIEG, CAROLYN HULL. 1988. Small mammals: pests or vital components of the ecosystem. In: Uresk, Daniel W.; Greg L. Schenbeck; and Rose Cefkin, tech. coords. 8th Great Plains wildlife damage control workshop proceedings; 1987 April 28-30; Rapid City, SD. Gen. Tech. Rep. RM-154. Fort Collins, CO: U.S. Department of Agriculture, Forest Service, Rocky Mountain Forest and Range Experiment Station: 88-92. (RM)

SINGER, FRANCIS J.; WAYNE T. SWANK; and EDWARD E. C. CLEBSCH. 1982. Some ecosystem responses to European wild boar rooting in a deciduous forest. Res./Res. Manage. Rep. 54. Gatlinburg, TN: U.S. Department of the Interior, National Park Service, Great Smoky Mountains National Park. 31 p. (SE) 
SKINNER, THOMAS H.; and JAMES O. KLEMMEDSON. 1978. Abert squirrels influence nutrient transfer through litterfall in a ponderosa pine forest. Res. Note. RM-353. Fort Collins, CO: U.S. Department of Agriculture, Forest Service, Rocky Mountain Forest and Range Experiment Station. 8 p. (RM)

SKOVLIN, JON M.; WILLIAM R. MEEHAN; JOHN C. BUCKHOUSE; and MARTIN VAVRA. 1977. Determining the influence of grazing on riparian and aquatic habitats in the Blue Mountains of northeastern Oregon. In: Menke, John W., ed. Livestock and wildlife-fisheries relationships in the Great Basin: Proceedings of a workshop; 1977 May 3-5, Sparks, NV. Spec. Publ. 3301. Berkeley, CA: University of California, Division of Agricultural Sciences: 164169. (PNW)

SZARO, ROBERT C.; and CHARLES P. PASE. 1983. Short-term changes in a cottonwood-ash-willow association on a grazed and an ungrazed portion of Little Ash Creek in central Arizona. Journal of Range Management. 36:382-384. (RM)

THILL, RONALD E.; ALTON MARTIN, JR.; HERSHEL F. MORRIS, JR.; and DIBUCE E. MCCUNE. 1987. Grazing and burning impacts on deer diets on Louisiana pine-bluestem range. Journal of Wildlife Management. 51: 873-880. (SO)

TISCHENDORF, JAY S. W.; CATHERINE FRAZER; and TERYL G. GRUBB. 1987. Interactions between bald eagles (Haliaeetus leucocephalus: Accipitridae) and river otters (Lutra canadensis:

Mustelidae). The Southwestern

Naturalist. 32:286-287. (RM)
URESK, DANIEL W. 1987. Effects of livestock grazing and thinning of overstory trees on understory woody plants. In: Provenza, Frederick D.; Jerran T. Flinders; and E. Durant McArthur, comps. Proceedings-symposium on plant-herbivore interactions; 1985 August 7-9; Snowbird UT. Gen. Tech. Rep. INT-222. Ogden, UT: U.S. Department of Agriculture, Forest Service, Intermountain Forest and Range Experiment Station: 168171. (RM)

URESK, DANIEL W.; and ARDELL J. BJUGSTAD. 1981. Effects of prairie dogs and cattle on vegetation of the northern high plains. 1981 May 3; South Dakota Stockgrowers Association. (RM)

URESK, DANIEL W.; and GREG L. SCHENBECK. 1987. Effect of zinc phosphide rodenticide on prairie dog colony expansion as determined from aerial photography. Prairie Naturalist. 19:57-61. (RM)

URESK, DANIEL W.; GREG L.

SCHENBECK; and ROSE CEFKIN, tech. coords. 1988. Proceedings, 8th Great Plains wildlife damage control workshop. Gen. Tech. Rep. RM-154. Fort Collins, CO: U.S. Department of Agriculture, Forest Service, Rocky Mountain Forest and Range Experiment Station. 231 p. (RM)

URESK, DANIEL W.; JAMES G. MACCRACKEN; and ARDELL J. BJUGSTAD. 1982. Prairie dog density and cattle grazing relationships. In: Proceedings, 5th Great Plains wildlife damage control workshop; 1981 October 13-15; Lincoln, NE: University of Nebraska, Institute of Agriculture and Natural Resources: 199-201. (RM) 
URESK, DANIEL W.; RUDY M. KING; ANTHONY D. APA; MICHELE S. DEISCH; and RAYMOND L. LINDER. 1988. Rodenticidal effects of zinc phosphide and strychnine on nontarget species. In: Uresk, Daniel W.; Greg L. Schenbeck; and Rose Cefkin, tech. coords. 8th Great Plains wildlife damage control workshop proceedings; 1987 April 28-30; Rapid City, SD. Gen. Tech. Rep. RM-154. Fort Collins, CO: U.S. Department of Agriculture, Forest Service, Rocky Mountain Forest and Range Experiment Station: 57-63. (RM)

URSIC, S. J.; and ROBERT J. ESHER. 1988. Influence of small mammals on stormflow responses on pine-covered catchments. Water Resource Bulletin. 24:133-139. (SO)

WOLFF, JERRY O. 1978. Burning and browsing effects on willow growth in interior Alaska. Journal of Wildlife Management. 42:135-140. (PNW)

WOLFF, JERRY O. 1980. Moose-snowshoe hare competition during peak hare densities. Proceedings of the North American Moose Conference and Workshop. 16:1-18. (PNW)

\section{General Wildlife Habitat Requirements}

ALLEN, CHARLES E.; and JAMES G. DICKSON. 1983. Development and impact of an industrial wildlife program. Proceedings of the Annual Conference of the Southeastern Association of Fish and Wildilife Agencies. 37:8-13. (SO)

\section{ANTHONY, ROBERT G.; E. CHARLES} MESLOW; and DAVID S. DECALESTA. 1987. The role of riparian zones for wildlife in westside Oregon forests-what we know and don't know. Tech. Bull. 514. National Council of the Paper Industry for Air and Stream Improvement. 8 p. (PNW)
BASILE, JOSEPH. 1982. Wildlife. In: Benson, Robert E., ed. Management consequences of alternative harvesting and residue treatment practices-lodgepole pine. Gen. Tech. Rep. INT132. Ogden, UT: U.S. Department of Agriculture, Forest Service, Intermountain Forest and Range Experiment Station: 26-28. (INT)

BOLEN, ERIC G. 1982. Playa wetlands of the U.S. southern high plains: their wildlife values and challenges for management. In: Gopal, Brij; R. Eugene Turner; Robert G. Wetzel; and Dennis F. Whigham, eds. Wetlands ecology and management: Proceedings, international wetlands conference; 1980 September 10-17; New Delhi, India: National Institute of Ecology and International Scientific Publications: 9-20. (RM)

BROMLEY, MARIANNE. 1985. Wildlife management implications of petroleum exploration and development in wildland environments. Gen. Tech. Rep. INT191. Ogden, UT: U.S. Department of Agriculture, Forest Service, Intermountain Forest and Range Experiment Station. 42 p. (INT)

BROOKS, ROBERT T. 1983. Vermont's first forest-wildlife habitat assessment. Habitat Highlights. 3(3):4. (NE)

BROOKS, ROBERT T.; and T. W. Birch. 1986. Opportunities and constraints for wildlife habitat management on private forests of the Northeast. Northern Journal of Applied Forestry. 3:109-113. (NE)

BROOKS, ROBERT T.; and DAWN M. DIOVANNI. 1989. Forest wildlife habitat statistics for Maryland and Delware-1986. Res. Bull. NE-110. Broomall, PA: U.S. Department of Agriculture, Forest Service, Northeastern Forest Experiment Station. 137 p. (NE) 
BROOKS, ROBERT T.; THOMAS S.

FRIESWYK; and ANNE M. MALLEY.

1987. Forest wildlife habitat statistics for

Vermont--1983. Res. Bull. NE-100.

Broomall, PA: U.S. Department of

Agriculture, Forest Service,

Northeastern Forest Experiment Station.

(NE)

BROWN, E. READE, ed. 1985. Management of wildlife and fish habitats in forests of Western Oregon and Washington: Part 1--Chapter narratives. Portland, OR: U.S. Department of Agriculutre, Forest Service, Pacific Northwest Region. 332 p. (PNW)

BROWN, E. READE, ed. 1985. Management of wildlife and fish habitats in forests of Western Oregon and Washington: Part 2--Appendices. Portland, OR: U.S. Department of Agriculutre, Forest Service, Pacific Northwest Region. 302 p. (PNW)

BUECH, RICHARD R.; LYNN L. ROGERS; and L. DAVID MECH. 1980. People and wildlife--bringing them together. Nature. 31(4):12-20. (NC)

CAREY, ANDREW B. 1981. Multivariate analysis of niche, habitat, and ecotope. In: Capen, David E., ed. The use of multivariate statistics in studies of wildlife habitat: Workshop proceedings; 1980 April 23-25; Burlington, VT. Gen. Tech. Rep. RM-87. Fort Collins, CO: U.S. Department of Agriculture, Forest Service, Rocky Mountain Forest and Range Experiment Station: 104-113. (NE)
CHEPKO-SADE, B. DIANE; WILLIAM M. SHIELDS; JOEL BERGER; ZULEYMA TANG-HALPIN; W. THOMAS JONES; LYNN L. ROGERS; JON P. ROOD; and ANDREW T. SMITH. 1987. The effect of dispersal and social structure on effective population size. In: ChepkoSade, B. Diane; and Zuleyma TangHalpin, eds. Mammalian dispersal patterns: the effects of social structure on population genetics. Chicago, IL: The University of Chicago Press: 287-381. (NC)

CLARK, WILLIAM R.; and RICHARD J. MEDCRAFT. 1986. Wildlife use of shrubs on reclaimed surface-mined land in northeastern Wyoming. Journal of Wildlife Management. 50:714-718. (RM)

CLINE, STEVEN P.; and CHARLES A. PHILLIPS. 1983. Coarse woody debris and debris-dependent wildlife in logged and natural riparian zone forests--a western Oregon example. In: Davis, Jerry W.; Gregory A. Goodwin; and Richard A. Ockenfels, tech. coords. Snag habitat management: Proceedings of the symposium; 1983 June 7-9; Flagstaff, AZ. Gen. Tech. Rep. RM-99. Fort Collins, CO: U.S. Department of Agriculture, Forest Service, Rocky Mountain Forest and Range Experiment Station: 33-39. (PNW)

CONNER, RICHARD N. 1979. Minimum standards and forest wildlife management. The Wildlife Society Bulletin. 7:293-296. (SO)

CONNER, RICHARD N. 1986. Wildlife in eastern wilderness and natural areas. In: Kulhavy, D. L.; and Richard N. Conner, eds. Wilderness and natural areas in the eastern United States: A management challenge. Nacogdoches, TX: Center for Applied Studies, School of Forestry, Stephen F. Austin State University: 34-35. (SO)

CONNER, RICHARD N. 1988. Wildlife populations: minimal viable or ecologically functional? The Wildlife Society Bulletin. 16:80-84. (SO) 
CONNER, RICHARD N. 1989. Wildlife populations: Minimal viable or ecologically functional? Forest Watch. 9(7):24-89. (SO)

CRAWFORD, HEWLETTE S. 1979. Managing wildlife on New England farms. Farmstead Magazine. 6(2):56-58. (NE)

CRAWFORD, HEWLETTE S.; and ROBERT M. FRANK. 1986. Is good forestry good wildlife management?--some examples. In: Is good forestry good wildlife management?; 1985 January 6-8; Portland, ME. Misc. Publ. 689. Orono, ME: University of Maine: 17-22. (NE)

CRAWFORD, HEWLETTE S.; and ROBERT M. FRANK. 1987. Wildlife responses to silvicultural practices in spruce-fir forests. Transactions of the North American Wildlife and Natural Resource Conference. 52:98-107. (NE)

CRAWFORD, HEWLETTE S.; and WARREN L. STUTZMAN. 1984. Wildlife habitat management and changing forest practices in the Northeast. Northern Journal Applied Forestry. 1:12-14. (NE)

CROUCH, GLENN L. 1981. Wildlife on ungrazed bottomlands on the South Platte River, northeastern Colorado. In: Peek, James A.; P. D. Dalke, eds. Proceedings, Wildlife-livestock relationships symposium; 1981 April 2022; Coeur d'Alene, ID. Moscow, ID: University of Idaho; Forest, Wildlife and Range Experiment Station: 186-197. (RM)

CUSHWA, CHARLES T.; J. E. BARBARD; G. R. GRAVATT; and C. W. DYBRICK. 1984. A preliminary assessment of forest wildlife habitat in Pennsylvania. In: Renewable resources management: Application of remote sensing; 1983 May 22-27; Seattle, WA. Falls Church, VA: American Society of

Photogrammetry: 110-115. (NE)
DEBYLE, NORBERT V. 1985. Wildlife. In: DeByle, Norbert V.; and Robert P. Winokur, eds. Aspen: ecology and management in the Western United States. Gen. Tech. Rep. RM-119. Fort Collins, CO: U.S. Department of Agriculture, Forest Service, Rocky Mountain Forest and Range Experiment Station: 135-152. (RM)

DEGRAAF, RICHARD M. 1978. Management of wooded areas for songbirds and other wildlife. In: Little, S. ed. Urban foresters notebook. Gen. Tech. Rep. NE-49. Broomall, PA: U.S. Department of Agriculture, Forest Service, Northeastern Forest Experiment Station. 190 p. (NE).

DEGRAAF, RICHARD M. 1978. House-lot landscaping for wildlife. In: Little, S. ed. Urban foresters notebook. Gen. Tech. Rep. NE-49. Broomall, PA: U.S. Department of Agriculture, Forest Service, Northeastern Forest Experiment Station. 190 p. (NE).

DEGRAAF, RICHARD M. 1984. Urban wildlife and fisheries. In: Wenger, Karl R., ed. Forestry handbook. 2nd ed. New York, NY: John Wiley \& Sons: 945-957. (NE)

DEGRAAF, RICHARD M. 1987. Urban wildlife research: application to landscape design. In: Adams, L. D.; and D. L. Leedy, eds. National symposium on integrating man and nature in urban environments; 1986 November 4-7; Chevy Chase, MD. Columbia, MD: National Institute for Urban Wildlife: 107111. (NE)

DEGRAAF, RICHARD M.; and DEBORAH D. RUDIS. 1986. New England wildlife: Habitat, natural history, and distribution. Gen. Tech. Rep. NE-108. Broomall, PA: U.S. Department of Agriculture, Forest Service, Northeastern Forest Experiment Station. 491 p. (NE) 
DEGRAAF, RICHARD M.; and JACK WARD

THOMAS. 1976. Wildlife habitat in or near human settlements. In: Andresen, John W. ed. Trees and forests for human settlement. Toronto, Ontario: University Toronto Press: 54-62. (PNW)

DICKSON, JAMES G. 1982. Impacts of forestry practices on wildlife in southern pine forests. In: Increasing forest productivity: Proceedings, 1981 convention of the Society of American Foresters; 1981 September 27-30; Orlando, FL. SAF 82-01. Bethesda, MD: Society of American Foresters: 224-230. (SO)

DICKSON, JAMES G. 1985. U.S. Department of Agriculture, Forest Service: Management, Research, and Cooperative Forestry for multiple benefits. Transactions of the North American Wildlife and Natural Resources Conference. 50:215-220. (SO)

DICKSON, JAMES G. 1987. Bottomland hardwood systems--an introduction. In: McMahan, C. A.; and R. G. Frye, eds. Bottomland hardwoods in Texas: Proceedings of a interagency workshop on status and ecology. Austin, TX: Texas Parks and Wildlife Department: 14. (SO)

DICKSON, JAMES G. 1989. Streamside zones and wildlife in southern U.S. forests. In: Gresswell, R. E.; B. A. Barton; and J. L. Kershner, eds. Riparian resource management: Proceedings of a workshop; Billings, MT. U.S. Department of Interior, Bureau of Land Management: 131-133. (SO)

DICKSON, JAMES G.; and J. C. HUNTLEY. 1987. Riparian zones and wildlife in southern forests: The problem and squirrel relationships. In: Dickson, J. D.; and $O$. E. Maughan, eds. Managing southern forests for wildlife and fish. Gen. Tech. Rep. SO-65. New Orleans, LA: U.S. Department of Agriculture, Forest Service, Southern Forest Experiment Station: 37-39. (SO)
DICKSON, JAMES G.; and JIMMY C.

HUNTLEY. 1985. Streamside management zones and wildlife in the southern coastal plain. In: Johnson, R. Roy; Charles D. Ziebell; David R. Patton; Peter F. Ffolliott; and R. H. Hamre, tech eds. Riparian ecosystems and their management: reconciling conflicting uses: Proceedings, 1st North American riparian conference; 1985 April 16-18; Tucson, AZ. Gen. Tech. Rep. RM-120. Fort Collins, CO: U.S. Department of Agriculture, Forest Service, Rocky Mountain Forest and Range Experiment Station: 263-264. (SO)

DICKSON, JAMES G.; and O. E. MAUGHAN, eds. 1987. Managing southern forests for wildlife and fish. Gen. Tech. Rep. SO-65. New Orleans, LA: U.S. Department of Agriculture, Forest Service, Southern Forest Experiment Station. 85 p. (SO)

DRISCOLL, R. S. 1977. National assessment needs. In: Proceedings, national symposium on classification, inventory, and analysis of fish and wildlife habitat; 1977 January 24-27. Phoenix, AZ: U.S. Department of Interior. Fish and Wildlife Service. (RM)

EDGERTON, PAUL J.; and JACK WARD THOMAS. 1977. Impacts of silviculture on wildlife habitats in the Blue Mountains. In: Integration of forest resource management in the Blue Mountains: Proceedings of a seminar; 1977 March; La Grande, OR. Corvallis, OR: Oregon State University, Extension Service and Blue Mountain Chapter Society American Forestry: 6l-63. (PNW)

EDGERTON, PAUL J.; and JACK WARD THOMAS. 1978. Silvicultural options and habitat values. Tech. Rep. PNW-64. Portland, OR: U.S. Department of Agriculture, Forest Service, Pacific Northwest Forest and Range Experiment Station. (PNW) 
EVANS, KEITH E.; and GEORGE E.

PROBASCO. 1977. Wildlife of the prairies and plains. Gen. Tech. Rep. NC-29. St. Paul, MN. U.S. Department of Agriculture, Forest Service, North Central Forest Experiment Station. $18 \mathrm{p}$. (NC)

FAABORG, JOHN R.; and WAYNE J.

ARENDT. 1985. Wildlife assessments in the Caribbean. Rio Piedras, PR: U.S. Department of Agriculture, Forest Service, Southern Forest Experiment Station, Institute of Tropical Forestry. 220 p. (SO)

FLATHER, CURTIS H.; HOEKSTRA, THOMAS W. 1989. An analysis of the wildlife and fish situation in the United States: 1989-2040: a technical document supporting the 1989 USDA Forest Service RPA assessment. Gen. Tech. Rep. Rm-178. Fort Collins, CO: U.S. Department of Agriculture, Forest Service, Rocky Mountain Forest and Range Experiment Station. 146 p. (RM)

GERMANO, DAVID J.; ROGER HUNGERFORD, and S. CLARK MARTIN. 1983. Responses of selected wildlife species to the removal of mesquite from desert grassland. Journal of Range Management. 36:309-311. (RM)

GUTHERY, FRED S.; and FRED A. STORMER. 1982. Brush, brush control, and wildlife in Texas. In: Proceedings, Great Plains Agricultural Council; 1982 June 7-9; North Platte, NE. Lincoln, NE: University of Nebraska: 1-6. (RM)

GUTHERY, FRED S.; and FRED A. STORMER. 1984. Wildlife management scenarios for playa vegetation. The Wildlife Society Bulletin. 12:227-234. (RM)
HALL, FREDERICK C. 1985. Wildlife habitats in managed rangelands--the Great Basin of southeastern Oregon: management practices and options. Gen. Tech. Rep. PNW-189. Portland, OR: U.S. Department of Agriculture, Forest Service, Pacific Northwest Forest and Range Experiment Station. $17 \mathrm{p}$. (PNW)

HALL, FREDERICK C.; and JACK WARD THOMAS. 1979. Silvicultural options. In: Thomas, Jack Ward, tech. ed. Wildlife habitats in managed forests--the Blue Mountains of Oregon and Washington. Washington, DC: Agric. Handb. 553. U.S. Department of Agriculture: 128147. Chapter 9. (PNW)

HALLS, LOWELL K. 1978. Effect of timber harvesting on wildlife, wildlife habitat and recreation values. In: Proceedings Symposium: Complete Tree Utilization of Southern Pine: 108-114. (SO)

HALLS, LOWELL K.; [and others] 1984. Forest wildlife and fish management. In: Wenger, Karl F., ed. Forest Handbook. New York: John Wiley \& Sons: 679-737. (SO)

HALLS, LOWELL K.; and HERMAN L. HOLBROOK. 1980. Wildlife management on southern national forests. In: Integrating timber and wildlife management in southern forests: 29th annual forestry symposium; 1980 April 9-10; Baton Rouge, LA: Louisiana State University, Division of Continuing Education: 33-40. (SO)

HAMEL, PAUL B.; and M. O. EFIRD. 1985. Wildlife and fish habitat relationships data base for the Forest Service Southern Region. In: McComb, W. C. ed. Proceedings, wordshop on management of nongame species and ecological communities; 1984 June 11 12; Lexington, $\mathrm{KY}$ : University of Kentucky: 44-52. (SE) 
HAMEL, PAUL B.; NOEL D. COST; and

RAYMOND M. SHEFFIELD. 1986. The consistent characteristics of habitats: A question of scale. In: Verner, Jared;

Michael L. Morrison; and C. John Ralph, eds. Wildlife 2000: Modeling habitat relationships of terrestrial vertebrates; 1984 October 7-11; Fallen Leaf, CA. Madison, WI: The University of Wisconsin Press: 121-128. (SE)

HARLOW, RICHARD F.; and DAVID H. VAN LEAR. 1981. Silvicultural effects on wildlife habitat in the South: an annotated bibliography 1953-1979. Tech. Pap. 14 Clemson, SC: Clemson University, Department of Forestry, College of Forestry and Recreation Resources. 30 p. (SE)

HARRIS, L. D. 1978. Effects of forest management practices on wildlife ecology: A list of citations. IMPAC Reports. 3(9):108. (SE)

HARRIS, L. D.; and P. J. SKOOG. 1980. Some wildlife habitat-forestry relations in the southeastern Coastal Plain. In: Proceedings, annual forestry symposium 29; Baton Rouge, LA: Louisiana State University: 103-119. (SE)

HARRIS, L. D.; D. H. HIRTH; and W. R. MARION. 1979. The development of silvicultural systems for wildlife. University of Florida, Gainesville. IMPAC Report. 4(5):24. (SE)

HARRIS, LARRY D.; CHRIS MASER, and ARTHUR MCKEE. 1983. Patterns of old growth harvest and implications for Cascades wildlife. Transactions of the North American Wild life and Natural Resources Conference. 48:374-392. (PNW)
HAWKES, CLIFFORD L.; DAVID E. CHALK; THOMAS W. HOEKSTRA; and CURT H. FLATHER. 1983. Prediction of wildlife and fish resources for national assessments and appraisals. Gen.

Tech. Rep. RM-100. Fort Collins, CO:

U.S. Department of Agriculture, Forest

Service, Rocky Mountain Forest and Range Experiment Station. 21 p. (RM)

HEALY, WILLIAM M. 1987. Habitat characteristics of uneven-aged stands. In: Managing northern hardwoods:

Proceedings of a silvicultural symposium; 1986 June 23-25; Syracuse, NY. 87-03. Washington, DC: Society of American Foresters: 338-347. (NE)

HIRSCH, ALLAN; WILLIAM KROHN; DENNIS SCHWEITZER; and CARL THOMAS. 1979. Trends and needs in federal inventories of wild life habitat. Transactions of the North American Wildlife and Natural Resources Conference. 44:340-359. (RM)

HODORFF, ROBERT A.; CAROLYN HULL SIEG; and RAYMOND L. LINDER. 1988. Wildlife response to stand structure of deciduous woodlands. Journal of Wildlife Management. 54:667673. (RM)

HOEKSTRA, THOMAS W.; CURTIS $H$. FLATHER; and PATRICIA A. FLEBBE. 1987. Regional fish and wildlife habitat models: application for national multiple resource planning. In: Land and resource evaluation for national planning in the tropics: international conference and workshop; 1987 January 25-31; Chetumal, Mexico. Gen. Tech. Rep. WO-39. Washington, DC: U.S. Department of Agriculture, Forest Service: 404-409. (RM) 
HOEKSTRA, THOMAS W.; DENNIS SCHWEITZER; CHARLES CUSHWA; [and others]. 1979. Preliminary evaluation of a national wildlife and fish data base. Transactions of the North American Wildlife and Natural Resources Conference. 44:380-391. (RM)

HOEKSTRA, THOMAS W.; JACK WARD THOMAS; MICHAEL A. LENNARTZ; and DAVID P. WORLEY. 1981. Managing of federal lands for production and use of wildlife and fish. Transactions of the North American Wildlife and Natural Resources Conference. 46:336344. (RM)

HOLECEK, DONALD F. 1983. Michigan's land leasing program for public hunting. Transactions of the North American Wildlife and Natural Resources Conference. 48:108-115. (NC)

HUNTLEY, JIMMY C.; and DALE H. ARNER. 1981. The effect of utility right-of-way maintenance upon game food plants. In: Environmental concerns in rights-of-way management; Proceedings of second symposium; 1979 October 16-18; Ann Arbor, MI: EPRI WS-78-141. Mississippi State, MS: Mississippi State University: $31-1$ to $31-13$. (SO)

KIE, JOHN G.; and WILLIAM F. LAUDENSLAYER, JR. eds. 1986.

Transactions of the Western Section of the Wildlife Society; 1986 January 2325; Sparks, NV. Sacramento, CA: Western Section of The Wildlife Society. 138 p. (PSW)

KRAMER, BRUCE M. 1982. Legal aspects of use and development of wildife resources on private lands: Colorado, Kansas, New Mexico, Oklahoma, Texas. Publ. 103. Lincoln, NE: Great Plains Agricultural Council. 70 p. (RM)
KULHAVY, D. L.; and RICHARD N. CONNER, ed. 1986. Wilderness and natural areas in the eastern United States: a management challenge. Nacogdoches, TX: Center for Applied Studies, School of Forestry, Stephen F. Austin State University. 416 p. (SO)

LANDRES, PETER B.; JARED VERNER; and JACK WARD THOMAS. 1988.

Ecological uses of vertebrate indicator species: a critique. Conservation Biology. 2(4):1-13. (PNW)

LARSON, FREDRICK L.; PETER F. FFOLLIOTT; and WARREN P. CLARY. 1986. Managing wildlife habitat. Journal of Forestry. 84(3):40-42. (RM)

LYON, L. JACK. 1976. Wildlife-land use conflicts. Proceedings, Annual meeting Montana chapter, The Wildlife Society: 11-12. (INT)

LYON, L. JACK. 1978. USDA information requirements for wildlife management. Gen. Tech. Rep. RM-55; Fort Collins, CO: U.S. Department of Agriculture, Forest Service, Rocky Mountain Forest and Range Experiment Station: 45-52. (INT)

LYON, L. JACK. 1978. Information requirements for wildlife management. In: Lund, H. Gyde; Vernon J. Labau; Peter F. Ffolliott; and David W. Robinson, tech coords. Integrated inventories of renewable natural resources: Proceedings of the workshop; 1978 January 8-12, Tucson, AZ. Gen. Tech. Rep. RM-55. Fort Collins, CO: U.S. Department of Agriculture, Forest Service, Rocky Mountain Forest and Range Experiment Station: 45-52. (INT) 
LYON, L. JACK. 1989. Succession modeling and wildlife habitat management. In: Ferguson, Dennis E.; Penelope Morgan; and Frederic D. Johnson, comps.

Proceedings--land classifications based on vegetation: applications for resource management; 1987 November 17-19; Moscow, ID. Gen. Tech. Rep. INT-257. Ogden, UT: U.S. Department of Agriculture, Forest Service, Intermountain Research Station: 74-80. (INT)

MARCOT, BRUCE G.; MARTIN G. RAPHAEL; and KRISTIN H. BERRY. 1983. Monitoring wildlife habitat and validation of wildlife-habitat relationships models. Transactions of the North American Wildlife and Natural Resources Conference. 48:315-329. PSW)

MARCOT, BRUCE G.; R. SCOTT MCNAY; and RICHARD E. PAGE. 1988. Use of microcomputers for planning and managing silviculture-habitat relationships. Gen. Tech. Rep. PNW228. Portland, OR: U.S. Department of Agriculture, Forest Service, Pacific Northwest Research Station. 19 p. (PNW)

MARQUIS, DAVID A. 1986. Integration of timber and wildlife in silvicultural prescription writing. In: 18th IUFRO World Congress; 1986 September 2-21; Ljubjana, Yugoslavia. Division 1, Volume II. International Union of Forestry Research Organizations: 565573. (NE)

MASER, CHRIS J.; MICHAEL GEIST; DIANE M. CONCANNON; [and others]. 1979. Wildlife habitats in managed rangelands--the Great Basin of southeastern Oregon: Geomorphic and edaphic habitats. Gen. Tech. Rep. PNW-99. Portland, OR: U.S. Department of Agriculture, Forest Service, Pacific Northwest Forest and Range Experiment Station. 84 p. (PNW)
MASER, CHRIS; and JACK WARD

THOMAS. 1978. Ecosystems, habitats, wildlife, and management. In: Gen.

Tech. Rep. PNW-64. Portland, OR: U.S.

Department of Agriculture, Forest

Service, Pacific Northwest Forest and

Range Experiment Station: 1-4. (PNW)

MASER, CHRIS; and JACK WARD

THOMAS. 1983. Wildlife habitats in managed rangelands--the Great Basin of southeastern Oregon: Introduction. Gen. Tech. Rep. PNW-160. Portland, OR: U.S. Department of Agriculture, Forest Service, Pacific Northwest Forest and Range Experiment Station. $15 \mathrm{p}$. (PNW)

MASER, CHRIS; and JAY S. GASHWILER. 1978. Interrelationships of wildlife and western juniper. In: Martin, Robert E.; J. Edward Dealy; and David L. Caraher, eds. Proceedings of the western juniper ecology and management workshop; 1977 January; Bend, OR. Gen. Tech. Report PNW-74; Portland, OR: U.S. Department of Agriculture, Forest Service, Pacific Northwest Forest and Range Experiment Station: 37-82. (PNW)

MASER, CHRIS; JACK WARD THOMAS; and RALPH G. ANDERSON. 1984. Wildlife habitats in managed rangelands--the Great Basin of southeastern Oregon: The relationship of terrestrial vertebrates to plant communities, Part I, Text. Gen. Tech. Rep. PNW-172. Portland, OR: U.S. Department of Agriculture, Forest Service, Pacific Northwest Forest and Range Experiment Station. 25 p. (PNW) 
MASER, CHRIS; JACK WARD THOMAS; and RALPH G. ANDERSON. 1984. Wildlife habitats in managed rangelands--the Great Basin of southeastern Oregon: The relationship of terrestrial vertebrates to plant communities, Part 2, Appendices. Gen. Tech. Rep. PNW-172. Portland, OR: U.S. Department of Agriculture, Forest Service, Pacific Northwest Forest and Range Experiment Station. 237 p. (PNW)

\section{MASER, CHRIS; JACK WARD THOMAS;}

IRA DAVID LUMAN; and RALPH

ANDERSON. 1979. Wildlife habitats in managed rangelands--the Great Basin of southeastern Oregon: Manmade habitats. Gen. Tech. Rep. PNW-86. Portland, OR: U.S. Department of Agriculture, Forest Service, Pacific Northwest Forest and Range Experiment Station. 40 p. (PNW)

MASER, CHRIS; RALPH G. ANDERSON; KERMIT CROMACK, JR.; JERRY T. WILLIAMS; and ROBERT E. MARTIN. 1979. Dead and down woody material. In: Thomas, Jack Ward, tech. ed. Wildlife habitats in managed forests--the Blue Mountains of Oregon and Washington. Agric. Handb. 553. Washington, DC: U.S. Department of Agriculture, Forest Service: 78-95. Chapter 6. (PNW)

MESLOW, E. CHARLES; CHRIS MASER; and JARED VERNER. 1981. Old-growth forests as wildlife habitat. Transactions of the North American Wildlife and Natural Resources Conference. 46:329335. (PSW)

MONSEN, STEPHEN B.; and NANCY SHAW. comps. 1983. Managing Intermountain rangelands--Improvement of range and wildlife habitats:

Proceedings of symposia; 1981 September 15-17; Twin Falls, ID. 1982 June 22-24. Elko, NV. Gen. Tech. Rep. INT-157. Ogden, UT: U.S. Department of Agriculture, Forest Service, Intermountain Forest and Range Experiment Station. 194 p. (INT)
MORE, T. 1977. Formation of wildlife perceptions. In: Transactions, Northeast Fish and Wildlife Confrence: 81-85. (NE)

OHMANN, JANET L.; DAN CARLESON; PHILIP L. LEE; and ART L. OAKLEY. 1988. Status of forest-related wildlife and fish resources in Oregon. In: Lettman, Gary J., tech. ed. Assessment of Oregon's forests. Salem, OR: Oregon State Department of Forestry, Forest Resources Planning Section: 17-32. (PNW)

PATTON, DAVID R. 1977. Managing aspen for wildlife in the southwest. Gen. Tech. Rep. RM-37. Fort Collins, CO: U.S. Department of Agriculture, Forest Service, Rocky Mountian Forest and Range Experiment Staion. 7 p. (RM)

PATTON, DAVID R. 1982. Wildife habitat in land management planning: some ideas and principles. In: The effects of land management practices on fish and wildlife in southwestern conifer forests: Proceedings of a workshop; 1982 February 16-17; Tucson, AZ: School of Renewable Natural Resources, University of Arizona: 33-38. (RM)

PATTON, DAVID R. 1987. Is the use of "management indicator species" feasible? Western Journal of Applied Forestry. 2(1):33-34. (RM)

PERALA, DON; and RICHARD BUECH. 1981. The weed tree and wildlife. Minnesota Volunteer. 44(256):51-53. (NC)

PHILLIPS, L. N.; RICHARD N. CONNER; and D. L. KULHAVY. 1986. An introduction to wilderness management issues. In: Kulhavy, D. L.; and Richard N. Conner, eds. Wilderness and natural areas in the eastern United States: a management challenge. Nacogdoches, TX: Stephen F. Austin State University, Center for Applied Studies, School of Forestry: 146-147. (SO) 
PROBST, JOHN R.; DONALD RAKSTAD; and KATHY BROSDAHL. 1983.

Diversity of vertebrates in wildlife waterimpoundments on the Chippewa

National Forest. Res. Pap. NC-235. St.

Paul, MN: U.S. Department of

Agriculture, Forest Service, North

Central Forest Experiment Station. 22 p. (NC)

RAPHAEL, MARTIN G. 1987. Nongame wildlife research is subalpine forests of the central Rocky Mountains. In: Troendle, Charles A.; Merrill R. Kaufmann; R. H. Hamre; and Robert P. Winokur, tech. coords. Managment of subalpine forests: building on 50 years of research: Proceedings of a technical conference; 1987 July 6-9; Silver Creek, CO. Gen. Tech. Rep. RM-149. Fort Collins, CO: U.S. Department of Agriculture, Forest Service, Rocky Mountain Forest and Range Experiment Station: 113-122. (RM)

RAPHAEL, MARTIN G. 1987. The Coon Creek Wildlife Project: Effects of water yield augmentation on wildlife. In: Troendle, Charles A.; Merrill R. Kaufmann; R. H. Hamre; and Robert P. Winokur, tech. coords. Managment of subalpine forests: building on 50 years of research: Proceedings of a technical conference; 1987 July 6-9; Silver Creek, CO. Gen. Tech. Rep. RM-149. Fort Collins, CO: U.S. Department of Agriculture, Forest Service, Rocky Mountain Forest and Range Experiment Station: 173-179. (RM)

RAPHAEL, MARTIN G. 1987. Wildlife-tanoak associations in Douglas-fir forests of northwestern California. In: Multiple-use management of California's hardwood resources: Proceedings of the symposium; 1986 November 12-14; San Louis Obispo, CA. Gen. Tech Rep. PSW-100. Berkeley, CA: U.S. Department of Agriculture, Forest Service, Pacific Southwest Forest and Range Experiment Station: 183-189. (RM)
RAPHAEL, MARTIN G. 1988. Douglas-fir. In: Mayer, K. E.; and W. F. Laudenslayer, Jr., eds. A guide to wildlife habitats in California. Sacramento, CA: California Department of Forestry and Fire Protection: 52-53. (RM)

RAPHAEL, MARTIN G.; and REGINALD H. BARRET. 1984. Diversity and abundance of wildlife in late successional Douglas-fir forests. In: New forests for a changing world: Proceedings, Society of American Foresters; 1983 October 16-20; Portland, OR. SAF Publ. 84-03. Washington, DC: Society of American Foresters: 352-360. (PSW)

RODIEK, JON.; and JACK WARD THOMAS. 1980. Wildlife habitat planning and landscape architecture. Landscape Resource. 5(3):12-16. (PNW)

ROSENBERG, KENNETH V.; and MARTIN G. RAPHAEL. 1986. Effects of forest fragmentation on vertebrates in Douglas-fir forests. In: Verner, Jared; Michael L. Morrison; and C. John Ralph, eds. Wildlife 2000: Modeling habitat relationships of terrestrial vertebrates; 1984 October 7-11; Fallen Leaf, CA. Madison, WI: The University of Wisconsin Press: 263-272. (RM)

RUMBLE, MARK A. 1989. Wildlife associated with scoria outcrops: implications for reclamation of surface-mined lands. Res. Pap. RM-275. Fort Collins, CO: U.S. Department of Agriculture, Forest Service, Rocky Mountain Forest and Range Experiment Station. 7 p. (RM)

SALWASSER, HAL; and FRED B. SAMSON. 1985. Cumulative effects analysis: an advance in wildlife planning and management. Transactions of the North American Wildlife and Natural Resources Conference. 50:313-321. (PNW) 
SAMSON, FRED B.; FRANCISCO PEREZTREZO; HAL SALWASSER; LEONARD F. RUGGIERO; and MARK L. SHAFFER. 1985. On determining and managing minimum population size. The Wildlife Society Bulletin. 13:425-433. (PNW)

SCHMIEGE, DON. 1980. Why study wildlife? Alaska Fish Tales \& Game Trails. 12(1):3-31. (PNW)

SCHOENFELD, CLARENCE A.; and JOHN C. HENDEE. 1978. Wildlife management in wilderness. Pacific Grove, CA: The Boxwood Press. 172 p. (PNW)

SCHWEITZER, DENNIS L.; CHARLES T. CUSHWA; and THOMAS W. HOEKSTRA. 1979. The 1979 national assessment of wildlife and fish: A progress report. Transactions of the North American Wildlife and Natural Resources Conference. 43:266-273. (RM)

SCHWEITZER, DENNIS L.; THOMAS W. HOEKSTRA; and CHARLES T. CUSHWA. 1981. Lessons from past national assessments of wildlife and fish: information and coordination needs for the future. Transactions of the North American Wildlife and Natural Resources Conference. 46:147-155. (RM)

SCOTT, VIRGIL E.; GLENN L. CROUCH; and JILL A. WHELAN. 1982. Responses of birds and small mammals to clearcutting in a subalpine forest in central Colorado. Res. Note RM-422. Fort Collins, CO: U.S. Department of Agriculture, Forest Service, Rocky Mountain Forest and Range Experiment Station. 6 p. (RM)
SHAFER, DONNA M.; PETER F. FFOLLIOTT; and DAVID R. PATTON. 1982. Management of riparian vegetation for southwestern wildlife. RUN WILD wildlife/habitat relationships. Wildlife Unit Tech. Rep. Albuquerue, NM: U.S. Department of Agriculture, Forest Service, Southwestern Region. 20 p. (RM)

SHORT, HENRY L.; and CLAY Y. MCCULLOCH. 1977. Managing pinyonjuniper ranges for wildlife. Gen. Tech. Rep. RM-47. Fort Collins, CO: U.S. Department of Agriculture, Forest Service, Rocky Mountain Forest and Range Experiment Station. 10 p. (RM)

SIEG, CAROLYN HULL; and ROBERT A. HODORFF. 1985. Stand condition as a variable influencing wildlife use of green ash woodlands. In: Noble, Daniel L.; and Robert P. Winokur, eds. Symposium proceedings, Wooded draws: Characteristics and values for the northern Great Plains; 1984 June 12-13; Rapid City SD: Great Plains Agriculture Council, Wildlife Resources Committee: 36-39. (RM)

STORMER, FRED A.; and FRED S. GUTHERY. 1982. Irrigation and wildlife in the southern and central Great Plains. In: Proceedings, Great Plains Agricultural Council; 1982 June 7-9; North Platte, NE. Lincoln, NE: University of Nebraska: 41-48. (RM)

STORMER, FRED A.; and GARY L. VALENTINE. 1981. Management of shelterbelts for wildife. In: Windbreaks-agriculture: A new beginning: Proceedings, 33rd annual meeting of the forestry committee, Great Plains Agricultural Council; 1981 June 16-18; Lubbock, TX. Pub. 102. Lincoln, NE: Great Plains Agricultural Council: 169181. (RM) 
STREETER, ROBERT G.; DAVID E. CHALK; CARL H. THOMAS; and WILLIAM B. KROHN. 1983. National appraisal for wildlife habitat: from inventory to management. In: Bell, J. F.; and T. Atterbury, eds. Renewable resource inventories for monitoring changes and trends: Proceedings of an international conference; 1983 August 15-19; Corvallis, OR: Oregon State University, College of Forestry: 674-677. (RM)

SWANSON, G. A., tech. coord. 1979. The mitigation symposium: A national workshop on mitigating losses of fish and wildlife habitats; 1979 July 16-20. Gen. Tech. Rep. RM-65. Fort Collins, CO: U.S. Department of Agriculture, Forest Service, Rocky Mountain Forest and Range Experiment Station. 685 p. (RM)

SWEENEY, JAMES M.; and CARROL L. HENDERSON. 1986. An integrated approach to nongame management. In: Hale, James B.; Louis B. Best; and Richard L. Clawson, eds. Symposium on management of nongame wildlife in the Midwest: a developing art: Proceedings, 47th Midwest Fish and Wildlife Conference; 1985 December 17; Grand Rapids, MI The North Central Section, The Wildlife Society: 1-10. (NC)

TEER JAMES G.; ERNEST D. ABLES; F. E. BUSBY; DONALD L. HEDRICK; FRED A. STORMER; and JACK W. THOMAS. 1982. Impacts of agricultural trends on western rangeland habitats. In: Impacts of emerging agricultural trends on fish and wildlife habitat. Washington, DC: National Research Council: 122-158. (PNW)

THOMAS, CARL H.; ROBERT G.

STREETER; DAVID E. CHALK; and BARRY D. SROUFE. 1983.

Computerized national appraisal of wildlife habitat - 1985. In: Proceedings of a national workshop on computer uses in fish and wildlife programs; 1983 December 5-7; Blacksburg, VA: Virginia Polytechnic Institute and State University: 69-74. (RM)
THOMAS, J. WARD. 1981. Wildlife habitats in managed forests: a case study in the Blue Mountains of Oregon and Washington. In: Integrated data base for the wildland and forest land use management in Alberta: Proceedings of a workshop; 1981 August 13-14; Calgary, $A B$ : Kananaskis Centre for Environmental Research: 3-7. (PNW)

THOMAS, JACK W. 1985. Toward the managed forest: Going places that we've never been. Renewable Resources Journal. 3(3):12-16. (PNW)

THOMAS, JACK WARD, tech. ed. 1979. Wildlife habitats in managed forests--the Blue Mountains of Oregon and Washington. Agric. Handb. 553. Washington, DC: U.S. Departmentof Agriculture. 512 p. (PNW)

THOMAS, JACK WARD. 1979. Introduction. In: Thomas, Jack Ward, tech. ed. Wildlife habitats in managed forests--the Blue Mountains of Oregon and Washington. Agric. Handb. 553. Washington, DC: U.S. Department of Agriculture, Forest Service: 10-21. Chapter 1. (PNW)

THOMAS, JACK WARD. 1982. Needs for and approaches to wildlife habitat assessment. Transactions of the North American Wildlife and Natural Resources Conference. 47:35-46. (PNW)

THOMAS, JACK WARD. 1983.

Species/habitat relationships--a key to considering wildlife in planning and land management decisions. In: Mason, William T., Jr., tech. ed. Research on fish and wildlife habitat. EPA-600/8-82002 Washington, DC: U.S.

Environmental Protection Agency, Office of Research and Development: 27-36. (PNW)

THOMAS, JACK WARD. 1985.

Professionalism--commitment beyond employment. Cal-Neva Wildlife Transactions. 1985:1-10. (PNW) 
THOMAS, JACK WARD. 1985. Wildlife in managed forests--a matter of commitment. In: Proceedings, Canada's forests: A commitment to the future; 1986 April 9-10; Ottawa, ON. Portland, OR: National Forest Congress: E65E70. (PNW)

THOMAS, JACK WARD. 1987. Do we know enough to manage subalpine wildlife habitats?--it all depends. In: Management of subalpine forests: building on 50 years of research. Proceedings of a technical conference; 1987 July 6-9; Silver Creek, CO. Gen. Tech. Rep. RM-GTR-149. Fort Collins, CO: U.S. Department of Agriculture, Forest Service, Rocky Mountain Forest and Range Experiment Station: 123125. (PNW)

THOMAS, JACK WARD. 1987. Multiple-use forestry: moving from platitudes to reality. In: Northwest forestry in transition: the 1987 Starker Lecture Series. Corvallis, OR: Oregon State University, College of Forestry: 43-52. (PNW)

THOMAS, JACK WARD; and EVELYN L. BULL. 1987. Wildlife habitat in managed forests: what to think about while chopping. Western Wildlands. 13(1):4-7. (PNW)

THOMAS, JACK WARD; and JARED VERNER. 1986. Forests. In: Cooperrider, Allen Y.; Raymond J. Boyd; and Stuart R. Hanson, comps. eds. Inventory and monitoring of wildlife habitat. Denver, CO: U.S. Department of the Interior, Bureau of Land Management, Service Center: 73-91. (PNW)

THOMAS, JACK WARD; CHRIS MASER; and FREDERICK C. HALL. 1980.

Silvicultural for improved wildlife habitat. In: Town meeting --forestry issues for the 1980's: Proceedings 1979 convention; Washington, DC: Society of American Foresters: 84-89. (PNW)
THOMAS, JACK WARD; CHRIS MASER; and JON E. RODIEK. 1979. Riparian zones. In: Thomas, Jack Ward, tech. ed. Wildlife habitats in managed forests--the Blue Mountains of Oregon and Washington. Agric. Handb. 553. Washington, DC: U.S. Department of Agriculture, Forest Service: 40-47. Chapter 3. (PNW)

THOMAS, JACK WARD; CHRIS MASER; and JON E. RODIEK. 1979. Riparian zones in managed rangelands--their importance to wildlife. In: Cope, Oliver B. ed. Proceedings of the forum--grazing and riparian/stream ecosystems; 1978 November 3-4; Denver, CO. Vienna, VA: Trout Unlimited: 2I-3l. (PNW)

THOMAS, JACK WARD; CHRIS MASER; and JON E. RODIEK. 1979. Wildlife habitats in managed rangelands--the Great Basin of southeastern Oregon: Riparian zones. Gen. Tech. Rep. PNW80. Portland, OR: U.S. Department of Agriculture, Forest Service, Pacific Northwest Forest and Range Experiment Station. 18 p. (PNW)

THOMAS, JACK WARD; DONAVIN A. LECKENBY; LEONARD J. ERICKSON; SYLVAN R. THOMAS; DENNIS L. ISAACSON; and R. JAY MURRAY. 1986. Wildlife habitat by design: national forests in the Blue Mountains of Oregon and Washington. Transactions of the North American Wildlife and Natural Resources Conference. 51:203-214. (PNW)

THOMAS, JACK WARD; JOHN D. GILL; JAMES C. PACK; WILLIAM M. HEALY; and $H$. REED SANDERSON. 1976. Influence of forest land characteristics on spatial distribution of hunters. Journal of Wildlife Management. 40:500-506. (PNW) 
THOMAS, JACK WARD; ROD MILLER; CHRIS MASER; RALPH ANDERSON; and BERNIE CARTER. 1978. The relationship of terrestrial vertebrates to plant communities and their successional stages. In: Classification, inventory, and analysis of fish and wildlife habitat; Proceedings of a national symposium; FWS/Obs78/76. Washington, DC: U.S. Department Interior, Biolgy Service Program: 28I-303. (PNW)

THOMAS, JACK WARD; RODNEY J. MILLER; HUGH BLACK; [and others]. 1976. Guidelines for maintaining and enhancing wildlife habitat in forest management in the Blue Mountains of Oregon and Washington. Transactions of the North American Wildlife and Natural Resources Conference. 41:453476. (PNW)

TOTH, EDWARD F.; and JOHN W. BAGLIEN. 1986. Summary: When habitats fail as predictors--the managers viewpoint. In: Verner, Jared; Michael L. Morrison; and C. John Ralph, eds. Wildlife 2000: modeling habitat relationships of terrestrial vertebrates; 1984 October 7-11; Fallen Leaf Lake, CA. Madison, WI: The University of Wisconsin Press: 255-256. (PSW)

TOTH, EDWARD F.; DAVID M. SOLIS; and BRUCE G. MARCOT. 1986. A management strategy for habitat diversity: Using models of wildlife-habitat relationships. In: Verner, Jared; Michael L. Morrison; and C. John Ralph, eds. Wildlife 2000: modeling habitat relationships of terrestrial vertebrates; 1984 October 7-11; Fallen Leaf Lake, CA. Madison, WI: The University of Wisconsin Press: 139-144. (PSW)

TUBBS, CARL H. 1986. Silvicultural technique for improving wildlife tree habitat in northern hardwood forests. In: The northern hardwood resource: management and potential; 1986 August 18-20; Houghton, MI. Barrington, $\mathrm{NH}$ : Michigan Tech University: 244-249. (NE)
TUBBS, CARL H.; RICHARD DEGRAAF; MARIKO YAMASAKI; and WILLIAM M. HEALY. 1987. Guide to wildlife tree management in New England northern hardwoods. Gen. Tech. Rep. NE-118. Broomall, PA: U.S. Department of Agriculture, Forest Service, Northeastern Forest Experiment Station. 30 p. (NE)

URESK, DANIEL W. 1982. Importance of woodlands to wildlife and livestock use on the northern High Plains. In:

Proceedings, Great Plains Agricultural Council; 1982 June 7-9; North Platte, NE. Lincoln, NE: University of Nebraska Press: 7-12. (RM)

VAN HORNE, B. 1983. Density as a misleading indicator of habitat quality. Journal of Wildlife Management. 47:893901. (PNW)

VERNER, JARED. 1986. Future trends in management of nongame wildlife: $A$ researcher's viewpoint. In: Management of nongame wildlife in the midwest: $A$ developing art; 1985 December 17; Grand Rapids, MI. 47th Midwest Fish and Wildlife Conference: 149-171. (PSW)

VERNER, JARED. 1986. Summary: Predicting effects of habitat patchiness and fragmentation. In: Verner, Jared; Michael L. Morrison; and C. John Ralph, eds. Wildlife 2000: Modeling habitat relationships of terrestrial vertebrates; 1984 October 7-11; Fallen Leaf, CA. Madison, WI: The University of Wisconsin Press: 327-330. (PSW)

VERNER, JARED; and ALLEN S. BOSS, tech. coords. 1980. California wildlife and their habitats: Western Sierra Nevada. Gen. Tech. Rep. PSW-37. Berkeley, CA: U.S. Department of Agriculture, Forest Service, Pacific Southwest Forest and Range Experiment Station. 439 p. (PSW) 
VERNER, JARED; and ALLEN S. BOSS. 1980. Introduction and scope. In: Verner, Jared; and Allen S. Boss, tech. coords. California wildlife and their habitats: Western Sierra Nevada. Gen. Tech. Rep. PSW-37. Berkeley, CA: U.S. Department of Agriculture, Forest Service, Pacific Southwest Forest and Range Experiment Station: 1-7. (PSW)

VERNER, JARED; and ALLEN S. BOSS. 1980. Using the publication. In: Verner, Jared; and Allen S. Boss, tech. coords. California wildlife and their habitats: Western Sierra Nevada. Gen. Tech. Rep. PSW-37. Berkeley, CA: U.S. Department of Agriculture, Forest Service, Pacific Southwest Forest and Range Experiment Station: 9-11. (PSW)

VERNER, JARED; ROBERT PASTOROK; JOEL O'CONNOR; WILLIAN SEVERINGHAUS; NORMAN GLASS; and BENEE SWINDEL. 1985.

Ecological community structure analyses in the formulation, implementation, and enforcement of law and policy. The American Statistician. 39:393-402. (PSW)

WESLEY, DAVID E.; CARROLL J. PERKINS; and ALFRED D. SULLIVAN. 1981. Wild life in cottonwood plantations. Southern Journal of Applied Forestry. 5:37-42. (SO)

WHELAN, JAMES B. 1982. Interagency coordination of wildlife and fish resource inventories. In: In-place resource inventories: principles and practices: Proceedings of a national workshop; 1981 August 9-14; Orono, ME. SAF 8202. Bethesda, MD; Society of American Foresters: 588-591.

WICK, HERBERT L.; and PAUL R. (Rod) CANUTT. 1979. Impacts on wood production. In: Thomas, Jack Ward, tech. ed. Wildlife habitats in managed forests--the Blue Mountains of Oregon and Washington. Agric. Handb. 553. Washington, DC: U.S. Department of Agriculture, Forest Service: 148-161. Chapter 10. (PNW)
WILCOVE, DAVID W.; and FRED B. SAMSON. 1989. Innovative wildlife management: listening to Leopold. Transactions of the North American Wildlife and Natural Resources Conference. 52:327-332. (PNW)

YOAKUM, JAMES; W. P. DASMANN; $H$. REED SANDERSON; C. M. NIXON; and HEWLETTE S. CRAWFORD. 1980. Habitat improvement techniques. In: Schemnitz, S. D., ed. Wildlife Management Techniques Manual. 4th Edition. Washington, DC: The Wildlife Society: 329-403. (NE)

\section{Fish And Their Habitat}

BENKE, R. J.; and MARK ZARN. 1976. Biology and management of threatened and endangered western trout. Gen. Tech. Rep. RM-28. Fort Collins, CO: U.S. Department of Agriculture, Forest Service, Rocky Mountain Forest and Range Experiment Station. 45 p. (RM)

BJORNN, T. C.; M. A. BRUSVEN; M. P. MOLNAU; J. H. MILLIGAN; R. A. KLAMT (SIC R. R.); E. CHACHO; and T. SCHAYE. 1977. Transport of granitic sediment in streams and its effects on insects and fish. Bull. 17. Moscow, ID: University of Idaho, Forest, Wildlife and Range Experiment Station. 43 p. (PNW)

BOWERS, WAYNE; BILL HOSFORD; ART OAKLEY; and CARL BOND. 1979. Wildlife habitats in managed rangelands--the Great Basin of southeastern Oregon: Native trout. Gen. Tech. Report PNW-84. Portland, OR: U.S. Department of Agriculture, Forest Service, Pacific Northwest Forest and Range Experiment Station. 16 p. (PNW)

BROWN, SANDRA; and ARIEL E. LUGO. 1981. Management and status of U. S. commercial marine fisheries. Washington, DC: Council on Environment Quality. 45 p. (SO) 
BRUSVEN, M. W.; W. R. MEEHAN; and J. F. WARD. 1986. Summer use of simulated undercut banks by juvenile chinook salmon in an artificial Idaho Channel. North American Journal of Fish Management. 6:36-37. (PNW)

BRYANT, M. D. 1984. The role of beaver dams as coho salmon habitat in southeast Alaska streams. In: Walton, J. M.; and D. B. Houston, eds.

Proceedings of the Olympic Wild Fish Conference; 1983 March 23-25; Port Angeles, WA. National Park Service and Peninsula College: 183-192. (PNW)

BRYANT, MASON D. 1985. Changes 30 years after logging in large woody debris, and its use by salmonids. In: Johnson, R. Roy; Charles D. Ziebell; David R. Patton; Peter F. Ffolliott; and R. H. Hamre, tech eds. Riparian ecosystems and their management: Reconciling conflicting uses: Proceedings, First North American riparian conference; 1985 April 16-18; Tucson, AZ. Gen. Tech. Rep. RM-120. Fort Collins, CO: U.S. Department of Agriculture, Forest Service, Rocky Mountain Forest and Range Experiment Station: 329-334. (PNW)

BRYANT, MASON D. 1988. Gravel pit ponds as habitat enhancement for juvenile coho salmon. Gen. Tech. Rep. PNW212. Portland, OR: U.S. Department of Agriculture, Forest Service, Pacific Northwest Research Station. 10 p. (PNW)

BUSDOSH, M.; MIKE MCSORLEY; and JOHN N. RINNE. 1978. Age and growth of channel catfish, Ictalurus punctatus, in the Salt River, Arizona. Journal Arizona-Nevada Academy Science. 13(2). (RM)

CANTON, STEVEN P.; LEO D. CLINE; ROBERT A. SHORT; and JAMES V. WARD. 1984. The macroinvertebrates and fish of a Colorado stream during a period of fluctuating discharge.

Freshwater Biology. 14:311-316. (RM)
CONSTANTZ, GEORGE D. 1979. Life history patterns of livebearing fish in contrasting environments. Oecologia. (Berlin) 40:189-201.

DEBANO, LEONARD F.; and BURCHARD H. HEEDE. 1987. Enhancement of riparian ecosystems with channel structures. Arizona Water Resources Bulletin. 23:463-470. (RM)

DOLLOFF, C. ANDREW. 1987. Seasonal population characteristics and habitat use by juvenile coho salmon in a small southeast Alaska stream. Transactions of the American Fisheries Society. 116:829-838. (PNW)

EVEREST, FRED H. 1979. How to demonstrate the importance of fishery resources to interdisciplinary planning teams. Fisheries. 4(1):15-19. (PNW)

EVEREST, FRED H. 1980. Perspectives on National Forest fishery values for landuse planning. Cal-Neva Wildlife Transactions. 1980:64-70. (PNW)

EVEREST, FRED H. 1987. Salmonids of western forested watersheds. In: Proceedings of a symposium: Streamside management: forestry and fishery interactions; 1986 February 1214; Seattle, WA: University of Washington, Institute of Forest Resources: 3-8. (PNW)

EVEREST, FRED H.; GORDON H. REEVES; and JAMES H. SEDELL. 1986. Abundance, behavior, and habitat utilization by coho salmon and steelhead trout in Fish Creek, Oregon, as influenced by habitat enhancement. Portland, OR: U.S. Department of Energy, Bonneville Power Administration. 100 p. (PNW) 
EVEREST, FRED H.; GORDON H. REEVES; JAMES R. SEDELL; DAVID B.

HOHLER; and THOMAS CAIN. 1987.

The effects of habitat enhancement on steelhead trout and coho salmon smolt producton, habitat utilization, and habitat availability in Fish Creek, Oregon.

Portland, OR: U.S. Department of Energy, Bonneville Power

Administration. 128 p. (PNW)

EVEREST, FRED H.; NEIL B.

ARMANTROUT; STEVEN M. KELLER; WILLIAM D. PARANTE; and JAMES R.

SEDELL; [and others]. 1985. Salmonids. In: Brown, E. Reade, ed. Management of wildlife and fish habitats in forests of Western Oregon and Washington. Portland, OR: U.S. Department of Agriculture, Forest Service: 199-230. Chapter 10. (PNW)

EVEREST, FRED H.; ROBERT L. BESCHTA; J. CHARLES SCRIVENER; K.V. KOSKI; JAMES R. SEDELL; and C. JEFF CEDERHOLM. 1987. Fine sediment and salmonid production: a paradox. In:

Proceedings of a symposium: streamside management: forestry and fishery interactions; 1986 February 1214; Seattle, WA: University of Washington, Institute of Forest Resources: 98-142. (PNW)

FAUSCH, KURT D.; CLIFFORD L. HAWKES; and MIT G. PARSONS. 1988. Models that predict standing crop of stream fish from habitat variables: 1950-85. Gen. Tech. Rep. PNW-GTR-213. Portland, OR: U.S. Department of Agriculture, Forest Service, Pacific Northwest Research Station. 52 p. (PNW)

FLEBBE, PATRICIA A. 1988. Regional coldwater fish abundance projections. In: Gelinas, R.; D. Bond; and B. Smit, eds. Perspectives on land modelling: Proceedings, land modelling:

Perspectives on land modelling workshop; Canada Committee on Ecological Land Classification; Toronto, Canada. Montreal, Canada, Polyscience Publications, Inc.: 49-58. (RM)
FLEBBE, PATRICIA A.; THOMAS W. HOKSTRA; and N. D. COST. 1988. Recent historical and projected regional trends of trout in the Southeastern United States. Gen. Tech. Rep. RM-160. Fort Collins, CO: U.S. Department of Agriculture, Forest Service, Rocky Mountain Forest and Range Experiment Station. 19 p. (RM)

GIBBONS, DAVE R.; WILLIAM R. MEEHAN; K. V. KOSKI; and THEODORE R. MERRELL, JR. 1987. History of studies of fisheries and forestry interactions in southeastern Alaska. In: Proceedings of a symposium: streamside management: forestry and fishery interactions; 1986 February 12-14; Seattle, WA: University of Washington, Institute of Forest Resources: 297-329. (PNW)

GROSSMAN, G. D.; and MARY C. FREEMAN. 1987. Microhabitat use in a stream fish assemblage. Journal of Zoology [London]. 212:151-176. (SE)

HILLMAN, T. W.; J. S. GRIFFITH; and WILLIAM S. PLATTS. 1987. Summer and winter habitat selection by juvenile chinook salmon in a highly sedimented Idaho stream. Transactions of the American Fisheries Society. 116:185195. (INT)

HOEKSTRA, THOMAS W.; and NOEL D. COST. 1988. Recent historical and projected regional trends of trout in the Southeastern United States. Gen. Tech. Rep. RM-160. Fort Collins, CO: U.S. Department of Agriculture, Forest Service, Rocky Mountain Forest and Range Experiment Station. 19 p. (RM)

JOHNSON, JAMES E.; and JOHN N. RINNE. 1982. The endangered species act and southwest fishes. Fisheries. 7(4):2-8. (RM)

LEE, RAYMOND M.; and JOHN N. RINNE. 1980. Critical thermal maxima of five trout species in the Southwestern United States. Transactions American Fishery Society. 109:632-635. (RM) 
LISLE, T.E. 1986. Effects of woody debris on anadromous salmonid habitat, Prince of Wales Island, Alaska. North American Journal of Fisheries Management. 6:538-550. (PSW)

LOUDENSLAYER, ERIC J.; JOHN N. RINNE; G. A. E. GALL; and ROBERT E. DAVID. 1986. Biochemical genetic studies of native Arizona and New Mexico trout. The Southwestern Naturalist. 31:221234. (RM)

MEEHAN, WILLIAM R. 1983. Seagoing migrants: our Northwestern salmon and trout. In: Using our natural resources: 1983 Yearbook of Agriculture. Washington, DC: U.S. Department of Agriculture: 306-315. (PNW)

MEEHAN, WILLIAM R.; and DOUGLAS N. SWANSTON. 1977. Effects of gravel morphology on fine sediment accumulation and survival of incubating salmon eggs. Res. Pap. PNW-220. Portland, OR: U.S. Department of Agriculture, Forest Service, Pacific Northwest Forest and Range Experiment Station. 16 p. (PNW)

MEEHAN, WILLIAM R.; MERLYN A. BRUSVEN; and JOHN F. WARD. 1987. Effects of artificial shading on distribution and abundance of juvenile chinook salmon (Oncorhynchus tshawytscha). Great Basin Naturalist. 47:22-31. (PNW)

MEEHAN, WILLIAM R.; THEODORE R. MERRELL JR.; and THOMAS A. HANLEY, eds. 1984. Fish and wildlife relationships in old-growth forests:

Proceedings of a symposium; 1982 April 12-15; Juneau, AK. American Institure of Fishery Research Biologists. 425 p. (PNW)

MEFFEE, GARY K.; DEAN A. HENDRICKSON; and JOHN N. RINNE. 1982. Description of a new topminnow population in Arizona, with observation on topminnow/mosquitofish cooccurrence. Southwest Naturalist. 27:226-228. (RM)
MEFFEE, GARY K.; DEAN A.

HENDRICKSON; W. L. MINCKLEY; and JOHN N. RINNE. 1983. Factors resulting in decline of the endangered Sonoran topminnow Poeciliopsis occidentalis (Atheriniformes: Poeciliidae) in the United States. Biology Conservation. 25:135-159. (RM)

MINCKLEY, W. L.; JOHN N. RINNE; and JAMES E. JOHNSON. 1977. Status of the gila topminnow (Peociliopsis $O$. occidentalis) and its co-occurrence with mosquitofish, (Gambusia affinis). Res. Pap. RM-198. Fort Collins, CO: U.S. Department of Agriculture, Forest Service, Rocky Mountain Forest and Range Experiment Station. 8 p. (RM)

NELSON, RODGER L.; WILLIAM S. PLATTS; and OSBORNE CASEY. 1987.

Evidence for variability in spawning behavior of interior cutthroat trout in response to environmental uncertainty. Great Basin Naturalist. 47:480-487. (INT)

NOLAN, K. M.; T. E. LISLE; and H. M. KELSEY. 1987. Bankfall discharge and sediment transport in northwestern California. In: Erosion and sedimentation in the Pacific Rim; 1987 August; Corvallis, OR: International Association of Hydrological Sciences: 439-450. (PSW)

PEARSON, HENRY A.; JAMES L. WOLFE; and RENNE R. LOHOEFENNER. 1987. Fish diversity and abundance in streams of the DeSoto National Forest, Mississippi. In: Pearson, Henry A.; Fred Smeins; and Ronald E. Thill, comps. 1987. Ecological, physical, and socioeconomic relationships within southern National Forests: Proceedings of the southern evaluation project workshop; 1987 May 26-27; Long Beach, MS. Gen. Tech. Rep. SO-68. New Orleans, LA: U.S. Department of Agriculture, Forest Service, Southern Forest Experiment Station: 179-185. (SO) 
PLATTS, WILLIAM S. 1979. Including the fishery system in land planning. Gen. Tech. Rep. INT-60. Ogden, UT: U.S. Department of Agriculture, Forest Service, Intermountain Forest and Range Experiment Station. 37 p. (INT)

PLATTS, WILLIAM S. 1986. Managing fish and livestock on Idaho rangelands. Rangelands. 8:213-216. (INT)

PLATTS, WILLIAM S.; and FRED E. PARTRIDGE. 1978. Rearing of chinook salmon in tributaries of the South Fork Salmon River, Idaho. Res. Pap. INT205. Ogden, UT: U.S. Department of Agriculture, Forest Service, Intermountain Forest and Range Experiment Station. 11 p. (INT)

PLATTS, WILLIAM S.; and RODGER LOREN NELSON. 1983. Population fluctuations and genetic differentiation in the Humboldt cutthroat trout of Gance Creek, Nevada. Cal-Neva Wildlife Transactions. 1983:15-19. (INT)

REEVES, GORDON H.; and FRED H. EVEREST. 1987. Interactions between the redside shiner (Richardsonius balteatus) and the steelhead trout (Salmo gaidner) in western Oregon: the influence of water temperature. Canadian Journal of Fisheries and Aquatic Sciences. 44(9):1603-1613. (PNW)

REISER, D. W.; and T. C. BJORNN. 1979. Habitat requirements of anadromous salmonids. In: Meehan, William R.; tech. ed. Influence of forest and rangeland management on anadromous fish habitat in western North America. Gen. Tech. Rep. PNW-96. Portland, OR: U.S. Department of Agriculture, Forest Service, Pacific Northwest Forest and Range Experiment Station. $54 \mathrm{p}$. Chapter 1. (PNW)
RICHARDSON, FRANK; and R. H. HAMRE. tech. eds. 1985. Wild trout III.

Proceedings of the symposium; 1984 September 24-25; Yellowstone National Park, WY. Vienna, VA: Trout Unlimited. 192 p. (RM)

RINNE, JOHN N. 1980. Arizona trout. In: Lee, David S.; [and others], eds. Atlas of North American freshwater fishes.

Publication 1980-12. Raleigh, NC: North Carolina Biological Survey, North Carolina State Museum: 104. (RM)

RINNE, JOHN N. 1980. Gila trout. In: Lee, David S.; [and others], eds. Atlas of North American freshwater fishes. Publication 1980-12. Raleigh, NC: North Carolina Biological Survey. North Carolina State Museum: 107. (RM)

RINNE, JOHN N. 1980. Spawning habitat and behavior of Gila trout, a rare salmonid of the southwestern United States. Transactions of American Fisheries Society. 109:83-91. (RM)

RINNE, JOHN N. 1982. Movement, home range, and growth of a rare southwestern trout in improved and unimproved habitats. North American Journal Fish Management. 2(2):150157. (RM)

RINNE, JOHN N. 1985. Endangered and nongame fish programs in the West: their role in the conservation of native fishes. In: Western proceedings: 64th annual conference of the Western Association of Fish and Wildlife Agencies; 1984 July 16-19; Victoria, BC Sacramento, CA: Western Association of Fish and Wildlife Agencies: 456-469. (RM)

RINNE, JOHN N. 1989. Physical habitat use by loach minnow, Tiaroga cobitis (Pices: Cyprinidae), in southwestern desert streams. Southwestern Naturalist. 34:109-117. (RM) 
RINNE, JOHN N.; and BENNIE WANJALA. 1983. Maturity, fecundity, and breeding seasons of the major catfishes in Lake Victoria, East Africa. Journal of Fisheries Bulletin. 23:357-363. (RM)

RINNE, JOHN N.; BEN ROBERTSON; RON MAJOR; and KEN HARPER. 1979.

Sport fishing for the native Arizona trout, Salmo apache (Miller), in Christmas Tree Lake: A case study. In: Wild trout II symposium; 1979 September 24-25; Mammoth, WY. 7 p. (RM)

RINNE, JOHN N.; BRYCE RICKEL; and DEAN HENDRICKSON. 1980. A new Gila topminnow locality in southern Arizona. Res. Note RM-362. Fort Collins, CO: U.S. Department of Agriculture, Forest Service, Rocky Mountain Forest and Range Experiment Station. 4 p. (RM)

RINNE, JOHN N.; JAMES E JOHNSON; BUDDY L. JENSEN; ALAN W. RUGER; and ROGER SORENSON. 1986. The role of hatcheries in the management and recovery of threatened and endangered fishes. In: Stroud, Richard $H$., ed. Fish culture in fisheries management; 1985 March 31-April 3; Lake Ozark, MO. Bethesda, MD: American Fisheries Society: 271-285. (RM)

RINNE, JOHN N.; ROGER SORENSEN; and SCOTT C. BELFIT. 1985. An analysis of F1 hybrids between Apache, (Salmo apache) and rainbow trout, (Salmo gairdnerii). Journal of the ArizonaNevada Academy of Science. 20(2):6369. (RM)

RODGERS, J. D.; R. D. EWING; and J. D. HALL. 1987. Physiological changes during the outmigration of wild juvenile coho salmon (Oncorhynchus kisutch). Canadian Journal of Fisheries and Aquatic Sciences. 44:452-457. (PNW)
SEDELL, JAMES R.; P. S. BISSON; J. A. JUNE; and R. W. SPEAKER. 1982. Ecology and habitat requirements of fish populations in South Fork Hoh River, Olympic National Park. In: Starkey, Edward E.; Jerry F. Franklin; and Jean W. Matthews, tech. coords. Ecological research in National Parks of the Pacific Northwest: Proceedings, 2nd conference on scientific research in the National Parks; 1979 November; San Francisco, CA. Corvallis, OR: Oregon State University, Forest Research Laboratory: 34-42. (PNW)

SEYEDBAGHERI, KATHLEEN A.; MICHAEL L. MCHENRY; and WILLIAM S. PLATTS. 1987. An annotated bibliography of the hydrology and fishery studies of South Fork Salmon River, Gen. Tech. Rep. INT-235. Ogden, UT: U.S. Department of Agriculture, Forest Service, Intermountain Research Station. 27 p. (INT)

SIGLER, JOHN W.; T. C. BJORNN; and FRED H. EVEREST. 1984. Effects of chronic turbidity on density and growth of steelheads and coho salmon. Transactions of the American Fishery Society. 113:142-150. (PNW)

SULLIVAN, KATHLEEN; THOMAS E LISLE; C. ANDREW DOLLOFF; GORDEN E. GRANT; and LESLIE M REID. 1987. Stream channels: the link between forests and fishes. In: Salo, Ernest O.; and Terrance W. Cundy, eds.

Proceedings of a symposium:

Streamside management: forestry and fishery interactions: 1986 February 1214; Seattle, WA: University of Washington, Institute of Forest Resources: 40-97. (PNW)

WILZBACK, M. A. 1985. Relative roles of food abundance and cover in determining the habitat distribution of stream-dwelling cutthroat trout (Salmo clarki). Canadian Journal of Fish and Aquatic Sciences. 42:1669-1672. (PNW) 
ZINKL, JOSEPH S.; PATRICK J. SHEA; RODNEY J. NAKAMOTO; and JOSH CALLMAN. 1987. Brain cholinesterase activity of rainbow trout poisoned by carbaryl. Bulletin of Environmental Contamination and Toxicology. 38:2935. (PSW)

\section{Stream Ecosystems And Aquatic} Habitats

BAROSS, J. A.; C. N. DAHM; A. K. WARK; M. D. LILLEY; and J. R. SEDELL. 1982. Initial microbiological response in lakes to the Mt. St. Helens eruption. Nature. 296:49-52. (PNW)

BAROSS, J. A.; M. D. LILLEY; C. N. DAHM; and L. I. GORDON. 1982. Evidence for microbial linkages between $\mathrm{CH}_{4}$ and $\mathrm{CO}$ in aquatic environments. Eos. 63:155. (PNW)

BESCHTA, ROBERT L.; and WILLIAM S. PLATTS. 1986. Morphological features of small streams: Significance and function. Water Resources Bulletin. 22:369-379. (INT)

BISSON, PETER A.; ROBERT E. BILBY; MASON D. BRYANT; C. ANDREW DOLLOFF; GLENN B. GRETTE; ROBERT A HOUSE; [and others]. 1987. Large woody debris in forested streams in the Pacific Northwest: past, present, and future. In: Proceedings of a symposium: streamside management: forestry and fishery interactions; February 12-14, 1986; Seattle, WA: Institute of Forest Resources, University of Washington: 143-190. (PNW)

CANTON, STEVEN P.; LEO D. CLINE; ROBERT A. SHORT; and JAMES V. WARD. 1984. The macroinvertebrates and fish of a Colorado stream during a period of fluctuating discharge.

Freshwater Biology. 14:311-316. (RM)
CLINE, L. D.; R. A. SHORT; J. V. WARD; and C. A. CARLSON. 1979. The inertia and resiliency of a mountain stream to construction impact. In: G. A. Swanson, tech. coord. The mitigation symposium: a national workshop on mitigating losses of fish and wildlife habitats. 1979 July 16-20. Gen. Tech. Report RM-65. Fort Collins, CO: U.S. Department of Agriculture, Forest Service, Rocky Mountain Forest and Range Experiment Station: 617-620. (RM)

CUMMINS, K. W.; G. W. MINSHALL; J. R. SEDELL; and R. C. PETERSEN. 1984. Stream ecosystem theory. E.

Schweiaerhart'ache

Verlasbuchhandlung, D-7000. Stuttgart. (PNW)

CUMMINS, K. W.; J. R. SEDELL; F. J. SWANSON; G. W. MINSHALL; S. G. FISHER; C. E. CUSHING; R. C. PETERSON; and R. L. VANNOTE. 1983. Organic matter budgets for stream ecosystems: problems in their evaluation. In: Barnes, James R.; and G. Wayne Minshall, eds. Stream ecology: application and testing of general ecological theory. New York, NY: Plenum Press: 299-353. (PNW)

CUSHING, C. E.; C. D. McINTIRE; J. R. SEDELL; D. W. CUMMINS; G. W. MINSHALL; R. C. PETERSON; and R. L. VANNOTE. 1980. Comparitive study of physical-chemical variables of streams using multivariate analyses. Archiv fuer Hydrobiologie. 89(3):343352. (PNW)

CUSHING, C. E.; C. D. MCINTIRE; K. W. CUMMINS; G. W. MINSHALL; R. C. PETERSEN; J. R. SEDELL; and R. L. VANNOTE. 1983. Relationships among chemical, physical, and biological indices along river continua based on multivariate analyses. Archive fuer Hydrobiologie. 98(3):317-326. (PNW) 
DAHM, C. N.; J. A. BAROSS; A. K. WARD; M. D. LILLEY; and J. R. SEDELL. 1983. Initial effects of the eruption of Mt. St. Helens on nitrogen cycle and related chemical processes in Ryan Lake. Applied and Environmental Microbiology. 45:1633-1645. (PNW)

DAHM, C. N.; J. A. BAROSS; M. D. LILLEY; A. K. WARD; and J. R. SEDELL. 1980. Microbial and chemical responses of lakes in the blast zone of Mt. St. Helens, 1980 and 1981. Eos. 62:868. (PNW)

DAHM, CLIFFORD N.; JAMES R. SEDELL; and ELENORA H. TROTTER. 1987. Role of anerobic zones and processes in stream ecosystem productivity. In: Averett, R. C.; and D. M. McNight, comps., eds. The book of chemical quality of water in the hydrologic cycle. Lewis Publishers, Inc.: 157-178. (PNW)

DAHM, CLIFFORD N.; JOHN A. BAROSS; MARVIN D. LILLEY; AMELIA K. WARD; and JAMES R. SEDELL. 1982. Lakes in the blast zone of Mt. St. Helens: chemical and microbial responses following the May 18, 1980 eruption. In: Mt. St. Helens: effects on water resources: proceedings of the conference; 1981 October 7-8; Jantzen Beach, OR. Rep. 41. Pullman, WA: Washington State University and University of Washington, State of Washington Water Research Center: 98-137. (PNW)

DUNCAN, W. F.; and M. A. BRUSVEN. 1985. Energy dynamics of three low-order Southeast Alaskan streams: Allochthonous production. Journal of Freshwater Ecology. 3:233-248. (PNW)

DUNCAN, W. F.; and M. A. BRUSVEN. 1985. Energy dynamics of three low-order Southeast Alaskan streams: Autochthonous production. Journal of Freshwater Ecology. 3:155-166. (PNW)
ESTEP, MARGARET A.; and ROBERT L. BESCHTA. 1985. Transport of bedload sediment and channel morphology of a southeast Alaska stream. Res. Note PNW-430. Portland, OR: U.S. Department of Agriculture, Forest Service, Pacific Northwest Forest and Range Experiment Station. 15 p. (PNW)

FRANKLIN, JERRY F.; FREDERICK J. SWANSON; and JAMES R. SEDELL. 1980. Relationships within the valley floor ecosystems in western Olympic National Park: a summary. In: Proceedings, 2nd conference on scientific research in National Parks. NPS/ST-80/02-7. Washington, D.C.: National Park Service. 7:47-63. (PNW)

FRANKLIN, JERRY F.; KERMIT CROMACK, JR.; WILLIAM DENISON; ARTHUR MCKEE; CHRIS MASER; JAMES R. SEDELL; FRED SWANSON; and GLEN JUDAY. 1980. Ecological characteristics of old-growth Douglas-fir forests. Gen. Tech. Rep. PNW-118. Portland, OR: U.S. Department of Agriculture, Forest Service, Pacific Northwest Forest and Range Experiment Station. 48 p. (PNW)

FRISSELL, CHRISTOPHER A.; WILLIAM J. LISS; CHARLES E. WARREN; and MICHAEL D. HURLEY. 1986. A hierarchical framework for stream habitat classification viewing streams in a watershed context. Environmental Management. 10:199-214.

HARMON, M. E.; J. F. FRANKLIN; F. J. SWANSON; P. SOLLINS; S. V. GREGORY; J. D. LATTIN; N. H. ANDERSON; S. P. CLINE; N. G. AUMEN; J. R. SEDELL; G. W. LIENKAEMPER; K. CROMACK, JR.; and K. W. CUMMINS. 1986. Ecology of coarse woody debris in temperate ecosystems. Advances in Ecological Research. 15:133-302. (PNW) 
HARSHBARGER, T. J. 1978. Factors affecting regional trout stream productivity. In: Proceedings of the southeastern trout resource: ecology and management symposium; 1975 October; Blacksburg, VA: 11-27. (SE)

HARSHBARGER, T. J.; and $H$.

BHATTACHARYYA. 1981. An application of factor analysis in an aquatic habitat study. In: Capen, David E., ed. The use of multivariate statistics in studies of wildlife habitat: Workshop proceedings; 1980 April 23-25; Burlington, VT. Gen. Tech. Rep. RM-87. Fort Collins, CO: U.S. Department of Agriculture, Forest Service, Rocky Mountain Forest and Range Experiment Station: 180-184. (SE)

HAWKES, CLIFFORD L. 1979. Aquatic habitat of coal and bentonite clay strip mine ponds in the northern Great Plains. In: Mohan K. Wali, ed. Ecology and coal resource development, Volume II. New York, NY: Pergamon Press: 609-614. (RM)

HAWKES, CLIFFORD L. 1980. Aquatic habitat of wetlands, ponds, and lakes of semi-arid regions: An annotated bibliography of selected literature. NTIS: PB81-131682. Springfield, VA. 150 p. (RM)

HAWKES, CLIFFORD L.; and LOGAN A. NORRIS. 1977. Chronic oral toxicity of 2, 3, 7, 8-Tetrachlorodibenzo-p-dioxin (TCCD) to rainbow trout. Transactions, American Fishery Society. 106(6):641645. (RM)

HAWKINS, CHARLES P.; and JAMES R. SEDELL. 1980. Longitudinal and seasonal changes in functional organization of macroinvertebrate communities in four Oregon streams. Ecology. 62:387-397. (PNW)
HEEDE, BURCHARD H. 1985. The evolution of salmonid systems. In: Wild trout III: Proceedings of the symposium, Yellowstone National Park, Wyoming; 1984 September 24-25; Yellowstone, WY. Vienna, VA: Wild Trout: 33-37. (RM)

HEEDE, BURCHARD H. 1986. Balance and adjustment processes in stream and riparian systems. In: Brosz, Donald J.; and J. Daniel Rodgers, coords.

Proceedings: Wyoming water and streamside zone conference; 1986 April 28-30; Casper, WY. Laramie, WY: University of Wyoming: Wyoming Water Research Center: 3-7. (RM)

JUDAY, GLENN PATRICK; and JOHN C. ZAZADA. 1984. Structure and development of an old-growth white spruce forest on an interior Alaska floodplain. In: Meehan, William R.; Theodore R. Merrell, JR.; and Thomas A. Hanley, eds. Fish and wildlife relationships in old-growth forests; Proceedings of a symposium; 1982 April 12-15; Juneau, AK. Morehead City, NC: American Institute of Fishery Research Biologists: 227-234. (PNW)

LIENKAEMPER, G. W.; and F. J. SWANSON. 1987. Dynamics of large woody debris in streams in old-growth Douglas-fir forests. Canadian Journal of Forest Research. 17:150-156. (PNW)

LISLE, THOMAS E. 1983. The role of structure in the physical habitat of anadromous salmonids. In: Toole, Christopher; Bruce Wyatt; Sari Sommarstrom; and Ken Hashagen, eds. 1st California salmon and steelhead restoration conference; 1983 January 22-23; Bodega Bay, CA. Eureka, CA: University of California, Cooperative Extension Sea Grant Program: 43-46. (PSW) 
LISLE, THOMAS E. 1987. Channel morphology and sediment transport in steepland streams. In: erosion and sedimentation in the Pacific Rim; 1987 August; Corvallis, OR: International Association of Hydrological Sciences: 287-297. (PSW)

LOTSPEICH, FREDERICK B.; and WILLIAM E. PLATTS. 1981. An integrated landaquatic classification. In: Armantrout, Neil B., ed. Acquisition and utilization of aquatic habitat inventory information: Proceedings of a symposium; 1981 October 28-30; Portland, OR. Bethesda, MD: Western Division, American Fisheries Society: 103-108. (INT)

MAURER, M. A.; and M. A. RRUSVEN. 1983. Insect abundance and colonization rate in Fontinalis neo-mexicana (Bryophyta) in an Idaho batholith stream, U.S.A. Hydrobiologia. 98:9-15. (PNW)

MEEHAN, WILLIAM R.; and WILLIAM S. PLATTS. 1978. Livestock grazing and the aquatic environment. Journal of Soil and Water Conservation. 33:274-278. (PNW)

MEEHAN, WILLIAM R.; FREDERICK J. SWANSON; and JAMES R. SEDELL. 1977. Influences of riparian vegetation on aquatic ecosystems with particular reference to salmonid fishes and their food supply. In: Johnson, R. Roy; and Dale A. Jones, tech. eds. Importance, preservation and management of the riparian habitat: Symposium proceedings; 1977 July 9; Tucson, AZ: Gen. Tech. Rep. RM-43. Fort Collins, CO: U.S. Department of Agriculture, Forest Service, Rocky Mountain Forest and Range Experiment Station: 137145. (PNW)

MINKLEY, W. L.; and JOHN N. RINNE. 1985. Large woody debris in hot-desert streams: An historical review. Desert Plants. 7:142-153. (RM)
MINSHALL, G. WAYNE; KENNETH W. CUMMINS; ROBERT C. PETERSON; COLBERT E. CUSHING; DALE A. BURNS; [and others]. 1985. Developments in stream ecosystem theory. Canadian Journal of Fisheries and Aquatic Science. 42(5):1045-1055. (PNW)

MINSHALL, G. WAYNE; ROBERT C. PETERSEN; KENNETH W. CUMMINS; THOMAS L. BOTT; JAMES R. SEDELL; COLBERT E. CUSHING; and ROBIN L. VANNOTE. 1983. Interbiome comparison of stream ecosystem dynamics. Ecological Monograph. 53:125. (PNW)

NAIMAN, ROBERT J.; and JAMES R. SEDELL. 1979. Bethic organic matter as a function of stream order in Oregon. Archives of Hydrobiology. 87:404-422. (PNW)

NAIMAN, ROBERT J.; and JAMES R. SEDELL. 1980. Relationships between metabolic parameters and stream order in Oregon. Canadian Journal Fish Aquatic Science. 37(5):834-847. (PNW)

NAIMAN, ROBERT J.; and JAMES R. SEDELL. 1980. Stream ecosystem research in a watershed perspective. Verh. Int. Ver. Limnol. 21: 804-811. (PNW)

PLATTS, WILLIAM S. 1976. The place of the aquatic specialist in the interdisciplinary approach to solving streamflow problems. In: Proceedings, Symposium and special conference on instream flow needs: 1976 May 3-6; Boise, ID: West Division American Fisheries Society and American Society Civil Engineering: 636-647. Volume II. (INT)

PLATTS, WILLIAM S. 1979. Relationships among stream order, fish populations, and aquatic geomorphology in an Idaho river drainage. Fisheries. 4(2):5-9. (INT)

PLATTS, WILLIAM S. 1980. A plea for fishery habitat classification. Fisheries. 5(1):2. (INT) 
PLATTS, WILLIAM S. 1981. Streamside management to protect bank-channel stability and aquatic life. In:

Baumgartner, David M., ed.

Proceedings, Interior West watershed management symposium; 1980 April 810; Spokane, WA. Pullman, WA: Washington State University, Cooperative Extension: 245-255. (INT)

PLATTS, WILLIAM S. 1983. Vegetation requirements for fisheries habitats. In: Monsen, Stephen B.; and Nancy Shaw, comps. Managing Intermountain rangelands--improvement of range and wildlife habitats: Proceedings of symposia; 1981 September 15-17; Twin Falls, ID. 1982 June 22-24. Elko, NV. Gen. Tech. Rep. INT-157. Ogden, UT: U.S. Department of Agriculture, Forest Service, Intermountain Forest and Range Experiment Station: 184-188. (INT)

PLATTS, WILLIAM S. 1983. How many stream habitat evaluation systems do we need? -- less than a million. In: Proceedings, $63 \mathrm{~d}$ annual conference of the Western Association of Fish and Wildlife Agencies; 1983 July 10-14; Teton Village, WY. Boise, ID: Western Association of Fish and Wildlife Agencies: 212-220. (INT)

PLATTS, WILLIAM S. 1983. Those vital streambanks. Idaho Wildlife. 3(9):6-10. (INT)

PLATTS, WILLIAM S. 1986. Managing riparian stream habitats. In: Proceedings Wyoming water and streamside zone conference; 1986 April 28-30; Casper, WY. Laramie, WY: University of Wyoming: 59-62. (INT)

PLATTS, WILLIAM S. 1986. Riparian-stream management. In: National range conference proceedings; 1985 November 6-8; Oklahoma City, OK. Washington, DC: U.S. Department of Agriculture: 70-74. (INT)
PLATTS, WILLIAM S. 1987. Riparian stream management. Transactions Western Section, The Wildlife Society. 22:90-93. (INT)

PLATTS, WILLIAM S.; and RODGER LOREN NELSON. 1985. Impacts of rest-rotation grazing on stream banks in forested watersheds in Idaho. North American Journal of Fisheries Management. 5:547-556. (INT)

PLATTS, WILLIAM S.; RODGER LOREN NELSON; OSBORNE CASEY; and VAL CRISPIN. 1983. Riparian-stream habitat conditions on Tabor Creek, Nevada, under grazed and ungrazed conditions. In: Proceedings, 63d annual conference of the Western Association of Fish and Wildlife Agencies; 1983 July 10-14; Teton Village, WY. Boise, ID: Western Association of Fish and Wildlife Agencies: 162-174. (INT)

PRIMBS, EDWARD R. J.; and WILLIAM S. PLATTS. 1976. The colonization of the South Fork of the Salmon River by the Columbia Sculpin (Cottus hubbsi). Journal Idaho Academy Science. 12(1):47-49. (INT)

RINNE, JOHN N.; W. L. MINCKLEY; and P. O. BERSELL. 1981. Factors influencing fish distribution in two desert reservoirs, central Arizona. Hydrobiologia. 80:3142. (RM)

RUMBLE, MARK A.; M. T. ANDERSON; and C. L. HAWKES. 1984. Morphometry of coal and bentonite surface mine and livestock impoundments in the northern High Plains. Reclamation and Revegetation Research. 3(1984/85):293-300. (RM)

SEDELL, JAMES R. 1984. Stream characteristics and fallen tress. In: Maser, Chris; and James M. Trappe, eds. The seen and unseen world of the fallen tree. Gen. Tech. Rep. PNW-164. Portland, OR: U.S. Department of Agriculture, Forest Service, Pacific Northwest Forest and Range Experiment Station: 38-46. (PNW) 
SEDELL, JAMES R.; and FREDERICK J.

SWANSON. 1985. Ecological characteristics of streams in old-growth forests of the Pacific Northwest. In: Meehan, William R.; Theodore R. Merrell and Thomas A. Hanley, eds. Fish and wildlife relationships in oldgrowth forests: Proceedings of a Symposium; 1982 April 12-15; Juneau, AK. American Institute of Fishery Research Biologists: 9-16. (PNW)

SEDELL, JAMES R.; FRED H. EVEREST; and DAVID R. GIBBONS. 1987. Streamside vegetation management for aquatic habitat. In: Proceedings of the national silviculture workshop: Silviculture for all resources; 1987 May 11-14; Sacramento, CA. Washington, DC: U.S. Department of Agriculture, Forest Service, Timber Management: 115-125. (PNW)

SEDELL, JAMES R.; JERRY F. FRANKLIN; and FREDERICK J. SWANSON. 1980. Out of the ash. American Forests. 83(10):26-29, 67-68. (PNW)

SEDELL, JAMES R.; ROBERT J. NAIMAN; KENNETH W. CUMMINS; G. WAYNE MISHALL; and ROBIN L. VANNOTE. 1978. Transport of particulate organic material in streams as a function of physical processes. Verh. Int. Ver. Limnol. 20:1366-1375. (PNW)

SEKULICH, P. T.; and T. C. BJORNN. 1977. The carrying capacity of streams for rearing salmonids as affected by components of the habitat. Moscow, ID: University of Idaho, Forestry Wildlife and Range Experiment Station. 79 p. (PNW)

SILVEY, WILLIAM; JOHN N. RINNE; and ROGER SORENSON. 1984. Index to natural drainage systems of Arizona--A computer compatible digital identification of perennial lotic waters. RUN WILD wildlife/habitat relationships. Wildlife Unit Tech. Rep Albuquerque, NM: U.S. Department of Agriculture, Forest Service, Southwestern Region. 36 p. (RM)
STALEY, J. T.; L. G. LEHMICKE; F. E. PALMER; R. W. PEET; and R. C. WISSMAR. 1982. Impact of Mount St. Helens eruption on bacteriology of lakes in the blast zone. Applied and Environmenatal Microbiology. 43(3):664670. (PNW)

SULLIVAN, K.; T. E. LISLE; C. A. DOLLOFF; G. E. GRANT; and L. M. REID. 1987. Stream channels--the link between forests and fish. In: Streamside management--forestry and fishery interactions; 1986 February 12-14; Seattle, WA.: University of Washington, Institute of Forest Resources: 39-97. Chapter 3. (PSW)

SWANSON, F. J.; S. V. GREGORY; J. R. SEDELL; and A. G. CAMPBELL. 1982. Land-water interactions: the riparian zone. In: Edmonds, Robert L., ed. Analysis of coniferous forest ecosystems in the western United States. Stroudsberg, PA: Hutchinson Ross Publishing: 267-291. (PNW)

SWANSON, FREDERICK J.; GEORGE W. LIENKAEMPER; and JAMES R. SEDELL. 1976. History, physical effects, and management implications of large organic debris in western Oregon streams. Gen. Tech. Rep. PNW-56. Portland, OR: U.S. Department of Agriculture, Forest Service, Pacific Northwest Forest and Range Experiment Station. 15 p. (PNW)

SWANSON, FREDERICK J.; MASON D. BRYANT; GEORGE W. LIENKAEMPER; and JAMES R. SEDELL. 1984. Organic debris in small streams, Prince of Wales Island, southeast Alaska. Gen. Tech. Rep. PNW-166. Portland, OR: U.S. Department of Agriculture, Forest Service, Pacific Northwest Forest and Range Experiment Station. 12 p. (PNW) 
SWANSON, FREDERICK J.; T. K. KRATZ; N. CAINE; and R. G. WOODMANSEE. 1988. Landform effects on ecosystem patterns and processes: geomorphic features of the earth's surface regulate the distribution of organisms and processes. BioScience. 18(2):91-98. (PNW)

SWANSTON, DOUGLAS N. 1980. Impacts of natural events. In: Meehan, William R., tech. ed. Influence of forest and rangeland management on anadromous fish habitat in western North America. Gen. Tech. Rep. PNW-104. Portland, OR: U.S. Department of Agriculture, Forest Service, Pacific Northwest Forest and Range Experiment Station. 27 p. Chapter 2. (PNW)

TIEDEMANN, A. R. 1981. Stream chemistry, nutrient economy, and site productivity consequences of wildland management activities. In: Proceedings interior west watershed conference; 1980 April 8-10; Pullman, WA: Washington State University; Agricultural Extension Service, and Pacific Northwest Forest and Range Experiment Station: 83-201. (INT)

TRISKA, FRANK J.; JAMES R. SEDELL; and STAN V. GREGORY. 1982. Coniferous forest streams. In: Edmonds, Robert L., ed. Analysis of coniferous forest ecosystems in the western United States. Stroudsburg, PA: Hutchinson Ross Publishing: 292-332. (PNW)

TRISKA, FRANK J.; JAMES R. SEDELL; DERMIT CROMACK, JR.; STAN V. GREGORY; and F. MICHAEL F. MCCORISON. 1984. Nitrogen budget for a small coniferous forest stream. Ecological Monographs. 54:119-140. (PNW)
WARD, A. K. ; J. A. BAROSS; C. N. DAHM; M. D. LILLEY; and J. R. SEDELL. 1983. Qualitative and quantitative observations on aquatic algal communities and recolonization within the blast zone of Mount St. Helens, 1980 and 1981. Journal of Phycology. 19:238-247. (PNW)

WEBSTER, J. R.; E. BLOOD; S. V. GREGORY; M. E. GURTZ; R. E. SPARKS; and M. THURMAN. 1985. Long-term research in stream ecology. Bulletin of the Ecological Society of America. 66:346-353. (SE)

WEBSTER, J. R.; M. E. GURTZ; J. J. HAINS; J. L. MEYER; W. T. SWANK; [and others]. 1983. Stability of stream ecosystems. In: Barnes, James R.; and G. Wayne Minshall, eds. Stream ecology. New York, NY: Plenum Publishing: 355-395. (SE)

WESCHE, THOMAS A.; and WILLIAM F. MCTERNAN. 1977. Aquatic biota and abiota of selected streams on Thunder Basin National Grassland, Wyoming. Laramie, WY. University of Wyoming, Water Resources Research Institute. 204 p. (RM)

WESCHE, THOMAS A.; BARRON L. WEAND; GARRY W. ROSENLIEB; and LORA S. JOHNSON. 1978. Aquatic biota and abiota of selected streams on Thunder Basin National Grassland, Wyoming. Part III. Laramie, WY: University of Wyoming. Water Resources Research Institute. 153 p. (RM)

WISSMAR, ROBERT C. 1980. Dissolved organics and $\mathrm{pH}$ in lakes within Mt. St. Helens blast zone. EOS. 62: 868. (PNW)

WISSMAR, ROBERT C. ; ALLEN H. DEVOL; AHMAD E. NEVISSI; and JAMES R. SEDELL. 1982. Chemical changes of lakes within the Mount St. Helens blast zone. Science. 216:175-178. (PNW) 
WISSMAR, ROBERT C.; ALLEN H. DEVOL; JAMES T. STALEY; and JAMES R. SEDELL. 1982. Biological responses of lakes in the Mount St. Helens blast zone. Science. 216:178-181. (PNW)

\section{Aquatic Invertebrates And Their Habitats}

ANDERSON, MARK T. 1981. Improved method for separating zooplankton from detritus. Progressive Fish-Culturist. 43:42-44. (RM)

DUDLEY, TOM; and N. H. ANDERSON. 1982. A survey of invertebrates associated with wood debris in aquatic habitats. Melanderia. 39:1-21; 1982. Taken from: Tech. Pap. 6419. Corvallis, OR: Oregon Agricultural Experiment Station. (PNW)

DUNCAN, W. F.; and M. A. BRUSVEN. 1985. Benthic macroinvertebrates in logged and unlogged low-order Southeast Alaska streams. Freshwater Invertebrate Biology. 4:125-132. (PNW)

GEORGIAN, TED; and J. BRUCE WALLACE. 1982. Seasonal production dynamics in a guild of periphyton-grazing stream insects. BioScience. 34:42-43. (SE)

GURTZ, M. E.; J. P. WEBSTER; and J. B. WALLACE. 1979. Season dynamics in southern Appalachian streams: effects of clearcutting. Canadian Journal Fisheries and Aquatic Sciences. 37:624631. (SE)

GURTZ, MARTIN E.; and J. BRUCE WALLACE. 1986. Substratumproduction relationships in net-spinning caddisflies (Trichoptera) in disturbed and undisturbed hardwood catchments. Journal of the North American

Benthological Society. 5:230-236. (SE)
HAEFNER, J. D.; and J. B. WALLACE. 1981. Shifts in aquatic insect populations in a first-order southern Appalachian stream following a decade of old field succession. Canadian Journal Fishery Aquatic Science. 38:353-359. (SE)

HAWKINS, C. P.; and J. R. SEDELL. 1981. Longitudinal and seasonal changes in functional organization of macroinvertebrate communities in four Oregon streams. Ecology. 62:387-397. (PNW)

HOGUE, CHARLES L.; and TED GEORGIAN. 1986. Recent discoveries in the Blepharicera tenuipes group, including descriptions of two new species from Appalachia (Diptera:Blephariceridae). Contributions in Science. 377:1-20. (SE)

HORNICK, L. E.; J. R. WEBSTER; and E. F. BENFIELD. 1981. Periphyton production in an Appalachian Mountain trout stream. American Midland Naturalist. 106:22-36. (SE)

MAURER, M. A.; and M. A. BRUSVEN. 1983. Insect abundance and colonization rate in Fontinalis neo-mexicana (Bryophyta) in an Idaho Batholith stream, U.S.A. Hydrobiologia. 98:9-15. (INT)

MCLEMORE, CARL E.; and WILLIAM R. MEEHAN. 1988. Invertebrates of Meadow Creek, Union County, Oregon, and their use as food by trout. Res. Pap. PNW-RP-394. Portland, OR: U.S. Department of Agriculture, Forest Service, Pacific Northwest Research Station. 13 p. (PNW)

MINCKLEY, W. L.; and PAULA MIHALICK. 1982. Effects of chemical treatment for fish eradication on stream-dwelling invertebrates. Journal Arizona-Nevada Academy Science. 16(3):79-82. (RM) 
MOLDENKE, ANDREW R.; and BECKY L. FICHTER. 1988. Invertebrates of the $\mathrm{H}$. J. Andrews Experimental Forest, western Cascade Mountains, Oregon: IV. The oribatid mites (Acari: Cryptostigmata). Gen. Tech. Rep. PNW217. Portland, OR: U.S. Department of Agriculture, Forest Service, Pacific Northwest Research Station. 112 p. (PNW)

MOLLES, MANUEL C., JR. 1980. Effects of road salting on aquatic invertebrate communities. Eisenhower Consortium Bulletin 10. Fort Collins, CO: Colorado State University, Eisenhower Consortium for Western environmental forestry research. 9 p. (RM)

O'HOP, JOE; J. BRUCE WALLACE; and JOHN D. HAEFNER. 1984. Production of a stream shredder, Peltoperla maria (Plecoptera: Peltoperlidae) in disturbed and undisturbed hardwood catchments. Freshwater Biology. 14:13-2I. (SE)

PLATTS, WILLIAM S.; and DOUGLAS A. ANDREWS. 1981. Aquatic macroinvertebrates within the phosphate mining area of eastern Idaho. Res. Note. INT-298. Ogden, UT: U.S. Department of Agriculture, Forest Service, Intermountain Forest and Range Experiment Station. 18 p. (INT)

RINNE, JOHN N. 1978. Standing crops of Chrionomidae and Tubificidae in two desert reservoirs, central Arizona. Hydrobiologia. 57(3):217-224. (RM)

ROSS, DOUGLAS H.; and J. BRUCE WALLACE. 1984. Longitudinal patterns of production, food consumption, and seston utilization by net-spinning caddisflies (Trichoptera) in a Southern Appalachian stream (USA). Holarctic Ecology. 6(3):270-284. (SE)

SHORT, ROBERT A.; and JAMES V. WARD. 1980. Life cycle and production of Skwala parallela (Frison)(Plecoptera Perlodidae) in a Colorado montane stream. Hydrobiologia. 69(3):273-275.

(RM)
SHORT, ROBERT A.; and JAMES V. WARD. 1980. Macroinvertebrates of a Colorado high mountain stream. The Southwestern Naturalist. 25(1):23-32. (RM)

SIEG, CAROLYN HULL; DANIEL W. URESK; and RICHARD M. HANSEN. 1987. Impact of bentonite mining on selected arthropods. Journal of Range Management. 40:128-131. (RM)

SMITH-CUFFNEY, FRANCIE L.; and J. BRUCE WALLACE. 1987. The influence of microhabitat on availability of drifting invertebrate prey to a net-spinning caddisfly. Freshwater Biology. 17:91-98. (SE)

VINEYARD, RICHARD N. 1982. An annotated checklist of the caddisflies (Trichoptera) of SE Alaska. Journal Entomology. Society British Columbia. 79:71-75. (PNW)

WALLACE, J. B.; and J. O'HOP. 1979. Fine particle suspension feeding capabilities of Isonychia spp. (Ephemeroptera:

Siphlonuridae). Annals of the Entomological Society American. 72:353-357.

WALLACE, J. BRUCE; T. F. CUFFNEY; C. C. LAY; and D. VOGEL. 1987. The influence of an ecosystem-level manipulation on prey consumption by a lotic dragonfly. Canadian Journal of Zoology. 65:35-40. (SE) 
WARD, G. MILTON; KENNETH W

CUMMINS; ROBERT W. SPEAKER;

AMELIA K. WARD; STANLEY V.

GREGORY; and THOMAS L. DUDLEY.

1982. Habitat and food resources for

invertebrate communities in South Fork

Hoh River, Olympic National Park,

Washington. In: Starkey, Edward E.;

Jerry F. Franklin; and Jean W.

Matthews, tech. coords. Ecological

research in National Parks of the Pacific

Northwest: Proceedings, 2nd

conference on scientific research in the

National Parks; 1979 November; San

Francisco, CA. Corvallis, OR: Oregon

State University, Forest Research

Laboratory: 9-14. (PNW)

WARD, J. F.; and R. A. SHORT. 1978. Macroinvertebrate community structure of four special lotic habitats in Colorado, U.S.A. Proceedings International Association for Theoretical and Applied Limnology Congress. (20):1382-1387.

(RM)

WEBSTER, JACKSON R. 1983. The role of benthic macroinvertebrates in detritus dynamics of streams: a computer simulation. Ecological Monograph. 53:383-404. (SE)

\section{Management Influnces}

ALEXANDER, GAYLORD R.; and EDWARD A. HANSEN. 1977. The effects of sediment from a gas-oil well drilling accident on trout in the Williamsburg area, Michigan. Fish. Res. Rep. 1851. Lansing, Ml: Michigan Department of Natural Resources. 15 p. (NC)

ALEXANDER, GAYLORD R.; and EDWARD A. HANSEN. 1983. Effects of sand bedload sediment on a brook trout population. Fish. Res. Rep. 1906. Ann Arbor, MI: Michigan Department of Natural Resources, Fisheries Division. 50 p. (NC)
ALEXANDER, GAYLORD R.; and EDWARD A. HANSEN. 1986. Sand bed load in a brook trout stream. North American Journal of Fisheries Management. 6:923. (NC)

BENDA, LEE E. 1985. Behavior and effect of debris flows on streams in the Oregon Coast Range. In: Delineation of landslide, flash flood, and debris flow hazards in Utah. A symposium; 1984 June 14-15; Logan, UT: Utah State University: 153-162. (PNW)

BENDA, LEE E. 1985. Delineation of channels susceptible to debris flows and debris floods. International Symposium on Erosion, Debris Flow and Disaster Prevention; 1985 September 3-5; Tsukuba, Japan: 195-201. (PNW)

BENDA, LEE E.; FRED H. EVEREST; and JAMES R. SEDELL. 1987. Influences of forest management on channel environments in the Oregon Coast Range. In: Proceedings of symposium: managing Oregon's riparian zones for timber, fish, and wildlife. NCASI. Tech. Bull. No. 514. New York, NY: National Council of the Paper Industry for Air and Stream Improvement: 40-46. (PNW)

BENDA, LEE; and THOMAS DUNNE. 1987. Sediment routing by debris flow. In: Proceedings of symposium: erosion and sedimentation in the Pacific Rim; 1987 August 3-7; Corvallis, OR. Washington, DC: International Association of Hydrological Sciences: 213-223. (PNW)

BISSON, PETER A.; and JAMES R. SEDELL. 1984. Salmonid populations in streams in clear-cut vs. old-growth forests of western Washington. In: Meehan, William R.; Theodore R. Merrell, Jr. and Thomas A. Hanley, eds. Fish and wildlife relationships in old-growth forests: Proceedings of a Symposium; 1982 April 12-15; Juneau, AK. American Institute of Fishery Research Biologists: 121-129. (PNW) 
BRYANT, MASON D. 1980. Evolution of large, organic debris after timber harvest: Maybesco Creek, 1949 to 1978. Gen. Tech. Rep. PNW-101. Portland OR: U.S. Department of Agriculture, Forest Service, Pacific Northwest Forest and Range Experimemt Station. $30 \mathrm{p}$. (PNW)

BRYANT, MASON D. 1983. The role and management of woody debris in west coast salmonid nursery streams. North American Journal of Fisheries Management. 3:322-330. (PNW)

BRYANT, MASON D. 1985. Changes 30 years after logging in large woody debris, and its use by salmonids. In: Johnson, R. Roy; Charles D. Ziebell; David R. Patton; Peter F. Ffolliott; and R. H. Hamre, tech eds. Riparian ecosystems and their management: Reconciling conflicting uses: Proceedings, First North American riparian conference; 1985 April 16-18; Tucson, AZ. Gen. Tech. Rep. RM-120. Fort Collins, CO: U.S. Department of Agriculture, Forest Service, Rocky Mountain Forest and Range Experiment Station: 329-334. (PNW)

BUSH, P. B.; D. G. NEARY; J. W. TAYLOR, JR.; and W. L. NUTTER. 1986. Effects of insecticide use in a pine seed orchard on pesticide levels in fish. Water Resources Bulletin. 22:817-827. (SE)

CHAMBERLIN, T. W. 1982. Timber harvest. In: Meehan, William R., tech. ed. Influence of forest and rangeland management on anadromous fish habitat in western North America. Gen. Tech. Rep. PNW-136. Portland, OR: U.S. Department of Agriculture, Forest Service, Pacific Northwest Forest and Range Experiment Station. $30 \mathrm{p}$. Chapter 3. (PNW)
CINTRON, GILBERTO; ARIEL E. LUGO; RAMON MARTINEZ; BARBARA B. CINTRON; and LUIS ENCARNACION. 1981. Impact of oil in the tropical marine environment. Tech. Publ. San Juan, PR: Puerto Rico Department of Natural Resources, Division of Marine Resources. 40 p. (SO)

CLARK, RAGER N.; DAVE R. GIBBONS; and GIIBERT B. PAULEY. 1985. Influence of recreation. In: Meehan, William R., tech. ed. Influence of forest and rangeland management on anadromous fish habitat in western North America. Gen. Tech. Rep. PNW-178. Portland, OR: U.S. Department of Agriculture, Forest Service, Pacific Northwest Forest and Range Experiment Station. $31 \mathrm{p}$. Chapter 10. (PNW)

DAVIS, E. A. 1989. Prescribed fire in Arizona chaparral: effects on stream water quality. Forest Ecology and Management. 26:189-206. (RM)

DUNCAN, W. F.; and M. A. BRUSVEN. 1985. Benthic macroinvertebrates in logged and unlogged low-order Southeast Alaska streams. Freshwater Invertebrate Biology. 4:125-132. (PNW)

ELLIOTT, STEVE; K. V. KOSKI; and BILL MEEHAN. 1980. Chain logs, food chains \& fish streams. Juneau, AK: Alaska Department of Fish and Game, Alaska Fish Tales \& Game Trails. 12(1):14-16. (PNW)

EVEREST, FRED H. 1984. Coordinating fish and wildlife habitat with other forest management activities. In: Wenger, Karl F., ed. Forestry Handbook. 2nd ed. New York: John Wiley: 731-736. (PNW) 
EVEREST, FRED H.; and R. DENNIS HARR. 1982. Silvicultural treatments. In: Meehan, William R., tech ed. Influence of forest and rangeland management on anadromous fish habitat in western North America; Gen. Tech. Rep. PNW134. Portland, OR: U.S. Department of Agriculture, Forest Service, Pacific Northwest Forest and Range

Experiment Station. 19 p. Chapter 6. (PNW)

EVEREST, FRED H.; and WILLIAM R. MEEHAN. 1981. Some effects of debris torrents on habitat of anadromous salmonids. Tech. Bull. 353. New York: National Council for the Paper Industry for Air and Stream Improvement: 23-30. (PNW)

EVEREST, FRED H.; and WILLIAM R. MEEHAN. 1982. Forest management anadromous fish habitat productivity. Transactions of the North American Wildlife and Natural Resources Conference. 46:521-530. (PNW)

FARIS, TAMRA L.; and KENNETH D. VAUGHN. 1985. Log transfer and storage facilities in southeast Alaska; a review. Gen. Tech. Rep. PNW-174. Portland, OR: U.S. Department of Agriculture, Forest Service, Pacific Northwest Forest and Range Experiment Station. 24 p. (PNW)

FISHER, CARLA J.; and CHARLES D. ZIEBELL. 1980. Effects of watershed use on water quality and fisheries in an Arizona mountain lake. Eisenhower Consortium Bulletin 7.8 p. (RM)

GIBBONS, DAVE R.; WILLIAM R. MEEHAN; K. V. KOSKI; and THEODORE R. MERRELL, JR. 1987. History of studies of fisheries and forestry interactions in southeastern Alaska. In: Proceedings of a symposium: streamside management: forestry and fishery interactions; 1986

February 12-14; Seattle, WA: Institute of Forest Resources, University of Washington: 297-329. (PNW)
GREGORY, S. V.; G. A. LAMBERTI; K. V. KOSKI; M. L. MURPHY; J. R. SEDELL; and D. C. ERMAN. 1987. Influences of forest practices on aquatic production. In: Proceedings of Symposium, Streamside Management: Forestry and Fishery Interactions; 1986 February 1214; Seattle, WA: Institute of Forest Resources, University of Washington: 233-255. (PNW)

MARTIN, SUSAN B.; and WILLIAM S. PLATTS. 1981. Effects of mining. In: Meehan, William R.; tech. ed. Influence of forest and rangeland management on anadromous fish habitat in western North America. Gen. Tech. Rep. PNW119. Portland, OR: U.S. Department of Agriculture, Forest Service, Pacific Northwest Forest and Range Experiment Station. 15 p. Chapter 8. (INT)

MEEHAN, WILLIAM R.; and WILLIAM S. PLATTS. 1978. Livestock grazing and the aquatic environment. Journal of Soil and Water Conservation. 33:274-278. (PNW)

MEGAHAN, WALTER F.; WILLIAM S. PLATTS; and BERT KULESZA. 1980. Riverbed improves over time: South Fork Salmon. In: Symposium on watershed management 1980; New York, NY: American Society of Civil Engineers: 380-395. (INT)

MODDE, TIMOTHY; HENRY G. DREWES; and MARK A. RUMBLE. 1986. Effects of watershed alternation on the brook trout populations of a small Black Hills stream. Great Basin Naturalist. 46:3945. (RM) 
NORRIS, L. A.; H. W. LORZ; and S. V. GREGORY. 1983. Forest chemicals. In: Meehan, William R., tech. ed. Influence of forest and rangeland management on anadromous fish habitat in western North America. Gen. Tech. Rep. PNW149. Portland, OR: U.S. Department of Agriculture, Forest Service, Pacific Northwest Forest and Range Experiment Station. 95 p. Chapter 9. (PNW)

PLATTS, WILLIAM S. 1981. Impairment, protection and rehabilitation of Pacific salmonid habitats on sheep and cattle ranges. In: Hassler, Thomas J., ed. Proceedings: propagation, enhancement, and rehabilitation of anadromous salmonid populations and habitat in the Pacific Northwest symposium; 1981 October 15-17; Arcata, CA. Arcata, CA: Humboldt State University, California Cooperative Fishery Research Unit: 82-92. (INT)

PLATTS, WILLIAM S. 1981. Protection and enhancement of Pacific salmonids on ranges grazed by livestock: an overview. In: Hassler, Thomas J., ed.

Proceedings: propagation, enhancement, and rehabilitation of anadromous salmonid populations and habitat in the Pacific Northwest symposium; 1981 October 15-17; Arcata, CA. Arcata, CA: Humboldt State University, California Cooperative Fishery Research Unit: 62-65. (INT)

PLATTS, WILLIAM S. 1981. Effects of livestock grazing. In: Meehan, William R., tech. ed. Influence of forest and rangeland management on anadromous fish habitat in western North America; pt. 7. Gen. Tech. Rep. PNW-124. Portland, OR: U.S. Department of Agriculture, Forest Service, Pacific Northwest Forest and Range Experiment Station. 25 p. Chapter 7. (PNW)
PLATTS, WILLIAM S. 1982. Road standards --fisheries. In: Forest access;

Proceedings of a symposium; 1982 November 12-13; Coeur d'Alene, ID. Moscow, ID: University of Idaho, College of Forestry, Wildlife and Range Sciences: 21-22. (INT)

PLATTS, WILLIAM S.; and SUSAN B. MARTIN. 1978. Hydrochemical influences of the fishery within the phosphate mining area of Eastern Idaho. Res. Note INT-246. U.S. Department Agriculure, Forest Service. 15 p. (INT)

PLATTS, WILLIAM S.; and WILLIAM R. MEEHAN. 1983. Livestock grazing and fish environments: situation and needs. In: Menke, John W., ed. Livestock and wildlife-fisheries relationships in the Great Basin: Proceedings of a workshop; 1977 May 3-5; Sparks, NV. Spec. Pub. 3301 . Berkeley, CA: University of California, Division of Agricultural Sciences: 30-35. (INT)

PLATTS, WILLIAM S.; KARL A. GEBHARDT; and WILLIAM L. JACKSON. 1985. The effects of large storm events on basinrange riparian stream habitats. In: Johnson, R. Roy; Charles D. Ziebell; David Patton; Peter F. Ffolliott; and R. H. Hamre, tech. coords. Riparian ecosystems and their management: reconciling conflicting uses:

Proceedings, 1 st American riparian conference; 1985 April 16-18; Tucson, AZ. Gen. Tech. Rep. RM-120. Fort Collins, CO: U.S. Department of Agriculture, Forest Service, Rocky Mountain Forest and Range Experiment Station: 30-34. (INT) 
PLATTS, WILLIAM S.; ROBERT J. BEHNKE; JOHN C. BUCKHOUSE; OSBORNE E. CASEY; ERROL W. CLAIRE; JAMES COOPER; DONALD A. DUFF; WILLIS A. EVANS; GORDON HAUGEN; PAT E. MARCUSON; WILLIAM R. MEEHAN; ROBERT W. PHILLIPS; ROBERT F. RALEIGH; and JON M SKOVLIN. 1983. Livestock interactions with fish and their environments. In: Menke, John W., ed. Livestock and wildlife-fisheries relationships in the Great Basin: Proceedings of a workshop; 1977 May 3-5; Sparks, NV. Spec. Pub. 3301. Berkeley, CA: University of California, Division of Agricultural Sciences: 36-41. (INT)

REEVES, GORDON H.; ROBERT L. BESCHTA; FREDERICK J. SWANSON; MARGARET H. MCHUGH; and MICHELLE D. MCSWAIN. 1987. The Elk River basin: an integrated investigation of forest management impacts on fish habitat. Tech. Bull. No. 514. New York, NY: National Council of the Paper Industry for Air and Stream Improvement: 47-51. (PNW)

RINNE, JOHN N. 1988. Effects of livestock grazing exclosure on aquatic macroinvertebrates in a montane stream, New Mexico. Great Basin Naturalist. 48:146-153. (RM)

RINNE, JOHN N. 1988. Grazing effects on stream habitat and fishes: research design consideration. North American Journal of Fisheries Management. 8:240-247. (RM)

RINNE, JOHN N.; and T. THARLSON. 1987. Effects of domestic livestock grazing on montane streams: Aquatic macroinvertebrates. In: Proceedings, 66th Annual Conference, Western Association of Fish and Wildlife Agencies; 1986 July 20-23; Portland, OR. Sacramento, CA: Western Association of Fish and Wildlife Agencies: 91-98. (RM)
RUMBLE, MARK A. 1989. Surface mine impoundments as wildlife and fish habitat. Gen. Tech. Rep. RM-183. Fort Collins, CO: U.S. Department of Agriculture, Forest Service, Rocky Mountain Forest and Range Experiment Station. 6 p. (RM)

SCHMIEGE, DONALD C. 1980. Processing mills and camps. In: Meehan, William $R$., tech. ed. Influence of forest and rangeland management on anadromous fish habitat in western North America. Gen. Tech. Rep. PNW-113. Portland, OR: U.S. Department of Agriculture, Forest Service, Pacific Northwest Forest and Range Experiment Station. $17 \mathrm{p}$. Chapter 11. (PNW)

SEDELL, JAMES R.; and CLIFFORD N. DAHM. 1984. Catastrophic disturbances to stream ecosystems: volcanism and clear-cut logging. In: Klug, M. J. and C. A. Reddy, eds. Current perspectives in microbial ecology; 1983 August 7-12; East Lansing, MI. Washington, D.C: American Society for Microbiology: 531539. (INT)

SEDELL, JAMES R.; and WAYNE S. DUVAL. 1985. Water transportation and storage of logs. In: Meehan, William R., tech. ed. Influence of forest and rangeland management on anadromous fish habitat in western North America. Gen. Tech. Rep. PNW-186. Portland, OR: U.S. Department of Agriculture, Forest Service, Pacific Northwest Forest and Range Experiment Station. 68 p. Chapter 5. (PNW)

SEDELL, JAMES R.; FRED H. EVEREST; and FREDERICK J. SWANSON. 1981. Fish habitat and streamside management--past and present. In: Increasing forest productivity:

Proceedings, 1981 convention of the Society of American Foresters; 1981 September 27-30; Orlando, FL. SAF 8201. Bethesda, MD: Society of American Foresters: 244-255. (PNW) 
SEDELL, JAMES R.; FRED H. EVEREST;

LEE E. BEBDS; FRANK N. LEONE;

JOHN R. WOLFE; and DAVID A.

HELLER. 1985. Effects of boulder

berms on the fish habitat structure in a

fifth order stream basin. In: Western

proceedings: 64th annual conference of

the Western Association of Fish and

Wildlife Agencies; 1984 July 16-19;

Victoria, BC. Sacramento, CA: Western

Association of Fish and Wildlife

Agencies: 435-445. (PNW)

SEDELL, JAMES R.; FREDERICK J. SWANSON; and STANLEY V.

GREGORY. 1985. Evaluating fish response to woody debris. In: Hassler, Thomas J., ed. Pacific Northwest stream habitat management workshop:

Proceedings of a workshop; 1985

October 10-12; Arcata, CA: Humboldt

State University: 222-245. (PNW)

SIGLER, JOHN W.; T. C. BJORNN; and FRED H. EVEREST. 1984. Effects of chronic turbidity on density and growth of steelheads and coho salmon. Transactions American Fisheries Society. 113:142-150. (PNW)

SKOVLIN, JON M.; WILLIAM R. MEEHAN; JOHN C. BUCKHOUSE; and MARTIN VAVRA. 1983. Determining the influence of grazing on riparian and aquatic habitats in the Blue Mountains of northeastern Oregon. In: Proceedings, workshop on livestock and wildlifefisheries relationships in the Great Basin; 1977 May 3-5; Sparks, NV. Spec. Publ. 3301. Berkeley, CA: University of California: 164-169. (PNW)
SWANSON, FREDERICK J.; LEE E. BENDA; STANLEY H. DUNCAN; GORDON E. GRANT; WALTER F. MEGAHAN; LESLIE M. REID; [and others]. 1987. Mass failures and other processes of sediment production in Pacific Northwest forest landscapes. In: Proceedings of symposium, Streamside management: Forestry and fishery interaction; 1986 February 12-14; Seattle, WA: Institute of Forest

Resources, University of Washington: 938. (PNW)

SWANSTON, DOUGLAS N. 1980. Impacts of natural events. In: Meehan, William R., tech. ed. Influence of forest and rangeland management on anadromous fish habitat in western North America. Gen. Tech. Rep. PNW-104. Portland, OR: U.S. Department of Agriculture, Forest Service, Pacific Northwest Forest and Range Experiment Station. 27 p. Chapter 2. (PNW)

WOLTERING, D. M.; J. L. HEDTKE; and L. J. WEBER. 1978. Predator-prey interactions of fishes under the influence of ammonia. Transactions of the American Fisheries Society. 107(3):500504. (PNW)

YEE, CARLTON S.; and TERRY D. ROELOFS. 1980. Planning forest roads to protect salmonid habitat. In: Meehan, William R.; tech. ed. Influence of forest and rangeland management on anadromous fish habitat in western North America. Gen. Tech. Rep. PNW109. Portland, OR: U.S. Department of Agriculture, Forest Service, Pacific Northwest Forest and Range Experiment Station. 39 p. Chapter 4. (PNW) 
Habitat Restoration and Enhancement

ALEXANDER, GAYLORD R.; and EDWARD A. HANSEN. 1982. Sand sediments in a Michigan trout stream. Part 2: Effects of reducing sand bedload on a trout population. Fish. Res. Rep. 1902. Lansing, Ml: Michigan Department of Natural Resources; 20 p. (NC)

ANDERSON, LYNETTE; and MASON BRYANT. 1980. Fish passage at road crossings: An annotated bibliography. Gen. Tech. Rep. PNW-117. Portland, OR: U.S. Department of Agriculture, Forest Service, Pacific Northwest Forest and Range Experiment Station. $10 \mathrm{p}$. (PNW)

BRANSON, BRANLEY A.; DONALD L. BATCH; and WILLIE R. CURTIS. 1984. Small-stream recovery following surface mining in East-Central Kentucky. Transaction, Kentucky Academy Science. 45(1-2):55-72. (NE)

BRYANT, MASON D. 1982. Organic debris in salmonid habitat in southeast Alaska: measurement and effects. In: Armantrout, Neil B., ed. Acquisition and utilization of aquatic habitat inventory information: Proceedings of a symposium; 1981 October 28-30; Portland, OR. Bethesda, MD: Western Division, American Fisheries Society: 259-265. (PNW)

DEBANO, LEONARD F.; and LARRY J. SCHMIDT. 1989. Improving southwestern riparian areas through watershed management. Gen. Tech. Rep. RM-182. Fort Collins, CO: U.S. Department of Agriculture, Forest Service, Rocky Mountain Forest and Range Experiment Station. 33 p. (RM)

DOLLOFF, C. ANDREW. 1986. Effects of stream cleaning on juvenile coho salmon and Dolly Varden in southeast Alaska. Transactions of the American Fisheries Society. 115:743-755. (PNW)
EVEREST, FRED $H_{\text {. }}$; and DANIEL $R$.

TALHELM. 1982. Evaluating projects for improving fish and wildlife habitat on National Forests. Gen. Tech. Rep. PNW-146. Portland, OR: U.S. Department of Agriculture, Forest Service, Pacific Northwest Forest and Range Experiment Station. 12 p. (PNW)

EVEREST, FRED H.; and JAMES R. SEDELL. 1984. Evaluation of fisheries enhancement projects on Fish Creek and Wash Creek, 1982 and 1983. In: Natural propagation and habitat improvement; Portland, OR: U.S. Department of Energy, Bonneville Power Administration, Division of Fish and Wildlife 99 p. Supplement A. 1 vol. (PNW)

EVEREST, FRED H.; and JAMES R. SEDELL. 1985. Evaluating effectiveness of stream enhancement projects. In: Hassler, Thomas J., ed. Pacific Northwest stream habitat management workshop: Proceedings of a workshop; 1985 October 10-12; Arcata CA: Humboldt State University: 246-256. (PNW)

EVEREST, FRED H.; GORDON H. REEVES; JAMES R. SEDELL; JOHN WOLFE; DAVID HOHLER; and DAVID A. HELLER. 1986. Abundance, behavior, and habitat utilization by coho salmon and steelhead trout in Fish Creek, Oregon, as influenced by habitat enhancement. Portland, OR: U.S. Department of Energy, Bonneville Power Administration. 100 p. (PNW)

EVEREST, FRED H.; JAMES R. SEDELL; GORDON H. REEVES; and JOHN WOLFE. 1985. Fisheries enhancement in the Fish Creek basin--an evaluation of in-channel and off-channel projects, 1984. Portland, OR: U.S. Department of Energy, Division of Fish and Wildlife, Bonneville Power Administration. 228 p. (PNW) 
FONTAINE, BARBARA L.; and THOMAS D. MERRITT. 1988. An anchoring system for fish habitat structures: field technique, evaluation, and application. Res. Note PNW-RN-481. Portland, OR: U.S. Department of Agriculture, Forest Service, Pacific Northwest Research Station. 11 p. (PNW)

HALL, JAMES D.; and CALVIN O. BAKER. 1982. Rehabilitating and enhancing stream habitat: 1 . Review and evaluation. In: Meehan, William R., tech. ed. Influence of forest and rangeland management on anadromous fish habitat in western North America. Gen. Tech. Rep. PNW-138. Portland, OR: U.S. Department of Agriculture, Forest Service, Pacific Northwest Forest and Range Experiment Station. 29 p. Chapter 12. (PNW)

HANSEN, EDWARD A.; GAYLORD R. ALEXANDER; and WILLIAM H. DUNN. 1982. Sand sediments in a Michigan trout stream. Part I. In-stream sediment basins: a technique for removing sand bedload from streams. Fisheries Res. Rep. 1901. Lansing, Ml: Michigan Department of Natural Resources, Fisheries Division. 26 p. (NC)

HARSHBARGER, THOMAS J.; and PAMELA E. PORTER. 1982. Embryo survival and fry emergence from two methods of planting brown trout eggs. North American Journal Fish Management. 2:84-89. (SE)

HARSHBARGER, THOMAS J.; and PAMELA E. PORTER. 1979. Survival of brown trout eggs: two planting techniques compared. Progressive Fish-Culturist. 41:206-209. (SE)

HEEDE, BURCHARD H. 1979. Predicting impact of a restoration project on river dynamics: A case history. Gen. Tech. Rep. RM-62. Fort Collins, CO: U.S. Department of Agriculture, Forest Service, Rocky Mountain Forest and Range Experiment Station. 8 p. (RM)
HOUSE, ROBERT A.; and PAUL L. BOEHNE. 1987. The effect of stream cleaning on salmonid populations in a coastal Oregon stream. Western Journal of Applied Forestry. 2(3):84-87. (PNW)

LISLE, THOMAS. 1979. A sorting mechanism for a riffle pool sequence. Geological Society American Bulletin. 90(1):616617, 1142-1157. (PSW)

LISLE, THOMAS E. 1983. Roughness elements: A key resource to improve anadromous fish habitat. In: Hassler, Thomas J., ed. Proceedings: propagation, enhancement, and rehabilitation of anadromous salmonid populations and habitat in the Pacific Northwest symposium; 1981 October 15-17; Arcata, CA. Arcata, CA:

California Cooperative Fishery Research Unit, Humboldt State University: 93-98. (PSW)

LISLE, THOMAS E. 1986. Stabilization of a gravel channel by large streamside obstructions and bedrock bends, Jacoby Creek, California. Geological Society of America Bulletin. 97:999-1011. (PSW)

MEGAHAN, WALTER F.; WILLIAM S. PLATTS; and BERT KULESZA. 1980. Riverbed improves over time: South Fork Salmon. In: Symposium on watershed management 1980; New York, NY: American Society of Civil Engineers: 380-395. (INT)

PLATTS, WILLIAM S.; and FRED J. WAGSTAFF. 1984. Fencing to control livestock grazing on riparian habitats along streams: is it a viable alternative? North American Journal of Fishery Management. 4:266-272. (INT)

PLATTS, WILLIAM S.; and SUSAN B. MARTIN. 1980. Return of the South Fork Salmon. Idaho Wildlife. 2(4):3-9. (INT) 
REEVES, GORDON H. 1985. Evaluation of streams for salmonid enhancement projects. In: 3rd California salmon and steelhead restoration conference; 1985 February 23-24; Ukiah, CA. Davis, CA: Sea Grant Marine Advisory Program: 34. (PNW)

REEVES, GORDON H.; and TERRY D. ROELOFS. 1982. Rehabilitating and enhancing stream habitat: 2 . Field applications. In: Meehan, William R., tech. ed. Influence of forest and rangeland management on anadromous fish habitat in western North America. Gen. Tech. Rep. PNW-140. Portland, OR: U.S. Department of Agriculture, Forest Service, Pacific Northwest Forest and Range Experiment Station. 38 p. Chapter 13. (PNW)

RINNE, JOHN N. 1981. Stream habitat improvement and native southwestern trouts. Res. Note RM-409. Fort Collins, CO: U.S. Department of Agriculture, Forest Service, Rocky Mountain Forest and Range Experiment Station. 4 p. (RM)

SEDELL, JAMES R.; and KAREN J. LUCHESSA. 1982. Using the historical record as an aid to salmonid habitat enhancement. In: Armantrout, Neil B., ed. Acquisition and utilization of aquatic habitat inventory information:

Proceedings of a symposium; 1981 October 28-30; Portland, OR: Western Division, American Fisheries Society: 210-223. (PNW)

WALLACE, J. BRUCE; DAVID S. VOGEL; and T. F. CUFFNEY. 1986. Recovery of a headwater stream from an insecticideinduced community disturbance. Journal of the North American Benthological Society. 5(2):115-126. (SE)
Habitat and Population Inventories

BRYANT, MASON D. 1982. Organic debris in salmonid habitat in southeast Alaska: measurement and effects. In:

Armantrout, Neil B., ed. Acquistion and utilization of aquatic habitat inventory information: Proceedings of a symposium; 1981 October 28-30; Portland, OR. Bethesda, MD: Western Division, American Fisheries Society: 259-265. (PNW)

BRYANT, MASON D. 1984. Distribution of salmonids in the Trap Bay basin, Tenakee Inlet. In: Meehan, William R.; Theodore R. Merrell, Jr.; and Thomas A. Hanley, eds. Fish and wildlife relationships in old-growth forests:

Proceedings of a symposium; 1982 April 12-15; Juneau, AK. American Institute of Fishery Research Biologists: 17-31. (PNW)

DUDLEY, TOM; and N. H. ANDERSON. 1982. A survey of invertebrates associated with wood debris in aquatic habitats. Melanderia. 19:1-21. (PNW)

GAMBLIN, MARK S.; J. S. GRIFFITH; and WILLIAM S. PLATTS. 1986. Response of trout populations in the St. Joe River drainage, Idaho, to Mount St. Helens tephra. In: Keller, S. A. C., ed. Mount St. Helens: five years later [Date and place unknown]. Cheney, WA: Eastern Washington University Press: 297-306. (INT)

HANKIN, D. G.; and G. H. REEVES. 1988. Estimating total fish abundance and total habitat area in small streams based on visual estimation methods. Canadian Journal of Fisheries and Aquatic Science. 45:834-844. (PNW)

HILL, JENNIFER; and GARY D. GROSSMAN. 1987. Home range estimates for three North American stream fishes. Copeia. 1987:376-380. (SE) 
LOTSPEICH, FREDERICK B.; and WILLIAM S. PLATTS. 1982. An integrated landaquatic classification system. North American Journal of Fisheries Management. 2:138-149. (PNW)

MCLEMORE, CARL E.; FRED H. EVEREST; WILLIAM R. HUMPHREYS; and MARIO F. SOLAZZO. 1989. A floating trap for sampling downstream migrant fishes. Res. Note. PNW-490. Portland, OR: U.S. Departmant of Agriculture, Forest Service, Pacific Northwest Research Station. 7 p. (PNW)

PLATTS, WILLIAM S.; and FRED E. PARTRIDGE. 1983. Inventory of salmon, steelhead trout, and bull trout: South Fork Salmon River, Idaho. Res. Note INT-324. Ogden, UT: U.S. Department of Agriculture, Forest Service, Intermountain Forest and Range Experiment Station. 8 p. (INT)

PLATTS, WILLIAM S.; and MICHAEL L. MCHENRY. 1988. Density and biomass of trout and char in western streams. Gen. Tech. Rep. INT-241. Ogden, UT: U.S. Department of Agriculture, Forest Service, Intermountain Research Station. 17 p. (INT)

PLATTS, WILLIAM S.; and RODGER L. NELSON. 1988. How to trout populations and their implications for land-use evaluation. North American Journal of Fisheries Management. 8:333-345. (INT)

RINNE, JOHN N. 1982. Problems associated with habitat evaluation of an endangered fish in headwater environments. In: Armantrout, Neil B., ed. Acquisition and utilization of aquatic habitat inventory information: Proceedings of a symposium; 1981 October 28-30; Portland, OR: Western Division, American Fisheries Society: 202-209. (RM)
SEDELL, JAMES R.; JOSEPH E. YUSKA; and ROBERT W. SPEAKER. 1984. Habitats and salmonid distribution in pristine, sediment-rish river valley systems: S. Fork Hoh and Queets River, Olympic National Park. In: Meehan, William R.; Theodore R. Merrell, Jr.; and Thomas A. Hanley, eds. Fish and wildlife relationships in old-growth forests: Proceedings of a symposium; 1982 April 12-15; Juneau, AK. American Institute of Fishery Research Biologists: 33-46. (PNW)

SWANSTON, DOUGLAS N.; WILLIAM R. MEEHAN; and JAMES A. MCNUTT. 1977. A quantitative geomorphic approach to predicting productivity of pink and chum salmon streams in southeast Alaska. Res. Pap. PNW-227. Portland, OR: U.S. Department of Agriculture, Forest Service, Pacific Northwest Forest and Range Experiment Station. 16 p. (PNW)

\section{Laboratory and Field Techniques}

ANDERSON, LYNETTE; and MASON D. BRYANT. 1980. Fish passage at road crossings: and annotated bibliography. Gen. Tech. Rep. PNW-117. Portland, OR: U.S. Department of Agriculture, Forest Service, Pacific Northwest Forest and Range Experiment Station. $10 \mathrm{p}$. (PNW)

BAKER, MALCHUS B., JR. 1986. A supercritical flume for measuring sediment-laden streamflow. Arizona Water Resources Bulletin. 22:847-851. (RM)

BRYANT, MASON D. 1981. Evaluation of a small diameter baffled culvert for passing juvenile salmonids. Res. Note PNW-384. Portland, OR: U.S. Department of Agriculture, Forest Service, Pacific Northwest Forest and Range Experiment Station. 8 p. (PNW) 
BRYANT, MASON D.; and WILLIAM J. WALKOTTEN. 1980. Carbon dioxide freeze branding device for use on juvenile salmonids. Progressive FishCulturist. 42:55-56. (PNW)

EVEREST, FRED H. 1983. Subsurface anlysis. In: Platts, William S.; Walter F. Megahan; and Wayne G. Minshall, eds. Methods for evaluating stream, riparian, and biotic conditions. Gen. Tech. Rep. INT-138. Ogden UT: U.S. Department of Agriculture, Forest Service, Intermountain Forest and Range Experiment Station: 17-21. (PNW)

EVEREST, FRED H.; and JEFFREY RODGERS. 1982. Two economical photoperiod controls for laboratory studies. Progressive Fish-Culturist. 44:113-114. (PNW)

EVEREST, FRED H.; CARL E. MCLEMORE; and JOHN F. WARD. 1980. An improved tri-tube cryogenic gravel sampler. Res. Note PNW-350. Portland OR: U.S. Department of Agriculture, Forest Service, Pacific Northwest Forest and Range Experiment Station. 8 p. (PNW)

EVEREST, FRED; G. B. LOTSPEICH; and W. R. MEEHAN. 1982. New perspectives on sampling, analysis, and interpretation of gravel quality. In: Armantrout, Neil B., ed. Proceedings of a symposium on acquisition and utilization of aquatic habitat inventory information, 1981 October 28-30, Portland, OR. Bethesda, MD: West Division of American Fisheries Society: (PNW)

HANKIN, D. G. 1986. Sampling designs for estimating the total number of fish in small streams. Res. Pap. PNW 360. Portland, OR: U.S. Department of Agriculture, Forest Service, Pacific Northwest Forest and Range Experiment Station. 33 p. (PNW)
HILL, JENNIFER; and GARY D. GROSSMAN. 1987. Effects of subcutaneous marking on stream fishes. Copeia. 1987:492-495. (SE)

KETCHESON, GARY L. 1986. Sediment rating equations: an evaluation for streams in the Idaho batholith. Gen. Tech Rep. INT-213. Ogden, UT: U.S. Department of Agriculture, Forest Service, Intermountain Research Station. 12 p. (INT)

LISLE, THOMAS E. 1988. Using 'residual depths' to monitor pool depths independently of discharge. Res. Note PSW-394. Berkeley, CA: U.S. Department of Agriculture, Forest Service, Pacific Southwest Forest and Range Experiment Station. 4 p. (PSW)

LOTSPEICH, FREDRICK; and FRED $H$. EVEREST. 1980. A new method for reporting and interpreting textural composition of spawning gravel. Res. Note PNW-369. Portland, OR: U.S. Department of Agriculture, Forest Service, Pacific Northwest Forest and Range Experiment Station. 11 p. (PNW)

MEEHAN, WILLIAM R.; and RICHARD A. MILLER. 1978. Stomach flushing: effectiveness and influence on survival and condition of juvenile salmonids. Journal of the Fisheries Research Board of Canada. 35(10):1359-1363. (PNW)

NELSON, RODGER L.; CHARLES K. GRAHAM; and WILLIAM S. PLATTS. 1988. Relative suitabilities of regression models in electronic analysis of riparian vegetation. Res. Note INT-382. Ogden, UT: U.S. Department of Agriculture, Forest Service, Intermountain Research Station. 5 p. (INT)

ORCHARD, RICHARD D. 1988. New method for measuring water seepage through salmon spawning gravel. Res. Note PNW-483. Portland, OR: U.S. Department of Agriculture, Forest Service, Pacific Northwest Research Station. 15 p. (PNW) 
PINCHAK, ALFRED C. 1984. Controlling a pulsed heat transfer probe for porous media with a CMOS single board microcomputer. In: Proceedings, 3rd International Offshore Mechanics and Arctic Engineering Symposium. 3:83-90. (PNW)

PINCHAK, ALFRED C.; and EMERY G. PETRAS. 1980. CMOS microprocessor based dual-bridge thermistor system for measurement of intragravel water flow. In: Durgin, W. W., ed. Flow: its measurement and control in science and industry, Vol. 2. Research Triangle Park, N.C.: Instrument Society of America: 637-648. (PNW)

PLATTS, WILLIAM S. 1976. Validity of methodologies to document stream environments for evaluating fishery conditions. In: Proceedings, Symposium and special conference on instream flow needs: 1976 May 3-6; Boise, ID: West Division American Fisheries Society and American Society Civil Engineering: 267-284. Volume II. (INT)

PLATTS, WILLIAM S.; CARL ARMOUR; GORDON D. BOOTH; MASON BRYANT; JUDITH L. BUFFORD; PAUL CUPLIN; [and others]. 1987. Methods of evaluating riparian habitats with applications to management. Gen. Tech. Rep. INT-222. Ogden, UT: U.S. Department of Agriculture, Forest Service, Intermountain Research Station. 177 p. (INT)

PLATTS, WILLIAM S.; MOSTAFA A. SHIRAZI; and DONALD H. LEWIS. 1979. Sediment particle sizes used by salmon for spawning with methods for evaluation. Rep. No. EPA-600/3-79-043. Washington, DC: U.S. Environmental Protection Agency, Office Resource Development. (INT)
REEVES, GORDON H.; FRED H. EVEREST; and CARL E. MCLEMORE. 1983. A recirculating stream aquarium for ecological studies. Res. Note PNW-403. Portland, OR: U.S. Department of Agriculture, Forest Service, Pacific Northwest Forest and Range Experiment Station. 8 p. (PNW)

RINNE, JOHN N.; W. L. MINCKLEY; and JAMES N. HANSON. 1982. Chemical treatment of Ord Creek, Apache County, Arizona to re-establish Arizona trout. Journal Arizona-Nevada Academy Science. 16(3):74-78. (RM)

STURGES, DAVID L.; and C. JAMES WINTER. 1989. Automated collection of water quality and discharge data on streams. In: Proceedings, 57th western snow conference; 1989 April 18-20; Fort Collins, CO: Colorado State University. (RM)

THOMAS, ROBERT B. 1988. Monitoring baseline suspended sediment in forested basins: the effects of sampling on suspended sediment rating curves. Hydrological Sciences Journal. 33:499514. (PSW)

WALKOTTEN, WILLIAM H.; and MASON D. BRYANT. 1980. An instrument to measure stream channel gradient and profiles. Res. Note PNW-345. Portland, OR: U.S. Department of Agriculture, Forest Service, Pacific Northwest Forest and Range Experiment Station. $5 p$ (PNW)

WARD, JOHN F.; and WILLIAM R. MEEHAN. 1984. Inexpensive digital daylight integrator. Progressive Fish Culturist. 46:52-66. (PNW) 


\section{Birds}

Cavity And Snag Nesters

BECKWITH, ROY C.; and EVELYN L. BULL. 1985. SCAT analysis of the arthropod component of pileated woodpecker diet. The murrelet. 66:90-92. (PNW)

BRAWN, J. D.; and B. TANNENBAUM. 1984. Nest site characteristics of cavity nesting birds in central Missouri. Res. Note. NC314. St. Paul, MN: U.S. Department of Agriculture, Forest Service, North Central Forest Experiment Station. 6 p. (NC)

BRAWN, JEFFREY D.; WILLIAM H. ELDER; and KEITH E. EVANS. 1982. Winter foraging by cavity nesting birds in an oak-hickory forestry. The Wildlife Society Bulletin. 10:271-275. (NC)

BULL, EVELYN L. 1978. Roosting activities of a male pileated woodpecker. The Murrelet. Spring:35-36. (PNW)

BULL, EVELYN L. 1987. Ecology of the pileated woodpecker in northeastern Oregon. Journal of Wildlife Management. 51:472-481. (PNW)

BULL, EVELYN L.; and E. CHARLES MESLOW. 1977. Habitat requirements of the pileated woodpeckers in Northeastern Oregon. Journal of Forestry. 75:335-337. (PNW)

BULL, EVELYN L.; and E. CHARLES MESLOW. 1988. Breeding biology of the pileated woodpecker--management implications. Res. Note. PNW-GTR-474. Portland, OR: U.S. Department of Agriculture, Forest Service, Pacific Northwest Research Station. 8 p. (PNW)

BULL, EVELYN L.; ANTHONY L. WRIGHT; and MARK G. HENJUM. 1989. Nesting and diet of long-eared owls in conifer forests, Oregon. The Condor. 91:908912. (PNW)
BULL, EVELYN L.; STEVEN R. PETERSON; and JACK WARD THOMAS. 1986.

Resource partitioning among woodpeckers in northeastern Oregon. Res. Note. PNW-444. Portland, OR: U.S. Department of Agriculture, Forest Service, Pacific Northwest Forest and Range Experiment Station. 19 p. (PNW)

CONNER, RICHARD N. 1979. Food storing by yellow-bellied sapsuckers. The Auk 96:195. (SO)

CONNER, RICHARD N. 1979. Seasonal changes in woodpecker foraging methods; strategies for winter survival. In: Proceedings symposium: role of insectivorous birds in forest ecosystems: 95-105. (SO)

CONNER, RICHARD N. 1980. Bill and body size in three syntopic woodpeckers. The Raven. 51(1):7-11. (SO)

CONNER, RICHARD N. 1980. Foraging habitats of woodpeckers in southwestern Virginia. Journal Field Ornithology. 51:119-127. (SO)

CONNER, RICHARD N. 1981. Fatal aerial collision and stomach contents of a chimney swift. Texas Ornithological Society Bulletin. 14:25. (SO)

CONNER, RICHARD N. 1981. Seasonal changes in woodpecker foraging fatterns. The Auk. 98:562-570. (SO)

CONNER, RICHARD N.; and BRIAN A. LOCKE. 1983. Artificial innoculation of red heart fungus into loblolly pines. In: Wood, Don A., ed. Proceedings, 2nd red-cockaded woodpecker symposium; 1983 January 27-29; Panama City, FL. Tallahassee, FL: Florida Game and Fresh Water Fish Commission: 81-82. (SO) 
CONNER, RICHARD N.; JAMES C. KROLL; and DAVID L. KULHAVY. 1983. The potential of girdled and 2,4-D-injected southern red oaks as woodpecker nesting and foraging sites. Southern Journal Applied Forestry. 7:125-128. (SO)

DICKSON, JAMES G.; and RICHARD N. CONNER. 1981. Cavity nesting birds. In: Byrd, Nathan A., comp. A forester's guide to observing wildlife use of forest habitat in the South. For. Rep. SA-FR15. Atlanta, GA: U.S. Department of Agriculture, Forest Service, Southeastern Area, State and Private Forestry: 23-30. (SO)

GUTZWILLER, KEVIN J.; and STANLEY H. ANDERSON. 1987. Multiscale associations between cavity-nesting birds and features of Wyoming streamside woodlands. The Condor. 89:534-548.(RM)

GUTZWILLER, KEVIN, J.; and STANLEY H. ANDERSON. 1987. Trees used simultaneously and sequentially by breeding cavity-nesting birds. Great Basin Naturalist. 46:358-360. (RM)

HARDIN, KIMBERLY I.; and KEITH E. EVANS. 1977. Cavity nesting bird habitat in the oak-hickory forests--a review. Gen. Tech. Rep. NC-30. St.

Paul, MN: U.S. Department of Agriculture, Forest Service, North Central Forest Experiment Station. $23 \mathrm{p}$. (NC)

KROLL, JAMES C.; RICHARD N. CONNER; and ROBERT R. FLEET. 1980. Woodpeckers and the southern pine beetle. Argic. Handb. 564. Washington, DC: U.S. Department of Agriculture, Forest Pest Research and Development Program. 23 p. (SO)
MARZLUFF, JOHN M.; and L. JACK LYON. 1983. Snags as indicators of habitat suitability for open nesting birds. In: Davis, Jerry W.; Gregory A. Goodwin; and Richard A. Ockenfels, tech. coords. Snag habitat management: Proceedings of the symposium; 1983 June 7-9; Flagstaff, AZ. Gen. Tech. Rep. RM-99. Fort Collins, CO: U.S. Department of Agriculture, Forest Service, Rocky Mountain Forest and Range Experiment Station: 140-146. (INT)

MCCLELLAND, B. RILEY. 1979. Cavity nesters: part of Montana's bird heritage. Montana Outdoors. 10(4):34-37.

MCCLELLAND, B. RILEY. 1980. Influences of harvesting and residue management on cavity-nesting birds. In: Environmental consequences of timber harvesting in Rocky Mountain coniferous forests: Symposium proceedings; 1979 September 11-13; Missoula, MT: Gen. Tech. Rep. INT-90. Ogden, UT: U.S. Department of Agriculture, Forest Service, Intermountain Forest and Range Experiment Station: 469-496. (INT)

POLK, S. R.; W. L. ROBINSON; and G. G. ERDMANN. 1980. Territorial characteristics and behavior of radiomarked yellow-bellied sapsuckers. In: Proceedings 1980 Society of American Foresters Wisconsin-Michigan Section Meeting; 1980 September 18-19; Marquette, MI: Society of American Foresters, Upper Peninsula Chapter: 3951. (NC)

RAPHAEL, MARTIN G. 1987. Use of pacific madrone by cavity-nesting birds. In: Multiple-use management of California's hardwood resources: Proceedings of the symposium; 1986 November 12-14; San Louis Obispo, CA. Gen. Tech Rep. PSW-100. Berkeley, CA: U.S. Department of Agriculture, Forest Service, Pacific Southwest Forest and Range Experiment Station: 198-202. (RM) 
RITTER, LYMAN V.; and KATHRYN

PURCELL. 1983. Cavity-nesting

Brewer's blackbirds. West Birds. 14:205. (PSW)

SCOTT, VIRGIL E.; and JOHN L.

OLDEMEYER. 1983. Cavity nesting bird requirements and responses to snag cutting in ponderosa pine. In: Davis, Jerry W.; Gregory A. Goodwin; and Richard A. Ockenfels, tech. coords. Snag habitat management: Proceedings of the symposium; 1983 June 7-9; Flagstaff, AZ. Gen. Tech. Rep. RM-99. Fort Collins, CO: U.S. Department of Agriculture, Forest Service, Rocky Mountain Forest and Range Experiment Station: 19-23. (RM)

SCOTT, VIRGIL E.; JILL A. WHALAN; and ROBERT R. ALEXANDER. 1978. Dead trees use by cavity-nesting birds on the Fraser Experimental Forest: A case history. Res. Note. RM-360. Fort Collins, CO: U.S. Department of Agriculture, Forest Service, Rocky Mountain Forest and Range Experiment Station. 4 p. (RM)

SCOTT, VIRGIL E.; KEITH E. EVANS; DAVID R. PATTON; and CHARLES E. STONE. 1977. Cavity-nesting birds of North American forests. Agric. Handb. 511. Washington, DC: U.S. Department Agriculture, Forest Service. 112 p. (RM)

Raptors, Including Spotted Owl

BALAZA, GEORGE H.; and C. JOHN RALPH. 1979. A Steller's sea eagle at Kure and Midway: first Hawaii record. 'Elepaio. 39:117-118. (PSW)

BECKER, DALE M. 1985. Food habits of Richardson's merlins in southeastern Montana. Wilson Bulletin. 97:226-230. (RM)

BECKER, DALE M. 1986. Early nesting records of merlins in Montana and North Dakota. Journal of Raptor Research. 19:102. (PNW)
BECKER, DALE M. 1987. Use of black-billed magpie nests by American kestrels in southeastern Montana. Prairie Naturalist. 19:41-42. (RM)

BECKER, DALE M.; and CAROLYN HULL SIEG. 1985. Breeding chronology and reproductive success of Richardson's merlins in southeastern Montana. Journal of Raptor Research. 19:52-55. (RM)

BECKER, DALE M.; and CAROLYN HULL SIEG. 1987. Eggshell quality and organochlorine residues in eggs of merlins, Falco columbarius, in southeastern Montana. Canadian FieldNaturalist. 101-369-372. (RM)

BECKER, DALE M.; and CAROLYN HULL SIEG. 1987. Home range and habitat utilization of breeding male merlins, Falco columbarius, in southeastern Montana. Canadian Field-Naturalist. 101:398-403. (RM)

BRYAN, TERRY; and ERIC D. FORSMAN. 1987. Distribution, abundance, and habitat of great gray owls in southcentral Oregon. The Murrelet. 68:45-49. (PNW)

BULL, EVELYN; and HOLLY A. AKENSON. 1985. Common barn owl diet in northeastern Oregon. The Murrelet. 66:65-68. (PNW)

BULL, EVELYN L. 1987. Capture techniques for owls. In: Symposium proceedings: biology and conservation of northern forest owls; 1987 February 3-7; Winnipeg, Manitoba. Gen. Tech. Rep. RM-142. Fort Collins, CO: U.S. Department of Agriculture, Rocky Mountain Forest and Range Experiment Station: 291-293. (PNW)

BULL, EVELYN L.; and MARK G. HENJUM. 1987. The neighborly great gray owl. Natural History. 96(9):32-41. (PNW) 
BULL, EVELYN L.; and RALPH G. ANDERSON. 1978. Notes on flammulated owls in northeastern Oregon. The Murrelet. Spring:26-27. (PNW)

BULL, EVELYN L.; JANET E. HOHMANN; and MARK G. HENJUM. 1987. Northern pygmy-owl nests in northeastern Oregon. Journal of Raptor Research. 21(2):77-78. (PNW)

BULL, EVELYN L.; MARK G. HENJUM; and RALPH G. ANDERSON. 1987. Nest platforms for great gray owls. In: Symposium proceedings: biology and conservation of northern forest owls; 1987 February 3-7; Winnipeg, Manitoba. Gen. Tech. Rep. RM-142. Fort Collins, CO: U.S. Department of Agriculture, Forest Service, Rocky Mountain Forest and Range Experiment Station: 87-90. (PNW)

BULL, EVELYN L.; MARK G. HENJUM; and RONALD S. ROHWEDER. 1988. Home range and dispersal of great gray owls in northeastern Oregon. Journal of Raptor Research. 22(4):101-106. (PNW)

BULL, EVELYN L.; MARK G. HENJUM; and RONALD S. ROHWEDER. 1988. Nesting and foraging habitat of great gray owls. Journal of Raptor Research. 22(4):107-115. (PNW)

BULL, EVELYN L.; MARK G. HENJUM; and RONALD S. ROHWEDER. 1989. Diet and optimal foraging of great gray owls. Journal of Wildlife Management. 53:4750. (PNW)
CAREY, ANDREW B. 1985. A summary of the scientific basis for spotted owl management. In: Gutierrez, Ralph J.; and Andrew B. Carey, tech. eds.

Ecology and management of the spotted owl in the Pacific Northwest:

Proceedings of a symposium; 1984 June 19-23; Arcata, CA. Gen. Tech. Rep. PNW-185. Portland, OR: U.S. Department of Agriculture, Forest Service, Pacific Northwest Forest and Range Experiment Station: 100-114. (PNW)

CAREY, ANDREW B.; and L. F. RUGGIERO. 1985. Spotted owl management: Meeting NFMA requirements through monitoring. In: Gutierrez, Ralph J.; and Andrew B. Carey, tech. eds. Ecology and management of the spotted owl in the Pacific Northwest: Proceedings of a symposium; 1984 June 19-23; Arcata, CA. Gen. Tech. Rep. PNW-185. Portland, OR: U.S. Department of Agriculture, Forest Service, Pacific Northwest Forest and Range Experiment Station: 34-38. (PNW)

CHAPLIN, SUSAN B.; DONALD A. DIESEL; and JAMES A. KASPARIE. 1984. Body temperature regulation in red-tailed hawks and great horned owls: responses to air temperature and food deprivation. The Condor. 86:175-181. (NC)

CONNER, RICHARD N.; JAMES G. DICKSON; and J. HOWARD WILLIAMSON. 1981. Raptor use of an east Texas clearcut. Texas Ornithological Society Bulletin. 14:22-24. (SO)

DAWSON, WILLIAM R.; J. DAVID LIGON; JOSEPH R. MURPHY; J. P. MYERS; DANIEL SIMBERLOFF; and JARED VERNER. 1987. Report of the scientific advisory panel on the spotted owls. The Condor. 89:205-229. (PSW) 
DAWSON, WILLIAM R.; J. DAVID LIGON; JOSEPH R. MURPHY; J. P. MYERS; DANIEL SIMBERLOFF; and JARED VERNER. 1986. Report of the advisory panel on the spotted owl. Audubon Conserv. Rep. 7. New York, NY: National Audubon Society. 47 p. (PSW)

EAKLE, WADE L.; and TERYL G. GRUBB. 1986. Prey remains from golden eagle nests in central Arizona. Western Birds. 17:87-89. (RM)

FORSMAN, ERIC D. 1981. Molt of the spotted owl. The Auk. 98:735-742. (PNW)

FORSMAN, ERIC D.; CHARLES MESLOW; and HOWARD M. WRIGHT. 1984. Distribution and biology of the spotted owl in Oregon. Wildlife Monographs No. 87. Washington, DC: The Wildlife Society. 64 p. (PNW)

FORSMAN, ERIC D.; E. CHARLES MESLOW; and MONICA J. STRUB. 1976. Spotted owl abundance in second-growth versus old-growth forest, Oregon. The Wildlife Society Bulletin. 5:43-47. (PNW)

FORSMAN, ERIC; and EVELYN L. BULL. 1988. Great horned, great gray, spotted and barred owls. In: Pendleton, Beth Giron; Cynthia E. Ruibal; and Diane L. Krahe; [and others], eds. Proceedings of the western raptor management symposium workshop; 1987; Boise, ID. Washington, DC: The National Wildlife Federation: 116-123. (PNW)

GRUBB, TERYL G. 1977. The breeding and wintering ecology of eagles in the state of Washington. In: Proceedings of bald eagle days; 1977 January; Eagle Valley Environmentalists, Inc. Box 155, Apple River, IL. (RM)

GRUBB, TERYL G.; LARRY A. FORBIS; MARTA MCWHORTER; and DAVID R. SHERMAN. 1988. Adaptive perch selection as a mechanism of adoption by a replacement bald eagle. Wilson Bulletin. 100:302-305. (RM)
GRUBB, TERYL G.; SANDRA J. NAGELLER; WADE L. EAKLE; and GREGORY A. GOODWIN. 1989. Winter roosting patterns of bald eagles (Haliaeetus leucocephalus) in north-central Arizona. Southwestern Naturalist. 34:453-459. (RM)

GUTIERREZ, RALPH J. 1985. An overview of recent research on the spotted owl. In: Gutierrez, Ralph J.; and Andrew B. Carey, tech. eds. Ecology and management of the spotted owl in the Pacific Northwest: Proceedings of a symposium; 1984 June 19-23; Arcata, CA. Gen. Tech. Rep. PNW-185. Portland, OR: U.S. Department of Agriculture, Forest Service, Pacific Northwest Forest and Range Experiment Station: 39-49.

GUTIERREZ, RALPH J.; ALAN B. FRANKLIN; WILLIAM LAHAYE; VICKY J. MERETSKY; and J. PATRICK WARD. 1985. Juvenile spotted owl dispersal in northwestern California: Preliminary results. In: Gutierrez, Ralph J.; and Andrew B. Carey, tech. eds. Ecology and management of the spotted owl in the Pacific Northwest:

Proceedings of a symposium; 1984 June 19-23; Arcata, CA. Gen. Tech. Rep. PNW-185. Portland, OR: U.S. Department of Agriculture, Forest Service, Pacific Northwest Forest and Range Experiment Station: 60-65.

GUTIERREZ, RALPH J.; and ANDREW B. CAREY, tech. eds. 1985. Ecology and management of the spotted owl in the Pacific Northwest. Proceedings of a symposium; 1984 June 19-23; Arcata, CA. Gen. Tech. Rep. PNW-185. Portland, OR: U.S. Department of Agriculture, Forest Service, Pacific Northwest Forest and Range Experiment Station. 120 p. (PNW) 
GUTIERREZ, RALPH J.; DAVID MUNOZ SOLIS; and CHARLES SISCO. 1983. Habitat ecology of the spotted owl in northwestern California: Implications for management. In: New forests for a changing world: Proceedings of the 1983 SAF national convention; 1983 October 16-20; Portland, OR. Bethesda, MD: Society of American Foresters: 5055.

\section{LAYMON, STEPHEN A. 1985. General}

habitats and movements of spotted owls in the Sierra Nevada. In: Gutierrez, Ralph J.; and Andrew B. Carey, tech. eds. Ecology and management of the spotted owl in the Pacific Northwest: Proceedings of a symposium; 1984 June 19-23; Arcata, CA. Gen. Tech. Rep. PNW-185. Portland, OR: U.S. Department of Agriculture, Forest Service, Pacific Northwest Forest and Range Experiment Station: 66-68. (PSW)

LINKHART, BRIAN D.; and RICHARD T. REYNOLDS. 1987. Brood division and post-nesting behavior of flammulated owls. Wilson Bulletin. 99:240-243. (RM)

MASER, CHRIS; SAM SHAVER; CARL SHAVER; and BRADFORD PRICE. 1980. A note on the food habits of the barn own in Malheur County, Oregon. The Murrelet. 61:78-80. (PNW)

MCNABB, D. H. ANNE; ROGER A. MCNABB; IRVINE D. PRATHER; [and others]. 1980. Nitrogen excretion by turkey vultures. The Condor. 82:219-223. (PNW)
MILLER, GARY S.; and E. D. MESLOW. 1985. Dispersal data for juvenile spotted owls: The problem of small sample size. In: Gutierrez, Ralph J.; and Andrew B. Carey, tech. eds. Ecology and management of the spotted owl in the Pacific Northwest: Proceedings of a symposium; 1984 June 19-23; Arcata, CA. Gen. Tech. Rep. PNW-185. Portland, OR: U.S. Department of Agriculture, Forest Service, Pacific Northwest Forest and Range Experiment Station: 69-73. (PNW)

MILLER, GARY S.; KIM NELSON; and WILL C. WRIGHT. 1985. Two-year-old female spotted owl breeds successfully. Western Birds. 16:93-94. (NE)

NERO, ROBERT W.; RICHARD J. CLARK; RICHARD J. KNAPTON; and R. H. HAMRE, eds. 1987. Biology and conservation of northern forest owls: Symposium proceedings; 1987 February 3-7; Winnipeg, MB. Gen. Tech. Rep. RM-142. Fort Collins, CO: U.S. Department of Agriculture, Forest Service, Rocky Mountain Forest and Range Experiment Station. 309 p. (RM)

NICHOLLS, THOMAS H.; and MARK R. FULLER. 1987. Territorial aspects of barred owl home range and behavior in Minnesota. In: Nero, Robert W.; Richard J. Clark; Richard J. Knapton; and R. H. Hamre, eds. Biology and conservation of northern forest owls: symposium proceedings; 1987 February 3-7, Winnipeg, Canada. Gen. Tech. Rep. RM-142. Fort Collins, CO: U.S. Department of Agriculture, Forest Service, Rocky Mountain Forest and Range Experiment Station: 121-128. (NC)

PAULSON, DEBORAH D.; and CAROLYN HULL SIEG. 1984. A concentration of long-eared owls nesting in Badlands National Park. South Dakota Bird Notes. 36:72-75. (RM)

PROBASCO, GEORGE E.; and CHARLES W. PUTNAM. 1977. A turkey vulture nest in Missouri. Bluebird. 44:14 (NC) 
REYNOLDS, RICHARD T. 1983.

Management of western coniferous forest habitat for nesting Accipiter hawks. Gen. Tech. Rep. RM-102. Fort Collins, CO: U.S. Department of Agriculture, Forest Service, Rocky Mountain Forest and Range Experiment Station. 7 p. (RM)

REYNOLDS, RICHARD T. 1987. Census of flammulated owls. In: Nero, Robert W.; Richard J. Clark; Richard J. Knapton; and R. H. Hamre, eds. Biology and conservation of northern forest owls: symposium proceedings; 1987 February 3-7; Winnipeg, MB. Gen. Tech. Rep. RM-142. Fort Collins, CO: U.S. Department of Agriculture, Forest Service, Rocky Mountain Forest and Range Experiment Station: 308-309. (RM)

REYNOLDS, RICHARD T. 1989. Accipiters. In: Proceedings of the western raptor management symposium and workshop; 1987 October 26-28; Boise, ID. National Wildlife Federation Scientific and Technical Series No. 12:92-101. (RM)

REYNOLDS, RICHARD T. 1989. The flammulated owl and old-growth forests. Biologue. 3(2):13. (RM)

REYNOLDS, RICHARD T.; and BRIAN D. LINKHART. 1987. Fidelity to territory and mate in flammulated owls. In: Nero, Robert W.; Richard J. Clark; Richard J.Knapton; and R. H. Hamre, eds. Biology and conservation of northern forest owls: symposium proceedings; 1987 February 3-7; Winnipeg, MB. Gen. Tech. Rep. RM-142. Fort Collins, CO: U.S. Department of Agriculture, Forest Service, Rocky Mountain Forest and Range Experiment Station: 234-238. (RM)
REYNOLDS, RICHARD T.; and BRIAN D. LINKHART. 1987. The nesting biology of flammulated owls in Colorado. In: Nero, Robert W.; Richard J. Clark; Richard J.Knapton; and R. H. Hamre, eds. Biology and conservation of northern forest owls: symposium proceedings; 1987 February 3-7; Winnipeg, Mb. Gen. Tech. Rep. RM142. Fort Collins, CO: U.S. Department of Agriculture, Forest Service, Rocky Mountain Forest and Range Experiment Station. 239-248. (RM)

\section{REYNOLDS, RICHARD T.; E. CHARLES} MESLOW; and HOWARD M. WIGHT. 1982. Nesting habitat of coexisting accipiters in Oregon. Journal of Wildlife Management. 46:124-138. (RM)

REYNOLDS, RICHARD T.; RONALD A. RYDER; and BRIAN D. LINKHART. 1989. Small forest owls. In: Proceedings of the western raptor management symposium and workshop; 1987 October 26-28; Boise, ID. National Wildlife Federation Scientific and Technical Series No. 12:134-143. (RM)

RITTER, LYMAN V. 1983. Growth, development, and behavior of nestling turkey vultures in central California. In: Wilbur, Sanford R.; and Jerome Jackson, eds. Vulture biology and management. Berkeley, CA: University California Press: 287-302. (PSW)

SANTANA, C. EDUARDO; and STANLEY A. TEMPLE. 1986. Status and seasonal patterns of abundance of turkey vultures in Puerto Rico. Journal of Field Ornithology. 53:235-238. (SO)

SANTANA, C. EDUARDO; EDDIE N. LABOY; JAMES A. MOSHER; and STANLEY A. TEMPLE. 1986. Red-tailed hawk nest sites in Puerto Rico. Wilson Bulletin. 98:561-570. (SO) 
SANTANA, C. EDUARDO; GREG A. POTTER; and STANLEY A. TEMPLE. 1986. Home range and activity patterns of turkey vulture in Puerto Rico. Caribbean Journal of Science. 22:175177. (SO)

TESCHENDORF, JAY S. W.; CATHERINE FRAZER; and TERYL G. GRUBB. 1987. Interactions between bald eagles

(Haliaeetus leucocephalus: Accipitridae) and river otters (Lutra canadensis:

Mustelidae). The Southwestern

Naturalist. 32:286-287. (RM)

WILEY, JAMES W. 1985. Status and conservation of forest raptors in the West Indies. In: Chancellor, R.; and I. Newton, eds. Conservation studies on raptors. Tech. Publ. 5. Cambridge, EN: International Council for Bird Preservation: 199-204. (SO)

WILEY, JAMES W.; and BETH NETHERY WILEY. 1981. Breeding season ecology and behavior of Ridgeway's hawk. The Condor. 83:132-151. (SO)

\section{Threatened And Endangered Birds}

BELANGER, ROGER P.; ROY L. HEDDEN; and MICHAEL R. LENNARTZ. 1988. The potential impact of the southern pine beetle on red-cockaded woodpecker colonies in the Georgia Piedmont. Southern Journal of Applied Forestry. 12:194-199. (SE)

BUECH, RICHARD R. 1980. Vegetation of a Kirtland's warbler breeding area and 10 nest sites. The Jack-Pine Warbler. 58:59-72. (NC)

COLLINS, MARK S. 1984. Observations on the nesting of the Hawaii 'Akepa.

'Elepaio. 45:1-2. (PSW)
CONNER, RICHARD N. 1989. Injection of 2,4-D to remove hardwood midstory within red-cockaded woodpecker colony areas. Res. Pap. SO-251. New Orleans, LA: U.S. Department of Agriculture, Forest Service, Southern Forest Experiment Station. 4 p. (SO)

CONNER, RICHARD N.; and BRIAN A. LOCKE. 1982. Fungi and red-cockaded woodpeckers cavity trees. Wilson Bulletin. 94:64-70. (SO)

CONNER, RICHARD N.; and BRIAN A. LOCKE. 1983. Artificial innoculation of red heart fungus into loblolly pines. In: Wood, Don A., ed. Proceedings, 2nd red-cockaded woodpecker symposium; 1983 January 27-29; Panama City, FL. Tallahassee, FL: Florida Game and Fresh Water Fish Commission: 81-82. (SO)

CONNER, RICHARD N.; and KATHLEEN A. O'HALLORAN. 1987. Cavity-tree selection by red-cockaded woodpeckers as related to growth dynamics of southern pines. Wilson Bulletin. 99:398412. (SO)

CONNER, RICHARD N.; and RUDOLPH D. CRAIG. 1989. Red-cockaded woodpecker colony status and trends on the Angelina, Davy Crockett, and Sabine National Forests. Res. Pap. SO-250. New Orleans, LA: U.S. Department of Agriculture, Forest Service, Southern Forest Experiment Station. 15 p. (SO)

ELLIS, DAVID H. 1982. The peregrine falcon in Arizona: Habitat utilization and management recommendations. Res. Rep. 1. Oracle, AZ: Institute for Raptor Studies. 24 p. (RM)

GOWATY, PATRICIA ADAIR; and MICHAEL R. LEMMARTZ. 1985. Sex ratios of nestling and fledgling red-cockaded woodpeckers (Picoides borealis) favor males. American Naturalist. 126(3):347353. (SE) 
GRUBB TERYL; and DUANE M. RUBINK. 1978. First bald eagle eggs collected for analysis in Arizona. Res. Note. RM-352. Fort Collins, CO: U.S. Department of Agriculture, Forest Service, Rocky Mountain Forest and Range Experiment Station. 2 p. (RM)

GRUBB, TERYL G. 1978. A summary of current bald eagle research in the Southwest. In: Proceedings of bald eagle days; 1978 January; Eagle Valley Environmentalists, Inc. Box 155, Apple River, IL. (RM)

GRUBB, TERYL G. 1980. An artificial bald eagle nest structure. Res. Note. RM383. Fort Collins, CO: U.S. Department of Agriculture, Forest Service, Rocky Mountain Forest and Range Experiment Station. 4 p. (RM)

GRUBB, TERYL G. 1983. Bald eagle activity at an artificial nest structure in Arizona. Journal of Raptor Research. 17:114121. (RM)

GRUBB, TERYL G.; [and others]. 1983. A five-year comparison of bald eagle productivity in Washington and Arizona. In: Bird, David H., ed. Biology and management of bald eagles and ospreys: Proceedings, 1st international symposium on bald eagles and ospreys; 1981 October 28-29; Montreal, Canada. Raptor Research Foundation: 35-45. (RM)

GRUBB, TERYL G.; and CHARLES E. KENNEDY. 1982. Bald eagle winter habitat on southwestern National Forests. Res. Pap. RM-237. Fort Collins, CO: U.S. Department of Agriculture, Forest Service, Rocky Mountain Forest and Range Experiment Station. $13 \mathrm{p}$. (RM)
GRUBB, TERYL G.; and CHARLES E. KENNEDY. 1982. Bald eagle winter habitat on the National Forest System in the Southwest. RUN WILD wildlife/habitat relationships. Wildlife Unit Tech. Rep. Albuquerque, NM: U.S. Department of Agriculture, Forest Service, Southwestern Region. 116 p. (RM)

GRUBB, TERYL G.; and MICHAEL A. COFFEY. 1982. Evidence of bald eagles feeding on freshwater mussels. Wilson Bulletin. 94:84-85. (RM)

GRUBB, TERYL G.; and R. J. HENSEL. 1978. Food habits of bald eagles on Kodiak Island, Alaska. The Murrelet. Summer 1978:70-72. (RM)

GRUBB, TERYL G.; DUANE M. RUBINK; STEPHEN W. HOFFMAN; and LARRY A. FORBIS. 1982. Management of breeding bald eagles in Arizona problems and perspectives. In: Ingram, Terrence N., ed. Proceedings of the bald eagle conference on bald eagle restoration; 1982 August 13-15; Tech. Rep. BED-82 Rochester, NY. Apple River, IL: Eagle Valley Environmentalists: 73-88. (RM)

HAMEL, PAUL B. 1977. The wood stork in South Carolina, a review. Chat. 41(2):24-25. (SE)

HAMEL, PAUL B. 1979. Bachman's warbler: the decline (and fall?) of an endangered species. American Zoologist. 19:1003. (SE)

HAMEL, PAUL B. 1982. The field identification of Bachman's warbler (Vermivora bachmanii Audubon). American Birds. 36:235-240. (SE)

HAMEL, PAUL B.; and ROBERT G. HOOPER. 1979. Bachman's warbler: the most critically endangered. In: Forsythe, Dennis M. and William B. Ezell, Jr., eds. Proceedings first South Carolina endangered species symposium; 1976 November; Charleston, SC: 164-168. (SE) 
HAMEL, PAUL B.; and ROBERT G. HOOPER. 1979. Status of Bachman's warbler's progress report. In: Odom, Ron R. and Larry Lander, eds. Proceedings, rare and endangered wildlife symposium; 1978 August; Tech. Bull. WL-4. Athens, GA: Georgia Department of Natural Resources, Game and Fish Division: 112-121. (SE)

HARLOW, RICHARD F. 1983. Effects of fidelity to nest cavities on the reproductive success of the redcockaded woodpecker in South Carolina. In: Wood, Don A., ed. Proceedings, $2 d$ red-cockaded woodpecker symposium; 1983 January 27-29; Panama City, FL. Tallahassee, FL: State of Florida Game and Fresh Water Fish Commission: 94-97. (SE)

HARLOW, RICHARD F.; and MICHAEL R. LENNARTZ. 1977. Foods of nestling red-cockaded woodpeckers in coastal South Carolina. The Auk. 94:376-377. (SE)

HARLOW, RICHARD F.; and MICHAEL R. LENNARTZ. 1983. Interspecific competition for red-cockaded woodpecker cavities during the nesting season in South Carolina. In: Wood, Don A., ed. Proceedings, $2 d$ redcockaded woodpecker symposium; 1983 January 27-29; Panama City, FL. Tallahassee, FL: State of Florida Game and Fresh Water Fish Commission: 4I43. (SE)

HARLOW, RICHARD F.; ROBERT G. HOPPER; and MICHAEL R. LENNARTZ. 1983. Estimating numbers of red-cockaded woodpecker colonies. The Wildlife Society Bulletin. 11:360363. (SE)

HAYES, JACK P.; JOHN R. PROBST; and DON RAKSTAD. 1986. Effect of mating status and time of day on Kirtland's warbler song rates. The Condor. 88:386388. (NC)
HOOPER, ROBERT G. 1982. Use of dead cavity trees by red-cockaded woodpeckers. The Wildlife Society Bulletin. 10:163-164. (SE)

HOOPER, ROBERT G. 1983. Colony formation by red-cockaded woodpeckers: hypotheses and management implications. In: Wood, Don A., ed. Proceedings, 2nd redcockaded woodpecker symposium; 1983 January 27-29; Panama City, FL. Tallahassee, FL: State of Florida Game and Fresh Water Fish Commission: 7277. (SE)

HOOPER, ROBERT G. 1988. Longleaf pines used for cavities by red-cockaded woodpeckers. Journal of Wildlife Management. 52:392-398. (SE)

HOOPER, ROBERT G.; and MICHAEL R. LENNARTZ. 1981. Foraging behavior of the red-cockaded woodpecker in South Carolina. The Auk. 98:321-334. (SE)

HOOPER, ROBERT G.; and MICHAEL R. LENNARTZ. 1983. Roosting behavior of red-cockaded woodpecker clans with insufficient cavities. Journal of Field Ornithology. 54:72-76. (SE)

HOOPER, ROBERT G.; and RICHARD F. HARLOW. 1986. Forest stands selected by foraging red-cockaded woodpeckers.

Res. Pap. SE-259. Asheville, NC: U.S. Department of Agriculture, Forest Service, Southeastern Forest Experiment Station. 10 p.(SE)

HOOPER, ROBERT G.; ANDREW F. ROBINSON, JR.; and JEROME A. JACKSON. 1980. The red-cockaded woodpecker: Notes on life history and management. Gen. Rep. SA-GR 9. Atlanta, GA: U.S. Department of Agriculture, Forest Service, Southern Region. 8 p. (SE) 
HOOPER, ROBERT G.; LAWRENCE J. NILES; RICHARD F. HARLOW; and GENE W. WOOD. 1982. Home ranges of red-cockaded woodpeckers in coastal South Carolina. The Auk. 99:675-682. (SE)

HOVIS, JULIE A.; and RONALD F. LABISKY. 1985. Vegetative associations of redcockaded woodpecker colonies in Florida. The Wildlife Society Bulletin. 13:307-314. (SE)

JACKSON, J. A.; M. R. LENNARTZ; and R. G. HOOPER. 1979. Tree age and cavity initiation by red-cockaded woodpeckers. Journal of Forestry. 77:102-103. (SE)

JACKSON, J. A.; RICHARD N. CONNER; and B. J. S. JACKSON. 1986. The effects of wilderness on the endangered red-cockaded woodpecker. In: Kulhavy, D. L. ; and Richard N. Conner, eds. Wilderness and natural areas in the eastern United States: a management challenge. Nacogdoches, TX: Center for Applied Studies, School of Forestry, Stephen F. Austin State University: 7178. (SO)

KULHAVY, D. L.; J. H. MITCHELL; and RICHARD N. CONNER. 1988. The southern pine beetle and red-cockaded woodpecker: Potential for interaction. In: Payne, T. L.; and H. Saarenmaa, eds. Integrated control of scolytid bark beetles: Proceedings symposium, XVII International Congress of Entomology; Vancouver, British Columbia: 337-343. (SO)

LENNARTZ, MICHAEL R. 1988. The redcockaded woodpecker: old-growth species in a second-growth landscape. Natural Areas Journal. 83:160-165. (SE)
LENNARTZ, MICHAEL R.; and DAVID G. HECKEL 1988. Population dynamics of a red-cockaded woodpecker population in Georgia Piedmont loblolly pine habitat. In: Odum, Ron R.; Kenneth A. Riddleberger; and James C. Ozier, eds. 3rd southeastern nongame and endangered wildlife symposium; 1987 August 8-10; Athens, GA. Social Circle, GA: Georgia Department of Natural Resources; 48-55. (SE)

LENNARTZ, MICHAEL R.; and J. D. METTEAUER. 1986. Test of a population estimation technique for redcockaded woodpeckers. In: Proceedings, Annual Conference Southeastern Association Fish and Wildlife Agencies. 40:320-324. (SE)

LENNARTZ, MICHAEL R.; and JOE P. MCCLURE. 1979. Estimating the extent of red-cockaded woodpecker habitat in the southeast. In: Frayer, W. E., ed. Forest resource inventories workshop proceedings; 1979 July; Fort Collins, CO: Colorado State University, Department of Forest and Wood Sciences: 48-62. Volume 1. (SE)

LENNARTZ, MICHAEL R.; and RICHARD F. HARLOW. 1979. The role of parent and red-cockaded woodpeckers at the nest. Wilson Bulletin. 91:331-335. (SE)

LENNARTZ, MICHAEL R.; and ROBERT C. LEE. 1983. An aberrantly-colored male red-cockaded woodpecker in Georgia. In: Wood, Don A., ed. Proceedings, 2nd red-cockaded woodpecker symposium; 1983 January 27-29; Panama City, FL. Tallahassee, FL: State of Florida Game and Fresh Water Fish Commission: 109110. (SE) 
LENNARTZ, MICHAEL R.; HERBERT A. KNIGHT; JOE P. MCCLURE; and VICTOR A. RUDIS. 1983. Status of redcockaded woodpecker nesting habitat in the South. In: Wood, Don A., ed.; Proceedings, 2nd red-cockaded woodpecker symposium; 1983 January 27-29; Panama City, FL. Tallahassee, FL: State of Florida Game and Fresh Water Fish commission: 13-19. (SE)

LENNARTZ, MICHAEL R.; PAUL H. GEISSLER; RICHARD F. HARLOW; RANDALL C. LONG; KENNETH M. CHITWOOD; and JEROME A. JACKSON. 1983. Status of the redcockaded woodpecker on federal lands in the South. In: Wood, Don A., ed. Proceedings, 2nd red-cockaded woodpecker symposium 2; 1983 January 27-29; Panama City, FI. Tallahassee, FL: State of Florida Game and Fresh Water Fish Commission: 7-12 (SE)

LENNARTZ, MICHAEL R.; ROBERT G. HOOPER; and RICHARD F. HARLOW. 1979. The red-cockaded woodpecker: management research needs. In: Forsythe, Dennis M; and William B. Ezell, Jr., eds. Proceedings, 1st South Carolina endangered species symposium. 1976 November Charleston, SC: 151-158. (SE)

LENNARTZ, MICHAEL R.; ROBERT G. HOOPER; and RICHARD F. HARLOW. 1987. Sociality and cooperative breeding of red-cockaded woodpeckers, Picoides borealis. Behavioral Ecology and Sociobiology. 20:77-88. (SE)

\section{LIGON, J. D.; P. B. STACEY; RICHARD N.} CONNER; C. E. BOCK; and C. S. ADKISSON. 1986. Report of the American Ornithologists' Union committee for the conservation of the red-cockaded woodpecker. The AUK. 103:848-855. (SO)
LOCKE, BRIAN A.; and RICHARD N.

CONNER. 1983. A statistical analysis of the orientation of entrances to redcockaded woodpecker cavities. In: Wood, Don A., ed. Proceedings, 2d redcockaded woodpecker symposium; 1983 January 27-29; Panama City, FL. Tallahassee, FL: Florida Game and Fresh Water Fish Commission: 108-109. (SO)

LOCKE, BRIAN A.; RICHARD N. CONNER; and JAMES C. KROLL. 1979. Redcockaded woodpecker stuck in cavity entrance resin. Bird-Banding. 50:368369. (SO)

LOCKE, BRIAN A.; RICHARD N. CONNER; and JAMES C. KROLL. 1983. Factors influencing colony site selection by redcockaded woodpeckers. In: Wood, Don A., ed. Proceedings, $2 d$ red-cockaded woodpecker symposium; 1983 January 27-29; Panama City, FI. Tallahassee, FL: Florida Game and Fresh Water Fish Commission: 46-50. (SO)

MATTSON, J. P.; and A. H. GREWE, JR. 1976. Bald eagle nesting in the Superior National Forest. Res. Note. NC-198. St. Paul, MN: U.S. Department of Agriculture, Forest Service, North Central Forest Experiment Station. (NC)

ORGEGO, B.; RICHARD N. CONNER; and RUDOLPH D. CRAIG. 1988. Status of the red-cockaded woodpecker in Texas, 1985-1987. Bulletin Texas Ornithological Society. 21(1 \& 2):22-24. (SO)

PROBST, JOHN R. 1985. Summer records and management implications of Kirtland's warbler in Michigan's Upper Peninsula. Jack-Pine Warbler. 63(1):[not paged]. (NC)

PROBST, JOHN R. 1986. A review of factors limiting the Kirtland's warbler on its breeding grounds. American Midland Naturalist. 116(1):87-100. (NC) 
PROBST, JOHN R. 1988. Kirtland's warbler breeding biology and habitat management. In: Hoeksta, Thomas W.; and Jack Capp, comps. Integrating forest management for wildlife and fish. Gen. Tech. Rep. NC-122. St. Paul, MN: U.S. Department of Agriculture, Forest Service, North Central Forest Experiment Station: 28-35. (NC)

PROBST, JOHN R.; and JACK P. HAYES. 1987. Pairing success of Kirtland's warblers in marginal vs. suitable habitat. The Auk. 104:234-241. (NC)

SAKAI, HOWARD F.; and C. JOHN RALPH. 1978. A recent sighting of the 'Akiapol' au in South Kona, Hawaii. 'Elepaio'. 39:49-50. (PSW)

SAKAI, HOWARD F.; and C. JOHN RALPH. 1980. An observation of 'Akiapola' au nest construction. 'Elepaio'. 41:4-5. (PSW)

SAKAI, HOWARD F.; and C. JOHN RALPH. 1980. Observations on the Hawaiian crow in South Kona, Hawaii. 'Elepaio'. 40:133-138. (PSW)

SAKAI, HOWARD F.; and C. JOHN RALPH. 1980. Nest construction of the Hawaiian creeper near Volcano, Hawaii. 'Elepaio'. 40:117-119. (PSW)

SAKAI, HOWARD F.; and THEA C. JOHANOS. 1983. The nest, egg, young, and aspects of the life history of a race of the endangered Hawaii creeper. West Birds. 14:73-84 (PSW)

SAKAI, HOWARD F.; C. JOHN RALPH; and C. D. JENKINS. 1986. Foraging ecology of the Hawaiian crow, an endangered genera list. The Condor. 88:211-219. (PSW)

SEAGLE, STEVEN W.; RICHARD A LANCIA; and DAVID A. ADAMS. 1987. A multivariate analysis of rangewide redcockaded woodpecker habitat. Journal of Environmental Management. 25:4556. (SE).
SEAGLE, STEVEN W.; RICHARD A LANCIA; DAVID A. ADAMS; MICHAEL R. LENNARTZ; and HUGH A. DEVINE. 1987. Integrating timber and redcockaded woodpecker habitat management. Transactions of the North American Wildlife and Natural Resources Conference. 52:41-52. (SE)

STANGEL, PETER W.; and MICHAEL R. LENNARTZ. 1988. Survival of redcockaded woodpecker nestlings unaffected by sampling blood and feather pulp for genetic studies. Journal of Field Ornithology. 59:389-394. (SE)

U.S. FISH AND WILDLIFE SERVICE. 1985. Red-cockaded woodpecker recovery plan. Atlanta, GA: U.S. Department of Interior, Fish and Wildlife Service. 77 p. (SE)

VERNER, JARED. 1978. California condors: status of the recovery effort. Gen. Tech. Rep. PSW- 28. Berkeley, CA: U.S. Department of Agriculture, Forest Service, Pacific Southwest Forest and Range Experiment Station. 30 p. (PSW)

WILEY, JAMES W. 1980. The Puerto Rican parrot (Amazona vittata): its decline and the program for its conservation. In:

Pasquir, Roger F., ed. Conservation of new world parrots: proceedings of the ICBP parrot working group meeting; 1980; St. Lucia, PR: Tech. Pub. No. 1. Washington, DC: Smithsonian Institution Press: 133-159. (SO)

WILEY, JAMES W. 1983. The role of captive propagation in the conservation of the Puerto Rican parrot. In: Schulman, G. L., ed. Proceedings Jean Delacour/IFCB symposium on breeding birds in captivity. Los Angeles, CA: International Foundation for Conservation of Birds. 1983:441-453. (SO)

WILEY, JAMES W. 1985. The captive programme for the endangered Puerto Rican parrot Amazona vittata. Avicultural Magazine. 91:110-116. (SO) 
ARENDT, WAYNE J.; T. A. VARGAS MORA; and JAMES W. WILEY. 1980. Whitecrowned pigeon: status rangewide and in the Dominican Republic. Proceedings Annual Conference Southeastern Association Fish and Wildlife Agencies. 33:111-122. (SO)

AULT, STACEY E.; and FRED A STORMER. 1983. Seasonal food selection by scaled quail in northwest Texas. Journal of Wildlife Management 47:222-228. (RM)

BEASOM, SAMUEL L.; and OLIVER $\mathrm{H}$. PATTEE. 1980. The effect of selected climatic variables on wild turkey productivity. In: Proceedings, 4th national wild turkey symposium; Little Rock, AK: 127-135. (RM)

BJUGSTAD, ARDELL J., tech. coord. 1988. Prairie chickens on the Sheyenne National Grasslands. Proceedings of the symposium; 1987 September 18; Crookston, MN. Gen. Tech. Rep. RM159. Fort Collins, CO: U.S. Department of Agriculture, Forest Service, Rocky Mountain Forest and Range Experiment Station. 73 p. (RM)

CAIN, J. RICHARD; SAMUEL L. BEASOM; LENTON O. ROWLAND; and LOYD D. ROWE. 1982. The effects of varying dietary phosphorus on breeding bobwhites. Journal of Wildlife Management. 46:1061-1065. (RM)

CRAWFORD, JOHN A.; and FRED A. STORMER. 1980. A bibliography of the lesser prairie chicken, 1873-1980. Gen. Tech. Rep. RM-80. Fort Collins, CO: U.S. Department of Agriculture, Forest Service, Rocky Mountain Forest and Range Experiment Station. 8 p. (RM)

CRITES, MARK JEFFREY. 1988. Ecology of the Merriam's wild turkey in north-central Arizona. Tucson, AZ: University of Arizona, School of Renewable Resources. 59 p. (PNW)
DICKSON, JAMES G. 1986. Wilderness as wild turkey habitat in the eastern United States. In: Kulhavy, D. L.; and Richard N. Conner, eds. Wilderness and natural areas in the eastern United States: a management challenge. Nacogdoches, TX: Stephen F. Austin State University, Center for Applied Studies, School of Forestry: 86-88.(SO)

DOERR, TED B.; and FRED S. GUTHERY. 1980. Effects of shinnery oak control on lesser prairie chicken habitat. In: Vohs, P. A.; and F. L. Knoff, eds. Proceedings, prairie grouse symposium; 1980

September 17-18; Stillwater, OK: Oklahoma State University: 59-63. (RM)

FLATHER, CURTIS.; THOMAS W. HOEKSTRA; DAVID E. CHALK; NOEL D. COST; and VICTOR A. RUDIS. 1989. Recent historical and projected regional trends of white-tailed deer and wild turkey in the southern United States. Gen. Tech. Rep. RM-172 Fort Collins, CO: U.S. Department of Agriculture, Forest Service, Rocky Mountain Forest and Range Experiment Station. 22 p. (RM)

GOODWIN, JOHN G., JR.; and C. ROGER HUNGERFORD. 1977. Habitat use by native Gambel's and scaled quail and released masked bobwhite quail in Southern Arizona. Res. Pap. RM-197. Fort Collins, CO: U.S. Department of Agriculture, Forest Service, Rocky Mountain Forest and Range Experiment Station. 8 p. (RM)

GUTHERY, FRED S. 1979. Problems and potentials of panhandle pheasants. Texas Hunter's Hotline. 1979(7):42-43. (RM)

GUTHERY, FRED S. 1980. Bobwhites and brush control. Rangelands. 2:202-204. (RM)

GUTHERY, FRED S. 1980. Must the prairie gobbler fade? The Cattleman. 67:132134. (RM) 
GUTHERY, FRED S.; JAY CUSTER; and MIKE OWEN. 1980. Texas panhandle pheasants: their history, habitat needs, habitat development opportunities, and future. Gen. Tech. Rep. RM-74. Fort Collins, CO: U.S. Department of Agriculture, Forest Service, Rocky Mountain Forest and Range Experiment Station. 11 p. (RM)

HALLS, LOWELL K. 1980. Wild turkey restoration in the United States. In: Proceedings, IV symposium game biology; 1976 October 15-16; Belgrade, Yugoslavia. Yugoslavia Institute of Forestry and Wood Industry: 49-52. (SO)

HATCH, JEREMY J. 1985. Lateral asymmetry of the bill of Loxops coccineus

(Drepanidinae). The Condor. 87:546547.(PSW)

HEALY, WILLIAM M. 1977. Wild turkey winter habitat in West Virginia cherry-maple forests. Transactions, Northeast Fish and Wildlife Conference. 34:7-12. (NE)

HEALY, WILLIAM M. 1981. Habitat requirements of wild turkeys in the southeastern mountains. In: Habitat requirements and habitat management for the wild turkey in the Southeast. Ellistown, VA: Virginia Wild Turkey Foundation: 24-34. (NE)

HEALY, WILLIAM M.; and EDWARD S. NENNO. 1983. Winter feeding; some food for thought. Turkey Call. 10(5):1618. (NE)

HEALY, WILLIAM M.; and EDWARD S. NENNO. 1978. Turkey broods and hairy snoods. Turkey Call. 5(3):12-17. (NE)

HEALY, WILLIAM M.; and EDWARD S. NENNO. 1980. Growth parameters and sex and age criteria for juvenile eastern wild turkeys. National Wild Turkey Symposium. 4:168-185. (NE)
HEALY, WILLIAM M.; and EDWARD S. NENNO. 1983. Minimum maintenance versus intensive management of clearings for wild turkeys. The Wildlife Society Bulletin. $\|(2): 113-120$. (NE)

HEALY, WILLIAM M.; and JAMES D. PACK. 1983. Managing seeps for wild turkeys in northern hardwood forest types in West Virginia. In: Yahner, Richard H., ed. Transactions of the Northeast Section, The Wildlife Society: 40th Northeast Fish and Wildlife Conference; 1983 May 15-18; West Dover, VT. Washington, DC: The Wildlife Society: 9-18. (NE)

HEALY, WILLIAM M.; RICHARD O. KIMMEL; DAVID A. HOLDERMANN; and WILLIAM HUNYADI. 1980. Attracting ruffed grouse broods with tape-recorded chick calls. The Wildlife Society Bulletin. 8:69-71. (NE)

HOLBROOK, HERMAN L.; and WILLIAM M. HEALY. 1981. Wild turkeys. In: Byrd, Nathan B., comp. Something's been using my habitat. A forester's guide to observing wildlife use of forest habitat in the South. Atlanta, GA. U.S. Department of Agriculture, Forest Service, Southeastern Area, State and Private Forestry: 32-34. (SE)

KIMMEL, R. O.; J. R. LUDGWIG; G. C. NELSON; W. HUNYADI; F.

THOMPSON; and V. L. KIMMEL. 1982. Attracting broods with tape-recorded chick calls, applications for ruffed grouse, wild turkey, and other gallinaceous species, In: 44th Midwest Fish and Wildlife Conference; 1982 December 12-15; Des Moines, IA: lowa Conservation Commission and lowa State University: 115-116. (NC)

LEWIS, CLIFFORD E. ; and THOMAS J. HARSHBARGER. 1986. Burning and grazing effects on bobwhite foods in the southeastern coastal plain. The Wildlife Society Bulletin. 14:455-459. (SE) 
MEDINA, ALVIN L. 1988. Diets of scaled quail in southern Arizona. Journal of Wildlife Management 52:753-757. (RM)

NENNO, EDWARD S. 1980. The history and role of the northeast wild turkey committee. In: Transactions, 37th Northeast Fish and Wildlife Conference; 1980, April 27-30, Ellenville, NY: Northeast Section, The Wildlife Society. 1980:249-257. (NE)

NENNO, EDWARD S.; and JAMES S. LINDZEY. 1979. Wild turkey poultry feeding activity in old field, agricultural clearing, and forest communities. Transactions of the Northeast Fish and Wildlife Conference. 36:97-109. (NE)

NENNO, EDWARD S.; and WILLIAM M. HEALY. 1979. Effects of radio packages on behavior of wild turkey hens. Journal of Wildlife Management. 43:760-765. (NE)

NEWELL, JAY A.; JOHN E. TOEPFER; and MARK A. RUMBLE. 1988. Summer brood-rearing ecology of the greater prairie chicken on the Sheyenne National Grasslands. In: Bjugstad, Ardell J., tech. coord. Prairie chickens on the Sheyenne National Grasslands: symposium proceedings; 1987 September 18; Crookston, MN. Gen Tech. Rep. RM-159. Fort Collins, CO: U.S. Department of Agriculture, Forest Service, Rocky Mountain Forest and Range Experiment Station: 24-31. (RM)

RUMBLE, MARK A.; JAY A. NEWELL; and JOHN E. TOEPFER. 1988. Diets of greater prairie chickens on the Sheyenne National Grasslands. In: Bjugstad, Ardell J., tech. coord. Prairie chickens on the Sheyenne National Grasslands: symposium proceedings; 1987 September 18; Crookston, MN. Gen Tech. Rep. RM-159. Fort Collins, CO: U.S. Department of Agriculture, Forest Service, Rocky Mountain Forest and Range Experiment Station: 49-54. (RM)
SEEHORN, MONTE E.; RICHARD F. HARLOW; and MICHAEL T. MENGAK. 1984. Foods of ruffed grouse from three locations in the Southern Appalachian Mountains. In: Sweeney, John R., ed. Proceedings, 35th annual conference Southeastern Association Fish and Wildlife Agencies; 198 I October 18-21; Tulsa, OK. Nashville, TN: SE Association Fish and Wildlife Agencies. 35:216-224. (SE)

SEVERSON, KIETHE. 1978. A bibliography of blue grouse--1889-1977. Gen. Tech. Rep. RM-59. Fort Collins, CO: U.S. Department of Agriculture, Forest Service, Rocky Mountain Forest and Range Experiment Station. 10 p. (RM)

SEVERSON, KIETH E. 1986. Spring and early summer habitats and foods of male blue grouse in Arizona. Journal of the Arizona-Nevada Academy of Science. 21:13-18. (RM)

STORMER, FRED A. 1981. Characteristics of scaled quail loafing coverts in northwest Texas. Res. Note. RM-395. Fort Collins, CO: U.S. Department of Agriculture, Forest Service, Rocky Mountain Forest and Range Experiment Station. 6 p. (RM)

STORMER, FRED A. 1984. Night-roosting habitat of scaled quail. Journal of Wildlife Management. 48:192-197. (RM)

TAYLOR, MAPLE A.; and FRED $S$. GUTHERY. 1980. Status, ecology, and management of the lesser prairie chicken. Gen. Tech. Rep. RM-77. Fort Collins, CO: U.S. Department of Agriculture, Forest Service, Rocky Mountain Forest and Range Experiment Station. 15 p. (RM)

THOMPSON, FRANK R., III; and ERIK K. FRITZELL. 1988. Ruffed grouse winter roost site preference and influence on energy demands. Journal of Wildlife Management. 52:454-460. (NC) 
THOMPSON, FRANK R., III; DERETHA A. FREILING; and ERIK K. FRITZELL. 1987. Drumming, nesting, and brood habitats of ruffed grouse in an oakhickory forest. Journal of Wildlife Management. 51:568-575. (NC)

WELCH, BRUCE L.; JORDAN C. PEDERSON; and RONALD L. RODRIQUEZ. 1988. Selection of big sagebrush by sage grouse. Great Basin Naturalist. 48:274-279. (INT)

WHITESIDE, RICHARD W.; and FRED S. GUTHERY. 1979. Effects of macrohabitat on pheasants in the Texas Panhandle. In: Sosebee, Ronald E.; and Henry Wright, eds. Wildlife management; Lubbock, TX: Texas Tech University. 63 p. (RM)

WIGLEY, T. BENTLY; JAMES M. SWEENEY; MICHAEL E. GARNER; and M.

ANTHONY MELCHOIRS. 1985. Forest habitat use by wild turkeys in the Ouachita Mountains. In: Proceedings of the 5th national wild turkey symposium; 1985 June 17-21; Des Moines, IA. Edgefield, SC: The National Wild Turkey Federation. 1985:183-197. (NC)

WIGLEY, T. BENTLY; JAMES M. SWEENEY; MICHAEL E. GARNER; and M.

ANTHONY MELCHOIRS. 1986. Wild turkey home ranges in the Ouachita Mountains. Journal of Wildlife Management. 50:540-544. (NC)

WIGLEY, T. BENTLY; JAMES M. SWEENEY; MICHAEL E. GARNER; and M.

ANTHONY MELCHOIRS. 1986. Effects of forest characteristics on wild turkey habitat use in the Ouachita Mountains. Bull. 887. Fayetteville, AR: Arkansas Agricultural Experiment Station. 24 p. (NC)

WILEY, JAMES W. 1981. The status of the white-crowned pigeon in Puerto Rico. Proceedings, International whitecrowned pigeon conference; Nassau, Bahamas: 11-16. (SO)
ZEEDYK, WILLIAM D.; and JAMES G. DICKSON. 1985. Fifth national wild turkey symposium summary. In: Proceedings of the 5th national wild turkey symposium; 1985 June 17-21; Des Moines, IA. Edgefield, SC: The National Wild Turkey Federation. 1985:333-339. (SO)

\section{Songbirds}

ANDERSON, MARY E.; and RICHARD N. CONNER. 1985. Northern cardinal song in three forest habitats in eastern Texas. Wilson Bulletin. 97:436-449. (SO)

ARENDT, WAYNE J.; and ANGELA I. ARENDT. 1986. Bill deformity in a pearly-eyed thrasher from Montserrat, West Indies. North American Bird Bander. 11:41-52. (SO)

BRAWN, JEFFREY D.; and FRED B. SAMSON. 1983. Winter behavior of tufted titmice. Wilson Bulletin. 95:222232. (NC)

BUECH, RICHARD R. 1982. Nesting ecology and cowbird parasitism of clay-colored, chipping, and field sparrows in a Christmas tree plantation. Journal Field Ornithology. 53:363-369. (NC)

CONNER, RICHARD N. 1985. Vocalizations of common ravens in Virginia. The Condor. 87:379-388. (SO)

CONNER, RICHARD N. 1986. Nest chronology of common ravens in Virginia. The Raven. 57:5-11. (SO)

CONNER, RICHARD N.; IRVINE D. PRATHER; and JERRY W. VIA. 1980. An old world bird the raven. Virginia Wildlife. 41:21. (SO)

CONNER, RICHARD N.; JAMES G. DICKSON; BRIAN A. LOCKE; and CHARLES A. SEGELQUIST. 1983. Vegetation characteristics important to common songbirds in east Texas. Wilson Bulletin. 95:349-361. (SO) 
CONNER, RICHARD N.; MARY E.

ANDERSON; and JAMES G. DICKSON. 1986. Relationships among territory size, habitat, song, and nesting success on northern cardinals. The Auk. 103:2331. (SO)

CRAWFORD, HEWLETTE S.; ROBERT G. HOOPER; and R. W. TITTERINGTON. 1981. Songbird population response to silvicultural practices in central Appalachian hardwoods. Journal of Wildlife Management. 45:680-692. (NE)

DEBYLE, NORBERT V. 1981. Songbird populations and clearcut harvesting of aspen in northern Utah. Res. Note. INT302. Ogden, UT: U.S. Department of Agriculture, Forest Service, Intermountain Forest and Range Experiment Station. 7 p. (INT)

DEGRAAF, RICHARD M., tech. coord. 1978. Proceedings, nongame bird habitat management in the coniferous forests of the western. 1977 February 7-9; U. S. Gen. Tech. Rep. PNW-64. Portland, OR: U.S. Department of Agriculture, Forest Service, Pacific Northwest Forest and Range Experiment Station. 100 p. (NE)

DEGRAAF, RICHARD M., tech. coord. 1980. Management of western forests and grasslands for non-game birds. Workshop proceedings; 1980 February 11-14; Salt Lake City, UT. Gen. Tech. Rep. INT-86. Ogden, UT: U.S. Department of Agriculture, Forest Service, Intermountain Forest and Range Experiment Station. 535 p. (NE)

DEGRAAF, RICHARD M.; and KEITH E. EVANS. tech. coords. 1979. Workshop proceedings--management of North Central and Northeastern forests for nongame birds. Gen. Tech. Rep NC-51. St. Paul, MN: U.S. Department of Agriculture, Forest Service, North Central Forest Experiment Station. 268 p. (NE)
DICKSON, JAMES G.; WAYNE R. MARION; WILLIAM C. MCCOMB; and JOHN J. MORIARTY. 1982. A partial bibliography on management of non-game birds in the southeast, 1960-1980. Gen. Tech. Rep. SO-47. New Orleans, LA: U.S. Department of Agriculture, Forest Service, Southern Forest Experiment Station: 11 p. (SO)

EDDLEMAN, WILLIAM R.; KEITH E. EVANS; and WILLIAM H. ELDER. 1980. Habitat characteristics and management of Swainson's warbler in southern Illinois. The Wildlife Society Bulletin. 8:228-233. (NC)

EHRHART, RICHARD L.; and RICHARD N. CONNER. 1986. Habitat selection by the northern cardinal in three eastern Texas forest stands. The Southwestern Naturalist. 31:191-199. (SO)

EVANS, KEITH E. 1978. Forest management opportunities for songbirds.

Transactions of the North American Wildlife and Natural Resources Conference. 43:69-77. (NC)

EVANS, KEITH E. 1980. A recent nestling record of the chestnut-sided warbler in Missouri. The Bluebird. 47(4):6-7. (NC)

FINCH, DEBORAH M. 1981. Nest predation of Abert's towhees by coachwhips and roadrunners. The Condor. 88:389. (RM)

FINCH, DEBORAH M. 1982. Rejection of cowbird eggs by crissal thrashers. The Auk. 99:719-724. (RM)

FINCH, DEBORAH M. 1983. Seasonal variation in nest placement of Abert's towhees. The Condor. 85:111-113. (RM)

FINCH, DEBORAH M. 1984. Parental expenditure of time and energy in the Abert's Towhee (Pipilo aberti). The Auk. 101:473-486. (RM)

FINCH, DEBORAH M. 1989. Relationships of surrounding riparian habitat to nest-box use and reproductive outcome in house wrens. The Condor. 91:848-859. (RM) 
FINCH, DEBORAH M.; STANLEY H.

ANDERSON; and WAYNE A HUBERT.

1987. Habitat suitability index models:

lark bunting. Biological Report

82(10.137). Washington, DC: U.S.

Department of Interior, Fish and Wildlife Service, National Ecology Center. 16 p. (RM)

FRANZREB, KATHLEEN E. 1983. Intersexual habitat partitioning in yellow-rumped warblers during the breeding season. Wilson Bulletin. 95:581-590. (RM)

FRENZREB, KATHLEEN E. 1984. Foraging habits of ruby-crowned and goldencrowned kinglets in an Arizona montane forest. The Condor. 86:139-145. (RM)

HAMEL, P.; and MICHAEL R. LENNARTZ. 1976. Worm-eating warblers in the South Carolina coastal plain in June. Chat. 40:98-100. (SE)

HAMEL, P. B.; and L. M. WRIGHT. 1979. Lawrence's warbler at Francis Beidler Forest: first sight record for South Carolina. Chat. 43:66-676. (SE)

HAMEL, P. B.; S. M. WINTON; and B. E. CASSIE. 1979. May and June observations of the whip-poor-will in the South Carolina coastal plain. Chat. 43:65-66.(SE)

HARDIN, KIMBERLY I.; and GEORGE E. PROBASCO. 1983. The habitat characteristics and life requirements of Bachman's sparrow. Birding. 15(4/5):189-197. (NC)

HARDIN, KIMBERLY I.; THOMAS S. BASKETT; and KEITH E. EVANS. 1982. Habitat of Bachman's sparrows breeding on Missouri glades. Wilson Bulletin. 94:208-212. (NC)

HENKE, ROBERT J. 1981. The common yellowthroat in Missouri. The Bluebird. 48(2):18-19. (NC)

HOOPER, ROBERT G. 1977. Nesting habitat of common ravens in Virginia. Wilson Bulletin. 89:233-242. (SE)
HOOPER, ROBERT G.; and PAUL B.

HAMEL. 1979. Swainson's warbler in

South Carolina. In: Forsythe, Dennis M.

and William B. Ezell, Jr., eds.

Proceedings, 1 st South Carolina endangered species symposium, 1976 November; Charleston, SC: 178-182. (SE)

JENNINGS, D. T.; and HEWLETTE S. CRAWFORD. 1983. Pine siskin preys on egg masses of the spruce budworm, Choristoneura fumiferana (Lepidoptera: Tortricidas). Canadian Entomology. 115:439-440. (NE)

JOHANOS, THEA; and DAWN BREESE. 1984. An albinistic 'Amakihi' sighted on the island of Hawaii. 'Elepaio. 44:88. (PSW)

KROODSMA, DONALD E.; and JARED VERNER. 1978. Complex singing behaviors among Cistothorus wrens. The Auk. 95:703-706. (PSW)

LOWTHER, PETER E.; and STEPHEN I. ROTHSTEIN. 1980. Head-down or "preening invitation" displays involving juvenile brown-headed cowbirds. The Condor. 82:459-460. (PSW)

MANNAN, R. WILLIAM. 1984. Habitat use by Hammond's flycatchers in old-growth forests, northeastern Oregon. The Murrelet. 65:84-86. (PNW)

MATTSON, WILLIAM J., JR. 1979. Shrub nesting of the red-eyed vireo in relation to structure of aspen forests. Res. Note. NC-245, St. Paul, MN: U.S. Department of Agriculture, Forest Service, North Central Forest Experiment Station. 3 p. (NC)

MCARTHUR, E. DURANT; STEPHEN B. MONSEN; and DEAN E. MEDIN. 1986. Grazing and passerine breeding birds in a Great Basin low-shrub desert. Great Basin Naturalist. 46:567-572. (INT) 
MCCLUSKEY, D. C. 1979. Mountain bluebirds in northeast Oregon--natural nesting sites investigated. Sialia. 1(2):57-58, 62. (PNW)

MCCLUSKEY, D. CALVIN; JACK WARD THOMAS; and E. CHARLES MESLOW. 1977. Effects of aerial application of DDT on reproduction in house wrens and mountain and western bluebirds. Res. Pap. PNW-228. Portland, OR: U.S. Department of Agriculture, Forest Service, Pacific Northwest Forest and Range Experiment Station. 22 p., illus. (PNW)

MEDIN, DAVID E. 1986. Grazing and passerine breeding birds in a Great Basin low-shrub desert. Great Basin Naturalist. 46:557-572. (INT)

NORRIS, DOUGLAS J.; and WILLIAM H. ELDER. 1982. Decline of the roadrunner in Missouri. Wilson Bulletin. 94:354-355. (NC)

NORRIS, DOUGLAS J.; and WILLIAM H. ELDER. 1982. Distribution and habitat characteristics of the painted bunting in Missouri. In: Transactions, Missouri Academy Science. 16:77-83. (NC)

O'HALLORAN, K. A.; and RICHARD N. CONNER. 1987. Habitat used by brownheaded nuthatches. Bulletin Texas Ornithological Society. 20(1\&2):7-13. (SO)

POST, WILLIAM; and JAMES W. WILEY. 1977. Reproductive interactions of the shiny cowbird and the yellow-shouldered black-bird. The Condor. 79(2):176-184. (SO)

POST, WILLIAM; and JAMES W. WILEY. 1977. The shiny cowbird in the West Indies. The Condor. 79(1):119-121. (SO)

PUTNAM, CHARLES W. 1979. The yellowbreasted chat in Missouri. Bluebird. 46(3):25-27. (NC)
RITTER, LYMAN V. 1983. Nesting ecology of scrub jays in Chico, California. West Birds. 14:147-158. (PSW)

RITTER, LYMAN V.; and KATHRYN PURCELL. 1983. Cavity-nesting Brewer's blackbirds. West Birds. 14:205. (PSW)

ROTHSTEIN, STEPHEN I.; and ROBERT C. FLEISCHER. 1987. Brown-headed cowbirds learn flight whistles after the juvenile period. The Auk. 104:512-516. (PSW)

ROTHSTEIN, STEPHEN I.; and ROBERT C. FLEISCHER. 1987. Vocal dialects and their possible relation to honest signalling in the brown-headed cowbird. The Condor. 89:1-23. (PSW)

ROTHSTEIN, STEPHEN I.; DAVID A. YOKEL; and ROBERT C. FLEISCHER. 1986. Social dominance, mating and spacing systems, female fecundity, and vocal dialects in captive and freeranging brown-headed cowbirds. In: Johnston, Richard F., ed. Current ornithology. New York, NY: Plenum Press: 127-185. Volume 3. (PSW)

ROTHSTEIN, STEPHEN I.; JARED VERNER; ERNEST STEPHENS; and LYMAN V. RITTER. 1987. Behavioral differences among sex and age classes of the brown-headed cowbird and their relation to the efficacy of a control program. Wilson Bulletin. 99:322-337. (PSW)

ROTHSTEIN, STEPHEN I.; JARED VERNER; and ERNEST STEVENS. 1980. Range expansion and diurnal changes in dispersion of the brownheaded cowbird in the Sierra Nevada. The Auk. 97:253-267. (PSW)

RUSSELL, STEPHEN M.; and C. JOHN RALPH. 1981. The first observation of the nest of the Oahu 'Amakihi.' 'Elepaio.' 42:(6):53-54. (PSW) 
SAKAI, HOWARD F. 1983. The diversity of nesting sites utilized by the 'Apapane. 'Elepaio. 44(1):2-5. (PSW.)

SCHAID, TIM A.; DANIEL W. URESK; W. LEE TUCKER; and RAYMOND L. LINDER. 1983. Effects of surface mining on the vesper sparrow in the northern Great Plains. Journal of Range Management. 36:500-503. (RM)

STRANSKY, J. J.; L. K. HALLS; and E. S. NIXON. 1976. Plants following timber harvest: importance to songbirds. Texas Forestry Paper. 28. Nacogdoches, TX: Stephen F. Austin State University, School of Forestry. 13 p. (SO)

SWEENEY, J. M.; and W. D. DIJAK. 1985. Ovenbird habitat capability model for an oak-hickory forest. Proceedings of the Annual Conference of the Southeastern Association of Fish and Wildlife Agencies. 39:430-438. (NC)

TITTERINGTON, R. W.; H. S. CRAWFORD; and B. N. BURGASON. 1979. Songbird responses to commercial clearcutting in Maine spruce-fir forests. Journal of Wildlife Management. 43:602-609. (NE)

TOMBACK, DIANA F.; and KATHRYN A. KRAMER. 1980. Limber pine seed harvest by Clark's nutcracker in the Sierra Nevada: timing and foraging behavior. The Condor. 82:467-468. (PSW)

VERNER, JARED; and LYMAN V. RITTER. 1983. Current status of the brownheaded cowbird in the Sierra National Forest. The Auk. 100:355-368. (PSW)

WINTER, W. R. 1981. Role of feeding stations in managing nongame bird habitat in urban and suburban areas. Transactions of the North American Wildlife and Natural Resources Conference. 46:414-423.

\section{Shorebirds And Waterfowl}

ARENDT, WAYNE J. 1988. Range expansion of the cattle egret (Bubulcus ibis) in the Greater Caribbean Basin. Colonial Waterbirds. 11:252-262. (SO)

ARENDT, WAYNE J.; and ANGELA L. ARENDT. 1988. Aspects of the breeding biology of the cattle egret (Bubulcus ibis) in Monserrat, West Indies, and its impact on nest vegetation. Colonial Waterbirds. 11:72-84. (SO)

BALDASSARRE, GUY A.; RICHARD J. WHYTE; EILEEN E. QUINLAND; and ERIC G. BOLEN. 1983. Dynamics and quality of waste corn available to postbreeding waterfowl in Texas. The Wildlife Society Bulletin. 11:25-31. (RM)

CONANT, SHELIA; and MARK S. COLLINS. 1983. Frigatebird nests with two chicks. 'Elepaio. 44:37-38. (PSW)

DOWNING, R. L. 1980. Survey of interior least tern (Sterna albifrous athalassos) nesting populations. American Birds. 34:209-216. (SO)

FELLOWS, D. T.; P. W. PATON; L. F. PANK; and P. Q. TOMICH. 1987. Cattle egret ecology, behavior, and control at General Lyman Field, Hilo, Hawaii. Public Bird Damage Res. Rep. No. 391. Denver, CO: U.S. Department of Interior, Fish and Wildlife Service, Denver Wildlife Research Center. $42 \mathrm{p}$. (PSW)

GRAYSON, DONALD K.; and CHRIS MASER. 1978. First record for the longtailed jaeger in eastern Oregon. The Murrelet. 59:75-77. (PNW)

GUTHERY, FRED S. 1981. Playa basins and resident wildlife in the Texas panhandle. In: Proceedings, playa lakes symposium; 1979 December 4-5; Arlington, TX. FWS/OBS-81/07. Washington, DC: U.S. Department of the Interior, Fish and Wildlife Service: 47-51. (RM) 
GUTHERY, FRED S.; and FRED A. STORMER. 1984. Managing playas for wildlife in the southern high plains of Texas. Manage. Note 4. Lubbock, TX: Texas Tech. University, College of Agricultural Sciences. 5 p. (RM)

GUTHERY, FRED S.; SUSAN M. OBENBERGER; and FRED A. STORMER. 1984. Predictors of site use by ducks on the Texas High Plains. The Wildlife Society Bulletin. 12:35-40. (SO)

GUTZWILLER, KEVIN J.; and STANLEY H. ANDERSON. 1987. Habitat suitability index models: marsh wren. Biol. Rep. 82(10.137). Washington, DC: U.S. Department of Interior, Fish and Wildlife Service, National Ecology Center. 16 p. (RM)

HATCH, JEREMY J. 1986. The white tern may be unable to hover in still air. Journal of Field Ornithology. 56:427428. (PSW)

KANIA, G. S.; and H. R. SMITH. 1986. Observations of agonistic interactions between a pair of feral mute swans and nesting waterfowl. The Connecticut Warbler. Fairfield, CT: Connecticut Ornithological Association. 6(3):35-37. (NE)

KROODSMA, DONALD E.; and JARED VERNER. 1987. Use of song repertoires among marsh wren populations. The Auk. 104:63-72. (PSW)

LARSEN, REYNOLD T.; and C. JOHN RALPH. 1984. The arrival, departure, and residency of a small population of the lesser golden-plover in Hawaii. 'Elepaio. 45:12-13. (PSW)

OLSON, RICHARD A.; and WILLIAM T. BARKER. 1979. Strip-mine impoundments for the birds. Rangelands. 1:248-249. (RM)
PATON, PETER W. C.; DAVID P. FELLOWS; and P. QUENTIN TOMICH. 1986. Distribution of cattle egret roosts in Hawaii with notes on the problems egrets to airports. Elepaio. 46:143-147. (PSW)

PATON, PETER W. C.; J. MICHAEL SCOTT; and TIMOTHY A. BURR. 1986.

American coot and black-necked stilt on the island of Hawaii. Western Birds. 16:175-181. (PSW)

REAM, C. H. 1976. Loon productivity, human disturbance, and pesticide residues in northern Minnesota. Wilson Bulletin. 88:427-432. (NC)

REINECKE, KENNETH J.; TIMOTHY L. STONE; and RAY B. OWEN, JR. 1982. Seasonal carcass composition and energy balance of female black ducks in Maine. The Condor. 84:420-426. (NE)

RUMBLE, MARK A. 1989. Surface mine impoundments as wildlife and fish habitat. Gen. Tech. Rep. RM-182. Fort Collins, CO: U.S. Department of Agriculture, Forest Service, Rocky Mountain Forest and Range Experiment Station. 6 p. (RM)

SIMPSON, C. DAVID; ERIC G. BOLEN; RICHARD L. MOORE; and FRED A. STORMER. 1981. Significance of playas to migratory wildlife. In: Proceedings, playa lakes symposium; 1979 December 4-5; Arlington, TX. FSW/OBS-81/07. Washington, DC: U.S. Department of the Interior, Fish and Wildlife Service: 35-45. (RM)

SORG, CINDY F.; and LOUIS J. NELSON. 1987. Net economic value of waterfowl hunting in Idaho. Res. Bull. RM-14. Fort Collins, CO: U.S. Department of Agriculture, Forest Service, Rocky Mountain Forest and Range Experiment Station. 21 p. (RM) 
STORMER, FRED A.; ERIC G. BOLEN; and C. DAVID SIMPSON. 1981.

Management of playas for migratory birds--information needs. In:

Proceedings, Playa lakes symposium; 1979 December 4-5; Arlington, TX.

FWS/OBS-81/07. Washington, DC: U.S Department of the Interior, Fish and Wildlife Service: 52-61. (RM)

SWIFT, BRYAN L.; JOSEPH S. LARSON; and RICHARD M. DEGRAAF. 1984. Relationship of breeding bird density and diversity to habitat variables in forested wetlands. Wilson Bulletin. 96(1):48-59. (NE)

SZARO, ROBERT C. 1981. Bird population responses to converting chaparral to grassland and riparian habitats. Southwestern Naturalist. 26:251-256. (RM)

SZARO, ROBERT C.; GARY HENSLER; and GARY H. HEINZ. 1981. Effects of chronic ingestion of no. 2 fuel oil on mallard ducklings. Journal Toxicology and Environmental Health. 7:789-799. (RM)

SZARO, ROBERT C.; NANCY COON; and WILLIAM STOUT. 1980. Weathered petroleum: Effects on mallard egg hatchability. Journal of Wildlife Management. 44:709-713. (RM)

TILGHMAN, NANCY G. 1980. The black tern survey, 1979. Passenger Pigeon. 42:18. (NC)

TITUS, JAMES R.; and LARRY W. VAN DRUFF. 1981. Response of the common loon to recreational pressure in the Boundary Waters Canoe Area, northeastern Minnesota. Wildlife Monographs No. 79. Washington, DC: The Wildife Society. 60 p. (NC)

URESK, DANIEL W.; and KIETH E. SEVERSON. 1988. Waterfowl and shorebird use of surface-mined and livestock water impoundments on the northern Great Plains. Great Basin Naturalist. 48:353-357. (RM)
ZEILLEMAKER, C. F.; and C. JOHN RALPH. 1977. First breeding record of laysan albatross on Kauai. 'Elepaio. 38(5):5153. (PSW)

\section{General Avian Biology And Ecology}

ANDERSEN, DOUGLAS C.; and JAMES A. MACMAHON. 1986. An assessment of ground-nest depradation in a catastrophically disturbed region, Mount St. Helens, Washington. The Auk. 103:622-626.

BELANGER, ROGER P.; ROY L. HEDDEN; and MICHAEL R. LENNARTZ. 1988. The potential impact of the southern pine beetle on red-cockaded woodpecker colonies in the Georgia Piedmont. Southern Journal of Applied Forestry. 12:194-199. (NE)

BLAKE, J. G.; and J. R. KARR. 1985. Species composition of bird communities and the conservation benefit of large versus small forests. Biological Conservation. 30:173-187. (NC)

BLAKE, JOHN G. 1983. Trophic structure of bird communities in forest patches in east-central Illinois. Wilson Bulletin. 95:416-430. (NC)

BLAKE, JOHN G. 1986. Species-area relationship of migrants in isolated woodlots in east-central Illinois. Wilson Bulletin. 98:291-296. (NC)

BOCK, CARL E. 1987. Distributionabundance relationships of some Arizona landbirds: a matter of scale. Ecology. 68:124-129. (RM)

BOWMAN, G. BRUCE; and L. D. HARRIS. 1980. Effect of spatial heterogeneity on ground-nest depredation. Journal of Wildlife Management. 44:806-813. (SE)

BUECH, R. R. 1976. Avian nesting success under gamma radiation exposure. The Auk. 93:627-629. (NC) 
BUECH, R. R. 1977. Observations of nesting avifauna under gamma-radiation exposure. In: Zavitkovsky, J., ed. Enterprise Radiation Forest. TID-26113P2. Springfield, VA: USDC. National Technical Information Service: 181-184. (NC)

CAPEN, D. E.; R. J. COOPER; and R. M. DEFRAAF. 1979. Population trends of northeastern birds. Transactions, 36th Northeastern Fish and Wildlife Conference: 69-75. (NE)

CAREY, ANDREW B. 1984. A critical look at the issue of species-habitat dependency. In: New forests for a changing world: Proceedings of the 1983 Society for American Foresters national convention; 1983 October 1620; Portland, OR. Bethesda, MD: Society of American Foresters: 346-351. (PNW)

CRAWFORD, H. S. 1984. Silvicultural practices and bird predation on spruce budworm. Forest Techniques. 84(9):12. (NE)

CRAWFORD, H. S.; and D. T. JENNINGS. 1982. Relationships of birds and spruce budworm--literature review and annotated bibliography. BLA No. 24. Washington, DC: U.S. Department of Agriculture. 38 p. (NE)

CRAWFORD, H. S.; D. M. HARDY; and W. A. ABLER. 1978. A survey of bird use of strip-mined areas in southern West Virginia. In: Proceedings, surface mining and fish/wildlife needs in the Eastern United States; 1978 December 3-6; Morgantown, WV. FWS/OBS-78/81; Washington, DC: U.S. Department of the Interior, Fish and Wildlife Service: 241-246. (NE)

CRAWFORD, H. S.; R. W. TITTERINGTON; and D. T. JENNINGS. 1983. Bird predation and spruce budworm populations. Journal of Forestry. $81(7): 433-435,478$. (NE)
CRAWFORD, HEWLETTE S.; and DANIEL T. JENNINGS. 1985. Effects of bird predation on spruce budworm: A pilot study. In: Recent advances in spruce budworms research: Proceedings of the CANUSA spruce budworms research symposium; 1984 September 16-20; Bangor, ME. Ottawa, ON: Canadian Forestry Service and U.S. Department of Agriculture, Forest Service: 98-99. (NE)

CRAWFORD, HEWLETTE S.; and ROBERT M. FRANK. 1987. Wildlife responses to silvicultural practices in spruce-fir forests. Transactions of the North American Wildlife and Natural Resources Conference. 52:98-107. (NE)

DEGRAAF, R. M. 1987. Breeding birds and gypsy moth defoliation: short-term responses of species and guilds. The Wildlife Society Bulletin. 15:217-221. (NE)

DEGRAAF, R. M.; and D. G. HOLLAND. 1978. Response of breeding birds to gypsy moth defoliation. Transactions 35th Northeastern Wildlife Congress. 105-119. (NE).

DEGRAAF, R. M.; and N. L. CHADWICK. 1984. Habitat classification: A comparison using avian species and guilds. Environmental Management. 8:511-518. (NE)

DEGRAAF, RICHARD M. 1987. Breeding birds and gypsy moth defoliation: shortterm responses of species and guilds. The Wildlife Society Bulletin. 15:217221. (NE)

DEGRAAF, RICHARD M. 1987. Breeding birds and Gypsy moth defoliation: shortterm responses of species and guilds. The Wildlife Society Bulletin. 15:217221. (NE)

DEGRAAF, RICHARD M.; NANCY G. TILGHMAN; and STANLEY H. ANDERSON. 1985. Foraging guilds of North American birds. Environmental Management. 9:493-536. (NE) 
DICKSON, JAMES G.; and JOHN W.

GOERTZ. 1981. Nesting effort and territorial male birds in a breeding bird community. Proceedings of the Annual Conference of the Southeastern Association of Fish and Wildlife Agencies. 35:97-100. (SO)

FINCH, DEBORAH M.; and RICHARD T. REYNOLDS. 1988. Bird response to understory variation and conifer succession in aspen forests. In: Issues and technology in the management of impacted wildlife: proceedings of national symposium; 1987 November 24; Colorado Springs, CO. Boulder, CO: Thorne Ecological Institute: 87-96. (RM) 198

FRANZBLAU, MARK A.; and JAMES P. COLLINS. 1980. Test of a hypothesis of territory regulation in an insectivorous bird by experimentally increasing prey abundance. Oecologia. (Berl). 46:164170.

GOLDSTEIN, EDWARD L.; MEIR GROSS; and RICHARD M. DeGRAAF. 1981. Explorations in bird-land geometry. Urban Ecology. 5:113-124. (NE)

GOLDSTEIN; E. L.; M. GROSS; and R. M. DEGRAAF. 1986. Breeding birds and vegetation: A quantative assessment. Urban Ecology. 9:377-385. (NE)

HEJL, SALLIE J.; and EDWARD C. BEEDY. 1986. Weather-induced variation in the abundance of birds. In: Verner, Jared; Michael L. Morrison; and C. John Ralph, eds. Wildlife 2000: modeling habitat relationships of terrestrial vertebrates; 1984 October 7-11; Fallen Leaf Lake, CA. Madison, WI: The University of Wisconsin Press: 241-244. (PSW)

HOLMES, R. T. 1986. Foraging patterns of forest birds: male-female differences. Wilson Bulletin. 98:196-213. (NE)
HOLMES, R. T.; and H. F. RECHER. 1986. Determinants of guild structure in forest bird communities: an intercontinental comparison. The Condor. 88:427-439. (NE)

HOLMES, R. T.; T. W. SHERRY; and F. W. STURGES. 1986. Bird community dynamics in a temperate deciduous forest: long-term trends at Hubbard Brook. Ecological Monographs. 56:201220. (NE)

HORN, JOHN C. 1984. Short-term changes in bird communities after clearcutting in western North Carolina. Wilson Bulletin. 96:684-689. (SE)

LANDRES, PETER B.; JARED VERNER; and JACK WARD THOMAS. 1988. Ecological uses of vertebrate indicator species: a critique. Conservation Biology. 2(4):1-13. (PNW)

LANGELIER, LISA A.; and EDWARD O. GARTON. 1986. Management guidelines for increasing populations of birds that feed on western spruce budworm. Agric. Handb. 653. Washington, DC: U.S. Department of Agriculture. 19 p. (PNW)

LARSON, DIANE L; and CARL E BOCK. 1986. Determining avian habitat preference by bird-centered vegetation sampling. In: Verner, Jared; Michael L. Morrison; and C. John Ralph, eds. Wildlife 2000: Modeling habitat relationships of terrestrial vertebrates; 1984 October 7-11; Fallen Leaf Lake, CA. Madison, WI: The University of Wisconsin Press: 37-43. (RM)

MORRISON, MICHAEL L.; KIMBERLY A. WITH; IRENE C. TIMOSSI; WILLIAM M. BLOCK; and KATHLEEN A. MILNE. 1987. Foraging behavior of barkforaging birds in the Sierra Nevada. The Condor. 89:201-204. (PSW) 
NICHOLLS, THOMAS H.; LEANNE M.

EGELAND; and FRANK G.

HAWKSWORTH. 1989. Birds of the

Fraser Experimental Forest, Colorado, and their role in dispersing lodgepole pine dwarf mistletoe. The Colorado Field Ornithologists' Quarterly. 23(1):3-12. (NC)

PATTON, DAVID R. 1987. Is the use of "management indicator species" feasible? Western Journal of Applied Forestry. 2(1):33-34. (RM)

RALPH, C. JOHN; and HOWARD F. SAKAI. 1979. Forest bird and fruit bat populations and their conservation in Micronesia: notes on a survey. 'Elepaio. 40:20-26. (PSW)

RAPHAEL, MARTIN G.; and KENNITH V. ROSENBERG; and BRUCE G. MARCOT. 1989. Large-scale changes in bird populations of Douglas-fir forests, northwestern California. In: Jackson, Jerome A., ed. Bird conservation. Madison, WI: The University of Wisconsin Press: 63-83. (RM)

RAPHAEL, MARTIN G.; MICHAEL L. MORRISON; and MICHAEL P. YODERWILLIAMS. 1987. Breeding bird populations during twenty-five years of postfire succession in the Sierra Nevada. The Condor. 89:614-626. (RM)

ROSENBERG, KENNETH V.; and MARTIN G. RAPHAEL 1986. Effects of forest fragmentation on vertebrates in Douglas-fir forests. In: Verrier, Jared; Michael L. Morrison; and C. John Ralph, eds. Wildlife 2000: Modeling habitat relationships of terrestrial vertebrates; 1984 October 7-11; Fallen Leaf Lake, CA. Madison, WI: The University of Wisconsin Press: 263-272. (RM)

SANTANA C., EDUARDO; and BROOK G. MILLIGAN. 1984. Behavior of toucanets, bellbirds, and quetzals feeding on lauraceous fruits. Biotropica. 16(2):152154. (SO)
SZARO, ROBERT C. 1986. Guild management: an evaluation of avian guilds as a predictive tool. Environmental Management. 10:681688. (RM)

VERCH, RICHARD L. 1986. Nongame breeding bird activity in an intensively cultured Populus plantation. Res. Note NC-336. St. Paul, MN: U.S. Department of Agriculture, Forest Service, North Central Forest Experiment Station. 6 p. (NC)

VERNER, J. 1977. On the adaptive significance of territoriality. American Naturalist. 111:769-775. (PSW)

VERNER, JARED; EDWARD C. BEEDY; STEPHEN L. GRANHOLM; [and others]. 1980. Birds. In: Verner, Jared; and Allen S. Boss, tech. coords. California wildlife and their habitats: Western Sierra Nevada. Gen. Tech. Rep. PSW-37. Berkeley, CA: U.S. Department of Agriculture, Forest Service, Pacific Southwest Forest and Range Experiment Station: 75-319. (PSW)

WILEY, J. W. 1985. Bird conservation in the United States. In: Temple, S. A., ed. Bird conservation 2. Madison, Wl: The University of Wisconsin Press: 107-159. (SO)

WINTER, W. R. 1981. Role of feeding stations in managing nongame bird habitat in urban and suburban areas. Transactions of the North American Wildlife and Natural Resources Conference. 46:414-423.

ZINKL, JOSEPH G.; PAUL D. MACK; MICHAEL E. MOUNT; and PATRICK J. SHEA. 1984. Brain cholinesterase activity and brain and liver residues in wild birds of a forest sprayed with acephate. Environmental Toxicology and Chemical. 3:79-88. (PSW) 
Eastern Forests And Urban Habitats

BRIGGS, JAMES I., JR.; HAROLD E. GARRETT; and KEITH E. EVANS. 1982. Oak-pine conversion and bird populations in the Missouri Ozarks. Journal Forestry. 80:651-653, 659; (NC)

BUECH, RICHARD R. 1980. Christmas tree plantation--for the birds? American Christmas Tree Journal. 24(1):22-24. (NC)

CAREY, ANDREW B.; and JOHN D. GILL. 1983. Direct habitat improvements-some recent advances. In: Davis, Jerry W.; Gregory A. Goodwin; and Richard A. Ockenfels, tech. coords. Snag habitat management: Proceedings of the symposium; 1983 June 7-9; Flagstaff, AZ. Gen. Tech. Rep. RM-99. Fort Collins, CO: U.S. Department of Agriculture, Forest Service, Rocky Mountain Forest and Range Experiment Station: 80-87. (NE)

CONNER, RICHARD N.; and BRIAN A. LOCKE. 1983. Artificial innoculation of red heart fungus into loblolly pines. In: Wood, Don A., ed. Proceedings, 2nd red-cockaded woodpecker symposium; 1983 January 27-29; Panama City, FL. Tallahassee, FL: Florida Game and Fresh Water Fish Commission: 81-82. (SO)

CONNER, RICHARD N.; JERRY W. VIA; and IRVINE D. PRATHER. 1979. Effects of pine-oak clearcutting on winter and breeding birds in southwestern Virginia. Wilson Bulletin. 91:301-316. (SO)

CRAWFORD, H. S.; and R. W.

TITTERINGTON. 1979. Silviculture and upland spruce-fir bird communities. In:

DeGraff, Richard M., tech. coord. Management of North Central and Northeastern forests for nongame birds: Workshop proceedings; 1979 January 23-25; Minneapolis, MN. Gen. Tech. Rep. NC-51. St. Paul, MN: U.S. Department of Agriculture, Forest Service, North Central Forest Experiment Station: 110-119. (NE)
CRAWFORD, HEWLETTE S. 1985. Effects of silviculture practices on bird predation. In: Spruce-fir management and spruce budworm; SAF Technical Conference; 1984 April. Gen. Tech. Rep. NE-99. Broomall, PA: U.S. Department of Agriculture, Forest Service, Northeastern Forest Experiment Station: 173-175. (NE):

CRUZ, ALEXANDER. 1980. Avian assemblages in Puerto Rico. Caribbean Journal Science. 15(3-4):21-25. (SO)

DAWSON, DEANNA K.; and JOHN R. PROBST. 1978. Aspen clearcut. American Birds. 32:79. (NC)

DAWSON, DEANNA K.; and JOHN R. PROBST. 1978. Aspen-birch forestry. American Birds. 32:65. (NC)

DAWSON, DEANNA K.; and JOHN R. PROBST. 1978. Mature aspen-northern hardwoods forestry. American Birds. 32:65-66. (NC)

DEGRAAF, R. M. 1978. Avian communities and habitat associations in cities and suburbs. In: Wildlife and people. Lafayette, IN: Purdue University, Department Forestry and Natural Resources: 7-24. (NE).

DEGRAAF, R. M. 1986. Urban bird habitat relationships: application to landscape design. Transactions of the North American Wildlife and Natural Resources Conference. 51:232-248. (NE)

DEGRAAF, R. M. 1987. Managing northern hardwoods for breeding birds. In: Nyland, R. D., ed. Managing northern hardwoods: Proceedings of a silvicultural symposium; 1986 June 2325; Syracuse, NY. SAF Pub. 87-03. Washington, DC: Society of American Foresters: 348-362. (NE)

DEGRAAF, R. M. 1978. New life from dead trees. National Wildlife. 16:28-31. (NE) 
DEGRAAF, R. M., tech. coord. 1978.

Proceedings of a workshop--

Management of southern forest for

nongame birds. Gen. Tech. Rep. SE-14.

Asherville, NC: U.S. Department of

Agriculture, Forest Service,

Southeastern Forest Experiment

Station. 175 p. (NE)

DEGRAAF, R. M.; and C. W. STIHLER. 1979. Nesting habitats of five common suburban bird species. Transactions of the 36th Northeastern Fish and Wildlife Conference: 52-59. (NE)

DEGRAAF, R. M.; and D. A. RICHARD. 1987. Forest wildlife of Massachusetts. Coop.

Ext. Ser. Bull. C-182. Amherst, MA: University of Massachusetts. 53 p. (NE)

DEGRAAF, R. M.; and G. M. WITMAN. 1979. Trees, shrubs and vines for attracting birds: a manual for the Northeast. Amherst, MA: University of Massachusetts Press. 194 p. illus. (NE)

DEGRAAF, R. M.; and J. M. WENTWORTH. 1981. Urban bird communities and habitats in New England. Transactions of the North American Wildlife and Natural Resources Conference. 46:396413. (NE)

DEGRAAF, R. M.; H. R. PYWELL; and JACK WARD THOMAS. 1985. Relationships between nest height, vegetation, and harvesting density in New England suburbs. Transactions, 32nd Northeast Section, The Wildlife Society: 130-150. (NE)

DEGRAAF, RICHARD M. 1985. Breeding bird assemblages in New England northern hardwoods. In: The impact of timber management practices on nongame birds in Vermont; 1982 August 7; Johnson, VT. Montpelier, VT: Vermont Fish and Wildlife Department: 5-22. (NE)
DEGRAAF, RICHARD M. 1986. Urban bird habitat relationships: application to landscape design. Transactions of the North American Wildlife and Natural Resources Conference. 51:232-248. (NE)

DEGRAAF, RICHARD M. 1987. Managing northern hardwoods for breeding birds. In: Managing northern hardwoods: Proceedings of a silvicultural symposium; 1986 June 23-25; Syracuse, NY. Washington, DC: Society of American Foresters: 348-362. (NE)

DEGRAAF, RICHARD M. 1987. Urban wildlife habitat research-application to landscape design. In: National symposium on urban wildlife; 1986 November 4-7; Chevy Chase, MD. Columbia, MD: National Institute for Urban Wildlife: 108-111. (NE)

DEGRAAF, RICHARD M.; and JAMES M. WENTWORTH. 1986. Avian guild structure and habitat associations in suburban bird communities. Urban Ecology. 9:399-412. (NE)

DEGRAAF, RICHARD M.; and Keith E. Evans. tech. coords. 1979. Workshop proceedings--Management of North Central and Northeastern forests for nongame birds. Gen. Tech. Rep NC-51. St. Paul, MN: U.S. Department of Agriculture, Forest Service, North Central Forest Experiment Station. 268 p. (NE)

DEGRAAF, RICHARD M.; and NAN L. CHADWICK. 1987. Forest type, timber size class, and New England breeding birds. Journal of Wildlife Management. 51:212-217. (NE)

DEGRAAF, RICHARD M.; GRETCHIN M. WITMAN; JOHN W. LANIES;

BARBARA J. HILL; and JAMES M. KINESTON. 1981. Forest habitat for birds of the Northeast. Washington, DC: U.S. Department of Agriculture, Forest Service, Northeast Forest Experiment Station and Eastern Region. 598 p. (NE) 
DICKSON, J. G. 1988. Bird communities in oak-gum-cypress forests. In: Jackson, J. A., ed. Bird conservation 3. Madison, WI: University Press for International Council for Bird Preservation, United States Section: 51-62. (SO)

DICKSON, JAMES G. 1978. Forest bird communities of the bottomland hardwoods. Gen. Tech. Rep. SE-14. Asville, NC: U.S. Department of Agriculture, Forest Service, Southeastern Forest Experiment Station: 66-73. (SO)

DICKSON, JAMES G. 1978. Seasonal bird populations in a south central Louisiana bottomland hardwood forest. Journal of Wildlife Management. 42:875-883. (SO)

DICKSON, JAMES G. 1979. Seasonal populations of insectivorous birds in a mature bottomland hardwood forest in south Louisiana. In: Proceedings, symposium a role of insectivorous birds in forest ecosystems: 26I-268. (SO)

DICKSON, JAMES G. 1989. Streamside zones and wildlife in southern U.S. forests. In: Gresswell, R. E.; B. A. Barton; and J. L. Kershner, eds. Riparian resource management: Proceedings of a workshop; Billings, MT. U.S. Department of Interior, Bureau of Land Management: 131-133. (SO)

DICKSON, JAMES G.; and CHARLES A. SEGELQUIST. 1979. Breeding bird populations in pine and pine-hardwood forests in Texas. Journal of Wildlife Management. 42:875-883. (SO)

DICKSON, JAMES G.; and CHARLES A. SEGELQUIST. 1979. Winter bird populations in pine and pine-hardwood forest stands in east Texas.

Proceedings of the Annual Conference of the Southeastern Association Fish And Wildlife Agencies. 31:I34-I37. (SO)
DICKSON, JAMES G.; RICHARD N. CONNER; and JAMES H. WILLIAMSON. 1980. Relative abundance of breeding birds in forest stands in the southeast. Southern Journal Applied Forestry. 4:174-179. (SO)

DICKSON, JAMES G.; RICHARD N. CONNER; and J. HOWARD WILLIAMSON. 1984. Bird community changes in a young pine plantation in east Texas. Southern Journal Applied Forestry. 8:47-51. (SO)

DICKSON, JAMES G.; WAYNE R. MARION; WILLIAM C. MCCOMB; and JOHN J. MORIARTY. 1982. A partial bibliography on management of non-game birds in the southeast, 1960-1980. Gen. Tech. Rep. SO-47. New Orleans, LA: U.S. Department of Agriculture, Forest Service, Southern Forest Experiment Station: 11 p. (SO)

EVANS, KEITH E. 1978. Oak-pine and oakhistory forest bird communities and management options. Gen. Tech. Rep. SE-14. Asheville, NC: U.S. Department of Agriculture, Forest Service, Southeastern Forest Experiment Station: 76-89. (NC)

EVANS, KEITH E.; and D. K. DAWSON. 1976. The breeding bird survey in Missouri--1967-1975. Bluebird 43(3):1222. (NC)

EVANS, KEITH E.; and ROGER A. KIRKMAN. 1981. Guide to bird habitats of the Ozark plateau. Gen. Tech. Rep. NC-68. St. Paul, MN: U.S. Department of Agriculture, Forest Service, North Central Forest Experiment Station. 79 p. (NC)

GILL, JOHN D. 1980. Tree farming - for the birds? West Virginia Tree Farm News. 1980(4):7. (NE) 
GOLDSTEIN, EDWARD L.; MEIR GROSS; and RICHARD M. DEGRAAF. 1986.

Breeding birds and vegetation: $A$ quantitative assessment. Urban Ecology. 9:377-385. (NE)

HAMEL, PAUL B.; HARRY E. LEGRAND, JR.; MICHAEL R. LENNARTZ; and SIDNEY A. GAUTHREAUX, JR. 1982. Bird-habitat relationships on Southeastern forest lands. Gen. Tech. Rep. SE-22. Asheville, NC: U.S. Department of Agriculture, Forest Service, Southeastern Forest Experiment Station. 417 p. (SE)

HARLOW, R. F.; and D. H. VANLEAR. 1987. Silvicultural effects on wildlife habitat in the South: An annotated bibliography 1980-1985. Tech. Pap. 17. Clemson, SC: Clemson University, Department of Forestry, College of Forestry and Recreation Research. 42 p. (SE)

HEALY, WILLIAM M. 1987. Habitat characteristics of uneven-aged stands. In: Managing northern hardwoods: Proceedings of a silvicultural symposium; 1986 June 23-25; Syracuse, NY. Washington, DC: Society of American Foresters: 338-347. (NE)

HIRTH, D. H.; and W. R. MARION. 1979. Bird communities of a south Florida flatwoods. Florida Scientist. 42(3):|42-I5|. (SE)

HOOPER, R. G. 1978. Cove forests: Bird communities and management options. Gen. Tech. Rep. SE-14. Asheville, NC: U.S. Department of Agriculture, Forest Service, Southeastern Forest Experiment Station: 90-97. (SE)

HORN, JOHN C. 1984. Short-term changes in bird communities after clearcutting in western North Carolina. Wilson Bulletin. 96:684-689. (SE)
MAURER, BRIAN A.; LAURENCE B. MCARTHUR; and ROBERT C.

WHITMORE. 1982. Effects of logging on guild structure of a forest bird community in West Virginia. Ecology. 35:11-13. (NE)

MILLER DONALD; LEE GRADISCHER; JOSEPH ORZEL; WILLIAM B. LEAK; and ELLEN MILLER. 1987. Changes in vegetation and breeding bird use in an Atlantic white cedar swamp from 1951 to 1984. In: Laderman, Aimlee D., ed. Atlantic white cedar wetlands symposium; 1987 October 9-11; Woods Hole, MA: Marine Biological Laboratory: 229-230.(NE)

PEARSON, CONNIE J.; and JOHN R. PROBST. 1979. Aspen clear-cut (2year). American Birds. 33:77. (NC)

PEARSON, CONNIE J.; and JOHN R. PROBST. 1979. Aspen forest (50-year). American Birds. 33:64. (NC)

PEARSON, CONNIE J.; and JOHN R. PROBST. 1979. Aspen forest (20-year). American Birds. 33:64. (NC).

PROBASCO, GEORGE E. 1978. Bird habitatwoody plant relations on Missouri limestone glades. In: 5th midwest prairie conference proceedings; Ames, IA: lowa State University: 107-109. (NC)

PROBST, JOHN R. 1979. Oak forest bird communities. In: DeGraaf, Richard M., tech. coord. Management of North Central and Northeastern forests for nongame birds: Workshop proceedings; 1979 January 23-25: Minneapolis, MN. Gen. Tech. Rep. NC-51. St. Paul, MN: U.S. Department of Agriculture, Forest Service, North Central Forest Experiment Station: 80-89. (NC)

RAKSTAD, DON; and JOHN R. PROBST. 1981. Aspen clearcut (1st year). American Birds. 35:59. (NC)

RAKSTAD, DON; and JOHN R. PROBST. 1981. Aspen clearcut (4th year). American Birds. 35:59. (NC) 
RAKSTAD, DON; and JOHN R. PROBST. 1981. Jack pine forest. American Birds. 35:70. (NC)

RAKSTAD, DON; and JOHN R. PROBST. 1981. Mixed conifer-hardwood forest. American Birds. 35:66. (NC)

RAKSTAD, DON; and JOHN R. PROBST. 1982. 36. Mature aspen-northern hardwoods forest. American Birds. 36:62. (NC)

RAKSTAD, DON; and JOHN R. PROBST. 1982. 37. Mature birch-aspen. American Birds. 36:62. (NC)

RAKSTAD, DON; and JOHN R. PROBST. 1982. 39. Aspen clearcut. American Birds. 36:62-63. (NC)

RAKSTAD, DON; and JOHN R. PROBST. 1982. 40. Aspen clearcut. American Birds. 36:63. (NC)

RAKSTAD, DON; and JOHN R. PROBST. 1982. 41. Aspen clearcut. American Birds. 36:63 (NC)

RAKSTAD, DON; and JOHN R. PROBST. 1982. 42. Aspen clearcut. American Birds. 36:63. (NC)

RAKSTAD, DON; and JOHN R. PROBST. 1982. 69. Mature aspen-fir. American Birds. 36:70. (NC)

RAKSTAD, DON; and JOHN R. PROBST. 1983. Aspen clearcut. American Birds. 37:65-66. (NC)

RAKSTAD, DON; and JOHN R. PROBST. 1983. Jack pine forest. American Birds. 37:72. (NC)

RAKSTAD, DON; and JOHN R. PROBST. 1983 Red pine plantation. American Birds. 37:72. (NC)

RAKSTAD, DONALD; and JOHN R. PROBST. 1979. Aspen clear-cut (8year). American Birds. 33:77. (NC)
RAKSTAD, DONALD; and JOHN R. PROBST. 1979. Aspen-birch forests. American Birds. 33:63-64. (NC)

RAKSTAD, DONALD; and JOHN R. PROBST. 1979. Mature aspen forests. American Birds. 33:63. (NC)

RAKSTAD, DONALD; and JOHN R. PROBST. 1980. Aspen clearcut $(6$ years). American Birds. 34:67. (NC)

RAKSTAD, DONALD; and JOHN R. PROBST. 1980. Aspen forest (19 years). American Birds. 34:51. (NC)

RAKSTAD, DONALD; and JOHN R. PROBST. 1980. Mature aspen--northern hardwoods. American Birds. 34:52. (NC)

RAKSTAD, DONALD; and JOHN R. PROBST. 1980. Red pine plantation. American Birds. 34:67. (NC)

RAKSTAD, DONALD; and JOHN R. PROBST. 1980. Young aspen forest. American Birds. 34:52. (NC)

RALPH, C. J. 1977. The summer season: Hawaiian Islands region. American Birds. 31:1049-1050. (PSW)

RALPH, C. J.; and R. L. PYLE. 1977. The summer season: Hawaiian Islands region. American Birds. 31:1049-1050. (PSW)

RALPH, C. J.; and R. L. PYLE. 1977. The fall season: Hawaiian Islands region. American Birds. 31:1192-1193. (PSW)

RALPH, C. J.; and R. L. PYLE. 1978. The spring season: Hawaiian Islands region. American Birds. 32:402-403. (PSW)

REPENNING, ROBERT W.; and RONALD F. LABISKY. 1985. Effects of even-age timber management on bird communities of the longleaf pine forest in northern Florida. Journal of Wildlife Management. 49:1088-1098. (SE) 
ROWSE, L. A.; and W. R. MARION. 1981.

Effects of silvicultural practices on birds in a north Florida flatwoods. In:

Proceedings, 1st biennial southern silvicultural research conference; 1980 November 6-7; Atlanta, GA. Gen. Tech. Rep. SO-34. New Orleans, LA: U.S. Department of Agriculture, Forest Service, Southern Forest Experiment Station: 349-357. (SO)

SCHULTZ, J. L. 1978. Bird consumption of scarlet elder fruit in Michigan's Upper Peninsula. Jack-Pine Warbler. 56(1):3-7. (NC)

STRELKE, WILLIAM K.; and JAMES G. DICKSON. 1980. Effect of forest clearcut edge on breeding birds in east Texas. Journal of Wildlife Management. 44:559-567. (SO)

SWIFT, B. L.; J. S. LARSON; and R. M. DEGRAAF. 1984. Relationship of breeding bird density and diversity to habitat variables in forested wetlands. Wilson Bulletin. 96:48-59. (NE)

THOMAS, JACK WARD; and RICHARD M. DEGRAAF. 1976. Wildlife habitats in the city. In: Proceedings of the symposium-wildlife in urban Canada; 1975 May; Guelph, Ontario, Canada; University of Guelph, Office Continuning Education University: 48-68. (PNW)

THOMAS, JACK WARD; RICHARD M. DEGRAAF; and JOSEPH C. MAWSON. 1977. Determination of habitat requirements for birds in suburban areas. Res. Pap. NE-357. Upper Darby, PA: U.S. Department of Agriculture, Forest Service, Northeastern Forest Experiment Station. 15 p. (PNW)

TILGHMAN, NANCY G. 1985. Managing urban woodlands for a variety of birds. NE-INF-63-85. Broomall, PA: U.S. Department of Agriculture, Forest Service, Northeastern Forest Experiment Station. 8 p. (NE)
VERCH, RICHARD L. 1983. Some implications of Populus intensive culture on nongame birds. In: Hansen, Edward A., comp. Intensive plantation culture: 12 years research. Gen. Tech. Rep. NC91. St. Paul, MN: U.S. Department of Agriculture, Forest Service, North Central Forest Experiment Station: 110114. (NC)

WILLIAMSON, R. D.; and R. M. DeGRAAF. 1981. Habitat associations of ten bird species in Washington, DC. Urban Ecology. 5:125-136. (NE)

YAMASAKI, MARIKO; and CARL H. TUBBS. 1986. Wildlife tree management in New England northern hardwood forests. In: Joint conference of the New England Society of American Forester, Maine Chapter of the Wildlife Society, and the Atlantic International Chapter of the American Fisheries; 1986 April 1; Misc. Pub. Portland, ME: Maine Agricultural Experiment Station: 109-134. (NE)

YOAKUM, J.; W. P. DASMANN; H. R. SANDERSON; C. M. NIXON; and H. S. CRAWFORD. 1980. Habitat improvement techniques. In: Schemnitz, S. D., ed. Wildlife management techniques manual. 4th Edition. Washington, DC: The Wildlife Society: 329-403. (NE)

\section{Western Forest And Rangeland Habitats}

ANDERSEN, DOUGLAS C.; and JAMES A. MACMAHON. 1986. An assessment of ground-nest depradation in a catastrophically disturbed region, Mount St. Helens, Washington. The Auk. 103:622-626.

ARNO, STEPHEN F. 1986. Whitebark pine cone crops--a diminishing source of wildlife food? Western Journal of Applied Forestry. 1:92-94. 
BOHN, CAROLYN; CHRISTIE GALEN; CHRIS MASER; and JACK WARD THOMAS. 1980. Homesteads-manmade avian habitats in the rangelands of southeastern Oregon. The Wildlife Society Bulletin. 8:332-341. (PNW)

BULL, EVELYN L., and JON M. SKOVLIN. 1982. Relationships between avifauna and streamside vegetation. Transactions of the North American Wildlife and Natural Resources Conference. 47:496506. (PNW)

CALL, MAYO W.; and CHRIS MASER. 1985. Wildlife habitats in managed rangelands--the Great Basin of southeastern Oregon: Sage grouse. Gen. Tech. Rep. PNW-187. Portland, OR: U.S. Department of Agriculture, Forest Service, Pacific Northwest Forest and Range Experiment Station. 29 p. (PNW)

CAREY, ANDREW B.; and JOHN D. GILL. 1983. Direct habitat improvements-some recent advances. In: Davis, Jerry W.; Gregory A. Goodwin; and Richard A. Ockenfels, tech. coords. Snag habitat management: Proceedings of the symposium; 1983 June 7-9; Flagstaff, AZ. Gen. Tech. Rep. RM-99. Fort Collins, CO: U.S. Department of Agriculture, Forest Service, Rocky Mountain Forest and Range Experiment Station: 80-87. (NE)

DEBYLE, NORBERT V. 1981. Songbird populations and clearcut harvesting of aspen in northern Utah. Res. Note INT302. Ogden, UT: U.S. Department of Agriculture, Forest Service, Intermountain Forest and Range

Experiment Station. 7 p. (INT)
DEGRAAF, R. M. 1978. The role of birds in ecosystems. In: Proceedings, nongame bird habitat management in the coniferous forests of the western United States; 1977 February 7-9; Gen. Tech. Rep. PNW-64. Portland, OR: U.S. Department of Agriculture, Forest Service, Pacific Northwest Forest and Range Experiment Station. 100 p. (NE)

DEGRAAF, RICHARD M., tech. coord. 1978. Nongame bird habitat management in the coniferous forests of the western. Proceedings; 1977 February 7-9; U. S. Gen. Tech. Rep. PNW-64. Portland, OR: U.S. Department of Agriculture, Forest Service, Pacific Northwest Forest and Range Experiment Station. 100 p. (NE)

DEGRAAF, RICHARD M., tech. coord. 1980. Management of western forests and grasslands for non-game birds. Workshop proceedings; 1980 February 11-14; Salt Lake City, UT. Gen. Tech. Rep. INT-86. Ogden, UT: U.S. Department of Agriculture, Forest Service, Intermountain Forest and Range Experiment Station. 535 p. (NE)

FINCH, DEBORAH M. 1982. Interspecific nest use by aridland birds. Wilson Bulletin. 94:582-584. (RM)

FINCH, DEBORAH M. 1986. Similarities in riparian bird communities among elevational zones in southeastern Wyoming. In: Brosz, Donald J.; and J. Daniel Rodgers, coords. Proceedings: Wyoming water and streamside zone conference; 1986 April 28-30; Casper, WY. Laramie, WY: University of Wyoming: Wyoming Water Research Center: 105-110. (RM) 
FINCH, DEBORAH M. 1987. Bird-habitat relationships in subalpine riparian shrublands of the central Rocky Mountains. In: Troendle, Charles A.; Merrill R. Kaufmann; R. H. Hamre; and Robert P. Winokur, tech. coords. Management of subalpine forests: building on 50 years of research: Proceedings of a technical conference; 1987 July 6-9; Silver Creek, CO. Gen. Tech. Rep. RM-149. Fort Collins, CO: U.S. Department of Agriculture, Forest Service, Rocky Mountain Forest and Range Experiment Station: 167-172. (RM)

FINCH, DEBORAH M. 1989. Habitat use and habitat overlap of riparian birds in three elevational zones. Ecology. 70:866-880. (RM)

FRANZREB, KATHLEEN E. 1977. Bird population changes after timber harvesting of a mixed conifer forest in Arizona. Res. Pap. RM-184. Fort Collins, CO: U.S. Department of Agriculture, Forest Service, Rocky Mountain Forest and Range Experiment Station. 26 p. (RM)

FRANZREB, KATHLEEN E. 1983. A comparison of avian foraging behavior in unlogged and logged mixed-coniferous forest. Wilson Bulletin. 95:60-76. (RM)

HALL, FREDERICK C. 1980. Western forest types and avian management practices. In: DeGraff, Richard M., tech. ed. Proceedings, management of western forests and grasslands for nongame birds. Gen. Tech. Rep. INT-86. Salt Lake City, UT: U.S. Department of Agriculture, Forest Service, Intermountain Forest and Range Experiment Station: 27-37. (PNW)

HODORFF, ROBERT A.; and CAROLYN HULL SIEG. 1986. Bird species associated with green ash woodlands in the Slim Buttes, South Dakota. South Dakota Bird Notes. 38:56-60. (RM)
HOPKINS, R. B.; and M. D. SCHWARTZ. 1982. Avian community studies in North Dakota. American Birds. 35:91-94. (RM)

HOPKINS, RICK B.; J. FRANK CASSEL; and ARDELL J. BJUGSTAD. 1986.

Relationships between breeding birds and vegetation in four woodland types of the Little Missouri National Grasslands.

Res. Pap. RM-270. Fort Collins, CO: U.S. Department of Agriculture, Forest Service, Rocky Mountain Forest and Range Experiment Station. 12 p. (RM)

LANGELIER, LISA A.; and EDWARD 0. GARTON. 1986. Management guidelines for increasing populations of birds that feed on western spruce budworm. Agric. Handb. 653. Washington, DC: U.S. Department of Agriculture. 19 p. (PNW)

LOVIO, JOHN C.; KATHLEEN A. MILNE; ROBERT S. SUYDAM; and CHRISTOPHER R. CUTLER. 1986. Mature upper mixed-coniferous forestmontane chaparral. American Birds. 40:71. (PSW)

MANUWAL, DAVID A.; and MARK H. HUFF. 1987. Spring and winter bird populations in a Douglas-fir forest sere. Journal of Wildlife Management. 51:586-595. (PNW)

MEDIN, DEAN E. 1984. Breeding birds of an ancient bristlecone pine stand in east central Nevada. Great Basin Naturalist. 44:272-276. (INT)

MEDIN, DEAN E. 1985. Breeding bird responses to diameter-cut logging in west-central Idaho. Res. Pap. INT-355. Ogden, UT: U.S. Department of Agriculture, Forest Service, Intermountain Forest and Range Experiment Station. 12 p. (INT)

MEDIN, DEAN E. 1988. Breeding birds of an alpine habitat in the southern Snake Region, Nevada. Western Birds. 18:163168, (INT) 
MEDIN, DEAN E.; and GORDON D. BOOTH. 1989. Responses of birds and small mammals to single-tree selection logging in Idaho. Res. Pap. INT-408. Ogden, UT: U.S. Department of Agriculture, Forest Service, Intermountain Research Station. 11 p. (INT)

MORRISON, MICHAEL L.; and E. CHARLES MESLOW. 1983. Avifauna associated with early growth vegetation on clearcuts in the Oregon Coast Ranges. Res. Pap. PNW-305. Portland, OR: U.S. Department of Agriculture, Forest Service, Pacific Northwest Forest and Range Experiment Station. 12 p. (PNW)

NICHOLLS, THOMAS H.; LEANNE M. EGELAND; and FRANK G. HAWKSWORTH. 1989. Birds of the Fraser Experimental Forest, Colorado, and their role in dispersing lodgepole pine dwarf mistletoe. The Colorado Field Ornithologists' Quarterly. 23(1):3-12. (NC)

PETERSON, STEVEN R. 1980. The role of birds in western communities. In: DeGraaf, Richard M., tech. coord. Management of western forests and grasslands for nongame birds: Workshop proceedings; 1980 February 11-14; Salt Lake City, UT: Gen. Tech. Rep. INT-86. Ogden, UT: U.S. Department of Agriculture, Forest Service, Intermountain Forest and Range Experiment Station: 6-12. (INT)

PETERSON, STEVEN R. 1983. A preliminary survey of forest bird communities in northern Idaho. Northwest Science. 56(4):287-298. (INT)

PYLE, R. L.; and C. J. RALPH. 1978. The winter season: Hawaiian Islands region. American Birds. 32:265-267. (PSW)

PYLE, ROBERT L.; and C. JOHN RALPH. 1978. Hawaiian Islands region. American Birds. 32:1057-1058. (PSW)
PYLE, ROBERT L.; and C. JOHN RALPH. 1979. Hawaiian Islands region. American Birds. 33:317-318. (PSW)

PYLE, ROBERT L.; and C. JOHN RALPH. 1979. Hawaiian Islands region. American Birds. 33:218-220. (PSW)

PYLE, ROBERT L.; and C. JOHN RALPH. 1979. The summer season: Hawaiian Islands region. American Birds. 33:898899. (PSW)

PYLE, ROBERT L.; and C. JOHN RALPH. 1980. Hawaiian Islands region. American Birds. 34:204-205. (PSW)

PYLE, ROBERT L.; and C. JOHN RALPH. 1980. The winter season: Hawaiian Islands region. American Birds. 34:309310. (PSW)

PYLE, ROBERT L.; and C. JOHN RALPH. 1981. The spring migration: Hawaiian Islarids region. American Birds. 35:865866. (PSW)

PYLE, ROBERT L.; and C. JOHN RALPH. 1982. The autumn migration: Hawaiian Islands region. American Birds. 36:221 223. (PSW)

RALPH, C. JOHN. 1982. Birds of the forest. Natural History. 91(12):40-45. (PSW)

RALPH, C. JOHN. 1985. Habitat association patterns of forest and steppe birds of northern Patagonia, Argentina. The Condor. 87:471-483. (PSW)

RALPH, C. JOHN; and CHARLES VAN RIPER, III. 1985. Historical and current factors affecting Hawaiian native birds. In: Temple, Stanley A., ed. Bird conservation 2. Madison, WI: The University of Wisconsin Press: 43-70. (PSW)

RALPH, C. JOHN; and HOWARD F. SAKAI. 1979. Forest bird and fruit bat populations and their conservation in Micronesia: notes on a survey. 'Elepaio. 40:20-26. (PSW) 
RALPH, C. JOHN; and ROBERT L. PYLE. 1978. Hawailian Islands region. American Birds. 32:1211. (PSW)

RALPH, C. JOHN; and ROBERT L. PYLE. 1979. The spring migration: Hawaiian Islands region. American Birds. 33:807808. (PSW)

RALPH, C. JOHN; and ROBERT L. PYLE. 1979. First record of the buff-breasted sandpiper in Hawaii. 'Elepaio. 39(II):140. (PSW)

RALPH, C. JOHN; and ROBERT L. PYLE. 1981. The nesting season: Hawaiian Islands region. American Birds. 35:980981. (PSW)

RALPH, C. JOHN; and ROBERT L. PYLE. 1981. The winter season: Hawaiian Islands region. American Birds. 35:337338. (PSW)

RALPH, C. JOHN; and RON LEVALLEY. 1986. The Changing Season. American Birds. 40:437-441. (PSW)

RAMSDEN, DAVID J.; L. JACK LYON; and GARY L. HALVERSON. 1979. Small bird populations and feeding habitats-Western Montana in July. American Birds. 33:II-16. (INT)

RAPHAEL, MARTIN G.; MICHAEL L. MORRISON; and MICHAEL P. YODERWILLIAMS. 1987. Breeding bird populations during twenty-five years of postfire succession in the Sierra Nevada. The Condor. 89:614-626. (RM)

RUMBLE, MARK A. 1987. Avian use of scoria rock outcrops. Great Basin Naturalist. 47:625-630. (RM)
SANDERSON, H. REED.; EVELYN L. BULL; and PAUL J. EDGERTON. 1980. Bird communities in mixed conifer forests of the Interior Northwest. In: DeGraaf, Richard M., tech. coord. Management of western forests and grasslands for nongame birds: Workshop proceedings; 1980 February 11-14; Salt Lake City, UT: Gen. Tech. Rep. INT-86. Ogden, UT: U.S. Department of Agriculture, Forest Service, Intermountain Forest and Range Experiment Station: 224237. (PNW)

SCOTT, VIRGIL E.; and GERALD J. GOTTFRIED. 1983. Bird response to timber harvest in a mixed conifer forest in Arizona. Res. Pap. RM-245. Fort Collins, CO: U.S. Department of Agriculture, Forest Service, Rocky Mountain Forest and Range Experiment Station. 8 p. (RM)

SCOTT, VIRGIL E.; and GLEN L. CROUCH. 1988. Breeding birds and small mammals in pole-sized lodgepole pine and small inclusions of aspen in central Colorado. Res. Note. RM-482. Fort Collins, CO; U.S. Department of Agriculture, Forest Service, Rocky Mountain Forest and Range Experiment Station. 4 p. (RM)

SCOTT, VIRGIL E.; and GLEN L. CROUCH. 1988. Breeding birds in uncut aspen and 6- to 10-year-old clearcuts in southwestern Colorado. Res. Note. RM485. Fort Collins, CO; U.S. Department of Agriculture, Forest Service, Rocky Mountain Forest and Range Experiment Station. 5 p. (RM)

SCOTT, VIRGIL E.; and GLEN L. CROUCH. 1988. Summer bird and mammals of aspen-conifer forests in west-central Colorado. Res. Pap. RM-280. Fort Collins, CO; U.S. Department of Agriculture, Forest Service, Rocky Mountain Forest and Range Experiment Station. 5 p. (RM) 
SZARO, ROBERT C. 1980. Factors influencing bird populations in southwestern riparian forests. In: DeGraaf, Richard M., tech. coord. Management of western forests and grasslands for nongame birds: Workshop proceedings; 1980 February 11-14; Salt Lake City, UT. Gen. Tech. Rep. INT-86. Ogden, UT: U.S. Department of Agriculture, Forest Service, Intermountain Forest and Range Experiment Station: 403-418. (RM)

SZARO, ROBERT C. 1981. Bird population responses to converting chaparral to grassland and riparian habitats. Southwestern Naturalist. 26:251-256. (RM)

SZARO, ROBERT C.; and MARTIN D. JAKLE. 1985. Avian use of a desert riparian island and its adjacent scrub habitat. The Condor. 87:511-519. (RM)

SZARO, ROBERT C.; and RUSSELL P. BALDA. 1979. Bird community dynamics in a ponderosa pine forest. Studies in Avian Biology No. 3. Cooper Ornithological Society. 66 p. (RM)

SZARO, ROBERT C.; and RUSSELL P. BALDA. 1979. Effects of harvesting ponderosa pine on nongame bird populations. Res. Pap. RM-212. Fort Collins, CO: U.S. Department of Agriculture, Forest Service, Rocky Mountain Forest and Range Experiment Station. 8 p. (RM)

SZARO, ROBERT C.; and RUSSELL P. BALDA. 1986. Relationships among weather, habitat structure, and ponderosa pine forest birds. Journal of Wildlife Management. 50:253-260. (RM)
VERNER, JARED. 1980. Bird communities of mixed-conifer forests in the Sierra Nevada. In: Degraff, R. M., tech. coord. Workshop proceedings, management of western forests and grasslands for nongame birds; 1980 February 11-14; Salt Lake City, UT. Gen. Tech. Rep. INT-86. Ogden, UT: U.S. Department of Agriculture, Forest Service, Intermountain Forest and Range Experiment Station: 198-223. (PSW)

VERNER, JARED. 1981. Birds of California oak-habitats--management implications. In: Plumb, T. R., tech. coord.

Proceedings of the symposium on the ecology, management and utilization of California oaks; 1979 June 26-28;

Claremont, CA. Gen. Tech. Rep. PSW44. Berkeley, CA: U.S. Department of Agriculture, Forest Service, Pacific Southwest Forest and Range Experiment Station: 246-264. (PSW)

VERNER, JARED; EDWARD C. BEEDY; STEPHEN L. GRANHOLM; [and others]. 1980. Birds. In: Verner, Jared; and Allen S. Boss, tech. coords. California wildlife and their habitats: Western Sierra Nevada. Gen. Tech. Rep. PSW-37. Berkeley, CA: U.S. Department of Agriculture, Forest Service, Pacific Southwest Forest and Range Experiment Station: 75-319. (PSW)

YOAKUM, J.; W. P. DASMANN; H. R. SANDERSON; C. M. NIXON; and H. S. CRAWFORD. 1980. Habitat improvement techniques. In: Schemnitz, S. D., ed. Wildlife management techniques manual. 4th Edition. Washington, DC: The Wildlife Society: 329-403. (NE) 


\section{Large Mammals}

\section{Ungulate Food Habits}

ALEXANDER, LYNN E.; DANIEL W. URESK; and RICHARD M. HANSEN. 1983.

Summer food habits of domestic sheep

in southeastern Montana. Journal of Range Management. 36:307-308. (RM)

BAKER, R. L.; and JEFF POWELL. 1982. Effect of atrazine, fertilizer, and 2,4-D on winter grazing preferences of beef cows on northcentral Oklahoma tallgrass prairie. Journal of Range Management. 35:505-507. (SO)

BAKER, R. L.; D. E. JOHNSON; L. H. CARPENTER; O. C. WALLMO; and R. B. GILL. 1979. Energy requirements of mule deer fawns in winter. Journal of Wildlife Management. 43:162-169. (RM)

BEASOM, SAMUEL L.; LARRY LAPLANT; and V.W. HOWARD. 1981. Similarity of pronghorn, cattle, and sheep diets in southeastern New Mexico. In: Peek, James A., and P. D. Dalke, eds. Proceedings, wildlife-livestock relationships symposium; 1981 April 2022; Coeur d'Alene, ID. Moscow, ID: University of Idaho; Forest, Wildlife and Range Experiment Station: 565-572. (RM)

BEASOM, SAMUEL L.; LARRY LAPLANT; and V. W. HOWARD, JR. 1982. Fecal $\mathrm{pH}$ of pronghorn and sheep as related to diet. Journal of Wildlife Management. 46:1101-1104; 1982. (RM)

BLAIR, ROBERT M.; and HANS G. ENGHARDT. 1976. Deer forage and overstory dynamics in a loblolly pine plantation. Journal of Range Management. 29:104-108. (SO)

BLAIR, ROBERT M.; and LOUIS E. BRUNETT. 1980. Seasonal browse selection by deer in a southern pinehardwood habitat. Journal of Wildlife Management. 44:79-88. (SO)
CAMPBELL, DAN L.; JAMES EVANS; GERALD D. LINDSEY; and WILLIAM E. DUSENBERRY. 1981. Acceptance by black-tailed deer of foliage treated with herbicides. Res. Pap. PNW-290. Portland, OR: U.S. Department of Agriculture, Forest Service, Pacific Northwest Forest and Range Experiment Station. 31 p. (PNW)

CANON, S. K.; P. J. URNESS; and N. V. DEBYLE. 1987. Habitat selection, foraging behavior, and dietary nutrition of elk in burned aspen forest. Journal of Range Management. 40:433-438. (INT)

CARPENTER, L. H.; O. C. WALLMO; and R. B. GILL. 1979. Forage diversity and dietary selection by wintering mule deer. Journal of Range Management. 32:226229. (RM)

CLARY, WARREN P.; PETER F.

FFOLLIOTT; and FREDERIC R. LARSON. 1978. Factors affecting forage consumption by cattle in Arizona ponderosa pine forests. Journal of Range Management. 31:9-10. (RM)

CLUFF, L. K.; B. L. WELCH; J. C. PEDERSON; and J. D. BROTHERSON. 1982. Concentration of monterpenoids in the rumen ingesta of wild mule deer. Journal of Range Management. 35:192194. (INT)

CRAWFORD, H. S. 1976. Integrating deer habitat evaluation into forest land use planning. Proceedings, 10th northeast deer study group, Yarmouth; 1974 September; Nova Scotia, Canada: 6-14. (NE)

CRAWFORD, HEWLETTE S. 1982. Seasonal food selection and digestibility by tame white-tailed deer in central Maine. Journal of Wildlife Management. 46:974982. (NE) 
CROUCH, GLENN L. 1979. Food habits of black-tailed deer on forested habitats in the Pacific Northwest. In: Proceeding, sitka black-tailed deer conference: Juneau, AK: U.S. Department of Agriculture, Forest Service, Alaska Region, in cooperation with State of Alaska, Department of Fish and Game. Series No. R10-48. 231 p. (RM)

CROUCH, GLENN L. 1981. Coniferous forest habitats, Part I. Food habits and nutrition. In: Wallmo, Olof C., ed. Mule and black-tailed deer of North America. A Wildlife Management Institute book developed in cooperation with U.S. Department of Agriculture, Forest Service. Lincoln, NE: University of Nebraska Press: 423-433. Chapter 11. Part 1. (RM)

CURRIE, P. O.; D. W. REICHERT; J. C MALECHEK; and O. C. WALLMO. 1977. Forage selection comparisons for mule deer and cattle under managed ponderosa pine. Journal of Range Management. 30:352-356. (RM)

DEALY, J. EDWARD; PAUL J. EDGERTON; and WAYNE G. WILLIAMS. 1986. Use of curlleaf mountain-mahogany by mule deer on a transition range. Res. Note PNW-439. Portland, OR: U.S. Department of Agriculture, Forest Service, Pacific Northwest Forest and Range Experiment Station. 5 p. (PNW)

DUNCAN, D. A.; and W. J. CLAWSON. 1980. Livestock utilization of California's oak woodlands. In: Plumb, T. R., tech. coord. Proceedings of the symposium on the ecology, management and utilization of California oaks; 1979 June 22-26; Claremont, CA. Gen. Tech. Rep. PSW-44. Berkeley, CA: U.S. Department of Agriculture, Forest Service, Pacific Southwest Forest and Range Experiment Station: 306-313. (PSW)
GALT, H. D.; BRENT THEURER; and S. CLARK MARTIN. 1982. Botanical composition of steer diets on mesquite and mesquite free desert grassland. Journal of Range Management. 35:320325. (RM)

HALLS, LOWELL K. 1984. What do deer eat and why? In: White, Larry D., ed. Proceedings, international ranchers roundup; 1984 July 30-August 3; San Angelo, TX. College Station, TX: Texas A\&M University, Texas Agricultural Extension Service: 266-280. (SO)

HANLEY, THOMAS A. 1982. Cervid activity patterns in relation to foraging constraints: western Washington. Northwest Science. 56:208-217. (PNW)

HANLEY, THOMAS A.; and KATHLEEN A. HANLEY. 1982. Food resource partitioning by sympatric ungulates on Great Basin rangeland. Journal of Range Management. 35:152-158. (INT)

HANLEY, THOMAS A.; CHARLES T. ROBBINS; and DONALD E. SPALINGER. 1989. Forest habitats and the nutritional ecology of Sitka blacktailed deer: a research synthesis with implications for forest management. Gen. Tech. Rep. PNW-230. Portland, OR: U.S. Department of Agriculture, forest Service, Pacific Northwest Research Station. 52 p. (PNW)

HARLOW, R. F.; D. F. URBSTON; and J. G. WILLIAMS, JR. 1979. Forages eaten by deer in two habitats at the Savannah river plant. Res. Note. SE-275.

Asheville, N.C.: U.S. Department of Agriculture, Forest Service, Forest Service, Southeastern Forest Experiment Station. 3 p. (SE)

HOBBS, N. T.; and R. A. SPOWART. 1984. Effects of prescribed fire on nutrition of mountain sheep and mule deer during winter and spring. Journal of Wildlife Management. 48:551-560. (RM) 
HOBBS, N. T.; D. L. BAKER; J. E. ELLIS; and D. M. SWIFT. 1979. Composition and quality of elk diets during winter and summer. A preliminary analysis. In: Boyce, Mark S.; and Larry D. HaydenWing, eds. North American elk: ecology, behavior and management. Laramie, WY: University of Wyoming: 47-53. (RM)

HOBBS, N. THOMPSON; and DON L.

BAKER. 1979. Rearing and training elk calves for use in food habits studies. Journal of Wildlife Management. 43:568570. (RM)

HOLECHEK, J. L.; and M. VAVRA. 1983. Fistula sample numbers required to determine cattle diets on forest and grassland ranges. Journal of Range Management. 36:323-326. (PNW)

HOLECHEK, JERRY L.; and M. VAVRA. 1982. Forage intake by cattle on forest and grassland ranges. Journal of Range Management. 35:737-741. (PNW)

HOLECHEK, JERRY L.; MARTIN VAVRA; JON SKOVLIN; and WILLIAM C. KRUEGER. 1982. Cattle diets in the Blue Mountains of Oregon, I. Grasslands. Journal of Range Management. 35:109-112. (PNW)

JOHNSON, MARK K.; and HENRY A. PEARSON. 1981. Esophageal, fecal, and exclosure estimates of cattle diets on a longleaf pine-bluestream range. Journal of Range Management. 34:232234. (SO)

JOHNSON, MARK K.; HELEN WOFFORD; and HENRY A. PEARSON. 1983. Digestion and fragmentation: Influence on herbivore diet analysis. Journal of Wildlife Management. 47:877-879. (SO)

JOHNSON, MARK K.; HELEN WOFFORD; and WILMA MITCHELL. 1982.

Contamination during nylon-bag digestion trials. Journal of Wildlife Management. 46:253-255.
KIE, JOHN G.; and TIMOTHY S. BURTON. 1984. Dietary quality, fecal nitrogen and 2,6 diaminopimelic acid in black-tailed deer in northern California. Res. Note. PSW-364. Berkeley, CA: U.S. Department of Agriculture, Forest Service, Pacific Southwest Forest and Range Experiment Station. 3 p. (PSW)

KIE, JOHN G.; TIMOTHY S. BURTON; JOHN W. MENKE; and WILLIAM E.

GRENFELL, JR. 1984. Food habits of black-tailed deer, Odocoileus hemionus columbianus, in Trinity County, California. California Fish and Game. 70:183-186. (PSW)

KORFHAGE, ROBERT C.; JACK R.

NELSON; and JON M. SKOVLIN. 1980. Summer diets of Rocky Mountain elk in northeastern Oregon. Journal of Wildlife Management. 44:746-750. (PNW)

LAUTENSCHLAGER, R. A.; and H. S. CRAWFORD. 1984. Training whitetailed deer, Odocoileus virginianus, for food habit studies. Canadian FieldNaturalist. 98:503-505. (NE)

LEEGE, T. A.; J. R. NELSON; and J. W. THOMAS. 1977. Food habits and diet quality of North American elk. In: CRC handbook series in nutrition and food. Section G: Diets, culture media, food supplements. Volume I: Diets for mammals. Cleveland, $\mathrm{OH}$ : CRC Press: 221-241. (PNW)

LESLIE, DAVID M., JR.; EDWARD E. STARKEY; and BRADLEY G. SMITH. 1987 . Forage acquisition by sympatric cervids along an old-growth sere. Journal of Mammalogy. 68:430-434. (PNW)

LI, C. Y.; CHRIS MASER; and FAY HARLAN. 1986. Initial survey of acetylene reduction and selected microorganisms in the feces of 19 species of mammals. Great Basin Naturalist. 46:646-650. (PNW) 
MANZANARES, DANIEL; JERRY

HOLECHEK; JAMES P. NEEL; [and others]. 1987. Cattle diet botanical composition on riparian and upland ranges. In: Livestock research briefs and cattle growers' short course; 1987 April 2; Las Cruces, NM: New Mexico State University. 57 p. (RM)

MEDCRAFT, J. RICHARD; and WILLIAM R. CLARK. 1986. Big game habitat use and diets on a surface mine in northeastern Wyoming. Journal of Wildlife Management. 50:135-142. (RM)

PEARSON, HENRY A. 1976. Botanical composition of cattle diets on southern pine-bluestem browse range. Res. Note. SO-216. New Orleans, LA: U.S. Department of Agriculture, Forest Service, Southern Forest Experiment Station. 4 p. (SO)

PEARSON, HENRY A.; HAROLD. E. GRELEN; E. A. EPPS; MARK K. JOHNSON; and B. W. BLAKEWOOD. 1982. Botanical composition and nutritive value of cattle diets on southern pine range. Res. Pap. SO-178. New Orleans, LA: U.S. Department of Agriculture, Forest Service, Southern Forest Experiment Station. 24 p. (SO)

QUINN, RONALD D. 1986. Mammalian herbivory and resilency in Mediterranean-climate ecosystems. In: Dell, B; A. J. M. Hopkins; and B. B. Lamont, comps., eds. Resilience in Mediterranean-type ecosystems.

Dordrecht: Dr. W. Junk Publishers: 113128. (PSW)

REGELIN, WAYNE L.; RICHARD M. BARTMAN; DONALD W. REICHERT; and PAUL H. NEIL. 1976. The influence of supplemental feed on food habits of tamed deer. Res. Note. RM-316. Fort Collins, CO: U.S. Department of Agriculture, Forest Service, Rocky Mountain Forest and Range Experiment Station. 4 p. (RM)
SCHWARTZ, CHARLES C.; WAYNE L.

REGELIN; and JULIUS G. NAGY. 1980.

Deer preference for juniper forage and volatile oil treated foods. Journal of Wildlife Management. 44:114-120. (RM)

SEVERSON, KIETH E. 1981. Food habits and nutritional relationships of mule deer in southwestern United States. In:

Ffolliot, Peter F.; and Sonia Gallina, eds. Deer biology, habitat requirements, and management in western North American Publ. 9. Mexico City: Institute of Ecology: 151-164. (RM)

SHORT, HENRY L. 1977. Food habits of mule deer in a semidesert grass-shrub habitat. Journal of Range Management. 30:206-209. (RM)

SHORT, HENRY L. 1981. Nutrition and metabolism. In: Wallmo, Olof C., ed. Mule and black-tailed deer in North America. A Wildlife Management Institute Book developed in cooperation with U.S. Department of Agriculture, Forest Service. Lincoln, NE: University of Nebraska Press: 99-127. Chapter 3. (RM)

SIMPSON, C. DAVID; LESLIE J. KRYSL; and TONY G. DICKINSON. 1980. Food habits of Barbary sheep in the Guadalupe Mountains, New Mexico. In: Simpson, C. David, ed. Proceedings of the symposium on ecology and management of Barbary sheep; 1979 November 19-21; Lubbock, TX: Texas Tech University: 87-91. (RM)

SKOVLIN, JON; and MARTIN VAVRA. 1979. Winter diets of elk and deer in the Blue Mountains, Oregon. Res. Pap. PNW260. Portland, OR: U.S. Department of Agriculture, Forest Service, Pacific Northwest Forest and Range Experiment Station. 21 p. (PNW)

SPALINGER, D. E.; T. A. HANLEY; and C. T. ROBBINS. 1988. Analysis of the functional response in foraging in the Sitka black-tailed deer. Ecology. 69:1166-1175. (PNW) 
SPALINGER, DONALD E.; CHARLES T. ROBBINS; and THOMAS A. HANLEY. 1986. The assessment of handling time in ruminants: the effect of plant chemical and physical structure o the rate of breakdown of plant particles in the rumen of mule deer and elk. Canadian Journal of Zoology. 64:312-321. (PNW)

THILL, RONALD E. 1983. Deer and cattle forage selection on Louisiana pinehardwood sites. Res. Pap. SO-196. New Orleans, LA: U.S. Department of Agriculture, Forest Service, Southern Forest Experiment Station. 35 p. (SO)

THILL, RONALD E. 1984. Deer and cattle diets on Louisiana pine-hardwood sites. Journal of Wildlife Management. 48:788798. (SO)

THILL, RONALD E.; ALTON MARTIN, JR.; HERSHEL F. MORRIS, JR.; and DIBUCE E. MCCUNE. 1987. Grazing and burning impacts on deer diets on Louisiana pine-bluestem range. Journal of Wildlife Management. 51: 873-880. (SO)

THILL, RONALD E.; and ALTON MARTIN. 1979. Deer and cattle diet overlap in Louisiana pine-hardwood forests. Proceedings of the Annual Conference of the Southeastern Association Fish and Wildlife Agencies. 33:64-71. (SO)

THILL, RONALD E.; and ALTON MARTIN, JR. 1986. Deer and cattle diet overlap on Louisiana pine-bluestem range. Journal of Wildlife Management. 50-707713. (SO)

THILL, RONALD E.; and ALTON MARTIN, JR. 1989. Deer and cattle diets on heavily grazed pine-bluestem range. Journal of Wildlife Management. 53:540548. (SO)

URESK, D. W. 1978. Ingestion of radioiodine by range cattle. In: Vaughn, B. E., ed. Ecological Sciences. Pacific Northwest Report. Washington, DC: Department of Energy. 234 p. (RM)
URESK, DANIEL W. 1986. Food habits of cattle on mixed-grass prairie on the Northern Great Plains. Prairie Naturalist. 18:211-218. (RM)

WALLMO, OLOF C.; and WAYNE L. REGELIN. 1981. Food habits and nutrition. In: Wallmo, Olof C., ed. Mule and black-tailed deer in North America. A Wildlife Management Institute Book developed in cooperation with U.S. Department of Agriculture, Forest Service. Lincoln, NE: University of Nebraska Press: 387-398. Chapter 10. Part 1. (PNW)

WELCH, BRUCE L.; and E. DURANT MCARTHUR. 1986. Wintering mule deer preference for 21 accessions of big sagebrush. Great Basin Naturalist. 46:281-286. (INT)

WELCH, BRUCE L.; E. DURANT

MCARTHUR; and JAMES N. DAVIS.

1981. Differential preference of wintering mule deer for accessions of big sagebrush and for black sagebrush. Journal of Range Management. 34:409411. (INT)

WELCH, BRUCE L.; E. DURANT MCARTHUR; and JAMES N. DAVIS. 1983. Mule deer preference and monoterpenoids (essential oils). Journal of Range Management. 36:485-487. (INT)

WELCH, BRUCE L.; E. DURANT MCARTHUR; and RONALD L. RODRIGUEZ. 1987. Variations in utilization of big sagebrush accessions by wintering sheep. Journal of Range Management. 40:113-115. (INT)

WIGGERS, ERNIE P.; DIANA D. WILCOX; and FRED C. BRYANT. 1984. Cultivated cereal grains as supplemental forages for mule deer in the Texas Panhandle. The Wildlife Society Bulletin. 12(3):240-245. (RM) 


\section{Ungulates And Their Habitats}

BLACK, HUGH; RICHARD J. SCHERZINER; and JACK WARD THOMAS. 1976.

Relationships of Rocky Mountain elk and Rocky Mountain mule deer habitat to timber management in the Blue Mountains of Oregon and Washington. In: Elk-logging-roads symposium proceedings; 1975 December Moscow, ID. University Idaho. Forest Wildlife and Range Experiment Station: 11-31. (PNW)

CARL, GARY R.; and CHARLES T. ROBBINS. 1988. The energetic cost of predator avoidance in neonatal ungulates: hiding versus following. Canadian Journal of Zoology. 66:239246. (PNW)

COLLINS, WILLIAM B.; and PHILIP J. URNESS. 1983. Feeding behavior and habitat selection of mule deer and elk on northern Utah summer range. Journal of Wildlife Management. 47:646-663. (INT)

CROUCH, GLENN L. 1987. Big game habitat research in subalpine forests in the central Rocky Mountains. In: Troendle, Charles A.; Merrill R. Kaufmann; R. H. Hamre; and Robert P. Winokur, tech. coords. Managment of subalpine forests: building on 50 years of research: Proceedings of a technical conference; 1987 July 6-9; Silver Creek, CO. Gen. Tech. Rep. RM-149. Fort Collins, CO: U.S. Department of Agriculture, Forest Service, Rocky Mountain Forest and Range Experiment Station: 106-112. (RM)

DAVIS, PETER R. 1977. Mule deer and elk responses to forest fire and clearcutting in southwest Wyoming. Journal of Wildlife Management. 41:785-788. (RM)

HANLEY, THOMAS A. 1983. Black-tailed deer, elk, and forest edge in a western Cascades watershed. Journal of Wildlife Management. 47:237-242. (PNW)
JAIRELL, ROBERT L.; and R. A. SCHMIDT. 1988. Portable animal protection shelter and wind screen. In: Proceedings, 56th western snow conference; 1988 April 19-21; Kalispell, MT. Fort Collins, CO: Colorado State University: 170-173. (RM)

KIE, JOHN G. 1987. Measures of wild ungulate performance: population density and condition of individuals. In: Symposium proceedings, monitoring animal performance and poduction; 1987 February 12; Boise, ID. Denver, $\mathrm{CO}$ : Society for Range Management: 23-26. (PSW)

KIE, JOHN G. 1988. Performance in wild ungulates: measuring population density and condition of individuals. Gen. Tech. Rep. PSW-106. Berkeley, CA: U.S. Department of Agriculture, Forest Service, Pacific Southwest Forest and Range Experiment Station. 17 p. (PSW)

LAUTENSCHLAGER, R. A.; and HEWLETTE S. CRAWFORD. 1985. You can lead a moose to a study plot, but you have to finesse a deer. American Forest. $91(3): 40-43$. (NE)

LYON, L. JACK; and CHESTER E. JENSEN. 1980. Management implication of elk and deer use of clearcuts in Montana. Journal of Wildlife Management. 44:352362. (INT)

LYON, L. JACK; and JOSEPH V. BASILE. 1980. Influences of timber harvesting and residue management on big game. In: Environmental consequences of timber harvesting in Rocky Mountain coniferous forests, Symposium proceedings. 1979 September 11-13; Missoula, MT: Gen. Tech. Rep. INT-90. Ogden, UT: U.S. Department of Agriculture, Forest Service, Intermountain Forest and Range Experiment Station: 441-454. (INT) 
MCARTHUR, E. DURANT; A. PERRY

PUMMER; and JAMES N. DAVIS. 1978.

Rehabilitation of game range in the Salt

Desert. In: Wyoming shrublands:

Proceedings, 7th Wyoming shrub ecology workshop; 1978 May 31-June 1; Laramie, WY: University of Wyoming,

Range Management Division: 23-50. (INT)

MIQUELLE, D. G.; and V. VAN

BALLENBERGHE. 1985. The moose bell: $A$ visual or olfactory communicator. Alces. 21:191-213. (NE)

MONTHEY, R. W. 1984. Effects of timber harvesting on ungulates in northern Maine. Journal of Wildlife Management. 48:279-285. (NE)

NEFF, DON J. 1980. Effects of watershed treatments on deer and elk range use. Final Rep. W-78-R. Arizona Game and Fish Department, Federal Aid in Wildlife Restoration Project. 37 p. (RM)

NELSON, KURT J. 1980. Sterilization of dominant males will not limit feral horse population. Res. Pap. RM-226. Fort Collins, CO: U.S. Department of Agriculture, Forest Service, Rocky Mountain Forest and Range Experiment Station. 7 p. (RM)

NIELSEN, DARWIN B.; FRED J. WAGSTAFF; and DENNY LYTLE. 1986. Big-game animals on private range. Rangelands. 8:36-38. (INT)

PARKER, KATHERINE L.; CHARLES T. ROBBINS; and THOMAS A. HANLEY. 1984. Energy expenditures for locomotion by mule deer and elk. Journal of Wildlife Management. 48(2):474-488. (PNW)

PATTON, DAVID R. 1976. Timber harvesting increases deer and elk use of a mixed conifer forest. Res. Note RM-329. Fort Collins, CO: U.S. Department of Agriculture, Forest Service, Rocky Mountain Forest and Range Experiment Station. 3 p. (RM)
ROST, GREGORY R.; and JAMES A. BAILEY. 1979. Distribution of mule deer, and elk in relation to roads. Journal of Wildlife Management. 43:634-641. (RM)

RUDD, WILLIAM J.; A. LORIN WARD; and LARRY L. IREIN. 1983. Do split hunting seasons influence migrations from Yellowstone National Park? The Wildlife Society Bulletin. 11:328-331. (RM)

SEVERSON, KIETH E.; and ALVIN L. MEDINA. 1983. Deer and elk habitat management in the Southwest. Journal of Range Management. Monograph 2. 63 p. (RM)

SHORT, HENRY L.; WAIN EVANS; and ERWIN L. BOEKER. 1977. The use of natural and modified pinyon pine-juniper woodlands by deer and elk. Journal of Wildlife Management. 4l:543-559. (RM)

STEVENS, RICHARD. 1987. Thirty years of pinyon-juniper big game habitat improvement projects: what have we learned? In: Everett, Richard L., comp. Pinyon-juniper conference; 1986 January 13-16; Reno, NV. Gen. Tech. Rep. INT-215. Ogden, UT: U.S. Department of Agriculture, Forest Service, Intermountain Research Station: 558-571. (INT)

THILL, RONALD E. 1985. Cattle and deer compatibility on southern forest range. In: Baker, Frank H.; and R. Katherine Jones, eds. Proceedings of a conference on multi-species grazing; 1985 June 25-28; Morrilton, AR: Winrock Institute for Agricultural Development: 159-177. (SO)

THOMAS, JACK WARD; HUGH BLACK, JR.; RICHARD J. SCHERZINGER; and RICHARD J. PEDERSEN. 1979. Deer and elk. In: Thomas, Jack Ward, tech. ed. Wildlife habitats in managed forests-the Blue Mountains of Oregon and Washington. Agric. Handb. 553. Washington, DC: U.S. Department of Agriculture, Forest Service: 104-127. Chapter 8. (PNW) 
WARD, A. L.; J. J. CUPAL; G. A. GOODWIN; and H. D. MORRIS. 1976. Effects of highway construction and use on big game populations. Fed. Highway Admin. Rep. No. FHWA-RD-76-174. Washington, DC: Office of Research and Development. 92 p. (RM)

WARD, A. LORIN. 1980. Multiple use of timbered areas; views of a wildlife manager specifically for elk and mule deer. In: Proceedings of Rocky Mountain forest industries conference; 1980 May 7-10; Jackson, WY: 1-24. (RM)

WARD, A. LORIN. 1983. Multiple use of timbered areas: Views of a wildlife manager specifically for deer and elk. In: Timber harvesting in the central Rockies: problems and opportunities; 1983 January 4-6; Publ. IXCM-87; Fort Collins, CO. Colorado State University, Cooperative Extension Service: 269291. (RM)

WARD, A. LORIN; NEVIN E. FORNWALT; STEPHEN E. HENRY; and ROBERT A. HODORFF. 1980. Effects of highway operation practices and facilities on elk, mule deer, and pronghorn antelope. Rep. FHWA RD-79-143. Washington, DC: Federal Highway Administration, Office of Research and Development. 48 p. (RM)

\section{Deer And Their Habitat}

\section{ARMLEDER, H. M.; D. A. LECKENBY; D. J.} FREDDY; and L. L. HICKS. 1989. Integrated management of timber and deer: interior forests of Western North America. Gen. Tech. Rep. PNW-227. Portland, OR: U.S. Department of Agriculture, Forest Service, Pacific Northwest Research Station. 23 p. (PNW)
ARNO, STEPHEN F.; GEORGE E. GRUELL; JOHN G. MUNDINGER; and WYMAN C. SCHMIDT. 1987. Developing silvicutural prescriptions to provide both deer winter habitat and timber. Western Wildlands. 12(4):19-24. (INT)

BLAIR, ROBERT M.; and LOUIS A. BRUNETT. 1977. Deer habitat potential of pine-hardwood forests in Louisiana. Res. Pap. SO-136. New Orleans, LA: U.S. Department of Agriculture, Forest Service, Southern Forest Experiment Station. 11 p. (SO)

BLOOM, ARTHUR M. 1978. Sitka black-tailed deer winter range in the Kadashan Bay area, southeast Alaska. Journal of Wildlife Management. 42:108-112. (PNW)

CARPENTER, LEN H.; and OLOF C. WALLMO. 1981. Habitat evaluation and management. In: Wallmo, Olof C., ed. Mule and black-tailed deer of North America. A Wildlife Management Institute book developed in cooperation with U.S. Department of Agriculture, Forest Service. Lincoln, NE: University of Nebraska Press; 399-421. Chapter 10. Part 2. (RM)

CONNOLLY, GUY E.; and OLOF C. WALLMO. 1981. Management challenges and opportunities. In: Wallmo, Olof C., ed. Mule and blacktailed deer of North America. A Wildlife Management Institute book developed in cooperation with U.S. Department of Agriculture, Forest Service. Lincoln, NE: University of Nebraska Press; 537-545. Chapter 15. (PNW)

CRAWFORD, HEWLETTE S. 1984. Habitat management. In: Halls, L. K., ed. Whitetailed deer: Ecology and management; Wildlife Management Institute, Washington, DC. Harrisburg, PA. Stackpole Books: 642-661. (NE) 
CROUCH, GLENN L. 1980. Postseason hunting to reduce deer damage to Douglas-fir in western Oregon. Res. Note PNW-. Portland, OR: U.S. Department of Agriculture, Forest Service, Pacific Northwest Forest and Range Experiment Station. 6 p. (RM)

CROUCH, GLENN L. 1981. Coniferous forest habitats, Part 3. Effects of deer on forest vegetation. In: Wallmo, Olof C., ed. Mule and black-tailed deer of North America. A Wildlife Management Institute book developed in cooperation with U.S. Department of Agriculture, Forest Service. Lincoln, NE: University of Nebraska Press: 449-457. Chapter 11. Part 3. (RM)

DEALY, J. EDWARD. 1976. Mule deer habitat research at the La Grande range and wildlife habitat research laboratory. In: Interstate wildlife study newsletter: Proceeding. interstate deer herd; Tech. Commun. Seminar. No. 4. Klamath Falls, OR: 37-39. (PNW)

\section{DELGIUDICE, GLENN D.; L. DAVID MECH;} and ULYSSES S. SEAL. 1988.

Chemical analysis of deer bladder urine and urine collected from snow. The Wildlife Society Bulletin. 16:324-326. (NC)

DELGIUDICE, GLENN D.; L. DAVID MECH; and ULYSSES S. SEAL. 1988.

Physiological assessment of deer populations by analysis of urine in snow. Journal of Wildlife Management. 53:284291. (NC)

DELGIUDICE, GLENN D.; L. DAVID MECH; ULYSSES S. SEAL; and PATRICK KARNS. 1987. Winter fasting and refeeding effects on urine characteristics in white-tailed deer. Journal of Wildlife Management. 51:860-864. (NC)

DELGIUDICE, GLENN D.; L. DAVID MECH; ULYSSES S. SEAL; and PATRICK O. KARNS. 1987. Effects of winter fasting and refeeding on white-tailed deer blood profiles. Journal of Wildlife Management. 51:865-873. (NC)
DELGIUDICE, GLENN D.; L. DAVID MECH; WILLIAM J. PAUL; and PATRICKD. KARNS. 1986. Effects on fawn survival and multiple immobilizations of captive pregnant white-tailed deer. Journal of Wildlife Diseases. 22:245-248. (NC)

DELGIUDICE, GLENN D.; ULYSSES S. SEAL; and L. DAVID MECH. 1988. Response of urinary hydroxyproline to dietary protein and fasting in white-tailed deer. Journal of Wildlife Diseases. 24:75-79. (NC)

DICKINSON, T. G.; G. W. GARNER; G. WAMPLER; and C. D. SIMPSON. 1980. Mortality of desert mule deer fawns. In: Proceedings of the 60th Annual Conference of the Western Association of Fish and Wildlife Agencies; 1980 July 13-17; Kalispell, MT: 581-592. (RM)

DORIO, JOHN C.; and D. A. MARQUIS. 1986. White-tailed deer management in the Allegheny National Forest. In: Integrated pest management symposium for northern forests; proceedings of a symposium; 1986 March 24-27; Madison, WI: The University of Wisconsin Press: 303-313. (NE)

DOWNING, ROBERT L. 1981. Deer harvest sex ratios: a symptom, a prescription, or what? The Wildlife Society Bulletin. 9:813. (SO)

FAGER, LEON; [and others]. 1981. Coordination guidelines for timber management in Black Hills deer habitat. Custer, SD: U.S. Department of Agriculture, Forest Service, Black Hills National Forest. 31 p. (RM)

FENWOOD, J. D.; D.F. URBSTON; and R. F. HARLOW. 1984. Determining deer habitat capability in Ouachita National Forest pine stands. Proceedings of the Annual Conference of the Southeastern Association of Fish and Wildlife Agencies. 38:13-22. (SE) 
FFOLLIOTT, PETER F.; and SONIA

GALLINA, eds. 1981. Deer biology,

habitat requirements, and management in western North American. Pub. 9. Mexico City, Mexico: Institute of Ecology. 238 p. (RM)

FISCH, GORDON. 1979. Deer pellet deterioration. In: Sitka black-tailed deer: Wallmo, O. C. and J. W. Schoen, eds. Proceedings of a conference in Juneau, AK. R10-48. Juneau, AK: U.S. Department of Agriculture, Forest Service, Alaska Region: 207-218. (PNW)

FLATHER, CURTIS.; THOMAS W. HOEKSTRA; DAVID E. CHALK; NOEL D. COST; and VICTOR A. RUDIS. 1989. Recent historical and projected regional trends of white-tailed deer and wild turkey in the southern United States. Gen. Tech. Rep. RM-172 Fort Collins, CO: U.S. Department of Agriculture, Forest Service, Rocky Mountain Forest and Range Experiment Station. 22 p. (RM)

FOWLER, W. B.; and J. E. DEALY. 1987. Behavior of mule deer on the Keating winter range. Res. Pap. PNW-RP-373. Portland, OR: U.S. Department of Agriculture, Forest Service, Pacific Northwest Research Station. 25 p. (PNW)

GOODWIN, G. A.; and A. L. WARD. 1976. Mule deer mortality on Interstate 80 in Wyoming: Causes, patterns, and recommendations. Res. Note RM-332. Fort Collins, CO: U.S. Department of Agriculture, Forest Service, Rocky Mountain Forest and Range Experiment Station. 4 p. (RM)

GRUELL, GEORGE E. 1986. Post-1900 mule deer irruptions in the Intermountain West: Principal cause and influences. Gen. Tech. Rep. INT-206. Ogden, UT: U.S. Department of Agriculture, Forest Service, Intermountain Forest and Range Experiment Station. 37 p. (INT)
HALLS, L. K. 1986. White-tailed deer in eastern wilderness areas. In: Kulhavy, D. L.; and Richard N. Conner, eds. Wilderness and natural areas in the eastern United States: a management challenge. Nacogdoches, TX: Center for Applied Studies, School of Forestry, Stephen F. Austin State University: 6266. (SO)

HALLS, LOWELL K. 1978. White-tailed deer. In: Schmidt, J. L.; and D. L. Gilbert, eds. Big game of North America. Washington, DC: Wildlife Management Institute, and Harrisburg, PA: Stackpole Books: 43-65. (SO)

HALLS, LOWELL K. 1981. White-tailed deer. In: Byrd, Nathan A., comp. A forester's guide to observing wildlife use of forest habitat in the Southern Forests. Rep. SA-FR-15. Atlanta, GA: U.S. Department of Agriculture, Forest Service, Southeastern Area, State and Private Forestry: 12-15. (SO)

HALLS, LOWELL. K., ed. 1984. White-tailed deer: ecology and management. Washington, DC: Wildlife Management Institute, and Harrisburg, PA: Stackpole Books. 870. (SO)

HALLS, LOWELL K.; and CHARLES E. BOYD. 1982. Influence of managed pine stands and mixed pine/hardwood stands on well being of deer. Res. Pap. SO183. New Orleans, LA: U.S. Department of Agriculture, Forest Service, Southern Forest Experiment Station. 18 p. (SO)

HANLEY, THOMAS A. 1984. Relationships between Sitka black-tailed deer and their habitat. Gen. Tech. Rep. PNW-168. Portland, OR: U.S. Department of Agriculture, Forest Service, Pacific Northwest Forest and Range Experiment Station. 21 p. (PNW) 
HANLEY, THOMAS A.; CHARLES T. ROBBINS; and DONALD E.

SPALINGER. 1989. Forest habitats and the nutritional ecology of Sitka blacktailed deer: a research synthesis with implications for forest management. Gen. Tech. Rep. PNW-230. Portland, OR: U.S. Department of Agriculture, Forest Service, Pacific Northwest Research Station. 52 p. (PNW)

HANLEY, THOMAS. A.; FRED L. BUNNEL; EDWARD E. STARKEY; SUSAN K. STEVENSON; and ALTON S. HARESTAD. 1983. Habitat relationships of Cervidae (deer) in old-growth forests. In: New forests for a changing world; Proceedings, 1983 Society of American Foresters National Convention; 1983 October 16-20; Portland, OR. SAF 8403. Bethesda, MD: Society of American Foresters: 361-367. (PNW)

HARLOW, RICHARD F. 1984. Habitat evaluation. In: Halls, L. K., ed. Whitetailed deer: ecology and management. Washington, DC: Wildlife Management Institute, and Harrisburg, PA: Stackpole Books: 601-628. (SE)

HARLOW, RICHARD F.; BEN A. SANDERS; JAMES B. WHELAN; and L. CARLTON CHAPPEL. 1980. Deer habitat on the Ocala National Forest: improvement through forest management. Southern Journal Applied Forestry. 4:98-102. (SE)

HEALY, WILLIAM M.; ROBERT T. BROOKS; and PAUL J. LYONS. 1987. Deer and forests on Boston's municipal watershed after 50 years as a wildlife sanctuary. In: Deer, forestry, and agriculture: interactions and strategies for management; 1987 June 15-17; Warren, PA. Erie, PA: Plateau and Northern Hardwood Chapters, Allegheny Society of American Foresters: 3-22. (NE)
HOLT, COLEMAN. 1980. Impacts of high deer population on forest regeneration and herd condition in the Allegheny hardwood region of Pennsylvania. The Allegheny News; Allegheny Section; Society of American Foresters. Winter. 2 p. (SE)

HOSKINSON, REED L.; and L. DAVID MECH. 1976. White-tailed deer migration and its role in wolf predation. Journal of Wildlife Management. 40:429441. (NC)

IRWIN, LARRY L.; MARK MASON; and WARD A. LORIN. 1981. Lead compounds in mule deer and vegetation, southeastern Wyoming. Washington, DC: National Transportation Resource Record 786. (RM)

KIE, JOHN G.; and MARSHALL WHITE. 1986. Tooth failure is not an important mortality factor in a white-tailed deer herd in Texas. Southwestern Naturalist. 31:266-267. (PSW)

KIE, JOHN G.; JOHN W. MENKE; JAMES R. DAVID; and WILLIAM M. LONGHURST. 1980. Mitigating the effects of reservoir development on black-tailed in Trinity County, California. Cal-Neva Wildlife Transactions. 1980:27-40. (PSW)

KIE, JOHN G.; MARSHALL WHITE, and D. LYNNE DRAWE. 1983. Condition parameters of white-tailed deer in Texas. Journal of Wildlife Management. 47:583-594. (PSW)

KIE, JOHN G.; TIMOTHY S. BURTON; and JOHN W. MENKE. 1982. Deer populations and reservoir construction in Trinity County, California. California Fish and Game. 68:109-117. (PSW)

KIE, JOHN G.; TIMOTHY S. BURTON; and JOHN W. MENKE. 1984. Comparative condition of black-tailed deer, Odocoileus hemionus columbianus, in two herds in Trinity County, California. California Fish and Game. 70:78-88. (PSW) 
LECKENBY, DONAVIN; and DALE E. TOWEILL. 1979. Seeding response of selected plant species and mule deer winter range in south-central Oregon. Final Rep. W-53-R-12 and W-70-R-1 Through W-70-R-7, Mule Deer Winter Range Ecology and Management Study 22. Portland, OR: Oregon Department Fish and Wildlife. (PNW)

LECKENBY, DONAVIN A. 1978. Mule deer occupancy of plant communties on a South-Central Oregon Winter Range. Final Rep. W-70-R, Silver Lake Mule Deer Study 77. Portland, OR: Oregon Department Fish and Wildlife. (PNW)

LECKENBY, DONAVIN A. 1978. Mule deer subpopulations on a south-central Oregon winter range. Final Rep. W-70R, Silver Lake Mule Deer Study 28. Portland, OR: Oregon Department Fish and Wildlife. (PNW)

LECKENBY, DONAVIN A. 1978. Western juniper management for mule deer. In: Martin, Robert E.; J. Edward Dealy; and David L. Caraher, eds: Proceedings of the western juniper ecology and management workshop; 1977 January; Bend, OR. Gen. Tech. Rep. PNW-74. Portland, OR: U.S. Department of Agriculture, Forest Service, Pacific Northwest Forest and Range Experiment Station: 137-161. (PNW)

LECKENBY, DONAVIN A. 1978. Weather severity index for mule deer on a southcentral Oregon winter range. Final Rep. W-70-R, Silver Lake Mule Deer Study 27. Portland, OR: Oregon Department Fish and Wildlife. (PNW)

LECKENBY, DONAVIN A.; and ARTHUR W. ADAMS. 1986. A weather severity index on a mule deer winter range. Journal of Range Management. 39:244-248.

(PNW)
LECKENBY, DONAVIN A.; and DALE E. TOWEILL. 1983. Response of forage species seeded for mule deer in western juniper types of south-central Oregon. Journal of Range Management. 36: 98103. (PNW)

LECKENBY, DONAVIN A.; and DALE E. TOWEILL. 1983. Response of selected plant species seeded on mule deer winter range. Journal of Range Management. 36:312-316. (PNW)

LECKENBY, DONAVIN A.; DENNIS P. SHEEHY; CARL H. NELLIS; RICHARD J. SCHERZINGER; IRA D. LUMAN; WAYNE ELMORE; JAMES C. LEMOS, LARRY DOUGHTY; and CHARLES E. TRAINER. 1982. Wildlife habitats in managed rangelands--the Great Basin of southeastern Oregon: Mule deer. Gen. Tech. Rep. PNW-139. Portland, OR: U.S. Department of Agriculture, Forest Service, Pacific Northwest Forest and Range Experiment Station. $40 \mathrm{p}$. (PNW)

LESLIE, DAVID M., JR.; EDWARD E. STARKEY; and BRADLEY G. SMITH. 1987. Forage acquisition by sympatric cervids along an old-growth sere. Journal of Mammalogy. 68:430-434. (PNW)

LOFT, ERIC R.; JOHN W. MENKE; JOHN G. KIE; and RON C. BERTRAM. 1987. Influence of cattle stocking rate on the structural profile of deer hiding cover. Journal of Wildlife Management. 51:655664. (PSW)

MARQUIS, DAVID A. 1987. Silvicultural techniques for circumventing deer browsing. In: Deer, forestry, and agriculture: interactions and strategies for management; 1987 June 15-17; Warren, PA. Erie, PA: Plateau and Northern Hardwood Chapters, Allegheny Society of American Foresters: 125-136. (NE) 
MATSCHKE, GEORGE H.; KATHLEEN A. FAGERSTONE; FRANK A. HAYES; WARREN PARKER; and DANIEL $O$. TRAINER; RICHARD F. HARLOW; and VICTOR F. NETTLES. 1984. Population influences. In: Halls, L. K., ed. Whitetailed deer: ecology and management. Washington, DC: Wildlife Management Institute, and Harrisburg, PA: Stackpole Books: 169-188. (SE)

MCARTHUR, E. DURANT; A. CLYDE BLAUER; and STEWART C.

SANDERSON. 1988. Mule deer-induced mortality of mountain big sagebrush. Journal of Range Management. 41:114117. (INT)

MECH, L. DAVID; and GLENN D. DELGIUDICE. 1985. Limitations of the marrow-fat technique as an indicator of body condition. The Wildlife Society Bulletin. 13:204-206. (NC)

MECH, L. DAVID; R. E. MCROBERTS; R. O. PETERSON; and R. E. PAGE. 1987. Relationship of deer and moose populations to previous winters' snow. Journal of Animal Ecology. 56:615-627. (NC)

MEDIN, DEAN E.; and ALLEN E.

ANDERSON. 1979. Modeling the dynamics of a Colorado mule deer population. Wildlife Monographs No. 68. Washington, DC: The Wildlife Society. 78 p. (INT)

MYERS, CLIFFORD A. 1977. Simulating timber and deer food potential in loblolly pine plantations. Tech. Rep. SO-12. New Orleans, LA: U.S. Department of Agriculture, Forest Service, Southern Forest Experiment Station. 29 p. (SO)

NEAL, DONALD L. 1981. Fawn mortality in the North Kings deer herd: some preliminary results. Cal-Neva Wildlife Transactions. 1981:68-71. (PSW)
NEAL, DONALD L. 1981. Improvement of Great Basin deer winter range with livestock grazing. In: Peek, James A.; and P. D. Dalke, eds. Proceedings, wildife-livestock relationships symposium; 1981 April 20-22; Coeur d'Alene, ID. Moscow, ID: University of Idaho; Forest, Wildlife and Range Experiment Station: 61-73. (PSW)

NEAL, DONALD L. 1985. The effect of mountain lion predation on the North Kings deer herd in California. In: Proceedings of the 2nd mountain lion workship; 1984 November 27-29; Zion National Park, UT. Logan, UT: Utah Division of Wildlife Research, Utah Cooperative Wildlife Research Unit: 138-140. (PSW)

NELSON, MICHAEL E. 1979. Home range location of white-tailed deer. Res. Pap. NC-173. St. Paul, MN: U.S. Department of Agriculture, Forest Service, North Central Forest Experiment Station. 10 p. (NC)

NELSON, MICHAEL E.; and L. DAVID $\mathrm{MECH}$. 1984. Home-range formation and dispersal of deer in Northeastern Minnesota. Journal of Mammalogy. 65:567-575. (NC)

NELSON, MICHAEL E.; and L. DAVID MECH. 1985. Observation of a wolf killed by a deer. Journal of Mammalogy. $66: 187-188$. (NC)

NELSON, MICHAEL E.; and L. DAVID MECH. 1986. Mortality of white-tailed deer in northeastern Minnesota. Journal of Wildlife Management. 50:691-698. (NC)

NELSON, MICHAEL E.; and L. DAVID MECH. 1986. Deer population in the central Superior National Forest, 19671985. Res. Pap. NC-271. St. Paul, MN: U.S. Department of Agriculture, Forest Service, North Central Forest Experiment Station. 8 p. (NC) 
NELSON, MICHAEL E.; and L. DAVID MECH. 1986. Relationship between snow depth and gray wolf predation on white-tailed deer. Journal of Wildlife Management. 50:471-474. (NC)

NELSON, MICHAEL E; and L. DAVID MECH. 1987. Demes within a northeastern Minnesota deer population. In: ChepkoSade, B. Diane; and Zuleyma Tang Halpin, eds. Mammalian dispersal patterns: the effects of social structure on population genetics. Chicago, IL: The University of Chicago Press: 27-40. (NC)

NIXON, CHARLES M.; and PAUL A. BREWER. 1988. Characteristics of winter habitats used by deer in Illinois. Journal of Wildlife Management. 52:552555. (NC)

NYBERG, J. BRIAN; R. SCOTT MCNAY; MATTHEW D. KIRCHHOFF; [and others]. 1989. Integrated management of timber and deer: coastal forests of British Columbia and Alaska. Gen. Tech. Rep. PNW-226. Portland, OR: U.S. Department of Agriculture, Forest Service, Pacific Northwest Research Station. 65 p. (PNW)

PATTON, DAVID R. 1981. Managing the habitat for mule deer in southwestern United States. In: Ffolliott, Peter F.; and Sonia Gallina, eds. Deer biology, habitat requirements, and management in western North America. Pub. 9. Mexico City: Institute of Ecology: 167-180. (RM)

REDDING, JIM. 1987. Impact of deer on forest vegetation and timber production in northern Pennsylvania. In: Deer, forestry, and agriculture: interactions and strategies for management; 1987 June 15-17; Warren, PA. Erie, PA: Plateau and Northern Hardwood Chapters, Allegheny Society of American Foresters: 23-32. (NE)
RODGERS, KENNETH J.; PETER F FFOLLIOTT; and DAVID R. PATTON. 1978. Home range and movement of five mule deer in a semidesert grassshrub community. Res. Note. RM-355. Fort Collins, CO: U.S. Department of Agriculture, Forest Service, Rocky Mountain Forest and Range Experiment Station. 6 p. (RM)

RODRIQUEZ, RONALD L.; and BRUCE L. WELCH. 1989. Effects of heavy grazing by mule deer on Hobble Creek mountain big sagebrush seed stalk production. In: Wallace, Arthur; E. Durant McArthur; and Marshall R. Haferkamp, comps. Proceedings--symposium on shrub ecophysiology and biotechnology; 1987 June 30-July 2; Logan, UT. Gen. Tech. Rep. INT-256. Ogden, UT: U.S. Department of Agriculture, Forest Service, Intermountain Research Station: 141-143. (INT)

ROGERS, KENNETH; PETER F. FFOLLIOTT; and DAVID R. PATTON. 1978. Home range and movement of five mule deer in a semidesert grassshrub community. Res. Note. RM-355. Fort Collins, CO: U.S. Department of Agriculture, Forest Service, Rocky Mountain Forest and Range Experiment Station. 6 p. (RM)

ROGERS, LYNN. 1981. Walking with deer. In: Nesbitt, William H., ed. Records of North American big game. Alexandria, VA: Boone and Crockett Club: 29-34. (NC)

ROGERS, LYNN L. 1980. Deer distribution in relation to wolf pack territory edges. Journal of Wildlife Management. 44:253258. (NC)

ROGERS, LYNN L. 1987. Seasonal changes in defecation rates of free-ranging whitetailed deer. Journal of Wildlife Management. 51:330-333. (NC) 
ROGERS, LYNN L.; AARON N. MOEN; and MARY L. SHEDD. 1987. Rectal temperatures of 2 free-ranging whitetailed deer fawns. Journal of Wildlife Management. 51:59-62. (NC)

ROGERS, LYNN L.; JACK J. MOOTY; and DEANNA DAWSON. 1981. Foods of white-tailed deer in the Upper Great Lakes Region--a review. Gen. Tech.

Rep. NC-65. St. Paul, MN: U.S.

Department of Agriculture, Forest

Service, North Central Forest

Experiment Station. 24 p. (NC)

SCHOEN, JOHN W.; and O. C. WALLMO. 1978. Deer and logging relationships in southeastern Alaska. Juneau, AK: Alaska Department Fish and Game. (PNW)

SCHOEN, JOHN W.; and O. C. WALLMO. 1979. Timber management and deer in southeast Alaska: current problems and research direction. In: Wallmo, O. C.; and J. W. Schoen, eds. Sitka blacktailed deer: Proceedings of a conference. R-10-48. Juneau, AK: U.S. Department of Agriculture, Forest Service, Alaska Region: 69-85. (PNW)

SCHWARTZ, CHARLES C.; JULIUS G. NAGY; and WAYNE L. REGELIN. 1980. Juniper oil yield, terpenoid concentration and antimicrobial effects on deer. Journal of Wildlife Management. 44:107113. (RM)

SEAL, ULYSSES S.; MICHAEL E. NELSON; L. DAVID MECH; and REED L. HOSKINSON. 1978. Metabolic indicators of habitat differences in four Minnesota deer populations. Journal of Wildlife Management. 42:746-754. (NC)

SEVERSON, KIETH E. 1981. Plains habitats. In: Wallmo, Olof C., ed. Mule and blacktailed deer in North America. A Wildlife Management Institute Book developed in cooperation with U.S. Department of Agriculture, Forest Service. Lincoln, NE: University of Nebraska Press: 459-485. Chapter 12. (RM)
SEVERSON, KIETH E.; and ARTHUR V. CARTER. 1978. Movements and habitat use by mule deer in the Northern Great Plains, South Dakota. In: Hyder, Donald N., ed. Proceedings, 1st international rangeland congress; 1978 August 1418; Denver, CO: Society for Range Management: 466-468. (RM)

SEVERSON, KIETH E.; and JEREMIAH J. KRANZ. 1978. Management of bur oak on deer winter range. The Wildlife Society Bulletin. 6:212-2/5. (RM)

SHORT, HENRY L. 1979. Deer in Arizona and New Mexico: Their ecology and a theory explaining recent population decreases. Gen. Tech. Rep. RM-70. Fort Collins, CO: U.S. Department of Agriculture, Forest Service, Rocky Mountain Forest and Range Experiment Station. 25 p. (RM)

SKOOG, P. J.; and L. D. HARRIS. 1981. Utilization of pine plantations by whitetailed deer in north Florida. IMPAC Reports. 6(2):19 p. (SE)

SMITH, JAMES L.; W. M. LONGHURST; D. L. NEAL; [and others]. 1978. An evaluation of possible effects of weather modification upon deer and their habitat in the American River Basin, California. In: Sierra ecology project; Denver, CO: U.S. Department Interior, Office of Atmospheric Resource Management, Bureau Reclamation: III-1 to III-99. Volume 1. (PSW)

SPALINGER, D. E.; T. A. HANLEY; and C. T. ROBBINS. 1988. Analysis of the functional response in foraging in the Sitka black-tailed deer. Ecology. 69:1166-1175. (PNW)

STEUTER, ALLEN A.; and HENRY A. WRIGHT. 1980. White-tailed deer densities and brush cover on the Rio Grande Plains. Journal Range Management. 33:328-331. (RM) 
STRANSKY, JOHN J. 1980. Deer habitat quality of major forest types in the southern United States. In: Proceedings, IV symposium game biology; 1976 October 15-16; Belgrade, Yugoslavia: Institute of Forestry and Wood Industry: 46-47. (SO)

SWEENEY, JAMES M.; MICHAEL E. GARNER; and RONALD P. BURKERT. 1984. Analysis of white-tailed deer use of forest clearcuts. Journal of Wildlife Management. 48:652-655. (NC)

URESK, D. W.; and V. A. URESK. 1978. Diets and habitat analyses of mule deer on the 200 acres of the Hanford reservation in southcentral Washington. PNL-246I. Richland, WA: Battelle Northwest Laboratories. (RM)

URESK, DANIEL W.; and DONALD R. DIETZ. 1981. White-tailed deer habitat studies in the Black Hills--an overview. In: Proceedings, Black Hills deer management workshop; 1980 January 9-10; Rapid City, SD. Custer, SD: U.S. Department of Agriculture, Forest Service, Black Hills National Forest: 2021. (RM)

URESK, DANIEL W.; and LEON FAGER, comps. 1981. Proceedings, Black Hills deer management workshop. 1980 January 9-10; Rapid City, SD. Custer, SD: U.S. Department of Agriculture, Forest Service, Black Hills National Forest. 39 p. (RM)

URESK, DANIEL W.; and VIRGINIA A. URESK. 1982. Diets and habitats of mule deer in south-central Washington. Northwest Science. 56(2):138-147. (RM)

VAN BALLENBERGHE, VICTOR. 1983. Rate of increase of white-tailed deer on the George Reserve: A re-evaluation. Journal of Wildlife Management. 47:1245-1247. (PNW)
WALLMO, O. C.; L. H. CARPENTER; W. L. REGELIN; R. B. GILL; and D. J. BAKER. 1977. Evaluation of deer habitat on a nutritional basis. Journal Range Management. 30:122-127. (RM)

WALLMO, OLOF C. 1978. Mule and blacktailed deer. In: Wallmo, Olof C., ed. Mule and black-tailed deer in North America. A Wildlife Management Institute Book developed in cooperation with U.S. Department of Agriculture, Forest Service. Lincoln, NE: University of Nebraska Press: 31-41. Chapter 3. (PNW)

WALLMO, OLOF C. 1981. Mule and blacktailed deer distribution and habitats. In: Wallmo, Olof C., ed. Mule and blacktailed deer in North America. A Wildlife Management Institute Book developed in cooperation with U.S. Department of Agriculture, Forest Service. Lincoln, NE: University of Nebraska Press: 1-25. Chapter 1. (PNW)

WALLMO, OLOF C., ed. 1981. Mule and black-tailed deer in North America. A Wildlife Management Institute Book developed in cooperation with U.S. Department of Agriculture, Forest Service. Lincoln, NE: University of Nebraska Press. 605 p. (PNW)

WALLMO, OLOF C.; ALBERT LECOUNT; and SAM L. BROWNLEE. 1981. Habitat evaluation and management. In: Wallmo, Olof C., ed. Mule and blacktailed deer in North America. A Wildlife Management Institute Book developed in cooperation with U.S. Department of Agriculture, Forest Service. Lincoln, NE: University of Nebraska Press: 366-385. Chapter 9. Part 2. (PNW)

WALLMO, OLOF C.; and JOHN W. SCHOEN, eds. 1979. Sitka black-tailed deer: Proceedings of a conference. R10-48. Juneau, AK: U.S. Department of Agriculture, Forest Service, Alaska Region. 231 p. (PNW) 
WALLMO, OLOF C.; and JOHN W.

SCHOEN. 1980. Response of deer to

secondary forest succession in

southeast Alaska. Forestry Science.

26(3):448-462. (PNW)

WALLMO, OLOF C.; and JOHN W.

SCHOEN. 1981. Forest management for deer. In: Wallmo, Olof C., ed. Mule and black-tailed deer in North America. A Wildlife Management Institute Book developed in cooperation with U.S. Department of Agriculture, Forest Service. Lincoln, NE: University of Nebraska Press: 434-448. Chapter 11. Part 2. (PNW)

WALLMO, OLOF C.; DALE F. REED; and LEN H. CARPENTER. 1976. Alteration of mule deer habitat by wildfire, logging, highways, housing developments, and agriculture. In: Mule deer decline in the west: A symposium. Logan, UT: Utah State University: 37-47. (RM)

WARD, A. LORIN. 1982. Mule deer behavior in relation to fencing and underpasses on Interstate 80 in Wyoming. Transp. Res. Rec. 859:8-13. (RM)

\section{Elk And Their Habitat}

BASILE, JOSEPH V. 1979. Elk-aspen relations on a prescribed burn. Res. Note. INT-271. Ogden, UT: U.S. Department of Agriculture, Forest Service, Intermountain Forest and Range Experiment Station. 7 p. (INT)

BASILE, JOSEPH V.; and TERRY N. LONNER. 1979. Vehicle restrictions influence elk and hunter distribution in Montana. Journal Forestry. 77(3):155159. (INT)
BRYANT, LARRY D.; and CHRIS MASER. 1982. Classification and distribution. In: Thomas, Jack Ward; and Dale E. Toweill, eds. Elk of North America: Ecology and management. Harrisburg, PA: Stackpole Books: 1-59. Chapter 1. A Wildlife Management Institute book in cooperation with U.S. Department of Agriculture, Forest Service. (PNW)

CANON, S. K.; P. J. URNESS; and N. V. DEBYLE. 1987. Habitat selection, foraging behavior, and dietary nutrition of elk in burned aspen forest. Journal of Range Management. 40:433-438. (INT)

DEBYLE, NORBERT V. 1979. Potential effects of stable versus fluctuating elk populations in the aspen ecosystem. In: Mark S. Boyce and Larry D. HaydenWing, eds. North American elk: ecology, behavior and management. Laramie, WY: University of Wyoming: 13-19. (INT)

GEIST, J. MICHAEL; PAUL J. EDGERTON; and A. W. "BUD" ADAMS. 1983. Elk pellets aren't all alike. Rangelands. 5:2829. (PNW)

HARMON, MARK E.; and JERRY F. FRANKLIN. 1983. Age distribution of western hemlock and its relation to Roosevelt elk populations in the South Fork Hoh River Valley, Washington. Northwest Science. 57:249-255. (PNW)

IRWIN, LARRY L.; and JAMES M. PEEK. 1983. Elk habitat use relative to forest succession in Idaho. Journal of Wildlife Management. 47:664-672. (INT)

LECKENBY, DONAVIN A. 1979. Rocky Mountain elk--the other 50 weeks. Oregon Wildlife. 34(11):6-7. (PNW) 
LECKENBY, DONAVIN A.; JACK WARD THOMAS; MARK G. HENJUM; and LEONARD J. ERICKSON. 1987. An index to evaluate forage quantity and quality interactions: one of four variables proposed for modeling elk habitat effectiveness on winter ranges in the Blue Mountains of Oregon and Washington. In: Proceedings of the 1986 western states and provinces elk workshop; 1986 March 17-19; Coos Bay, OR. Portland, OR: Oregon Department of Fish and Wildlife. 195212. (PNW)

LYON, L. J.; CARL NELLIS; and ARNOLD OLSEN. 1986. Concepts in managing elk hunting opportunity. Missoula, MT: U.S. Department of Agriculture, Forest Service, Northern Region. 8 p. (INT)

LYON, L. JACK. 1976. Elk use as related to characteristics of clearcuts in western Montana. Proceedings, elk-logging roads symposium; Moscow, ID: University of Idaho: 69-72. (INT)

LYON, L. JACK. 1979. Habitat effectiveness for elk as influenced by roads and cover. Journal Forestry. 77:658-660. (INT)

LYON, L. JACK. 1979. Influences of logging and weather on elk distribution in western Montana. Res. Pap. INT-236. Ogden, UT: U.S. Department of Agriculture, Forest Service, Intermountain Forest and Range Experiment Station. 11 p. (INT).

LYON, L. JACK. 1981. Coordinating forestry and elk management. Transactions of the North American Wildlife and Natural Resources Conference. 45:278-287. (INT)

LYON, L. JACK. 1983. Road density models describing habitat effectiveness for elk. Journal Forestry. 81:592-595, 613. (INT)
LYON, L. JACK. 1984. Field tests of elk/timber coordination guidelines. Res. Pap. INT-325. Ogden, UT: U.S. Department of Agriculture, Forest Service, Intermountain Forest and Range Experiment Station. 10 p. (INT)

LYON, L. JACK. 1987. HIDE2: evaluation of elk hiding cover using a personal computer. Res. Note. INT-365. Ogden, UT: U.S. Department of Agriculture, Forest Service, Intermountain Research Station. 2 p. (INT)

LYON, L. JACK; and C. LES MARCUM. 1987. A report on a field test of a PC program designed to evaluate hiding cover for elk. In: Western States and Provinces elk workshop; 1986 March; Coos Bay, OR. Salem, OR: Oregon Department of Fish and Wildlife: 271 274. (INT)

LYON, L. JACK; and JACK WARD THOMAS. 1987. Elk: Rocky Mountain majesty. In: Kallman, Harmon; C. Phillip Agee; W. Reid Goforth; and J. P. Linduska, comps. eds. Restoring America's wildlife--1937-1987: The first 50 years of the Federal Aid in Wildlife Restoration [Pittman-Robertson] Act; Washington, DC: U.S. Department of the Interior, Fish and Wildlife Service: 145-159. (INT)

NELSON, LOUIS J.; and JAMES M. PEEK. 1982. Effect of survival and fecundity on rate of increase of elk. Journal of Wildlife Management. 46:535-540. (INT)

PEDERSON, RICHARD J.; A. W. ADAMS; and JON SKOVLIN. 1979. Elk management in Blue Mountain habitats. Portland OR: Oregon Department of Fish and Wildlife. 27 p. (PNW)

PEDERSEN, RICHARD J.; A. W. "BUD" ADAMS; and JON M. SKOVLIN. 1980. Elk habitat use in an unlogged and logged forest. Environ. Widlife Res. Rep. 9. Portland, OR: Oregon Department of Fish and Wildlife, Research and Development Section: 1-121. (PNW) 
PEEK, JAMES M.; RICHARD J. PEDERSON; and JACK WARD THOMAS. 1982. The future of elk and elk hunting. In: Thomas, Jack Ward; and Dale E. Toweill, eds. Elk of North America: ecology and management. A Wildife Management Institute book developed in cooperation with U.S. Department of Agriculture, Forest Service. Harrisburg, PA: Stackpole Books: 599-625. Chapter 15. (PNW)

SCHUSTER, ERVIN G.; SIDNEY S. FRISSELL; ELDON E. BAKER; and ROBERT S. LOVELESS, JR. 1985. The Delphi method: application to elk habitat quality. Res. Pap. INT-353. Ogden, UT: U.S. Department of Agriculture, Forest Service, Intermountain Forest and Range Experiment Station. 32 p. (INT)

SKOVLIN, JON M. 1982. Habitat requirements and evaluations. In: Thomas, Jack Ward; and Dale E. Toweill, eds. Elk of North America: ecology and management. A Wildife Management Institute book developed in cooperation with U.S.Department of Agriculture, Forest Service. Harrisburg, PA: Stackpole Books: 369-413. Chapter 9. (PNW)

SKOVLIN, JON M.; LARRY D. BRYANT; and PAUL J. EDGERTON. 1989. Timber harvest affects elk distribution in the Blue Mountains of Oregon. Res. Pap. PNW-415. Portland, OR: U.S. Department of Agriculture, Forest Service, Pacific Northwest Research Station. 10 p. (PNW)

SKOVLIN, JON M.; PAUL J. EDGERTON; and BURT R. MCCONNELL. 1983. Elk use of winter range as affected by cattle grazing, fertilizing, and burning in southeastern Washington. Journal of Range Management. 36:184-189. (PNW)
SORG, CINDY F.; and LOUIS J. NELSON. 1986. Net economic value of elk hunting in Idaho. Res. Bull. RM-12. Fort Collins, CO; U.S. Department of Agriculture, Forest Service, Rocky Mountain Forest and Range Experiment Station. $21 \mathrm{p}$. (RM)

SWEENEY, J. M.; and J. R. SWEENEY. 1985. Snow depths influencing winter movements of elk. Journal of Mammalogy. 65:524-526. (NC)

THOMAS, J. WARD.; and DALE E. TOWEILL, eds. 1982. Elk of North America: ecology and management. A Wildife Management Institute book developed in cooperation with U.S.Department of Agriculture, Forest Service. Harrisburg, PA: Stackpole Books: Harrisburg, PA: Stackpole Books. 698 p. (PNW)

THOMAS, JACK WARD. 1987. Elk management-new days and new ways. In: Proceedings of the 1986 western states and provinces elk workshop; 1986 March 17-19; Coos Bay, OR. Portland, OR: Oregon Department of Fish and Wildlife: 309-316. (PNW)

THOMAS, JACK WARD. 1988. Elk in our future?--a time to choose. Bugle. 5(2):710. (PNW)

THOMAS, JACK WARD; and LARRY D. BRYANT. 1987. The elk. In: Di Silvestro, Roger L., comps. ed. Audubon wildlife report 1987. New York, NY: Academic Press, Inc.: 495-507. (PNW)

THOMAS, JACK WARD; DONAVIN A. LECKENBY; MARK HENJUM; RICHARD J. PEDERSEN; and LARRY D. BRYANT. 1988. Habitat-effectiveness index for elk on Blue Mountain winter ranges. Gen. Tech. Rep. PNW-218. Portland, OR: U.S. Department of Agriculture, Forest Service, Pacific Northwest Research Station. 28 p. (PNW) 
THOMAS, JACK WARD; DONAVIN A. LECKENBY; L. JACK LYON; [and others]. 1988. Integrated management of timber-elk-cattle: interior forest of Western North America. Gen. Tech. Rep. PNW-225. Portland, OR: U.S. Department of Agriculture, Forest Service, Pacific Northwest Research Station. 12 p. (PNW)

WARD, A. L. 1976. Elk behavior in relation to timber harvest operations and traffic on the Medicine Bow Range in southcentral Wyoming. In: Proceedings, elk logging roads symposium. Moscow, ID: University of Idaho: 32-43. (RM)

WARD, A. LORIN. 1981. Telemetered heart rate of three elk as affected by activity and human disturbance. In: Planning for trailbike recreation, Part II; Washington, DC: U. S. Dep. Interior, Heritage Conservation and Recreation Service: 28-33. (RM)

WARD, A. LORIN; and JERRY J. CUPAL. 1979. Telemetered heart rate of three elk as affected by activity and human disturbance. In: Proceedings, trails and rivers symposium; 1979 November 7-8; Laramie, WY: University of Wyoming: 93-102. (PNW)

WILTMER, G. W.; and D. S. DECALESTA. 1983. Habitat use by female Roosevelt elk in the Oregon coast range. Journal of Wildlife Management. 47:933-939. (PNW)

WITMER, GARY; and MICHAEL WISDOM. 1987 Some important elk-forest habitat relationships for western Oregon and Washington. In: Proceedings of the 1986 western states and provinces elk workshop; 1986 March 17-19; Coos Bay, OR. Portland, OR: Oregon Department of Fish and Wildlife: 149157. (PNW)
Moose, Caribou, And Their Habitat

CRAWFORD, HEWLETTE S. 1986. Moose in eastern wilderness--A role for prescribed fire. In: Kalhavy, D. L.; and Richard N. Conner, eds. Wilderness and natural areas in the Eastern United States: a management challenge; 1985 May 1315; Nacogdoches, TX: Stephen F. Austin State University, School of Forestry, Center for Applied Studies: 6770. (NE)

CUSHWA, CHARLES T.; and JOHN COADY. 1976. Food habits and moose (Alces alces) in Alaska: a preliminary study using rumen contents analysis. Canadian Field-Naturalist. 90:11-16. (PNW)

LAUTENSCHLAGER, R. A.; and H. S. CRAWFORD. 1983. Halter-training moose. The Wildlife Society Bulletin. II:I87-189. (NE)

MECH, L. DAVID; MICHAEL E. NELSON; and HARRY F. DRABIK. 1982. Reoccurrence of caribou in Minnesota. American Midland Naturalist. 108:206208. (NC)

MECH, L. DAVID; R. E. MCROBERTS; R. O. PETERSON; and R. E. PAGE. 1987. Relationship of deer and moose populations to previous winters' snow. Journal of Animal Ecology. 56:615-627. (NC)

PEEK, J. M.; V. VAN BALLENGERGHE; and D. G. MIQUELLE. 1986. Intensity of interactions between rutting bull moose in central Alaska. Journal of Mammalogy. 67:423-426. (PNW)

SERVHEEN, GREGG; and L. JACK LYON. 1989. Habitat use by woodland caribou in the Selkirk Mountains. Journal of Wildlife Management. 53:230-237. (INT)

VAN BALLENBERGHE, V. 1989. Wolf predation on the Nelchina caribou herd: a comment. Journal of Wildlife Management. 53:243-250. (PNW) 
VAN BALLENBERGHE, VICTOR. 1983. Rate of increase in moose populations. Alces. 19:98-117. (PNW)

VAN BALLENBERGHE, VICTOR. 1987. Effects of predation on moose numbers: a review of recent North American studies. In: Proceedings of the 2nd international moose symposium; 1984 August; Swedish Wildlife Research Viltrevy, Suppl. 1, Part 2:431-460. (PNW)

VAN BALLENBERGHE, VICTOR. 1987. Giants of the wilderness: Alaskan moose. National Geographic. August:260-155. (PNW)]

WOLF, JERRY O. 1980. Moose-snowshoe hare competition during peak hare densities. Proceedings of the North American Moose Conference and Workshop. 16:1-18. (PNW)

WOLFF, JERRY O.; and JOANNE COWLING. 1981. Moose browse utilization in Mount McKinley National Park Alaska. Canadian Field-Naturalist. 95:85-88. (PNW)

WOLFF, JERRY O.; and JOHN C. ZASADA. 1979. Moose habitat and forest succession on the Tanana River floodplain and Yukon-Tanana upland. Proceedings of the North American Moose Conference and Workshop. 15:213-244. (PNW)

\section{Pronghorn Antelope And Their Habitat}

GOODWIN, GREGORY A. 1977. Golden eagle predation of pronghorn antelope. The Auk. 94:789-790. (RM)
KINDSCHY, ROBERT R.; CHARLES SUNDSTROM; and JAMES D. YOAKUM. 1982. Wildlife habitats in managed rangelands--the Great Basin of southeastern Oregon: Pronghorns. Gen. Tech. Rep. PNW-145. Portland, OR: U.S. Department of Agriculture, Forest Service, Pacific Northwest Forest and Range Experiment Station. $18 \mathrm{p}$. (PNW)

LEFTWICH, TIMOTHY J.; and C. DAVID SIMPSON. 1977. A re-evaluation of the history of pronghorn abundance in west Texas. Proceedings of the Annual Conference of the Southeastern Association of Fish and Wildlife Agencies. 31:151-158 (RM)

SIMPSON, C. DAVID; and TIMOTHY J. LEFTWICH. 1978. Historic range change in the Texas pronghorn. In: Proceedings, 8th biennial pronghorn antelope workshop; 1978 May 2-4; Jasper, Alberta; Alberta Recreation, Parks and Wildlife, Fish and Wildlife Division: 121-146. (RM)

THOMAS, JACK WARD; W. LESLIE PENGELLY; and LAURENCE R. JAHN. 1979. Foreward. In: American pronghorn antelope. Washington, DC: The Wildlife Society. 244 p. (PNW)

Sheep, Goats, (wild) And Their Habitat

BARRETT, REGINALD H.; and SAMUEL L. BEASOM. 1980. Research needs for management of Barbary sheep in the future. In: Simpson, C. David, ed. Ecology and management of Barbary sheep: Proceedings of a symposium; 1979 November 19-21; Lubbock, TX. Lubbock, TX: Texas Tech University; 106-107. (RM) 
DICKINSON, TONY G.; and C. DAVID

SIMPSON. 1980. Dispersal and establishment of Barbary sheep in southeast New Mexico. In: Simpson, C. David, ed. Proceedings of the symposium on ecology and management of Barbary sheep; 1979 November 19-21; Lubbock, TX: Texas Tech University: 33-45. (RM)

DICKINSON, TONY G.; and C. DAVID SIMPSON. 1980. Home range, movements, and topographic selection of Barbary sheep in the Guadalupe Mountains, New Mexico. In: Simpson, C. David, ed. Proceedings of the symposium on ecology and management of Barbary sheep; 1979 November 19-21, Lubbock, TX: Texas Tech University: 78-86. (RM)

FOX, JOSEPH L.; and CHRISTIAN A. SMITH. 1988. Winter mountain goat diets in southeast Alaska. Journal of Wildlife Management. 52:362-365. (PNW)

FOX, JOSEPH L.; CHRISTAIN A. SMITH; and JOHN W. SCHOEN. 1989. Relation between mountain goats and their habitat in southeastern Alaska. Gen. Tech. Rep. PNW-246. Portland, OR: U.S. Department of Agriculture, Forest Service, Pacific Northwest Research Station. 25 p. (PNW)

SINGER, FRANCIS, J.; and JONATHON L. DOHERTY. 1985. Managing mountain goats at a highway crossing. The Wildlife Society Bulletin. 13:469-477. (INT)

VAN DYKE, WALTER A.; ALAN SANDS; JIM YOAKUM; ALLAN POLENZ; and JAMES BLAISDELL. 1983. Wildlife habitats in managed rangelands--the Great Basin of southeastern Oregon: Bighorn sheep. Gen. Tech. Rep. PNW159. Portland, OR: U.S. Department of Agriculture, Forest Service, Pacific Northwest Forest and Range Experiment Station. 37 p. (PNW)

\section{Livestock Management}

BRYANT, LARRY D. 1982. Response of livestock to riparian zone exclusion. Journal of Range Management. 35:780785. (PNW)

CLARY, WARREN P.; and HAROLD E. GRELEN. 1978. Comparison of beef gain potentials on cool semiarid and subtropical pine forest ranges. In: Hyder, Donald N., ed. Proceedings, 1st international rangeland congress; 1978 August 14-18; Denver, CO: Society for Range Management: 600-602.(SO)

CURRIE, PAT O. 1979. Cattle weight gain comparisons under seasonlong and rotation grazing systems, In:

Proceedings, 1 st international rangeland congress; 1978 August 14-18, Denver, CO: Society for Range Management: 579-580. (RM)

HARNISS, R. O.; and H. A. WRIGHT. 1981. Summer grazing of sagebrush-grass range by sheep--a photo record. Rangelands. 3:160-162. (INT)

HARNISS, R. O.; and H. A. WRIGHT. 1982. Summer grazing of sagebrush-grass range by sheep. Journal of Range Management. 35:13-17. (INT)

HOLECHEK, J. L.; M. VAVRA; and J. SKOVLIN. 1981. Diet quality and performance of cattle on forest and grassland range. Journal Animal Science. 53:291-298. (PNW)

HOLECHEK, J. L.; M. VAVRA; J. M. SKOVLIN; and R. L. PHILLIPS. 1979. Cattle performance under three grazing systems in northeastern Oregon. In: 1979 progress report: research in beef cattle nutrition and management. Spec. Rep. 534. Corvallis, OR: Oregon State University, Agricultural Experiment Station: 5-9. (PNW) 
HOLECHEK, J. L.; M. VAVRA; J. M.

SKOVLIN; and R. L. PHILLIPS. 1978.

Cattle performance on forested and grassland range. In: 1978 progress

report: research in beef cattle nutrition and management. Spec. Rep. 505.

Corvallis, OR: Oregon State University; Agriculture Experiment Station: 7-10. (PNW)

HOLECHEK, JERRY L.; TIMOTHY J. BERRY; MARTIN VAVRA. 1987. Grazing influences on cattle performance on mountain range. Journal of Range Management. 40:5559. (PNW)

KIESLING, HERMAN; JIM NEEL; DANIEL MANZANARES; GARY DONART; JERRY HOLECHEK; and TIM GOODMAN. 1987. Determining behavior and habitat use in pastures with varying proportions of riparian habitats. In: Livestock research briefs and cattle growers' short course; 1987 April 2; Las Cruces, NM: New Mexico State University: 24-25. (RM)

MEDINA, ALVIN L.; and JORGE SEPULVEDA BETANCOURT. 1987. Strategies for enhanced production of beef and jojoba on Northern Baja California rangelands. In: Aldon, Earl F.; Carlos E. Gonzales Vicente; and William H. Moir, tech. coords. Strategies for classification and management of native vegetation for food production in arid zones: symposium proceedings; 1987 October 12-16; Tucson, AZ. Gen. Tech. Rep. RM-150. Fort Collins, CO: U.S. Department of Agriculture, Forest Service, Rocky Mountain Forest and Range Experiment Station: 190-195. (RM)

PLATTS, WILLIAM S. 1986. Managing fish and livestock on Idaho rangelands. Rangelands. 8:213-216. (INT)

RATLIFF, RAYMOND D. 1986. Cattle responses to continuous and seasonal grazing of California annual grassland. Journal of Range Management. 39:482485. (PSW)
THILL, RONALD E. ; and GALE L.

WOLTERS. 1979. Cattle production on a southern pine-hardwood forest. Rangelands. 1:60-61. (SO)

THOMAS, JACK WARD; DONAVIN A. LECKENBY; L. JACK LYON; [and others]. 1988. Integrated management of timber-elk-cattle: interior forest of Western North America. Gen. Tech. Rep. PNW-225. Portland, OR: U.S. Department of Agriculture, Forest Service, Pacific Northwest Research Station. 12 p. (PNW)

URESK, DANIEL W. 1982. Importance of woodlands to wildlife and livestock use on the northern High Plains. In: Proceedings, Great Plains agricultural council; 1982 June 7-9; North Platte, NE. Lincoln, NE: University of Nebraska Press: 7-12. (RM)

VAVRA, M.; J. L. HOLECHEK; and R. L. PHILLIPS. 1979. Improved beef production from forested rangelands. In: 1979 progress report: research in rangeland management. Spec. Rep. 549. Corvallis, OR: Oregon State University, Agriculture Experiment Station: 29-34. (PNW)

WELCH, BRUCE L. ; E. DURANT MCARTHUR; and RONALD L. RODRIGUEZ. 1987. Variation in utilization of big sagebrush accessions by wintering sheep. Journal of Range Management. 40:113:115. (INT)

WOLTERS, G. L. [n.d.]. Sulfur or sulfur plus nitrogen increases carrying capacity and beef production on annual range. In: Proceedings, 2nd international rangeland congress: working papers; 1984 May; Adelaide, Australia. Deniliquin, NSW: Reliance Printing: 6c. (WO) 
Bear And Their Habitat

BARNES, D. M.; and L. L. ROGERS. 1980. Clostridial myonecrosis in a black bear associated with drug administration. Journal Wildlife Diseases. 16:315-317. (NC)

BASILE, JOSEPH V. 1982. Grizzly bear distribution in the Yellowstone area, 1973-79. Res. Note INT-321. Ogden, UT: U.S. Department of Agriculture, Forest Service, Intermountain Forest and Range Experiment Station. $11 \mathrm{p}$. (INT)

CONTRERAS, GLEN P.; and KEITH E. EVANS, comps. 1986. Grizzly bear habitat. Proceedings of a symposium; 1985 April 30-May 2; Missoula, MT. Gen. Tech. Rep. INT-207. Ogden, UT: U.S. Department of Agriculture, Forest Service, Intermountain Forest and Range Experiment Station. 252 p. (INT)

HAMER, DAVID; STEPHEN HERRERO; and LYNN ROGERS. 1981. Differentiating black and grizzly bear feces. The Wildlife Society Bulletin. 9:210-212. (NC)

KNIGHT, RICHARD; JOSEPH BASILE; KENNETH GREER; STEVEN JUDD; LLOYD OLDENBURG; and LARRY ROOP. 1976. Yellowstone grizzly bear investigations. Misc. Rep. No. 9. U.S. Department of Interior, National Park Service, 1975 Interagency Study Team. 46 p. (INT)

KNIGHT, RICHARD; JOSEPH BASILE; KENNETH GREER; STEVEN JUDD; LLOYD OLDENBURG; and LARRY ROOP. 1977. Yellowstone grizzly bear investigations. Misc. Rep. No. 10. U.S. Department of Interior, National Park Service, 1976 Interagency Study Team. 75 p. (INT)
MAXEWELL, ROBERT; JEFFREY

THORKELSON; LYNN L. ROGERS; and ROBERT B. BRANDER. 1988. The field energetics of winter-dormant black bear (Ursus americanus) in northeastern Minnesota. Canadian Journal of Zoology. 66:2095-2103. (NC)

MCMILLIN, J. MICHAEL; U. S. SEAL; LYNN L. ROGERS; and A. W. ERICKSON. 1976. Annual testosterone rhythm in black bear (Ursus americanus). Biology of Reproduction. 15:163-167. (NC)

MEEHAN, WILLIAM R.; and JOHN F. THILENIUS. 1983. Safety in bear country: protective measures and bullet performance at short range. Gen. Tech. Rep. PNW-152. Portland, OR: U.S. Department of Agriculture, Forest Service, Pacific Northwest Forest and Range Experiment Station. 16 p. (PNW)

NELSON, E. E. 1989. Black bears prefer urea-fertilized trees. Western Journal of Applied Forestry. 4(1):13-15. (PNW)

NOBLE, DELPHA. 1979. Grizzly bear in the Yellowstone ecosystem. Brochure. Ogden, UT: U.S. Department of Agriculture, Forest Service, Intermountain Forest and Range Experiment Station. [n.p.] (INT)

ROGERS, L. L. 1976. Effects of mast and berry crop failures on survival, growth, and reproductive success of black bears. Transactions of the North American Wildlife and Natural Resources Conference. 41:431-438. (NC)

ROGERS, L. L. 1977. The fourth international conference on bear research and management--A review. The Wildlife Society Bulletin. 5(4):38. (NC)

ROGERS, L. L. 1977. The ubiquitous black bear. In: Nesbitt, W. H.; and J. S. Parker, eds. North American big game. Washington, DC: National Rifle Association, Publications Division. (NC) 
ROGERS, L. L. 1987. Effects of food supply and kinship on social behavior, movements, and population dynamics of black bears in northeastern Minnesota. Wildlife Monographs No. 97. Washington, DC: The Wildlife Society. 72 p. (NC)

ROGERS, L. L. 1987. Factors influencing dispersal; in black bears. In: ChepkoSade, B. Diane; and Zuleyma Tang Halpin, eds. Mammalian dispersal patterns: the effects of social structure on population genetics. Chicago, IL: University of Chicago Press: 75-84. (NC)

ROGERS, L. L. 1987. Navigation by adult black bears. Journal of Mammalogy. 68:185-188. (NC)

ROGERS, L. L.; D. W. K. KUEHN; A. W. ERICKSON; E. M. HARGER; L. J. VERME; and J. J. OZOGA. 1976. Characteristics and management of black bears that feed in garbage dumps, campgrounds, or residential areas. In: International conference on bear research and management. 3:169-175. (NC)

ROGERS, LYNN. 1987. Portrait of a black bear. Encounters. 10(2):10-13. (NC)

ROGERS, LYNN L. 1978. Interpretation of cementum annuli in first premolars of bears. In: Hugie, Roy D., ed. Proceedings, 4th Eastern black bear workshop. Orono, ME: Maine Department of Inland Fisheries and Wildlife: 102-112. (NC)

ROGERS, LYNN L. 1980. Inheritance of coat color and changes in pelage coloration in black bears in northeastern Minnesota. Journal of Mammalogy. 61:324-337. (NC)
ROGERS, LYNN L. 1983. Effects of food supply, predation, cannibalism, parasites, and other health problems on black bear populations. In: Bunnell, Fred L.; Donald S. Eastman; and James M. Peek, co-eds. Natural regulation of wildlife populations: Proceedings, Northwest Section, The Wildlife Society; 1978 March 10; Vancouver, BC. Proc. 14. Moscow, ID: University of Idaho, Forest, Wildlife and Range Experiment Station: 194-211. (NC)

ROGERS, LYNN L. 1984. Reactions of freeranging black bears to capsaicin spray repellent. The Wildlife Society Bulletin. 12(1):59-61. (NC)

ROGERS, LYNN L. 1985. Aiding the wild survival of orphaned bear cubs. In: Beaver, Paul, ed. Proceedings of the 4th annual symposium of the national wildlife rehabilitators' association; 1985 March 21-24; St. Paul, MN. Brighton, IL: National Wildlife Rehabilitators' Association: 104-111. (NC)

ROGERS, LYNN L. 1986. Effects of translocation distance on frequency of return by adult black bears. The Wildlife Society Bulletin. 14:76-80. (NC)

ROGERS, LYNN L. 1986. Long-term survival of adopted black bear cubs in suboptimal habitat. The Wildlife Society Bulletin. 14:81-83. (NC)

ROGERS, LYNN L. 1987. Evidence that black bears reduce peripheral blood flow during hibernation. Journal of Mammalogy. 68:876-878. (NC)

ROGERS, LYNN L. 1988. How to live with black bears. HT-66. St. Paul, MN: U.S. Department of Agriculture, Forest Service, North Central Forest Experiment Station. 8 p. (NC) 
ROGERS, LYNN L. 1989. Black bears, people, and garbage dumps in Minnesota. In: Bromley, Marianne, ed. Bear-people conflicts: Proceedings of a symposium on management strategies; 1987 April 6-10; Yellowknife, Canada: Northwest Terrritories Department of Renewable Resources: 43-46. (NC)

ROGERS, LYNN L.; and AL TAYLOR. 1986. Why black bears are masters at winter survival. National Woodlands. 9(6):1112. (NC)

ROGERS, LYNN L.; and ARTHUR W ALLEN. 1987. Habitat suitability index models: black bear, upper Great Lakes Region. Biol. Rep. 82(10.144). Washington, DC: U.S. Department of the Interior, Fish and Wildlife Service. 54 p. (NC)

ROGERS, LYNN L.; GREGORY A. WILKER; and ARTHUR W. ALLEN. 1988.

Managing northern forests for black bears. In: Hoekstra, Thomas W.; and Jack Capp, comps. Integrating forest management for wildlife and fish. Gen. Tech. Rep. NC-122. St. Paul, MN: U.S. Department of Agriculture, Forest Service, North Central Forest Experiment Station: 36-42. (NC)

\section{Small Mammals}

\section{Small Mammal Habitat Management}

AGNEW, WILLIAN; DANIEL W. URESK; and RICHARD M. HANSSEN. 1986. Flora and fauna associated with prairie dog colonies and adjacent ungrazed mixedgrass prairie in western South Dakota. Journal of Range Management. 19:135139. (RM)

ANDERSEN, DOUGLAS C.; and JAMES A. MACMAHON. 1985. The effects of catastrophic ecosystem disturbance: the residual mammals at Mount St. Helens. Journal of Mammalogy. 66:581-585.
ANTHONY, R. G.; E. D. FORSMAN; G. A. GREEN; [and others]. 1987. Small mammal populations in riparian zones of different-aged coniferous forests. The Murrelet. 68:94-102. (PNW)

BROOKS, ROBERT T.; and WILLIAM M. HEALY. 1988. Response of small mammal communities to silvicultural treatments in Eastern hardwood forests of West Virginia. In: Szaro, Robert C.; Kieth E. Severson; and David R. Patton, tech. coords. Management of amphibians, reptiles, and small mammals in North America:

Proceedings of the symposium; 1988 July 19-21; Flagstaff, AZ. Gen. Tech. Rep. RM-166. Fort Collins, CO: U.S. Department of Agriculture, Forest Service, Rocky Mountain Forest and Range Experiment Station: 313-318. (NE)

BUCKNER, CHRISTINE A.; and DONALD J. SHURE. 1985. The response of Peromyscus to forest opening size in the southern Appalachian Mountains. Journal of Mammalogy. 66:299-307. (SE)

BUECH, R. R. 1977. Small mammals in a gamma-irradiated northern forest community. In: Zavitkovski, J., ed. Enterprise Radiation Forest. TID-26113P2. Springfield, VA: USDC. National Technical Information Service: 167-180. (NC)

BUECH, RICHARD R. 1984. Ontogeny and diurnal cycle of fecal reingestion in the North American beaver (Castor canadensis). Journal Mammalogy. 65:347-350. (NC) 
BUECH, RICHARD R. 1985. Beaver in water impoundments: understanding a

problem of water-level management. In: Knighton, M. Dean, ed. Proceedings, water-impoundments for wild life: a habitat management workshop; 1982 August 31-September 2; Bemidji, MN. Gen. Tech. Rep. NC-100. St. Paul, MN: U.S. Department of Agriculture, Forest Service, North Central Forest Experiment Station: 95-105. (NC)

BUECH, RICHARD R.; ROBERT M. TIMM; and KARL SIDERITS. 1977. A second population of rock voles, Microtus chrotorrhinus, in Minnesota, with comments on habitat. Canadian FieldNaturalist. 91:413-414. (NC)

BUSKIRK, STEVEN W.; STEVEN C.

FORREST; MARTIN G. RAPHAEL; and HENRY J. HARLOW. 1989. Winter resting site ecology of marten in the central Rocky Mountains. Journal of Wildlife Management. 53:191-196. (RM)

CINCOTTA, R. P.; D. W. URESK; and R. M. HANSEN. 1987. Demography of blacktailed prairie dog populations reoccupying sites treated with rodenticide. Great Basin Naturalist. 47:339-343. (RM)

CINCOTTA, R. P.; D. W. URESK; and R. M. HANSEN. 1988. A statistical model of expansion in a colony of black-tailed prairie dogs. In: Uresk, Daniel W.; Greg L. Schenbeck; and Rose Cefkin, tech. coords. 8th Great Plains wildlife damage control workshop proceedings; 1987 April 28-30; Rapid City, SD. Gen. Tech. Rep. RM-154. Fort Collins, CO: U.S. Department of Agriculture, Forest Service, Rocky Mountain Forest and Range Experiment Station: 30-33. (RM)

CORN, P. S.; and R. B. BURY. 1986. Habitat use and terrestrial activity by red tree voles (Arborimus longicaudus) in Oregon. Journal of Mammalogy. 67:404406.
COSTA, RALPH; PETER F. FFOLLIOTT; and DAVID R. PATTON. 1976. Cottontail responses to forest management in southwestern ponderosa pine. Res. Note RM-330. Fort Collins, CO: U.S. Department of Agriculture, Forest Service, Rocky Mountain Forest and Range Experiment Station. 4 p. (RM)

CRAWFORD, H. S.; R. G. HOOPER; and R. F. HARLOW. 1976. Woody plants selected by beavers in the Appalachian Ridge and Valley Province. Res. Pap. NE-356. Broomall, PA: U.S. Department of Agriculture, Forest Service, Northeastern Forest Experiment Station. 8 p. (NE)

DEGRAAF, RICHARD M.; GRETCHIN M. WHITMAN; and DEBORAH D. RUDIS. 1981. Forest habitat for mammals of the Northeast. Broomall, PA: U.S. Department of Agriculture, Forest Service, Northeastern Forest Experiment Station; Milwaukee, WI: U.S. Department of Agriculture, Forest Service, Eastern Region. 182 p. (NE)

DICKSON, JAMES G.; and J. HOWARD WILLIAMSON. 1988. Small mammals in streamside management zones in pine plantations. In: Szaro, Robert C.; Kieth E. Severson; and David R. Patton, tech. coords. Management of amphibians, reptiles, and small mammals in North America: Proceedings of the symposium; 1988 July 19-21; Flagstaff, AZ. Gen. Tech. Rep. RM-166. Fort Collins, CO: U.S. Department of Agriculture, Forest Service, Rocky Mountain Forest and Range Experiment Station: 375-378. (SO)

EVERETT, RICHARD L.; and RICHARD STEVENS. 1981. Deer mouse consumption of bitterbrush seed treated with four repellents. Journal of Range Management. 34:393-396. (INT) 
FFOLLIOTT, PETER F.; RONALD E. THILL; WARREN P. CLARY; and FREDERICK R. LARSON. 1977. Animal use of ponderosa pine forest openings. Journal of Wildlife Management. 41:782-784.

(RM)

FLYGER, VAGN; and DEBORAH A. SMITH. 1980. A comparison of Delmarva fox squirrel and gray squirrel habitats and home range. Transactions, Northeast Fish and Wildlife Conference. 36:19-22. (NE)

FOX, BARRY J.; RONALD D. QUINN; and G. J. BREYTENBACH. 1986. A comparison of small-mammal succession following fire in shrublands of Australia, California, and South Africa. Proceedings Ecological Society of Australia. 14:179197.

FRITTS, STEVEN H.; WILLIAM J. PAUL; and L. DAVID MECH. 1985. Can relocated wolves survive? The Wildlife Society Bulletin. 13:459-463. (NC)

FRITZELL, ERIK K.; and KURT J. HAROLDSON 1982. Urocyon cinereoargenteus. Mammalian Species. 189:1-8. (NC)

HALLS, LOWELL K. 1980. Small game is big hunting. Forest and People. 30(3):14-17. (SO)

HAROLDSON, KURT J.; and ERIK K. FRITZELL. 1984. Home ranges, activity, and habitat use by gray foxes in an oakhickory forest. Journal of Wildlife Management. 48:222-227. (NC)

HAYES, JOHN P.; and STEPHEN P. CROSS. 1987. Characteristics of logs used by western red-backed voles, Clethrionomys californicus, and deer mice, Peromyscus maniculatus. Canadian Field-Naturalist. 101:543-546. (PNW)
HINGTEN, TERRENCE M.; CLARK, WILLIAM R. 1984. Small mammal recolonization of reclaimed coal surfacemined land in Wyoming. Journal of Wildlife Management. 48:1255-1261. (RM)

HUNTLEY, J. C. 1986. Wilderness areas: Impact on gray and fox squirrels. In: Kulhavy, D. L.; and Richard N. Conner, eds. Wilderness and natural areas in the eastern United States: a management challenge. Nacogdoches, TX: Center for Applied Studies, School of Forestry, Stephen F. Austin State University: 5461. (SO)

HUNTLEY, JIMMY C. 1983. Squirrel tree den management: Reducing incompatibility with timber production in upland hardwoods. In: Jones, Earle P., Jr., ed. Proceedings of the 2nd biennial southern silvicultural research conference; 1982 November 4-5; Atlanta, GA. Gen. Tech. Rep. SE-24. Asheville, NC: U.S. Department of Agriculture, Forest Service, Southeastern Forest Experiment Station: 488-495. (SO)

KIRKLAND, GORDON L., JR. 1977. Responses of small mammals to clearcutting of northern Appalachian forests. Journal of Mammalogy. 58:600109. (NE)

LI, C. Y.; CHRIS MASER; ZANE MASER; and BRUCE A CALDWELL. 1986. Role of three rodents in forest nitrogen fixation in western Oregon: another aspect of mammal-mycorrhizal fungus-tree mutualism. Great Basin Naturalist. 46:411-414. (PNW)

MACCRACKEN, JAMES G.; and VICTOR VAN BALLENBERGHE. 1987. Age- and sex-related differences in fecal pellet dimensions of moose. Journal of Wildlife Management. 51:360-364. (PNW) 
MACCRACKEN, JAMES G.; DANIEL W. URESK; and RICHARD M. HANSEN. 1985. Rodent-vegetation relationships in southeastern Montana. Northwest Science. 59:272-278. (RM)

MALAJCZUK, N.; J. M. TRAPPE; and R. MOLINA. 1987. Interrelationships among some ectomycorrhizal trees, hypogeous fungi and small mammals: Western Australian and northwestern American parallels. Australian Journal of Ecology. 12:53-55. (PNW)

MASER, CHRIS; and GERALD S. STRICKLER. 1978. The sage vole, Lagurus curtatus, as an inhabitant of subalpine sheep fescue, Festuca ovina, communities on Steena Mountain--an observation and interpretation. Northwest Science. 52:276-284, illus. (PNW)

MASER, CHRIS; and STEPHEN P. CROSS. 1981. Notes on the distribution of Oregon bats. Res. Note. PNW-379. Portland, OR: U.S. Department of Agriculture, Forest Service, Pacific Northwest Forest and Range Experiment Station. 28 p. (PNW)

MASER, CHRIS; JAMES M. TRAPPE; and RONALD A. NUSSBAUM. 1978. Fungal-small mammal interrelationships with emphasis on Oregon coniferous forests. Ecology. 59:799-809. (PNW)

MAZZOTTI, FRANK J.; [and others]. 1981. Effects of the exotic plants Melaleuca quinquenervia and Casuarina equisetifolia on small mammal populations in the eastern Florida Everglades. Florida Scientist. 44:65-71. (SE)

MCCULLOUGH, CHARLES R.; and ERIKK. FRITZELL. 1984. Ecological observations of eastern spotted skunks on the Ozark Plateau. Transactions, Missouri Academy of Science. 18:25-32. (NC)
MECH, L. D.; and L. L. ROGERS. 1977. Status, distribution and movements for martens in northeastern Minnesota.

Res. Pap. NC-143. St. Paul, MN: U.S. Department of Agriculture, Forest Service, North Central Forest Experiment Station. 7 p. (NC)

MECH, L. D.; and R. P. PETERS. 1977. The study of chemical communication in free-ranging mammals. In: MullerSchwarze, D.; and M. M. Mozell, eds. Chemical signals in vertebrates. New York, NY: Plenum Publishing Corp.: 321-332. (NC)

MEDIN, DEAN E. 1986. Small mammal responses to diameter-cut logging in an Idaho Douglas-fir forest. Res. Note INT362. Ogden, UT: U.S. Department of Agriculture, Forest Service, Intermountain Research Station. 6 p. (INT)

MEDIN, DEAN E. 1986. The impact of logging on red squirrels in an Idaho conifer forest. Western Journal of Applied Forestry. 1:73-76. (INT)

MEDIN, DEAN E.; and GORDON D. BOOTH. 1989. Responses of birds and small mammals to single-tree selection logging in Idaho. Res. Pap. INT-408. Ogden, UT: U.S. Department of Agriculture, Forest Service, Intermountain Research Station. 11 p. (INT)

MEDIN, DEAN E.; and KATHRYN E. TORQUEMADA. 1988. Beaver in western North America: an annotated bibliography, 1966 to 1986 . Gen, Tech. Rep. INT-242. Ogden, UT: U.S. Department of Agriculture, Forest Service, Intermountain Research Station. 18 p. (INT)

MOWREY, ROBERT A. 1982. The northern flying squirrel in Alaska. Wildlife Notebook Service. Juneau, AK: Alaska Department of Fish and Game. 2 p. (PNW) 
OSTRENKO, W.; and F. MAZZOTTI. 1981. Small mammal populations in Melaleuca quinquenervia communities in the eastern Florida everglades. In:

Proceedings, Melaleuca symposium; 1980 September 23-24; Ft. Myers, FL. Tallahassee, FL: Florida Division of Forestry: 91-98. (SE)

PATTON, DAVID R. 1977. Managing southwestern ponderosa pine for the Abert squirrel. Journal of Forestry. 75:265-267. (RM)

PLATTS, BILL; and MARTIN ONISHUK. 1988. "Good" beavers "bad" beavers. Idaho Wildlife. 8(2):22-25. (INT)

POWELL, ROGER A. 1980. Fisher arboreal activity. Canadian Field-Naturalist. 94:90-91. (NC)

PROBST, JOHN R.; and DONALD S. RAKSTAD. 1987. Small mammal communities in three aspen stand-age classes. Canadian Field-Naturalist. 101:362-368. (NC)

RAPHAEL, MARTIN G. 1988. Habitat associations of small mammals in a subapline forest, Southeastern Wyoming. In: Szaro, Robert C.; Kieth E. Severson; and David R. Patton, tech. coords. Management of amphibians, reptiles, and small mammals in North America: Proceedings of the symposium; 1988 July 19-21; Flagstaff, AZ. Gen. Tech. Rep. RM-166. Fort Collins, CO: U.S. Department of Agriculture, Forest Service, Rocky Mountain Forest and Range Experiment Station: 359-367. (RM)

RUMBLE, MARK A. 1984. Biota of uranium mill tailings near the Black Hills. In: Proceedings, 1982 July 18-22; Annual conference of the Western Association of Fish and Wildlife Agencies; Las Vegas, NV: 278-292. (RM)
SAMSON. FRED B.; FRITZ L. KNOPF; and LISA B. HASS. 1988. Small mammal response to the introduction of cattle into a cottonwood floodplain. In: Szaro, Robert C.; Kieth E. Severson; and David R. Patton, tech. coords. Management of amphibians, reptiles, and small mammals in North America:

Proceedings of the symposium; 1988 July 19-21; Flagstaff, AZ. Gen. Tech. Rep. RM-166. Fort Collins, CO: U.S. Department of Agriculture, Forest Service, Rocky Mountain Forest and Range Experiment Station: 432-438. (PNW)

SANDERSON, H. REED.; CHARLES $M$. NIXON; ROBERT W. DONOHOE; and LONNIE P. HANSEN. 1980.

Grapevines--an important component of gray and fox squirrel habitat. The Wildlife Society Bulletin. 8:307-310. (PNW)

SANDERSON, H. REED; WILLIAM M. HEALY; JAMES C. PACK; JOHN D. GILL; and JACK W. THOMAS. 1977. Gray squirrel habitat and nest tree preference. Proceedings of the Annual Conference of the Southeastern Association Game and Fish Commissioners. 30:609-616. (NE)

SANDERSON, S. C.; R. L. PENDLETON; E. D. MCARTHUR; and K. T. HARPER. 1987. Saponin effect on small mammal forage preference in a planting of Atriplex canescens. In: Provenza, Frederick D.; Jerran T. Flinders; and E. Durant McArthur, comps. Proceedings-symposium on plant-herbivore interactions; 1985 August 7-9; Snowbird, UT. Gen. Tech. Rep. INT-222. Ogden, UT: U.S. Department of Agriculture, Forest Service, Intermountain Research Station: 74-77. (INT) 
SCOTT, VIRGIL E.; and GLEN L. CROUCH. 1988. Breeding birds and small mammals in pole-sized lodgepole pine and small inclusions of aspen in central Colorado. Res. Note. RM-482. Fort Collins, CO; U.S. Department of Agriculture, Forest Service, Rocky Mountain Forest and Range Experiment Station. 4 p. (RM)

SCOTT, VIRGIL E.; and GLEN L. CROUCH. 1988. Summer bird and mammals of aspen-conifer forests in west-central Colorado. Res. Pap. RM-280. Fort Collins, CO; U.S. Department of Agriculture, Forest Service, Rocky Mountain Forest and Range Experiment Station. 5 p. (RM)

SEVERSON, KIETH E. 1986. Small mammals in modified pinyon-juniper woodlands. Journal of Range Management. 39:31-34. (RM)

SEVERSON, KIETH E.; and B. J. HAYWARD. 1988. Rodent weights in modified pinyon-juniper woodlands of southwestern New Mexico. Great Basin Naturalist. 48:554-557. (RM)

SHIFLEY, STEPHEN R.; GARY J. BRAND; and LEWIS F. OHMANN. 1986. Timber and squirrels: forecasting and evaluating the options. Northern Journal of Applied Forestry. 3(2):46-49. (NC)

\section{SIEG, CAROLYN HULL. 1988. Small}

mammals: pests or vital components of the ecosystem. In: Uresk, Daniel W.; Greg L. Schenbeck; and Rose Cefkin, tech. coords. Proceedings, 8th Great Plains wildlife damage control workshop. Gen. Tech. Rep. RM-154. Fort Collins, CO: U.S. Department of Agriculture, Forest Service, Rocky Mountain Forest and Range Experiment Station: 88-92. (RM)
SIEG, CAROLYN HULL. 1988. The value of Rocky Mountain juniper (Juniperus scopulorum) woodlands in South Dakota as small mammal habitat. In: Szaro, Robert C.; Kieth E. Severson; and David R. Patton, tech. coords. Management of amphibians, reptiles, and small mammals in North America: Proceedings of the symposium; 1988 July 19-21; Flagstaff, AZ. Gen. Tech. Rep. RM-166. Fort Collins, CO: U.S. Department of Agriculture, Forest Service, Rocky Mountain Forest and Range Experiment Station: 328-332. (RM)

SIEG, CAROLYN HULL; DANIEL W. URESK; and RICHARD M. HANSEN. 1986. The value of bentonite mine spoils in southeastern Montana as small mammal habitat. Northwest Science. 60:218-224. (RM)

SMITH, H. R.; R. J. SLOAN; and G. S. WALTON. 1981. Some management implications between harvest rate and population resiliency of the muskrat (Ondatra zibethicus). In: Proceedings, 1st worldwide furbearers conference; 1980 August 3-11; Frostburg, MD. R. R. Donelly, VA: 425-442. (NE)

SMITH, HARVEY R.; and ROBERT W. CAMPBELL. 1978. Woodland mammals and the gypsy moth. American Forestry. 84(5):22-25. (NE)

SZARO, ROBERT C. 1988. The management of amphibians, reptiles, and small mammals in North America: historical perspective and objectives. In: Szaro, Robert C.; Kieth E. Severson; and David R. Patton, tech. coords. Management of amphibians, reptiles, and small mammals in North America: Proceedings of the symposium; 1988 July 19-21; Flagstaff, AZ. Gen. Tech. Rep. RM-166. Fort Collins, CO: U.S. Department of Agriculture, Forest Service, Rocky Mountain Forest and Range Experiment Station: 1-3. (RM) 
SZARO, ROBERT C.; KIETH E. SEVERSON; and DAVID R. PATTON, tech. coords. 1988. Management of amphibians, reptiles, and small mammals in North America. Proceedings of the symposium; 1988 July 19-21; Flagstaff, AZ. Gen. Tech. Rep. RM-166. Fort Collins, CO: U.S. Department of Agriculture, Forest Service, Rocky Mountain Forest and Range Experiment Station. 458 p. (RM)

TAYLOR, CATHY A.; C. JOHN RALPH; and ARLENE T. DOYLE. 1988. Differences in the ability of vegetation models to predict small mammal abundance in different aged Douglas-fir forests. In: Szaro, Robert C.; Kieth E. Severson; and David R. Patton, tech. coords. Management of amphibians, reptiles, and small mammals in North America: Proceedings of the symposium; 1988 July 19-21; Flagstaff, AZ. Gen. Tech. Rep. RM-166. Fort Collins, CO: U.S. Department of Agriculture, Forest Service, Rocky Mountain Forest and Range Experiment Station: 368-374. (PSW)

TESCHENDORF, JAY S. W.; CATHERINE FRAZER; and TERYL G. GRUBB. 1987. Interactions between bald eagles (Haliaeetus leucocephalus: Accipitridae) and river otters (Lutra canadensis: Mustelidae). The Southwestern Naturalist. 32:286-287. (RM)

TURKOWSKI, FRANK J.; and J. ROBERT VAHLE. 1977. Desert rodent abundance in southern Arizona in relation to rainfall. Res. Note. RM-346. Fort Colllins, CO: U.S. Department of Agriculture, Forest Service, Rocky Mountain Forest and Range Experiment Station. 4 p. (RM).

TURKOWSKI, FRANK J.; and ROSS K. WATKINS. 1976. White-throated woodrat (Neotoma albigula) habitat relations in modified pinyon-juniper woodland of southwestern New Mexico. Journal of Mammalogy. 57:586-591.

(RM)
VAHLE, J. ROBERT; and DAVID R.

PATTON. 1983. Red squirrel cover requirements in Arizona mixed conifer forests. Journal of Forestry. 81:14-15, 22. (RM)

VAN HORNE, BEATRICE. 1981. Demography of Peromyscus maniculatus populations in seral stages of coastal coniferous forest in southeast Alaska. Canadian Journal Zoology. 59:1045-1061. (PNW)

VAN HORNE, BEATRICE. 1982. Demography of the longtail vole Microtus longicaudus in seral stages of coastal coniferous forest southeast Alaska. Canadian Journal Zoology. 60:1690-1709. (PNW)

VAN HORNE, BEATRICE. 1982. Niches of adult and juvenile deer mice (Peromyscus maniculatus) in seral stages of conferous forest. Ecology. 63:992-1003. (PNW)

WHITAKER, JOHN O., JR.; STEPHEN P. CROSS; and CHRIS MASER. 1983. Food of vagrant shrews (Sorex vagrans) from Grant County, Oregon, as related to livestock grazing pressures. Northwest Science. 57(2):107-111. (PNW)

WHITESIDE, RICHARD W.; and FRED S. GUTHERY. 1981. Coyote use of playas in the Texas high plains. Priarie Naturalist. 13(2):42-44. (RM)

WILLIAMS, DANIEL F. 1984. Habitat associations of some rare shrews (Sorex) from California. Journal of Mammalogy. 65:325-328. (PSW)

WOLFF, JAMES L.; and REN LOHOEFENER. 1983. The small mammal fauna of a longleaf-slash pine forest in southern Mississippi. Journal Mississippi Academy Science. 28:37-47. (SO) 
WOLFF, JERRY O. 1980. The role of habitat patchiness in the population dynamics of snowshoe hares. Ecology Monograph. 50:111-130. (PNW)

WOLFF, MICHAEL L.; NORBERT V. DEBYLE; CLARK S. WINCHELL; and THOMAS R. MCCABE. 1982. Snowshoe hare cover relationships in northern Utah. Journal of Wildlife Management. 46:662-670. (INT)

\section{Food Habits And Population Dynamics}

AGNEW, W.; D. W. URESK; and R. M. HANSEN. 1988. Arthropod consumption by small mammals on prairie dog colonies and adjacent ungrazed mixed grass prairie in western South Dakota. In: Uresk, Daniel W.; Greg L.

Schenbeck; and Rose Cefkin, tech. coords. 8th Great Plains wildlife damage control workshop proceedings; 1987 April 28-30; Rapid City, SD. Gen. Tech. Rep. RM-154. Fort Collins, CO: U.S. Department of Agriculture, Forest Service, Rocky Mountain Forest and Range Experiment Station: 81-87. (RM)

BERRY, LARRY A.; EDWIN D. MICHAEL; and $H$. REED SANDERSON. 1978. Effect of population density on captive gray squirrels. Transactions Northeast Fish and Wildlife Conference. 35:53-59. (NE)

CASPER, HOWARD H.; MICHAEL E. MOUNT; REX E. MARSH; and ROBERT H. SCHMIDT. 1986. Fluoroacetate residues in ground squirrel and coyote tissues due to primary or secondary 1080 poisoning. Journal of the Association of Official Analytic Chemists. 69(3):441-442. (NC)
CROUCH, GLENN L.; and LARRY R.

FRANK. 1979. Poisoning and trapping pocket gophers to protect conifers in northeastern Oregon. Res. Pap. PNW261. Portland, OR: U.S. Department of Agriculture, Forest Service, Pacific Northwest Forest and Rande Experiment Station. 8 p. (PNW)

EARLE, RICHARD D.; and KENNETH R. KRAMM. 1982. Correlation between fisher and porcupine abundance in Upper Michigan American Midland Naturalist. 107:244-249. (NC)

ESHER, R. J.; and J. L. WOLFE. 1981. Least shrew (Cryptotis parva) mortality during simulated rainfall. American Midland Naturalist. 106:201-202.

EVERETT, R. L.; and A. W. KULLA. 1976. Rodent cache seedlings of shrub species in the Southwest. Tree Planter Notes. 27(3):11-12. (INT)

EVERETT, RICHARD L.; RICHARD O. MEEUWIG; and RICHARD STEVENS. 1978. Deer mouse preference for seed of commonly planted species, indigenous weed seed, and sacrifice foods. Journal of Range Management. 31:70-73. (INT)

FFOLLIOTT, PETER F.; and DAVID R.

PATTON. 1978. Abert squirrel use of ponderosa pine as feed trees. Res. Note RM-362. Fort Collins, CO: U.S.

Department of Agriculture, Forest Service, Rocky Mountain Forest and Range Experiment Station. 4 p. (RM)

GOODWIN, JOHN G., JR.; and C. ROGER HUNGERFORD. 1979. Rodent population densities and food habits in Arizona ponderosa pine forests. Res. Pap. RM-214. Fort Collins, CO: U.S. Department of Agriculture, Forest Service, Rocky Mountain Forest and Range Experiment Station. 12 p. (RM) 
GOTTFRIED, GERALD J.; and DAVID R. PATTON. 1984. Pocket gopher food habits on two disturbed forest sites in central Arizona. Res. Pap. RM-225. Fort Collins, CO: U.S. Department of Agriculture, Forest Service, Rocky Mountain Forest and Range Experiment Station. 9 p. (RM)

GUNTHER, PAMELA M.; BRENDA S. HORN; and GEOFFREY D. BABB. 1983. Small mammal populations and food selection in relation to timber harvest practices in the western Cascade Mountains. Northwest Science. 57:32-44. (PSW)

HEALY, WILLIAM M.; and ROBERT T. BROOKS. 1988. Small mammal abundance in northern hardwood stands in West Virginia. Journal of Wildlife Management. 52-491-496. (NE)

HENNESSY, DAVID F.; DONALD H. OWINGS; MATTHE P. ROWE; RICHARD G. COSS; and DANIEL W. LEGER. 1981. The information afforded by a variable signal: constraints on snake-elicited tail flagging by California ground squirrels. Behaviour. 78:220223. (PSW)

JONES, GWILYM S.; JOHN O. WHITAKER, JR.; and CHRIS MASER. 1978. Food habits of jumping mice (Zapus trinotatus and $Z$. princeps) in western North America. Northwest Science. 52:57-60. (PNW)

KIRKLAND, GORDON L. 1975. Notes on the cloudland deer mouse (Peromyscus maniculatus nubiterrae) in West Virginia. West Virginia Academy of Science Proceedings. 47(2):74-79. (NE)

KUEHN, DAVID W.; TODD K. FULLER; L. DAVID MECH; WILLIAM J. PAUL; STEVEN H. FRITTS; and WILLIAM E. BERG. 1986. Trap-related injuries to gray wolves in Minnesota. Journal of Wildlife Management. 50:90-91. (NC)
LEGER, DANIEL W.; DONALD H. OWINGS; and DEBORAH H. GELFAND. 1980. Single-note vocalizations of California ground squirrels: Graded signals and situation-specificity of predator and socially evoked calls. Zeithschrift Tierpsychologie. 52:227-245. (PSW)

LI, C. Y.; CHRIS MASER; and FAY HARLAN. 1986. Initial survey of acetylene reduction and selected microorganisms in the feces of 19 species of mammals. Great Basin Naturalist. 46:646-650. (PNW)

LYNCH, G. ROBERT; F. DANIEL VOGT; and HARVEY R. SMITH. 1978. Seasonal study of spontaneous daily torpor in the whitefooted mouse, Peromyscus leucopus. Physiological Zoology. 52:289-299. (NE)

MACCRACKEN, JAMES G. 1982. Coyote foods in southern California suburban land. The Wildlife Society Bulletin. 10:280-281. (RM)

MASER, CHRIS; and ZANE MASER. 1987. Notes on mycophagy in four species of mice in the genus Peromyscus. Great Basin Naturalist. 47:308-313. (PNW)

MASER, CHRIS; and ZANE MASER. 1988. Interactions among squirrels, mycorrhizal fungi, and coniferous forests in Oregon. Great Basin Naturalist. 48:358-369. (PNW)

MASER, CHRIS; and ZANE MASER. 1988. Mycophagy of red-backed voles, Clethrionomys califoricus and C. gapperi. Great Basin Naturalist. 48:269273. (PNW)

MASER, CHRIS; JAMES M. TRAPPE; and DOUGLAS C. URE. 1978. Implications of small mammal mycophagy to the management of western coniferous forests. Transactions of the North American Wildlife and Natural Resources Conference. 43:78-88. (PNW) 
MASER, CHRIS; ZANE MASER; and RANDY MOLINA. 1988. Small-mammal

mycophagy in rangelands of central and southeastern Oregon. Journal of Range Management. 41:309-312. (PNW)

MASER, CHRIS; ZANE MASER; JOSEPH W. WITT; and GARY HUNT. 1987. The northern flying squirrel: a mycophagist in southwestern Oregon. Canadian Journal of Zoology. 64:2086-2089. (PNW)

MASER, ZANE; and CHRIS MASER. 1987. Notes on mycophagy of the yellow-pine chipmunk (Eutamias amoenus) in northeastern Oregon. The Murrelet. 68:24-27. (PNW)

MECH, L. DAVID. 1986. Wolf population in the central Superior National Forest, 1967-1985. Res. Pap. NC-270. St. Paul, MN: U.S. Department of Agriculture, Forest Service, North Central Forest Experiment Station. 6 p. (NC)

OWINGS, DONALD H.; and DANIEL W. LEGER. 1980. Chatter vocalizations of California ground squirrels: predator-and social-role specificity. Zeitschrift fuer Tierpsychologie. 54:163-184. (PSW)

PATTON, DAVID R.; and ROBERT J. VAHLE. 1986. Cache and nest characteristics of the red squirrel in an Arizona mixed-conifer forest. Western Journal of Applied Forestry. 1:48-51. (RM)

PATTON, DAVID R.; THOMAS D. RATCLIFF; and KENNETH J. RODGERS. 1976. Weight and temperature of the Abert and Kaibab squirrels. Southwest Naturalist. $21(2): 236-238$. (RM)

POWELL, R. A. 1981. Hunting behavior and food requirements of the fisher (Martes pennanti). In: Chapman, Joseph A.; and Duane Pursley, eds. Proceedings, worldwide furbearer conference; 1980 August 3-11; Frostburg, MD. Frostburg, MD: Appalachian Environmental Laboratory. 1:883-917. (NC)
POWELL, R. A.; and R. B. BRANDER. 1977. Adaptions of fishers and porcupines in relation to their predator-prey-system. In: Phillips, R. L.; and C. J. Jonkel, eds. Proceedings of the 1975 predator symposium. Missoula, MT: University of Montana, School of Forestry, Montana Forest and Conservation Experiment Station. (NC)

POWELL, ROGER A. 1978. A comparison of fisher and weasel hunting behavior. Carnivore I. (1):28-34. (NC)

POWELL, ROGER A. 1979. Ecological energetics and foraging strategies of the fisher (Martes pennanti). Journal of Animal Ecology. 48:195-212. (NC)

POWELL, ROGER A. 1979. Fishers, population models, and trapping. The Wildlife Society Bulletin. 7(3):149-154. (NC)

POWELL, ROGER A. 1979. Mustelid spacing patterns: variations on a theme by Mustela. Zeitschrift fur Tierphychologic. 50:153-165. (NC)

POWELL, ROGER A. 1980. Fisher arborial activity. Canadian Field-Naturalist. 94:90-91. (NC)

POWELL, ROGER A. 1980. Stability in a onepredator-three-prey community.

American Naturalist. 115:567-579. (NC)

POWELL, ROGER A. 1982. The fisher: life history, ecology, and behavior. Minneapolis, MN: University of Minnesota Press. 217 p. (NC)

RADWAN, M. A.; G. L. CROUCH; C. A. HARRINGTON; and W. D. ELLIS. 1982. Terpenes of ponderosa pine and feeding preferences by pocket gophers. Journal Chemistry Ecology. 8(1):241-253. (RM)

RAPHAEL, MARTIN G. 1984. Late fall breeding of the northern flying squirrel, Glaucomys sabrinus. Journal of Mammalogy. 65:138-139. (PSW) 
RAPHAEL, MARTIN G. 1988. Long-term trends in abundance of amphibians, reptiles, and mammals in Douglas-fir forsets of Northwestern Oregon. In: Szaro, Robert C.; Kieth E. Severson; and David R. Patton, tech. coords. Management of amphibians, reptiles, and small mammals in North America: Proceedings of the symposium; 1988 July 19-21; Flagstaff, AZ. Gen. Tech. Rep. RM-166. Fort Collins, CO: U.S. Department of Agriculture, Forest Service, Rocky Mountain Forest and Range Experiment Station: 23-31. (RM)

ROHWEDER, RONALD; JACK MELLAND; and CHRIS MASER. 1979. A new record of Washington ground squirrels in Oregon. The Murrelet. 60(1):29. (PNW)

SCHITOSKEY, FRANK JR.; and SARAH WOODMANSEE. 1978. Energy requirements and diet of the California ground squirrel. Journal of Wildlife Management. 42:373-382. (PSW)

SHORT, HENRY L. 1976. Composition and squirrel use of acorns of black and white oak groups. Journal of Wildlife Management. 40:479-483. (SO)

SIEG, CAROLYN HULL. 1988. Small mammals: pests or vital components of the ecosystem. In: Uresk, Daniel W.; Greg L. Schenbeck; and Rose Cefkin, tech. coords. 8th Great Plains wildlife damage control workshop proceedings; 1987 April 28-30; Rapid City, SD. Gen. Tech. Rep. RM-154. Fort Collins, CO: U.S. Department of Agriculture, Forest Service, Rocky Mountain Forest and Range Experiment Station: 88-92. (RM)

SIEG, CAROLYN HULL; DANIEL W. URESK; and RICHARD M. HANSEN. 1986.

Seasonal diets of deer mice on bentonite mine spoils and sagebrush grasslands in southeastern Montana. Northwest Science. 60:81-89. (RM)
SMITH, H. R. 1980. Growth, reproduction, and survival in Peromyscus leucopus carrying intraperitoneally implanted transmitters. In: Amlaner, C.J. Jr.: and D. W. Macdonald, eds. Handbook of biolemetry and radio tracking. Oxford. Pergamon, Press: 367-374. (NE)

URESK, DANIEL W. 1978. Diets of the blacktailed hare in steppe vegetation. Journal of Range Management. 31:439-442. (RM)

URESK, DANIEL W. 1984. Black-tailed prairie dog food habits and forage relationships in western South Dakota. Journal of Range Management. 37:325-329. (RM)

URESK, DANIEL W.; and ARDELL J. BJUGSTAD. 1980. Prairie dogs as ecosystem regulators on the northern High Plains. In: Proceedings, 7th North American prairie conference; 1980 August 4-6; Springfield, MO: 91-94. (RM)

URESK, DANIEL W.; RUDY M. KING; ANTHONY D. APA; and RAYMOND LINDER. 1986. Efficacy of zinc phosphide and strychnine for blacktailed prairie dog control. Journal of Range Management. 39:113-116. (RM)

VAN HORNE, BEATRICE. 1983. Summertime activity pattern of the longtail vole in Alaska. Holarctic Ecology. 6:199-203. (PNW)

VOTH, ELVER H.; CHRIS MASER; and MURRAY L. JOHNSON. 1983. Food habits of Arborimus albipes, the whitefooted vole, in Oregon. Northwest Science. 57(1):1-7. (PNW)

WEST, STEPHEN D. 1977. Manipulative behavior by a red squirrel. Canadian Field-Naturalist. 91:417-418. (PNW)

WEST, STEPHEN D. 1977. Midwinter aggregation in the northern red-backed vole, Clethrionomys rutilus. Canadian Journal Zoology. 55(9):1404-1409. (PNW). 
WEST, STEPHEN D. 1982. Dynamics of colonization and abundance in central Alaskan populations of the northern redbacked vole, Clethrionomys rutilus. Journal of Mammalogy. 63:128-143. (PNW)

WEST, STEPHEN D.; R. GLENN FORD; and JOHN C. ZASADA. 1980. Population response of the northern red-backed vole (Clethrionomys rutilus) to differentially cut white spruce forest. Res. Note. PNW-362. Portland, OR: U.S. Department of Agriculture, Forest Service, Pacific Northwest Forest and Range Experiment Station. 15 p. (PNW)

WHITAKER, JOHN O., JR.; CHRIS MASER; and RICHARD J. PEDERSEN. 1979. Food and ectoparasitic mites of Oregon moles. Northwest Science. 53:268-273. (PNW)

WHITAKER, JOHN O., JR.; CHRIS MASER; and STEPHEN P. CROSS. 1981. Food habits of eastern Oregon bats, based on stomach and scat analysis. Northwest Science. 55:281-292. (PNW)

WHITAKER, JOHN O., JR.; CHRIS MASER; and STEPHEN P. CROSS. 1981. Foods of Oregon silver-haired bats, Lasionycteris noctivagans. Northwest Science. 55:75-77. (PNW)

WHITAKER, JOHN O.; CHRIS MASER; and LAUREL E. KELLER. 1977. Food habits of bats of western Oregon. Northwest Science. 51:46-55. (PNW)

WHITE, SUSAN M.; JERRAN T. FLINDERS; and BRUCE L. WELCH. 1982.

Preference of pygmy rabbits (Brachylagus idahoensis) for various populations of big sagebrush (Artemisia tridentata). Journal of Range Management. 35:724-726. (INT)

WILLIAMS, KENNETH L.; D. T. STALLING; and J. H. SCARBOROUGH. 1981. Range extension of the woodland vole in west central Louisiana. Louisiana Academy of Science. 43:12-14. (SO)
WILLIAMS, ROBERT D.; and J. W. VANSAMBEEK. 1984. Implications of black walnut parent-tree selection and breeding to squirrel management. The Wildlife Society Bulletin. 12(2):185-189. (NC)

WOLFF, J. L.; and R. J. ESHER. 1981.

Relative abundance of the southeastern shrew. Journal of Mammalogy. 62:649650. (SO)

WOLFF, JAMES L.; and ROBERT J. ESHER. 1980. Toxicity of carbofuran and lindane to the old-field mouse (Peromyscus polionotus) and the cotton mouse ( $P$. gossypinus). Bulletin of Environmental Contamination and Toxicology. 24:894902. (SO)

WOLFF, J. O.; and W. Z. LIDICKER, JR. 1981. Population ecology of the taiga vole, Microtus xanthognathus, in interior Alaska. Canadian Journal Zoology. 58:1800-1812. (PNW)

WOLFF, J. O.; and WILLIAM Z. LIDICKER, JR. 1981. Communal winter nesting and food sharing in taiga voles. Behavorial Ecology and Sociobiol. 9:237-240. (PNW)

WOLFF, JERRY O. 1978. Food habits of snowshoe hares in interior Alaska. Journal of Wildlife Management. 42:148153. (PNW)

WOLFF, JERRY O. 1980. Social organization of the taiga vole (Microtus xanthognathus). Biologist. 62(1-4):3445. (PNW)

WOLFF, JERRY O. 1982. Refugia, dispersal, predation, and geographic variation in snowshoe hare cycles. In: Myers, K.; and C. D. Maclnnes, eds. Proceedings, world lagomorph conference; 1979 August 12-16; Guelph, ON: 441-449. (PNW) 
WOLFF, JERRY O.; and MARTHA F. JOHNSON. 1979. Scent marking in taiga voles, Microtus xanthognathus. Journal of Mammalogy. 60:400-404. (PNW)

WOLFF, JERRY O.; and W. D. BERRY. 1977. The return of the snowshoe hare. Alaska. April: 60, 96. (PNW)

Canid, Felid, And Their Habitat

ANDELT, WILLIAM F.; JOHN G. KIE; FREDERICK F. KNOWLTON; and KEAN CARDWELL. 1987. Variation in coyote diets associated with season and successional changes in vegetation. Journal of Wildlife Management. 51:273277. (PSW)

ASA, CHERYL S.; ERIC K. PETERSON; U. S. SEAL; and L. DAVID MECH. 1985. Deposition of anal-sac secretions by captive wolves (Canis lupus). Journal of Mammalogy. 66:89-83. (NC)

ASA, CHERYL S.; L. DAVID MECH; and ULYSSES S. SEAL. 1985. The use of urine, feces, and anal-gland secretions in scent-marking by a captive wolf (Canis lupus) pack. Animal Behavior. 33:1034-1036. (NC)

ASA, CHERYL; U. S. SEAL; EDWARD D. PLOTKA; MARC A. LETELLIER; and L. DAVID MECH. 1986. Effect of anosmia on reproduction in male and female wolves (Canus lupis). Behavioral and Neural Biology. 46:272-284. (NC)

BERG, WILLIAM E.; and DAVID W. KUEHN. 1980. A study of the timber wolf population on the Chippewa National Forest, Minnesota. Minnesota Wildlife Research Quarterly. 40(1):1-16. (NC)

BUECH, RICHARD R.; DAVID J. RUGG; and NANCY L. MILLER. 1989. Temperature in beaver lodges and bank dens in a near-boreal environment. Canadian Journal of Zoology. 67:1061-1066. (NC)
DELGIUDICE, GLENN D.; ULYSSES S. SEAL; and L. DAVID MECH. 1987 Effects of feeding and fasting on wolf blood and urine characteristics. Journal of Wildlife Management. 51:1-10. (NC)

FLOYD, THEODORE J.; L. DAVID MECH; and PETER A. JORDAN. 1978. Relating wolf scat content to prey consumed. Journal of Wildlife Management. 42:528532. (NC)

FRITTS, STEVEN H.; WILLIAM J. PAUL; and L. DAVID MECH. 1984. Movements of translocated wolves in Minnesota. Journal of Wildlife Management. 48:709721. (NC)

GOYAL, SAGAR M; L. DAVID MECH; RUTH A RADEMACHER; MUHAMMAD A. KHAN; and ULYSSES S. SEAL. 1986. Antibodies against canine parvovirus in wolves of Minnesota: a serologic study 1975 through 1985. Journal of the American Veterinary Medical Association. 189:1092-1094. (NC)

HARRINGTON, FRED H.; and L. DAVID MECH. 1978. Wolf vocalization. In: Wolf and man: evolution in parallel. New York, NY: Academic Press: 109-132. (NC)

HARRINGTON, FRED H.; and L. DAVID MECH. 1978. Howling at two Minnesota wolf pack summer homesites. Canadian Journal Zoology. 56:2024-2028. (NC)

HARRINGTON, FRED H.; and L. DAVID MECH. 1979. Wolf howling and its role in territory maintenance. Behaviour. 76:207-249. (NC)

HARRINGTON, FRED H.; and L. DAVID $\mathrm{MECH}$. 1982. An analysis of howling response parameters useful for wolf pack censusing. Journal of Wildlife Management. 46:686-693. (NC)

HARRINGTON, FRED H.; and L. DAVID MECH. 1982. Fall and winter homesite use by wolves in northeastern Minnesota. Canadian Field-Naturalist. 96:79-84; 1982. (NC) 
HARRINGTON, FRED H.; and L. DAVID MECH. 1982. Patterns of homesite attendance in two Minnesota wolf packs. In: Harrington, Fred $\mathrm{H}_{\text {. }}$; and Paul C. Paquet, eds. Wolves of the world: perspectives of behavior, ecology, and conservation. Park Ridge, NJ: Noyes Publications: 81-105. (NC)

HARRINGTON, FRED H.; and L. DAVID MECH. 1983. Wolf pack spacing: howling as a territory-independent spacing mechanism in a territorial population. Behavioral Ecology and Sociobiology. 12:161-168. (NC)

KNIPE, O. D. 1985. Predator deterrent electric fence for rough terrain. Rangelands. 7:148-153. (RM)

KREEGER, TERRY J.; ALICIA M. FAGGELLA; ULYSSES S. SEAL; and L. DAVID MECH. 1987. Cardiovascular and behavior responses of gray wolves to ketamine-xylaxzine immobilization and antagonism by yohimbine. Journal of Wildlife Diseases. 23:463-470. (NC)

MACCRACKEN, JAMES G.; and RICHARD M. HANSEN. 1987. Coyote feeding strategies in southeastern Idaho: optimal foraging by an opportunistic predator. Journal of Wildlife Management. 5:278285. (PNW)

MASER, CHRIS; and RONALD S. ROHWEDER. 1983. Winter food habits of cougars from northeastern Oregon. Great Basin Naturalist. 43:425-428. (PNW)

MECH, L. D. 1977. Population trend and winter deer consumption in a Minnesota wolf pack. In: Phillips, R. L.; and C. J. Jonkel, eds. Proceedings, 1975 predator symposium; Missoula, MT: University of Montana, School of Forestry, Montana Forest and Conservation Experiment Station. (NC)
MECH, L. D. 1979. Making the most of radio tracking--a summary of wolf studies in Northeastern Minnesota. In: Amlaner, C. J. Jr,; and D. W. MacDonald, eds. Handbook on biotelemetry and radio tracking. New York, NY: Pergamon Press: 85-89. (NC)

MECH, L. DAVID. 1977. Productivity, mortality and population trend in wolves from northeastern Minnesota. Journal of Mammalogy. 58:559-574. (NC)

MECH, L. DAVID. 1977. Record movement of a canadian lynx. Journal of Mammalogy. 58:676-677. (NC)

MECH, L. DAVID. 1977. Wolf-pack buffer zones as prey reservoirs. Science. 198:320-321. (NC)

MECH, L. DAVID 1979. Why some deer are safe from wolves. Natural History. 88(1):7077. (NC)

MECH, L. DAVID. 1980. Age, sex, reproduction, and spatial organization of lynxes colonizing northeastern Minnesota. Journal of Mammology. 61:261-267. (NC)

MECH, L. DAVID. 1987. Age, season, distance, direction, and social aspects of wolf dispersal from a Minnesota pack. In: Chepko-Sade, B. Diane; and Zuleyma Tang-Halpin, eds. Mammalian dispersal patterns: the effects of social structure on population genetics. Chicago, IL: The University of Chicago Press: 55-74. (NC)

MECH, L. DAVID. 1988. Longevity in wild wolves. Journal of Mammalogy. 69:197198. (NC)

MECH, L. DAVID. 1988. Wolf population survival in an area of high road density. American Midland Naturalist. 121:387389. (NC)

MECH, L. DAVID. 1989. Stubborn hunter in a harsh land. National Wildlife. 27(5):2024. (NC) 
MECH, L. DAVID. 1989. Wolf longevity in the wild. Endangered Species Tech. Bull. 14(5). Washington, DC: U.S.

Department of Interior, U.S. Fish and Wildlife Service. 8 p. (NC)

MECH, L. DAVID; and H. H. HERTEL. 1983. An eight-year demography of a Minnesota wolf pack. Acta Zoology Fennica. 174:249-250. (NC)

MECH, L. DAVID; and MARK KORB. 1979. An unusually long pursuit of a deer by a wolf. Journal of Mammalogy. 59:860861. (NC)

MECH, L. DAVID; and MICHAEL E. NELSON. 1989. Polygyny in a wild wolf pack. Journal of Mammalogy. 70:675676. (NC)

MECH, L. DAVID; and PATRICK D. KARNS. 1977. Role of the wolf in a deer decline in the Superior National Forest. Res.

Pap. NC-148. St. Paul, MN: U.S.

Department of Agriculture, Forest

Service, North Central Forest

Experiment Station. 23 p. (NC)

MECH, L. DAVID; and STEVEN T. KNICK. 1978. Sleeping distance in wolf pairs in relation to the breeding season. Behavioral Biology. 23:521-525. (NC)

MECH, L. DAVID; and ULYSSES S. SEAL. 1987. Premature reproductive activity in wild wolves. Journal of Mammalogy. 68:871-873. (NC)

MECH, L. DAVID; STEVEN H. FRITTS; GLENN L. RADDE; and WILLIAM J. PAUL. 1988. Wolf distribution and road density in Minnesota. The Wildlife Society Bulletin. 16:85-87.

MECH, L. DAVID; STEVEN H. FRITTS; and WILLIAM J. PAUL. 1988. Relationship between winter severity and wolf depredations on domestic animals in Minnesota. The Wildlife Society Bulletin. 16:269-272. (NC)
MECH, L. DAVID; U. S. SEAL; and S. M. ARTHUR. 1984. Recuperation of a severely debilitated wolf. Journal of Wildlife Discovery. 20:166-168. (NC)

MECH, L. DAVID; ULYSSES S. SEAL; and GLENN D. DELGIUDICE. 1987. Use of urine in snow to indicate condition of wolves. Journal of Wildlife Management. $51: 10-13$. (NC)

MUNEER, MOHAMMAD A.; IBRAHIM O. FARAH; KEM A. POMEROY; $M$. GOYAL SAGAR; and L. DAVID MECH. 1988. Detection of parvovirus in wolf feces by electron microscopy. Journal of Wildlife Diseases. 24:170-172. (NC)

O'NEAL, G. TIMOTHY; JERRAN T. FLINDERS; and WARREN P. CLARY. 1987. Behavior ecology of the Nevada kit fox (Vulpes macrotis nevadensis) on a managed desert rangeland. In: Hugh H. Genoways, comp. Current mammalogy; [City and state unknown]: Plenum Publishing Corp: 443-481. Volume 1. (INT)

PACKARD, JANE M.; and DAVID L. MECH. 1983. Population regulation in wolves. In: Bunnell, Fred L.; Donald S. Eastman; and James M. Peek, co-eds.

Symposium on natural regulation of wildlife populations: Proceedings, Northwest Section, The Wildlife Society; 1978 March 10; Vancouver, BC. Proc. 14. Moscow, ID: University of Idaho, Forest, Wildlife and Range Experiment Station: 151-174. (NC)

PACKARD, JANE M.; L. DAVID MECH; and ULYSSES S. SEAL. 1983. Social influences on reproduction in wolves. In: Carbyn, Ludwig N., ed. Wolves in Canada and Alaska: their status, biology, and management: Proceedings: wolf symposium; 1981 May 12-14; Edmonton, AL. Canadian Wildlife Service Rep. Ser. 45. Edmonton, Alberta: Alberta Department of Energy and Natural Resources, Fish and Wildlife Division: 78-86. (NC) 
PACKARD, JANE M.; ULYSSES S. SEAL; L. DAVID MECH; and EDWARD D.

PLOTKA. 1985. Causes of reproductive failure in two family groups of wolves

(Canis lupis). Zeitschrift fuer

Tierpsychologie. 68:24-40. (NC)

PASITSCHNIAK-ARTS, MARIA; MARK E.

TAYLOR; and L. DAVID MECH. 1989.

Note on skeletal injuries in an adult arctic wolf. Arctic and Alpine Research.

20(3):363-365. (NC)

PETERS, ROGER; and L. DAVID MECH. 1978. Scent-marking in wolves. In: Wolf and man. New York, NY: Academic Press Inc.: 133-147. (NC)

RAYMER, J.; D. WIESLER; M. NOVOTNY; C. ASA; U. S. SEAL; and L. D. MECH. 1984. Volatile constituents of wolf (Canis lupus) urine as related to gender and season. Experientia. 40:707-709. (NC)

RAYMER, J.; D. WIESLER; M. NOVOTNY; C. ASA; U. S. SEAL; and L. D. MECH. 1985. Chemical investigations of wolf (Canis lupus) anal-sac secretion in relation to breeding season. Journal of Chemical Ecology. 11:593-608. (NC)

RAYMER, J.; D. WIESLER; M. NOVOTNY; C. ASA; U. S. SEAL; and L. D. MECH. 1986. Chemical scent constituents in urine of wolf (Canis lupis) and their dependence on reproductive hormones. Journal of Chemical Ecology. 12:297314. (NC)

ROGERS, LYNN L. 1988. Homing tendencies of large mammals: a review. In: Nielsen, Leon; and Robert D. Brown, eds.

Translocation of wild animals. Milwaukee, WI: Wisconsin Humane Society, Inc., and Kingsville, TX: Caesar Kleberg Wildlife Research Institute: 7692. (NC)

ROTHMANN, RUSSELL; and L. DAVID MECH. 1979. Scent-making in lone wolves and newly formed pairs. Animal Behaviour. 27:750-760. (NC)
SEAL, ULYSSES S.; EDWARD D. PLOTKA; L. DAVID MECH; and JANE M.

PACKARD. 1987. Seasonal metabolic and reproductive cycles in wolves. In: Frank H., ed. Man and wolf. Dordrect, The Netherlands: Dr. W. Junk Publishers: 109-125. (NC)

SHORT, HENRY L. 1979. Food habits of coyotes in a semidesert grass-shrub habitat. Res. Note RM-364. Fort Collins, CO: U.S. Department of Agriculture, Forest Service, Rocky Mountain Forest and Range Experiment Station. 4 p. (RM)

TOWEILL, DALE E.; CHRIS MASER; MURRAY L. JOHNSON; and LARRY D. BRYANT. 1984. Size and reproductive characteristics of western Oregon cougars. In: Proceedings, 2nd mountain lion workshop; 1984 November 27-29; Salt Lake City, UT. Portland, OR: Utah Division of Wildlife Resources: 176-184. (PNW)

TURKOWSKI, FRANK J. 1980. Carnivora food habits and habitat use in ponderosa pine forests. Res. Pap. RM215. Fort Collins, CO: U.S. Department of Agriculture, Forest Service, Rocky Mountain Forest and Range Experiment Station. 9 p. (RM)

URESK, DANIEL W.; and JON C. SHARPS. 1986. Denning habitat and diet of the swift fox in western South Dakota. Great Basin Naturalist. 46:249-253. (RM)

\section{Amphibian, Reptile, And Their Habitat}

ARENDT, WAYNE J. 1986. An observation of iguana feeding on eggs of the cattle egret (Bubulcus ibis) at Fox's Bay, Montserrat, West Indies: a case of predation or scavenging? Caribbean Journal of Science. 22:221-222. (SO) 
ARENDT, WAYNE J. 1986. Bat predation by the St. Lucia boa (Boa constrictor orophias). Caribbean Journal of Science. 22:219-220. (SO)

AUBRY, KEITH B.; L. C. LAWRENCE; and PARTICIA A. HALL. 1988. Use of woody debris by Plethodontid salamanders in Douglas-fir forests in Washington. In: Managment of amphibians, reptiles, and small mammals in North America. 1988 July 19-21; Flaagstaff, AZ. Gen. Tech. Rep. RM-166. Fort Collins, CO: U.S. Department of Agriculture, Forest Service, Rocky Mountain Forest and Range Experiment Station: 32-37. (PNW)

DEGRAAF, RICHARD M.; and DEBORAH D. RUDIS. 1981. Forest habitat for reptiles and amphibians of the Northeast. Broomall, PA: U.S. Department of Agriculture, Forest Service, Northeastern Forest Experiment Station, Milwaukee, WI: U.S. Department of Agriculture, Forest Service, Eastern Region. 239 p. (NE)

DEGRAAF, RICHARD M.; and DEBORAH D. RUDIS. 1983. Amphibians and reptiles of New England: Habitats and natural history. Amherst, MA: University of Massachusetts Press. 85 p. (NE)

ELICK, GERALD E.; JOHN A. SEALANDER; and RONALD J. BEUMER. 1979. Temperature preferenda, body temperature tolerances, and habitat selection of small colubrid snakes. Transactions Missouri Academy of Science. 13:21-31. (NC)

HARISTON, NELSON G. 1980. Species packing in the salamander genus Desmogna thus: what are the interspecific interactions involved? American Naturalist. 115:354-366.

JONES, LAWRENCE L. C.; and KEITH B. AUBRY. 1984. Dicamptodon copei (Cope's giant salamander). Herpetological Review. 15(4):114.
JONES, LAWRENCE L. C.; and MARTIN G. RAPHAEL. 1989. Plethodon elongatus elongatus (striped Del Norte salamander). Herpetological Review. 20(1):11. (PNW)

LOHOEFENER, REN. 1982. Gopher tortoise ecology and land-use practices in southern DeSoto National Forest, Harrison County, Mississippi. In: Franz, Richard; and Rhoda J. Brant, eds. The gopher tortoise and its sandhill habitat: Proceedings, 3rd annual meeting of the gopher tortoise council; 1982 October 30; Tallahassee, FL. Gainesville, FL: Florida State Museum: 50-74. (SO)

PEARSON, HENRY A.; RENNE R. LOHOEFENER; and JAMES L. WOLFE. 1987. Amphibians and reptiles on longleaf-slash pine forests in southern Mississippi. In: Pearson, Henry A.; Fred Smeins; and Ronald E. Thill, comps. 1987. Ecological, physical, and socioeconomic relationships within southern National Forests: Proceedings of the southern evaluation project workshop; 1987 May 26-27; Long Beach, MS. Gen. Tech. Rep. SO-68. New Orleans, LA: U.S. Department of Agriculture, Forest Service, Southern Forest Experiment Station: 157-165. (SO)

RAPHAEL, MARTIN G. 1988. Long-term trends in abundance of amphibians, reptiles, and mammals in Douglas-fir forests of Northwestern Oregon. In: Szaro, Robert C.; Kieth E. Severson; and David R. Patton, tech. coords. Management of amphibians, reptiles, and small mammals in North America: Proceedings of the symposium; 1988 July 19-21; Flagstaff, AZ. Gen. Tech. Rep. RM-166. Fort Collins, CO: U.S. Department of Agriculture, Forest Service, Rocky Mountain Forest and Range Experiment Station: 23-31. (RM)

SOUTHERLAND, MARK T. 1986 . The effects of variation in streamside habitats on the composition of mountain salamander communities. Copeia. 1986:731-741. (SE) 
SZARO, ROBERT C. 1988. The management of amphibians, reptiles, and small mammals in North America: Historical perspective and objectives. In: Szaro, Robert C.; Kieth E. Severson; and David R. Patton, tech. coords. Management of amphibians, reptiles, and small mammals in North America:

Proceedings of the symposium; 1988 July 19-21; Flagstaff, AZ. Gen. Tech. Rep. RM-166. Fort Collins, CO: U.S. Department of Agriculture, Forest Service, Rocky Mountain Forest and Range Experiment Station: 1-3. (RM)

SZARO, ROBERT C.; and SCOTT C. BELFIT. 1986. Herpetofaunal use of a desert riparian island and its adjacent scrub habitat. Journal of Wildlife Management. 50:752-761. (RM)

SZARO, ROBERT C.; KIETH E. SEVERSON; and DAVID R. PATTON, tech. coords. 1988. Management of amphibians, reptiles, and small mammals in North America. Proceedings of the symposium; 1988 July 19-21; Flagstaff, AZ. Gen. Tech. Rep. RM-166. Fort Collins, CO: U.S. Department of Agriculture, Forest Service, Rocky Mountain Forest and Range Experiment Station. 458 p. (RM)

WELSH, HARTWELL H., JR. 1988. A ecogeographic analysis of the herpetofauna of the Sierra San Pedro Martir Region, Baja California, with a contribution to the biogeography of the Baja California herpetofauna.

Proceedings of the California Academy of Sciences. 46(1):1-72. (PSW)

WHITAKER, JOHN O., JR.; CHRIS MASER; ROBERT M. STORM; and JOSEPH J. BEATTY. 1986. Food habits of clouded salamanders (Aneides ferreus) in Curry County, Oregon (Amphibia: Caudata: Plethodontidae). Great Basin Naturalist. 46:228-249. (PNW)
WHITAKER, JOHN O., JR.; STEPHEN P. CROSS; JOHN M. SKOVLIN; and CHRIS MASER. 1983. Food habits of the spotted frog (Rana pretiosa) from managed sites in Grant County, Oregon. Northwest Science. 57(2):147-154. (PNW)

\section{Monitoring Terrestrial Wildlife}

BEASOM, SAMUEL L.; JEFFREY C. HOOD; and J. RICHARD CAIN. 1981. The effect of strip width on helicopter censusing of deer. Journal of Range Management. 34:36-37. (RM)

BUECH, RICHARD R. 1985. Methodologies for observing beavers (Castor canadensis) during the activity period. In: Brooks, Robert P., ed. Nocturnal mammals: techniques for study: Proceedings of a workshop; 1985 August; Edmonton, AB. Resour. Res. Pap. 48. University Park, PA: The Pennsylvania State University, School of Forest Resources: 29-34. (NC)

BULL, EVELYN L. 1981. Indirect estimates of abundance of birds. In: Ralph, C. John; and J. Michael Scott, eds. Estimating numbers of terrestrial birds: Proceedings of an international symposium; 1980 October 26-31; Asilomar, CA. Studies in Avian Biology No. 6. Cooper Ornithological Society: 76-80. (PNW)

BURY, R. BRUCE; and MARTIN G.

RAPHAEL. 1983. Inventory methods for amphibians and reptiles. In: Bell, John F.; and Toby Atterbury, eds. Renewable resource inventories for monitoring changes and trends: Proceedings of an international conference; 1983 August 15-19; Corvallis, OR. SAF 83-14. Corvallis, OR: Oregon State University, College of Forestry: 416-419. (PSW) 
CANDIELD, JODIE E.; L. JACK LYON; and J. MICHAEL HILLIS. 1986. The influence of viewing angle on elk hiding cover in young timber stands. Res. Pap. INT371. Ogden, UT: U.S. Department of Agriculture, Forest Service, Intermountain Forest and Range Experiment Station. 6 p. (INT)

\section{CAREY, ANDREW B. 1983. Monitoring} diurnal, cavity-using bird populations. In: Davis, Jerry W.; Gregory A. Goodwin; and Richard A. Ockenfels, tech. coords. Snag habitat management: Proceedings of the symposium; 1983 June 7-9; Flagstaff, AZ. Gen. Tech. Rep. RM-99. Fort Collins, CO: U.S. Department of Agriculture, Forest Service, Rocky Mountain Forest and Range Experiment Station: 188-199. (NE)

CAREY, ANDREW B.; ANDREW J. MAIN, JR.; and MARION G. CAREY. 1981. Sampling populations of small mammals in Connecticut forests. Northeast fish and wildlife. In: Proceedings, Northeast fish and wildlife conference; 1981 April 19-22; Virginia Beach, VA: 90-104. (NE)

CHEPKO-SADE, B. DIANE; WILLIAM M. SHIELDS; JOEL BERGER; ZULEYMA TANG-HALPIN; W. THOMAS JONES; LYNN L. ROGERS; JON P. ROOD; and ANDREW T. SMITH. 1987. The effect of dispersal and social structure on effective population size. In: ChepkoSade, B. Diane; and Zuleyma TangHalpin, eds. Mammalian dispersal patterns: the effects of social structure on population genetics. Chicago, IL: The University of Chicago Press: 287-381. (NC)

CONANT, SHEILA; MARK S. COLLINS; and C. JOHN RALPH. 1981. Effects of observers using different methods upon the total population estimates of two resident island birds. In: Ralph, C. John; and J. Michael Scott, eds. Estimating numbers of terrestrial birds: Proceedings of an international symposium; 1980 October 26-31; Asilomar, CA. Studies in Avian Biology No. 6. Cooper Ornithological Society: 377-381. (PSW)
CONNER, RICHARD N.; and JAMES G. DICKSON. 1980. Strip transect sampling and analysis for avian habitat studies. The Wildlife Society Bulletin. 8:4-10. (SO)

CZAPLEWSKI, R.; D. CROWE; and L. MCDONALD. 1983. Sample sizes and confidence intervals for wildlife population ratios. The Wildlife Society Bulletin. 1:121-128. (RM)

DICKSON, JAMES G. 1982. Birds in bottomland hardwood forests. In: Davis, David E., ed. CRC handbook of census methods for terrestrial vertebrates. Boca Raton, FL: CRC Press, Inc.: 299-300. (SO)

DOWNING, R. L. 1980. Vital statistics of animal populations. In: Schemnitz, S. D., ed. Wildlife management techniques manual; 4th ed. Washington, DC: The Wildlife Society: 247-267. Chapter 15. (SO)

FINCH, DEBORAH M. 1985. Multivariate analysis of early and late nest sites of Abert's towhees. Southwestern Naturalist. 30:427-432. (RM)

FITZNER, R. E.; L. E. ROGERS; and D. W. URESK. 1978. Techniques useful for determining raptor prey-species abundance. Journal of Raptor Research. $11: 67-71$. (RM)

FLOYD, THEODORE J.; L. D. MECH; and M. E. NELSON. 1982. Deer in forested areas. In: Davis, David E., ed. CRC handbook of census methods for terrestrial vertebrates. Boca Raton, FL: CRC Press, Inc.: 254-256. (NC)

FLOYD, THEODORE J.; L. DAVID MECH; and MICHAEL E. NELSON. 1979. An improved method of censusing deer in deciduous-coniferous forests. Journal of Wildlife Management. 43:258-261. (NC) 
FORSMAN, ERIC D. 1984. Methods and materials for locating and studying spotted owls. Gen. Tech. Rep. PNW162. Portland, OR: U.S. Department of Agriculture, Forest Service, Pacific Northwest Forest and Range Experiment Station. 8 p. (PNW)

HAMEL, P. B. 1984. Comparison of variable circular-plot and spot-map censusing methods in temperate deciduous forest. Ornis Scandinavica. 15:266-274. (SE)

HAMEL, PAUL B.; NOEL D. COST; and RAYMOND M. SHEFFIELD. 1986. The consistent characteristics of habitats: a question of scale. In: Verner, Jared; Michael L. Morrison; and C. John Ralph, eds. Wildlife 2000: modeling habitat relationships of terrestrial vertebrates; 1984 October 7-11; Fallen Leaf Lake, CA. Madison, WI: The University of Wisconsin Press: 121-127. (SE)

HANKIN, D. G. 1986. Sampling designs for estimating the total number of fish in small streams. Res. Pap. PNW-360. Portland, OR: U.S. Department of Agriculture, Forest Service, Pacific Northwest Forest and Range Experiment Station. 33 p. (PNW)

HARSHBARGER, THOMAS J. 1984. Fish census. In: Wenger, Karl F., ed. Forestry handbook. 2nd ed. New York, NY: John Wiley \& Sons: 706-708. (SE)

JOHNSON, MARK K.; LEE G. DAVIS; KENNETH F. RIBBECK; and HENRY A. PERASON. 1987. Cross-country track stations for indexing wildlife populations. In: Pearson, Henry A.; Fred Smeins; and Ronald E. Thill, comps. 1987. Ecological, physical, and socioeconomic relationships within southern National Forests: Proceedings of the southern evaluation project workshop; 1987 May 26-27; Long Beach, MS. Gen. Tech. Rep. SO-68. New Orleans, LA: U.S. Department of Agriculture, Forest Service, Southern Forest Experiment Station: 138-143. (SO)
KIE, JOHN G. 1987. Measures of wild ungulate performance: population density and condition of individuals. In: Symposium proceedings, monitoring animal performance and poduction; 1987 February 12; Boise, ID. Denver, CO: Society for Range Management: 23-26. (PSW)

KIE, JOHN G. 1988. Performance in wild ungulates: measuring population density and condition of individuals. Gen. Tech. Rep. PSW-106. Berkeley, CA: U.S. Department of Agriculture, Forest Service, Pacific Southwest Forest and Range Experiment Station. 17 p. (PSW)

LAYMON, STEPHEN A.; and JANICE A. REID. 1986. Effects of grid-cell size on tests of a spotted owl HSI model. In: Verner, Jared; Michael L. Morrison; C. John Ralph, eds. Wildlife 2000: Modeling habitat relationships of terrestrial vertebrates; 1984 October 711; Fallen Leaf, CA. Madison, WI: The University of Wisconsin Press: 93-96. (PSW)

LENNARTZ, MICHAEL R.; and JOE DEAN METTEAUER. 1987. Test of a population estimation technique for redcockaded woodpeckers. Proceedings of the Annual Conference of the Southeastern Association Fish and Wildlife Agencies. 40:320-324. (SE)

MILLER, STEPHEN A. 1982. Problems in standardizing animal production capability. In: In-place resource inventories: principles and practices: Proceedings of a national workshop; 1981 August 9-14; Orono, ME. SAF 8202. Bethesda, MD: Society of American Foresters: 607-610. (RM)

MILLER, STEPHEN A. 1984. Estimation of animal production numbers for national assessments and appraisals. Gen. Tech. Rep. RM-105. Fort Collins, CO: U.S. Department of Agriculture, Forest Service, Rocky Mountain Forest and Range Experiment Station. 23 p. (RM) 
O'MEARA, TIMOTHY E. 1981. A field test of two density estimators for transect data. In: Ralph, C. John; and J. Michael Scott, eds. Estimating numbers of terrestrial birds: Proceedings of an international symposium; 1980 October 26-31; Asilomar, CA. Studies in Avian Biology No. 6. Cooper Ornithological Society: 193-196.

RALPH, C. JOHN. 1981. Terminology used in estimating numbers of birds. In: Ralph, C. John; and J. Michael Scott, eds. Estimating numbers of terrestrial birds: Proceedings of an international symposium; 1980 October $26-31$; Asilomar, CA. Studies in Avian Biology No. 6. Cooper Ornithological Society: 577-578. (PSW)

RALPH, C. JOHN.; and J. MICHAEL SCOTT, eds. 1981. Estimating numbers of terrestrial birds. Proceedings of an international symposium; 1980 October 26-31; Asilomar, CA. Studies in Avian Biology No. 6. Cooper Ornithological Society. 640 p. (PSW)

RAPHAEL, MARTIN G. 1987. Estimating relative abundance of forest birds: simple versus adjusted counts. Wilson Bulletin. 99:125-131. (RM)

RAPHAEL, MARTIN G. 1988. A portable computer-compatible system for collecting bird count data. Journal of Field Ornithology. 59:280-285. (RM)

RAPHAEL, MARTIN G. 1988. A portable data-acquisition system for recording wildlife counts. In: Buhyoff, Gregory J., ed. Proceedings, resource technology 88: international symposium on advanced technology in natural resource management; 1988 June 20-23; Fort Collins, CO. Falls Church, VA: American Society for Photogrammetry and Remote Sensing: 234-235. (RM)
RAPHAEL, MARTIN G.; and BRUCE G. MARCOT. 1986. Validation of a wildlifehabitat-relationships model: vertebrates in a Douglas-fir sere. In: Verner, Jared; Michael L. Morrison; and C. John Ralph, eds. Wildlife 2000: modeling habitat relationships of terrestrial vertebrates; 1984 October 7-11; Fallen Leaf Lake, CA. Madison, WI: The University of Wisconsin Press: 129-138. (RM)

RAPHAEL, MARTIN G.; and KENNETH V. ROSENBERG. 1983. An integrated approach to wildlife inventories in forested habitats. In: Bell, John F.; and Toby Atterbury, eds. SAF 83-14. Renewable resource inventories for monitoring changes and trends. Proceedings of an international conference; 1983 August 15-19; Corvallis, OR. Corvallis, OR: College of Forestry, Oregon State University: 219222. (PSW)

RAPHAEL, MARTIN G.; CATHY A. TAYLOR; and REGINALD H. BARRETT. 1986. Smoked aluminum track stations record flying squirrel occurrence. Res. Note PSW-384. Berkeley, CA: U.S. Department of Agriculture, Forest Service, Pacific Southwest Forest and Range Experiment Station. 3 p. (PSW)

REYNOLDS, R. T.; J. M. SCOTT; and R. A. NUSSBAUM. 1980. A variable circularplot method for estimating bird numbers. The Condor. 82:309-313. (RM)

REYNOLDS, RICHARD T. 1982. North American accipiter hawks. In: Davis, David E., ed. CRC handbook of census methods for terrestrial vertebrates. Boca Raton, FL: CRC Press Inc.: 288-289. (RM) 
RINNE, JOHN N. 1978. Development and applicability of methods of population estimation and habitat evaluation for management of the Arizona and Gila trouts. In: Moring, John R., ed.

Proceedings, wild trout-catchable trout symposium. 1978 February 15-17;

Eugene, OR; Oregon Department Fish and Wildlife, Resource and

Development Section: 113-125. (RM)

RUMBLE, MARK A.; and LESTER D. FLAKE, 1982. A comparison of two waterfowl brood survey techniques. Journal of Wildlife Management. 4:1048-1053.(RM)

SALWASSER, HAL. 1986. Modeling habitat relationships of terrestrial vertebrates-the manager's viewpoint. In: Verner, Jared; Michael L. Morrison; and C. John Ralph, eds. Wildlife 2000: modeling habitat relationships of terrestrial vertebrates; 1984 October 7-11; Fallen Leaf Lake, CA. Madison, WI: The University of Wisconsin Press: 419-424. (WO)

SCHENBECK, GREG L.; and RICHARD J. MYHRE. 1986. Aerial photography for assessment of black-tailed prairie dog management on the Buffalo Gap National Grassland, South Dakota. Rep. 86-7. Fort Collins, CO: U.S. Department of Agriculture, Forest Service, Forest Pest Management, Methods Application Group. 15 p. (WO)

SCOTT, J. MICHAEL; and C. JOHN RALPH. 1981. Introduction. In: Ralph, C. John; and J. Michael Scott, eds. Estimating numbers of terrestrial birds: Proceedings of an international symposium; 1980 October 26-31; Asilomar, CA. Studies in Avian Biology No. 6. Cooper Ornithological Society: 1-2. (PSW)
STORMER, FRED A.; and DOUGLAS H. JOHNSON. 1986. Introduction:

Biometric approaches to modeling. In:

Verner, Jared; Michael L. Morrison; and C. John Ralph, eds. Wildlife 2000: modeling habitat relationships of terrestrial vertebrates; 1984 October 7 11; Fallen Leaf Lake, CA. Madison, WI: The University of Wisconsin Press: 159160. (WO)

SWEENEY, J. M. 1985. Estimating wildlife production with habitat models. CalNeva Wildlife Transactions. 1984:50-54. (NC)

SZARO, ROBERT C.; and MARTIN D. JAKLE. 1982. Comparison of varible circular-plot and spot-map methods in desert riparian and scrub habitats. Wilson Bulletin. 94(4):546-550. (RM)

SZARO, ROBERT C.; and RUSSELL P. BALDA. 1982. Selection and monitoring of avian indicator species: an example from a ponderosa pine forest in the Southwest. Gen. Tech. Rep. RM-89. Fort Collins, CO: U.S. Department of Agriculture, Forest Service, Rocky Mountain Forest and Range Experiment Station. 8 p. (RM)

SZARO, ROBERT C.; SCOTT C. BELFIT; J. KEVIN AITKIN; and RANDALL D. BABB. 1988. The use of timed fixedarea plots and a mark-recapture technique in assessing riparian garter snake populations. In: Szaro, Robert C.; Kieth E. Severson; and David R. Patton, tech. coords. Management of amphibians, reptiles, and small mammals in North America:

Proceedings of the symposium; 1988 July 19-21; Flagstaff, AZ. Gen. Tech. Rep. RM-166. Fort Collins, CO: U.S. Department of Agriculture, Forest Service, Rocky Mountain Forest and Range Experiment Station: 239-246. (RM) 
THOMAS, DONALD W.; and STEPHEN D. WEST. 1984. On the use of ultrasonic detectors for bat species identification and the calibration of QMC mini bat detectors. Canadian Journal of Zoology. 62:2677-2679.

TILGHMAN, NANCY G.; and DONALD H. RUSCH. 1981. Comparison of linetransect methods for estimating breeding bird densities in deciduous woodlots. In: Ralph, C. John; and J. Michael Scott, eds. Estimating numbers of terrestrial birds: Proceedings of an international symposium; 1980 October 26-31; Asilomar, CA. Studies in Avian Biology No. 6. Cooper Ornithological Society: 202-208. (NC)

VERNER, JARED. 1981. Measuring responses of avian communities to habitat manipulation. In: Ralph, C. John; and J. Michael Scott, eds. Proceedings of the symposium on estimating numbers of terrestrial birds; 1980 October 26-31; Asilomar, CA. Studies in Avian Biology No.6. Cooper Ornithological Society: 543-547. (PSW)

VERNER, JARED. 1981. Sampling design: Chairman's introductory remarks. In: Ralph, C. John; and J. Michael Scott, eds. Proceedings of the symposium on estimating numbers of terrestrial birds; 1980 October 26-31; Asilomar, CA. Studies in Avian Biology No. 6. Cooper Ornithological Society: 391. (PSW)

VERNER, JARED. 1983. An integrated system for monitoring wildlife on the Sierra National Forest. Transactions of the North American Wildlife and Natural Resources Conference. 48:355-366. (PSW)

VERNER, JARED. 1984. The guild concept applied to management of bird populations. Environmental Management. 8(1):1-14. (PSW)
VERNER, JARED. 1986. Future trends in management of nongame wildlife: $A$ researcher's viewpoint. In: Management of nongame wildlife in the midwest: a developing art; 1985 December 17; Grand Rapids, Ml. 47th Midwest Fish and Wildlife Conference: 149-171. (PSW)

VERNER, JARED. 1988. Optimizing the duration of point counts for monitoring trends in bird populations. Res. Note PSW-395. Berkeley, CA: U.S. Department of Agriculture, Forest Service, Pacific Southwest Forest and Range Experiment Station. 4 p. (PSW)

VERNER, JARED; and LYMAN V. RITTER. 1986. Hourly variation in morning point counts of birds. The Auk. 103:117-124. (PSW)

VERNER, JARED; and LYMAN V. RITTER. 1988. A comparison of transects and spot mapping in oak-pine woodlands of California. The Condor. 90:401-419. (PSW)

VERNER, JARED; and ROBERT N. LEHMAN. 1982. Identifying individual bald eagles with voiceprints: a feasibility study. Res. Note PSW-359. Berkeley, CA: U.S. Department of Agriculture, Forest Service, Pacific Southwest Forest and Range Experiment Station. 5 p. (PSW)

VERNER, JARED; MICHAEL L. MORRISON; and C. JOHN RALPH. 1986. Introduction. In: Verner, Jared; Michael L. Morrison; and C. John Ralph, eds. Wildlife 2000: modeling habitat relationships of terrestrial vertebrates; 1984 October 7-11; Fallen Leaf Lake, CA. Madison, WI: The University of Wisconsin Press: xi-xv. (PSW) 
WHITING, R. MONTAGUE, JR.; ROBERT R. FLEET; and HENRY A. PEARSON. 1983. Implementing and maintaining a system to monitor small mammal and bird populations. In: Bell, John F.; and Toby Atterbury, eds. Renewable resource inventories for monitoring changes and trends. Proceedings of the international conference; 1983 August 15-19; Corvallis, OR. SAF 83-14. Bethesda, MD: Society of American Foresters: 420-423. (SO)

\section{Vertebrate Capture Techniques}

BALDASSARE, GUY A.; RICHARD J. WHYTE; and ERIC G. BOLEN. 1980. Patagial tags for pintails wintering on the southern High Plains of Texas. Inland Bird Banding. 52(2):13-18. (RM)

BALDASSARRE, GUY A.; RICHARD J. WHYTE; and ERIC G. BOLEN. 1980. Use of ultrasonic sound to estimate body fat depots in the mallard. Prairie Naturalist. 12:79-86. (RM)

BOWDEN, DAVID C.; ALLEN E. ANDERSON; and DEAN E. MEDIN. 1984. Sampling plans for mule deer sex and age ratios. Journal of Wildlife Management. 48:500-509. (INT)

BRACK, VIRGIL, JR.; and RUSSELL E. MUMFORD. 1983. Mist netting: a technique for flying squirrel capture. Indiana Audubon Quarterly. 61(2):80-81. (NC)

BRAUN HILL, S. E.; and DANIEL F. WILLIAMS. 1986. A method for determining optimum distance between traps on line transects. Acta Treriologica. 31:353-358. (PSW)

BRYANT, MASON D.; and WILLIAM J. WALKOTTEN. 1980. Carbon dioxide freeze-branding device for use on juvenile salmonids. Progressive FishCulturist. 42:55-56. (PNW)
BUECH, RICHARD R. 1983. Modification of the Bailey live trap for beaver. The Wildlife Society Bulletin. 11:66-68. (NC)

BULL, EVELYN L.; ; and RICHARD J. PEDERSEN. 1978. Two methods of trapping adult pileated woodpeckers at their nest cavities. North American Bird Bander. 3:95-99. (PNW)

BURY, R. BRUCE; and PAUL STEPHEN CORN. 1987. Evaluation of pitfall trapping in Northwestern forests: trap arrays with drift fences. Journal of Wildlife Management. 51:112-119. (PNW)

CAREY, ANDREW B.; SCOTT P. HORTON; and JANICE A REID. 1989. Optimal sampling for radiotelemetry studies of spotted owl habitat and home range. Res. Pap. PNW-416. Portland, OR: U.S. Department of Agriculture, Forest Service, Pacific Northwest Research Station. 17 p. (PNW)

CARPENTER, L. H.; D. REICHERT; and F. WOLFE, JR. 1977. Lighted collars to aid night observations of mule deer. Res. Note RM-338. Fort Collins, CO: U.S. Department of Agriculture, Forest Service, Rocky Mountain Forest and Range Experiment Station. 4 p. (RM)

CHAPMAN, RICHARD C.; MICHAEL E. HAMERLY; and L. DAVID MECH. 1985. A microcomputer-based capture collar. In: Weeks, Richard W.; and Francis M. Long, eds. Proceedings, 5th international conference on wildlife biotelemetry; Chicago, IL: International Conference on Wildlife Biotelemetry: 7884. (NC)

CONNER, RICHARD N.; JAMES G. DICKSON; and J. HOWARD WILLIAMSON. 1983. A comparison of breeding bird census techniques with mist netting results. Wilson Bulletin. 95:276-280. (SO) 
CUPAL, J. J. 1977. A portable, microprocessor based heart-rate and animal activity recorder for use with biotelemetry. In: Proceedings, 1st international conference on wildlife biotelemetry; 1977 July 27-29, Laramie, WY: University of Wyoming: 9-14. (RM)

CUPAL, J. J. 1977. A transmitter identifier for use with wildlife biotelemetry. In:

Proceedings, 1st international conference on wild life biotelemetry; 1977 July 27-29, Laramie, WY: University of Wyoming: 22-29. (RM)

CUPAL, J. J.; R. W. WEEKS; and C. KALTENBACK. 1976. A heart-rateactivity biotelemetry system for use on wild big game animals. In: 3rd international conference on wildlife biotelemetry; 1976 May 17-20; Pacific Grove, CA: 219-222. (RM)

DICKSON, JAMES G.; RICHARD N. CONNER; and J. HOWARD WILLIAMSON. 1982. An evaluation of techniques for marking cardinals. Journal Field Ornithology. 53:420-42I. (SO)

EARLE, RICHARD D.; and KENNETH R. KRAMM. 1980. Techniques for age determination in the Canadian porcupine. Journal of Wildlife Management. 44:413-419. (NC)

EVEREST, F. H. 1978. Diver-operated device for immobilizing fish with a small explosive charge. Progressive FishCulturist. 40:I2l-I22. (PNW)

GRUBB, TERYL G. 1988. A portable rocketnet system for capturing wildlife. Res. Note RM-484. Fort Collins, CO; U.S. Department of Agriculture, Forest Service, Rocky Mountain Forest and Range Experiment Station. 8 p. (RM)
GRUBB, TERYL G.; and WADE L. EAKLE. 1988. Recording wildlife locations with the Universal Transverse Mercator (UTM) grid system. Res. Note RM-483. Fort Collins, CO; U.S. Department of Agriculture, Forest Service, Rocky Mountain Forest and Range Experiment Station. 3 p. (RM)

HARSHBARGER, THOMAS J. 1979. Scraping improves silver nitrate brands on trout. Progressive Fish-Culturist. 41:209. (SE)

HOSKINSON, REED L. 1976. The effect of different pilots on aerial telemetry error. Journal of Wildlife Management. 40:137139. (NC)

KIMMEL, RICHARD O.; and WILLIAM M. HEALY. 1987. Imprinting: A technique for wildlife research. In: Perdix IV: Gray partridge workshop; 1986 September 29-October 4; Regina, Saskatchewan. Madelia, MN: Minnesota Department of Natural Resources: 39-52. (NE)

KOELN, GREGORY T. 1980. A computer technique for analyzing radiotelemetry data. In: Proceedings, 4th national wild turkey symposium; Arkansas chapter, Wildlife Society: 262-271. (RM)

LOHOEFENER, REN; and JIM WOLFE. 1984. A "new" live trap and a comparison with a pitfall trap. Herp Review. 15(1):25-26. (SO)

MASER, CHRIS; ROBERT E. KINDSCHY; and VERN ATKINS. 1978. A field ice box. Tech. Note T/N 320. U.S. Department of the Interior, Bureau of Land Management. 3 p. (PNW)

MECH, L. D. 1982. Wolves (radio-tracking). In: Davis, David E., ed. CRC handbook of census methods for terrestrial vertebrates. Boca Raton, FL: CRC Press, Inc.: 227-228. (NC)

MECH, L. DAVID. 1984. Handbook of animal radio-tracking. University Handbook. Minneapolis, MN: University of Minnesota Press. 107 p. (NC) 
MECH, L. DAVID; GLENN D. DELGUIDICE;

PATRICK D. KARNS; and ULYSSIS S.

SEAL. 1985. Yohimbine hydrochloride

as an antagonist to xylazine

hydrochloride-ketamine hydrochloride

immobilization of white-tailed deer.

Journal of Wildlife Diseases. 21:405-

410. (NC)

MECH, L. DAVID; RICHARD C. CHAPMAN; WILLIAM W. COCHRAN; LEE SIMMONS; and ULYSESS S. SEAL. 1984. Radio-triggered anesthetic-dart collar for recapturing large mammals. The Wildlife Society Bulletin. 12:69-74. (NC)

MEDINA, ALVIN L.; and H. DWAIN SMITH. 1986. Designs for an antenna boom and masts for telemetry applications. The Wildlife Society Bulletin. 14:291-297. (RM)

NICHOLLS, THOMAS H.; and MARK R. FULLER. 1987. Owl telemetry techniques. In: Nero, Robert W.; Richard J. Clark; Richard J. Knapton; and R. H. Hamre, eds. Biology and conservation of northern forest owls: symposium proceedings; 1987 February 3-7; Winnipeg, Canada. Gen. Tech. Rep. RM-142. Fort Collins, CO: U.S. Department of Agriculture, Forest Service, Rocky Mountain Forest and Range Experiment Station: 294-301. (NC)

PATON, PETER W. C.; and LARRY PANK. 1986. A technique to mark incubating birds. Journal of Field Ornithology. 57:232-233. (PSW)

PATTON, K. T.; W. C. CRAWFORD, JR.; and W. SAWYER. 1985. Telemetry of heart rates in large raptors: a method of transmitter and electrode placement. Journal of Raptor Research. 18:59-61. (NC)
PLATTS, WILLIAM S.; and VANCE E. PENTON. 1980. A new freezing technique for salmonid redds. Res. Pap. INT-248. Ogden, UT: U.S. Department of Agriculture, Forest Service, Intermountain Forest and Range Experiment Station. 22 p. (INT)

REYNOLDS, RICHARD T.; and BRIAN D. LINKHART. 1984. Methods and materials for capturing and monitoring flammulated owls. Great Basin Natural. 44:49-51. (RM)

RINNE, JOHN N. 1985. Notes on collecting and photographing of fishes in northern Mexico, June 1981. In: Proceedings of desert fishes council; 1981 November 19-21; Furnace Creek, CA. Bishop, CA: Desert Fishes Council: 8-15 \& 22-28. (RM)

RINNE, JOHN N.; and MARTIN D. JAKLE. 1981. The photarium: a device for taking natural photographs of live fish.

Progressive Fish-Culturist. 43:201-204. (RM)

RINNE, JOHN N.; and SCOTT C. BELFIT. 1985. Notes on collecting and photographing of fishes in Sonora and Chihuahua, Mexico, June 1982. In: Proceedings of the desert fishes council; 1982 November 18-20; Tempe, AZ. Bishop, CA: Desert Fishes Council: 8-15 \& 138-150. (RM)

ROGERS, L. L. 1986. Homing by radiocollared black bears (Ursus americanus) in Minnesota. Canadian Field-Naturalist. 100:350-353. (NC)

ROGERS, L. L.; C. M. STOWE; and A. W. ERICKSON. 1976. Succinylcholine chloride immobilization of black bears. In: International conference on bear research and management. 3:431-436. (NC)

RUMBLE, M. A.; and D. A. DENISON. 1986. An alternative technique for attaching thermoluminescent dosimeters to small mammals. Health Physics. 51:245-248. (RM) 
SAKAI, HOWARD F.; and C. DAVID JENKINS. 1983. Capturing the endangered Hawaiian crow with mist nets. North American Bird Bander. 8(2):54-55. (PSW)

SCHUMACHER, ROBERT W.; CARROLL J. PERKINS; ALFRED D. SULLIVAN; and DAVID E. WESLEY. 1978. Heatshrinkable tubing as a means of securing harness knots. Journal of Wildlife Management. 42:685-686. (SO)

SCHUMACHER, ROBERT W.; GREGORY T. KOELN; BENTLY WIGLEY; and DAVID E. WESLEY. 1977. Wild turkey nest location using telemetry. In Proceeding, 1st international conference on wildlife biotelemetry: 101-108. (SO)

SHORT, HENRY L. 1978. Analysis of cuticular scales on hairs using the scanning electron microscope. Journal of Mammalogy. 59:261-268. (RM)

SMITH, H. DWAIN; FRED A. STORMER; and RALPH D. GODFREY. 1981. A collapsible quail trap. Res. Note RM400. Fort Collins, CO: U.S. Department of Agriculture, Forest Service, Rocky Mountain Forest and Range Experiment Station. 3 p. (RM)

SMITH, H. R. 1980. Intraperitoneal transmitter implants in suckling white-footed mice, Peromyscus leucopus. Biotelemetry and Patient Monitoring, Volume 7, Special Issue. S. Karger AG, Basel, Switzerland. (NC)

STEGER, GEORGE N.; and DONALD L. NEAL. 1981. Night lightning: a technique to locate and capture fawns. Cal-Neva Wildlife Transactions. 1981:155-158. (PSW)

STONER, D. L.; A. P. LUCINDO; J. W. STUTH; [and others]. 1980. An implantable telemetry system for monitoring grazing dynamics of wild and domestic ungulates. Biomedical Sciences Instrumentation. 16:123:128. (SO)
STONER D. L.; J. F. HUNTER; J. W. STUTH; and H. A. PEARSON. 1979. Transduction of changes in esophageal geometry associated with swallowing. In: Proceedings, Rocky Mountain bioengineering symposium; 1979 April; Denver, CO: 113-116. (SO)

STUTH, J. W.; K. J. KANOUSE; J. F. HUNTER; and H. A. PEARSON. 1981. Multiple electrode impedance plethysmography system for monitoring grazing dynamics. Biomedical Sciences Instrumentation. 17:121-124. (SO)

SZARO, ROBERT C.; LEE H. SIMONS; and SCOTT C. BELFIT. 1988. Comparative effectiveness of pitfalls and live-traps in measuring small mammal community structure. In: Szaro, Robert C.; Kieth E. Severson; and David R. Patton, tech. coords. Management of amphibians, reptiles, and small mammals in North America: Proceedings of the symposium; 1988 July 19-21; Flagstaff, AZ. Gen. Tech. Rep. RM-166. Fort Collins, CO: U.S. Department of Agriculture, Forest Service, Rocky Mountain Forest and Range Experiment Station: 282-288. (RM)

VAN HORNE, BEATRICE. 1982. Effective trapped area for live-trap grids. Journal of Mammalogy. 63:155-157.

VANDEVENTER, JOHN S.; and WILLIAM S. PLATTS. 1983. Sampling and estimating fish populations from streams. Transactions of the North American Wildlife and Natural Resources Conference. 48:349-354. (INT)

VERNER, JARED; and ROBERT N. LEHMAN. 1982. Identifying individual bald eagles with voiceprints: a feasibility study. Res. Note PSW-359. Berkeley, CA: U.S. Department of Agriculture, Forest Service, Pacific Southwest Forest and Range Experiment Station. 5 p. (PSW) 
WEEKS, R. W.; F. M. LONG; and J. J. CUPAL. 1977. An improved repeater heart-rate system for use on wildlife. In:

Proceedings, 1st international conference on wildlife biotelemetry; 1977 July 27-29, Laramie, WY: University of Wyoming: 2-5. (RM)

WEST, S. D. 1985. Differential capture between old and new models of the museum snap-trap. Journal of Mammalogy. 66:798-800.

WILLIAMS, DANIEL F.; and SUZANNE E. BRAUN. 1983. Comparison of pitfall and conventional traps for sampling small mammal populations. Journal of Wildlife Management. 47:841-845. (PSW)

WOLFF, JERRY O.; and DAN F. HOLLEMAN. 1978. Use of radioisotope labels to establish genetic relationships in free-ranging small mammals. Journal of Mammalogy. 59:859-860. (PNW)

YEATMAN, HARRY C. 1978. Research trapping. Fur-Fish-Game. 74(2):51-52. (SO)

\section{Special Habitats}

BULL, EVELYN L. 1978. Specialized habitat requirements of birds: snag management, old growth, and riparian habitat. Gen. Tech. Rep. PNW-64. Portland, OR: U.S. Department of Agriculture, Forest Service, Pacific Northwest Forest and Range Experiment Station: 74-82. (PNW)

BULL, EVELYN L. 1983. Longevity of snags and their use by woodpeckers. In: Davis, Jerry W.; Gregory A. Goodwin; and Richard A. Ockenfels, tech. coords. Snag habitat management: Proceedings of the symposium; 1983 June 7-9; Flagstaff, AZ. Gen. Tech. Rep. RM-99. Fort Collins, CO: U.S. Department of Agriculture, Forest Service, Rocky Mountain Forest and Range Experiment Station: 64-67. (PNW)
BULL, EVELYN L. 1986. Ecological value of dead trees to cavity nesting birds in northeastern Oregon. Oregon Birds. 12:91-99. (PNW)

BULL, EVELYN L.; and ARTHUR D. PARTRIDGE. 1986. Methods of killing trees for use by cavity nesters. The Wildlife Society Bulletin. 14:142-146. (PNW)

BULL, EVELYN L.; ARTHUR D.

PARTRIDGE; and WAYNE G. WILLIAMS. 1981. Creating snags with explosives. Res. Note. PNW-393. Portland, OR: U.S. Department of Agriculture, Forest Service, Pacific Northwest Forest and Range Experiment Station. 4 p. (PNW)

BULL, EVELYN L.; ASA D. TWOMBLY; and THOMAS M. QUIGLEY. 1980.

Perpetuating snags in managed mixed conifer forests of the Blue Mountains, Oregon. In: DeGraff, Richard M., tech. coord. Management of western forests and grasslands for nongame birds: Workshop proceedings; 1980 February 11-14; Salt Lake City, UT. Gen. Tech. Rep. INT-86. Ogden, UT: U.S.

Department of Agriculture, Forest

Service, Intermountain Forest and Range Experiment Station: 325-336. (PNW)

BULL, EVELYN L.; JACK WARD THOMAS; and KIRK HORN. 1986. Snag management on national forests in the Pacific Northwest--1984. Western Journal of Applied Forestry. 1:41-43. (PNW)

CAREY, ANDREW B. 1983. Cavities in trees in hardwood forests. In: Davis, Jerry W.; Gregory A. Goodwin; and Richard A. Ockenfels, tech. coords. Snag habitat management: Proceedings of the symposium; 1983 June 7-9; Flagstaff, AZ. Gen. Tech. Rep. RM-99. Fort Collins, CO: U.S. Department of Agriculture, Forest Service, Rocky Mountain Forest and Range Experiment Station: 167-184. (NE) 
CAREY, ANDREW B.; and H. REED SANDERSON. 1981. Routing to accelerate tree-cavity formation. The Wildlife Society Bulletin 9:14-21. (NE)

CAREY, ANDREW B.; and WILLIAM M. HEALY. 1981. Cavities in trees around spring seeps in the maple-beech-bird forest type. Res. Pap. NE-80. Broomall, PA: U.S. Department of Agriculture, Forest Service, Northeastern Forest Experiment Station. 7 p. (NE)

CLINE, STEVEN P.; ALAN B. BERG; and HOWARD M. WIGHT. 1980. Snag characteristics and dynamics in Douglas-fir forests, western Oregon. Journal of Wildlife Management. 44:773786. (PNW)

CONNER, RICHARD N. 1978. Snag management for cavity nesting birds. Gen. Tech. Rep. SE-14. Asheville, NC: U.S. Department of Agriculture, Forest Service, Southeastern Forest Experiment Station: 120-128. (SO)

CONNER, RICHARD N.; JAMES G. DICKSON; and BRIAN A. LOCKE. 1981. Herbicide-killed trees infected by fungi: potential cavity sites for woodpeckers. The Wildlife Society Bulletin. 9:308-310. (SO)

CRAWFORD, H. S.; W. A. ABLER; and D. M. HARDY. 1978. Nesting of birds on stripmine highwalls in southern West Virginia. In: Proceedings, 1978 Northeast Fish and Wildlife Conference; White Sulphur Springs, WV: 87-91. (NE).

CUNNINGHAM, JAMES B.; RUSSELL P. BALDA; and WILLIAM S. GAUD. 1980. Selection and use of snags by secondary cavity-nesting birds of the ponderosa pine forest. Res. Pap. RM222. Fort Collins, CO: U.S. Department of Agriculture, Forest Service, Rocky Mountain Forest and Range Experiment Station. 15 p. (RM)
DAVIS, JERRY W.; GREGORY A. GOODWIN; and RICHARD A. OCKENFELS, tech. coords. 1983. Snag habitat management. Proceedings of the symposium; 1983 June 7-9; Flagstaff, AZ. Gen. Tech. Rep. RM-99. Fort Collins, CO: U.S. Department of Agriculture, Forest Service, Rocky Mountain Forest and Range Experiment Station. 226 p. (RM)

DEGRAAF, R. M. 1984. Managing New England woodlands for wild life that uses tree cavities. Coop. Ext. Bull. C-171. Amherst, MA: University of Massachusetts. 17 p. (NE)

DEGRAAF, RICHARD M.; and ALEX L. SHIGO. 1985. Managing cavity trees for wildlife in the northeast. Gen. Tech. Rep. NE-101. Broomall, PA: U.S. Department of Agriculture, Forest Service, Northeastern Forest Experiment Station. 21 p. (NE)

DICKSON, JAMES G.; RICHARD N. CONNER; and J. HOWARD WILLIAMSON. 1983. Snag retention increases bird use of a clear-cut. Journal of Wildlife Management. 47:799-804. (SO)

EVANS, KEITH E. 1980. How to attract cavity-nesting birds to your woodlot. St. Paul, MN: U.S. Department of Agriculture, Forest Service, North Central Forest Experiment Station. 6 p. (NC)

EVANS, KEITH E.; and RICHARD N. CONNER. 1979. Snag management. In: DeGraff, Richard M., tech. coord. Management of North Central and Northeastern forests for nongame birds: Workshop proceedings; 1979 January 23-25; Minneapolis, MN. Gen. Tech. Rep. NC-51. St. Paul, MN: U.S. Department of Agriculture, Forest Service, North Central Forest Experiment Station: 214-225. (NC) 
FINCH, DEBORAH M. 1989. Relationships of surrounding riparian habitat to nest-box use and reproductive outcome in house wrens. The Condor. 91:848-859. (RM)

GARY, HOWARD L.; and MEREDITH J. MORRIS. 1980. Constructing wooden boxes for cavity-nesting birds. Res. Note RM-381. Fort Collins, CO: U.S. Department of Agriculture, Forest Service, Rocky Mountain Forest and Range Experiment Station. 7 p. (RM)

GLINSKI, RICHARD L.; TERYL G. GRUBB; and LARRY A. FORBIS. 1983. Snag use by selected raptors. In: Davis, Jerry W.; Gregory A. Goodwin; and Richard A. Ockenfels, tech. coords. Snag habitat management: Proceedings of the symposium; 1983 June 7-9; Flagstaff, AZ. Gen. Tech. Rep. RM-99. Fort Collins, CO: U.S. Department of Agriculture, Forest Service, Rocky Mountain Forest and Range Experiment Station: 130-133. (RM)

GRUBB, THOMAS D.; DANIEL R. PETIT; and DENNIS L. KRUSAC. 1983. Artificial trees for primary cavity users. In: Davis, Jerry W.; Gregory A. Goodwin; and Richard A. Ockenfels, tech. coords. Snag habitat management: Proceedings of the symposium; 1983 June 7-9; Flagstaff, AZ. Gen. Tech. Rep. RM-99. Fort Collins, CO: U.S. Department of Agriculture, Forest Service, Rocky Mountain Forest and Range Experiment Station: 151-154. (NE)

GUTZWILLER, KEVIN J.; and STANLEY H. ANDERSON. 1986. Use of abandoned cliff swallow nests by breeding house wrens. Prairie Naturalist. 18:53-54.

HARLOW, RICHARD F.; and DAVID C. GUYNN, JR. 1983. Snag densities in managed stands of the southern Carolina coastal plain. Southern Journal Applied Forestry. 7:224-229. (SE)
HARRIS, L. D.; and J. D. McELVEEN. 1981. Effect of forest edges on north Florida breeding birds. IMPAC Reports 6(4):24. (SE)

MANNAN, R. WILLIAM; E. CHARLES MESLOW; and HOWARD M. WIGHT. 1980. Use of snags by birds in Douglasfir forests, western Oregon. Journal of Wildlife Management. 44:787-797. (PNW)

MASER, CHRIS; JON E. RODIEK; and JACK WARD THOMAS. 1979. Cliffs, talus, and caves. In: Thomas, Jack Ward, tech. ed. Wildlife habitats in managed forests--the Blue Mountains of Oregon and Washington. Agric. Handb. 553. Washington, DC: U.S. Department of Agriculture, Forest Service: 96-103. Chapter 7. (PNW)

MCCLELLAND, B. RILEY; SIDNEY S. FRISSELL; WILLIAM C. FISCHER; and CURTIS H. HALVORSON. 1979. Habitat management for hole-nesting birds in forests of western larch and Douglas-fir. Journal of Forestry. 77:480483. (INT)

MORRISON, MICHAEL L.; MARK F. DEDON; MARTIN G. RAPHAEL; MICHAEL P. YODER-WILLIAMS. 1986. Snag requirements of cavity-nesting birds: Are U.S. Department of Agriculture, Forest Service guidelines being met? Western Journal of Applied Forestry. 1:38-40. (RM)

MOWREY, ROBERT A.; and JOHN C. ZASADS. 1984. Den tree use and movements of northern flying squirrels in interior Alaska and implications for forest management. In: Meehan, William R.; Theodore, R. Merrel, Jr.; and Thomas A. Hanley, eds. Fish and wildlife relationships in old-growth forests; 1982 April 12-15; Juneau, AK. Morehead City, NC: American Institute of Fishery Research Biologists: 351-356. (PSW) 
RAPHAEL, MARTIN G.; and MARSHALL WHITE. 1984. Use of snags by cavitynesting birds in the Sierra Nevada. Wild life Monographs No. 86. Washington, DC: The Wildlife Society. 66 p. (RM)

RUMBLE, MARK A. 1987. Avian use of scoria rock outcrops. Great Basin Naturalist. 47:625-630. (RM)

SZARO, ROBERT C. 1980. Factors influencing bird populations in southwestern riparian forests. In: DeGraaf, Richard M., tech. coord. Management of western forests and grasslands for nongame birds:

Workshop proceedings; 1980 February

11-14; Salt Lake City, UT. Gen. Tech.

Rep. INT-86. Ogden, UT: U.S. Department of Agriculture, Forest Service, Intermountain Forest and Range Experiment Station: 403-418. (RM)

THOMAS, JACK WARD; CHRIS MASER; and JON E. RODIEK. 1978. Edges-their interspersion, resulting diversity and its measurement. Gen. Tech. Rep. PNW-64. Portland, OR: U.S. Department of Agriculture, Forest Service, Pacific Northwest Forest and Range Experiment Station: 91-100. (PNW)

THOMAS, JACK WARD; CHRIS MASER; and JON E. RODIEK. 1979. Edges. In: Thomas, Jack Ward, tech. ed. Wildlife habitats in managed forests--the Blue Mountains of Oregon and Washington. Agric. Handb. 553. Washington, DC: U.S. Department of Agriculture, Forest Service: 48-59. Chapter 4. (PNW)

THOMAS, JACK WARD; CHRIS MASER; and JON E. RODIEK. 1979. Wildlife habitats in managed rangelands--the Great Basin of southeastern Oregon: edges. Gen. Tech. Rep. PNW-85. Portland, OR: U.S. Department of Agriculture, Forest Service, Pacific Northwest Forest and Range Experiment Station. 17 p. (PNW)
THOMAS, JACK WARD; RALPH G.

ANDERSON; CHRIS MASER; and EVELYN L. BULL. 1979. Snags. In: Thomas, Jack Ward, tech. ed. Wildlife habitats in managed forests--the Blue Mountains of Oregon and Washington. Agric. Handb. 553. Washington, DC: U.S. Department of Agriculture, Forest Service: 60-77. Chapter 5. (PNW)

\section{Computerized Data Systems And Models}

BALDA, RUSSELL P.; WILLIAM S. GAUD; and JEFFREY D. BRAWN. 1983. Predictive models for snag nesting birds. In: Davis, Jerry W.; Gregory A. Goodwin; and Richard A. Ockenfels, tech. coords. Snag habitat management: Proceedings of the symposium; 1983 June 7-9; Flagstaff, AZ. Gen. Tech. Rep. RM-99. Fort Collins, CO: U.S. Department of Agriculture, Forest Service, Rocky Mountain Forest and Range Experiment Station. 216-220. (RM)

BEKOFF, MARC; and L. DAVID MECH. 1984. Computer simulation: simulation analyses of space use: home range estimates, variability, and sample size. Behavior Research Methods, Instrumentation and Computers. 16(1):32-37. (NC)

BRAND, GARY J.; STEPHEN R. SHIFLEY; and LEWIS F. OHMANN. 1986. Linking wildlife and vegetation models to forecast the effects of management. In: Verner, Jared; Michael L. Morrison; and C. John Ralph, eds. Wildlife 2000: Modeling habitat relationships of terrestrial vertebrates; 1984 October 7 11; Fallen Leaf, CA. Madison, WI: The University of Wisconsin Press: 383-387. (NC) 
CASNER, WILSON B.; BARBARA

KULONGOWSKI; DAVID R. PATTON;

and SANDRA J. PINKERTON. 1978.

RUN WILD--for the UNIVAC 1100

series, implementation and

maintenance. Gen. Tech. Rep. RM-51A.

Fort Collins, CO: U.S. Department of

Agriculture, Forest Service. Rocky

Mountain Forest and Range Experiment

Station. 31 p. (RM)

CIMON, NORM. 1983. A simple model to predict snag levels in managed forests. In: Davis, Jerry W.; Gregory A.

Goodwin; and Richard A. Ockenfels, tech. coords. Snag habitat management:

Proceedings of the symposium; 1983 June 7-9; Flagstaff, AZ. Gen. Tech. Rep. RM-99. Fort Collins, CO: U.S. Department of Agriculture, Forest Service, Rocky Mountain Forest and Range Experiment Station: 200-204. (PNW)

CUSHWA, CHARLES T.; DAVID R. PATTON; WILLIAM R. MASON; and LAWRENCE J. SLASKI. 1978. RUN WILD East: A computerized data systems for fish and wildlife resource. In: Transactions Northeastern Wildlife Conference; 1978 February; White Sulphur Springs, West Virginia. (RM)

FAUSCH, KURT D.; CLIFFORD L. HAWKES; and MIT G. PARSONS. 1988. Models that predict standing crop of stream fish from habitat variables: 1950-85. Gen. Tech. Rep. PNW-GTR-213. Portland, OR: U.S. Department of Agriculture, Forest Service, Pacific Northwest Research Station. 52 p. (PNW)

FLEBBE, PATRICIA A. 1988. Regional coldwater fish abundance projections. In: Gelinas, R.; D. Bond; and B. Smit, eds. Perspectives on land modelling: Proceedings, land modelling: Perspectives on land modelling workshop; Canada Committee on Ecological Land Classification; Toronto, Canada. Montreal, Canada, Polyscience Publications, Inc.: 49-58. (RM)
FORNITO, LENA; R. LEE; and S. J. TAJCHMAN. 1982. Heat transfer models for nesting cavities. Archiv Meterologie Geophysik und Bioklimatologie Serie B. 30:271-282.

HOKSTRA, THOMAS W.; C. H. FLATHER; and PATRICIA A. FLEBBE. 1987. Regional fish and wildlife habitat models: application for national resource planning assessment. In: Lund, $\mathrm{H}$. Gyde; Miguel Cabellero-Deloya; and Raul Villarreal-Canton, eds. Land and resource evaluation for national planning in the tropics; Proceeding of the International Conference and Workshop; 1987 January 25-31; Chetumal, Mexico. Gen. Tech. Rep. WO-39. Washington, DC: U.S. Department of Agriculture, Forest Service: 404-409. (RM)

HUNTLEY, JIMMY C.; and ROBERT R. PUGH. 1982. Using life requirements, extensive inventory data, and IMGRID to determine wildlife habitat suitability on Catoosa Wildlife Management Area. In: In-place resource inventories: principles and practices; proceedings of a national workshop; 1981 August 9-14; Orono, ME. SAF 82-02. Bethesda, MD: Society of American Foresters: 718-722. (SO)

JAYNES, RICHARD A. 1978. A hydrologic model of aspen-conifer succession in the Western United States. Res. Pap. INT-213. Ogden, UT: U.S. Department of Agriculture, Forest Service, Intermountain Forest and Range Experiment Station. 17 p. (INT)

LAYMON, STEPHEN A.; and REGINALD H. BARRETT. 1986. Developing and testing habitat-capability models: pitfalls and recommendations. In: Verner, Jared; Michael L. Morrison; and C. John Ralph, eds. Wildlife 2000: Modeling habitat relationships of terrestrial vertebrates; 1984 October 7-11; Fallen Leaf, CA. Madison, WI: The University of Wisconsin Press: 87-91. (PSW) 
LEHMKUHL, JOHN F.; and DAVID R.

PATTON. 1982. User's manual for the

RUN WILD III data storage and retrieval

system. RUN WILD wildlife/habitat

relationships. Wildlife Unit Tech. Rep.

Albuquerque, NM: U.S. Department of

Agriculture, Forest Service,

Southwestern Region. 68 p. (RM)

LYON, L. JACK. 1983. Road density models describing habitat effectiveness for elk. Journal Forestry. 81:592-595, 613. (INT)

LYON, L. JACK. 1989. Application of Geographic Information Systems in wildlife research. In: Winn, David S.; Beverly, Roberta E.; and Glenda W. Moore, comps. Proceedings-geographic information systems awareness seminar; 1988 May 16-19; Salt Lake City, UT. Ogden, UT: U.S. Department of Agriculture, Forest Service, Intermountain Region: 26-31. (INT)

MARCOT, BRUCE G. 1986. Summary: Biometric approaches to modeling. In: Verner, Jared; Michael L. Morrison; and C. John Ralph, eds. Wildlife 2000 modeling habitat relationships of terrestrial vertebrates; 1984 October 7 11; Fallen Leaf Lake, CA. Madison, WI: The University of Wisconsin Press: 203204. (PNW)

MARCOT, BRUCE G. 1986. Use of expert systems in wildlife-habitat modeling. In: Verner, Jared; Michael L. Morrison; and C. John Ralph, eds. Wildlife 2000: modeling habitat relationships of terrestrial vertebrates; 1984 October 711; Fallen Leaf Lake, CA. Madison, WI: The University of Wisconsin Press: 145150. (PNW)

MARCOT, BRUCE G.; R. SCOTT MCNAY; and RICHARD E. PAGE. 1988. Use of microcomputers for planning and managing silviculture-habitat relationships. Gen. Tech. Rep. PNW228. Portland, OR: U.S. Department of Agriculture, Forest Service, Pacific Northwest Research Station. $19 \mathrm{p}$. (PNW)
MAURER, BRIAN A. 1986. Predicting habitat quality for grassland birds using densityhabitat correlations. Journal of Wildlife Management. 50:556-566. (RM)

MEDIN, DEAN E.; and ALLEN E. ANDERSON. 1979. Modeling the dynamics of a Colorado mule deer population. Wildlife Monographs No. 68. Washington, DC: The Wildlife Society. 78 p. (INT)

NELLIS, C. H.; and DEAN E. MEDIN. 1978. Models and wildlife. Idaho Wildlife. 1(3):27-28. (INT)

NELSON, RODGER L.; CHARLES K. GRAHAM; and WILLIAM S. PLATTS. 1988. Relative suitabilities of regression models in electronic analysis of riparian vegetation. Res. Note. INT-382. Ogden, UT: U.S. Department of Agriculture, Forest Service, Intermountain Research Station. 5 p. (INT)

PATTON, DAVID R. 1978. RUN WILD: a storage and retrieval system for wildlife habitat information. Gen. Tech. Rep. RM-51. Fort Collins, CO: U.S. Department of Agriculture, Forest Service, Rocky Mountain Forest and Range Experiment Station. 8 p. (RM)

PATTON, DAVID R. 1979. How to use RUN WILD data files stored on microfiche. Res. Note. RM-377. Fort Collins, CO: U.S. Department of Agriculture, Forest Service, Rocky Mountain Forest and Range Experiment Station. 2 p. (RM)

PATTON, DAVID R. 1979. RUN WILD II: a storage and retrieval system for wildlife data. Transactions of the North American Wildlife and Natural Resources Conference. 44:425-429. (RM)

PATTON, DAVID R. 1979. RUN WILD II data files on microfiche. National Technical Information Service Document Number PB 296984. Springfield, VA: U.S. Department of Commerce, 28 fiche. (RM) 
PATTON, DAVID R.; and KIETH E.

SEVERSON. 1989. WILDHARE: a wildlife habitat relationships data model for southwestern ponderosa pine. In:

Tecke, Aregai; W. Wallace Covington; and R. H. Hamre, tech. coords. Multiresource management of ponderosa pine forests: proceedings of the symposium; 1989 November 14-16; Flagstaff, AZ. Gen. Tech. Rep. RM-185. Fort Collins, CO: U.S. Department of Agriculture, Forest Service, Rocky Mountain Forest and Range Experiment Station: 268-276. (RM)

PENDLETON, DENNIS F.; JOHN W. MENKE; WILLIAM A. WILLIAMS; and ROBERT G. WOODMANSEE. 1983. Annual grassland ecosystem model. Hilgardia. 51(1):1-44. (PSW)

RAPHAEL, MARTIN G.; and GLEN E. BRINK. 1988. Bootstrap estimation of home range area: user's guide to program HOMERANG. Gen. Tech. Rep. RM-166. Fort Collins, CO: U.S. Department of Agriculture, Forest Service, Rocky Mountain Forest and Range Experiment Station. 14 p. (RM)

RAPHAEL, MARTIN G.; and BRUCE G. MARCOT. 1986. Validation of a wildlifehabitat-relationships model: vertebrates in a Douglas-fir sere. In: Verner, Jared; Michael L. Morrison; and C. John Ralph, eds. Wildlife 2000: modeling habitat relationships of terrestrial vertebrates; 1984 October 7-11; Fallen Leaf Lake, CA. Madison, WI: The University of Wisconsin Press: 129-138. (RM)

RASMUSSEN, WILLIAM O.; and PETER F. FFOLLIOTT. 1983. A model to predict snag development. The Wildlife Society Bulletin. 11:291-292. (RM)
SALWASSER, HAL. 1986. Modeling habitat relationships of terrestrial vertebrates-the manager's viewpoint. In: Verner, Jared; Michael L. Morrison; and C. John Ralph, eds. Wildlife 2000: modeling habitat relationships of terrestrial vertebrates; 1984 October 7-11; Fallen Leaf Lake, CA. Madison, WI: The University of Wisconsin Press: 419-424. (WO)

SCOTT, M. D. 1979. Computerized evaluation of the wildlife habitat option as a post mining land use. In: Proceedings, mitigation symposium. Gen. Tech. Rep. RM-65. Fort Collins, CO: U.S. Department Agriculture, Forest Service, Rocky Mountain Forest and Range Experiment Station: 622-623.

STARR, G. LYNN; and J. MICHAEL GEIST. 1988. Soil bulk density and soil moisture calculated with a FORTRAN 77 program. Gen. Tech. Rep. PNW-GTR211. Portland, OR: U.S. Department of Agriculture, Forest Service, Pacific Northwest Research Station. 6 p. (PNW)

STORMER, FRED A.; and DOUGLAS H. JOHNSON. 1986. Introduction:

Biometric approaches to modeling. In: Verner, Jared; Michael L. Morrison; and C. John Ralph, eds. Wildlife 2000: modeling habitat relationships of terrestrial vertebrates; 1984 October 711; Fallen Leaf Lake, CA. Madison, WI: The University of Wisconsin Press: 159160. (WO)

SWEENEY, J. M. 1985. Estimating wildlife production with habitat models. CalNeva Wildlife Transactions. 1984:50-54. (NC)

SWEENEY, J. M. ; and H. S. BHULLAR. 1983. A computer tool for integrated resource management. In: Bell, John F. ed. Proceedings, international conference on renewable resource inventories for monitoring changes and trends; 1983 August 15-19; Corvallis, OR: 295-297. (NC) 
SWEENEY, JAMES M. 1986. Refinement of DYNAST's forest structure simulation. In: Verner, Jared; Michael L. Morrison; and C. John Ralph, eds. Wildlife 2000: modeling habitat relationships of terrestrial vertebrates; 1984 October 711; Fallen Leaf Lake, CA. Madison, WI: The University of Wisconsin Press: 357360. (NC)

SWEENEY, JAMES M. 1986. Summary: Linking wildlife models with models of vegetation succession--the researcher's viewpoint. In: Verner, Jared; Michael L. Morrison; and C. John Ralph, eds. Wildlife 2000: modeling habitat relationships of terrestrial vertebrates; 1984 October 7-11; Fallen Leaf Lake, CA. Madison, WI: The University of Wisconsin Press: 415-416. (NC)

SWEENEY, JAMES M.; and CARROL L. HENDERSON. 1986. An integrated approach to nongame management. In: Hale, James B.; Louis B. Best; and Richard L. Clawson, eds. Symposium on management of nongame wildlife in the Midwest: a developing art: Proceedings, 47th Midwest Fish and Wildlife Conference; 1985 December 17; Grand Rapids, MI The North Central Section of The Wildlife Society: 1-10. (NC)

SWEENEY, JAMES M.; and GALE L. WOLTERS. 1986. Techniques for future decisionmaking in range, wildlife, and fisheries management. In: 1986 Yearbook of Agriculture: Research for tomorrow. Washington, DC: U.S. Department of Agriculture: 209-212. (WO)
TAYLOR, CATHY A.; C. JOHN RALPH; and ARLENE T. DOYLE. 1988. Differences in the ability of vegetation models to predict small mammal abundance in different aged Douglas-fir forests. In: Szaro, Robert C.; Kieth E. Severson; and David R. Patton, tech. coords. Management of amphibians, reptiles, and simall mammals in North America: Proceedings of the symposium; 1988 July 19-21; Flagstaff, AZ. Gen. Tech. Rep. RM-166. Fort Collins, CO: U.S. Department of Agriculture, Forest Service, Rocky Mountain Forest and Range Experiment Station: 368-374. (PSW)

THOMAS, JACK WARD. 1986. Wildlifehabitat modeling--cheers, fears, and introspection. In: Verner, Jared; Michael L. Morrison; and C. John Ralph, eds. Wildlife 2000: modeling habitat relationships of terrestrial vertebrates; 1984 October 7-11; Fallen Leaf Lake, CA. Madison, WI: The University of Wisconsin Press: xix-xxv. (PNW)

TILGHMAN, NANCY G.; and KEITHE. EVANS. 1986. A framework for nongame management in midwestern forests. In: Hale, James B.; Louis B. Best; and Richard L. Clawson, eds. Symposium on management of nongame wildlife in the Midwest: a developing art: Proceedings, 47th Midwest Fish and Wildlife Conference; 1985 December 17; Grand Rapids, MI The North Central Section of The Wildlife Society: 97-115. (NE)

TOTH, EDWARD F.; DAVID M. SOLIS; and BRUCE G. MARCOT. 1986. A management strategy for habitat diversity: Using models of wildlife-habitat relataionships. In: Verner, Jared; Michael L. Morrison; and C. John Ralph, eds. Wildlife 2000: modeling habitat relationships of terrestrial vertebrates; 1984 October 7-11; Fallen Leaf Lake, CA. Madison, WI: The University of Wisconsin Press: 139-144. (PSW) 
VAN DEVENTER, JOHN S.; and WILLIAM S. PLATTS. 1985. A computer software system for entering, managing, and analyzing fish capture data from streams. Res. Note INT-352. Ogden, UT: U.S. Department of Agriculture, Forest Service, Intermountain Forest and Range Experiment Station. $12 \mathrm{p}$. (INT)

VERNER, JARED; MICHAEL L. MORRISON; and C. JOHN RALPH. 1986.

Introduction. In: Verner, Jared; Michael L. Morrison; and C. John Ralph, eds. Wildlife 2000: modeling habitat relationships of terrestrial vertebrates; 1984 October 7-11; Fallen Leaf Lake, CA. Madison, WI: The University of Wisconsin Press: xi-xv. (PSW)

VERNER, JARED; MICHAEL L. MORRISON; and C. JOHN RALPH, eds. 1986. Wildlife 2000: modeling habitat relationships of terrestrial vertebrates. Proceedings; 1984 October 7-11; Fallen Leaf Lake, CA. Madison, WI: The University of Wisconsin Press. $470 \mathrm{p}$. (PSW)

WISDOM, MICHAIL J.; LARRY R. BRIGHT; CHRISTOPHER G. CAREY; WILLIAM W. HINES; RICHARD J. PEDERSEN; DOUGLAS A. SMITHEY; JACK WARD THOMAS; and GARY W. WITMER. 1986. A model to evaluate elk habitat in western Oregon. Publ. R6-F\&WL-2161986. Portland, OR: U.S. Department of Agriculture, Forest Service, Pacific Northwest Region. 36 p. (PNW)

\section{Insects And Diseases Of Animals}

CAREY, ANDREW B. 1983. Colorado tick fever in Rocky Mountain National Park. Park Science. 3(3):16-17 PNW-1706.

CUDMORE, WYNN W. 1986. Ectoparasites of Neotoma cinera and $N$. fuscipes form western Oregon. Northwest Science. 60:174-178. (PNW)
DANCAK, KEN; DANNY B. PENCE; FRED A. STORMER; and SAMUEL L. BEASOM. 1982. Helminths of the scaled quail, Callipepla squamata, from northwest Texas. Proceedings of the Helminthology Society of Washington. 49(1):144-146. (RM)

DICKINSON, EARL O.; and JAMES R. CARLSON. 1978. Acute respiratory distress of rangeland cattle. In: Effects of poisonous plants on livestock. New York, NY: Academic Press: 251-259. (PNW)

EMERSON, K. C.; CHRIS MASER; and JOHN O. WHITAKER, JR. 1984. Lice (Mallophaga and Anoplura) from mammals of Oregon. Northwest Science. 58:153-160. (PNW)

FINCH, DEBORAH M. 1983. Brood parasitism of the Abert's towhee: timing, frequency, and effects. The Condor. 85:355-259. (RM)

GOYAL, SAGAR M; L. DAVID MECH; RUTH A RADEMACHER; MUHAMMAD A. KHAN; and ULYSSES S. SEAL. 1986. Antibodies against canine parvovirus in wolves of Minnesota: a serologic study 1975 through 1985. Journal of the American Veterinary Medical Association. 189:1092-1094. (NC)

GRUBB, TERYL G.; WADE L. EAKLE; and BENJAMIN N. TUGGLE. 1986. Haematosiphon inodorus (Hemiptera: Cimbicidae) in a nest of a bald eagle (Haliaeetus leucocephalis). Journal of Wildlife Disease. 22:125-127. (RM)

MECH, L. DAVID; and STEVEN H. FRITTS. 1987. Parvovirus and heartworm found in Minnesota wolves. Endangered Species Technical Bulletin. 12:5-6. (NC) 
MECH, L. DAVID; RICHARD P. THIEL; S. H. FRITTS; and W. E. BERG. 1985.

Presence and effects of the dog louse Trichodectes canis (Mallophaga, Trichodectidae) on wolves and coyotes from Minnesota and Wisconsin.

American Midland Naturalist. 114:404405. (NC)

MECH, L. DAVID; SAGAR M. GOYAL; CHRISSIE N. BOTA; and ULYSSES S. SEAL. 1986. Canine parvovirus infection in wolves (Canis lupus) from Minnesota. Journal of Wildlife Diseases. 22:104106. (NC)

MOORE, RICHARD L.; and C. DAVID SIMPSON. 1981. Disease mortality of waterfowl on Texas playa lakes. Southwest Naturalist. 25:566-568. (RM)

MPOAME, MBIDA; and JOHN N. RINNE. 1983. Parasites of some fishes native to Arizona and New Mexico. Southwest Naturalist. 28:399-405. (RM)

MUNEER, MOHAMMAD A.; IBRAHIM O. FARAH; KEM A. POMEROY; $M$. GOYAL SAGAR; and L. DAVID MECH. 1988. Detection of parvovirus in wolf feces by electron microscopy. Journal of Wildlife Diseases. 24:170-172. (NC)

NEWMAN, THOMAS F.; DON A. DUNCAN; and THOMAS K. HARP. 1976. The parasite Clinostomum marganatum in four Centrachids in California range ponds. Res. Note PSW-314. Berkeley, CA: U.S. Department of Agriculture, Forest Service, Pacific Southwest Forest and Range Experiment Station. $3 \mathrm{p}$. (PSW)

PENCE, DANNY B.; VALERIE E. YOUNG; and FRED S. GUTHERY. 1980. Helminths of the ring-necked pheasant, Phasianus colchicus (Gmelin) (Phasianidae), from the Texas Panhanlde. Proceedings Helminthological Society of Washington. 47(1):145-147. (RM)
RAUSCH, R. L.; and CHRIS MASER. 1977. Monococestus thomasi sp. N. (Cestoda: Anoplocephalidae) from the northern flying squirrel, Glaucomys sabrinus (Shaw), in Oregon. Journal Parasitology. 63(5):793-799. (PNW)

RAUSCH, R. L.; C. MASER; and E. P. HOBERG. 1983. Gastrointestinal helminths of the cougar, Felis concolor $\mathrm{L}$., in northeastern Oregon. Journal of Wildlife Diseases. 19(1):14-19. (PNW)

ROGERS, L. L.; and S. M. ROGERS. 1976. Parasites of bears: a review. In: Proceedings, 3rd international conference on bears-their biology and management. Morges, Switzerland. International Union for Conservation of nature and Natural Resources: 411-430. (NC)

ROGERS, LYNN L. 1983. Effects of food supply, predation, cannibalism, parasites, and other health problems on black bear populations. In: Bunnell, Fred L.; Donald S. Eastman; and James M. Peek, co-eds. Natural regulation of wildlife populations: Proceedings, Northwest Section, The Wildlife Society; 1978 March 10; Vancouver, BC. Proc. 14. Moscow, ID: University of Idaho, Forest, Wildlife and Range Experiment Station: 194-211. (NC)

SKOVLIN, JON M.; and D. LEROY WILLIAMSON. 1978. Bush control and associated tsetse fly problems of rangeland development on the coastal plain of East Africa. In: Hyder, Donald N., ed. Proceedings, 1st international rangeland congress; 1978 August 1418; Denver, CO: Society for Range Management: 58I-583. (PNW)

THIEL, RICHARD P.; L. DAVID MECH; GEORGE R. RUTH; JOHN R. ARCHER; and LEO KAUFMAN. 1987. Blasytomycosis in wild wolves. Journal of Wildlife Diseases. 23:321-323. (NC) 
UHAZY, LESLIE S.; and WAYNE J.

ARENDT. 1986. Pathogenesis associated with Philornid myiasis

(Diptera: Muscidae) on nestling pearlyeyed thrashers (Aves: Mimidae) in the Luquillo Rain Forest, Puerto Rico. Journal of Wildlife Diseases. 22:224237. (SO)

WHITAKER, JOHN O., JR.; and CHRIS MASER. 1979. Parasitic mites of voles of the genera Arborimus and Lagurus in Oregon. Northwest Science. 53(3):224227. (PNW)

WHITAKER, JOHN O., JR.; CHRIS MASER; and RICHARD J. PEDERSEN. 1979. Food and ectoparasitic mites of Oregon moles. Northwest Science. 53(4):268273. (PNW)

WHITAKER, JOHN O., JR.; CHRIS MASER; and WILLIAM M. WALLACE. 1979. Parasitic mites of the mountain beaver (Alpolondontia rufa) from Oregon. Northwest Science. 53(4):264-267. (PNW)

WHITAKER, JOHN O., JR.; CONRAD E. YUNKER; and CHRIS MASER. 1983. Acarine ectoparasites (mites) of bats of Oregon. Northwest Science. 57(2):97106. (PNW)

WHITAKER, JOHN O., JR.; E. ANDREA LYONS; MARTHA A. SMITH; and CHRIS MASER. 1983. Nest inhabitants and ectoparasites of northern flying squirrels, Glaucomys sabrinus (Shaw), from northeastern Oregon. Northwest Science. 57(4):291-295. (PNW)

WHITAKER, JOHN O., JR.; MARTHA A. SMITH; and CHRIS MASER. 1985. Mites and lice from the genus Peromyscus from Oregon. Northwest Science. 59:319-322. (PNW)

WILSON, N.; and E. L. BULL. 1977. Ectoparasites found in nest cavities of pileated woodpeckers in Oregon. BirdBanding. 48(2):171-173. (PNW) 


\section{Rangeland Soil And Water}

\section{Rangeland Soils}

ABEY, BURNS; JIM HERRON; DAVID G. SCHOLL; and JOHN BOKICH. 1987.

Particle size distribution. In: Reclaiming mine soils and overburden in the western United States; Ankeny, IA: Soil Conservation Society of America: 54-74. Chapter 4. (RM)

ALDON, EARL F. 1982. Use of organic amendments for biomass production on reclaimed strip mines in the Southwest. In: Sopper, William E.; Eileen M. Seaker; and Robert K. Bastian, eds. Utilization and municipal wastewater and sludge for land reclamation and biomass production: Proceedings, 1980 symposium and engineering assessment; 1980 September 16-18; Pittsburgh, PA. University Park, PA: Pennsylvania State University Press: 317-320. (RM)

ALDON, EARL F.; DAVID G. SCHOLL; P. R. FRESQUEZ; and RICHARD E. FRANCIS. 1988. Natural production potential of some Rio Puerco soils in New Mexico. Res. Note RM-481. Fort Collins, CO: U.S. Department of Agriculture, Forest Service, Rocky Mountain Forest and Range Experiment Station. 4 p. (RM)

BROWN, RAY W.; and ROBERT S. JOHNSTON. 1980. Bioassay of alpine mine spoils for plant growth and development. Res. Note INT-285. Ogden, UT: U.S. Department of Agriculture, Forest Service, Intermountain Forest and Range Experiment Station. $11 \mathrm{p}$.

BROWN, RAY W.; ROBERT S. JOHNSTON; and JEANNE C. CHAMBERS. 1984.

Responses of native grasses to repeated fertilizer applications on acidic alpine mine spoils. In: Colbert, T. A.; and R. L. Cuany, eds. Proceedings: highaltitude revegetation workshop no. 6; Information Series No. 53; 1984 March 5-6; Fort Collins, CO: Colorado State University, Water Resources Research Institute: 200-214. (INT)
CHAMBERS, JEANNE C.; RAY W. BROWN; and R. S. JOHNSTON. 1987. A comparison of soil properties and vegetation properties of seeded and naturally revegetated pyritic alpine mine spoil and reference sites. Landscape and Urban Planning. 14: 507-519. (INT)

CHAMBERS, JEANNE C.; ROY C. SIDLE; and C. VAL GRANT. 1989.

Relationships among soil deposition patterns, soil physical and chemical properties, and plant metal uptake on an abandoned zinc-lead tailings pond. In: Walker, D. G.; C. B. Powter; and M. W. Pole, comps. Reclamation, a global perspective: Proceedings of the conference; 1989 August 27-31; Calgary, Alberta, Canada. Alberta Land Conservation and Reclamation Council Report \# RRTAC 89-2:403-414. (INT)

CURRIE, PAT O.; and HOWARD L. GARY. 1978. Grazing and logging effects on soil surface changes in central Colorado's ponderosa pine type. Journal of Soil and Water Conservation. 33:176. 178. (RM)

DEBANO, LEONARD F. 1981. Water repellent soils: a state-of-the-art. Gen. Tech. Rep. PSW-46. Berkeley, CA: U.S. Department of Agriculture, Forest Service, Pacific Southwest Forest and Range Experiment Station. 21 p. (RM)

DEBANO, LEONARD F. 1989. Effects of fire on chaparral soils in Arizona and California and postfire management implications. In: Berg, Neil H., tech. coord. Symposium on fire and watershed management; 1988 October 26-28; Sacramento, CA. Gen. Tech. Rep. PSW-109. Berkeley, CA: U.S. Department of Agriculture, Forest Service, Pacific Southwest Forest and Range Experiment Station: 55-62. (RM) 
DEBANO, LEONARD F.; RAYMOND M. RICE; and C. EUGENE CONRAD. 1979. Soil heating in chaparral fires: effects on soil properties, plant nutrients, erosion, and runoff. Res. Pap. PSW145. Berkeley, CA: U.S. Department of Agriculture, Forest Service, Pacific Southwest Forest and Range Experiment Station. 21 p. (RM)

DUNN, P. H., and L. F. DEBANO. 1977. Fire's effect on biological properties of chaparral soils. Gen.Tech. Rep. WO-3. Washington, DC: U.S. Department of Agriculture, Forest Service: 75-84. (PSW)

EVANS, RAYMOND A.; and DONALD L. NEAL. 1982. Nutrient testing of soils to determine fertilizer needs on central Sierra Nevada deer-cattle range. Journal of Range Management. 35:159162. (PSW)

\section{EVERETT, RICHARD L.; STEVEN}

SHARROW; and DIANA THRAN. 1986.

Soil nutrient distribution under and adjacent to singleleaf pinyon crowns. Soil Science Society of America Journal. 50:788-792. (INT)

FRESQUEZ, P. R.; EARL F. ALDON; and G. L. DENNIS. 1988. Carbon dioxide evolution from an organically amended Rio Puerco soil. Res. Note RM-480. Fort Collins, CO: U.S. Department of Agriculutre, Forest Sevice, Rocky Mountain Forest and Range Experiment Station. 3 p. (RM)

FRESQUEZ, PHILLIP R.; and W. C. LINDEMANN. 1983. Greenhouse and laboratory evaluations of amended coalmine spoils. Reclamation Revegetation Resarch. 2:205-215. (RM)

FRESQUEZ, PHILLIP R.; W. C.

LINDEMANN; and D. C. LINDSEY.

1983. Nitrification potential of amended coal mine spoils. New Mexico Journal Science. 22(2):36-42. (RM)
GEIST, J. MICHAEL. 1977. Nitrogen response relationships of some volcanic ash soils. Journal Soil Science Society of America. 41:996-1000. (PNW)

GEIST, J. MICHAEL; and GERALD S. STRICKLER. 1978. Physical and chemical properties of some Blue Mountain soils in northeast Oregon. Res. Pap. PNW-236. Portland, OR: U.S. Department of Agriculture, Forest Service, Pacific Northwest Forest and Range Experiment Station. 19 p. (PNW)

GEIST, J. MICHAEL; and LEE EHMER. 1977. Soil resource impacts from forest management in the Blue Mountains. In: Proceedings, integration of forest resource management in the Blue Mountains. Corvallis, OR: Oregon State University Extension Service and Society American Forestry, Blue Mountain Chapter: 28-32. (PNW)

JONES, JOHN R.; and NORBERT V. DEBYLE. 1985. Soils. In: DeByle, Norbert V.; and Robert P. Winokur, eds. Aspen: ecology and management in the western United States. Gen. Tech. Rep. RM-119. Fort Collins, CO: U.S. Department of Agriculture, Forest Service, Rocky Mountain Forest and Range Experiment Station: 65-70. (INT)

KLEMMEDSON, J. O.; and A. R. TIEDEMANN. 1986. Long-term effects of mesquite removal on soil characteristics: II. Nutrient availability. Soil Science Society of America Journal. 50:476-480. (INT)

MUNN, L. C.; G. A. NIELSON; and W. F. MUEGGLER. 1978. Relationships of soils to maintain and foothill range habitat types and production in Western Montana. Soil Science Society American Journal. 42:135-139. (INT) 
RICHARDSON, BLAND Z.; and EUGENE E. FARMER. 1982. Changes in sodium absorption ratios following revegetation of coal mine spoils in southeastern Montana. Res. Pap. INT-287. Ogden, UT: U.S. Department of Agriculture, Forest Service, Intermountain Forest and Range Experiment Station. $4 \mathrm{p}$. (INT)

RUMBLE, MARK A.; MARK T. ANDERSON; and CLIFFORD L. HAWKES. 1985. Morphometry of coal and bentonite surface mine and livestock impoundments in the Northern High Plains. Reclamation and Revegetation Research. 3:293-300. (RM)

SCHOLL, DAVID G. 1983. Properties of coal spoils of the Navajo mine. In: Aldon, Earl F.; and Wendall R. Oaks, eds.

Reclamation of mined lands in the Southwest: Proceedings of the symposium; 1982 October 20-22; Albuquerque, NM: New Mexico Chapter of the Soil Conservation Society of America: 35-42. (RM)

SCHOLL, DAVID G. 1987. Soil salinity and water movement during irrigation of a topsoil-coal spoil profile. In:

Proceedings, 4th annual meeting, American Society for Surface Mining and Reclamation; 1987 March 17-19; Billings, MT. Princeton, WV: American Society for Surface Mining: D-3-1 to D3-7. (RM)

SCHOLL, DAVID G. 1989. Soil compaction from cattle trampling on a semiarid watershed in northwest New Mexico. New Mexico Journal of Science. 29(2):105-112. (RM)

SCHOLL, DAVID G.; and CHARLES P. PASE. 1984. Wheatgrass response to organic amendments and contour furrowing on coal mine spoils. Journal of Environmental Quality. 13:479-482. (RM)
SKUJINS, JOHN J.; and BLAND Z. RICHARDSON. 1985. Humic matter enrichment in reclaimed soils under semi-arid conditions. Geomicrobiology Journal. 4:299-311. (INT)

STARR, G. LYNN; and J. MICHAEL GEIST. 1988. Soil bulk density and soil moisture calculated with a FORTRAN 77 program. Gen. Tech. Rep. PNW-GTR211. Portland, OR: U.S. Department of Agriculture, Forest Service, Pacific Northwest Research Station. 6 p. (PNW)

SUPERFESKY, MICHAEL J.; and GEORGE P. WILLIAMS, JR. 1978. Shear strength of surface-mine spoils measured by triaxial and direct shear methods. Gen. Tech. Rep. NE-39. Broomall, PA: U.S. Department Agriculture, Forest Service, Northeastern Forest Experiment Station. 15 p. (NE)

TIEDEMANN, A. R.; and C. F. LOPEZ. 1983. Soil nutrient assessments of mine spoils. In: Aldon, Earl F.; and Wendall R. Oaks, eds. Reclamation of mined lands in the Southwest: Proceedings of the symposium; 1982 October 20-22; Albuquerque, NM: New Mexico Chapter of the Soil Conservation Society of America: 66-79. (INT)

TIEDEMANN, A. R.; and J. O. KLEMMEDSON. 1986. Long-term effects of mesquite removal on soil characteristics. 1: Nutrients and bulk density. Soil Science Society of America Journal. 50:472-475. (INT)

U.S. DEPARTMENT OF AGRICULTURE, FOREST SERVICE. 1989. An analysis of the minerals situation in the United States: 1989-2040: a technical document supporting the 1989 USDA Forest Service RPA assessment. Gen. Tech. Rep. RM-179. Fort Collins, CO: U.S. Department of Agriculture, Forest Service, Rocky Mountain Forest and Range Experiment Station. 38 p. (RM) 
VOGEL, WILLIS G. 1987. A manual for training reclamation inspectors in the fundamentals of soils and revegetation. Ankeny, IA: Soil and Water Conservation Society. 178 p. (NE)

WHISENANT, STEVEN G.; and WARREN P. CLARY. 1986. Spatial distribution of tebuthiuron in soil following application of pellets. Proceedings of the Western Society of Weed Science. 39:73-84. (INT)

WHISENANT, STEVEN G.; and WARREN P. CLARY. 1987. Tebuthiuron distribution in soil following application of pellets. Journal of Environmental Quality. 16:397-402. (INT)

WILLIAMS, B. D.; and P. E. PACKER. 1978. Sewage sludge and other organic materials as amendments for revegetation of spent oil shale. In: Proceedings, symposium on rehabilitation of drastically disturbed land; 1977 March; Philadelphia, PA: 353-358. (INT)

WURTELE, EVE SYRKIN. 1989. Responses of callus cultures, microshoot cultures, and whole plants of the halophyte, Atriplex canescens var. gigantea to exogenous $\mathrm{NaCl}$. In: Wallace, Arthur; E. Durant McArthur; and Marshall R. Haferkamp, comps. Proceedings-symposium on shrub ecophysiology and biotechnology; 1987 June 30-July 2; Logan, UT. Gen. Tech. Rep. INT-256. Ogden, UT: U.S. Department of Agriculture, Forest Service, Intermountain Research Station: 40-48. (INT)

\section{Soil Biota}

ALDON, EARL F. 1978. Endomycorrhizae enhance shrub growth and survival on mine spoils. In: Wright, Robert A., ed. The reclamation of disturbed arid lands. Albuquerque, NM: University New Mexico Press: 174-179. (RM)
ALDON, EARL F. 1980. Mycorrhizal enhancement of plant establishment and growth. In: Brittain, Richard G.; and Myhrman A. Matts, eds. Proceedings, vegetative reclamation of mine wastes and tailings in the Southwest; 1980 April 23-25; Tucson, AZ: Arizona Mining and Mineral Resources Research Institute: 17-1 to $17-3$. (RM)

ALDON, EARL F.; and NORMAN GREEN. 1980. Effects of endomycorrhizae on shrub and grass growth in the Southwest. In: Mineral waste stabilization liaison committee: meeting and field trip; 1980 July 16-18; Santa Fe, NM. Socorro, NM: New Mexico Bureau of Mines and Mineral Resources: 98106. (RM)

ALLEN, E. B.; J. C. CHAMBERS; K. F. CONNER; M. F. ALLEN; and R. W. BROWN. 1987. Natural reestablishment of mycrohizae in disturbed alpine ecosystems. Arctic and Alpine Research. 19(1):11-20. (INT)

ANDERSON, DAVID C.; and S. R. RUSHFORTH. 1977. The cryptogam flora of desert soil crusts in southern Utah, USA. Nova Hedwigia. 28:691-729. (INT)

ANDERSON, DAVID C.; K. T. HARPER; and S. R. RUSHFORTH. 1982. Recovery of cryptogamic soil crusts from grazing on Utah winter ranges. Journal of Range Management. 35:355-359. (INT)

ANDERSON, DAVID C.; KIMBALL R. HARPER; and RALPH C. HOLMGREN. 1982. Factors influencing development of cryptogamic soil crusts in Utah deserts. Journal of Range Management. 35:180-185. (INT)

DENNIS, G. L.; and P. R. FRESQUEZ. 1989. The soil microbial community in a sewage-sludge-amended semi-arid grassland. Biology and Fertility of Soils. 7:310-317. (RM) 
DUNN, PAUL H.; SUSAN C. BARRO; and M. POTH. 1987. Soil moisture affects survival of microorganisms in heated chaparral soil. Soil Biology and Biochemistry. 17(2):143-148. (PSW)

ELKINS, NED Z.; LAWRENCE W. PARKER; EARL F. ALDON; [and others]. 1984. Responses of soil biota to organic amendments in strip mine spoils in northwestern New Mexico. Journal of Environmental Quality. 13:215-219. (RM)

ETTERSHANK, GEORGE; NED Z. ELKINS; PERSEUS F. SANTOS; WALTER G. WHITFORD; and EARL F. ALDON. 1978. The use of termites and other soil fauna to develop soils on strip mine spoils. Res. Note. RM-361. Fort Collins, CO: U.S. Department of Agriculture, Forest Service, Rocky Mountain Forest and Range Experiment Station. $4 \mathrm{p}$. (RM)

FRECKMAN, DIANA W.; DON A. DUNCAN; and JEANNE R. LARSON. 1979. Nematode density and biomass in an annual grassland ecosystem. Journal of Range Management. 32:418-422. (PSW)

FRESQUEZ, P. R.; and B. R. SABEY. 1989. Microbial community in the rhizosphere of native plant species growing on reclaimed coal mine soils varying in age. Arid Soil Research and Rehabilitation. 3:369-384. (RM)

FRESQUEZ, P. R.; and R. M. KING. 1989. Number of fungal colonies required to describe species differences on reclaimed coal mine areas in New Mexico. Res. Note. RM-491. Fort Collins, CO: U.S. Department of Agriculture, Forest Service, Rocky Mountain Forest and Range Experiment Station. 2 p. (RM)

FRESQUEZ, P. R.; and W. C. LINDEMANN. 1982. Soil and rhizosphere microorganisms in amended coal mine spoils. Soil Science Society American Journal. 46:751-755. (RM)
FRESQUEZ, P. R.; B. R. SABEY; and D. A. KLEIN. 1988. Soil fungal communityplant rhizosphere interactions during the early stages of ecosystem development on reclaimed coal mine soils. In: 1988 Mine drainage and surface mine reclamation conference; 1988 April 1922; Pittsburgh, PA. Infor. Circ. 9184. Washington, DC: Department of the Interior, Bureau of Mines. Vol 2:9-14. (RM)

FRESQUEZ, P. R.; B. R. SABEY; and D. A. KLEIN. 1988. Early successional rhizosphere fungal populations in disturbed semi-arid ecosystems. In: Beckett, P. J., ed. Canadian land reclamation association: proceedings of the 12th annual meeting: 1987 July 711; Sudbury, Ontario, Canada. Laurentian University: 249-254. (RM)

FRESQUEZ, P. R.; E. F. ALDON; and D. L. SORENSEN. 1985. Microbial and soil enzyme activities in stockpiled topsoil and coal mine spoil overburden. In: Williams, Dean; and Scott Fisher, eds. Symposium of the American Society for Surface Mining and Reclamation; 1985 October 8-10; Denver, CO: 340-345. (RM)

FRESQUEZ, P. R.; EARL F. ALDON; and W. C. LINDEMANN. 1986. Changes in microbial populations and enzyme activities resulting from coal mine spoil reclamation. In: Symposium on mining, hydrology, sedimentology, and reclamation; 1986 December 8-11; Lexington, $\mathrm{KY}$ : University of Kentucky: 63-70. (RM).

FRESQUEZ, P. R.; EARL F. ALDON; and W. C. LINDEMANN. 1986. Microbial reestablishment and the diversity of fungal genera in reclaimed coal mine spoils and soils. Reclamation and Revegetation Research. 4:245-258. 
FRESQUEZ, P. R.; G. L. DENNIS; and R. E. FRANCIS. 1989. Soil fungi: an additional parameter for phyto-edaphic community classification. In:

Proceedings--land classifications based on vegetation: applications for resource management. Gen. Tech. Rep. INT-257. Ogden, UT: U.S. Department of Agriculture, Forest Service, Intermountain Research Station: 285287. (RM)

FRESQUEZ, P. R.; R. E. FRANCIS; and G. L. DENNIS. 1988. Fungal communities associated with phytoedaphic communities in the semiarid Southwest. Arid Soil Research and Rehabilitation. 2:187-202. (RM)

FRESQUEZ, P. R.; W. C. LINDEMANN; and D. C. LINDSEY. 1983. Soil biota in Southwestern coal strip-mined spoils. In: Aldon, Earl F.; and Wendall R. Oaks, eds. Reclamation of mined lands in the Southwest: Proceedings of the symposium; 1982 October 20-22; Albuquerque, NM: New Mexico Chapter of the Soil Conservation Society of America: 24-34. (RM)

FRESQUEZ, PHILIP R.; and EARL F. ALDON. 1984. Distribution of fungal genera in stockpiled topsoil and coal mine spoil overburden. Res. Note RM447. Fort Collins, CO: U.S. Department of Agriculture, Forest Service, Rocky Mountain Forest and Range Experiment Station. 4 p. (RM)

FRESQUEZ, PHILIP R.; EARL F. ALDON; and WILLIAM C. LINDEMANN. 1984. The distribution of fungal genera in reclaimed coal mine spoils in the arid Southwest. In: Graves, Donald H., ed. Proceedings--symposium on surface mining, hydrology, sedimentology and reclamation; 1984 December 2-7; Lexington, $\mathrm{KY}$. Bull. 136. Lexington, $\mathrm{KY}$ : University of Kentucky, College of Engineering: 215-219. (RM)
FRESQUEZ, PHILIP R.; LARRY T. CAMPBELL; and EARL F. ALDON. 1984. Response of soil fungi and soil and plant parameters to sewage sludge and sawdust amended coal mine spoils. Res. Note. RM-444. Fort Collins, CO: U.S. Department of Agriculture, Forest Service, Rocky Mountain Forest and Range Experiment Station. 4 p. (RM)

HO, IWAN. 1987. Vesicular-arbuscular mycorrhizae of halophytic grasses in the Alvord desert of Oregon. Northwest Science. 61(3):148-151. (PNW)

KLOPATEK, CAROLE COE; and JEFFREY M. KLOPATEK. 1987. Mycorrhizae, microbes, and nutrient cycling processes in pinyon-juniper systems. In: Everett, Richard L., comp. Proceedings-pinyon-juniper conference; 1986 January 13-16; Reno, NV. Gen. Tech. Rep. INT-215. Ogden, UT: U.S. Department of Agriculture, Forest Service, Intermountain Research Station: 360-364. (RM)

LENSKI, RICHARD E. 1984. Food limitation and competition: a field experiment with two Carabus species. Journal of Animal Ecology. 53:203-216. (SE)

LINDEMANN, W. C.; D. L. LINDSEY; and P. R. FRESQUEZ. 1984. Amendment of mine spoil to increase the number and activity of micro-organisms. Soil Science Society American Journal. 48:574-578. (RM) 
LINDSEY, D. L.; S. E. WILLIAMS; W. D.

BEAVIS; and EARL F. ALDON. 1984.

Vesicular-arbuscular mycorrhizae

associations in Atriplex canescens

(Pursh) Nutt. and Ceratoides lanata

(Pursh) J. T. Howell. In: Tiedemann,

Arthur R.; E. Durant McArthur; Howard

C. Stutz; Richard Stevens; and Kendall

L. Johnson, eds. Proceedings,

symposium on the biology of Atriplex

and related chenopods; 1983 May 2-6;

Provo, UT. Gen. Tech. Rep. INT-172.

Ogden, UT: U.S. Department of

Agriculture, Forest Service,

Intermountain Forest and Range

Experiment Station: 75-79. (RM)

LINDSEY, DONALD C. The role of vesiculararbuscular mycorrhizae in shrub establishment. In: Williams, Stephen E.; and Michael F. Allen, eds. VA mycorrhizae and reclamation of arid and semi-arid lands; 1982 August 17-19; Dubois, WY. Sci. Rep. SA 1261. Laramie, WY: University of Wyoming: 53-68. (RM)

NELSON, DAVID L. 1983. Occurrence and nature of actinorhizae on Cowania stansburiana and other Rosaceae. In: Tiedemann, Arthur R.; and Kendall L. Johnson, comps. Research and management of bitterbrush and cliffrose in western North America: Proceedings of a symposium; 1982 April 13-15; Salt Lake City, UT. Gen. Tech. Rep. INT152. Ogden, UT: U.S. Department of Agriculture, Forest Service, Intermountain Forest and Range Experiment Station: 225-240. (INT)

NELSON, DAVID L.; and PATTI L. SCHUTTLER. 1984. Histology of Cowania stansburiana actinorhizae. Northwest Science. 58:49-56. (INT)

OTIS, GARD W.; C. E. SANTANA; D. L. CRAWFORD; and M. L. HIGGINS. 1986. The effect of foraging army ants on leaf-litter arthropods. Biotropica. 18(1):56-61. (SO)
PARKER, L. W.; N. Z. ELKINS; E. F. ALDON; [and others]. 1987. Decomposition and soil biota after reclamation of coal mine spoils in an arid region. Biology and Fertility of Soils. 4(12):129-135. (RM)

SIEG, CAROLYN HULL; DANIEL W. URESK; and RICHARD M. HANSEN. 1987. Impact of bentonite mining on selected arthropods. Journal of Range Management. 40:128-131. (RM)

WHITFORD, WALTER G.; EARL F. ALDON; DIANA W. FRECKMAN; YOSEF STEINBERGER; and LAWRENCE W. PARKER. 1989. Effects of organic amendments on soil biota on a degraded rangeland. Journal of Range Management. 42:56-60. (RM)

\section{Rangeland Watersheds}

ANDERSON, MARK T.; and CLIFFORD L. HAWKES. 1984. Trace elements in northern Great Plains strip mine and livestock impoundment water. Water Resource Bulletin. 20:251-254. (RM)

ANDERSON, MARK T.; and CLIFFORD L. HAWKES. 1985. Water chemistry of Northern Great Plains strip mine and livestock water impoundments. Water Resources Bulletin. 21:499-505. (RM)

BARRETT, JAMES; PAUL C. DEUTSCH; FRANK G. ETHRIDGE; [and others]. 1980. Procedures recommended for overburden and hydrologic studies of surface mines: Thunder Basin Project. Gen. Tech. Rep. INT-71. U.S.

Department Agriculture Forest Service. Ogden, UT: Intermountain Forest and Range Experiment Station 106 p. (INT)

BECKER, CHARLES W.; FRANK W. WOODS; and WILLIE R. CURTIS. 1986. Water quality of mined and unmined watersheds in east Tennessee. Journal of the Tennessee Academy of Science. 61(4):98-104. (NE) 
BENDA, LEE; and THOMAS DUNNE. 1987. Sediment routing by debris flow. In: Proceedings of symposium, erosion and sedimentation in the Pacific Rim; 1987 August 3-7; Corvallis, OR. Washington, DC: International Association of Hydrological Sciences: 213-223. (PNW)

BLACKBURN, W. H.; J. C. WOOD; and M. G. DEHAVEN. 1986. Storm flow and sediment losses from site-prepared forestland in east Texas. Water

Resources Research. 22:776-784. (SO)

BLACKBURN, W. H.; J. C. WOOD; H. A. PEARSON; and R. W. KNIGHT. 1987. Storm flow and sediment loss from intensively managed forest watersheds in east Texas. In: Pearson, Henry A.; Fred Smeins; and Ronald E. Thill, comps. 1987. Ecological, physical, and socioeconomic relationships within southern National Forests: Proceedings of the southern evaluation project workshop; 1987 May 26-27; Long Beach, MS. Gen. Tech. Rep. SO-68. New Orleans, LA: U.S. Department of Agriculture, Forest Service, Southern Forest Experiment Station: 233-243. (SO)

BOYLE, G. 1982. Erosion from burned watersheds in San Bernardino National Forest. In: Conrad, C. Eugene,; and Walter C. Oechel, tech. coords. Proceedings of the symposium on dynamics and management of Mediterranean-type ecosystems; 1981 June 22-26; San Diego, CA. Gen. Tech. Rep. PSW-58. Berkeley CA; U.S. Department of Agriculture, Forest Service, Pacific Southwest Forest and Range Experiment Station: 409-410. (PSW)
BROCK, J. H.; and L. F. DEBANO. 1982. Runoff and sedimentation potentials influenced by litter and slope on a chaparral community in central Arizona. In: Conrad, C. Eugene,; and Walter C. Oechel, tech. coords. Proceedings of the symposium on dynamics and management of Mediterranean-type ecosystems; 1981 June 22-26; San Diego, CA. Gen. Tech. Rep. PSW-58. Berkeley, CA: U.S. Department of Agriculture, Forest Service, Pacific Southwest Forest and Range Experiment Station: 372-377. (RM)

BROWN, R. W.; and J. C. CHAMBERS. 1987. Measurements of in situ soil water potential with thermocouple psychrometers: a critical evaluation. In: Proceedings international conference on measurement of soil and plant water status; 1987 July 6-10; Logan, UT: Utah Agricultural Experiment Station: 125136. (INT)

BROWN, R. W.; R. S. JOHNSTON; and J. C. CHAMBERS 1984. Responses of native grasses to repeated fertilizer applications on acidic alpine mine spoils. In: Colbert, T. A.; and R. L. Cuany, eds. Proceedings: high-altitude revegetation workshop no. 6. Information Series No. 53; 1984 March 5-6; Fort Collins, CO: Colorado State University, Water Resources Research Institure: 200-214. (INT)

BUCKHOUSE, J. C.; and C. C. BOHN. 1983. Response to coliform bacteria concentration to grazing management. In: Research in rangeland management. Special Report 682. Corvallis, OR: Oregon State University, Agricultural Experiment Station:1-7. (PNW)

BUCKHOUSE, J. C.; and D. A. BOLOGNANI. 1982. Hydrologic response following rangeland improvement practices in eastern Oregon. In: Research in rangeland management. Special Report 663. Corvallis, OR: Oregon State University, Agricultural Experiment Station: 10-12. (PNW) 
BUCKHOUSE, J. C.; and J. L. MATTISON. 1980. Sediment potentials and high intensity storms on rangelands. In: Research in rangeland management. Special Report 586. Corvallis, OR: Oregon State University, Agricultural Experiment Station: 16-19. (PNW)

BUCKHOUSE, JOHN C.; and J. M. SKOVLIN. 1979. Streambank erosion in a Blue Mountain stringer meadow in response to livestock and big game grazing management. In: Research in rangeland management. Special Report 549. Corvallis, OR: Oregon State University, Agricultural Experiment Station: 2-4. (PNW)

BUCKHOUSE, JOHN C.; JON M. SKOVLIN; and ROBERT W. KNIGHT. 1981. Streambank erosion and ungulate grazing relationships. Journal of Range Management 34:339-340. (PNW)

BUCKHOUSE, JOHN C.; ROBERT W. KNIGHT; and JON M. SKOVLIN. 1979. Some erosional and water quality responses to selected animal grazing practices in northeastern Oregon. Proceedings of the Oregon Academy of Science. 15:13-22. (PNW)

CORBETT, EDWARD S.; and JAMES A. LYNCH. 1985. Management of streamside zones on municipal watersheds. In: Johnson, R. Roy; Charles D. Ziebell; David R. Patton; Peter F. Ffolliott; and R. H. Hamre, tech eds. Riparian ecosystems and their management: Reconciling conflicting uses: Proceedings, 1 st North American riparian conference; 1985 April 16-18; Tucson, AZ. Gen. Tech. Rep. RM-120. Fort Collins, CO: U.S. Department of Agriculture, Forest Service, Rocky Mountain Forest and Range Experiment Station: 187-190. (NE)

DAVIS, E. A. 1989. Prescribed fire in Arizona chaparral: effects on stream water quality. Forest Ecology and Management. 26:189-206. (RM)
DAVIS, E. A.; and L. F. DEBANO. 1986. Nitrate increases in soil water following conversion of chaparral to grass. Biogeochemistry. 2:53-65. (RM)

DAVIS, EDWIN A. 1984.Conversion of Arizona chaparral to grass increases water yield and nitrate loss. Water Resources Research. 20:1643-1649. (RM)

DAVIS, EDWIN A. 1987. Chaparral conversion and streamflow: nitrate increase is balanced mainly by a decrease in bicarbonate. Water Resources Research. 23:215-224. (RM)

DAVIS, EDWIN A.; and LEONARD F. DEBANO. 1986. Nitrate increases in soil water following conversion of chaparral to grass. Biogeochemistry 2:53-65. (RM)

DAVIS, RICHARD W.; and PAUL A. RICHARD. 1977. Effects of surface mining upon shallow aquifers in the eastern Powder River Basin, Wyoming. Water Resources Series No. 67. Laramie, WY: University of Wyoming, Water Resources Research Institute. (RM)

DEBANO, L. F.; and C. E.CONRAD. 1976. Nutrient lost in debris and runoff water from a burned chaparral watershed. In: Proceedings of the 3rd federal interagency sedimentation conference; 1976 March; Denver CO. Washington, DC: Water Resource Council: 3-13 to 3-27. (RM)

DEBANO, LEONARD F.; and BURCHARD $\mathrm{H}$. HEEDE. 1987. Enhancement of riparian ecosystems with channel structures. Arizona Water Resources Bulletin. 23:463-470. (RM)

DEBANO, LEONARD F.; and LARRY J. SCHMIDT. 1989. Improving southwestern riparian areas through watershed management. Gen. Tech. Rep. RM-182. Fort Collins, CO: U.S. Department of Agriculture, Forest Service, Rocky Mountain Forest and Range Experiment Station. 33 p. (RM) 
DEBYLE, NORBERT V. 1985. Water and watershed. In: DeByle, Norbert V.; and Robert P. Winokur, eds. Aspen: ecology and management in the Western United States. Gen. Tech. Rep. RM-119. Fort Collins, CO: U.S. Department of Agriculture, Forest Service, Rocky Mountain Forest and Range Experiment Station: 153-160. (INT)

DEUTSCH, PAUL C.; FRANK G. ETHRIDGE; WILLIAM T. FRANKLIN; [and others]. 1979. Overburden and hydrologic study of SEAM Thunder Basin study site, Campbell County, Wyoming. Final Report, Volume II. Surface Environment and Mining Thunder Basin Study. Fort Collins, CO: Colorado State University. 247 p. (RM)

DOBROWOLSKI, J.P.; W. H. BLACKBURN; and H. E. GRELEN. 1987. Sediment production from long-term burning of a longleaf pine-bluestem association. In: Pearson, Henry A.; Fred Smeins; and Ronald E. Thill, comps. 1987.

Ecological, physical, and socioeconomic relationships within southern National Forests: Proceedings of the southern evaluation project workshop; 1987 May 26-27; Long Beach, MS. Gen. Tech. Rep. SO-68. New Orleans, LA: U.S. Department of Agriculture, Forest Service, Southern Forest Experiment Station: 251-260. (SO)

\section{FARMER, E. E.; and B. Z. RICHARDSON.} 1980. Relationship of the snowpack to acid mine drainage from a western surface mine. In: Jackson, Charles L.; and Mark A. Schuster, eds.

Proceedings: high-altitude revegetation workshop no. 4; Information Series No. 42; 1980 February 26-27; Golden, CO. Fort Collins, CO: Colorado State University, Water Resources Research Institute: 79-100. (INT)

FARMER, EUGENE E. 1980. Phosphate mine dump hydrology. In: Symposium on watershed management; New York, NY: American Society of Civil Engineers: 846-853. Volume II. (INT)
FARMER, EUGENE E.; and BLAND Z. RICHARDSON. 1981. Acid mine waste revegetation: influence on soil-water quality. Res. Pap. INT-266. Ogden, UT: U.S. Department of Agriculture, Forest Service, Intermountain Forest and Range Experiment Station. 8 p. (INT)

FISHER, CARLA J.; and CHARLES D. ZIEBELL. 1980. Effects of watershed use on water quality and fisheries in an Arizona mountain lake. Eisenhower Consortium Bulletin No. 7.8 p. (RM)

GULDIN, RICHARD W. 1989. An analysis of the water situation in the United States: 1989-2040: a technical document supporting the 1989 USDA Forest Service RPA assessment. Gen. Tech. Rep. RM-177. Fort Collins, CO: U.S. Department of Agriculture, Forest Service, Rocky Mountain Forest and Range Experiment Station. 178 p. (RM)

HEEDE, B. H.; M. D. HARVEY; and J. R. LAIRD. 1988. Sediment delivery linkages in a chaparral watershed following a wildfire. Environmental Management 12:349-358. (RM)

HEEDE, BURCHARD H. 1979. Deteriorated watersheds can be restored: A case study. Environmental Management. 3:271-281.

HEEDE, BURCHARD H. 1987. The influence of pinyon-juniper on microtopography and sediment delivery of an Arizona watershed. In: Troendle, Charles A.; Merrill R. Kaufmann; R. H. Hamre; and Robert P. Winokur, tech. coords. Managment of subalpine forests: building on 50 years of research: Proceedings of a technical conference; 1987 July 6-9; Silver Creek, CO. Gen. Tech. Rep. RM-149. Fort Collins, CO: U.S. Department of Agriculture, Forest Service, Rocky Mountain Forest and Range Experiment Station: 195-198. (RM) 
HEEDE, BURCHARD H. 1988. The influence of vegetation and its spatial distribution on sediment delivery from selected Arizona forests and woodlands. In: Erosion control: stay in tune: proceedings of the 19th international erosion control association conference; 1988 February 25-26; New Orleans, LA. Steamboat Springs, CO: International Erosion Control Association: 383-392. (RM)

\section{HEEDE, BURCHARD H.; and JAMES} WEATHERRED. 1981. CAGCOM--A program for designing dams for gully control. WSDG-AD-00003. Washington, DC: U.S. Department of Agriculture, Forest Service, Watershed Systems Development Group. 20 p.

HEEDE, BURCHARD H.; MICHAEL D. HARVEY; and JEFFREY R. LAIRD. 1988. Sediment delivery linkages in a chaparral watershed following a wildfire. Environmental Management. 12(3):349358. (RM)

HIBBERT, ALDEN R. 1976. Percolation and streamflow in range and forest lands. In: Watershed management on range and forest lands; Proceedings, 5th workshop of U.S./Australia rangelands panel; 1975 June 15-22; Boise, ID: 69-80. (RM)

HIBBERT, ALDEN R. 1984. Stormflows after fire and conversion in chaparral. In: Proceedings, 4th international conference on mediterranean ecosystems; 1984 Aug. 13-17; Perth, Australia: 71-72. (RM)

HIGGINS, D. A.; A. R. TIEDEMANN; T. M. QUIGLEY; and D. B. MARX. 1989. Streamflow characteristics of small watersheds in the Blue Mountains of Oregon. Water Resources Bulletin. 25(6):1131-1149. (PNW)

HIGGINS, D. A.; S. B. MALONEY; A. R. TIEDEMANN; and T. M. QUIGLEY. 1989. Storm runoff characteristics of grazed watersheds in eastern Oregon. Water Resources Bulletin. 25(1):87-100. (PNW)
JEPPSON, ROLAND W.; and EUGENE E. FARMER. 1980. Composite water movement in a sloping phosphate mine dump. In: Symposium on watershed management. New York, NY: American Society of Civil Engineers: 855-866. Volume II. (INT)

JOHNSON, STEVEN R.; HOWARD L. GARY; and STANLEY L. PONCE. 1978. Range cattle impacts on stream water quality in the Colorado Front Range. Res. Note. RM-359. Fort Collins, CO: U.S. Department of Agriculture, Forest Service, Rocky Mountain Forest and Range Experiment Station. 8 p. (RM)

JOHNSTON, R. S.; and R. W. BROWN. 1979. Hydrolic aspects related to the management of alpine lands. In: Johnson, D. A., ed. Special management needs of alpine ecosystems. Range Science Series No. 5. Denver, CO: Society for Range Management: 65-75. (INT)

KETCHESON, GARY L. 1986. Sediment rating equations: an evaluation for streams in the Idaho batholith. Gen. Tech Rep. INT-213. Ogden, UT: U.S. Department of Agriculture, Forest Service, Intermountain Research Station. 12 p. (INT)

KNIGHTON, M. DEAN. 1978. Estimating infiltration rates for a loessal silt loam using soil properties. Res. Note. NC233. St. Paul, MN: U.S. Department of Agriculture Forest Service, North Central Forest Experiment Station. $4 \mathrm{p}$.

KNOPP, CHRISTOPHER M.; and EUGENE E. FARMER. 1980. Infiltration and erosion analysis of phosphate strip mine overburden. Res. Pap. INT-246. Ogden, UT: U.S. Department Agriculture, Forest Service, Intermountain Forest and Range Experiment Station. 11 p. (INT) 
LAMPKIN, ANDREW J., III; and MILTON R.

SOMMERFELD. 1983. Impact of reclamation on drainage from the Sheldon mine complex, Yavapai County, Arizona. Journal Arizona-Nevada Academy Science. 16:65-68. (RM)

LISLE, THOMAS. 1979. The Caspar Creek Experimental Watershed. In: Guidebook for a field trip to observe natural and management-related erosion in franciscan terrane of Northern California. Cordilleran Section, Geological Society of American: XIV-I to XIV-8. (PSW)

MARTIN, S. CLARK. 1979. Evaluating the impacts of cattle grazing on riparian habitats in the national forests of Arizona and New Mexico. In: Cope, Oliver B., ed. Proceedings of the forum-grazing and riparian/stream ecosystems. 1978 November 3-4; Denver, CO: Trout Unlimited: $35-38$. (RM)

MEDINA, ALVIN L.; and S. CLARK MARTIN. 1988. Stream channel and vegetation changes in sections of McKnight Creek, New Mexico. Great Basin Naturalist. 48:373-381. (RM)

NOLAN, K. M.; T. E. LISLE; and H. M. KELSEY. 1987. Bankfall discharge and sediment transport in northwestern California. In: Erosion and sedimentation in the Pacific Rim; 1987 August; Corvallis, OR: International Association of Hydrological Sciences: 439-450. (PSW)

PLATTS, WILLIAM S. 1987. Managing riparian stream habitats. In: Proceedings of the 21st annual meeting, American Fisheries Society, Colorado-Wyoming Chapter: 81-86. (INT)
PLATTS, WILLIAM S.; KARL A. GEBHARDT; and WILLIAM L. JACKSON. 1985. The effects of large storm events on basinrange riparian stream habitats. In: Johnson, R. Roy; Charles D. Ziebell; David Patton; Peter F. Ffolliott; and R. H. Hamre, tech. coords. Riparian ecosystems and their management: Reconciling conflicting uses:

Proceedings, 1st American riparian conference; 1985 April 16-18; Tucson, AZ. Gen. Tech. Rep. RM-120. Fort Collins, CO: U.S. Department of Agriculture, Forest Service, Rocky Mountain Forest and Range Experiment Station: 30-34. (INT)

PLATTS, WILLIAM S.; SUSAN B. MARTIN; and EDWARD R. J. PRIMBS. 1979. Water quality in an Idaho stream degraded by acid mine waters. Gen. Tech. Rep. INT-67. Ogden, UT: U.S. Department of Agriculture, Forest Service, Intermountain Forest and Range Experiment Station. 19 p. (INT)

RIEKERK, H. 1979. Forest hydrology and water quality. In: West, S. H., ed. Water program planning: IFAS Workshop Report. Gainesville, FL, University of Florida: 39-42. (SE)

RUMBLE, MARK A. 1985. Quality of water for livestock in man-made impoundments in the Northern High Plains. Journal of Range Management. 38:74-77. (RM)

SCHOLL, DAVID G.; and EARL F. ALDON. 1988. Runoff and sediment yield from two semiarid sites in New Mexico's Rio Puerco watershed. Res. Note. RM-488. Fort Collins, CO: U.S. Department of Agriculture, Forest Service, Rocky Mountain Forest and Range Experiment Station. 4 p. (RM) 
SEYEDBAGHERI, KATHLEEN A.; MICHAEL

L. MCHENRY; and WILLIAM S.

PLATTS. 1987. An annotated

bibliography of the hydrology and fishery studies of South Fork Salmon River, Gen. Tech. Rep. INT-235. Ogden, UT: U.S. Department of Agriculture, Forest Service, Intermountain Research Station. 27 p. (INT)

STURGES, D. L. 1979. Hydrologic relations of sagebrush lands. In: Proceedings, symposium sagebrush ecosystem. 1978 April; Logan, UT: Utah State University: 86-100. (RM)

SWANSON, FREDERICK J.; LEE E. BENDA; STANLEY H. DUNCAN; GORDON E. GRANT; WALTER F. MEGAHAN; LESLIE M. REID; [and others]. 1987. Mass failures and other processes of sediment production in Pacific Northwest forest landscapes. In: Proceedings of symposium, streamside management: forestry and fishery interaction; 1986 February 12-14; Seattle, WA: University of Washington, Institute of Forest Resources: 9-38. (PNW)

TIEDEMANN, A. R.; C. E. CONRAD; J. H. DIETERICH; J. W. HORNBECK; W. F. MEGAHAN; L. A. VIERECK; and D. D. WADE. 1979. Effects of fire on water. National Fire Effects Workshop; 1978 April; Denver, CO. Gen. Tech. Rep. WO-10. Washington, DC: U.S. Department of Agriculture, Forest Service. 28 p. (INT)

TIEDEMANN, A. R.; D. A. HIGGINS; T. M. QUIGLEY and H. R. SANDERSON. 1989. Stream chemistry responses to four range management strategies in eastern Oregon. Res. Pap. PNW-413. Portland, OR: U.S. Department of Agriculture, Forest Service, Pacific Northwest Research Station. 9 p. (PNW)
TIEDEMANN, A. R.; D. A. HIGGINS; T. M. QUIGLEY; H. R. SANDERSON; and D. B. MARX. 1987. Responses of fecal coliform in streamwater to four grazing strategies. Journal of Range Management. 40:322-329. (PNW)

TIEDEMANN, ARTHUR R.; THOMAS M. QUIGLEY; and TOM D. ANDERSON. 1988. Effects of timber harvest on stream chemistry and dissolved nutrient losses in northeast Oregon. Forest Science. 34:344-358. (PNW)

URSIC, S. J.; and ROBERT J. ESHER. 1988. Influence of small mammals on stormflow responses on pine-covered catchments. Water Resource Bulletin. 24:133-139. (SO)

VOORHEES, MARGUERITE E. 1986. Infiltration rate of bentonite mine spoil as affected by amendments of gypsum, sawdust and inorganic fertilizer. Reclamation and Revegetation Research. 5:483-490. (RM)

WALLACE, J. BRUCE; DAVID S. VOGEL; and T. F. CUFFNEY. 1986. Recovery of a headwater stream from an insecticideinduced community disturbance. Journal of the North American Benthological Society. 5(2):115-126. (SE)

WEBSTER, J. R.; and B. C. PATTEN. 1979. Effect of watershed perturbation on stream potassium and calcium dynamics. Ecological Monograph. 49:51-72. (RM)

WEBSTER, J. R.; E. BLOOD; S. V. GREGORY; M. E. GURTZ; R. E. SPARKS; and M. THURMAN. 1985. Long-term research in stream ecology. Bulletin of the Ecological Society of America. 66:346-353. (SE) 
WELLS, WADE G., II. 1981. Some effects of brushfires on erosion processes in coastal southern California. In: Erosion and sediment transport in Pacific Rim steeplands. 1981 January; Christ Church, New Zealand. Sponsored jointly by the Royal Society of New Zealand, New Zeland Hydrological Society, IAHS, and the National Water and Soil Conservation Authority of New Zealand. International Association of Hydrologic Publication Sciences. 132:305-342.

WOOD, J. C.; W. H. BLACKBURN; H. A. PEARSON; [and others]. 1987. Assessment of silvicultural and grazing treatment impacts on infiltration and runoff water quality of longleaf-slash pine forest, Kisatchie National Forest, Louisiana. In: Pearson, Henry A.; Fred Smeins; and Ronald E. Thill, comps. Ecological, physical, and socioeconomic relationships within southern National Forests: Proceedings of the southern evaluation project workshop; 1987 May 26-27; Long Beach, MS. Gen. Tech. Rep. SO-68. New Orleans, LA: U.S. Department of Agriculture, Forest Service, Southern Forest Experiment Station: 245-249. (SO)

WOODS, FRANK W. ; CHARLES W. BECKER; and WILLIE R. CURTIS. 1986. Recovery of water quality after strip mining. Tennessee Farm and Home Science. 140:10-13. (NE)

\section{Stream Flow Augmentation}

ALDON, EARL F. 1980. Micro-catchment water harvesting. In: Brittain, Richard G; and Myhrman A. Matts, eds. Proceedings, vegetative reclamation of mine wastes and tailings in the Southwest; 1980 April 23-25; Tucson, AZ: Arizona Mining and Mineral Resources Research Institute: 19-1 to 19-6. (RM)
ALDON, EARL F.; DWIGHT CABLE; and DÁVID SCHOLL. 1977. Plastic drip irrigation systems for establishing vegetation on steep slopes in arid climates. In: Proceedings, 7th international agricultural plastics congress; 1977 April II-16; San Diego, CA: 107-112. (RM)

ALDON, EARL F.; H. W. SPRINGFIELD; and WAYNE E. SOWARDS. 1976.

Demonstration test of two irrigation systems for plant establishment on coal mine spoils. In: 4th symposium on surface mine and reclamation. NCA/BCR Coal Conference and Exposition III; 1976 October; Louisville, KY: 201-214. (RM).

BABBITT, RONALD E. 1987. Improved streamflow and water quality monitoring using a microprocessor-based system. Res. Note INT-377. Ogden, UT: U.S. Department of Agriculture, Forest Service, Intermountain Research Station. 3 p. (INT)

BAKER, MALCHUS B., JR. 1986. A supercritical flume for measuring sediment-laden streamflow. Arizona Water Resources Bulletin. 22:847-851. (RM)

BAKER, MALCHUS B., JR. 1987. The diversity of streamflow response from upland basins in Arizona. In: Troendle, Charles A.; Merrill R. Kaufmann; R. H. Hamre; and Robert P. Winokur, tech. coords. Managment of subalpine forests: building on 50 years of research: Proceedings of a technical conference; 1987 July 6-9; Silver Creek, CO. Gen. Tech. Rep. RM-149. Fort Collins, CO: U.S. Department of Agriculture, Forest Service, Rocky Mountain Forest and Range Experiment Station: 211-215. (RM)

BELT, G. H.; J. G. KING; and H. F. HAUPT. 1977. Augmenting summer streamflow by use of a silicone anti-transpirant. Water Resource Research. 13:267-272. (INT) 
BROWN, THOMAS C.; and MARTIN M. FOGEL. 1987. Use of streamflow increases from vegetation management in the Verde River Basin. Water

Resources Bulletin. 23:1149-1160. (RM)

BURK, JACK H. 1978. Seasonal and diurnal water potential in selected chaparral shrubs. American Midland Naturalist. 99:244-248. (PSW)

CABLE, DWIGHT R. 1977. Soil water changes in creosotebush and bur-sage during a dry period in southern Arizona. Journal Arizona Academy Science. 12:15-20. (RM)

CABLE, DWIGHT R. 1980. Seasonal patterns of soil water recharge and extraction on semidesert ranges. Journal of Range Management. 33:9-15. (RM)

DAVIS, EDWIN A. 1987. Chaparral conversion and streamflow: Nitrate increase is balanced mainly by a decrease in bicarbonate. Water Resources Research. 23:215-224. (RM)

DAVIS, EDWIN A. 1987. Chaparral conversion to increase streamflow in Arizona: sequential treatments extend duration of nitrate loss to stream water. Forest Science. 33:89-103. (RM)

FARMER, EUGENE E. 1984. Hydrologic consequences of mined land disturbance in the Western United States. In: New forests for a changing world: Proceedings of the convention, Society of American Foresters; 1983 October 16-20; Portland, OR. Washington, DC: Society of American Foresters: 430-433. (INT)

FFOLLIOTT, PETER F.; and DAVID B. THORUD. 1977. Water yield improvement by vegetation management. Water Resource Bulletin. 13:563-571. (RM)
HIBBERT, A. R.; and E. A. Davis. 1986. Streamflow response to converting Arizona chaparral in a mosaic pattern. In: Hydrology and water resources in Arizona and the Southwest:

Proceedings of the Arizona section, American Water Resources Association and the hydrology section of the Arizona-Nevada Academy of Science and the Arizona Hydrological Society; 1986 April 19; Glendale, AZ. Tucson, AZ: Arizona Water Resources Association. 16:123-131. (RM)

HIBBERT, A. R.; E. A. DAVIS; and O. D. KNIPE. 1982. Water yield changes resulting from treatment of Arizona chaparral. Gen. Tech. Rep. PSW-58. Berkeley, CA: U.S. Department of Agriculture, Forest Servic, Pacific Southwest Forest and Range Experiment Station: 382-389. (RM)

HIBBERT, A. R.; O. D. KNIPE: and E. A. DAVIS. 1986. Streamflow response to control of chaparral shrubs along channels and upper slopes. In: Proceedings of the chaparral ecosystems research conference; 1985 May 16-17; Santa Barbara, CA. Rep. 62. Davis, CA: California Water Resources Center, University of California: 95-103. (RM)

HIBBERT, ALDEN R. 1976. Percolation and streamflow in range and forest lands. In: Watershed management on range and forest lands; Proceedings, 5th workshop of U.S./Australia rangelands panel; 1975 June 15-22; Boise, ID: 69-80. (RM)

HIBBERT, ALDEN R. 1977. Potential for augmenting flow of the Colorado River by vegetation management. In: Proceedings 21st annual Arizona watershed symposium. Arizona Water Commission Report. 10:16-21.

HIBBERT, ALDEN R. 1983. Water yield improvement potential by vegetation management on western rangelands. Water Resources Bulletin. 19:375-381. (RM) 
HIBBERT, ALDEN R. 1984.Stormflows after fire and conversion in chaparral. In: Proceedings of the 4th international conference on mediterranean ecosystems; Perth, Austalia: 71-72. (RM)

HIBBERT, ALDEN R. 1986. Water yield from channel-side, ridgeline, and mosaic treatment patterns in chaparral. In: 30th annual Arizona water symposium; 1986 September 17; Scottsdale, AZ. Phoenix, AZ: Arizona Water Resources Committee: 13-25. (RM)

RAPHAEL, MARTIN G. 1987. The Coon Creek Wildlife Project: Effects of water yield augmentation on wildlife. In: Troendle, Charles A.; Merrill R. Kaufmann; R. H. Hamre; and Robert P. Winokur, tech. coords. Managment of subalpine forests: building on 50 years of research: Proceedings of a technical conference; 1987 July 6-9; Silver Creek, CO. Gen. Tech. Rep. RM-149. Fort Collins, CO: U.S. Department of Agriculture, Forest Service, Rocky Mountain Forest and Range Experiment Station: 173-179. (RM)

SCHOLL, DAVID G. 1977. Laboratory evaluation of wax and silicone for water harvesting on coal mine spoil. Res. Note RM-321. Fort Collins, CO: U.S. Department of Agriculture, Forest Service, Rocky Mountain Forest and Range Experiment Station. 4 p. (RM)

SCHOLL, DAVID G; and EARL F. ALDON. 1979. Water harvesting to establish perennial plants on semi-arid coal mine spoil. In: Mohan, K. Wali, ed. Ecology and coal resource development: New York, NY: Pergamon Press: 735-739. Volume II. (RM)

STURGES, DAVID L. 1986. Snow fencing to increase streamflow: preliminary results. In: Proceedings, 54th annual western snow conference; 1986 April 15-17; Phoenix, AZ. Seattle, WA: Western Snow Conference: 18-29. (RM)
STURGES, DAVID L. 1989. Evaporation and seepage from a livestock reservoir equipped with a snow fence for water recharge. In: Proceedings, 57th annual western snow conference; 1989 April 18-20; Fort Collins, CO: Colorado State University. (RM)

TABLER, RONALD D.; and DAVID L.

STURGES. 1986. Watershed test of a snow fence to increase streamflow: Preliminary results. In: Kane, Douglas L., ed. Proceedings of a symposium: cold regions hydrology; 1986 July 22-25; Fairbanks, AK. TPS-86-1. Bethesda, MD: American Water Resources Association: 53-61. (RM) 


\section{Experimental Areas And Research Needs}

ALLEN, HARRIET; and LARRY W. BREWER. 1985. A review of current northern spotted owl (Strix occidentalis caurina)

research in Washington State. In: Gutierrez, Ralph J.; and Andrew B. Carey, tech. eds. Ecology and management of the spotted owl in the Pacific Northwest: Proceedings of a symposium; 1984 June 19-23; Arcata, CA. Gen. Tech. Rep. PNW-185. Portland, OR: U.S. Department of Agriculture, Forest Service, Pacific Northwest Forest and Range Experiment Station: 55-57. (PNW)

BOCK, J. H.; C. E. BOCK; and J. R. MCKNIGHT. 1976. A study of the effects of grassland fires at the research ranch in southeastern Arizona. Journal of the Arizona Academy of Sciences. 11:49-57. (RM)

CLARY, WARREN P.; and RALPH C. HOLMGREN. 1982. Desert experimental range: establishment and research contribution. Rangelands. 4:261-264; (INT)

COLE, DAVID N. 1989. Viewpoint: needed research on domestic and recreational livestock in wilderness. Journal of Range Management. 42:84-86. (INT)

DEBYLE, NORBERT V. 1978. Larch/douglasfir clearcutting and burning effects--a holistic research approach. In: Proceedings 51st Annual Meeting Northwest Soil Association; Pullman, WA. 37 p. (INT)

DUNCAN, DON A.; and SUSAN L. COON. 1985. Publications from the San Joaquin Experimental Range, 1935-1985. CATI/850902. Fresno, CA: California State University, California Agricultural Technology Institute. 101 p. (PSW)
DUNN, PAUL H.; SUSAN C. BARRO; WADE G. WELLS, II; MARK A. POTH; PETER M. WOHLGEMUTH; and CHARLES G. CLOVER. 1988. The San Dimas Experimental Forest: 50 years of research. Gen. Tech. Rep. PSW-104. Berkeley, CA: U.S. Department of Agriculture, Forest Service, Pacific Southwest Forest and Range Experiment Station. 49 p. (PSW)

EVEREST, FRED; and WILLIAM R. MEEHAN. 1978. Anadromous fish habitat research. Information Leaflet. Portland, OR: U.S. Department of Agriculture, Forest Service, Pacific Northwest Forest and Range Experiment Station. [n.p.] (PNW)

FOUNTAIN, M. S.; and J. M. SWEENEY. 1985. Ecological assessment of the Roaring Branch Research Natural Area. Res. Pap. SO-213. New Orleans, LA: U.S. Department of Agriculture, Forest Service, Southern Forest Experiment Station. 15 p. (NC)

FRANKLIN, J. F. 1987. Current ecosystem research topics in the United States. In: Hanxi, Yang; Zhan Wang; J. N. R. Jeffers; and P. A. Ward, eds. The temperate forest ecosystem:

Proceedings of international symposium on temperate forest ecosystem management and environmental protection; 1986 July 5-11; Antu, Jilin Province, People's Republic of China. ITE Symp. 20. (Place of publication unknown): Natural Environment Research Council, Institute of Terrestrial Ecology. 55-58. (PNW)

FRANKLIN, JERRY F. 1987. Importance and justification of long term studies in ecology. In: Likens, Gene E., ed. Longterm studies in ecology: approaches and alternatives: Proceedings of the 2 nd Carry conference; 1987 May 10-14; Millbrook, NY. New York: SpringerVerlag. 20 p. (PNW) 
GREAT PLAINS AGRICULTURAL RESEARCH COMMITTEE. 1976. Range research needs in the Great Plains. Publication No. 79. Great Plains Agricultural Council. 60 p. (RM)

GREENE, SARAH E. 1985. New rangeland research areas in Oregon. Rangelands. 7:165-166. (PNW)

GUTHERY, FRED S.; ERIC G. BOLEN; and FRED A. STORMER. 1984. Wildlife research programs, goals and issues. In: Boccus, John T., ed. Texas wildlife resources and land use: Proceedings of a symposuim; 1982 April 14-16; Austin, TX. Texas Chapter, The Wildlife Society: 142-156. (RM)

GUTIERREZ, R. J. 1985. Information and research needs for spotted owl management. In: Gutierrez, Ralph J.; and Andrew B. Carey, tech. eds.

Ecology and management of the spotted owl in the Pacific Northwest:

Proceedings of a symposium; 1984 June 19-23; Arcata, CA. Gen. Tech. Rep. PNW-185. Portland, OR: U.S. Department of Agriculture, Forest Service, Pacific Northwest Forest and Range Experiment Station: 115-118.

HALFFTER, GONZALO; PETER F. FFOLLIOTT; and WARREN P. CLARY. 1981. Visits to Mapimi and La Michilia biosphere reserves. In: Ffolliott, Peter F., and Gonzalo Halffter, tech. coords. Social and environmental consequences of natural resource policies--with special emphasis on biosphere reserves: Proceedings, international seminar; 1980 April 8-13; Durango, Mexico. Gen. Tech. Rep. RM-88. Fort Collins, CO: U.S. Department of Agriculture, Forest Service, Rocky Mountain Forest and Range Experiment Station: 52-53.

JUDAY, GLENN PATRICK. 1989. Alaska Research Natural Areas. 2: Limestone Jags. Gen. Tech. Rep. PNW-237. Portland, OR: U.S. Department of Agriculture, Forest Service, Pacific Northwest Research Station. 58 p. (PNW)
KIMBALL, THOMAS L. 1979. The role of biosphere reserves in the management of national and international ecosystems. In: Franklin, Jerry F.; and Stanley L. Krugman, coords. Selection, management and utilization of biosphere reserves. Gen. Tech. Rep. PNW-82. Portland, OR: U.S. Department of Agriculture, Forest Service, Pacific Northwest Forest and Range Experiment Station: 60-63 (PNW)

KLEMMENDSON, J. O.; REX D. PIEPER; DON D. DWYER; WALTER F. MUEGGLER; and M. J. TRLICA. 1978. Research needs on western rangelands. Journal of Range Management. 31:4-8 (INT)

MEEUWIG, RICHARD O.; and ROBERT B. MURRAY. 1978. Current research on pinyon-juniper in the great basin. In: Martin, Robert E.; J. Edward Dealy; and David L. Caraher, eds. Proceedings of the western juniper ecology and management workshop; 1977 January; Bend, OR. Gen. Tech. Rep. PNW-74; Portland, OR: U.S. Department of Agriculture, Forest Service, Pacific Northwest Forest and Range Experiment Station: 97-103. (INT)

MITCHELL, JOHN E.; and GARY R. EVANS. 1988. A prospectus for research needs created by passage of the Conservation Reserve Program. In: Mitchell, John E., ed. Impacts of the Conservation Reserve Program in the Great Plains: Symposium proceedings; 1987 September 16-18; Denver, CO. Gen. Tech. Rep. RM-158. Fort Collins, CO: U.S. Department of Agriculture, Forest Service, Rocky Mountain Forest and Range Experiment Station: 128-132. (RM)

MOIR, W. H. 1982. Fire history of the High Chisos, Big Bend National Park, Texas. Southwestern Naturalist. 27:87-98. (RM) 
PATTON, DAVID R. 1977. Riparian research needs. In: Johnson, R. Roy; and Dale A. Jones, tech. eds. Importance, preservation and management of the riparian habitat: Symposium proceedings; 1977 July 9; Tucson, AZ: Gen. Tech. Rep. RM-43. Fort Collins, CO: U.S. Department of Agriculture, Forest Service, Rocky Mountain Forest and Range Experiment Station: 80-82. (RM)

PATTON, DAVID R. 1983. El programa del Servicio Forestal de Investigacio'n sobre el Campo y la Fauna Silvestre en el Suroeste. In: Patton, David R.; [and others], tech. coords. Reunion sobre "la fauna y su medio ambiente" Noreste de Mexico Suroeste Estados Unidos de America: Workshop proceedings; 1981 April 20-24; Rio Rico, AZ: Gen. Tech. Rep. WO-36S, Washington, DC: U.S. Department of Agriculture, Forest Service: 67-70. (RM)

PATTON, DAVID R. 1983. The Forest Service's program of range and wildlife habitat research in the Southwest. In: Patton, David R.; [and others], tech. coords. Wildlife and range research needs in northern Mexico and southwestern United States: Workshop proceedings; 1981 April 20-24; Rio Rico, AZ: Gen. Tech. Rep. WO-36. Washington, DC: U.S. Department of Agriculture, Forest Service: 67-70. (RM)

PATTON, DAVID R. 1986. Administration of research. In: Cole, Richard A.; and William B. Zeedyk, eds. Proceedings, workshop on fish and wildlife research needs in New Mexico; 1984 October 34; Las Cruces, NM. Spec. Rep. 67. Las Cruces, NM: New Mexico State University: 118-121. (RM)
PATTON, DAVID R.; JOSE' M. DE LA PUENTE; PETER F. FFOLLIOTT; SONIA GALLIAN; and E. T. BARTLETT, tech. coords. 1983. Wildlife and range research needs in northern Mexico and southwestern United States: Workshop proceedings; 1981 April 20-24; Rio Rico, AZ. Gen. Tech. Rep. WO-36.

Washington, DC: U.S. Department of Agriculture, Forest Service. 108 p. (RM)

PATTON, DAVID R.; JOSE' M. DE LE PUANTE; PETER F. FFOLLIOTT; SONIA GALLIAN; and E. T. BARTLETT, tech. coords. 1983. Reunion sobre "la fauna y su medio ambiente" Noreste de Mexico Suroeste Estados Unidos de America. Workshop proceedings; 1981 April 20-24; Rio Rico, AZ. Gen. Tech. Rep. WO-36S. Washington, DC: U.S. Department of Agriculture, Forest Service. 120 p. (RM)

PEDERSEN, DICK. 1979. Northeast Oregon elk research. Oregon Wildlife. 34(11):35. (PNW)

PETERSON, ROGER S.; and ERIC RASMUSSEN. 1986. Research Natural Area in New Mexico. Gen. Tech. Rep. RM-136. Fort Collins, CO: U.S. Department of Agriculture, Forest Service, Rocky Mountain Forest and Range Experiment Station. 58 p. (RM)

PROUTY, MIKE. 1987. A riparian research program. Rangelands. 9:271-272. (INT)

QUINN, RONALD D. 1982. Research and management of animals in Mediterranean-type ecosystems: A summary and synthesis. In: Conrad, C. Eugene; and Walter C. Oechel, tech. coords. Proceedings of the symposium on dynamics and management of Mediterranean-type ecosystems; 1981 June 22-26; San Diego, CA. Gen. Tech. Rep. PSW-58. Berkeley, CA: U.S. Department of Agriculture, Forest Service, Pacific Southwest Forest and Range Experiment Station: 276-278. (PSW) 
RIETVELD, W. J.; STEPHEN E. MCDONALD; CHARLES W. FUDGE; and GARY L. HERGENRADER. 1989. The status and future of USDA forestry research on the Great Plains. In: Landis, Thomas D., tech. coord. Proceedings, Intermountain Forest Nursery

Association; 1989 August 14-18;

Bismarck, ND. Gen. Tech Rep. RM-184.

Fort Collins, CO: U.S. Department of Agriculture, Forest Service, Rocky Mountain Forest and Range Experiment Station: 8-12. (RM)

RUGGIERO, LEONARD F.; and ANDREW B. CAREY. 1984. A programmatic approach to the study of old-growth forest-wildlife relationships. In: New forests for a changing world: Proceedings, Society of American Foresters national convention; 1983 October 16-20; Portland, OR. Bethesda, MD: Society of American Foresters: 340-345. (PNW)

SEVERSON, KIETH E.; and ALVIN L. MEDINA. 1983. The Santa Rita Range. In: Patton, David R.; [and others], tech. coords. Wildlife and range research needs in northern Mexico and southwestern United States: Workshop proceedings; 1981 April 20-24; Rio Rico, AZ: Gen. Tech. Rep. WO-36.

Washington, DC: U.S. Department of Agriculture, Forest Service: 56-59. (RM)

SOKOLOV, V. E. 1979. Research on the higher vertebrates in Biosphere

Reserves. In: Franklin Jerry F.; and Stanley L. Krugman, coords. Selection, management and utilization of biosphere reserves. Gen. Tech. Rep. PNW-82. Portland, OR: U.S. Department of Agriculture, Forest Service, Pacific Northwest Forest and Range Experiment Station:216-219. (PNW)

SWANSON, FREDERICK J.; and JERRY F. FRANKLIN. 1988. The Long-Term Ecological Research Program. Eos. 69(3):33-35. (PNW)
TURNER, RAYMOND M.; [and others]. 1981. Arizona range reference areas. Gen. Tech. Rep. RM-79. Fort Collins, CO: U.S. Department of Agriculture, Forest Service, Rocky Mountain Forest and Range Experiment Station. 34 p. (RM)

VERNER, JARED. 1981. Report of the working group to identify future research needs. In: Ralph, C. John; and J. Michael Scott, eds. Proceedings of the symposium on estimating numbers of terrestrial birds; 1980 October 26-31; Asilomar, CA. Studies in Avian Biology No. 6. Cooper Ornithological Society: 584. (PSW)

WILEY, J. W. 1981. White-crowned pigeon research in Puerto Rico. In:

Proceedings, international whitecrowned pigeon conference; Nassau, Bahamas: 43-57. (SO)

WILSON, CARL C.; and JAMES B. DAVIS. 1988. Forest Fire Laboratory at Riverside and fire research in California: past, present, and future. Gen. Tech. Rep. PSW-105. Berkeley, CA: U.S. Department of Agriculture, Forest Service, Pacific Southwest Forest and Range Experiment Station. 22 p. (PSW)

WOLTERS, GALE L.; and RONALD D. LINDMARK. 1987. A basis for the southern evaluation program. In: Pearson, Henry A.; Fred Smeins; and Ronald E. Thill, comps. 1987. Ecological, physical, and socioeconomic relationships within southern National Forests: Proceedings of the southern evaluation project workshop; 1987 May 26-27; Long Beach, MS. Gen. Tech. Rep. SO-68. New Orleans, LA: U.S. Department of Agriculture, Forest Service, Southern Forest Experiment Station: 15-16. (WO) 


\section{Resource Economics}

BJUGSTAD, ARDELL J; and CINDY F. SORG. 1987. Northern high plains woodland values and regeneration. In: Issues and technology in the management of impacted western wildlife; 1985 February 4-6; Glenwood Springs, CO. Boulder, CO: Thorne Ecological Institute: 131-138. (RM)

BOYLE, KEVIN J.; and RICHARD C BISHOP. 1987. Valuing wildlife in benefit-cost analyses: a case study involving endangered species. Water Resources Research. 23:943-950. (RM)

BROWN, THOMAS C.; and BENJAMIN L. HARDING. 1987. A preliminary economic assessment of timber and water production in subalpine forests. In: Troendle, Charles A.; Merrill R. Kaufmann; R. H. Hamre; and Robert P. Winokur, tech. coords. Managment of subalpine forests: building on 50 years of research: Proceedings of a technical conference; 1987 July 6-9; Silver Creek, CO. Gen. Tech. Rep. RM-149. Fort Collins, CO: U.S. Department of Agriculture, Forest Service, Rocky Mountain Forest and Range Experiment Station: 126-137. (RM)

CLARY, WARREN P. 1983. Interfacing physical data and economics. In: Wagstaff, Fred J., comp. Proceedings-range economics symposium and workshop; 1982 August 31-September 2; Salt Lake City, UT. Gen. Tech. Rep. INT-149. Ogden, UT: U.S. Department of Agriculture, Forest Service, Intermountain Forest and Range Experiment Station: 115-119. (INT)

CLARY, WARREN P.; and FRED J.

WAGSTAFF. 1987. Biological and economic effectiveness of several revegetation techniques in the pinyonjuniper-sagebrush zone. In: Everett, Richard L., comp. Proceedings--pinyonjuniper conference; 1986 January 13-16; Reno, NV. Gen. Tech. Rep. INT-215. Ogden, UT: U.S. Department of Agriculture, Forest Service, Intermountain Research Station: 305315. (INT)
DONNELLY, DENNIS; CINDY SWANSON; and GEORGE PETERSON. 1988. Valuation of wildlife products: an overview with emphasis on wildlife. In: Raedeke, Kenneth J., ed. Streamside management: riparian wildlife and forestry interactions. Seattle, WA: University of Washington: 245-257. (RM)

DRIVER, B. L. 1985. Specifying what is produced by management of wildlife by public agencies. Leisure Sciences. 7:281-295. (RM)

EVEREST, FRED H. 1978. Anadromous fish habitat and forest management-economic considerations. In: Proceedings, 58th Annual Economic Western Association of Fish and Wildlife Agencies: 153-171. (PNW)

EVEREST, FRED H. 1980. Perspectives on National Forest fishery values for landuse planning. Cal-Neva Wildlife Transactions. 1980:64-70. (PNW)

EVEREST, FRED H.; and PHILLIP B. SUMMERS. 1982. The sport fishing resource of the National Forests--its extent, recreational use, and value. Washington, DC: U.S. Department of Agriculture, Forest Service, Wildlife and Fisheries Staff. 50 p. (PNW)

GLASS, RONALD J. 1988. Habitat improvement costs on state-owned wildlife management areas in New York. Res. Pap. NE-621. Broomall, PA: U.S. Department of Agriculture, Forest Service, Northeastern Forest Experiment Station. 15 p. (NE)

HANEY, HARRY L., JR. 1980. Economics of integrated cattle-timber land use. In: Proceedings, Southern forest range and pasture resources symposium; Morrilton, AR: Winrock International: 165-183. (SO) 
HOF, JOHN G.; and RICHARD C. FIELD. 1987. On the possibility of using joint cost allocation in forest management decision making. Forest Science. 33:1035-1046. (RM)

HOF, JOHN G.; and RICHARD C. FIELD. 1989. True separable costs versus accounting-based separable costs in multiple-use forestry. Forest Science. 35:263-270. (RM)

HORVATH, JOSEPH C.; DENNIS L. SCHWEITZER; and ENOCH F. BELL. 1978. Grazing on National Forest System lands: costs of increasing capacity in the Northern Region. Res. Pap. INT-2/5. Ogden, UT: U.S. Department of Agriculture, Forest Service, Intermountain Forest and Range Experiment Station. 56 p. (INT)

HUPPERT, DANIEL D.; ROGER D. FIGHT; and FRED H. EVEREST. 1985.

Economic considerations. In: Meehan, William R., tech. ed. Influence of forest and rangeland management on anadromous fish habitat in western North America. Gen. Tech. Rep. PNW181. Portland, OR: U.S. Department of Agriculture, Forest Service, Pacific Northwest Forest and Range Experiment Station. 27 p. (PNW)

LOOMIS, JOHN; CINDY F. SORG; and DENNIS M. DONNELLY. 1986. Economic losses to recreational fisheries due to small-head hydro-power development: A case study. Journal of Environmental Management. 22:85-94. (RM)

LOOMIS, JOHN; DENNIS DONNELLY; and CINDY SORG. 1988. Estimation of marginal values of wildlife and forage using the travel cost method. In: Loomis, John B., comp. Benefits and costs in natural resources planning; Interim report. Western Regional Research Publications W-133:157-174. (RM)
LUNDGREN, G. K.; J. R. CONNER; and H. A. PEARSON. 1984. Five forest-grazing management systems in the southeastern United States. MP-1551. College Station, TX: Texas Agriculture Experiment Station, Texas A \& M University Agricultural Experiment Station. 8 p. (SO)

LUNDGREN, G. K.; J. R. CONNER; and H. A. PEARSON. 1987. Aggregate economic impact of implementing forest grazing of beef cattle in the southern United States. In: Pearson, Henry A.; Fred Smeins; and Ronald E. Thill, comps. 1987. Ecological, physical, and socioeconomic relationships within southern National Forests: Proceedings of the southern evaluation project workshop; 1987 May 26-27; Long Beach, MS. Gen. Tech. Rep. SO-68. New Orleans, LA: U.S. Department of Agriculture, Forest Service, Southern Forest Experiment Station: 271-273. (SO)

LUNDGREN, GWYNEE; J. RICHARD CONNER; and HENRY A PEARSON. 1983. An economic analysis of forest grazing on four timber management situations. Southern Journal Applied Forestry. 7:119-124. (SO)

MARTIN, S. CLARK. 1986. Values and uses for mesquite. In: Patton, David R.; Carlos E. Gonzales V; Alvin L. Medina; A. Luis; T. Segura; and R. H. Hamre, eds. 1986. Management and utilization of arid land plants: symposium proceedings; 1985 February 18-22; Saltillo, Mexico. Gen. Tech. Rep. Rm135. Fort Collins, CO: U.S. Department of Agriculture, Forest Service, Rocky Mountain Forest and Range Experiment Station: 91-96. (RM)

MORE, T. 1979. The demand for nonconsumptive wildlife use: a review of the literature. Gen. Tech. Rep. NE-52. Broomall, PA: U.S. Department of Agriculture, Forest Service, Northeastern Forest Experiment Station. 16 p. (NE) 
PEARSON, HENRY A. 1977. Grazing cattle on forest range; nutrition and returns. In: White, L. D., ed. Beef crisis emphasizes value of range. Res. Rep. No. 4. Gainesville, FL: University of Florida, Institute, Food and Agriculture Science: 18-22. (SO)

PEARSON, HENRY A. 1982. Economic analysis of forest grazing. The Stockman/Farmer. 39(10):26, 28, 30, 32. (SO)

POPE, C. ARDEN, III; and FRED J. WAGSTAFF. 1987. An economic evaluation of the Oak Creek range management area, Utah. Gen. Tech. Rep. INT-224. Ogden, UT: U.S. Department of Agriculture, Forest Service, Intermountain Research Station. 14 p. (INT)

POPE, C. ARDEN, III; and FRED J. WAGSTAFF. 1987. Economics of the Oak Creek Range Management Project. Journal of Environmental Management. 25:157-165. (INT)

QUIGLEY, THOMAS M. 1987. Short-duration grazing: an economic perspective. Rangelands. 9:173-175. (PNW)

QUIGLEY, THOMAS M. 1989. Value shifts is multiple use products from rangelands. Rangelands. 11:275-279. (PNW)

QUIGLEY, THOMAS M.; and JACK WARD THOMAS. 1989. Range management and grazing fees on the National Forests: a time of transition. Rangelands. 11:28-32. (PNW)

QUIGLEY, THOMAS M.; and JOHN A TANAKA. 1988. The Federal grazing fee: a viewpoint. Rangelands. 10:130131. (PNW)
QUIGLEY, THOMAS M.; and R. G. TAYLOR. 1982. Econometric estimation of range forage demand. In: Wagstaff, Fred J., comp. Proceedings, range economics symposium and workshop; 1982 August 31-September 2; Salt Lake City, UT. Provo, UT: U.S. Department of Agriculture, Forest Service, Intermountain Forest and Range Experiment Station: 120-128. (PNW)

QUIGLEY, THOMAS M.; GARTH R.

TAYLOR; and R. MCGREGGOR CAWLEY. 1988. Public resource pricing: an analysis of range policy. Res. Bull. PNW-158. Portland, OR: U.S. Department of Agriculture, Forest Service, Pacific Northwest Research Station. 38 p. (PNW)

QUIGLEY, THOMAS M.; KENNETH GIBBS; and $H$. REED SANDERSON. 1986. Rancher response to changes in federally permitted livestock numbers in eastern Oregon. Rangelands. 8:276278. (PNW)

SHAW, WILLIAM W.; and ERVIN H. ZUBE, eds. 1980. Wildlife values. Institute Series Rep. 1. Tucson, AZ: University of Arizona, Center for Assessment of Noncommodity Natural Resource Values. 117 p. (RM)

SMITH, W. H.; and B. F. SWINDEL. 1978. Forest management-its impact of forest values. Florida Forestry Association Annual Meeting Magazine: 24-29. (SE)

SORG, CINDY F.; and JOHN B. LOOMIS. 1986. Economic value of Idaho sport fisheries with an update on valuation techniques. North American Journal of Fisheries Management. 6:494-503. (RM)

SORG, CINDY F.; and LOUIS J. NELSON. 1986. Net economic value of elk hunting in Idaho. Res. Bull. RM-12. Fort Collins, CO; U.S. Department of Agriculture, Forest Service, Rocky Mountain Forest and Range Experiment Station. $21 \mathrm{p}$. (RM) 
SORG, CINDY F.; and LOUIS J. NELSON. 1987. Net economic value of waterfowl hunting in Idaho. Resour. Bull. RM-14. Fort Collins, CO: U.S. Department of Agriculture, Forest Service, Rocky Mountain Forest and Range Experiment Station. 21 p. (RM)

STOECKER, ARTHUR; GENE A. MATHIA; HARLAN T. CARDWELL; and ALAN KNIGHT. 1981. Economic considerations of playa lake enhancements for wildlife. In: Proceedings, playa lakes symposium; 1979 December 4-5; Arlington, TX. FWS/OBS-81/07. Washington, DC: U. S. Department of the Interior, Fish and Wildlife Service: 112-123. (RM)

SWANSON, CINDY S.; MICHAEL THOMAS; and DENNIS M. DONNELLY. 1989. Economic value of big game hunting in southeast Alaska. Resour. Bull. RM-16. Fort Collins, CO: U.S. Department of Agriculture, Forest Service, Rocky Mountain Forest and Range Experiment Station. 11 p. (RM)

WAGSTAFF, FRED J. 1983. Economics as a tool for natural rangeland managers. Rangelands. 5:121-122. (INT)

WAGSTAFF, FRED J. 1983. Evaluating proposed improvements of public rangelands. Gen. Tech. Rep. INT-150. Ogden, UT: U.S. Department of Agriculture, Forest Service, Intermountain Forest and Range Experiment Station. 4 p. (INT)

WAGSTAFF, FRED J. 1983. Externalities caused by multiple use on public rangelands. In: Wagstaff, Fred J., comp. Proceedings--range economics symposium and workshop; 1982 August 31-September 2; Salt Lake City, UT. Gen. Tech. Rep. INT-149. Ogden, UT: U.S. Department of Agriculture, Forest Service, Intermountain Forest and Range Experiment Station: 82-85. (INT)
WAGSTAFF, FRED J. 1986. Economic issues of grazing and riparian area management. Transactions of the North American Wildlife and Natural Resources Conference. 51:272-279. (INT)

WAGSTAFF, FRED J. 1987. Economics of managing pinyon-juniper lands for woodland products. In: Everett, Richard L., comp. Proceedings--pinyon-juniper conference; 1986 January 13-16; Reno, NV. Gen. Tech. Rep. INT-215. Ogden, UT: U.S. Department of Agriculture, Forest Service, Intermountain Research Station: 168-172. (INT)

WAGSTAFF, FRED J., comp. 1983. Proceedings--range economics symposium workshop. 1982 August 31September 2; Salt Lake City, Utah. Gen. Tech. Rep. INT-149. Ogden, UT: U.S. Department of Agriculture, Forest Service, Intermountain Forest and Range Experiment Station. 151 p. (INT)

WAGSTAFF, FRED J., comp. 1986 Range and ranch economics bibliography: 1968-85. Gen. Tech. Rep. INT-216. Ogden, UT: U.S. Department of Agriculture, Forest Service, Intermountain Research Station. 30 p. (INT)

WAGSTAFF, FRED J.; and ARDEN C. POPE III. 1987. Finding the appropriate forage value for analyzing the feasibility of public range improvements. Res. Pap. INT-378. Ogden, UT: U.S. Department of Agriculture, Forest Service, Intermountain Research Station. 4 p. (INT)

WAGSTAFF, FRED J.; and DODI REESMAN, comps. 1989. Multiple users-multiple products. Proceedings of a symposium, 42 nd annual meeting of the Society for Range Management; 1989 February 21; Billings, MT. Western Regional Coordinating Committee on Range Economics WRCC-55. Corvallis, OR: Oregon State University. 262 p. (INT) 
Appendix 


\section{How To Obtain A Publication}

Many of the periodicals that contain articles

on range, wildlife and fish habitat and related research found in this bibliography, can be obtained at local libraries, particularly State agricultural university libraries. Many local libraries also contain Forest Service research publications (Research Notes, Research Papers, General Technical Reports, etc.). If a library does not have the desired publication, it can often be obtained through an interlibrary loan.

Some Forest Service research publications are also available through the publication office of the respective experiment station. The Forest Service experiment station where the article may be obtained is abbreviated in parentheses after each bibliography. The Technical Information Systems Division, National Agricultural Library, Beltsville, MD 20705 is another source of Forest Service research publications.
Articles available through the U.S.

Department of Commerce, National Technical Information System (NTIS), 5285 Port Royal Road, Springfield, VA 22161 are identified by a NTIS number.

Scientific and technical publications are also frequently available directly from the author. Addresses of authors are not provided since they are subject to change. 


\section{USDA Forest Service Experiment Station Addresses}

(INT) Intermountain Forest and Range Experiment Station

324 25th Street

Ogden, UT 84401

(NC) North Central Forest Experiment Station

1992 Folwell Avenue

St. Paul, MN 55108

(NE) Northeastern Forest Experiment Station

100 Matsonford Road, Suite 200

Radnor, PA 19087

(PNW) Pacific Northwest Forest and Range Experiment Station

P.O. Box 3890

Portland, OR 97208

(PSW) Pacific Southwest Forest and Range Experiment Station

P.O. Box 245

Berkeley, CA 94704

(RM) Rocky Mountain Forest and Range Experiment Station 240 West Prospect Street

Fort Collins, CO 80526-2098 
(SE) Southeastern Forest Experiment Station

200 Weaver Boulevard

P.O. Box 2680

Asheville, NC 28802

(SO) Southern Forest Experiment Station

$\mathrm{T}-10210$

U.S. Postal Service Building

701 Loyola Avenue

New Orleans, LA 70113

(WO) U.S. Department of Agriculture

Forest Service

P.O. Box 96090

Washington, DC 20090-6090 



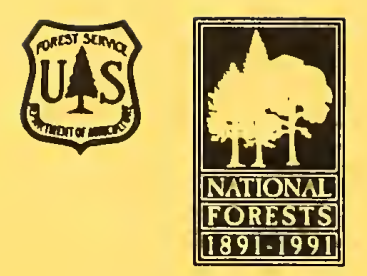

